
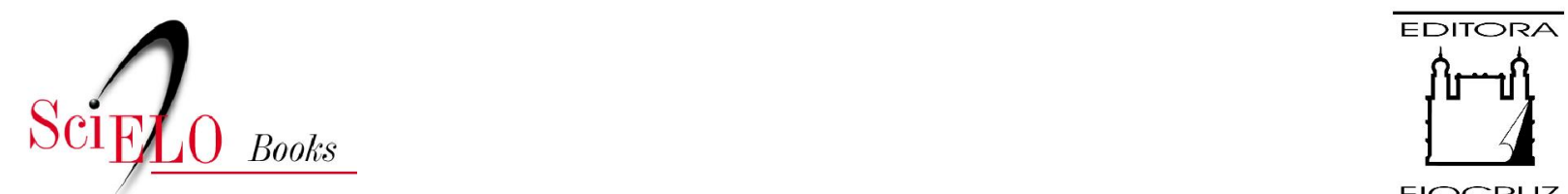

FIOCRUZ

\author{
Salud y equidad \\ una mirada desde las ciencias sociales \\ Roberto Bricefio-León \\ Maria Cecília de Souza Minayo \\ Carlos E. A. Coimbra Jr. \\ (coord.)
}

BRICEÑO-LEÓN, R., MINAYO, M. C. S., and COIMBRA JR., C. E. A., coord. Salud y equidad: una mirada desde las ciencias sociales [online]. Rio de Janeiro: Editora FIOCRUZ, 2000, 384 p. ISBN: 978-85-7541-512-2. Available from: doi: 10.7476/9788575415122. Also available in ePUB from: http://books.scielo.org/id/rmmbk/epub/leon-9788575415122.epub.

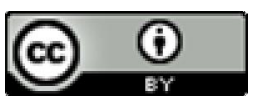

All the contents of this work, except where otherwise noted, is licensed under a Creative Commons Attribution 4.0 International license.

Todo o conteúdo deste trabalho, exceto quando houver ressalva, é publicado sob a licença Creative Commons Atribição 4.0.

Todo el contenido de esta obra, excepto donde se indique lo contrario, está bajo licencia de la licencia Creative Commons Reconocimento 4.0. 
Salud y Equidad: una mirada desde las ciencias sociales 


\section{FUNDAÇÃO OSWALDO CRUZ}

Presidente

Eloi de Sonza Garcia.

Vice-Presidente de Ambiente, Comunicación y Información

Maria Cecilia de Soura Minayo

\section{EDITORA FIOCRUZ}

\section{Coordinadora}

Maria Cecilia de Souza Minayo

\section{Comisión Editorial}

Carlos E. A. Coimbra Jr.

Carolina M. Bori

Charles Pessanba

Hooman Momen

Jaime L. Benchimol

José da Rocha Carvalbeiro

Luis David Castiel

Luiz Fernando Ferreira

Miriam Strucbiner

Paulo Amarante

Paulo Gadelha

Paulo Marchiori Buss

Vanize Macêdo

Zigman Brener

Coordinador Ejecutivo

João Carlos Canossa P. Mendes 


\title{
Salud y Equidad: una mirada desde las ciencias sociales
}

\author{
Roberto Briceño-León \\ Maria Cecília de Souza Minayo \\ Carlos E. A. Coimbra Jr. \\ Coordinadores
}

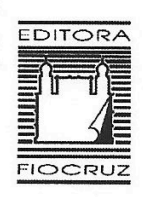


Copyright (C) 2000 de los autores

Derechos reservados a

FUNDAÇÃO OSWALDO CRUZ / EDITORA

ISBN 85-85676-85-X

Portada y projecto grafico: Carlota Rios/Leticia Magalhães

Editoración: Carlota Rios e Ramon Carlos de Moraes

Cuidado de texto y cibercoordinación editorial: Fanny Días

Traducción de español: Julio de Freitas Taylor

Catalogação-na-fonte

Centro de Informação Científica e Tecnológica

Biblioteca Lincoln de Freitas Filho

B849s Briceño-León, Roberto (coord.)

Salud y equidad: una mirada desde las ciencias sociales. / Coordenado por Roberto Briceño- León, Maria Cecília de Souza Minayo e Carlos E. A. Coimbra Jr. - Rio de Janeiro: Editora FIOCRUZ, 2000.

$384 \mathrm{p}$.

1.Saúde pública. 2.Condições sociais. 3.Qualidade de vida. I.Minayo, Maria Cecília de Souza (coord.). II.Coimbra Júnior, Carlos E. A. (coord.).

CDD - 20.ed. - 362.1 


\section{ÍNDICE}

I

la Salud en Cuestión

BIENESTAR, SALUD PÚBLICA Y CAMBIO SOCIAL

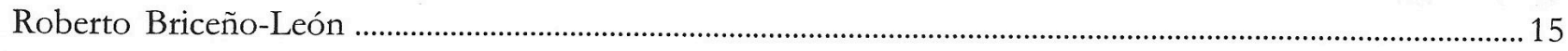

LA SALUD EN FORMA Y LAS FORMAS DE LA SALUD: SUPERANDO PARADIGMAS Y RACIONALIDADES

Madel T. Luz 25

MEDicina ALTERNATIVA (¿MEDICINA COMPLEMENTARIA?) COMO FENÓMENO SOCIAL. HACIA LA CONSTRUCCIÓN

DE UN NUEVO MODELO DE SALUD

Marianela Castés Boscán .41

II

SAlud, DEsigualdad Y CALIDAD DE VIDA

Condiciones De VIDA, DESIGUALDAD Y SALUD A PARTiR DEL CASO bRASILEÑo

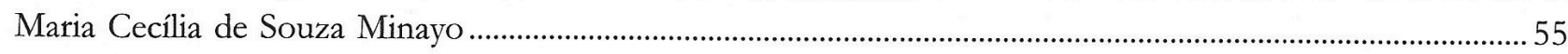

GLobaLización, POLÍTICAS NEOLIBERALES Y SALUd

Asa Cristina Laurell .73

PARTiCiPACIÓN SOCIAL, DERECHOS HUMANOS Y SALUD: PROCURANDO COMPRENDER LOS CAMINOS DE LAS CLASES POPULARES

Víctor Vincent Valla .85

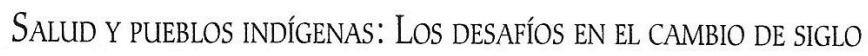

Esther Jean Langdon 107

III

ESPACIO, AMBIENTE Y SALUD

Desigualdades espaciales del bienestar y la salud en América Latina. Problemas Éticos y metodológicos

Luisa Iñiguez Rojas

Calidad de Vida, SERVicio público y desarrollo URbano en Venezuela

Esther Elena Marcano 137 
IV

VIOLENCIA Y DROGAS EN LA SALUD PÚBLICA

LA VIOLENCIA DESDE LA PERSPECTIVA DE LA SALUD PÚBLICA

Rodrigo Guerrero

LAS VIOLENCIAS, LA SALUD PÚBLICA Y LA CIUDADANÍA

Magally Huggins C.

EL CONSUMO DE DROGAS COMO PROBLEMA DE SALUD PÚBLICA: DESAFÍOS PARA

LA INVESTIGACIÓN Y LA FORMULACIÓN DE POLÍTICAS

Julio Bejarano.

175

V

LA PERSPECTIVA SUBJETIVA DE LA SALUD

EXPERIENCIAS DE AFLICCIÓN Y TRATAMIENTO EN EL ÁMBITO RELIGIOSO

Miriam Cristina Rabelo y Paulo César Alves

REPRESENTACIONES SOCIALES ACERCA DE LA SALUD Y LA ENFERMEDAD: UNA PUESTA AL DÍA

Ana Lía Kornblit

REPRESENTACIONES SOCLALES DE MADRES, MÉDICOS PEDIATRAS Y ENFERMERAS SOBRE EL

NIÑO PREESCOLAR Y SU SALUD: UN ESTUDIO DE CASO

Milagros C. García Cardona

VI

LOS SERVICIOS DE SALUD

DESCENTRALIZACIÓN Y PARTICIPACIÓN EN SALUD: NUEVOS APORTES PARA LA DISCUSIÓN

Mario Bronfman y Cristina Herrera Carnevale...

TECNOLOGíAS SANITARIAS EN EL CONTEXTO SOCIAL: UNA REFLEXIÓN BIoÉTICA

Fernando Lolas Stepke

VII

NuEVOS Y ANTIGUOS RIESGOS

ESTRATEGIAS DE INVESTIGACIÓN RELACIONADAS CON LA VIOLENCIA Y LA PRECARIZACIÓN DEL TRABAJO

Carlos Minayo-Gómez y Sonia Maria da Fonseca Thedim-Costa

CONSECUENCIAS ECONÓMICAS DE LA LEISHMANIASIS CUTÁNEA EN PACIENTES TRATADOS

en Trujllo, Área ANDina de Venezuela

Benito Díaz, Axel Kroeger y María Luisa Vázquez 
Situación MUNDIAL DE LA EPIDEMIA DEL SIDA

Angela Torres.

Psicosociología de las Infecciones de Transmisión Sexual y el SIDA

Leoncio Barrios

EPIDEMIOLOGÍA DE LA SALUD MENTAL

Carlos L.M. Cornaglia

LA SALUD Y EL BIENESTAR DE LOS ADULTOS MAYORES

Aquiles R. Salas J., Julieta González de Gago y Walter Mosca..

\section{VIII}

SALUD Y GÉNERO

MASCULINIDAD Y GÉNERO

Ellen Hardy y Ana Luisa Jiménez 349

ELEMENTOS PARA LA CONSTRUCCIÓN DE LA MASCULINIDAD: SEXUALIDAD, PATERNIDAD, COMPORTAMIENTO Y SALUD REPRODUCTIVA

Morelba Jiménez García

IX

LAS PUBLICACIONES EN CIENCIAS SOCIALES Y SALUD Y LA COMUNIDAD CIENTÍFICA

Desafíos del trabajo editorial científico en Ciencias Sociales y Salud Colectiva en América Latina

Carlos E. A. Coimbra Jr. 


\section{PRólogo}

Cuando uno observa los cambios en algunos indicadores dados en las condiciones de salud de la población mundial se puede evidenciar una importante mejoría. Para 1950 la esperanza de vida en el ámbito mundial era de 46 años y la tasa de mortalidad infantil era de 156 por cada 1000 nacimientos vivos; al finalizar el siglo la mortalidad infantil había disminuido a 62 por 1000 y la esperanza de vida había aumentado hasta los 66 años (WHO,1998). En países como Chile, que para 1910 tenía una esperanza de vida de 29 años en los hombres y 33 en las mujeres, cerró el siglo con una esperanza de vida de 72 años para los hombres y 78 para las mujeres; es decir, con una ganancia de 43 años para los hombres y de 45 años en las mujeres. En ese mismo período la ganancia de años para Suecia fue de 20 años para los hombres y de 22 para las mujeres y en USA de 24 años para los hombres y de 27 para las mujeres (WHO,1999). En consecuencia, al final del siglo, la diferencia en las esperanza de vida entre los hombres de Chile con los de USA o Suecia se redujo de 20 y 28 años a 1 y 3 años respectivamente. Es decir, no solo hubo un aumento en la esperanza de vida en cada país, sino una disminución de las diferencias entre los distintos países.

Sin embargo en otros indicadores los cambios no han sido totalmente positivos. En 1997 murieron diez millones de niños menores de cinco años, el 97\% de ellos en los países pobres, por una combinación de diarreas, neumonía y desnutrición. La mayoría d estas muertes se hubieran podido evitar, eran prevenibles. En el mundo más de mil millones de personas no tienen acceso a agua potable y cerca de tres millones no acceden a una adecuada disposición de excretas, estas cifras quieren decir que el $25 \%$ de los habitantes de los países llamados en desarrollo no tiene acceso al agua potable y el $65 \%$ no tenía provisión de excretas. En este mundo de gran tecnología cerca de 600 millones de personas no tienen acceso a los servicios de salud básicos. $Y$ a pesar que en los 40 últimos años del siglo la producción de alimentos se incrementó muy por encima del crecimiento de la población, desde los años ochenta se ha doblado la cantidad de personas desnutridas en el Africa al sur del Sahara, cada año nacen cerca de 25 millones de niños con bajo peso, y la mitad de los $31 \mathrm{mil}$ niños que mueren cada día son por causas relacionadas con el hambre. (WHO,1998,1999, Kim, Millen, Irwin, Gersman, 1999).

La salud de la población del mundo ha mejorado, pero seguimos teniendo graves problemas. Algunos de esos problemas hasta se pudiera afirmar que se han agravado, y ello a pesar del impresionante avance tecnológico que ha vivido la humanidad. ¿Cómo entonces pudiéramos evaluar lo que ha acontecido en salud desde un lugar como América Latina? Es posible tomar dos perspectivas: por un lado, podemos comparar la situación actual con la que se tenía en estas sociedades en los años cincuenta y a partir de allí ver los cambios ocurridos. Por otro, se puede comparar la situación de salud de la región con la existente en el resto del mundo, en particular con la máxima lograda en términos de salud y bienestar. Los resultados serían completamente distintos. 
Si se ve con el primer lente hay una mejoría global, si se observa con el segundo lo que se encuentra es una gran desigualdad. Desigualdad en las condiciones de salud, pues los pobres sufren más, viven con más incapacidades y se mueren antes. Desigualdad en el acceso a los servicios de atención médica: ya que la mayoría no pueden disfrutarlos o deben pagar por los servicios médicos un porcentaje mucho mayor de sus ingresos. Desigualdad en la investigación médica: el 90\% de los recursos que en el mundo se dedican a la investigación en salud están dirigidos a los problemas que afectan al 10\% de la población mundial.

Ante esa realidad el tema de la equidad en salud se vuelve extremadamente relevante. Relevante por la creciente inequidad que existe en un mundo dominado por la ideología de la democracia y la igualdad de oportunidades. Inequidad que se observa en el mundo de la tecnología, aspecto clave de la sociedad contemporánea y que se deriva de los avances tecnológicos que, de tantos y tan rápidos, están dejando fuera a grandes contingentes de la población mundial; sufrimos de mucha y no de poca tecnología. Pero este nos es una asunto tecnológico, sino propio de las diferencias sociales que existen y de las maneras desiguales de entender los derechos que tenemos. $Y$ es también y sin lugar un asunto que se relaciona con los cambios que se producen en la economía mundial, y que en América Latina combinan los problemas que crea al globalización con los tradicionales atrasos y deficiencias estructurales: en la región de cada 100 empleos que se crearon entre 1988 y 1998, 69 fueron en el sector informal de la economía (Cepal,2000). No se están creando empleos, ni siquiera en aquellos países economía donde hay un importante crecimiento. Crece la economía, pero no crece el empleo. Por eso pareciera que el crecimiento económico, pareciera ser necesario, pero no es suficiente. Por eso el asunto de la equidad en salud, al final, termina siendo también un asunto político; político pues se trata de cómo se moldea una sociedad y cómo las distintas fuerzas económicas, culturales y sociales se combinan para producir el futuro.

$Y$ porque la salud es un asunto social, económico y político, existe este libro y la organización que ha permitido su creación: el Foro Internacional de Ciencias Sociales y Salud. Este libro es el fruto de las deliberaciones del $V$ Congreso Latinoamericano de Ciencias Sociales y Medicina que tuvo lugar en la Isla Margarita, Venezuela, en Junio de 1999. Como su nombre lo indica era la quinta vez que se reunía este tipo de evento en la región: el primero fue en Chile, el segundo en Argentina, el tercero en Brasil, el cuarto en México. Creciendo en calidad, más no en tamaño (pues es un formato de evento que tiene un número máximo de 250 participante) estos congresos se han constituido en un hito, un punto de encuentro obligado de quienes trabajan la salud desde la perspectiva científica y pluralista de de las ciencias sociales. Congresos similares se han estado realizando en el mismo período de tiempo en Africa, Asia y el Pacífico, Asia Central y el Este del Mediterráneo y en los países del Mundo Arabe, todos ellos auspiciados por la misma organización, el International Forum for Social Sciences and Health, (IFSSH).

Para la realización del V Congreso en Venezuela fue de gran importancia el apoyo que se recibió de las instituciones internacionales que apoyan el IFSSH: la Carnegie Corporation of New York y la Fundación Ford. También del 
apoyo que en Venezuela brindó el Consejo de Desarrollo Científico y Humanístico $(\mathrm{CDCH})$ de la Universidad Central de Venezuela y el Consejo Nacional de Investigaciones Científicas y Tecnológicas (CONICIT).

Este libro recoge un grupo importante de los trabajos que se discutieron en el $\mathrm{V}$ Congreso, algunos como ponencias centrales, otros, como contribuciones de los participantes. Todos los trabajos que se recibieron fueron sometidos a la revisión de un grupo de arbitraje internacional, el cual seleccionó aquellos que podían tener una mayor relevancia para los lectores internacionales de un libro de esta naturaleza. Por méritos propios muchos otros textos merecían ser publicados, pero la obligada mesura que debe emplearse al producir un libro obligó a dejarlos fuera.

Desde el mismo evento la Fundación Fiocruz ofreció la posibilidad de publicar el libro del Congreso en Brasil. Se trataba de continuar con una tradición que había encontrado su expresión más reciente en los libros de la reunión fundacional del IFSSH en América Latina: Las Ciencias Sociales y la Salud en América Latina: un balance (Caracas, Fundación Polar) y el libro del IV Congreso de Ciencias Sociales y Medicina realizado en México en 1998 y que bajo el título Salud, Cambio Social y Politica publicaron M. Bronffman y R. Castro (México, Edamex). Los textos originales de este libro se encontraban en Portugués y Español, las dos lenguas de trabajo del Congreso, pero, la Editora Fiocruz consideró que en lugar de una edición bilingüe era mejor publicar el libro en castellano. Fue así que con el apoyo financiero recibido de la Fundación Ford y del CONICIT se tradujeron los textos y se cuidó la edición. Entre mensajes de correo y llamadas telefónicas dos equipos de trabajo, uno en Caracas y otro en Río de Janeiro, lograron producir el texto que ahora el lector tiene en sus manos.

Este libro es el producto de multiples investigaciones llevadas a cabo por sus autores, es la memoria de un evento científico, pero pretende ser sobre todo una contribución para un sueño, el sueño de construir una sociedad más equitativa a partir de comprender mejor los determinantes sociales de la salud.

Caracas-Río de Janeiro, Julio 2000

Roberto Briceño-León Maria Cecilia de Soura Minayo y Carlos E. A. Coimbra Jr.

\section{REFERENCIAS}

Bronffman M. y R. Castro (1999) Salud, Cambio Social y Política, México, Edamex.

Briceño-León, R. (1999) Las Ciencias Sociales y la Salud en América Latina: un balance Caracas, Fundación Polar..

CEPAL (2000) La Brecha de la Equidad: una segunda evaluación, Santiago de Chile, Cepal.

Kim, JY, JV Millen, A Irwin and J Gershman, (2000) Dying for Growth: Global Inequality and the Health of the Poor Monroe, Maine, Commom Courage Press.

WHO (1998) The World Health Report, Geneva, WHO.

WHO (1999) The World Health Report, Geneva, WHO. 


\section{I \\ LA SALUD EN CUESTIÓN}




\section{BIENESTAR, SALUD PÚBLICA YCAMBIO SOCIAL}

Roberto Briceño-León *

\section{INTRODUCCIÓN}

La salud es una síntesis; es la síntesis de una multiplicidad de procesos, de lo que acontece con la biología del cuerpo, con el ambiente que nos rodea, con las relaciones sociales, con la política y la economía internacional. La salud es un índice del bienestar, quizás el más importante indicador del bienestar alcanzado por una población. Una muestra palpable del nivel de desarrollo social alcanzado por una sociedad, y una condición esencial para la continuidad de ese mismo desarrollo.

La salud es también la base sobre la cual se construye la felicidad de los individuos, su realización como personas y su contribución al máximo de satisfacción colectiva. Pero, ¿cómo definiríamos la salud en este contexto? En un importante libro publicado en 1941, Medicine and Human Welfare, Sigerist propuso la siguiente reflexión:

Al igual que lo hicieron los antiguos, $y$ al igual que John Lock, pensamos en la salud como una condición física y mental: mens sana in corpore sano, continúa siendo nuestro lema. Pero podemos considerar también la salud del individuo en un sentido social. Un individuo sano es aquel que presenta un buen equilibrio entre su cuerpo y su mente y se haya bien ajustado a su entorno físico y social, controla plenamente sus facultades físicas y mentales, puede adaptarse a los cambios ambientales y contribuye al bienestar de la sociedad, según su capacidad. La salud no es, en consecuencia, la simple ausencia de la enfermedad, es algo positivo, una actitud alegre hacia la vida y una aceptación optimista de las responsabilidades que la vida impone al individuo.

Estas hermosas ideas fueron retomadas cuando se funda la Organización Mundial de la Salud
(OMS), y allí, en 1948, se parafrasea este texto y se establece la bien conocida definición, que rige más los documentos que las realidades de nuestros sistemas de salud. Se dice que salud es "un estado de bienestar físico, mental y social completo y no sólo ausencia de afecciones o enfermedades". Como se observa, la idea está previamente citada y editada siete años antes, y es retomada plenamente por la OMS.

Esta definición se ha escuchado hasta el aburrimiento, y la hemos aceptado por la fuerza sencilla de su razonamiento holista. Quisiera, sin embargo, traer a la discusión algunos aspectos de esta definición normativa, para poder adelantarnos a las reflexiones éticas que este concepto nos impone.

\section{EL CONCEPTO DE SALUD / \\ LA IDEA DEL COMPLETO BIENESTAR}

Una pregunta surge inmediatamente: ¿qué es eso de "completo bienestar"? En primer lugar, ¿qué queremos decir con "completo"? Esta idea es normativamente interesante, pues sería una búsqueda valiosa, una meta hacia la cual tender, pero una realidad imposible de alcanzar, pues nunca hay una salud completa, ni física ni mentalmente. La idea de completud es siempre ingenua y forma parte de una idea imaginaria de la vida y de la sociedad sin faltas; pero la falta es, y así nos los ha enseñado el psicoanálisis, siempre constitutiva del ser humano y de la sociedad (Lacan, 1976). La falta es la base del movimiento hacia adelante, hacia la superación de lo actual y real que tienen las personas y las sociedades. Por otra parte, la búsqueda de la completud es importante como una tendencia, una meta hacia la cual moverse sabiendo que, como en la definición

\footnotetext{
Sociólogo, doctor en ciencias sociales de la Universidad Central de Venezuela, profesor titular de esta misma institución y director del Laboratorio de Ciencias Sociales (LACso), Caracas. E-mail: lacso@reacciun.ve.
} 
matemática, siempre será inalcanzable, pues siempre la falta será mayor de lo alcanzado.

Adicionalmente, la idea de "completo bienestar" introduce la noción de normalidad en la salud, lo cual es siempre difícil, para no decir imposible, de establecer. Sabemos que las personas pueden estar enfermas sin saberlo, que muchos estados que hemos considerado sanos han sido apenas formas latentes de enfermedades, desconocidas en ese momento por limitaciones de nuestro saber. $Y$ si esto es difícil en el nivel estrictamente biológico, hoy nos resulta casi imposible establecerlo desde el punto de vista mental. La normalidad no existe. Hay patrones socialmente aceptados o socialmente deseables, pero no es posible construir a partir de allí una idea de normalidad que se imponga, excluyendo o considerando enfermos a quienes se salgan del patrón o modelo. Asumir esta postura puede conducir a construir una sociedad con rasgos no democráticos ni pluralistas.

Por otro lado está la idea del bienestar. El bienestar debe ser interpretado históricamente, no hay otro modo de hacerlo, pues éste depende de los recursos y saberes de los cuales disponga cada sociedad. A comienzos del siglo XX Estados Unidos, que era la sociedad más rica del planeta, tenía una esperanza de vida de 47 años; hoy en día esta cifra nos resulta inaceptable y es motivo de escándalo por su ocurrencia en el más pobre de los países africanos.

Igual sucede con los casos de algunas enfermedades, tales como las deformaciones producto del polio o la lepra, que hasta hace poco eran consideradas y aceptadas como fatalidades, es decir como normales en la tragedia, pero que hoy nos resultan inaceptables por el nivel de conocimientos y de herramientas - como vacunas o drogas- de los cuales disponemos en la actualidad.

La definición de lo que sería bienestar depende, entonces, desde el punto de vista objetivo, de las condiciones históricas de cada sociedad; y desde el punto de vista subjetivo, de la manera como cada sociedad se imagina su propio bienestar en tanto meta a lograr. Esto se hace muy complejo en el mundo contemporáneo globalizado, pues, en la actualidad, en la sociedad mundial se vuelven comunes los saberes y la oferta de tecnología, pero se hacen cada vez más diferenciadas las condiciones reales de vida y de riqueza. Es decir, hoy sabemos y disponemos de cada vez más productos tecnológicos para la atención médica, que impactan la conciencia de la sociedad e incrementa su nivel de expectativas, pero todo esto ocurre en un contexto histórico en el cual no se han modificado las condiciones sociales y económicas básicas de la vida cotidiana de millones de personas y donde la brecha tiende hacerse más grande entre ricos y pobres. Disponemos en el mundo de costosísimos y sofisticados equipos que nos pueden permitir medir o intentar reparar los daños que causa el hambre o la ausencia de agua potable...

Esta paradoja determina las dificultades de la concepción del bienestar. Por un lado habría que definirlo en el contexto de los saberes, los productos y la tecnología disponible en el ámbito mundial: es lo que hemos alcanzado como patrimonio de la humanidad y no podemos ignorarlos. Pero, por otra parte, hay que hacerlo en el contexto de los recursos de nuestras propias sociedades, de lo que es posible en cada sociedad, que tiene que evaluar y saber, como lo saben bien las familias desde siempre, que "cada quien se arropa hasta donde le llega la cobija”.

Este modelo debe, además, repensarse a nivel mundial, pues si aceptamos, por ejemplo, que un nivel de bienestar deseable sería el de Estados Unidos de América, esto sería imposible de alcanzar para el resto de la humanidad: Estados Unidos dispone del 5\% de la población mundial, pero utiliza el $22 \%$ de la energía mundial y percibe el $25 \%$ del producto mundial bruto. Es decir, que en las condiciones actuales, para tener ese modo y nivel de vida, y en consecuencia, ese parámetro para la salud, el resto de la población mundial requeriría disponer de $400 \%$ de la energía mundial y de $475 \%$ del producto mundial bruto. Es decir, entre 4 y 5 veces más de lo que en la actualidad se produce y se consume, lo cual es a todas luces imposible, o de ser posible, acarrearía consecuencias desastrosas en el ambiente y la salud (Hajek, 1994).

El bienestar es entonces el modo como cada sociedad establece sus ideales, y lo hace en la confrontación entre las aspiraciones que pretende alcanzar y los medios de los cuales dispone para hacerlo.

Lo que sí pareciera muy importante de la definición de la OMS, y que en negativo señala 
claramente el propósito, es que la salud no es la ausencia de la enfermedad. La exclusiva ausencia de la enfermedad no significa que se tenga salud. Tenemos ejemplos muy claros, con los cuales quisiera ilustrar lo que pudiéramos entender como que la ausencia de enfermedad no es la salud. Hoy disponemos de las sales de rehidratación oral con las cuales es posible combatir la diarrea infantil, sales que han disminuido radicalmente la mortalidad infantil y la sigue disminuyendo; pero no hemos alterado, casi nada, las condiciones del agua, el tratamiento de alimentos, la disposición de excretas de las viviendas en las que viven muchas de esas familias cuyos niños antes se morían, y ahora no.

Pero igual podemos pensarlo con lo que es el aire de las ciudades. En 1952 hubo en Londres un aumento significativo de la contaminación en el aire, que hizo que para ese año se produjeran más de 1000 muertes en exceso, producto de esta situación. Entre 1975 y 1988 aumentaron en Santiago de Chile esos niveles de contaminación a un nivel similar o superior al que se dio en Londres en 1952, pero no se registró un aumento en "exceso" de muertes como ocurrió en Inglaterra. Se registraron más muertes en el primer momento, pero posteriormente no. ¿Qué sucedió? La acción médica logró evitar las muertes producto de neumonías y bronquitis obstructivas que se producían por el nivel de contaminación en el aire. Se estableció un programa de detección precoz de emergencias respiratorias; se logró, con un programa con kinesiólogos, entrenar a las madres en cómo tratar a los niños en un momento de una obstrucción; se hizo un gran programa de distribución de broncodilatadores, y como resultado no se tienen niños muertos (Sandoval, 1992). ¿Pero podemos pensar que las condiciones de salud en Santiago de Chile, en Lima - en Caracas han mejorado por utilizar broncodilatadores o sales de rehidratación oral?

Igualmente pudiéramos observar esta situación con muchas de las enfermedades transmisibles. Tomemos el caso de la enfermedad de Chagas, que, como sabemos, está relacionada con las viviendas de los pobres que usan techo de palma o paja y paredes sin frisar donde se aloja el insecto triatomino que transmite la enfermedad. Por muchos años se ha realizado en el continente fumigaciones para matar el insecto, desde hace varios años inclusive se realiza en el cono sur de América un programa importante que está prácticamente erradicando la transmisión por el Triatoma infestan, el vector más importante de la enfermedad en esas zonas, y por vía del control de las transfusiones en los bancos de sangre se está interrumpiendo la otra forma importante de transmisión de la enfermedad. Esto es bueno, pues se puede detener la transmisión de la enfermedad, pero las familias continúan viviendo en las mismas casas pobres (Briceño-León, 1990, 1993). ¿Han mejorado las condiciones de salud o simplemente hemos evitado la enfermedad?

Con estos tres ejemplos podemos observar cómo la ausencia de enfermedad no es salud. Sin embargo, el modelo que se impone, el modelo dominante, es el de la ausencia de la enfermedad.

\section{LOS MODELOS DE SALUD Y LOS}

\section{CAMBIOS SOCIALES}

Debemos interpretar la salud como un momento y una realidad social. Esto incluye condiciones de vida dignas y sanas, de acuerdo a los conocimientos que hoy disponemos y a las condiciones históricas que vivimos. La carencia de salud muestra los límites y fracasos de la sociedad, la manera como establecemos nuestros ideales y cómo los llevamos a la práctica.

Este modelo de ausencia de la enfermedad es el modelo curativo que se difundió en el mundo durante el siglo XX, y que se impuso a partir de los grandes desarrollos y éxitos de la tecnología y de las drogas médicas. Las escuelas de salud pública se crearon a comienzos de siglo, y la orientación de los programas de estudio y la descripción de los propósitos de esas primeras escuelas de salud pública (la primera fue en 1915, luego sigue 1917, 1923) era, en todas, claramente sanitaria y preventiva. Cuando se crean las primeras oficinas de salud en Venezuela, tenían también funciones preventivas y sanitarias, y fue después cuando apareció lo que se llamó el modelo integrista. Pero, a escala mundial, en un proceso que repercute en Venezuela y América Latina, empieza posteriormente a dominar la atención curativa y 
privada, desplazando la medicina de prevención colectiva y estatal. Los cambios en la visión de la salud se corresponden con los cambios en la sociedad.

En Venezuela ese proceso se da en tres fases, tres momentos que evidentemente se relacionan con la renta y los ingresos petroleros del país (Baptista, 1997; Briceño-León, 1990b). La primera, que pudiéramos llamar fase preventiva de altos ingresos petroleros, permanece hasta más o menos 1960. Quizás el ejemplo más evidente y más claro de todo ese proceso fue el programa de erradicación de la malaria llevado a cabo entre 1945 y 1948 (Gabaldón, 1965, 1975a, 1975b). Ciertamente hubo muchísimos factores que intervinieron allí. Ciertamente había buenas relaciones, se conocía de la existencia del DDT, Venezuela había sido un aliado importante de Estados Unidos y por lo tanto se le iba a permitir el uso para fines civiles inmediatamente; todos esos factores estaban, pero, claramente, existían otros dos factores distintos: a) una visión sanitaria y preventiva en el personal que estaba a cargo de esos programas, y que llena de honores a esa institución, y b) unos importantes ingresos petroleros que permitían comprar ese producto y pagar al personal (Briceño-León, 1996).

Una segunda fase, que se desarrolla después de 1960 y cubre hasta mediados de 1980, pudiéramos llamarla fase curativa de altos ingresos. Es el momento en el cual se mueve ese modelo preventivo, sanitarista, hacia un modelo hospitalario y curativo, que se ve igualmente avalado, apoyado, por los altísimos ingresos petroleros que disponía el país y que permitía comprar tecnología, productos, insumos médicos, personal, hospitales; comprar lo que se quisiera. En ese momento se hizo muy dominante para el país la idea de que así como se compraban fábricas, así como se compraban videocaseteras o casas (porque en Venezuela se importaron casas durante todo ese período), también se podía comprar la salud en el esquema hospitalario (Briceño-León, 1992).

Finalmente hay una tercera fase, que ha sido la curativa de reducidos ingresos petroleros, en la cual está el país desde los años ochenta. A partir de 1980 los ingresos petroleros per cápita comienzan a disminuir, y en igual o mayor proporción disminuye el gasto per cápita en salud del Estado, pero se mantiene el esquema curativo que había predominado durante la fase de altos ingresos. Esto se refleja en datos oficiales del Ministerio de Sanidad, que señalan que el $71 \%$ de los gastos del Ministerio se van en atención hospitalaria; un $12,6 \%$ en atención ambulatoria; un $5,6 \%$ en atención del ambiente; $10,7 \%$ en epidemiología y $0,3 \%$ en promoción de la salud.

Lo particular de este modelo curativo, que se funda en la concepción de salud como tratamiento del daño y ausencia de la enfermedad, es que tiene un gran apoyo social de casi todos los actores del proceso. Tiene apoyo de los funcionarios, quienes quizás por la inercia propia del trabajo aprendido y de lo que se considera que es su deber en el sector salud, insisten en demandar grandes recursos para este tipo de trabajo en desmedro de otras áreas, como promoción de la salud. Tiene por supuesto el apoyo de los fabricantes y distribuidores de productos y tecnología médica. Pero lo más sorprendente e importante es que también tiene un altísimo apoyo de la población, inclusive la población más pobre, la cual exige que el Estado mantenga e impulse el modelo hospitalario. Lo hace porque ésta es la representación social dominante que existe de la salud y en ese contexto el modelo curativo proporcionado por el Estado es la única alternativa que ve para conservar o reponer la salud. Y esto es así porque esa representación es la única manera como se ha presentado la salud en la posible acción oficial —los políticos en busca de votos ofrecen hospitales, y siempre, al referirse a la atención médica y hospitalaria, la llaman "sector salud", en lugar de como debiera llamárselo: "sector hospitalario o médico".

Pero este modelo hace varios años entró en crisis en el mundo pues no logra satisfacer a la población ni reduce la inequidad. Este modelo curativo, medicalizado, no reduce la inequidad ni en los países pobres ni en los países ricos. Si no ha logrado reducir la inequidad en los países que tienen un excelente sistema de este tipo, como pudiera ser Inglaterra o Canadá, bien pocas esperanzas tenemos de que pueda lograrse en América Latina. Si uno observa la tasa estándar de mortalidad entre los grupos de menores ingresos y los grupos de mayores ingresos entre 1951 y 1981 en Inglaterra, verá que la diferencia de la tasa estándar de mortalidad entre los grupos más pobres y los grupos 
de mayores ingresos aumenta en vez de disminuir: en 1951 la diferencia fue 19 puntos; para 1961 subió a 35 puntos; en 1971 llegó a los 41 puntos y para 1981, treinta años más tarde, se había más que duplicado y subió a los 47 puntos (Terris, 1992).

Si tomamos el caso de Canadá (que por ejemplo en la ciudad de Toronto se da el lujo de cerrar hospitales, pues los hospitales y camas no son usadas y por lo tanto pueden eliminarse), la diferencia entre la esperanza de vida del grupo más pobre y el grupo más rico es de 4,5 años. Los ricos viven 4,5 años más que los pobres. Según el cálculo de los años de vida saludables, los pobres del Canadá viven 55 años de vida saludable, mientras los ricos viven 66 años de vida saludable. Once años de diferencia y de inequidad.

Ese modelo, sin embargo, es igualmente un modelo costoso y tiene notables diferencias. En Venezuela pudiéramos ver tres indicadores, que vamos a citar directamente del Ministerio de Sanidad, para no tomar otras fuentes sino las oficiales. Este modelo implica que tenemos una muy desigual distribución de las camas, una alta ineficiencia y una relación en la proporción profesional que no es adecuada. Tres indicadores simplemente: en Venezuela se tienen 1,55 médicos por 1000 habitantes y 0,7 enfermeras por 1000 habitantes: La relación que se establece a nivel mundial es un número similar o superior de enfermeras; pero la propia organización del sistema y los altos ingresos derivados del petróleo que ha dispuesto la sociedad, han permitido tener una gran cantidad de médicos, no así una suficiente calidad de enfermeras que los apoyen.

En algunos estados de Venezuela, como Barinas y Portuguesa, hay una cama por cada 1.000 habitantes; en otros, como el estado Zulia, cuatro camas por 1.000 habitantes; mientras en el Distrito Federal hay seis o más camas. Hay diferencias en los servicios, hay concentración y hay ineficiencias. Los datos del Ministerio de Sanidad apuntan que hay aproximadamente cinco empleados por cama de hospital. Los índices en el ámbito mundial indican que debería haber entre dos y cuatro empleados por cama de hospital. Este ha sido un modelo costoso, pero en la tercera fase que hemos establecido, cuando descienden los ingresos petroleros y se otorga menos recursos al sector, se observan claramente los problemas antes ocultos por el alto nivel de recursos y de divisas baratas de las cuales se disponía. Para 1983 Venezuela gastaba 112 dólares per cápita en este modelo; para 1990 se gastaban 50 dólares per cápita. Este modelo funcionó con altos costos por varias décadas, pero al disminuir los ingresos nacionales e incrementarse fuertemente los costos de la tecnología médica, se ha hecho cada vez más difícil de mantener.

Según datos de la Cepal, los precios del sector salud han estado, en toda América Latina, por encima del índice de precios al consumidor. Es decir, que el incremento de los precios en todo lo que se puede llamar sector salud, que es atención en el área médica, es muy superior a lo que sería en el resto de la sociedad, haciendo más insostenible el modelo curativo tecnológico (CEPAL, 1995, 1997).

\section{LOS CUATRO ENEMIGOS DE LA SALUD}

Hay cuatro grandes áreas, cuatros grandes enemigos de la salud, a los cuales debe dar respuesta un nuevo modelo de salud pública. Tomo como referencia la sociedad venezolana, pero son extensibles al resto de América Latina. Estos cuatro grandes enemigos son: la pobreza, el deterioro ambiental, los estilos de vida y la violencia.

Según datos de la Cepal, para Venezuela, en 1981 el 40\% más pobre tenía el 20,2\% del ingreso nacional, y el 10\% más rico el 21,8\%. Para 1992 la situación había cambiado: el $40 \%$ más pobre había disminuido su participación al 16,4\% y el $10 \%$ más rico la había aumentado al 28,1\% . En otros países como Brasil o Chile la desigualdad era mayor, aunque no se había modificado como en Venezuela (Cepal, 1995).

La pobreza repercute en la salud, a través de las condiciones generales de vida, de la nutrición, la desnutrición. En Venezuela, según los datos del Sistema Venezolano de Análisis Nutricional, tenemos insuficiencias de un $25 \%$ en peso/edad (menores de 10 años), del $30 \%$ en talla/edad y del 18\% de insuficiencia de peso general. La pobreza, además, influye y determina el aumento de las enfermedades transmisibles. Por ejemplo, el dengue y el cólera, dos enfermedades con gran impacto en América Latina, 
son enfermedades ligadas directamente a las condiciones de pobreza de la mitad de la población, pero también lo son el SIDA y la tuberculosis (Farmer, 1999).

La situación global ambiental también crea altos problemas para la salud y se asocia además a las condiciones de pobreza. Si se considera la relación entre pobreza y deterioro del medio ambiente, no es clara la direccionalidad causal, pero sí sus consecuencias. En algunos casos se puede observar, de manera muy evidente, cómo los pobres sufren el deterioro ambiental, y lo sufren en su salud, pero hay también otros casos en los cuales los pobres dañan el ambiente, en su esfuerzo por sobrevivir, y crean problemas adicionales para sí mismos y para la salud de toda la sociedad.

Si uno observa lo que pudiéramos llamar los daños ambientales generales, se puede prever que en el mundo va a aumentar la mortalidad por insolación y las enfermedades pulmonares debido a la acumulación de sustancias contaminantes en el aire; se prevé un aumento del cáncer en la piel, de melanomas y de cataratas por los rayos ultravioletas ligados al adelgazamiento de la capa de ozono; se prevé un debilitamiento de la respuesta inmune por la radiación de ultravioleta; se prevén cambios en los hábitos de los vectores de muchas enfermedades derivados de los cambios de las lluvias y de las temperaturas.

En el deterioro del ambiente hay un problema importante y global para la salud. Pero su impacto también está dividido socialmente: no es igual el nivel de contaminación que se produce entre países o entre grupos sociales. La India tiene el 16\% de la población mundial y produce el 3\% de bióxido de carbono; Estados Unidos tiene el 5\% de la población mundial y produce el $25 \%$ de bióxido de carbono. Las poblaciones ricas producen entre 7 y $12 \%$ más desechos y basura que las poblaciones pobres. Es decir, hay efectos que están claramente ligados al ambiente que tienen que ver con los cambios generales que se están dando y con los modelos de desarrollo y la globalización (Heggenhougen, 1999).

Hay cambios también en los estilos de vida. Hay claramente dos estilos de vida que se confrontan. Cuando uno habla de "estilos de vida", muy en la orientación que tiene la medicina norteamericana, está hablando fundamentalmente de estilos de vida individualizados y que mayormente tienen que ver con los individuos, con las personas, y no con su entorno. Pero, incluso en estos casos, son claramente referidos a las diferencias que pueden existir entre el estilo de vida de la abundancia y los estilos de vida de la escasez.

En los estilos de vida de la abundancia son muy claras las diferencias. En una encuesta llevada a cabo en 1960-1965 en Estados Unidos, se encontró que aproximadamente el 16\% de los negros pobres tenían una dieta sana, y solamente el 5\% de los ricos blancos la tenían. Pero también hay diferencias en la pobreza: los años de vida perdidos antes de los 65 años por enfermedades crónicas entre los hombres afroamericanos son muy superiores a las de los hombres blancos: $55 \%$ más por enfermedades del corazón, $100 \%$ por cáncer de pulmón, 180\% por infarto (Ommen, 1992). Esto, sin embargo, ha ido cambiando, y hoy en día tiende cada vez a igualarse, por los cambios que se han dado en la dieta, con grandes aportes a la salud.

Igualmente, se relaciona con otros tipos de hábitos y con la organización general de la sociedad. Un elemento que pudiera parecer no tan importante para la salud, como los impuestos, tiene un impacto muy importante en las condiciones de vida de la población. Si tomamos, por ejemplo, la cirrosis hepática, y hacemos una comparación entre Estados Unidos e Inglaterra, encontraremos notables diferencias. Notables diferencias que están fundadas, básicamente, en la forma de tributación que Inglaterra ha puesto por años al alcohol y al consumo de alcohol y a las limitaciones de horario que han establecido para su venta. En 1914, Estados Unidos tenía una tasa del 12\% para cirrosis hepática; en Inglaterra era del 10. Para 1975, en Inglaterra la tasa había descendido al $2 \%$ y en Estados Unidos había aumentado al 15,5. Es decir, los riesgos de enfermarse en Inglaterra por cirrosis hepática son menores y están claramente relacionados, cuando uno no lo ve socialmente, con la política estatal hacia el consumo de alcohol.

Asimismo, hay otra dimensión vinculada con los problemas de los estilos de vida de la escasez, y es que se consume productos que buenos o malos 
para la salud son además de mala calidad. Y esto sucede sea por carencias financieras, sea por desinformación o por la adopción de modelos de consumo negativos; es así que se ha dado entre los pobres una disminución del consumo de granos, vegetales y legumbres y un aumento del consumo de pastas y de grasas, pero también del mal alcohol porque no pueden tomar sino el mal alcohol-y de la droga más barata y dañina.

El cuarto gran enemigo de la salud es la violencia, la violencia que pudiera ser de las guerras o de las luchas políticas, pero que en América Latina se refiere simplemente a la violencia cotidiana y callejera, hoy convertida en un problema de salud pública (OPS, 1996). La violencia está entre las cinco primeras causas de muerte en la mayoría de los países de América. Para los jóvenes entre 15 y 30 años es la primera causa de muerte en muchos países, pero en Colombia, Brasil, Salvador, México y Venezuela empieza a ser muy claro que se convierte en la primera causa de años de vida perdidos (Reichenheim y Werneck, 1994). Venezuela tiene una tasa de alrededor de 22 homicidios por cada 100 mil habitantes, de la cual Caracas tiene alrededor del 65\%; Colombia, como conjunto, la tiene en 113, y Medellín en 400, mientras los barrios pobres de Cali están por encima de 800. Lamentablemente, no tenemos muchos datos diferenciados por sectores para Venezuela ni otros países, pero en su conjunto la violencia afecta fundamentalmente a los hombres, jóvenes y pobres de la región. La violencia empezó a ser un problema de salud pública significativo, tanto por la alta mortalidad y aún más alta morbilidad que ocasiona, como por los problemas que genera en el sistema de atención hospitalaria, que se congestiona y gasta los insumos destinados a atender a toda la población en atender a las víctimas de la violencia.

\section{CAMBio SOCIAL Y SALUD púBLICA}

Ante estos enemigos, sólo a partir de cambios sociales importantes es posible encontrar las salidas. En primer lugar debemos insistir que en la tríada atención médica, promoción de la salud y prevención de enfermedades transmisibles y lesiones, la atención médica es lo menos importante. Un sistema de salud deseable debe colocar su énfasis en la promoción y en la prevención y no en la atención médica.

En segundo lugar, la reforma del sector salud no avanzará si nos quedamos en el esquema curativo y en el modelo de salud como ausencia de la enfermedad. Comparado con la concepción del modelo, nos parece un problema de menor relevancia quién presta el servicio: si es privado, si es del Estado o si es una combinación, pues si nos mantenemos en ese esquema curativo, en el mejor de los casos, ¿cuál sería la respuesta a los grandes retos? Sales de rehidratación oral para la pobreza; broncodilatadores para los problemas del ambiente; pastillas adelgazantes para los obesos o programas de rehabilitación física para los lisiados por la violencia. La reforma del sector salud debe partir de un cambio sustancial en la concepción de salud y de lo que debe ser la intervención en salud.

En tercer lugar, un modelo de salud deseable tiene que atravesar, necesariamente, por el desarrollo y el desarrollo social. Necesitamos desarrollo social, necesitamos progreso económico; pero el progreso económico que se necesita para superar la pobreza puede también dañar el ambiente y puede enfermar a la población. El crecimiento económico implica transformaciones importantes, intervenir el medio ambiente y seguramente causarle daños. Quizá sea posible hacerlo de otro modo, suavizar o controlar los daños ambientales, pero es ingenuo o malintencionado creer que no sucederán. De manera que lo que podamos ganar por un lado, podemos complicarlo y perderlo por el otro. El desarrollo económico no se relaciona esencialmente con la acumulación de riqueza, sino con mejorar la vida que vivimos y las libertades que disfrutamos (Sen, 1999).

Y también habrá problemas importantes en lo que pudiera ser la sobreexplotación de la mano de obra, porque uno los grandes recursos con que puede disponer América Latina para un cambio social y un progreso económico es la abundancia de mano de obra, que requiere ser empleada para que pueda tener trabajo e ingresos económicos para mantener a su familia, pero que también puede ser explotada por aceptar trabajar en condiciones precarias. 
Ante esos grandes enemigos se requieren respuestas sencillas y poderosas. Ante la pobreza: trabajo y producción. Requerimos salud en una sociedad productiva, lo cual es distinto al esquema de salud que hemos tenido, por ejemplo, en la Venezuela rentista que vivía (y aún en buena parte vive) del consumo de la renta petrolera. No podremos eliminar la pobreza si no producimos más riqueza. El asunto, para el futuro de Venezuela y América Latina, claramente no es sólo de redistribución de la riqueza; es de producción de riqueza.

Esta producción de riqueza no implica que tengamos que plantearnos como modelo la riqueza dispendiosa de Estados Unidos. Lo que tenemos por delante es una sociedad con una vida modesta. Que no tenga pobreza, que no va a tener la riqueza, pero que puede tener unas condiciones de vida sanas y dignas. Como lo planteaba Gandhi: enough for need, but not for greed.

En términos del ambiente, requerimos el uso de los recursos naturales; del petróleo en Venezuela, pero también de los minerales y de los bosques del Amazonas en Brasil, Colombia, Ecuador, Perú y Venezuela; de los ríos; de las tierras altas, en fin de los recursos naturales que aún tenemos y que no han sido todavía devastados. Requerimos de una industria manufacturera importante y responsable. Requerimos de unas ciudades con un medio ambiente construido sano; esto implica claramente aceptar la realidad de los habitantes pobres de la ciudad, de los barrios de ranchos, favelas, pueblos jóvenes o callampas, que todavía no son aceptados en muchos lugares y por muchos políticos e intelectuales como parte de la ciudad. Hay que aceptarlos, que significa darles vida urbana, con derechos y responsabilidades. No podremos tener ciudades sanas mientras la mitad de nuestras ciudades no estén integradas a la vida urbana normal, y se mantengan allí los grandes problemas de salud urbana.

Ante los estilos de vida, necesitamos un modo más frugal de vivir. Un estilo de vida más sano para todos; para los que tienen abundantes recursos y para los que los tienen escasos. Y ante la violencia, necesitamos construir una cultura de la paz y de la convivencia. Se requiere de un modo sano de resolver conflictos. Los cambios en el sistema de justicia son básicos para apoyar los modos pacíficos de resolver conflictos; esto implica procesos judiciales confiables y castigos aplicables y funcionales. La impunidad y la injusticia son combustión de la violencia. También lo es el notable incremento de armas entre la población. Una política sincera de desarme es una política de salud pública de gran significación.

Necesitamos un enfoque multisectorial; un enfoque de múltiples agentes. Ya no es funcional un solo tipo de agente, se requiere de la intervención de una gran variedad de actores y de políticas públicas que desde otras áreas tengan un impacto favorable a la salud.

Se requiere de una aproximación biotecnológica, pues no tenemos por qué seguir considerando como benéficas las salidas de la alta o la altísima tecnología de la cual se dispone. El Centro de la Organización Panamericana de la Salud en Montevideo hizo una comparación de las diferencias que para la atención de la mujer embarazada existían cuando el médico usaba el ecosonograma en la atención a las embarazadas y cuando usaba el tacto y la cinta métrica, al final de varios años del estudio se encontró que no había ninguna diferencia en la atención prenatal ni en los resultados prospectivos que se obtenían usando la cinta métrica y el tacto o el ecosonograma. La mayor diferencia era que los médicos que usaban el ecosonograma ya no sabían hacer tacto ni utilizar la cinta métrica. Esto no quiere decir que nos opongamos a la tecnología más avanzada, pues tenemos que utilizarla; pero tenemos también que utilizar muchas otras alternativas tecnológicas.

Se requiere una integración en los aspectos de prevención de enfermedades y lesiones, con la promoción de la salud y con la atención curativa. Esto se ha dicho tanto, se repite tanto en los informes oficiales, que hasta da vergüenza escribirlo, pero es tan importante que hay que volverlo a decir: se requiere de integración. Y la integración es fundamental para lo que se pueda hacer.

Se requiere, además, de una permanencia en las políticas: en el tipo de políticas y en su continuidad. Hay dos problemas centrales en toda la reforma del sector salud que se ha intentado hacer en América Latina en este tiempo, el primero es la notable rotación 
de las autoridades sanitarias. En América Latina, el promedio de duración de los ministros de salud en sus cargos es de 1 año y 8 meses. La mayoría han sido educados en la medicina curativa, y muchos de ellos no tenían la menor noción de salud pública. El segundo es la conflictividad permanente, las repetidas huelgas que han paralizado los servicios, en especial de los trabajadores del Estado, y que fueron el rasgo dominante de los problemas laborales en la región durante los noventa. Esta conflictividad se debe al deterioro de los salarios de los trabajadores y al incumplimiento de los compromisos contractuales por parte del Estado como patrón, sea éste gobierno central o local. Otra de las raíces de la conflictividad ha sido la resistencia al cambio por parte de los trabajadores de salud, pues, sea este cambio de tipo neoliberal o socializante, significa una transformación importante, que no es fácil de aceptar por las dirigencias sindicales, ni por las mafias laboralesempresariales que funcionan en el sector salud. Estos conflictos, justificados o no, pero repetidos y similares en casi toda la región, han bloqueado las necesarias transformaciones del sector salud.

Finalmente, como una pauta importante hay que colocar el rescate del sentido humanitario de la medicina. La salida es profundamente conceptual y ética. La construcción de un nuevo sistema de salud implica aspectos técnicos y financieros, pero no es un asunto técnico ni financiero, sino ético. Tampoco es un asunto tecnológico. Se dice mucho: "no tenemos equipos, necesitamos una técnica más sofisticada. Hay carencia de presupuesto; hay déficit en el presupuesto". Ciertamente hay déficit en el presupuesto y debe mejorarse la tecnología, pero la experiencia de la sociedad venezolana muestra que se tuvo un gran presupuesto, mucho dinero y sofisticadísima tecnología y no avanzamos en la salud. Es un asunto fundamentalmente conceptual y ético, de la imagen que nos hacemos de nosotros mismos como sociedad y nos proponemos alcanzar en el futuro.

$Y$ es allí donde debemos retomar la idea del bienestar. Lo que pudiera uno entender como "completo bienestar", son simplemente los ideales que como sociedad, en el área de salud por supuesto, pero también en conjunto como sociedad y como individuos, nos trazamos. El bienestar sólo puede entenderse adecuadamente como la relación histórica entre las aspiraciones que se tienen y la posibilidad de ejercicio de nuestras capacidades para satisfacerlas (Sen, 1993). Los ideales de la sociedad, en tanto forma colectiva de las aspiraciones, nos pueden permitir reorganizar las acciones de promoción y atención de salud en la dirección que alcance la meta de salud para todos. Pero hacer todo esto no sólo requiere de cambios en el sector salud, sino de los muchos cambios en la sociedad que pueden permitir la construcción de una nueva salud pública.

La acción en salud que quiera ser coherente con el mandato de "no sólo la ausencia la enfermedad" debe ser entendida como promoción de salud y el bienestar. Y proponemos entender la promoción de la salud como una acción diseñada para impulsar cambios en la sociedad y en los individuos, que conlleven a la aparición o fortalecimiento de condiciones sostenibles para la producción de salud y que permitan a los individuos la libertad necesaria para ejercer sus capacidades.

\section{REFERENCIAS BILIOGRÁFICAS}

Baptista, A., 1997. Teoría económica del capitalismo rentístico. Caracas: Ediciones IESA.

Briceño-León, R., 1990a. La casa enferma. Caracas: Fondo Editorial Acta Científica Venezolana y Consorcio de Ediciones Capriles.

Briceño-León, R., 1990b. Los efectos perversos del petróleo. Caracas: Fondo Editorial Acta Científica Venezolana.

Briceño-León, R., 1992. Salud y las reformas de la sociedad y el Estado. En: Ciencia y tecnología en Venezuela: un reto, una esperanza. Caracas: Comisión Presidencial para la Reforma del Estado.

Briceño-León, R., 1993. Social aspects of Chagas disease. Knowledge, power and practice. The anthropology of medicine and everyday life (S. Linderbaum \& M. Lock, eds.), pp. 287300. Berkeley: Berkeley University of California Press.

Briceño-León, R., 1996a. El DDT y la modernización de Venezuela". Boletín de Malariología y Saneamiento Ambiental, Vol. XXXVI (12):44-50. 
Briceño-León, R., 1996b. Salud no rentista y postmoderna para el desarrollo humano. Cuadernos Medico Sociales (Argentina), 64:73-80.

Cepal, 1995. Panorama social de América Latina. Santiago de Chile: CEPAL.

Cepal, 1997. Panorama social de América Latina. Santiago de Chile: CEPAL.

Farmer, P., 1999. Infections and inequalities. The modern plagues. Berkeley, Los Angeles, Londres: University of California Press.

Gabaldón, A., 1965. Significado económico de la erradicación de la malaria en una politica Sanitaria. Caracas: Ministerio de Sanidad y Asistencia Social.

Gabaldón, A., 1975a. El milagro ¿fue del DDT o de los venezolanos? Boletín de la Dirección de Malariologiay Saneamiento Ambiental, Vol. XV (6).

Gabaldón. A., 1975b. Delenda est malaria et malaria fuit. Maracay: Dirección General Sectorial de Malariología y Saneamiento Ambiental, MSAS, 1992.

Hajek, E. (comp.), 1994. Pobreza y medio ambiente en América Latina. Buenos Aires: Ciedla y Fundación Konrad Adenauer.

Heggenhougen, K., 1999. Are the margilized the slagheap of economic growth and globalization? Disparity, health, and human rights. Health and Human Rights, 4 (1):205213.

Lacan, J, 1976. Ecrits. París: Seuil.

Ommen, G.S., 1992. On the status of public health: a view from the United States. The crisis of public health: reflections for the debate. Washington, DC: Pan American Health Organization, Scientific Publication N 540.

OPS (Organización Panamericana de la Salud), 1996. Violencia en las Américas: la pandemia social del siglo XX. Washington DC: OPS.

Reichenheim, W. \& Werneck, R., 1994. Anos potenciais de vida perdidos no Rio de Janeiro, 1990. As mortes violentas en questao. Cadernos de Saúde Pública, 10 (1):188-198.
Sandoval Orellana, H., 1992. Public health situation and trends. The crisis of public health: reflections for the debate. Washington, DC: Pan American Health Organization, Scientific Publication $\mathrm{N}^{\circ} 540$.

Sen, A., 1993. Capability and well-being. En: The quality of life (K. Nusbauun \& A. Sen, eds.), pp.3054. Oxford: Oxford University Press.

Sen, A., 1999. Health in development. Bulletin of the World Health Organization, 77 (8):619-623.

Sigerist, H.E., 1941. Medicine and human welfare. New Haven: Yale University Press.

Terris, M., 1992. La situación de salud en el continente americano. En: Salud internacional. Un debate norte-sur. Washington, DC: Pan American Health Organization, Serie de Desarrollo de Recursos Humanos, No 95.

Yunes, J. y Rajs, D. (1994). Tendencia de la mortalidad por causas violentas en la población general y entre los adolescentes y jóvenes de la región de las Américas. Cadernos de Saúde Pública, 10 (1): 88-125. 


\section{LA SALUD EN FORMA Y LAS FORMAS DE LA SALUD: SUPERANDO PARADIGMAS Y RACIONALIDADES}

Madel T. Luz.

\section{INTRODUCCIÓN}

Este artículo continúa una reflexión iniciada con el proyecto de investigación Racionalidades Médicas, desarrollado en el Instituto de Medicina Social de la Universidad del Estado de Río de Janeiro (IMS-UERJ) desde 1992. ${ }^{1}$ En este proyecto, actualmente en su tercera fase, comparé inicialmente sistemas médicos complejos (medicina homeopática, medicina tradicional china, medicina ayurvédica y biomedicina) en términos de paradigmas terapéuticos (correspondiente a la primera fase del proyecto) y, posteriormente, segunda fase, en términos de prácticas y representaciones de terapeutas y pacientes, buscando verificar la existencia de más de una racionalidad médica actuando en la cultura contemporánea.

De hecho, estas racionalidades coexisten en nuestra cultura, algunas veces de manera conflictiva, otras de manera pacífica y más o menos integrada, con frecuencia de modo híbrido o sincrético, ${ }^{2}$ tanto en términos conceptuales como empíricos; es decir, yuxtaponiendo o integrando un collage conceptual con aspectos de distintas racionalidades. Este proceso se verifica en la práctica y en las representaciones tanto de los agentes institucionales (médicos/profesionales) como en la de los pacientes involucrados en los procesos de diagnóstico y cura. ${ }^{3}$
En el trabajo Cultura contemporánea y medicinas alternativas: nuevos paradigmas en salud al final del siglo XX (1999), presenté los resultados de la primera y segunda fase del proyecto, discutiendo acerca de los nuevos paradigmas en salud en estos finales de siglo. Centramos nuestro trabajo en los actuales modelos de salud y cura propuestos por el conjunto de sistemas y prácticas designados institucionalmente como "medicinas alternativas", su proceso de integración, aunque circunscrito a los servicios de salud, su utilización por grupos crecientes de la sociedad civil y su adopción, también creciente, por los propios profesionales de la salud (médicos, fisioterapeutas, enfermeros, psicólogos, etc.).

Una de las principales hipótesis de aquel trabajo, de naturaleza socioantropológica, es que la sociedad occidental puede estar atravesando por una crisis cultural que abarca las relaciones entre sociedad y biomedicina. Esta crisis está "empujando" a pacientes y a profesionales a la búsqueda de otros paradigmas terapéuticos; a saber, otras racionalidades en medicina y salud, en las que las cuestiones relacionadas con el cuidado y la cura sean prioritarias, a diferencia del paradigma - entendido aquí en el sentido kuhniano de modelo epistemológico de una disciplina científica - de la biomedicina, en la que el diagnóstico y la enfermedad son categorías centrales, tanto en términos de ciencia como en términos de

Socióloga, doctora en Ciencias Políticas, profesora titular del Instituto de Medicina Social de la Universidad del Estado de Río de Janeiro, coordinadora de la línea de investigación Racionalidades Médicas. E-mail: madelluz@uol.com.br.

1 Una extensa producción de artículos, así como de tesis de maestría y doctorado, frutos de esta línea de investigación, pueden ser encontradas en Pbysis, Revista de Saúde Coletiva o Série Estudos em Saúde Coletivas, ambas del IMS de la UeRJ, así como en otras revistas nacionales e internacionales. El concepto idealtípico de racionalidad médica se encuentra definido en vatios textos de la bibliografía. Cf. también Luz (1997).

2 La idea de sincretismo de imágenes, representaciones, conceptos y otras hibridaciones culturales como marca de la postmodernidad globalizada ha sido planteada por Massimo Canevacci (1996).

3 A propósito del sincretismo terapéutico de distintas racionalidades médicas en servicios públicos de salud, véase Luz (1998). 
arte. En otras palabras, las patologías y sus diagnósticos ocupan el plano central no sólo en términos teóricos, en los aspectos doctrinario y conceptual, sino también en la práctica clínica de las múltiples especialidades de la medicina occidental, mientras las personas que sufren de alguna enfermedad o riesgo de enfermarse están en busca de cuidado y de cura. Es decir, del restablecimiento de su salud, o de alivio a sus sufrimientos, a sus "dolores" o sus "males", para emplear expresiones populares. De este choque cultural proviene, en gran parte, el éxito de las medicinas "alternativas" — como por ejemplo la homeopatía - en el mercado de la curación (Luz, 1999).

En el presente trabajo me interesa discutir, también desde una perspectiva socioantropológica de la cultura, los diferentes sentidos y significados de los paradigmas —empleándose aquí el término en el sentido de "modelos" a ser social y culturalmente imitados o implementados - de diferentes prácticas de actores (institucionales, "civiles") y de discursos (de saberes, de artes) implícitos en el, aparentemente, homogéneo y unificado paradigma de la salud tan en boga en este fin de siglo.

Al examinar actualmente esa diversidad, nos damos cuenta de que, desde el más duro modelo académico epidemiológico al más abierto programa de prácticas "alternativas" desarrolladas por terapeutas de formación menos convencional, ${ }^{4}$ todos los agentes institucionales afirman que lo fundamental es adquirir, tener, conservar, promover la "salud", o al menos "evitar los riesgos" (a la salud).

Por su parte, las personas, vistas individualmente, en grupos o incluso colectivamente, buscan cada vez más conservar su "salud" o "mantenerla en forma". La cacería de la salud se ha convertido en el presente en un verdadero mandamiento para los ciudadanos de todas las clases, edades, ocupaciones y géneros.

Es desde este aparentemente monolito simbólico, hasta cierto punto ideológico, que me interesa hablar aquí, haciendo énfasis en su polisemia, descubriendo la diversidad del conjunto híbrido de imágenes, representaciones, ideologías, directrices y prácticas sociales sintetizadas (o "sincretizadas") en el concepto, procurando demostrar el carácter fragmentario de la unidad simbólica bajo el término salud.

La hipótesis que deseo formular en este momento, resultado de observaciones en servicios de salud en la segunda fase del proyecto Racionalidades Médicas y de observaciones preliminares de las "actividades de salud" desarrolladas en diferentes grupos de clase media de la sociedad brasileña actual, específicamente en Río de Janeiro, ${ }^{5}$ es que hay más de un paradigma entendido aquí como estructura modelo simbólica a ser interiorizada y practicada por los sujetossubyacente al monolito salud. En este sentido del término, inicialmente pueden destacarse dos grandes paradigmas que atraviesan culturalmente las prácticas y las representaciones concernientes a la conservación o ampliación de la salud o, incluso, a la prevención de la enfermedad: el paradigma de la normalidad/ patología —epistemológicamente anclado en el saber biomédico del último siglo (en el conjunto de disciplinas que sirven de base a la medicina), hegemónico en nuestra cultura y dependiente de ély el paradigma de la vitalidad/energía — ligado a tradiciones y saberes médicos y no médicos, occidentales y no occidentales. En cada uno de ellos, diferentes representaciones del individuo/persona, cuerpo/espíritu, salud/enfermedad, cuidado/

4 Aunque, a decir verdad, los terapeutas de las prácticas de salud conocidas como "alternativas" desarrollen un modelo de formación y entrenamiento prácticamente "clonado" de los de formación académica de especialistas, con seminarios, pasantías y cursos con asignaturas con cargas horarias comparables a la de una especialización biomédica, etc., éstas tienden a constituirse en lo que Bordieu (1989) denomina un subcampo dentro del campo médico, o subcampo de las terapias, con su carrera profesional, sus jerarquías estatutarias, sus estrategias de legitimación, etc.

5 Reconozco que la categoría clase media es poco rigurosa conceptualmente, pues engloba un conjunto diversificado de estratos sociales con insersión de clase, mentalidad e ideologías diferenciadas - para no decir muchas veces opuestas. La adopto en este trabajo, llamando la atención al hecho de que esta categoría no debe ser empleada como si designara una unidad social indiferenciada. Estudios sociales, sobre todo en el área de comunicación, que aplican la categoría clase media a un conjunto social supuestamente uniforme, tienden a atribuir cierta omnipotencia ideológica y simbólica al estrato superior de la clase media, aquel con educación formal y renta superior a los demás estratos del compuesto social denominado como tal. 
tratamiento, curación/equilibrio están presentes en los distintos agentes sociales, pacientes o terapeutas y aun en individuos "sanos", es decir, sin referencia a padecimientos.

Las bases para las afirmaciones que serán presentadas a continuación, todavía hipotéticas en su mayor parte, se encuentran entre los resultados de la segunda fase del proyecto Racionalidades Médicas, en lecturas de otros trabajos de investigación y en reflexiones motivadas por observaciones participantes personales en actividades de ejercicios (tai chi chuan, yoga, gimnasia, stretching y baile de salón) desarrolladas en la ciudad de Río de Janeiro en los últimos tres años. Estas constituyen momentos de motivación para una nueva fase de la investigación, en la cual un levantamiento preliminar de modelos de prácticas y actividades físicas concebidas como "de salud" nos ponen en contacto con un modelo normativo de salud, universalista y fragmentario al mismo tiempo, dominante en la cultura urbana contemporánea.

\section{LA SALUD EN FORMA: EL PARADIGMA}

\section{UNIVERSAL O LA UTOPÍA DE LA SALUD}

Pese a la indiscutible hegemonía del modelo biomecánico ${ }^{6}$ en la cultura contemporánea y la extraordinaria "medicalización social" observada en la segunda mitad del siglo XX, comentada por varios autores desde la década de los setenta, ${ }^{7}$ quiero discutir la posible presencia de otros modelos y prácticas de salud actuantes en la sociedad civil e, incluso, en las instituciones de actuación médica en las últimas décadas, es decir, en los años ochenta y noventa. Tanto los modelos como las prácticas y representaciones se resguardaban sobre el "paraguas" simbólico de la "salud".
Este "paraguas" se constituirá en el gran paradigma, en el mandamiento universal (el monolito al cual hice mención anteriormente) dirigido a todos y a cada uno en particular. Todo el mundo debe tener salud, todo el mundo necesita tener salud $\mathrm{o}$, como se dice popularmente, "mantener la salud en forma", siendo responsables de ella delante de los suyos y de todo el mundo en general.

He aquí que la salud se convierte en un mandamiento, un paradigma universal con efecto normativo que adquiere, tal como afirma Lucien $\mathrm{Sfe} z,{ }^{8}$ las características de una utopía, de un proyecto que supera, por su naturaleza prácticamente religiosa (dado su carácter universalista), a la ideología, que pese a su pretensión de universalidad es reconocida socialmente como un discurso particular, es decir, originado en un sector de la sociedad, siendo por tanto un discurso parcial.

Desde mi punto de vista, el mandamiento "estar saludable", "tener salud" o "conservar la salud", no se limita a evitar las enfermedades, a "protegerse", a "no correr riesgos", a permanecer en la normalidad médica. Esta es sólo una de las versiones del paradigma/mandamiento o, si se prefiere, de la utopía de la salud. Esta versión es la hegemónica, la que predomina en la biomedicina. No obstante, decir predominante implica decir que ésta no es la única versión sobre qué es la salud existente en la actualidad dentro del conjunto de discursos y prácticas designadas por Foucault en los años setenta con el nombre de saber médico (Foucault, 1979).

Se puede afirmar que al menos en los últimos diez años se desarrolló y ganó espacio, tanto en la clínica de diversas especialidades (general, interna, cardiología, ginecología y endocrinología, entre otras)

6 Entiendo por modelo biomecánico el que está presente en la medicina occidental contemporánea, cuya base cosmológica se fundamenta en la física newtoniana y en la metáfora del cuerpo como máquina dirigida por la mente. Sobre este punto, véase Luz (1988).

7 Entre los más importantes debe destacarse Illich, con su polémico Némesis da medicina, a expropriação da saúde (1975), que destacaba el carácter de heterogeneidad y contraproductividad de la medicina actual, con la "medicalización" de diversas funciones de la vida social, anteriormente desempeñadas por otras agencias o instancias de la sociedad. También deben mencionarse, de la misma década, las obras de Dupuy y Karsenty (1974), Clavreul (1978), Attali (1979), Boltanski (1979) y, evidentemente, la extensa obra de Michel Foucault, con énfasis en el ya clásico Naissance de la clinique (1963). Todas esas reflexiones resaltaban el carácter socialmente invasivo y, al mismo tiempo, estrechamente ligado al orden político, social y económico de las sociedades industriales de la medicina nacida con la revolución industrial y convertida en dominante en los últimos ciento cincuenta años.

8 En su libro La santé parfaite (1995), partiendo del estudio de tres proyectos científicos basados en la genética y en la biología, Lucien Sfez defiende la tesis de la existencia en este final de siglo de una utopia (y no una ideologia, que estaría vigente en una sociedad marcada por la modernidad o por la postmodernidad) de la salud, que estará vigente en el nuevo milenio. Este trabajo pretende dar cuenta de las representaciones de la "salud" presentes no sólo en la ideología científica biológica sino también en otras áreas de la cultura, en la sociedad civil y en las actividades institucionales de atención médica. 
como en la epidemiología ( por cierto ligada a la clínica por la investigación clínico-epidemiológica), una versión positiva de la salud, procedente del enfoque preventivista de los "estilos de vida", pero distanciándose de éste y ganando una acepción marcadamente higienista y vitalista. Así, la salud es vista como "vitalidad", como "vivir bien la vida", o como una manera de aumentar la longevidad con "calidad de vida" a través de hábitos sanos, de ejercicios, de regímenes alimentarios y de sentimientos positivos (evitar el estrés, la competencia, la envidia, los disgustos y resentimientos, etc.).

Al leer suplementos como "Vida", "Salud", "Salud y Medicina", "Salud Alternativa", etc., de los grandes diarios de circulación diaria, además de las innumerables revistas dedicadas a este fin, cuyas columnas son generalmente firmadas por médicos especialistas o fisioterapeutas, se obtiene una clara indicación de que el paradigma de la salud/vitalidad se ha vuelto una parte significativa del saber médico actual.

Por otra parte, se han desarrollado en la última década todo un conjunto de investigaciones clínicas, sobre todo en Estados Unidos de Norteamérica, analizando factores de sobrevivencia o mejora de pacientes internos (víctimas de infartos al miocardio o derrame cerebral, por ejemplo) o crónicos (como enfermos de cáncer), en los que cierto tipo de circunstancias relacionadas con representaciones, creencias, sentimientos o prácticas religiosas de esos pacientes - como la oración, el optimismo o pertenecer a grupos de apoyo (religiosos o no)son considerados factores positivos para la recuperación de la salud (o vencer la enfermedad, o tener mejor calidad de vida, incluso estando enfermos) con relación a otros pacientes que no tienen esos mismos factores. En los últimos cinco años estas investigaciones han sido divulgadas por la gran prensa y por revistas de difusión científica (Valla, 1999).
Asimismo, en los últimos años se ha estado desarrollando una discusión teórica en el campo de la salud pública y de la epidemiología sobre el problema de la "prevención" (de los riesgos) y de la "promoción de la salud", ${ }^{10}$ subrayando los aspectos sociales y psicosociales que favorecen o no la "salud" de las poblaciones y los individuos, que, de manera inédita, pasaron a ser considerados como elemento teórico de la discusión; es decir, como "sujetos" de la salud, indicando con esto la incorporación de conceptos y perspectivas propios de las ciencias sociales en este campo. En esa discusión se encuentra implícito (y muchas veces explícito) que no basta prevenir las enfermedades o medicar las poblaciones: es necesario, además, asegurar una "calidad de vida" básica, lo cual no es competencia de la medicina sino del Estado y de la sociedad, para que pueda haber una población efectivamente sana.

En el campo de la salud colectiva -el simple cambio, en los años ochenta, de las expresiones medicina social o salud pública, históricamente marcadas por el paradigma de la prevención de la enfermedad, por salud colectiva es sintomático- es menester señalar la presencia de programas en servicios de salud pautados ya no por la sólida intervención campañista o por la "medicina comunitaria", sino por la atención local integrada. En estos programas, los "equipos de salud", muchas veces gestores de los servicios, pueden contar con representantes de la propia localidad -organizados (como por ejemplo las "asociaciones de vecinos") o no- como agentes de salud, y el médico — sea éste un médico familiar (en el caso del programa "médico familiar") o un elemento del equipo multiprofesional que actúa en la localidad - procura tener una visión de conjunto sobre las condiciones sociales de los grupos que están a su cargo, muchas veces con plena conciencia del peso de esas condiciones en la salud de aquellos a quienes asiste. $^{11}$

9 Aunque la expresión "calidad de vida" haya adquirido una imprecisión cada vez mayor debido a los muchos sentidos que ésta ofrece (qué definir como "calidad" en lo referente a la vida puede variar mucho con las tendencias y perspectivas de análisis), su propio surgimiento en la década de los ochenta indica la presencia de contenidos nuevos, afirmativos, con relación a la salud. Al respecto véase: Nogucira (1994).

10 Véase por ejemplo la discusión conceptual de Czeresnia (1999).

11 Recientemente vi en el programa informativo nocturno de mayor audiencia en la televisión brasileña a un médico de familia en una vivienda precaria "recetando" a los hijos enfermos de desnutrición de una familia pobre de la región norte de Brasil, la menos favorecida del país, un $\mathrm{kg}$ de arroz, un $\mathrm{kg}$ de granos, un litro de leche y un $\mathrm{kg}$ de harina de maíz, rematando con estas palabras: "lo que la familia tiene es hambre y mientras me tope con estas situaciones esto es la única receta que puedo y debo darles". 
Hasta el momento sólo he mencionado las transformaciones en el campo de la medicina y de las instituciones de salud, en lo referente a la absorción reciente de un paradigma de la salud/vitalidad, sin que esta incorporación represente necesariamente la superación del paradigma tradicional de la normalidad/patología en dicho campo. Se hace necesario, entonces, destacar que estoy hablando tan sólo de lo que puede resumirse bajo la expresión genérica orden médico.

\section{LA CULTURA DE LA FORMA: EL COSTO SOCLAL}

\section{DE LA SALUD}

Cuando se avanza en la dirección de las prácticas y representaciones de la salud que tiene la sociedad civil, los individuos, grupos y colectividades que la componen, por fuerza debe mencionarse la multiplicidad y la diversidad de modelos, discursos, prácticas y representaciones presentes en ésta, relacionados con saberes tradicionales o actuales, sistemas médicos complejos (como los sistemas tradicionales médicos indígenas) o terapias desvinculadas de una racionalidad médica específica y yuxtapuestas a otras, originadas en contextos culturales diferentes a los del collage efectuado. Diversidad, fragmentarismo, collage (o si se prefiere la expresión acuñada por Lévi-Strauss, bricolage), bibridismo y sincretismo, características culturales atribuidas a la postmodernidad, están seguramente presentes en el gran mercado social de la salud contemporánea. Aquí también lo positivo de la representación acerca de la salud ganó fuerza en los últimos treinta años, de cara a una visión hasta entonces dominante, la de la salud como normalidad/ ausencia de enfermedad, o capacidad/incapacidad de realizar actividades. ${ }^{12}$

Volveré a este tema más adelante, por el momento creo que es más importante discutir acerca del porqué de esta "unanimidad". ¿Por qué la "salud" se ha vuelto tan importante en la cultura actual, al punto de que Sfez (1995:11-35) se refiere a ella como una nueva utopía?
Creo que podemos comenzar por el costo social que la salud ha pasado a representar para los individuos, las familias, el Estado y la sociedad civil en los últimos veinte años. Adopto esta hipótesis, macroanalítica, como hipótesis interpretativa inicial en función de elemento teórico de contextualización socioeconómica. Ella, sin embargo, no es suficiente para explicar la pluralidad de sentidos y significados, de representaciones sociales y prácticas sintetizadas en la categoría salud presentes en la sociedad actual.

No obstante, esta pluralidad, que remite a la complejidad del universo simbólico presente en la cultura, demanda otro tipo de hipótesis, enclavadas en la sociología de la cultura y en la antropología cultural. Hipótesis éstas que deben ser capaces de interpretar la diversidad de atribuciones de sentidos y significados, representaciones y adopción de identidades individuales y colectivas generadas por lo que he llamado anteriormente monolito simbólico de la salud.

En lo que he designado con el nombre de universo simbólico de la cultura contemporánea existe un conjunto de otras representaciones, no relacionadas con la salud, derivadas de los valores dominantes en la sociedad, como el individualismo (la comprensión de los sujetos como unidades puntuales autónomas), la competencia entre los individuos como regla fundamental para relacionarse, el consumismo entendiendo con esta expresión la posibilidad y la disposición de los individuos para adquirir bienes materiales o simbólicos que puedan diferenciarlos jerárquicamente de otros individuos-, el cultivo del cuerpo como unidad central (y muchas veces única) delimitadora del individuo con relación a los otros y las estrategias de valorización de este cuerpo, en el sentido de obtener, a partir de él, dinero, estatus y poder.

Las estrategias dominantes relacionadas con esa valorización son básicamente estéticas, e incluyen representaciones e imágenes de juventud, belleza y fuerza. Esas representaciones y estrategias dominantes en la cultura penetran las representaciones y prácticas de la salud, sometiéndolas y dirigiéndolas en el sentido

12 La representación entre los individuos de las clases trabajadoras o asalariados en general acerca de la salud como capacidad o incapacidad de trabajar —en otras palabras, como fuerza de trabajo- continúa siendo dominante; no obstante, otras, como "disposición" (en el sentido de motivación para las actividades cotidianas), "alegría", “ausencia de dolor”, son también frecuentes. Véase: Luz (1979, 1998). 
de la ratificación y del fortalecimiento de los valores centrales de la sociedad.

Por otro lado, cuando hago referencia al costo social de la salud no es mi intención restringirme al aspecto socioeconómico solamente, mucho menos al gerencial o contable, que ha caracterizado gran parte de las discusiones sobre el tema en el campo de la salud colectiva, sobre todo en la planificación en salud. Resulta evidente para todo el mundo, excepto para los teóricos adeptos a la doctrina neoliberal, el gran deterioro social actual debido al proceso macroeconómico de las últimas décadas, denominado "globalización". El impacto de este proceso actúa en las relaciones de trabajo, provocando el surgimiento de la precariedad del empleo, la desestructuración de la organización clásica del sistema de división industrial del trabajo (y su representación política junto al Estado, a través de los sindicatos) y la progresiva desincorporación de sectores de la población a los servicios de seguridad - con la crisis fiscal del wellfare State. Asimismo se provoca la exclusión social de grandes capas poblacionales, incluso de población económicamente activa (o apta para el empleo, como los jóvenes, o ya insertos en ella), como fenómeno de gran impacto en las condiciones de salud de los asalariados (o "asalariables"). ${ }^{13}$

El problema de las condiciones de vida, del empleo, del trabajo, de la calidad de vida en el sentido social y psicosocial de la expresión, resurge en este contexto como lugar privilegiado, no sólo teórico sino también simbólico, en la definición de lo que es la salud. En la actualidad, para muchos tener salud es "poder trabajar", pero ya no en el sentido de tener disposición o fuerza física para el trabajo, sino en el sentido de estar empleado y, en la mejor de las hipótesis, de tener estabilidad en el empleo. Este es el sentido socioeconómico más amplio del costo social de la salud al que me referí anteriormente.

Evidentemente, este sentido está también relacionado con otro, que se refiere a los costos del cuidado médico (de los seguros y planes de salud) en el contexto actual de tecnificación de la medicina y su absorción por parte de la economía de mercado capitalista. En este contexto la medicina se ha venido transformando en una actividad de "producción de bienes" (en cuanto a ofertante de servicios médicos) y en instancia social de "consumo de bienes" de salud (por el lado de la "demanda" de servicios por el paciente, reducido a "cliente"). ${ }^{14}$

Desde este punto de vista tener salud significa, muchas veces, no poder enfermarse más, no tener más este derecho. En verdad, enfermarse significa para muchos individuos y familias en la actualidad, sea en América del Norte o en Europa, en América del Sur o en Asia, perder el empleo, declararse en quiebra, caer por debajo de la línea de la pobreza y, probablemente, no poder salir de nuevo. Cuidar la salud, o "mantener la salud en forma", implica en este momento cuidar también del empleo, y por tanto, de la propia sobrevivencia.

Esta situación de inseguridad e inestabilidad se vuelve, a su vez, fuente de constante incomodidad, inquietud y perturbación, designado como estrés, generador de enfermedades en grandes sectores de la población. Además de esto, como ya señalé (Luz, 1997), el cambio acelerado (en manifiesta disgregación) de valores en la cultura contemporánea -que toca relaciones sociales y sectores de la vida social relativamente estables, como las generaciones, los géneros, la sexualidad, las formas de socialización basadas en la educación y en el trabajo, además de la ética, e involucra relaciones interpersonales, profesionales y políticas - ha generado perturbaciones y agravios a la salud física y mental en sectores cada vez más amplios de individuos en la sociedad actual.

Se está produciendo un gran malestar psicosocial —que ocasiona síntomas y síndromes indefinidos, muchas veces difíciles de identificar por la biomedicina - responsable de la pérdida de millones de horas de trabajo en todo el mundo, lo cual configura una crisis sanitaria por la búsqueda de

13 En los últimos cinco años se viene desarrollando una gran discusión en torno al tema de la mundialización del capitalismo y sus consecuencias sociales, que involucra la economía, la sociología y la política. Al respecto véanse, entre muchos otros, los trabajos representativos de: R. Castell (1995); M.C. Tavares y J.L. Fiori (1997); I. Ramonet (1998); R. Kurz (1997); L.T. Soares (1999); C. Lessa, L. Tavares \& S. Dain (1997) y P.G. Casanova (1997).

14 Este proceso ha venido siendo expresado en inglés por el término "medical commodification", designando la absorción de la medicina por la economía de mercado. 
cuidado de las personas en un conjunto de actividades, vistas todas ellas como terapéuticas, entre las cuales sobresalen las "terapias alternativas" (Luz, 1997).

\section{LAS FORMAS DE LA SALUD: LA PLURALIDAD}

\section{DE ACTIVIDADES Y MODELOS}

La universalidad del paradigma o utopía de la salud puede ser constatada no sólo por la cantidad y por la diversidad de las actividades y prácticas actualmente designadas como "de salud", sino sobre todo en la tendencia a resignificar actividades anteriormente vistas en la sociedad como lúdicas, de juego u ocio, deporte o recreación, o incluso estéticas, y hasta eróticas, como "actividades de salud". El deporte, la danza, el cortejo, las relaciones sexuales, el alimentarse, el dormir, el caminar, el trabajar, todo puede y debe ser visto como "prácticas de salud", o de riesgo de enfermedad, dependiendo de la intención, de la intensidad, de la frecuencia y de la cantidad con que sea realizado, ya que todas las actividades deben ser practicadas con equilibrio, comedidamente; es decir, sin excesos...

Quiero llamar la atención acerca del problema del comedimiento como una de las representaciones fundamentales de la salud, aunque no única, en la cultura contemporánea, originada en las raíces de la propia sociedad moderna burguesa. ${ }^{15}$ Todo exceso es visto en este contexto como un riesgo a la salud, porque desequilibra, y el desequilibrio genera la enfermedad, es decir, la presencia de ésta. Entre los pacientes de la red pública de salud se encuentra, por ejemplo, con mucha frecuencia una representación autoculpabilizante de los "excesos": en el comer, el beber, o en otros hábitos, como origen de su enfermedad (Luz, 1998).

La medida del actuar, del comportarse o del controlarse, está en los sujetos, pues son ellos los responsables de no "dañar" su salud con excesos. El problema de la "falta", por otro lado, es siempre vista desde la perspectiva del exceso de alguna cualidad vital negativa: la falta de ejercicios, por ejemplo, es siempre vista en función de la vida sedentaria en la que "sobra el descanso" o "inactividad física”, y así por el estilo. El equilibrio en este caso es fruto no del acto de equilibrar entre fuerzas o pesos opuestos, sino de contención, y la contención supone el autocontrol de los sujetos.

La contención de los excesos no es el único modelo de comedimiento presente en la cultura contemporánea. Quiero subrayar que hay varios modelos de equilibrio que no se reducen al paradigma de la normalidad/enfermedad, escapando al modelo de comedimiento relacionado con el control médico. Existen representaciones positivas de equilibrio en grupos y colectividades de la sociedad civil asociados a la vitalidad y su conservación, al aumento de la "energía" (sinónimo de vitalidad en este modelo) vista como fuerza, juventud y belleza, o armonía, vista, a su vez, como sinónimo de salud; mantener la salud en forma es, en este caso, "mantener la forma", en el sentido más estético de la palabra forma ${ }^{16}$ Un conjunto muy importante de "actividades de salud", con un número creciente de adeptos, se ubica en este modelo. Regresaré a este tema más adelante.

Lo que me interesa señalar en este momento es que es la estética, más que la racionalidad médica y sus modelos (normalidad/patología o vitalidad/ energía), el criterio sociocultural más utilizado por los sujetos para determinar si realmente son "saludables" o si necesitan ejercer alguna "actividad de salud" a través del establecimiento de patrones rígidos de forma física. El verdadero mandamiento de la salud está más relacionado con la buena forma que con el modelo enfermedad/prevención/cura.

En este caso, las representaciones y prácticas actuales relacionadas con la salud, tanto las vinculadas a la biomedicina como las que se relacionan con las propuestas médicas vitalistas o incluso aquellas conocidas como naturistas, están profundamente

15 El comedimiento de la sociedad burguesa no debe ser visto como sinónimo de la "prudencia" griega, aristotélica, o el "camino del medio" de la doctrina zen, china. El comedimiento es, en nuestra cultura, un intento de controlar el miedo al desvío de los individuos por el exceso, y la consecuente perdida de los límites que pone en peligro el Orden, miedo éste que ronda a las sociedades excesivamente normalizadas y disciplinadas como la nuestra... Es necesario señalar que el comedimiento es un proceso educativo que se inicia en nuestra cultura en el siglo XVII, con la disciplina de los sentidos y de las pasiones.

16 Una versión en inglés de esta concepción es el término fitness, tan en boga en las revistas de moda y salud, y en las academias de actividades físicas. 
penetradas por representaciones estéticas relativas al cuerpo, las cuales están a su vez arraigadas en los valores individualistas dominantes en la cultura contemporánea.

De esta interpenetración simbólica entre salud influenciada por el orden médico, por la estética y por el individualismo, derivan una serie de consecuencias interesantes en términos de representaciones, prácticas y estrategias de inclusión/ exclusión social de individuos y grupos hacia los que me interesa llamar la atención en este trabajo, a lo cual dedicaré las páginas siguientes.

En primer lugar quiero llamar la atención hacia un conjunto de actividades calificadas como "de salud" que se organizan en la sociedad urbana actual, destinadas a lidiar - de acuerdo con los diferentes estratos sociales, su mentalidad y su inserción en la estructura de producción y en la cultura- con los procesos de inclusión o, más frecuentemente, de exclusión social derivados de la interpenetración arriba mencionada. Estas actividades tienden a convertirse en estrategias y tácticas de resistencia a esos procesos, o de creación de nuevos valores y prácticas de sociabilidad.

Las "actividades de salud" pueden ser vistas en este contexto como estrategias de sobrevivencia social, de ruptura con el aislamiento provocado por la cultura individualista y narcisista que predomina en las actuales sociedades capitalistas. Volveré a mencionar esas estrategias más adelante. A mi juicio, ellas indican la presencia de la diversidad de las representaciones sobre la salud en la cultura actual.

\section{LA SALUD SIGNIFICA FORMA: APOLO BIOMECÁNICO}

Abordaré ahora ese conjunto de "actividades" o "ejercicios" de salud, mencionados anteriormente, que con mayor frecuencia encontramos en los grandes centros urbanos. Se trata de las actividades físicas practicadas colectivamente en el espacio de las academias de gimnasia, en las que predomina los grupos etários más jóvenes (entre los 18 a 35 años) pero con tendencia de expansión a grupos etários más avanzados (entre 40 y 60 años).

Este conjunto de actividades, históricamente conocidas como gimnasia, posee una tradición secular en la cultura occidental, habiendo tenido gran desarrollo en la sociedad urbana durante el siglo XX. Asociada a la práctica del deporte, la gimnasia moderna nació bajo el signo del paradigma de la salud/vitalidad, estrechamente ligada al modelo higienista (posteriormente eugenista) del último tercio del siglo XIX (Luz, 1994). Evidentemente la tradición occidental más antigua asocia la gimnasia, el deporte y la competencia en la Grecia clásica de las ciudadesestados, práctica que alcanzó su mayor esplendor en el período de las disputas entre Atenas y Esparta. Allí también la gimnasia está asociada a la salud y a la belleza, representada como equilibrio/armonía. Mi intención, sin embargo, es limitarme al momento actual de la práctica, ascendente en nuestra cultura a partir de los años setenta. La gimnasia practicada hace un siglo atrás no tenía la misma finalidad social o ideológica de la de este final de siglo; la primera, relacionada con el deporte, era inequívocamente dependiente del paradigma de la salud/vitalidad, procurando el equilibrio cuerpo/mente de los individuos ciudadanos, en una recuperación moderna nacionalista de la concepción latina de mens sana in corpore sano. La segunda, vigente entre nosotros en el despuntar del tercer milenio, está estrechamente ligada a la estética del cuerpo, y busca "modelar" los cuerpos de los individuos para que éstos adquieran una forma coincidente con las rigurosas normas de belleza de la cultura física en boga.

No se trata ya de armonizar mente y cuerpo en la búsqueda del equilibrio/salud, sino de fortalecer y hacer visibles ciertos tejidos del cuerpo, "dibujando" músculos, "levantando" senos y glúteos, haciendo fuertes los músculos y tendones, modelando así una imagen de salud que asocia fuerza, juventud y belleza. La práctica sistemática de ejercicios repetidos bajo ritmos variados, frecuentemente acompañados por música, con miras a poner "en forma" el cuerpo, caracteriza ese conjunto de ejercicios físicos como un movimiento regido por la estética en la cultura actual. ${ }^{17}$

17 Existen actualmente muchas formas de ejercicios colectivos, conocidos bajo el título de actividades físicas, practicados algunas veces en el mismo espacio, es decir, en la misma "academia", que incluyen diversos modelos y distintos paradigmas, desde el más biomecánico hasta el más bioenergético, que absorbieron movimientos de yoga, de baile, de artes marciales, etc. En Río de Janeiro, por ejemplo, hay una gran demanda por parte del público para todo ese tipo de actividades. 
El resultado esperado por los practicantes de esos ejercicios es, normalmente, estético y no propiamente vital. No obstante, se considera en este medio que los individuos no practicantes están "fuera de forma", y consecuentemente, sin salud. Como la búsqueda de la belleza/juventud es el gran empeño en esa actividad, muchas veces hay un exceso en la práctica que termina dañando la salud. Es frecuente el uso de esteroides anabolizantes y sustancias químicas por parte de los practicantes, sobre todo los de sexo masculino, con el objeto de hacer crecer los músculos, volverlos más visibles y evitar el cansancio para poder practicar más ejercicios. La cultura física está fuertemente establecida en este medio, asociada a un individualismo competitivo y consumista, en el que el cuerpo es el criterio básico de reconocimiento y clasificación social establecido entre las personas.

La búsqueda del éxito, estatus y dinero, asociado al "cuerpo en forma" entre los jóvenes de clase media de las academias, es fácilmente percibible, aunque esos no sean los únicos valores presentes. El cuerpo está representado como "capital potencial", como una "inversión" que puede (y debe) tener "retorno". Se hace patente en este contexto, que el cuerpo individual es el centro del universo simbólico de este público, independientemente del género. ${ }^{18}$ Las relaciones sociables de cooperación que sobrepasen los umbrales del salón de la academia, a veces el propio horario de las clases frecuentadas por los alumnos, son desconocidas. Evidentemente esa generalización es grosera y está restringida a los estratos más jóvenes de los practicantes de la gimnasia hard. ${ }^{19}$ Esta incluye la gimnasia aeróbica en general, acompañada de tecno-music o de ritmos semejantes, conocida entre los brasileños como "malhação". Las prácticas más "suaves", como el estiramiento, el yoga, la biodanza y otros bailes practicados como gimnasia, inclusive la capoeira, comportan otras representaciones del cuerpo y la salud en las que la armonía y el equilibrio se presentan como base de la vitalidad. El propio ritmo de los ejercicios (y de la música que lo acompañan), con su concepción implícita del tiempo más lento y más singularizado de los movimientos, excluye la búsqueda de "productividad" que caracteriza al fisicoculturismo.

En el contexto de las academias de aeróbics y de levantamiento de pesas, los individuos tienen "prisa" en adquirir un cuerpo modelado para ser utilizado como instrumento de ascenso o promoción social, para la conquista de pareja con el mismo nivel de belleza y salud en el mercado sexual y para insertarse en el sector del mercado de trabajo basado en la forma estética del cuerpo, como modelo, actor, etc. La búsqueda de la juventud o del rejuvenecimiento a través del ejercicio físico, es decir, de la "forma física" como salud y de la salud como derivado de la belleza, de la juventud y de la fuerza, caracteriza el paradigma de estas actividades, como las representaciones que le son asociadas. El paradigma y las representaciones enraizados en la cultura del cuerpo, dominante entre jóvenes de la clase media de las grandes ciudades, están asociados a una floreciente industria del vestuario, cosméticos, alimentos y fármacos totalmente volcada a la conservación de la juventud, es decir, a la forma o fitness.

Bajo la égida de este paradigma, un número creciente de jóvenes de esta clase utiliza el recurso de la cirugía plástica en el sentido de "corregir defectos" de la naturaleza. La remodelación de orejas de "abanico" o narices grandes, reducción o aumento del tamaño de los senos, configuran un cuerpo de intervenciones médicas que persiguen "restituir la autoestima" o retirar del aislamiento a los jóvenes discriminados por sus imperfecciones físicas.

\section{SALUD SIGNIFICA CUIDADO: LA BÚSQUEDA}

\section{DEL ESCAPE DEL AISLAMIENTO}

Sin duda alguna, en la medida en que se avanza hacia un grupo etario más avanzado y se desciende en la estratificación social, el énfasis en estos valores

18 El patrón de belleza de las academias está en realidad poco diferenciado en términos de género, al punto de llevar al escritor norteamericano Tom Wolfe a referirse, en una entrevista realizada por la revista brasileña $V$ eja en 1998, a las mujeres que practican ejercicios físicos en ese tipo de academias como "muchachos con senos".

19 Todas las actividades físicas practicadas de manera colectiva en espacios cerrados (o incluso abiertos, como los parques, plazas y jardines públicos) terminan llevando a actividades de cooperación y de identidad de grupo, como paseos, excursiones, fiestas de cumpleaños de los practicantes, etc. Incluso en las academias de gimnasia. 
disminuye. La frecuencia de mujeres de mediana y tercera edad es predominante; ello, en realidad, ocurre en casi todas las actividades relacionadas con la salud en la actualidad. Un aparente atenuamiento de los valores individualistas puede ser notado en las clases de las academias frecuentadas predominantemente por mujeres de esos grupos etarios (entre los 40 y 65 años). ${ }^{20}$ Aparentemente, a través del cuidado de la salud (y de una soñada recuperación de la juventud) las mujeres en ese grupo etario buscan romper con el aislamiento en el que caen las mujeres maduras y ancianas en nuestra cultura, víctimas de los valores del cuerpo joven y bello como criterio de adquisición de estatus y de ascenso social. Aunque, a decir verdad, constituyen una minoría las mujeres maduras y ancianas que desean hacer gimnasia aeróbica, tipo de gimnasia practicada generalmente por jóvenes. En los espacios de las academias de "gimnasia modeladora" estas mujeres tienden a sentirse desubicadas e inferiores en función de la drepreciación de su cuerpo. Asimismo, los médicos, por regla general, no aconsejan este tipo de ejercicios a las personas mayores de cuarenta años, a menos que sea realizado bajo estricta supervisión. ${ }^{21}$

Generalmente las mujeres maduras y ancianas en Río de Janeiro que desean practicar ejercicios físicos colectivos buscan modalidades más "ligeras", como la hidrogimnasia, la antigimnasia y el estiramiento. Estas mujeres, en una proporción cada vez mayor, influidas por los medios, buscan ejercicios relacionados con las medicinas alternativas, como el tai chi chuan, el yoga, la biodanza y el baile de salón. En este caso, el paradigma de la vitalidad/energía está presente, y la salud se representa como equilibrio/armonía. El cuerpo es representado como una dimensión del sujeto, concebido como unidad bioespiritual. La búsqueda de la belleza y de la forma se asocian a la recuperación de la salud, de la flexibilidad o del rejuvenecimiento. La cordialidad y la cooperación entre las practicantes es muy frecuente.
Deseo señalar, sin embargo, que no sólo las mujeres maduras y ancianas son víctimas del aislamiento en la cultura de los cuerpos jóvenes, bellos y fuertes, es decir, de los cuerpos "saludables", 22 también los hombres de mediana y tercera edad se constituyen en víctimas de esta cultura, aunque con menos frecuencia que las mujeres, porque raramente están solos. Los obesos, los minusválidos, los enfermos mentales y, en menor medida, los jóvenes desprovistos de dinero y belleza, son, cuando no discriminados, situados en lugares inferiores de la escala social, donde el "capital cuerpo" está, por causa de su deterioro o su incapacidad, depreciado.

La separación entre juventud y belleza es posible no sólo por criterios estéticos, en los que la diferencia es vista como anormalidad o anomalía (orejas de "abanico", nariz o senos grandes, exceso o falta de altura, etc.), sino también raciales. Frecuentemente un joven negro o mulato, mayoría en el país, puede ser visto como feo, pues todavía el patrón internacional de belleza establece el blanco de ojos azules o verdes como medida estética a partir de la cual los individuos jóvenes son evaluados.

Por otro lado, los valores dominantes de la sociedad actual, mencionados en otro trabajo (Luz, 1997), entre los cuales sobresalen la competencia como forma estratégica de relación social, la búsqueda de éxito y de dinero como finalidad básica de la vida, el consumismo como forma de afirmación y diferenciación social y el uso narcisista del cuerpo como instrumento al servicio de esos valores, tienden a ocasionar el aislamiento progresivo de un número cada vez mayor de personas, con la pérdida de sentido y horizonte de sus vidas: el cultivo del pesimismo y de la desesperanza, del miedo y la desconfianza, con la incomunicación con otros seres humanos que de ella resulta y la presencia de angustia y depresión que llevan a la enfermedad física y mental.

Así, una parte considerable de los pacientes atendidos en ambulatorios de la red pública de las

20 Reconozco que esta observación es puntual y, hasta cierto punto, subjetiva; sin embargo, es fruto de la observación personal en diversos períodos de varios años de actividades físicas como gimnasia, natación, yoga, tai chi chuan, estiramiento y baile de salón.

21 Esta es una forma médica de evitar los "excesos" en los ejercicios, que pueden ocasionar tendonitis, desgarres musculares, dislocamientos y luxaciones de vértebras o, peor aún, infartos o derrames en esos grupos etarios.

22 Existe actualmente en Brasil un giro lingüístico para designar esos cuerpos, el término "sanados", lo que originalmente puede representar tanto a los "curados" como a los "sanos". 
metrópolis brasileñas — creo incluso que de todo el mundo contemporáneo-, estimada a veces en un $80 \%$, se debe a quejas relacionadas con lo que pudiéramos llamar sindrome de aislamiento y pobreza. Resalto la palabra pobreza para destacar su importancia en el momento actual de la sociedad capitalista en proceso de mundialización, con las graves y permanentes consecuencias que tiene sobre las condiciones de salud de las clases asalariadas del planeta. Con esto quiero subrayar que la situación socioeconómica refuerza el aislamiento ya propiciado por la cultura individualista, empeorando la situación de exclusión y de pérdida del horizonte vital de esas clases. Quiero destacar, asimismo, que a la pobreza psicológica y cultural en la que se encuentran inmersos viene a unírsele la pobreza material con su carga de privaciones, humillaciones y violencia cotidianas creciente.

Viejos y viejas, jubilados de ambos sexos, desempleados de todas las edades y calificación profesional, jóvenes pobres y menores abandonados, mujeres solas o con familia a su cargo, también ellos quieren tener salud. También ellos aspiran a estar saludables o, al menos, escapar del fatalismo de la enfermedad y de la muerte temprana. Aquellos que no están en las filas de atención de los servicios públicos, despojados de autonomía con relación a su propia salud, irreversiblemente medicalizados, ${ }^{23}$ también buscan "cuidar" su salud. Para este inmenso sector de la sociedad, que incluye los estratos medios y bajos de la escala social, obtener salud significa, en gran medida, ser cuidado.

La salud está, en este caso, representada como resguardo del dolor, del sufrimiento, del envejecimiento y, en la medida de lo posible, de la muerte precoz. ${ }^{24}$ Por otro lado, estar saludable es poder tener alegría, disposición para la vida, recuperar el placer de las cosas cotidianas y poder estar con los otros (con la familia, con los amigos). Desde este punto de vista, tener salud es poder romper con el aislamiento provocado por las situaciones a las que la sociedad contemporánea relega a una gran parte de sus componentes, por razones de edad, enfermedad, desempleo o pobreza, consideradas las principales fuentes de aislamiento, a pesar de existir otras, ya discutidas en este artículo.

La salud representa, en este caso, una victoria contra la muerte social. En otras palabras, la conquista de la "salud" no deja de ser, muchas veces, fruto de una victoria contra la cultura. Es precisamente en el grupo de población mencionado antes, que se ubica una cantidad considerable de la clientela de las medicinas alternativas y naturistas (Luz, 1997). Es también en este grupo que la representación del tratamicnto es mayormente interpretada como cuidado (Luz, 1998). También aquí podemos encontrar la búsqueda de salud como autocuidado, e incluso intercambio de cuidados, sobre todo en el sector medio con formación educativa universitaria, accesible y sensible a las doctrinas esotéricas, naturistas, psicológicas y morales de los manuales de autocuración new age, tan de moda en la cultura contemporánea. Desde mi punto de vista, esa búsqueda continua y constante de cuidados es parte de una estrategia de ruptura con el aislamiento impuesto por el individualismo y por la constante amenaza de pobreza y de pérdida del estatus a la que se encuentra expuesta esta población (Valla, 1999).

El universo simbólico de esta población y su mentalidad son, por decirlo de alguna manera, diferente al de público de las academias, con sus valores individualistas y fisicoculturistas. Por una parte, la reducción de los sujetos a un cuerpo "en forma", típica de este último público, no sucede entre los primeros. La presencia dominante de un espíritu o mente (algunas veces denominada también "cabeza") - significando un conjunto de funciones psíquicas y espirituales, tales como sensaciones, pensamientos, emociones y sentimientos - es fundamental en las representaciones acerca de la salud de las personas que forman parte de esta población.

Frecuentemente, las dos partes "cartesianas" del individuo (cuerpo/espíritu) son vistas como inseparables. Esta representación, susceptible de ser

23 Una gran parte de la población de ancianos, jubilados e incluso de hombres y mujeres trabajadores que forman la clientela de los servicios públicos de atención médica, está considerada como farmacodependiente.

24 Una representación frecuente y tradicional sobre el tratamiento y la cura en las clases populares es el "alivio del dolor", "la eliminación o disminución del sufrimiento del enfermo", siendo éste representado como un "sufridor" (sufre-dolor). 
encontrada también en los sectores más populares de la sociedad, difiere claramente de la representación física, de origen médico, en la cual la enfermedad es vista como producto de la invasión de un organismo por una patología, cuando las defensas de un organismo se encuentran debilitadas; lo que no significa que no exista convivencia con las representaciones mecánicas de la biomedicina, del cuerpo como máquina y de la salud como "buen funcionamiento de la máquina", etc.

En las representaciones populares de la enfermedad, la imagen de pérdida del equilibrio espiritual aparece con frecuencia como causante de la enfermedad. La cura dependerá, entonces, necesariamente de la recuperación de la totalidad espiritualmente determinada, expresando la importancia de la parte espiritual para reequilibrar el todo.

Es por esto que los sistemas que privilegian este aspecto tienen gran aceptación en este sector de la población. Entre ellos conviene destacar no sólo los sistemas religiosos de curación, como el espiritismo, la umbanda, el candomblé o las iglesias pentecostales, sino también las llamadas terapias alternativas, destacando entre éstas la homeopatía, la medicina tropical china, a través de la acupuntura, y la terapéutica tradicional con base fitoterapéutica, o mejor dicho, de terapias basadas en fuentes naturales: vegetales, animales y minerales (Luz, 1997).

Lo que considero importante resaltar aquí es el papel de la resignificación de la salud, de la enfermedad y de la cura que representan esas medicinas para sus enfermos y la contribución que efectivamente ofrecen para retirarlos del aislamiento social que implica, en nuestra sociedad, la pobreza, el envejecimiento y la enfermedad. Las prácticas o actividades de salud propiciadas por estos sistemas, sean colectivas o no, favorecen el establecimiento de la comunicación, de interacciones sociales, la formación de grupos, redes e incluso movimientos - si bien muchos de ellos localizados - por la "salud", o por lo menos por la cura.

Las relaciones de solidaridad o, al menos, de cooperación y apoyo mutuo, aunque localizadas y restringidas al espacio donde se desarrollan las actividades de salud, tienden a establecerse, convirtiéndose en el punto de partida para la renovación de la sociabilidad, para la constitución de "nuevos amigos" y de "intercambios sociales" (de informaciones, experiencias, consejos y orientaciones) que van, poco a poco, formando un tejido social comunicativo, con la creación y extensión de actividades fuera del ámbito de las prácticas de salud. ${ }^{25} \mathrm{El}$ aislamiento es, al poco tiempo, vencido, con el restablecimiento de la confianza en el otro, aunque esto se limite sólo al pequeño grupo donde se ejerce la actividad.

Estas formas de ejercicios focos de la solidaridad se convierten en pequeños y múltiples puntos de resistencia al individualismo dominante, sustituyendo la fraternidad y la cooperación por el valor dominante de la competencia. Aunque este tipo de relaciones esté especialmente favorecido por las actividades mencionadas, ello no significa que no se hagan presentes en actividades desarrolladas en instituciones médicas, como los hospitales y los ambulatorios, o dentro de los servicios locales de salud. Siempre que hay programas centrados en actividades grupales - y actualmente en el sistema brasileño de salud (SUS) hay varios de esos programas-, esas relaciones tienen tendencia a aparecer. Pueden aparecer incluso en las filas de espera para atención médica. ${ }^{26}$

Además de la diversidad de prácticas y modelos presentes en la cultura, con estas observaciones deseo subrayar que la búsqueda de la salud, pese a ser en la actualidad un mandamiento universal, no siempre reproduce los valores centrales

25 Resulta impresionante la creación de eventos o de oportunidades para reuniones de confraternidad, de excursiones, así como de paseos y fiestas, que los grupos de actividades relacionadas con la salud, independientemente de su modelo o paradigma, propician. Esto es una forma de inserción en el grupo, pero al mismo tiempo, un modo de sociabilidad propio de esas actividades. En el cartel de entrada de una academia de baile cualquiera, se pueden leer frases como "aprenda a bailar y haga nuevos amigos".

26 Un médico jefe de servicios de atención en el interior del estado de Minas Gerais que realizó una pasantía en la investigación Racionalidades Médicas, realizó un survey sobre las filas de espera para atención en su ciudad, Juiz de Fora, y descubrió, a través de la observación participante y de entrevistas, que dichas filas representaban un locus de sociabilidad para los pacientes (y no pacientes) que alli esperaban, muchas veces huyendo del aislamiento de sus casas. Hubo un gran movimiento del público que se mostraba contrario a la eliminación de las filas de espera a través de la racionalización del horario de las consultas. 
de esta cultura. Ciertas formas de actividades señaladas como actividades "de salud" favorecen más el individualismo y el cultivo del cuerpo que otras. Se trata también de afirmar que las ideologías y representaciones sobre salud, cuerpo, enfermedad y cura varían no sólo con el tipo de práctica de salud sino también de acuerdo con los grupos, las clases sociales y sus representaciones. Quiero decir con esto que la ideología y las representaciones físicas, narcisistas, individualistas y consumistas propias de la clase media alta cultivada son apenas parte de las representaciones e ideologías de la salud presentes en la cultura contemporánea, incluso, considerando su poder de difusión en la sociedad a través de los medios.

Los valores de cooperación, de apoyo y de solidaridad, así como de representaciones sobre la salud y la enfermedad irreductibles a lo puramente físico, están frecuentemente presentes en actividades de salud y prácticas de curación de diferentes estratos y grupos sociales, independientemente de la edad, el género y el origen social de quienes las practican. Así, la salud es vista, en este caso, como la recuperación de la vida y de la alegría individual y colectiva.

\section{LA SALUD ES ALEGRÍA (Y AGILIDAD):}

\section{Dionisio POPULAR Y EL BAILE DE SALÓN}

Deseo cerrar este trabajo presentando brevemente un ejemplo de este tipo de actividad con muchos seguidores en las prácticas de salud en la actualidad: el baile de salón. Nacido en Brasil a partir de las populares gafieiras, ${ }^{27}$ presentes en la sociedad carioca desde la primera mitad del siglo XX, profundamente influenciada en los centros urbanos por la cultura negra, se convirtió en las últimas décadas en una opción de recreación para la clase media cultivada: artistas, intelectuales, estudiantes y profesionales universitarios en general. Además, se ha transformado crecientemente en una recomendación médica para las depresiones, la melancolía, la timidez, el aislamiento, la osteoporosis, dolores en la columna, la obesidad y otros males crónicos hasta ahora no relacionados con ninguna patología médica conocida.

La expansión de las academias de baile de salón está centrada, sin lugar a dudas, en prácticamente todos los grupos etarios de la clase media. ${ }^{28} \mathrm{Me}$ gustaría contraponer esa "actividad física", sus valores de práctica, es decir, su ethos y sus representaciones así como el público que la practica, al modelo de las academias de gimnasia. Al Apolo biomecánico de las academias contrapondré un Dionisio popular, desde el punto de vista de las representaciones sobre el cuerpo y la salud y del conjunto de valores que caracteriza esas actividades.

En primer lugar, quiero examinar el problema de los cuerpos y su "forma" para el baile de salón: un cuerpo de bailarín de salón no necesita — ni puede, bajo pena de perder la flexibilidad - estar torneado rígidamente como el de quienes practican levantamiento de pesas. Los hombres sin músculos visibles o barrigones, las mujeres gordas, las jóvenes de baja estatura, los adolescentes muy delgados y casi imberbes, el rostro lleno de acné, jóvenes y viejos, blancos, negros y mulatos de ambos sexos: he aquí el universo físico del baile de salón.

Al contrario de la uniformidad de la academia de gimnasia, la academia de baile de salón cultiva la diversidad de formas de los cuerpos. Aquí no es el "moldeado" del cuerpo lo que importa, sino su agilidad, una agilidad que se sitúa sobre todo en los pies y las piernas. En oposición a la dureza, ligero no significa aquí ausencia de fuerza. La fuerza está en este caso al servicio de la agilidad y favorece el deslizamiento de los cuerpos; se puede ver fácilmente a un adolescente casi lampiño hacer girar rápidamente por el salón a la matrona gorda sin hacer uso, aparentemente, de esfuerzo alguno. Ello sólo es posible porque la rolliza dama es flexible - $-y$ graciosa - y el joven, vigoroso en llevarla.

En segundo lugar, desde el punto de vista ético, quiero señalar el papel del baile (considerado al mismo tiempo actividad artística y de recreación) como valor supremo para sus practicantes, por encima de los

27 Bailes de "rodas de samba". El tipo de actividades realizadas en estos bailes de salón pueden compararse a los realizados en México y otros países latinoamericanos, con la rumba, el bolero e incluso el tango (N.T.).

28 La invasión de las gafieiras por parte de la clase media y la moda internacional de bailes de salón en los noventa hizo aparecer el fenómeno de las "academias" de baile como un elemento importante en las llamadas actividades físicas de salud. 
individuos, que sólo pueden ser valorados si desarrollan su propio "estilo". El baile de salón es visto como un arte, el arte supremo para quienes lo practican; el aprendizaje conlleva un entrenamiento de maestro a discípulo, junto con práctica constante y disciplinada de un conjunto de reglas, constituyendo así la transmisión de un babitus, en el sentido en que Bourdieu definió este concepto (Bourdieu, 1989).

En este habitus, más allá de la, evidentemente, disciplina del horario y de las posturas del cuerpo, de la forma de vestirse y de dirigirse a los condiscípulos y profesores, la ética (del baile) tiene un papel muy importante. Una de las reglas de esta ética se orienta a la caballerosidad, entendiéndose como tal el tratamiento respetuoso y cordial hacia las damas, no siendo permitidas durante las clases tácticas o estrategias de seducción con las alumnas o, por el contrario, de discriminación por la edad, color o complexión física de las mismas. La competencia entre los alumnos sólo es permitida en función del desarrollo del "estilo": el mejor bailarín, por su mayor identificación con el "espíritu de baile de salón" (su técnica y su ética), es capaz de crear su propio estilo. ${ }^{29}$ Una señal de madurez entre los caballeros es el poder conducir a cualquier dama, haciéndola bailar independientemente de su conocimiento o habilidad para el baile, imputándosele a él la responsabilidad por los eventuales "errores" de su dama.

Una dama de salón, por su parte, debe tener la sutileza de estar en suspenso permanentemente, sin saber a priori hacia dónde se dirige, para poder estar sincronizada con el próximo paso de su caballero. Este "estar en suspenso" recuerda el estado de "plenitud" del tai chi chuan, en el que el guerrero sigue estratégicamente los movimientos de su adversario, no anticipándose a él ni confrontándolo.

Lo que quiero dejar claro con estas observaciones es que el estilo individualista competitivo de interacción social dominante entre nosotros, queda culturalmente dislocado con estas prácticas. El contacto con el cuerpo de la pareja, o adversario, la expectativa de sus movimientos, la necesidad de entrar en armonía rítmica con el compañero, como posibilidad misma de realización del baile (o del arte marcial), nos llevan al conocimiento de la existencia de otro patrón de interacción entre los sujetos a nivel individual y colectivo.

Deseo señalar también otra forma de relacionarse los sujetos con su propio cuerpo y con el del otro. Al contrario del "uso de la máquina" o del "control de la máquina", nos encontramos frente a un patrón de contacto placentero con el cuerpo, motivado por los movimientos rítmicos y por el contacto de un cuerpo con el otro.

La armonía aquí es sinónimo de integración tanto interna como externa. La dualidad cuerpo/ mente desaparece bajo la sensación de ser un cuerpo fluido en movimiento - a diferencia de tener un cuerpo que necesita ser "moldeado" por la gimnasia para recuperar u obtener su forma. La armonía, empero, sólo es alcanzada si quien practica el baile se abandona al ritmo del movimiento (arte o baile), "perdiendo el control" de la máquina. Este estado se traduce, en términos del sentimiento, como una especie de alegria, un deleite estrechamente ligado a los movimientos corporales, que deben desarrollarse sin "esfuerzo", lo que no ocurre con otros ejercicios físicos.

En el caso del baile de salón, cuando este deleite se instala en los sujetos se lleva a cabo el "espíritu" (ethos) del baile de salón. Para sus practicantes, la salud se resume sencillamente a este estado. En el espacio de ese baile, de aquella clase, la salud es alegría, deleite.

Volviendo al inicio del tema de este trabajo la salud como paradigma universal o como utopía, puedo en este momento formular la hipótesis de que la búsqueda de la salud se volvió tan importante en la cultura contemporánea porque los valores que aseguran su presencia están ausentes. La cooperación, la cordialidad, la solidaridad, esta última aunque esté "focalizada", y el placer de estar en contacto con el otro y consigo mismo que favorece la integración y la creatividad social, están negadas por los valores de la sociedad actual.

29 Sin embargo, es innegable la competencia entre las distintas academias de baile, manifestándose inclusive en el estilo de cada una. Cada academia posee sus propios bailes, que los alumnos practican. De hecho, ocurren con frecuencia las visitas de cortesía entre los alumnos de las distintas academias, siempre y cuando se trate del mismo "estilo", generalmente propio de un mismo maestro. Ocurre entre las academias un verdadero "tribalismo", en el sentido en que M. Maffesoli (1987:cap. IV) define este término. 
El hecho de que ciertas actividades estén de vuelta y consideradas fundamentales para la salud, nos indica que tal vez sea el momento de incorporarlas a la escena de la cultura para que la salud, vista como alegría, pueda ser una realidad y no una utopía. Ello supone, sin embargo, la superación ética y política de los valores dominantes en la actualidad. Supone, además, la superación ética del individualismo (y su apego a lo meramente físico, narcisista), de la competencia y del consumismo como fundamento de las relaciones sociales. Si las nuevas prácticas en salud pueden, o no, constituirse en un paso hacia esa dirección, es un tema que deberá ser profundizado en otro trabajo.

\section{REFERENCIAS BIBLIOGRÁFICAS}

Attali, J., 1979. L'ordre canibale. París: Grasset.

Boltansky, L., 1979. As classes sociais e o corpo. Río de Janeiro: Graal.

Bourdieu, P., 1989. O poder simbólico. Lisboa: Difel.

Canevacci, M., 1996. Sincretismos. Uma exploração das bibridações culturais. Sao Paulo: Studio Nobel.

Casanova, P.G., 1997. "Globalidade, neoliberalismo e democracia". En: $A$ sociologia no horizote do século XXI (L.C. Ferreira, org.). Sao Paulo: Boitempo Editorial.

Castel, R., 1995. Les metamorphoses de la question sociale. París: Fayard.

Clavreul, J.L., 1978. L'ordre medical. París: Seuil.

Czeresnia, D., 1999. "O conceito de saúde e prevenção e promoção". Cadernos de Saúde Pública, en prensa.

Dupuy, J.P. \& Karsenty, S., 1974. L'invasion pharmaceutique. París: Seuil.

Foucault, M., 1977 [1963]. O Nascimento da clínica. Río de Janeiro: Forense Universitária.

Foucault, M., 1979. Microfísica do poder. Río de Janeiro: Graal.

Illich, I., 1975. Nêmesis da medicina, a expropriação da saúde. Río de Janeiro: Nova Fronteira.

Kurz, R., 1997. Os últimos combates. Petrópolis: Vozes.

Lessa, C.; Tavares, L. \& Dain, S., 1997. Pobreza e política social. Exclusão social nos anos 90s". Estudos Marxistas, 3:63-87.
Luz, M.T., 1979. As instituções médicas no Brasil. Instituição e estratégia de begemonia. Río de Janeiro: Graal.

Luz, M.T., 1988. Natural racional, social. Razão médica e racionalidade científica moderna. Río de Janeiro: Campus (existe traducción a español: Editorial Lugar, Buenos Aires, 1997).

Luz, M.T., 1994. O corpo da cidade. En: Olhares sobre a cidade (R.M. Pechman, comp.), pp. 181193. Río de Janeiro: UfrJ.

Luz, M.T., 1997. Cultura contemporánea y medicinas alternativas: nuevos paradigmas en salud al final del siglo xx. En: Salud, cambio social y politica. Perspectivas desde América Latina (M.N. Bronfman y R. Castro, comps.), pp. 363-382. México, DF: EDAMEX/InsP (versión en portugués: Physis, Vol. 7, No 1, Río de Janeiro, UERJ/IMS, 1997).

Luz, M.T., 1998. Comparação de representações de corpo, saúde, doença e tratamento em pacientes e terapeutas de homeopatia, acupuntura e biomedicina. Estudos em Saúde Coletiva, 167:5-25.

Luz, M.T., 1999. Homeopatia, medicina e arte de curar. Comunicación presentada en la mesa redonda Sistema de Representações e Práticas Sociais sobre Doenças e Curas, XI Congresso Nacional de Sociólogos, Salvador de Bahía, 11-14 de mayo.

Maffesoli, M., 1987. O tempo das tribus. O declínio do individualismo nas sociedades de massa. Río de Janeiro: Forense Universitária.

Nogueira, R.P., 1994. Perspectivas da qualidade de vida. Río de Janeiro: QualityMark.

Nogueira, R.P., 1998. A saúde pelo svesso. Uma interpretação de Ivan Illich. Tesis de Doctorado en Salud Colectiva, Río de Janeiro: IMS/UERj.

Ramonet, I., 1998. Geopolítica do caos. Petrópolis: Vozes.

Sfez, L., 1995. La santé parfaite. París: Seuil.

Soares, L.T.R., 1999. Ajuste neoliberal e desajuste social na América Latina. Río de Janeiro: UfrJ.

Tavares, M.C. \& Fiori, J.L., 1997. Poder e dinheiro. Uma economia da globalização. Petrópolis: Vozes.

Valla, V.A. (de), 1999. A educação popular e a saúde e as formas alternativas de lidar com a saúde. Mimeo. Río de Janeiro.

Traducción a español: antropólogo Júlio de Freitas Taylor 


\section{MeDICINA ALTERNATIVA (iMEDICINA COMPLEMENTARIA?) COMO FENÓMENO SOCIAL. HACIA LA CONSTRUCCIÓN DE UN NUEVO MODELO DE SALUD}

Marianela Castés Boscán"

\section{EL PARADIGMA CARTESIANO DE LA SALUD}

Para una mejor comprensión de la medicina alternativa o complementaria como fenómeno social, debemos enmarcar este fenómeno en la percepción del mundo actual, caracterizado por sus interconexiones a un nivel global, en el que los fenómenos físicos, biológicos, psicológicos, sociales y ambientales son todos recíprocamente interdependientes. En la actualidad está en proceso la construcción de una nueva visión de la realidad, un nuevo "paradigma", es decir, una transformación fundamental de nuestro modo de pensar, de nuestro modo de percibir y de nuestro modo de valorar, y por supuesto el paradigma de la salud no está excepto de este cambio.

La medicina, como las otras ciencias, se ha apoyado durante trescientos años en el modelo newtoniano-cartesiano que le ha dado un estatus de cientificidad. De la influencia de este paradigma en el pensamiento médico resultó el llamado modelo biomédico, que constituye la base conceptual de la medicina científica tradicional, basada en dos grandes principios: el mecanicismo y el reduccionismo —el primero concibe los organismos vivientes como máquinas constituidas por diferentes partes, y el reduccionismo se basa en la idea de que todos los aspectos de un organismo pueden comprenderse reduciéndolos a sus constituyentes más pequeños y luego estudiando los mecanismos de interacción de éstos. La ciencia de la medicina sigue basándose, como escribe George Engel (1977), en el concepto del "cuerpo humano como una máquina que puede analizarse desde el punto de vista de sus partes; la enfermedad es la avería de la máquina, es decir, el funcionamiento defectuoso de los mecanismos biológicos que se estudian desde el punto de vista de la biología celular y molecular, y la tarea del médico es intervenir, física o químicamente, para corregir disfunciones de un mecanismo específico".

Sin embargo, el paradigma cartesiano comienza a derrumbarse y existen muchos problemas que los biólogos actuales no pueden resolver, debido a su enfoque físico, parcial y fragmentario, lo que parece estar relacionado con el funcionamiento de los sistemas vivientes como unidades y con las interacciones que éstos tienen con el entorno.

Hay una gran diferencia entre una máquina y un organismo. Las máquinas funcionan según cadenas lineales de causa y efecto, y cuando se estropean es posible identificar una causa única de la avería. Por el contrario, el funcionamiento de los organismos vivos sigue los modelos cíclicos de flujo de información conocidos como retroalimentación. Por ejemplo, el componente A puede afectar al B, éste puede influir en el C, y el C, a su vez, puede afectar retroactivamente al A, de suerte que el círculo se cierra. Los sistemas vivientes "autorganizadores" presentan un aspecto esencial, que es la autorrenovación. Mientras que una máquina se construye para fabricar un determinado producto, o para realizar una tarea específica, un organismo se ocupa principalmente de renovarse a sí mismo. El páncreas, por ejemplo, reemplaza la

Química, PhD en inmunología, jefa de la Cátedra de Inmunología de la Escuela José María Vargas, Facultad de Medicina, Universidad Central de Venezuela. E-mail: mcaste@telcel.net.ve 
mayoría de sus células cada 24 horas; la mucosa del estómago, cada 3 días; los glóbulos blancos se renuevan cada 10 días. Todos estos procesos se regulan de tal manera que conservan la estructura general del organismo. Una máquina dejará de funcionar cuando sus partes no funcionen de la manera rigurosamente predeterminada, pero un organismo seguirá funcionando en un ambiente cambiante, manteniéndose en condiciones y reparándose a través de la curación y de la regeneración (Capra, 1985).

Como señala Miguel Martínez Miguélez (1999), un concepto muy limitante del enfoque reduccionista es la creencia de que la estructura genética es lo único que determina los caracteres de un organismo. Este determinismo genético es una consecuencia directa de la concepción según la cual los organismos vivientes son máquinas controladas por cadenas lineales de causa y efecto. En la actualidad, los biólogos modernos entienden perfectamente el alfabeto del código genético, pero parece como si desconocieran casi por completo su sintaxis.

El mundo de los sistemas no-lineales, a que pertenecen todos los organismos vivos, puede ser impredecible, violento y dramático. Un pequeño cambio en un parámetro puede hacer variar una solución poco a poco, y de golpe, variar a un tipo totalmente nuevo de solución, como cuando en la física cuántica se dan los saltos cuánticos, que son un suceso absolutamente impredecible, que no está controlado por las leyes causales sino solamente previsto por las leyes de la probabilidad.

Para el modelo cartesiano, hablar de salud es referirse en términos concretos, operativos, a la ausencia de enfermedad. Es reducirla estrictamente al ámbito individual, al espacio clínico hospitalario, al cuidado del cuerpo que padece, centrado en el estudio y combate de la patología, es decir, a su diagnóstico, pronóstico, terapéutica y prevención tal como ha sido considerada tradicionalmente por la medicina curativa, con un marco de referencia biomédico, reduccionista, anatomoclínico. En otras palabras, es vista como ciencia natural, a consecuencia de lo cual desaparece la persona en toda su complejidad, como centro de estudio del campo de la medicina, para privilegiar la célula, los tejidos, los órganos. En ese miscroscópico espacio no tienen cabida las realizaciones cotidianas del hombre, su condición intrínsecamente social, ni su mundo interno, poblado de subjetividad, fantasía, sueños, creencias, ni su capacidad amatoria (Castés \& Canelones, 1999).

Los organismos vivientes requieren por lo tanto una visión integral, y esta visión es difícil de comprender desde la perspectiva de la ciencia clásica. Es así que en esta búsqueda de bases científicas para la construcción de un nuevo modelo de salud, nos aproximaremos a la psiconeuroinmunología, que nos está proporcionando nuevos conocimientos y herramientas para la elaboración de una visión integral del ser humano.

\section{Psiconeuroinmunología: Base CIENTífica}

\section{PARA LA CONSTRUCCIÓN DE UN NUEVO}

\section{MODELO DE SALUD}

\section{MEDICINA PSICOSOMÁTICA EN EL ORIGEN DE LA}

\section{PSICONEUROINMUNOLOGÍA}

Desde hace varias décadas se comenzó a desarrollar la medicina psicosomática como disciplina científica que se interesa particularmente por el estudio de las relaciones entre los aspectos biológicos y psicológicos de la salud. Los clínicos y los investigadores modernos son cada vez más conscientes del hecho de que prácticamente todos los trastornos son psicosomáticos, en el sentido de que suponen una continua interacción entre la mente y el cuerpo en su origen, desarrollo y curación. Los médicos tienden a clasificar como psicosomática cualquier enfermedad cuyo origen y desarrollo no resulten comprensibles dentro de la estructura biomédica y a etiquetar como efecto placebo cualquier proceso de curación introducido por las expectativas positivas del paciente y por su fe en el médico y en el tratamiento, mientras que la curación que ocurre sin ninguna intervención médica se denomina remisión espontánea. El verdadero significado de estas tres expresiones es muy similar: las tres se refieren a los poderes curativos de la actividad mental del paciente, que puede influir positivamente en la dinámica fisicoquímica de su cuerpo (Martínez-Miguélez, 1999). 
Como una consecuencia lógica de la medicina psicosomática, esta última década ha sido testigo de una verdadera explosión de información a nivel celular y molecular que revela que la respuesta inmunológica, al contrario de lo que se había planteado hace unos años, está sujeta a regulación por el sistema nervioso central (SNC) y el sistema endocrino. Esta regulación se realiza por intermedio de neurohormonas a través del eje hipotalamo-pituitaria-glandulas adrenales (eje HPA), neuro-transmisores centrales y periféricos y mediadores secundarios bajo su influencia (Ader, Felten \& Cohen, 1991; Besedovsky \& Sorkin, 1977; Besedovsky et al., 1991). El estudio de estas interacciones es el objeto de la psiconeuroinmunología (PNI), que es la ciencia transdisciplinaria que estudia las interacciones entre el comportamiento, el SNC, el sistema endocrino y el sistema inmunológico (revisado por Castés \& Pocino, 1999). Sus aspectos clínicos van desde el entendimiento de los mecanismos biológicos bajo la influencia de factores psicosociales, hasta los aspectos biorregulatorios, que incluyen la red compleja de interacciones generadas por los sistemas neuroendocrino e inmunológico en el mantenimiento de la salud y en la lucha contra las enfermedades (Solomon, 1993, 1995).

\section{SisTEMA INMUNOLÓGico}

Para la mejor comprensión de lo que esta nueva disciplina significa, es importante definir previamente, aunque sea de forma muy breve, lo que es el sistema inmunológico y el papel primordial que juega en la protección del organismo contra agentes patógenos. La palabra inmunidad viene del latín inmunis, que significa "libre de"... libre de sustancias extrañas. $\mathrm{Al}$ sistema inmunológico tradicionalmente se le ha concebido como el sistema de defensa del organismo, el que nos protege de invasores extraños, externos o internos, que nos pueden enfermar. Esas sustancias extrañas son principalmente los microorganismos que nos atacan desde afuera, como los hongos, las bacterias, los parásitos y los virus. Pero también podemos ser atacados desde el interior del organismo, por células que en el proceso normal de división y multiplicación celular pueden, por un error genético, transformarse en células malignas, y con el tiempo llegar a formar un tumor. Los organos transplantados también son percibidos por el organismo como un agente extraño que hay que rechazar. Todos estos elementos que son extraños al organismo es lo que se conoce en inmunología con el nombre de antígeno. Cuando un antígeno entra al organismo, el sistema inmunológico primeramente debe reconocctlo; este reconocimiento permite la activación de la respuesta inmunológica, lo cual a su vez conduce a la activación de los mecanismos efectores, que son los que en definitiva van a destruir al microorganismo en cuestión o a una célula tumoral, por ejemplo.

Sin embargo, recientemente también se ha reconocido que el sistema inmune es además un sistema endocrino y un sistema sensorial (Blalock, 1984, 1988). Un sistema endocrino en tanto que es capaz de producir prácticamente todas las hormonas que tradicionalmente se pensaba que sólo el sistema endocrino producía. También se ha postulado que el sistema inmune es un órgano sensorial en el cual los leucocitos reconocen estímulos tales como productos virales y bacteriales, que secretan señales que reportan este fenómeno al SNC y periférico.

\section{EVIDENCIAS ANATÓMICAS, FISIOLÓGICAS Y}

FUNCIONALES QUE DEMUESTRAN QUE EL SNC, EL

\section{SISTEMA ENDOCRINO Y EL SISTEMA INMUNOLÓGICO SE}

\section{COMUNICAN ENTRE SÍ}

1. Las evidencias anatómicas demuestran que el parénquima de órganos linfoides primarios (timo y medula ósea) y secundarios (bazo, ganglios linfáticos, tejido linfoide asociado al intestino) están inervados por fibras nerviosas noradrenérgicas postganglionares del sistema nervioso parasimpático y por fibras nerviosas peptidergicas (Felten et al., 1985). Estas fibras nerviosas están en contacto directo con los linfocitos y los macrófagos formando uniones neuroefectoras. Además, los neurotransmisores secretados por estos nervios pueden difundirse y actuar a una distancia considerable del sitio desde donde fueron liberados, en una forma paracrina, extendiendo así el rango fisiológico de la interacción entre el SNC y el sistema inmunológico. 
2. Las evidencias funcionales provienen de las lesiones practicadas en diversas regiones del cerebro, lo cual redunda en una alteración de diversos parámetros de la respuesta inmunológica (Berczi \& Nagy, 1991).

3. Las evidencias fisiológicas han demostrado la presencia de receptores en la membrana y citoplasma de los leucocitos, para una diversidad de hormonas y neuropeptidos, que brinda una oportunidad única a los leucocitos para recibir y transmitir señales del mundo exterior. Se ha demostrado que: i) las hormonas de las glándulas pituitaria y adrenal son inmunomodulatorias; ii) los linfocitos y células accesorias del sistema inmune poseen receptores para hormonas y neurotransmisores; iii) productos elaborados por los leucocitos pueden comunicarse y modular las respuestas del sistema nervioso y del sistema endocrino; iv) los linfocitos pueden producir hormonas (Ader, Felten \& Cohen, 1991).

Estas observaciones han permitido proponer que hormonas derivadas de los leucocitos sirven como reguladores endógenos del sistema inmune, así como mensajeros de la información del sistema inmune al sistema neuroendocrino. Además, la estimulación directa de las fibras nerviosas sensoriales pueden ser activadas por las citoquinas u otros productos de secreción del sistema inmune.

Asimismo, se ha demostrado que el condicionamiento clásico (Ader \& Cohen, 1975) puede influenciar la respuesta inmune en ambas direcciones: inmunosupresión e inmunoestimulación, y que el mismo ha sido usado para modificar el resultado de una enfermedad autoinmune en un modelo experimental (Ader \& Cohen, 1982).

\section{Modelo de INTERACCión entre el SNC, el}

\section{SISTEMA ENDOCRINO Y EL SISTEMA INMUNOLÓGICO:}

\section{EFECTO DEL ESTRÉS}

No se puede hablar de psiconeuroinmunología sin hablar de estrés. Estrés es la respuesta del organismo a influencias ambientales que tienden a empujar las funciones del sistema fuera de su balance normal. Un estresante es un estímulo que induce una respuesta fisiológica anormal. Se ha podido también demostrar la interacción entre el SNC, el sistema endocrino y el sistema inmunológico, explicando los eventos que se suceden cuando el SNC procesa la información sobre eventos estresantes, tanto de orden emocional como físico, lo cual va a depender del estado actual del individuo, así como de sus experiencias pasadas, que le servirán de base para la interpretación de dichos eventos. Esta información viaja a través del SNC, tanto por la vía del eje hipotalamo-pituitaria-adrenal como por la vía autonómica, hasta el sistema inmune. Es decir, que el estrés - ya sea por la vía neuroendocrina o por la vía autonómica - conduce a la liberación de moléculas en las glándulas adrenales, que tienen un efecto supresor sobre la respuesta inmune (Munck et al., 1984).

Un ejemplo del funcionamiento de este mecanismo se observa en los deprimidos crónicos, en quienes se ha demostrado que la producción de GC aumenta por encima de los valores normales, lo cual puede aumentar considerablemente el riesgo de enfermedad (Stein, Miller \& Trestman, 1991).

Todos estos hallazgos de laboratorio correlacionan con una literatura científica relativamente consistente que sugiere que individuos que experimentan cambios negativos en su vida reciente tienen un mayor riesgo de contraer una variedad de enfermedades, incluyendo enfermedades infecciosas (Cohen \& Syme, 1985). Asimismo, en varias condiciones de estrés crónico, tales como viudez, divorcio, pobre relación marital, familiares de pacientes con Alzheimer y estrés académico (KiegoltGlaser et al., 1987a, 1987b), se ha encontrado una disminución de parámetros inmunológicos, tales como disminución de la actividad de las células "natural killer" (esenciales en la lucha antitumoral), aumento del cortisol plasmático (que causa una supresión de la respuesta inmune), disminución de la respuesta de células $T$ frente a mitógenos (esenciales en la lucha contra una diversidad de patógenos) y aumento de los títulos de anticuerpos contra el virus de Epstein Barr (evidencia de una reactivación viral). Por ejemplo, los viudos (as) generalmente tienen una mayor morbilidad y mortalidad que los controles apareados y experimentan una mayor incidencia de mortalidad por cáncer que la población en general (Verbrudge, 1979). 


\section{UN NUEVO MODELO DE SALUD}

De los conceptos antes mencionados se evidencia cómo la psiconeuroinmunología ha generado un replanteamiento de temas de vital importancia para el discurso contemporáneo sobre la salud y la enfermedad y apoya ampliamente la muy acertada definición de salud de la Organización Mundial de la Salud: "La salud es un estado de completo bienestar físico, mental y social y no simplemente la ausencia de enfermedad o de males".

Por los aportes de las ciencias sociales hoy sabemos que la salud y la enfermedad, al igual que otras cualidades humanas, se expresan diferencialmente en las personas y son producto de la vida del hombre en una sociedad concreta, como miembro de una determinada clase, con un tipo particular de relaciones sociales que van a condicionar en forma diferente la aparición de enfermedades cuyas causas se encuentran íntimamente ligadas a su forma de vida, como afirma el demógrafo Vera Pinto: "El hombre no muere de muerte, muere de vida". De este modo la salud y la enfermedad están inscritas en la cultura del hombre, en sus relaciones sociales, calidad de vida, manejo del poder, como fuentes potenciales de estrés en la vida cotidiana (Castés y Canelones, 1999).

El desarrollo de la psiconeuroinmunología constituye uno de los ejemplos más recientes de las evidencias científicas que ponen de manifiesto que la enfermedad no es "un sin sentido", un accidente fortuito que irrumpe en la vida de la persona, sino que implica la participación del ser humano social como totalidad compleja en su proceso de salud o de enfermedad, y plantea nuevamente la participación individual y colectiva para la autodeterminación de la vida y la salud vista como un hecho con un profundo significado existencial.

Por lo tanto, como lo señala Pablo Canelones (Castés y Canelones, 1999), nos enfrentamos al reto de poder rescatar al hombre y sus realizaciones en todos sus espacios de expresión, sin prescindir del tubo de ensayo que nos pone en contacto con unidades de análisis a un nivel molecular, pero distinguiendo que un alto nivel de adrenalina o cualquier neurotransmisor en sangre nunca será equivalente a la profunda conmoción que experimenta una madre ante la muerte de un hijo.

Por lo tanto, la psiconeuroinmunología nos lleva a considerar la salud como "...esa tendencia a la armonización biopsicológica, que supone fuerzas, potencialidades, capacidades vitales humanas, expresiones de la dinámica biológica de ese sujeto, de su estructura y dinámica psíquica, que se han ido construyendo en su proceso muy concreto de historia vital, desde la misma concepción. Historia vital que es esencialmente social, por cuanto se construye en el compartir con los otros en una multiplicidad de relaciones, la satisfacción de las necesidades, el trabajo, la comprensión de la sociedad y de sí mismo..." (Pacheco, 1996).

En un nuevo enfoque de la salud y de la enfermedad basado en el nuevo paradigma holista, deberían reconocerse las posibilidades que un individuo tiene de sanar directamente, cultivando y desarrollando los procesos naturales, fisiológicos y psicológicos que facilitan la recuperación de la salud. La investigación biomédica tendrá que integrarse en un sistema de asistencia sanitaria mucho más extenso, que conciba las manifestaciones de los males de la humanidad como resultados de una interacción entre mente, cuerpo y entorno, y los trate de acuerdo con esta compleja interdependencia.

\section{MEDiCinA ALTERNATIVA, MEDICINA COMPLEMENTARIA}

La medicina complementaria (o alternativa, cuyo término es menos apropiado) debe ser evaluada a la luz de los cambios que está generando este nuevo modelo de salud anteriormente expuesto. Para comenzar, lo primero que intentaremos es una definición de medicina alternativa o medicina complementaria como aquella que se asocia con prácticas médicas fuera de la corriente médica oficial. Históricamente la medicina ortodoxa ha luchado con mucho vigor contra algunas prácticas de la medicina alternativa, denunciándolas, atacándolas, restringiendo el acceso a ellas, descalificándolas e inclusive imponiendo penas legales a sus practicantes. Sin embargo, cuando estas terapias persisten e incluso aumentan en popularidad, la medicina oficial se vuelve 
más amigable, las examina, identifica sus similitudes con la medicina ortodoxa, y finalmente las integra en su práctica mádica; entonces podemos hablar de medicina complementaria (Jonas, 1998). El mejor ejemplo lo tenemos en las terapias corporales como los masajes, hoy ampliamente reconocidos por su utilidad terapéutica y preventiva y recomendados por la medicina oficial.

Aunque el término medicina alternativa es el nombre usado comúnmente, a lo largo de este trabajo nos referiremos principalmente a medicina complementaria, que de hecho está sustituyendo ampliamente al de medicina alternativa, salvo en aquellos casos en los que queramos específicamente referimos al carácter alternativo de una práctica en particular.

Lo primero que hay que señalar es que la medicina complementaria (alternativa) se ha convertido en un fenómeno de alta prevalencia en la mayoría de los países industrializados. En Estados Unidos, $40 \%$ del público utiliza la medicina complementaria y supera por mucho las visitas a la medicina oficial (Eisemberg et al., 1998). En el Reino Unido cerca de una cuarta parte de la población usa al menos una forma de medicina alternativa o complementaria en un momento dado (Fisher y Ward, 1994). El impacto económico de la medicina complementaria es enorme, 12 billones de dólares se gastan cada año en los EEUU, excluyendo los costos de drogas y literatura (Eisenberg et al., 1993), y existen evidencias de un aumento continuo en la utilización de la medicina complementaria (Northcott y Bachynsky, 1993). El aumento en la popularidad de la medicina alternativa y complementaria refleja cambios en las necesidades y valores de la sociedad moderna en general, que tienen que ver con el cambio de paradigma al que nos hemos referido. Algunos de estos factores que deben ser tomados en consideración son: un aumento en la prevalencia de enfermedades crónicas, un aumento en el acceso que tiene el público a la información sobre la salud, el sentido más realista que tienen ahora las personas sobre lo que es calidad de vida, una reducida tolerancia al paternalismo, una disminución en la fe de que sólo la ciencia pueda ser relevante para el tratamiento individual de las enfermedades, así como un interés incrementado en la espiritualidad (Starr, 1982:514;
Furnham \& Forey, 1994). Unido a esto están los efectos adversos y elevados costos de la medicina convencional, que está ejerciendo presión para la búsqueda de nuevas alternativas para la prevención y manejo de la enfermedades (Astin, 1998).

Hoy en día se comienza a ver un esfuerzo para integrar las prácticas alternativas en la corriente oficial, convirtiéndolas en prácticas complementarias (Jonas, 1998). Por ejemplo, el 60\% de las escuelas de medicina han empezado a incluir en sus pensa prácticas de medicina complementaria, y ya muchos hospitales están creando programas de medicina complementaria (Wetzel et al., 1998). Organizaciones de investigación biomédica están invirtiendo cantidades sustanciales de dinero en la investigación de estas prácticas. Por ejemplo, la Oficina de Medicina Alternativa del Instituto Nacional de Salud Pública de Estados Unidos (1998) se ha convertido en el Centro Nacional para la Medicina Alternativa y Complementaria, con un presupuesto de 50 millones de dólares. Un número del Journal of American Medical Association (vol. 280, 1998) estuvo dedicado íntegramente a este tema e ilustra la calidad de la investigación científica que puede ser llevada a cabo y publicada en medicina complementaria.

Sin embargo, la medicina alternativa o complementaria, así como la medicina convencional, tiene sus pro y sus contras, los cuales analizaremos críticamente a continuación, algo sumamente importante para la construcción de un nuevo modelo de salud. Es necesario rescatar los beneficios de la medicina complementaria e integrarlos en la medicina oficial, lo que redundaría en una atención más integral y humanista al paciente y formas más óptimas de prevención.

\section{RIESGOS DE ABRAZAR LA MEDICINA}

\section{ALTERNATIVA}

\section{LA CALIDAD DEL CUIDADO}

Los componentes formales de una licenciatura o grado de doctor que se necesitan para ser profesional de la salud, no son requeridos para los. practicantes de la medicina alternativa. Esto incluye 
la longitud de los estudios, los exámenes, certificación y un código disciplinario de acción, entre otros (Milbank Memorial Fund, 1998). Por ejemplo, en Estados Unidos los 50 estados otorgan licenciaturas para la medicina quiropráctica, pero sólo la mitad lo da para la acupuntura y la terapia de masaje, y menos aún para la homeopatía y la naturopatía. En los países en vías de desarrollo la situación podría ser aún más dramática.

\section{LA CALIDAD DE LOS PRODUCTOS}

Los productos "naturales" usados por la medicina alternativa en su gran mayoría no están sujetos a control de calidad. Estos productos se encuentran en el mercado como suplementos de la dieta y pueden estar contaminados o variar ampliamente en su contenido, calidad y seguridad (Ernst, 1998). Así, si un producto demuestra su efectividad, ello no quiere decir que todos los productos que se vendan en el mercado serán igualmente efectivos.

\section{LA MEDICINA ALTERNATIVA NO ES CIENTÍFICA}

Ciertamente, la medicina oficial casi por definición ha luchando por ser científica, aunque en términos históricos la aplicación del método científico a la medicina es relativamente reciente, y no todos los procedimientos ortodoxos tienen bases científicas. Por ejemplo, se ha estimado que $85 \%$ de nuestro repertorio terapéutico no llena este criterio (Smith, 1991). Sin embargo, las fundaciones científicas de la medicina alternativa son aún más débiles que las de la medicina oficial. Con argumentos como que sus prácticas son muy individuales y holísticas para ser estudiadas científicamente, muchas de estas prácticas se esconden detrás de la anécdota, casos seriados o "investigaciones en curso" (Coulter, 1991). Aceptar tales puntos de vista equivale a rechazar las grandes batallas ganadas por la medicina oficial en las últimas décadas mediante el uso del conocimiento biológico, los estudios aleatorios y el desarrollo de protocolos clínicos controlados (Jonas, 1997). Adoptar la medicina alternativa sin desarrollar estándares de calidad para sus prácticas, productos e investigación sería fatal para el cuidado de la salud de la población en general. Por lo tanto, la medicina alternativa debe cambiar y tratar de adoptar estándares científicos. Todas las prácticas médicas tienen la obligación ética de retener estas fortalezas en beneficio de los pacientes.

\section{LA MEDICINA COMPLEMENTARIA NO ES MÁS QUE}

\section{UN EFECTO PLACEBO}

Se ha especulado a menudo que el aparente éxito de la medicina complementaria es debido a un poderoso efecto placebo (Oh, 1994). Esto puede ser verdad en algunos casos, pero no se debe generalizar. Varios tratamientos complementarios tienen acciones específicas, hasta el punto que los efectos colaterales son un problema (Soragna et al., 1993; D’Arcy, 1993), lo que hace pensar que no todo es solamente efecto placebo. Por supuesto, este argumento en contra debe también ser evaluado a la luz de los nuevos conocimientos que se tienen sobre el efecto placebo y su importante contribución en el proceso de autocuración.

\section{LA MEDICINA ALTERNATIVA NO RECONOCE SUS}

\section{LIIMITES}

La medicina alternativa (aquí me refiero más el término medicina alternativa que complementaria) puede ser profundamente dañina cuando previene un diagnóstico apropiado o efectivo, para lo cual la medicina oficial ha demostrado altamente su competencia. Como cualquier otra terapia, es definitivamente peligrosa cuando es usada en forma incompetente. Lamentablemente, debido al primer punto explicado en esta sección, abundan los practicantes abusivos e incompetentes en la medicina alternativa. También es dañina cuando hace perder al paciente recursos financieros y otros.

\section{BENEFICIOS DE LA MEDICINA COMPLEMENTARIA}

\section{El FENÓMENO DE LA SANACIÓN}

La mayoría de los sistemas de medicina complementaria prestan atención al sufrimiento que acompaña a las enfermedades. El tiempo que 
pasa un practicante de la medicina alternativa con un paciente generalmente excede al que pasa un médico convencional, y los pacientes se sienten más satisfechos en sus interacciones con la práctica no ortodoxa que con la ortodoxa (Ernst et al., 1997). Los practicantes de la medicina complementaria proporcionan a los pacientes una mayor comprensión, sentido y autocuidado para el manejo de su condición, así como una mayor sensación de poder y participación en el proceso de sanación. Este aspecto, en vista de los aportes de la psiconeuroinmunología, es sumamente importante. El tiempo y la atención personal son elementos esenciales de toda la medicina, y estos elementos se están perdiendo fácilmente con la subespecialización, tecnología y factores económicos de la medicina moderna. Por lo tanto, este es uno de los aspectos que debería apropiarse la medicina convencional, así como tratar de desarrollar un mejor lenguaje para el manejo de la enfermedad y el sufrimiento.

\section{EFeCTOS ADVERSOS DE LA TERAPÉUTICA}

\section{CONVENCIONAL}

La popularidad de la medicina complementaria (o alternativa) en este siglo también se ve incrementada por la percepción de que los tratamientos convencionales son muy agresivos para ser usados en las enfermedades crónicas o de alto riesgo (Furnham \& Forey, 1994). La enfermedad iatrogénica causada por la medicina convencional es una de las principales causas de muerte y hospitalización en Estados Unidos. Se ha podido determinar que uno de cada cinco pacientes admitidos en un hospital contrae una enfermedad iatrogénica, y de éstas la mitad son el resultado de complicaciones debidas a los medicamentos y más de un $10 \%$ son causadas por errores de diagnóstico. Muchas de las prácticas de la medicina alternativa han reducido sus efectos adversos. Sin embargo, no existe un tratamiento ideal sin un efecto dañino potencial. La medicina alternativa también puede tener efectos nocivos colaterales cuando se usa una hierba que es tóxica, o que está contaminada con una sustancia venenosa (MacGregor et al., 1989). Pero en general, la medicina convencional debería aprender de la medicina complementaria de cómo ser más suave en su aproximación al paciente, enfocándose en su inherente capacidad para la autocuración, que es algo que la medicina oficial ignora completamente (Antonovsky, 1987).

\section{LO QUE IMPORTA ES AYUDAR AL PACIENTE}

Este es el argumento más frecuentemente utilizado por los proponentes de la medicina complementaria y a simple vista puede parecer un poderoso argumento. Particularmente cuando tratan con condiciones para las cuales la medicina ortodoxa no ha encontrado cura (y éste parece ser el dominio de la medicina complementaria), los remedios complementarios se justifican: si no hay más nada, ellos proporcionan confort y esperanza. Aunque uno debiera puntualizar que empatía y confort deben ser también proporcionados por la medicina ortodoxa. La medicina ortodoxa sostiene que una falsa esperanza puede ser trágica para el paciente. Frente a esto el Dr. Norman Cousins (1989) afirma: "No hay tal cosa como una falsa esperanza, hay o no hay esperanza. La disyuntiva es entre una falsa esperanza y un falso miedo, y es importante saber que emociones negativas generadas por estos últimos se transforman en biología en el organismo". Esta aseveración se apoya en las bases científicas que nos proporciona la psiconeuroinmunología, que así lo demuestran. Frente a esta posición, la medicina ortodoxa postula argumentos en contra diciendo que pretender que un tratamiento específico contra tal dolencia ha sido descubierto, crearía un clima peligrosamente inhibidor para una búsqueda más fructífera del paciente en otros tratamientos.

También argumentan que si una persona fue ayudada en alguna oportunidad por el efecto placebo asociado con un método poco efectivo cuando sufría una condición benigna, esa persona estaría en peligro de optar por el mismo tratamiento en la oportunidad de una grave enfermedad. Podemos preguntarnos, si una vez la ayudó sus expectativas positivas, ¿no scría posible que la ayudara también en esta ocasión? 


\section{SÓlO LA MEDICINA COMPLEMENTARIA TRATA AL}

\section{INDIVIDUO COMO UN TODO}

El argumento holístico trata de separar la medicina complementaria de la medicina oficial. La medicina oficial, basada en el reduccionismo explicado anteriormente, se preocupa sólo de las partes de un individuo (órganos, un síntoma o un valor de laboratorio). La medicina complementaria proclama una mayor perspectiva del individuo como un todo, incluyendo su ambiente, psicología y espíritu. Sin embargo, se puede argumentar que la psicología y la sociología no son invenciones de la medicina complementaria. La actitud holística no es una invención de la medicina complementaria, sino que debe ser integrada en una buena práctica clínica. De hecho, basándose en el cambio de paradigma fundamentado en la PNI se están sentando las bases científicas para que la medicina oficial considere reintegrar la perspectiva del individuo como un todo en su práctica, ya que ésta ha sido olvidada o perdida en algún lugar.

\section{PRINCIPIOS RAZONABLES PARA APROXIMARSE}

\section{A LA MEDICINA ALTERNATIVA O}

\section{COMPLEMENTARIA}

Como vemos, hay varios aspectos favorables de la medicina complementaria, los cuales perfectamente pueden ser integrados en la práctica médica ortodoxa, que como explicamos anteriormente tienen que ver con el cambio de paradigma en el modelo de salud. Por lo tanto, nos hemos permitido enumerar algunos principios que nos parece razonable tener en mente al aproximarnos a la medicina alternativa:

1. Mantener una actitud de mente abierta acerca de nuevas intervenciones terapéuticas potencialmente buenas, que incluyen aquellas comúnmente referidas como medicina alternativa o complementaria. Si se quiere verdaderamente ayudar a los pacientes, ambas partes (medicina oficial y complementaria) deben tratar de liberarse de los prejuicios y estar conscientes de los hechos relevantes. Proponentes y opositores deben considerar el no continuar con el hábito de sólo citar selectivamente lo que les interesa, ignorando aquellos hechos que no fijan con sus argumentos.

2. Facilitar estudios controlados y cuidadosamente hechos de estas nuevas terapias. Se necesita urgentemente una mejor investigación en la medicina complementaria. Sistemáticamente deben ser evaluadas su efectividad, su seguridad y subsecuentemente su costo-efectividad. Es cierto también que sin fondos no hay investigación. Así, los organismos financiadores deben reconsiderar su política de financiamiento y comenzar a proporcionar fondos para la investigación de terapias alternativas y complementarias, y no sólo para aquellos que tiene que ver con la biotecnología.

3. No seguir ignorando o ridiculizando el potencial del efecto placebo para producir beneficios terapéuticos marcados. Ciertamente, existe una explicación fisiológica para tal efecto, por ejemplo, la liberación de endorfinas por parte del sistema nervioso central.

4. No aceptar incondicionalmente todas las nuevas terapias como eficaces. Los alardes sobre la eficacia terapéutica de una práctica determinada primeramente deben ser científicamente comprobados.

5. Evitar las actitudes arrogantes de algunos proponentes de cierto procedimiento o práctica de la medicina alternativa porque se pueden sentir abrumados por la demostración subsiguiente sobre su poca eficacia clínica.

La medicina oficial tiene lecciones que aprender, la lección acerca de disponer de más tiempo y empatía para el paciente, maximizar el efecto placebo y tomar seriamente, aunque sean pequeñas, las quejas de los pacientes. La forma como el doctor da un diagnóstico; la manera como crea un ambiente que conduzca a un tratamiento médico efectivo; la forma como inspira al paciente a convertirse en un participante activo en su proceso de recuperación; la forma como toma en cuenta las necesidades emocionales del paciente y de los miembros de su familia, son todos factores que deben ser atendidos en una relación médico-paciente eficaz, y éstas quizás 
son algunas de las lecciones que nos está aportando la medicina complementaria. Hay que revivir al buen doctor de cabecera, el cual muchos pacientes sienten que se ha perdido en nuestra moderna medicina altamente tecnológica.

\section{CONCLUSIÓN}

Como principal conclusión de este trabajo podemos afirmar que la psiconeuroinmunología está disolviendo el concepto de dualismo entre la mente y el cuerpo, y está proporcionando las bases científicas para una medicina humanística y el desarrollo de un nuevo modelo de salud y enfermedad. La medicina alternativa y complementaria se inscribe dentro de este cambio de paradigma en el modelo de salud.

La PNI está aportando la base científica para la construcción de un nuevo modelo de salud, obliga a reconsiderar el modelo biomédico actual basado en el reduccionismo y el mecanicismo, y apoya un abordaje integral de los pacientes, tomando en consideración su dimensión física, mental, emocional y espiritual. La medicina alternativa y complementaria tendrán su espacio en este nuevo modelo de salud, a partir de los importantes aportes que han hecho. Evaluar en profundidad el porqué de su amplia aceptación entre el publico, algunos de los cuales hemos expuesto aquí, nos daría mucha información sobre aquellos aspectos que están siendo descuidados por la medicina convencional. El siguiente paso sería, previa evaluación científica de dicho procedimiento, método o tratamiento, incorporarlo en la práctica médica, ya no como una práctica "alternativa", que obligue a escoger entre una terapéutica convencional sustentada también científicamente, sino integrándola plenamente en ese modelo de salud.

Llegará un momento en que no necesitaremos adjetivo para la medicina, "alternativa", "convencional" o "complementaria", sino solamente medicina, ya que el cambio fundamental que se está dando es el de considerar a la persona en su dimensión total, y entender que hay que atender todas esas dimensiones, tanto para la prevención como en el momento de una enfermedad. No podemos seguir ignorando el papel que las emociones, la esperanza, el deseo de vivir y el poder del contacto humano y cálido, juegan en el desenlace de una enfermedad. Este modelo también implica una nueva concepción de la relación médico-paciente, como por ejemplo tomar en cuenta, no sólo las creencias del paciente respecto a su enfermedad, sino también cómo la creencias del médico pueden influir en la actitud del paciente hacia su enfermedad y/o tratamiento. Finalmente hay que hacer énfasis en la salud de los profesionales que ejercen el arte de curar (médicos, psicólogos y otros), quienes también sufren la visión mecanicista del modelo biomédico, al descuidar las circunstancias cargadas de estrés en su vida profesional, perpetuando así un modelo de salud y enfermedad. La medicina complementaria, sustentada en las bases científicas que proporciona la psiconeuroinmunología, está así contribuyendo a transformar el modelo biomédico actual por una medicina más humanística, cuyo cambio fundamental esté vinculado a la transformación de la cultura y la sociedad en beneficio de un mayor desarrollo y bienestar para los seres humanos.

\section{REFERENCIAS BIBLIOGRÁFICAS}

Ader, R. \& Cohen, N., 1975. Behaviorally conditioned immunosuppresion. Psychosomatic Medicine, 37, 333-340.

Ader, R. \& Cohen, N., 1982. Behaviorally conditioned immunosuppression and murine systemic lupus erythematosus. Science, 214: 15341536.

Ader, R.; Felten, D.L. \& Cohen, N., 1991. Psychoneuroimmunology. Nueva York: Academic Press.

Antonovsky, A., 1987. Unraveling the mystery of bealth: bow people manage stress and stay well. San Francisco, California: Jossey-Bass.

Astin, JA., 1998. Why patients use alternative medicine: results of a national study. Journal of American Medicine Association, 279:1548-1553.

Berczi, I. \& Nagy, E., 1991. Effectos of hypophysectomy on immune function. En: Psychoneuroimmunology (R. Ader, D. Felten \& N. Cohen., eds), pp. 339-375. Nueva York: Academic Press. 
Besedovsky, H. \& Sorkin, E., 1977. Network of immune-neuroendocrine interactions. Clinical and Experimental Immunoloy, 27:1-12.

Besedovsky, H.O.; del Rey, A.; Klusman, I.; Furukawa, H.; Arditi, G.M. \& Kabiersch, A., 1991. Cytokines as modulators of the hypothalamus-pituitary-adrenal axis. Journal of Steroides and Biochemestry, 40: 613-618.

Blalock, J.E., 1984. The immune system as a sensory organ. Journal of Immunology, 132:1067-1070.

Blalock, J.E., 1988. Neuroendocrine peptide hormones in the immune system. Progress in Neuro-endocrine-immunology, 1:9-12.

Capra, F., 1985. Elpunto crucial. Ciencia, sociedad y cultura naciente. Barcelona, España: Integral.

Castés, M. \& Pocino, M., 1999. Bases científicas de la psiconeuroinmunología. En: II Curso Nacional Teórico Práctico de Aplicación Clínica y Social de la Psiconeuroinmunología, Libro de ponencias, pp. $42-$ 51. Caracas: Escuela de Medicina José María Vargas.

Castés, M. y Canelones, P., 1999. Psiconeuroinmunología en la salud y la enfermedad: modelo el cancer. En: II Curso Nacional Teórico Práctico de Aplicación Clínica y Social de la Psiconeuroinmunología, Libro de ponencias, pp. 52 64. Caracas: Escuela de Medicina José María Vargas.

Cohen, S. \& Syme, S.L., 1985. Social support and bealth. Nueva York: Academic Press.

Coulter H.L., 1991. The controlled clinical trial. An analysis. Washington, DC: Center for Empirical Medicine.

Coussins, N., 1989. The biology of hope and the healing power of the buman spirit. Londres: Penguin Books.

D'Arcy, P.F., 1993. Adverse reactions and interactions with herbal medicine. Advances Drug Reaction and Toxicolology Review, 12:147-62.

Eisenberg, D.M.; Davis, R.B.; Ettner, S.L. et al., 1998. Trends in alternative medicine use in the United States, 1990-1997: results of a follow-up national survey. Journal of American Medical Association, 280:1569-1575.
Eisenberg, D.M.; Kessler, R.C.; Foster, C.; Norlock, F.E.; Calkins, D.R. \& Delbanco, T.L., 1993. Unconventional medicine in the United States. New England Journal of Medicine, 328:246-252.

Engel, G.L., 1977. The need for a new medical model: a challenge for biomedicine. Science, April $8^{\text {th: }}$ 304-308.

Ernst, E., 1995. Complementary medicine: common misconceptions. Journal of the Royal Society of Medicine, 88:244-7.

Ernst, E., 1998. Harmless herbs? Journal of American Medical Association, 104:170-178.

Ernst, E.; Resch, K.L. \& Hill, S., 1997. Do complementary practitioners have a better bedside manner than physicians? Journal of the Royal Society of Medicine, 90:118-119.

Felten, D.L.; Felten, S.Y.; Carlson, S.L.; Olschowka, J.A. \& Livnat, S., 1985. Noradrenergic and peptidergic innervation of lymphoid tissue. Journal of Immunology, 135:755-765.

Fisher, P. \& Ward, A., 1994. Complementary medicine in Europe. British Journal of Medicine, 309:107-111.

Furnham, A. \& Forey, J., 1994. The attitudes, behaviors and beliefs of patients of conventional vs complementary (alternative) medicine. Journal of Clinical Psychology, 50:458-469.

Jonas, W.B, 1997. Clinical trials for chronic disease: randomized, controlled clinical trials are essential. Journal of the National Institut of Health Research, 9:33-39.

Jonas, W.B., 1998. Alternative medicine-learning from the past, examining the present, advancing to the future. Journal of American Medical Association, 280:18-20.

Kiecolt-Glaser, J.K.; Fisher, L.; Ogricki, P.; Stout, J.C. \& Glaser, R., 1987a. Marital quality, marital disruption, and immune function. Psychosomatic Medicine, 49:13-34.

Kiecolt-Glaser, J.K.; Glaser, R.; Dyer, C.; Shuttleworth, E.; Ogrocki, P. \& Speicher, C.E., 1987 b. Chronic stress and immunity in family caregivers of Alzheimer's disease victims. Psychosomatic Medicine, 49:523-535. 
MacGregor, F.B. et al., 1989. Hepatotoxicity of herbal remedies. British Medical Journal, 299:11561157.

Martínez Miguélez, M., 1999. Un enfoque paradigmático de la medicina. En: II Curso Nacional Teórico Práctico de Aplicación Clínica y Social de la Psiconeuroinmunología, Libro de ponencias, pp. 1318. Caracas: Escuela de Medicina José María Vargas.

Milbank Memorial Fund, 1998. Enchancing the accountability of alternative medicine. Nueva York: Milbank Memorial Fund.

Munck, A.; Guyre, P.M. \& Holbrook, N.J., 1984. Physilological functions of glucocorticoides in stress and their relation to pharmacological actions. Endocrine Reviens, 5:25-44.

National Institute of Health Office of Alternative Medicine, 1998. A report and plan of the Office of Alternative Medicine. Bethesda, Md: National Institute of Health.

Northcott, H.C. \& Bachynsky, J.A., 1993. Current utilization of chiropractic prescription medicines, nonprescription medicines and alternative health care. Social Science and Medicine, 37:431-435.

Oh, V.M., 1994. The placebo effect: how can we use it better. British Medical Journal, 309:69-70.

Pacheco, E., 1996. Desde la interpretación médica de la salud-enfermedad hacia una teoría de la salud como problema humano social. Cuadernos de Postgrado, 12. Caracas: Fondo Editorial Tropikos/CEAP.

Smith, R., 1991. Where is the wisdom? British Medical Journal, 303:798-9.

Solomon, G.F., 1993. Whither psychoneuroimmunology? A new era of immunology, of psychosomatic medicine, and of neuroscience. Brain, Behavior and Immunity, 7:352-366.

Solomon, G.F., 1995. Clinical and social implications of stress-induced neuroendocrin-immune interactions. En: Stress, hormones and the immune system (J.D. Buckingham, G.E. Gilles
\& A.M. Cowell, eds), pp. 1-24. Londres: John Wiley \& Sons.

Soragna, D; Montalbetti, L; Bo, P.; Sibilla, L. \& Savoldi, F., 1993. Chiropractic complications. Acta Neurology, 15:145-50.

Starr, P., 1982. The social transformation of american medicine. San Francisco, California: Harper Collins Publishers.

Stein, M.; Miller, A.H. \& Trestman, R.L., 1991. Depression and the immune system. En: Psychoneuroimmunology (R. Ader, D. Felten \& N. Cohen., eds), pp. 897-930. Nueva York: Academic Press.

Verbrugge, L.M., 1979. Marital status and health. Journal of Marriage and Family, 41:267-285.

Wetzel, M.S.; Elisenberg, D.M. \& Kaptchuk, T.J., 1998. Courses involving complementary and alternative medicine at US medical schools. Journal of American Medical Association, 280:784-787. 
II

SALUD, DESIGUALDAD Y CALIDAD DE VIDA 


\section{CONDICIONES DE VIDA, DESIGUALDAD Y SALUD A PARTIR DEL CASO BRASILEÑO}

Maria Cecília de Soura Minayo

\section{INTRODUCCIÓN}

La idea de que la salud tiene que ver con las condiciones de vida de las poblaciones ha sido reconocida desde hace miles de años; no obstante, es sólo a partir del nacimiento de la medicina social entre los siglos XVIII y XIX que investigaciones sistemáticas comenzaron a validar esta tesis y a dar subsidios, tanto para políticas públicas como para las reivindicaciones sindicales y de movimientos sociales. Estudios como La situación de la clase trabajadora en Inglaterra de Engels, - Mortalidad diferencial en Francia, realizado por Villermé, han sido citados por Rosen (1980) en la reconstrucción de la historia de la salud pública, mostrando la íntima relación que la sociedad y los especialistas de la cuestión social han encontrado siempre entre los indicadores de salud, la pobreza y las desigualdades sociales.

En verdad, la preocupación entre dichas relaciones está presente durante la historia de la medicina social occidental y latinoamericana, tal como puede verse en los estudios de Chadwick, 1945; Behm et al., 1970; Engels, 1975; Rosen, 1980; Mckeown, 1979; Brehilh et al., 1990; Loureiro, 1990; Cohn, 1997; Núñez, 1994; Paina, 1997; Bermúdez, 1995; Duchiade, 1995; Machado y Minayo, 1995; Monteiro, 1995.

Por ahora, el desafío teórico es aclarar las mediaciones que operan entre las condiciones reales de producción y de reproducción de los grupos humanos en sociedades concretas y la producción y reproducción de la salud y de la enfermedad. Existe una compleja relación entre el proceso demográfico, social y sanitario, complejidad mucho mayor de lo que aparece algunas veces en las imágenes dualistas con las que son frecuentemente presentados y operacionalizados.
Dicho de otra forma, el modo de producción, las condiciones de trabajo y el modo de vida continúan siendo la base para entender el proceso de salud, enfermedad y muerte. Aunque ese proceso no puede ser reducido a un modelo de polarización entre pobreza y riqueza, desarrollo y subdesarrollo, burguesía y proletariado, explotadores y explotados, campo y ciudad, agricultura e industria, pasado y presente, arcaico y moderno.

Así, en este artículo busco complejizar el campo semántico frecuentado habitualmente por los profesionales de la salud colectiva para tratar las diferenciaciones que se evidencian en los indicadores de mortalidad y morbilidad, donde los términos más utilizados son "pobreza», "desigualdad», "condiciones de vida», para referirse a las situaciones de opresión y privación, y «desarrollo social», «desarrollo humano», «calidad de vida», «desarrollo sustentable», que acostumbran a expresar las utopías, sobre todo de los gobiernos y de los organismos internacionales, cuando proyectan las metas de superación de los períodos denunciados como humillantes en los procesos de reproducción social.

Este texto se ha realizado a partir de datos secundarios, por lo tanto no es fruto de un trabajo empírico específico. Pretende ser un análisis a partir de los estudios hechos por científicos sociales, economistas, politólogos y sanitaristas que hoy discuten la problemática. Lo hago buscando aclarar el significado de los conceptos y los resultados de su aplicación. Aunque a veces tome como referencia datos internacionales, utilizaré como ejemplo el caso brasileño. 


\section{PobreZA Y DESIGUALDADES SOCLALES: \\ DISTINGUIENDO Y ACLARANDO CONCEPTOS}

El problema central de esta discusión es la diferenciación entre pobreza y desigualdad, y las consecuencias sociales y políticas de esa diferenciación. Según señala Cohn $(1997 ; 1999)$, la pobreza trae en sí un componente absoluto, es decir, es pobre aquel que no alcanza un número $\mathrm{X}$ de rendimientos estipulados y arbitrados oficialmente, en una visión de necesidades mínimas. Igualdad y desigualdad son nociones siempre relativas en un marco de diferencias de las condiciones generales de producción y reproducción de una determinada población total, expresadas hoy por la apropiación del PIB per cápita.

En este sentido, para un análisis crítico de la condición social debemos prestarle atención especial a los problemas de las desigualdades; ello no quiere decir que no tengamos que pensar y actuar en la erradicación de la pobreza y de la miseria, pues es sobre todo en las oposiciones entre esas dos situaciones, pobreza y riqueza, que las desigualdades se expresan. No obstante, cuando hablamos de desigualdades nos estamos refiriendo a las distancias relativas (con frecuencia extremas) que existen entre los estratos poblacionales, en la apropiación no sólo económica, sino además de los bienes, servicios y derechos sociales, políticos y culturales de un país, o entre países, cuando se trata de comparaciones internacionales, toda vez que existen relaciones sistémicas globales.

En América Latina las configuraciones de desigualdad son estructurales, han persistido a lo largo de su desarrollo histórico y social, acentuándose y ampliándose hoy día como fruto de las políticas económicas de integración del capital global, lo que ha radicalizado una nueva categoría social, la de «los excluidos», y propiciado el desarrollo de una nueva categoría sociológica: «exclusión social» (Escorel, 1998).

De esta forma, en el campo semántico centralizado por la noción desigualdad, cuyo opuesto es la idea de equidad, gravitan entre otros términos, pobreza, cuyo opuesto es riqueza, y exclusión, cuyo antónimo es inclusión. Recordar este último par de oposiciones es fundamental, pues el modelo de ajuste económico y la estabilización monetaria, actualmente hegemónica en nuestros países, pasó a producirlo en gran escala y a tratarlo ideológicamente como fatalidad o como efecto secundario del dinamismo del «dios mercado».

La exclusión puede ser definida como un proceso múltiple de separación de grupos y sujetos, presente y combinado en las relaciones económicas, sociales, culturales y políticas, resultando de él, pobreza, discriminación, no accesibilidad al mundo del trabajo y del consumo, y no representación social y pública. La producción de la exclusión social (de las poblaciones consideradas superfluas) para el mercado de producción y consumo, viene ocurriendo en el mundo entero y crece en Brasil en proporciones y magnitudes nunca antes vistas en el modelo tradicional de acumulación del capital. Al mismo tiempo, los discursos y las medidas oficiales tienden a escamotear la gravedad del fenómeno de separación por una visión parcial (e ideológica) de erradicación de la pobreza por medio del crecimiento económico y de algunas medidas sectorizadas y puntuales, volcadas al alivio de ese grupo de población que vive por debajo de una determinada base de ingresos. En este particular el caso brasileño es absolutamente ejemplar, como veremos a continuación.

Brasil tiene un nivel de ingreso per cápita que le permite no ser considerado pobre: más del $75 \%$ de la población mundial vive en países con un ingreso per cápita inferior al nuestro (Barros, 1999). También aquí han sido aplicadas algunas medidas enfocadas en situaciones específicas, obteniéndose resultados importantes, que pueden ser medidos y comparados con patrones internacionales, como el índice de desarrollo humano (IDH), que compone la Relatoría de Desarrollo Humano (RDH) del Programa de las Naciones Unidas para el Desarrollo Humano (PNUD).

Esta medida internacional de desarrollo fue creada en 1990 para contraponerse a otra, puramente economicista, adoptada anteriormente por las Naciones Unidas, que enfatizaba la noción de progreso económico como criterio de distinción y clasificación de países. El IDH incluye otras dimensiones, como la longevidad de la población (expresando esperanza de vida), los niveles educativos (reuniendo dos variables: la tasa de alfabetización de 
adultos y la tasa combinada de matrícula en los tres niveles de enseñanza), además del ingreso o el PIB per cápita.

Pues bien, siguiendo la metodología del PNuD, Brasil mejoró sensiblemente sus indicadores de desarrollo en los últimos cuarenta años. En 1960, ocupaba la $51^{\mathrm{a}}$ posición en comparación con 110 países, al situarse en el grupo de bajo desarrollo bumano con un índice de 0,394 (se considera que un país tiene bajo índice de desarrollo humano cuando su IDH está por debajo de 0,500). En 1970, el IDH brasileño pasó al nivel de 0,507, es decir, el país entró en el grupo de desarrollo humano medio (que se clasifica con valores entre 0,500 y 0,800); en 1980 alcanzó el 0,673 y finalmente, en 1995, alcanzó el índice de 0,809. Por primera vez está clasificado entre las naciones con alto desarrollo humano, mostrando una tendencia creciente de mejora de los indicadores, pues en 1996 ya había alcanzado el índice de 0,830 (IPEA/FJP/IBGE/ PNuD, 1998).

En 1999, el gobierno brasileño fue sorprendido por un cambio expresivo en la fórmula utilizada para medir el IDH. Según las reglas anteriormente vigentes, el país continuaría colocado entre los de alto desarrollo bumano con 0,826 puntos. Sin embargo, en el nuevo cálculo sólo alcanzó 0,739, retrocediendo al conjunto de las naciones de desarrollo medio. Ello no quiere decir que Brasil haya empeorado, por el contrario, incluso avanzó unos grados en su desarrollo: «Cualquiera que sea la metodología usada, la situación absoluta y relativa del Brasil mejoró a lo largo del período observado", pronunció el presidente del Instituto de Pesquisa Econômica Aplicada (Instituto de Investigación Económica Aplicada/IPEA) en una entrevista colectiva. No obstante, el actual IDH mantiene la tesis de que el aumento de los ingresos por sí mismo no significa una mejora en la calidad de vida.

La discusión intrínseca es que, a partir de una determinada base, el crecimiento del ingreso per cápita influye poco en el bienestar de la población. Por ejemplo, si el PIB de Sierra Leona - que en la actualidad es de 410 dólares - aumentara el doble, su efecto sería mucho mayor que si aumentara el doble en Brasil. Lo que el PNun hizo fue disminuir el peso del ingreso en el cálculo del IDH. Esa corrección fue realizada por el propio Amartya Sen, premio Nobel de economía y creador del índice. Para el país esto significa que para retornar al lugar que ocupaba anteriormente tendrá que continuar invirtiendo mucho más en la educación y en la disminución de las desigualdades.

Reflejando o promoviendo la mejoría de la situación nacional, en 1996 diez estados y el Distrito Federal ya habían alcanzado un alto nivel de desarrollo, y ningún estado permaneció, dentro de los criterios del IDH, en el nivel de bajo desarrollo. Tal constatación revela un enorme cambio en su geografía social, pues en 1970 ningún estado había alcanzado un espacio en el grupo principal y 19 se situaban en el grupo de bajo desarrollo. Desde el punto de las tres variables, en la década de los setenta lo que más influyó en los cambios fue el crecimiento del ingreso, pues vivíamos el llamado milagro económico al final del régimen militar. En las dos décadas subsiguientes, el aumento de la expectativa de vida (posiblemente reflejando el progreso económico) y la mejoría de las tasas de educación fueron los principales factores del proceso denominado "desarrollo humano". Otro dato importante es que el mejor desempeño del país se debió a un aumento del índice medio de todas las unidades de la Federación, aunque el crecimiento mucho más acelerado en algunas de ellas y más lento en otras repercutió y afianzó todavía más las diferenciaciones internas regionales desde el punto de vista industrial, de la acumulación de riqueza, de transacciones comerciales y financieras, de distribución demográfica y de desarrollo científico y tecnológico.

A pesar de la reducción en el ID sufrida por Brasil, el informe permite comparar algunos indicadores. La esperanza de vida al nacer brasileña $(66,6$ años en 1995) era superior a la media mundial $(63,6)$, así como la de los llamados países en desarrollo $(62,2)$, pero muy inferior a la de los países de gran desarrollo económico, que en aquel momento era de 74,2 años. Los índices de educación $(0,80)$ fueron también más altos que los de la media mundial $(0,72)$, que la de los países en desarrollo $(0,66)$ y que la de los países subdesarrollados $(0,45)$, pero muy inferiores a la de los industrializados $(0,93)$. Es en el $\mathrm{PIB}$ per cápita que se destacan las mayores diferencias internacionales. 
Mientras la media mundial del PIB en dólares es 5.990, la de Brasil era de 5.928, la de los países en desarrollo es de 3.068 , la de los subdesarrollados es de 1.008 y la de los industrializados es radicalmente más elevada: 16.337. De la misma forma, el estudio titulado Panorama social de América Latina de la CEPAL (1998) señala que a partir de los años noventa Brasil logró sacar 9 millones de personas del nivel de pobreza, siendo junto con Chile y Panamá los países que obtuvieron mejor desempeño, mientras en México y Venezuela la pobreza y la miseria aumentaron.

No obstante, la situación nacional no se presenta tan favorable cuando se realizan comparaciones más cuidadosas. Los investigadores del IPEA seleccionaron una muestra de países con más de 20 millones de habitantes, descritos en el RDH, para comprobar la posición de Brasil en el concierto de esas naciones. En este caso, Brasil ocupa el $17^{\circ}$ lugar, después de Malasia y por encima de Turquía. Empero, muy por debajo de Argentina, que ocupa la $10^{\circ}$ posición; de Venezuela, clasificada en la $11^{\circ}$; de México, que se presenta en la $12^{\circ}$; y por fin de Colombia, que está en $14^{\circ}$. Si miramos a América Latina, Brasil ocupa un lugar intermedio, que puede ser visto en el siguiente gráfico tomado de Human Development Report, 1998.

Todos esos datos tuvieron la función de mostrar que Brasil no es un país pobre y que, de hecho, tiende a disminuir la población clasificada en esa base. Pero queremos desviar el eje de la discusión hacia el parámetro de las desigualdades sociales. $\mathrm{Al}$ asumir ese enfoque, pasaré a trabajar con un referente éticamente más relevante desde el punto de vista

Gráfico 2.2 - IDH, Brasil e 21 países da América Latina e Caribe

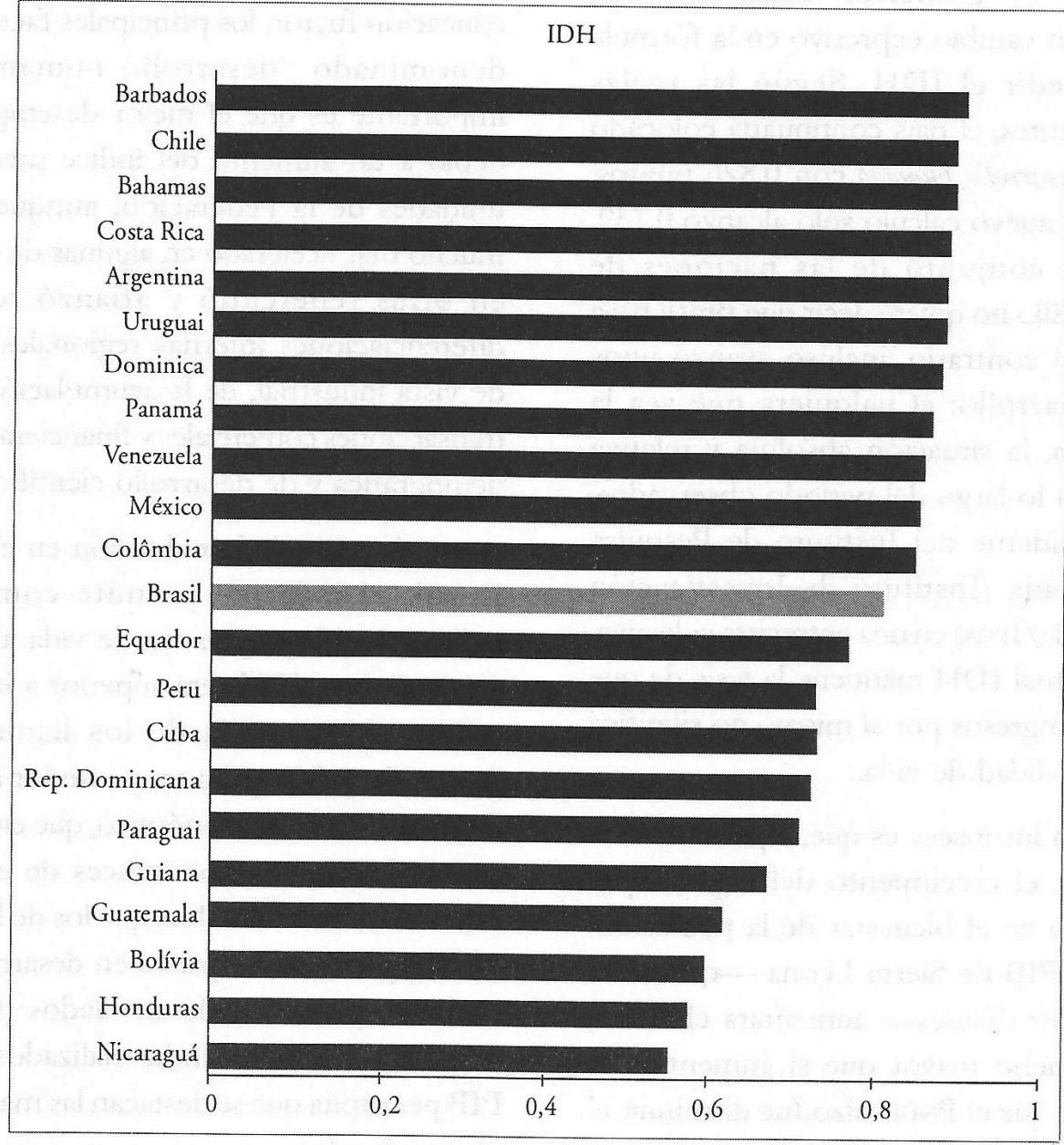

Fonte: UNDP, Human Development Report, 1998. 
empírico y científico. En primer lugar, el concepto de desigualdades establece una posibilidad comparativa, pues es relativo. Éste permite incorporar el análisis de los factores de acceso a la riqueza y a todos los bienes a los parámetros de desarrollo que la sociedad ya ha alcanzado; asimismo, supera la noción de límites de privación, forma negativa de dar dimensión a la pobreza, lo que lleva a tratarla sólo a través de programas puntuales. Incorpora, además, la óptica del desarrollo social como derecho, ampliando las nociones de oportunidades de escogencia y participación en las decisiones. En fin, incluye no sólo la evaluación de la producción y de la prosperidad, sino también del enriquecimiento colectivo de las vidas humanas que de ellas resultan.

Según lo indica un reciente informe de la CEPAL (Comisión Económica para América Latina y el Caribe), América Latina se encuentra hoy peor que en los años setenta. Hubo un retroceso en la equidad social, provocado por la crisis económica de la década de los ochenta y las reformas neoliberales de los años siguientes. En el caso de Brasil, en esas dos décadas no bubo aumento de la pobreza, pero sí de las desigualdades (Brasil, 1995), históricamente una de las mayores del mundo.

Algunos datos corroboran tal afirmación: el ingreso medio del $10 \%$ más rico es hoy cerca de 30 veces mayor que el del $40 \%$ más pobre, mientras en otros países con un desarrollo comparable al de Brasil, es apenas 10 veces mayor. Entre 1960 y 1990, el $50 \%$ más pobre redujo su participación en la renta nacional del $18 \%$ al $12 \%$, mientras la de los más ricos se elevó del $54 \%$ al $65 \%$ en el mismo período. Dentro del grupo de los más ricos también se afianzó la concentración: el 5\% más rico subió su participación de $31,9 \%$ en 1980 a $34,4 \%$ en 1990 ; y dentro de ese grupo, los que conforman el 1\% más rico aumentó de $12,1 \%$ a $13,9 \%$ en el referido período. Lo que más impresiona en Brasil no es la presencia de los superpobres que hacen más desigual nuestro país, sino la elevadísima renta media de los más ricos. «La desigualdad entre el $80 \%$ más pobre en Brasil es tan elevada como en otros países, como Estados Unidos", señala Barros (1999).

Las desigualdades pueden ser analizadas a partir de los más variados aspectos. Desde el punto de vista regional, las disparidades son tan grandes, que mientras el PIB per cápita brasileño, como hemos señalado anteriormente, era de 5.298 dólares en 1997, la del Piauí es de apenas 500 dólares, idéntica a la de Haití, país con uno de los menores ingresos del mundo. Existe cierta jerarquía de la pobreza en términos regionales, formándose una pirámide en cuya base se sitúan los estados más pobres — todos pertenecientes a la región nordeste- y en la cúspide, los estados de Sao Paulo, Río Grande del Sur y Santa Catarina así como Río de Janeiro.

En la media brasileña, los pobres (individuos cuyo ingreso familiar per cápita se sitúa por debajo de la línea de pobreza, es decir, de medio salario mínimo per cápita) constituyen hoy $30,2 \%$ de la población. En las medias regionales el nordeste se presenta con $45,8 \%$ de pobres de su población total; la región norte con $43,2 \%$; la centro-oeste $24,8 \%$; la sudeste con $23 \%$ y la sur con $20,1 \%$. En el discurrir de las últimas cuatro décadas no hubo cambios regionales significativos en el país, confirmándose el hecho de que mientras la pobreza ha disminuido, como resultado del crecimiento económico, las desigualdades no solamente persisten sino que se profundizan (IPEA/Fjp/IBGE/Pnud, 1998).

Además de la presentación de los datos generales por parte del IGBE, es apenas en la actualidad que se están desarrollando instrumentos más afinados de medición de las desigualdades, con capacidad de subsidiar políticas redistributivas. Este esfuerzo se debe principalmente a la Fundação João Pinbeiro (FJP), institución que tiene entre sus objetivos el construir indicadores y medidas de la realidad socioeconómica y política de Minas Gerais, con vías a asesorar al gobierno estatal en la formulación de políticas públicas.

Tomando como base el IDH, esta institución decidió producir un indicador más sofisticado y que fuese sensible en la medición de los problemas y adecuado para medir el desempeño de las intervenciones sociales al nivel local, llamado Indice de Condiciones de Vida (ICV). Este instrumento conceptual, metodológico y operacional, utilizado para la evaluación de todos los municipios del estado por medio de la cooperación técnica entre la FJP y el IPEA, ha sido extendido y utilizado para la medición de los municipios de todo el país. 
EVOLUÇÃO TEMPORAL DA DESIGUALDADE*

\begin{tabular}{|c|c|c|c|c|c|c|c|c|c|c|c|c|c|}
\hline Indicadores & & & & & & Ar & & & & & & & \\
\hline de desigualdades & 1981 & 1982 & 1983 & 1984 & 1985 & 1986 & 1987 & 1988 & 1989 & 1990 & 1992 & 1993 & 1995 \\
\hline $\begin{array}{l}\text { Proporção da renda apropriada pelos } \\
10 \% \text { mais pobres }\end{array}$ & 0,78 & 0,76 & 0,76 & 0,82 & 0,76 & 0,81 & 0,67 & 0,59 & 0,54 & 0,58 & 0,40 & 0,38 & 0,43 \\
\hline $\begin{array}{l}\text { Proporção da renda apropriada pelos } \\
20 \% \text { mais pobres }\end{array}$ & 2,5 & 2,4 & 2,4 & 2,5 & 2,4 & 2,5 & 2,2 & 2 & 1,9 & 2 & 1,9 & 1,8 & 1,9 \\
\hline $\begin{array}{l}\text { Proporção da renda apropriada pelos } \\
30 \% \text { mais pobres }\end{array}$ & 5 & 4,8 & 4,8 & 5,1 & 4,8 & 5 & 4,5 & 4,2 & 3,8 & 4,1 & 4,3 & 4,1 & \\
\hline $\begin{array}{l}\text { Proporção da renda apropriada pelos } \\
40 \% \text { mais pobres }\end{array}$ & 8,4 & 8,1 & 8,1 & 8,4 & 6 & 8,4 & 7,7 & 7,2 & 8,8 & 7,1 & 7,8 & 7,4 & \\
\hline $\begin{array}{l}\text { Proporção da renda apropriada pelos } \\
50 \% \text { mais pobres }\end{array}$ & 12,9 & 12,5 & 12,3 & 12,7 & 12,3 & 12,8 & 12 & 11,2 & 10,4 & 11,2 & 12,4 & 11,6 & \\
\hline Corficiente de Gini & 0,59 & 0,6 & 0,6 & 0,59 & 0,60 & 0,6 & 0,51 & 0,82 & 0,84 & 0,82 & 0,59 & 0,61 & 0,61 \\
\hline Grau de desigualdade* & $82 / 0$ & $78 / 0$ & $78 / 0$ & $92 / 0$ & $78 / 0$ & $89 / 0$ & $57 / 0$ & $30 \%$ & $25 /-11$ & $35 /-4$ & $7 /-5$ & $0 /-10$ & \\
\hline
\end{tabular}

Fonte: Ipea. Construída com base nas informações contidas na Pesquisa Nacional por Amostra de Domicílio (PNDA)

* A distribuição realizada foi a de indivíduos segundo a renda familiar per capita.

- O primeiro número refere-se ao incremento na renda de 1995 , medido como percentual a renda do ano da coluna.

** Necessário para que 1995 tenha um nível de pobreza menor que o do ano referido.

w- O ano de 1995 não é compatível com o ano referido na coluna.

- $\mathrm{O}$ ano de 1995 mostra um valor melhor para o indicador em questão do que o referido na coluna.

$\mathrm{O}$ ano de 1995 mostra um valor pior para o indicador em questão do que o referido na coluna.

El ICV está compuesto por 20 indicadores agregados en cinco dimensiones: (1) ingreso (ingreso familiar per cápita, grado de desigualdad, porcentaje de personas con ingresos insuficientes, insuficiencia media de ingresos, grado de desigualdad en la población con ingresos insuficientes); (2) educación (tasa de analfabetismo, número medio de años de estudio, porcentaje de la población con menos de cuatro años de estudio, porcentaje de la población con menos de ocho años de estudio, porcentaje de la población con más de once años de estudio); (3) infancia (porcentaje de niños que trabajan, porcentaje de niños que no frecuentan la escuela, desfase escolar medio, porcentaje de niños con más de un año de desfase escolar); (4) vivienda (porcentaje de la población en domicilios con densidad media por encima de dos personas por dormitorio, porcentaje de la población que vive en domicilios durables, porcentaje de la población que vive en domicilios con abastecimiento adecuado de agua, porcentaje de población que vive en domicilio con instalaciones adecuadas de cloacas); (5) longevidad (esperanza de vida al nacer y tasa de mortalidad infantil). El ICV se sintetiza por medio de varios artificios metodológicos, y puede ser comprendido en toda su extensión en el trabajo Desenvolvimiento bumano y condicões de vida (Desarrollo humano y condiciones de vida), cuyos autores son IpeA/FJP/IbGE/PNUd (1998).
El ICV tiene muchos méritos, entre los cuales citaré tres: trabaja con muchas variables sensibles para medir la desigualdad, llegando a la menor unidad de análisis político-territorial, el municipio. Permite incluso operaciones comparativas, como los cambios positivos y desigualdades intra e intermunicipales e incluso regionales, y posibilita señalar aspectos de mayor vulnerabilidad social. No obstante, el ICV no atiende los ámbitos familiares e individuales, que son, en última instancia, espacios esenciales de la definición de la calidad de vida. A pesar de todo esto, muchos cambios, persistencias y problemas pueden ser observados a partir de los cinco indicadores utilizados.

Observando los puntos que se relacionan con los cambios positivos, el ICV permitió confirmar varios aspectos señalados por el IDH, trabajando con datos retroactivos de la década de los setenta, cuando $91 \%$ de los municipios brasileños fueron clasificados como de bajo desarrollo humano; para entonces, 99,9\% de los municipios del nordeste entraban en esa categoría. En 1980, 46,4\% permanecían en ese nivel más bajo y pasaron al nivel medio; mientras que en el nordeste, 96,4\% todavía permanecían en la base inferior. En 1991, último año del estudio corroborado en el Censo Demográfico Nacional, 40,4\% permanecía en bajo desarrollo ( $92,9 \%$ de los 
municipios del nordeste continuaban en la clasificación inferior) y $57,8 \%$ en un nivel intermedio (de esos, apenas $7,1 \%$ estaban situados en el nordeste). Sólo 80 municipios, que corresponden a $1,8 \%$ del total, exclusivamente en los estados del sur y sudeste y el Distrito Federal, alcanzaron la categoría de alto desarrollo, aunque en ellos se concentra $20 \%$ de la población del país. Tres estados (Mato Grosso del Sur, Río de Janeiro y Sao Paulo) no tuvieron (en 1991) municipios en la categoría de bajo desarrollo. En términos generales, la proporción de personas que viven en municipios con bajo desarrollo descendió de $62 \%$ a $22 \%$.

Los municipios que mejoraron su desempeño fueron los más populosos, aunque los analistas señalen dos problemas concomitantes: un grado de extrema pobreza en los menores, especialmente en el nordeste $y$ en el norte, y en las periferias de las grandes metrópolis, donde se profundizan las condiciones de exclusión y de violencia social.

Observando el ICV bajo el prisma de las desigualdades de vida de las poblaciones, la situación regional es impresionante. En Brasil, la población que vivía en municipios de bajo desarrollo humano en 1970 era de 62,1\%; en el nordeste, esa proporción era de $92,6 \%$ (del total regional), mientras que en Alagoas, Ceará, Maranhão, Paraíba, Río Grande del Norte y Sergipe, la proporción era del 100\%. En el norte era del $77,1 \%$, aunque estados como Amapá, Acre, Rondônia, Roraima y Tocantins tenían también $100 \%$ de su población en municipios de bajo desarrollo humano. En el sudeste la proporción de la población en municipios en ese índice era de 38\%.

Para no ser exhaustiva, pero poder mantener el argumento sobre las desigualdades, es importante observar la evaluación para 1991 con datos del último censo demográfico. En el nordeste, $61,8 \%$ de la población permanece en municipios en el estrato inferior. Así, también en 1991, apenas 4,0\% de la población del sudeste permanecía en municipios en la base considerada de bajo desarrollo, $60,6 \%$ en el nivel medio y $35,3 \%$ en el estrato más alto, mientras que en el estrato inferior pesaba la situación de Minas Gerais con $15,7 \%$ de los municipios todavía con índices de bajo desarrollo y apenas $2,9 \%$ en el nivel más elevado (IPEA/FJP/IbGE/PNUD, 1998).
Desde la óptica del trabajo, en 1995 la población económicamente activa (PEA) estaba compuesta por $58 \%$ del total de los habitantes con diez o más años de edad, distribuidos de la siguiente forma: $5 \%$ de 10 a $14 ; 11 \%$ de 15 a 19; $50 \%$ de 20 a 39; $28 \%$ de 40 a 59; $6 \%$ de 60 años o más. Cerca de 3,6 millones de niños entre los 10 a 14 años se encontraban trabajando, $28 \%$ de ellos en el nordeste y $13 \%$ en la región sudeste.

Datos que relacionan la actividad de los menores con el ingreso familiar demuestran que la tasa de actividad de los niños entre 10 a 14 años era del 23\% entre las familias pobres. Las condiciones de trabajo infantil en general son precarias, sin garantías laborales, lo que para muchos pequeños trabajadores implica jornadas de más de cuarenta horas y rendimientos mensuales menores a un salario mínimo. En el período comprendido entre 1990 y 1995 la tasa de desempleo se mantuvo alrededor del $5 \%$ (en la actualidad llega al 11\%) pero se constata la reducción de los puestos de trabajo, disminución de vacantes en las industrias, reducción en el número de trabajadores formales y aumento en el número de trabajadores por cuenta propia, evidenciando lo que se denomina crecimiento de la precarización del trabajo.

En el ámbito educativo, es verdad que descendieron las tasas de analfabetismo, incluso en el nordeste, que en 1991 eran de 33\% y en 1995 pasaron a $23 \%$, pero hay un absoluto contraste con la situación residual de la región sur, 1,9\%. Se estima que la mayoría de los analfabetas $(23,3 \%)$ se concentran en la zona rural, mientras que el $36 \%$ de ellos están en el nordeste.

En la actualidad existe una paridad con ventaja para las mujeres, en lo referente a la escolaridad medida por género. La misma paridad no se observa con los negros y pardos, en cuyo grupo existe $35 \%$ de analfabetas, mientras que entre los blancos hay $15 \%$. En las comparaciones entre géneros se hacen patentes las desigualdades en el rendimiento del trabajo, los hombres reciben como media un salario $42 \%$ superior al de las mujeres; y en términos raciales los negros ganan como media $40 \%$ a $50 \%$ menos que los blancos.

En su análisis, los investigadores del ICV brasileño muestran que hay algunas categorías que 
especifican las posibles combinaciones de desarrollo/subdesarrollo social en el país: la primera es la tendencia a la dualidad, que se expresa en la profundización persistente de las diferencias entre los municipios más pobres de la región nordeste y norte y los de patrón de desarrollo alto del sur y del sudeste, incluso cuando en los primeros se observan cambios positivos. En las últimas tres décadas se redujeron las situaciones intermedias.

La segunda está dada por la disparidad interna de desarrollo entre los municipios de una misma región, si hacemos una comparación entre el 25\% más pobre y el $25 \%$ con mayores recursos. En fin, el criterio de desigualdad permite concluir que las mayores tendencias de diferenciación de ingreso per cápita se encuentran localizadas en el interior de los propios municipios ( $70 \%$ en 1991, contra $60 \%$ en 1970 ), son menores y disminuyen entre los municipios $30 \%$ contra $40 \%$ y continúan siendo muy fuertes entre regiones.

En síntesis, se pueden resumir así los grandes problemas sociales brasileños: el país es campeón en concentración de ingresos, con el 15,8\% de la población sin acceso a las condiciones mínimas de higiene, educación y salud. $17 \%$ de las personas viven en la miseria; $11,5 \%$ mueren antes de completar los 40 años; existe un $16 \%$ de analfabetas; $34 \%$ vive sin agua potable y $30 \%$ sin acceso a cloacas.

El gráfico con los datos de coeficiente de Gini expuesto abajo realiza una síntesis de la discusión aquí presentada. Los datos, que comprenden los años 1983 y 1998, muestran los picos extremos de desigualdad detectados en 1994 y 1995, al inicio del plan de estabilización fiscal, resaltando la evidencia de que mientras los índices de pobreza disminuyeron, las expresiones de desigualdad se afianzaron en los últimos cuarenta años.

\section{EVoluÇ̃̃o temporal do CoEficiente de GinI}

\section{Brasil Metropolitano}

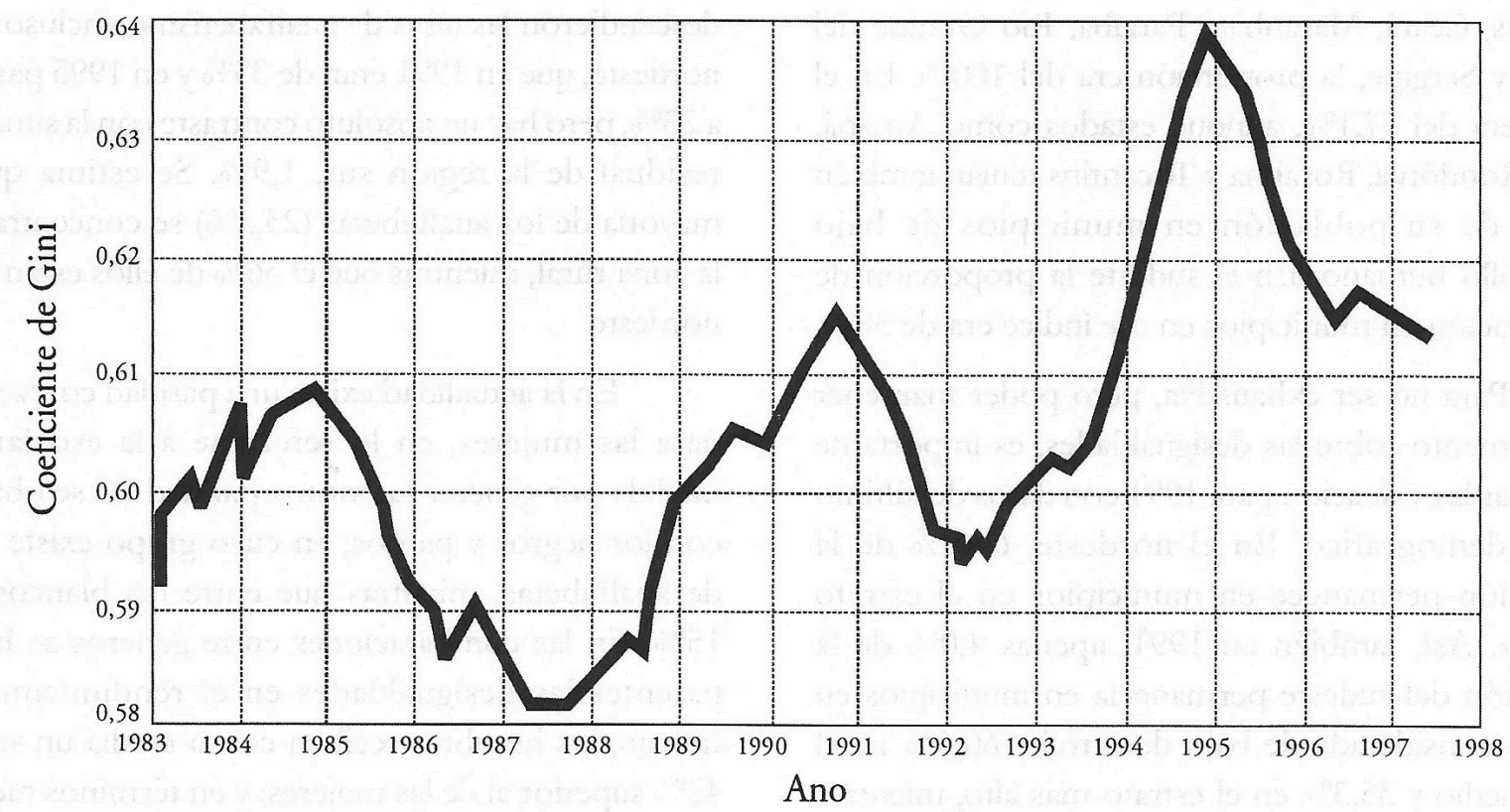

Fonte: Construído com base nas informações contidas na Pesquisa Mensal de Emprego (PME) de junho de 1982 a junho de 1997.

Nota 1: A distribuição utilizada foi a de indivíduos segundo a renda domiciliar de todos os trabalhos per capita. Nota 2: Gráfico elaborado pelo Ipea. 


\section{PobREZA, DESIGUALDAD Y SALUD:}

\section{INTERRELACIONES}

Hubo una intensa modificación en el perfil demográfico, que influyó en la morbimortalidad de la población brasileña en las últimas décadas. La tasa de fecundidad total se redujo en más del $50 \%$ entre 1960 y 1995, en tanto la tasa bruta de natalidad disminuyó de 31,23 nacidos vivos por cada mil habitantes en 1980, a 23,64 en 1990 y se estima que en 1999 se ubicó en 18. La esperanza de vida al nacer en 1998 era de 67,91 años (64,76 para los hombres y 71,18 para las mujeres).

Está disminuyendo la proporción de jóvenes en la pirámide demográfica, de tal forma que para esta transición de siglo, la llamada población dependiente (los mayores de 65 años, para los cuales, dicho sea de paso, el término «dependiente» se ha vuelto totalmente impropio; y los menores de 15 años, que por el contrario podrían haber ampliado su grupo de dependencia por causa de los cambios económicos y culturales actuales) es de $33 \%$, cuando en 1979 correspondía al 50\% del total.

Hubo también una sensible evolución positiva en los indicadores de morbimortalidad, sobre todo entre la población menor de cinco años. En el período comprendido entre 1980 y 1994, el peso de la mortalidad infantil en la mortalidad general descendió de $24 \%$ a $9,8 \%$, pasando a una media nacional de 56 por cada mil nacidos vivos en 1980 a 37,5 por cada mil en 1991. La mortalidad materna, que en 1982 se ubicaba en 156 por cada 100 mil, descendió a 114,2 en 1991. Me abstendré de hacer comentarios acerca de cada uno de los indicadores, así como de compararlos intencionalmente, aunque eso sea necesario para demostrar lo lejos que está el país de los indicadores ideales. Sin embargo, creo importante señalar que la mejoría de la situación de salud es el resultado de una combinación de factores demográficos, económicos y sociales con intervenciones planificadas y conjugadas del sector salud, que pueden ejemplificarse con los programas de terapia de rehidratación oral, inmunización en masa, incentivos al amamantamiento materno, ampliación de la cobertura de saneamiento básico y asistencia a la salud.
Una mirada sobre la totalidad nos ofrecería otros puntos para celebrar. Las tres principales causas de muerte estarían señalando esa transición epidemiológica descrita en un primer momento por Frederisksen (1969) y después por Omran (1971), tratada por este último como el modelo clásico occidental, que indica la progresiva reducción de la mortalidad y la fertilidad, acompañada de un nuevo perfil, en el que las enfermedades infecciosas han pasado a ser sustituidas por otras enfermedades causadas por el bombre. En éstas, el predominio de la causalidad estaría dado por variables de tipo ambiental y por el estilo de vida.

Ese marco clásico parece indicar la transición de una sociedad atrasada hacia un modelo moderno de desarrollo; así, al mismo tiempo que se redujeron las enfermedades infecciosas en Brasil, aumentaron las muertes en los grupos etarios mayores de 50 años (de $48,4 \%$ del total en 1980 , se pasó a $62,4 \%$ en 1994), y el perfil de mortalidad general se ha hecho semejante al de las naciones desarrolladas. Las primeras causas de deceso son las provocadas por enfermedades cardiovasculares (34\%), violencias $(14,8 \%)$ y neoplasias $(13 \%)$, mientras que las infecciosas descendieron del primero, hasta la década de los sesenta, al cuarto lugar, constituyendo en la actualidad el 11\% del total. Al mismo tiempo, como señalan Barreto y Carmo (1995), esa linealidad del proceso, tal como es visto en el modelo de Omran, no se aplica en Brasil, pues lo que existe aquí es una combinación entre las enfermedades simbólicas del desarrollo y la persistencia o la reemergencia de las enfermedades infecciosas, expresivas del subdesarrollo.

Las modificaciones en los patrones de morbimortalidad han venido ocurriendo desde el siglo pasado en casi todos los países, según varios estudios. No obstante, a partir de la década de los sesenta los análisis demográficos llaman la atención hacia la disminución de las tasas de mortalidad y reducción de las tasas de fecundidad en el mundo entero. Frederiksen (1969) intenta explicar ese tipo de cambios por medio del camino paralelo seguido por la transición demográfica y el perfil de morbimortalidad; según este autor, al pasar del estadio tradicional al moderno, las sociedades presentarían una tendencia a la reducción de las 
enfermedades infecciosas y el predominio de las enfermedades crónico-degenerativas. Omran (1971) denominaría ese modelo de cambio como transición epidemiológica, perfeccionando así la propuesta de Frederiksen.

Para Omran, las sociedades encajarían en tres modelos, a saber: (1) clásico, caracterizado por el paso progresivo del predominio de las enfermedades infecciosas hacia las crónicodegenerativas y causadas por el propio contexto social; (2) acelerado, marcado por cambios drásticos en el cuadro de mortalidad y fertilidad e inversión en el perfil de mortalidad; (3) tardío o contemporáneo, propio de los países en desarrollo, en el que la caída de la mortalidad no es seguida con la misma velocidad de la caída de la fecundidad. Posteriormente fue agregado otro estadio, el cual se refiere al declive de la mortalidad por enfermedades crónico-degenerativas a causa de cambios sustanciales en los estilos de vida, sobre todo en los países desarrollados (Barreto \& Carmo, 1995), así como por el desarrollo de una nueva generación de medicamentos que buscan compensar factores de riesgo asociados con el estrés y el desgaste por envejecimiento. Esta última constatación se une a la visión de Lalonde (1978), consagrada en la importante Conferencia de Otawa, según la cual la salud de una población es mucho más dependiente de las condiciones ambientales, de los estilos de vida y del desarrollo de la moderna biología que de los procedimientos médicos stricto sensu.

Los indicadores positivos de mejoría de las condiciones de salud de la población brasileña necesitan ser analizados en su complejidad, para entender su relación con el problema de las condiciones de vida y de la desigualdad. En el caso de las enfermedades cardiovasculares, éstas no pueden ser consideradas simplemente como «degenerativas» o inevitables, toda vez que los países desarrollados están en vías de modificar su incidencia, en la medida en que han sido capaces de identificar los factores de riesgo que las potencializan, ya que en su etiología y desarrollo se incluyen factores hereditarios y se evidencia, además, la influencia de los hábitos, comportamientos y condiciones socioeconómicas.
En el caso brasileño, los datos de morbimortalidad destacan la relación de ese tipo de enfermedades con las diferencias sociales. Por una parte, la mayor incidencia de enfermedades y muertes ocurre en los estados más desarrollados del sur y del sudeste, aunque tanto las tasas de morbilidad como las de mortalidad presentan mayor incidencia en los grupos de más bajos ingresos. Entre los motivos para que esto suceda Chor et al. (1995) señalan que, tal como acontece en los países desarrollados, el sector más favorecido de la población es sensible a los factores de riesgo, introduciendo nuevos comportamientos, estilos de vida y hábitos alimenticios más saludables, mientras que hay una fuerte presión del mercado para que los estratos inferiores consuman productos menos saludables. Además, las condiciones reales de existencia, los hábitos culturales y el acceso al conocimiento de los diversos segmentos de la clase trabajadora, sobre todo de los estratos inferiores, dificultan la adquisición de prácticas de conductas de menor riesgo.

Desde el punto de vista de la distribución de la mortalidad por enfermedades cardiovasculares, las regiones norte y nordeste son responsables por $16 \%$ del total de los decesos, menos de la mitad de las proporciones del sur y sudeste, donde corresponde a 33\%. En el nordeste prevalecen las enfermedades cerebrovasculares, que los estudiosos asocian con condiciones de pobreza, mientras en el sur y sudeste el patrón se corresponde con el de los países desarrollados. Así, es verdad que el crecimiento de esas enfermedades indica un aumento en la expectativa de vida y de los patrones de consumo, siendo responsables por los índices de mortalidad más elevados del país, y el mayor peso de su incidencia se encuentra en los estados con mayor patrón de desarrollo humano. No obstante, éstas tienen mayor crecimiento entre la población de bajos ingresos, mientras disminuyen o se encuentran mejor controladas entre los grupos de mayor poder adquisitivo (Chor et al., 1995).

El caso de la morbimortalidad por violencia es mucho más complejo en lo que respecta a su relación con las desigualdades. Cuando los estudiosos colocan este fenómeno como símbolo del desarrollo, se hace en el sentido de que algunas sociedades han logrado controlar gran parte de las enfermedades 
médico-biológicas, sea por la mejoría de las condiciones de existencia, sea por los avances de la medicina, eliminando entonces, como factores de enfermedad y muerte, problemas derivados de las relaciones sociales o los provocados por factores externos tales como tránsito, efecto de guerras y accidentes o autodestrucción. En el caso de Brasil, el crecimiento de las violencias contra la población más pobre muestra un proceso de exacerbación de las relaciones sociales, afecta inexorablemente e indica el aumento de las desigualdades, del efecto del desempleo creciente, de la falta de perspectivas de trabajo, del aumento del contrabando de armas y del número de armas en manos de la población civil, de la organización del crimen, de la impunidad, de la arbitrariedad policial y de la ausencia o falta de atención por parte del Estado con relación a las políticas públicas.

En el proceso que se dio después de la violencia explícita del Estado en los años de la dictadura militar, en la década de los ochenta, las tasas de mortalidad por causas externas pasaron a ser la segunda causa de decesos en el marco general de la mortalidad en el país. Más que un problema para el sector salud, la violencia se convirtió en un indicador del profundo afianzamiento de las contradicciones y de la exacerbación de las relaciones sociales. Tanto en los espacios rurales (conflictos de tierra, minas, disputas por reservas indígenas, rutas de tráfico de drogas), como en las grandes regiones metropolitanas, la situación se incrementó otra vez.

En estas áreas metropolitanas, afectadas por un marco existente cuya tendencia es a incrementarse, conformado por la exclusión, la miseria, el abandono social, se desarrolla hoy el crimen organizado en torno a grupos de exterminio, narcotráfico, bandas y narcoterrorismo. Es importante destacar que para el conjunto del país las violencias presentan un crecimiento más grande que las enfermedades cardiovasculares y las neoplasias, e inciden de forma mucho más clara en los grupos etarios más jóvenes, constituyendo la primera causa de muerte en los grupos de 5 a 49 años; en las personas de sexo masculino (con tasas de 121,09 entre 100 mil) más que en las de sexo femenino $(24,325)$; pobres, y entre los pobres, los negros y pardos. En las grandes regiones metropolitanas, que concentran $75 \%$ de las muertes violentas en el país, las víctimas se localizan en las áreas más pobres, en las favelas y en las zonas periféricas.

Hoy, la mayoría de las muertes violentas en Brasil se deben a accidentes de tránsito $(29,3 \%)$, cuyas víctimas son en su mayoría peatones, y a homicidios $(24,1 \%)$; pero son las tasas de homicidios las que presentan tendencias más evidentes de crecimiento, sobre todo en las grandes regiones metropolitanas, donde en todas ellas superan a las de tránsito. Incluso, aunque no podamos hacer una transposición mecánica de la profundización de las desigualdades para la intensificación de la criminalidad y del clima de conflicto y de desintegración social, existe una situación de sinergia entre ellas. No es mera coincidencia, por ejemplo, el hecho de que Recife sea la región metropolitana donde más crecieron las tasas de muerte violenta durante la década de los ochenta y donde los rendimientos del $1 \%$ más rico también crecieron desmesuradamente, siendo hoy 240 veces más elevados que los del 10\% más pobre. Su tasa de pobreza familiar es muy alta, alcanzando $51 \%$ de las familias en general y $57,2 \%$ de las familias en las cuales la jefe del hogar es la mujer, sin cónyuge.

Asimismo, durante los ochenta ocurrió un movimiento simultáneo en Río de Janeiro: la concentración de ingresos del 1\% del estrato más rico pasó a detentar el 20\% del ingreso, la más alta concentración del país, mientras el PIB de la región metropolitana de Río de Janeiro retrocedió en $8 \%$. Igualmente aumentó la violencia, la criminalidad y la corrupción. El fenómeno del incremento de la violencia en Sao Paulo corresponde en este momento al crecimiento de la concentración del ingreso, a los peligrosos índices de más de $20 \%$ de desempleo y al consecuente aumento de la exclusión social (Souza \& Minayo, 1995; Mello Jorge, 1998).

No quiero hacer aquí una peligrosa asociación entre pobreza y violencia sino más bien mostrar la evidente sinergia entre el crecimiento de las tasas de homicidio y el afianzamiento de los problemas sociales, sobre todo el desempleo y la desigualdad, en contraposición a la oferta de oportunidades fáciles en el mercado de la criminalidad.

$\mathrm{El}$ caso de las neoplasias debe ser visto en términos de desigualdades, aunque la relación sea 
menos evidente que en la situación de las causas externas y de las enfermedades cardiovasculares. Según estudios de Koifman (1995), la asociación con factores ambientales en general, la vinculación ya comprobada de determinados tipos de cáncer a procesos de trabajos insalubres y peligrosos, a la calidad de la alimentación, o el desarrollo de tumores evitables por la falta de acceso a los servicios preventivos de salud, revelan que la población de bajos ingresos está más expuesta y menos protegida. Ejemplo de esto es el caso de la incidencia del cáncer de cuello uterino, donde los coeficientes brasileños están entre los más elevados del mundo. Por ejemplo, en Recife, en 1980 era de 83,3 por cada 100 mil; en Campinas, 20,1 y en Finlandia 4,4. Este tipo de enfermedad refleja particularmente la precariedad de los servicios de salud. Igualmente, el crecimiento de la incidencia de tumores cerebrales, leucemias, linfomas no Hodking en Río Grande del Sur sugiere una fuerte asociación con la exposición ocupacional de agricultores a herbicidas y pesticidas (Koifman, 1995).

A pesar de haber abandonado su lugar como principal causa de mobimortalidad en Brasil, las enfermedades transmisibles continúan existiendo, como testimonios históricos de nuestras desigualdades sociales. La historia de la salud pública brasileña puede ser contada por el esfuerzo científico y por las estrategias políticas de tratar las epidemias y las endemias. Algunos estudiosos le dan el mérito a las técnicas de control sanitario -institucionalizadas a partir de la década de los cuarenta y democratizadas en los ochenta- del exitoso (aunque lento en su implantación) modelo de descentralización del sistema de salud actualmente en curso. Este movimiento, que ha venido profundizándose, ha permitido la ampliación de la cobertura ambulatoria y hospitalaria, aliada a intervenciones específicas, como terapia de rehidratación oral, inmunización masiva, extensión del saneamiento ambiental y aumento del uso de la leche materna. Sin embargo, la incidencia de enfermedades infecciosas continúa siendo alta en el país, destacándose las infecciones intestinales como responsables del $34 \%$ de los decesos, sobre todo en los niños; las septisemias, 16,8\%; el mal de Chagas, $13 \%$ y la tuberculosis con $9,7 \%$.

Como es bien sabido en el sector salud, las diarreas están particularmente asociadas a la falta de saneamiento básico, a la desnutrición y al hambre; las septisemias, a las limitaciones de los servicios hospitalarios; y la tuberculosis pulmonar a la pérdida de resistencia a las infecciones y a la desnutrición. Todos estos problemas están intimamente relacionados con las condiciones de vida de la población en estado de pobreza o de miseria, a la falta de acceso a los bienes sociales y culturales elementales y a la ausencia de políticas sociales adecuadas. En el ámbito de las desigualdades regionales, ya en 1988 mientras las enfermedades infecciosas en el sudeste ocasionaban el 5,2\% del total de la mortalidad; en el sur, el índice era de 4,5\%; en el norte éstas constituían $16,6 \%$ y en el nordeste $13,3 \%$, siendo en esas dos últimas regiones la segunda causa de muerte mientras que en el país representa la cuarta (Sabroza et al., 1995). Obviamente estas cifras pueden relacionarse con los ICV de las respectivas regiones.

En lo que respecta a la morbilidad se observa el aumento de la incidencia de enfermedades transmisibles junto a la reducción de la mortalidad, ocurrida por intervenciones específicas y mayor acceso a los servicios de salud, pues permanecieron las condiciones generales de vida así como las referidas al comportamiento y al medio ambiente que propician la reproducción de los parásitos. De esta forma, los casos registrados de varias endemias expresan su persistencia y recrudecimiento: en 1980 fueron notificados 169.871 casos de malaria y en 1997 , 456.216. En ese mismo intervalo, los registros apuntaron 4.408 y 19.461 de leishmaniasis; 58.786 y 33.358 de tuberculosis pulmonar; 14.515 y 43.933 de mal de Hansen; además de las frecuentes epidemias de cólera, con 2.927 casos, y de dengue, con 254.947 reportes en 1997, según datos de Sabroza et al. (1995) y del CenepI (1998).

En la década de los ochenta surge el SIDA en el país y su propagación, inicialmente más circunscrita a determinados grupos considerados de riesgo en la época y a las áreas metropolitanas, también pasó a interiorizarse y a cada vez más hacer víctimas a los más pobres, al punto de haber hoy 11.318 casos identificados (Cenepr, 1998). Pese a la política del Ministerio de la Salud, que generalizó la distribución en los servicios públicos de los medicamentos 
esenciales, la epidemia alteró el cuadro de incidencia de las enfermedades infecciosas, sobre todo la tuberculosis, como enfermedad oportunista.

Como en los países desarrollados, el SIDA tiende a transformarse en una enfermedad endémica fuertemente asociada a la población de bajos ingresos. Ello ocurre ya sea por limitaciones financieras para la compra de preservativos, sea por menor nivel de escolaridad - lo que dificulta la comprensión de las estrategias de prevención - , por problemas culturales asociados con las relaciones de género;, o por los altos costos que el tratamiento, los cambios de hábitos de vida y el seguimiento requieren (Bastos et al., 1995).

Muchos otros problemas pudieron ser tratados aquí, a partir del tema de las desigualdades sociales. Sobre las condiciones de trabajo, Machado \& Minayo Gómez (1995) revelan que tanto la mortalidad como la morbilidad están fuertemente asociadas con la falta de protección social de los trabajadores y la precarización del trabajo, lo que frecuentemente se suma al alto nivel de explotación de la fuerza de trabajo y la falta de actuación del Estado. En la actualidad, frente al creciente fenómeno llamado "desempleo tecnológico", que tiene poco de tecnológico y mucho de política de concentración de capital en nombre de la disminución del "costo Brasil", se profundiza cada vez más la exclusión social y la creación de una población superflua, utilizando la expresión de Hannah Arendt (1980). Al mismo tiempo se produce una descarada pérdida de reglamentación del trabajo y una pérdida de los derechos sociales ya consagrados. El peso del trabajo informal en la PEA es cada vez mayor, llegando a alcanzar más del 50\% de los trabajadores. Los efectos físicos, morales y mentales de estas nuevas formas de exclusión y de relaciones de producción sobre los individuos y su sociedad han sido poco estudiadas, pero las investigaciones iniciales de Minayo Gómez (incluidas en este mismo volumen) están revelando su articulación con problemas mentales, accidentes no notificados y no cubiertos por la asistencia social, y por encima de todo, aumento de la violencia social.

\section{(IN)Conclusiones}

El panorama expuesto en este trabajo permite comprender que existe una diferencia fundamental entre pobreza y desigualdad, pero, al mismo tiempo, se produce una profunda sinergia entre esos dos conceptos, utilizados para la comprensión de la realidad social. Las desigualdades son las mayores responsables de las grandes diferencias en la calidad de vida de las poblaciones y éstas tienden a profundizarse en países como Brasil, donde los procesos sociales y políticos no contemplaron la consolidación de los patrones del llamado wellfare State (Estado de bienestar social) y el actual gobierno tiene como meta desmontar las conquistas sociales obtenidas en un marco de ciudadanía regulada (Santos, 1999). Este fenómeno, que se extiende por toda América Latina, tiene su expresión más fuerte en Brasil, propiciando un marco social en que, al mismo tiempo que el país ha dejado de ser pobre y logró clasificarse como alto/medio dentro del patrón del llamado desarrollo bumano, por otro lado se han fortalecido las desigualdades y los procesos de exclusión social. Se concluye, entonces, que los diseños de las estrategias de desarrollo social deben pasar necesariamente por políticas que combinen el desarrollo económico con la superación efectiva de las desigualdades.

Según varios investigadores -entre ellos Roque \& Corrêa (1999), (IBASE, 1999) y miembros del Observatorio de la Ciudadania-, el gobierno brasileño podría decir que está preocupado con el problema social: invierte 184 millones de dólares (sumando los recursos del gobierno federal, estatal y municipal) en políticas sociales; ratificó todas las Convenciones de Derechos Humanos; debate en la actualidad un marco regulador para sus organizaciones sociales y comunitarias con miras a ampliar el papel del tercer sector en la ejecución de políticas dirigidas hacia los problemas sociales; sus políticas de educación y salud se descentralizaron y existen mecanismos reconocidos de participación y control social; además de definir políticas de atención especial a niños, adolescentes, mujeres y minusválidos.

Asimismo, se le ha dado prioridad a los diagnósticos sobre mercado trabajo y se desarrollan programas de empleo y renta en los cuales participa el movimiento sindical, buscando responder a las nuevas demandas del mercado globalizado de trabajo. Existe una política de reforma agraria, aunque, necesario es decirlo, permanentemente presionada por el incansable Movimiento de los Sin Tierra (MST), 
actualmente el movimiento social con mayor capacidad de actuación en el país. La legislación brasileña sobre discriminación es rigurosa, y los indígenas tienen una política definida de producción, aunque de baja eficacia. En el ámbito de la salud, existe un movimiento de expansión de la cobertura de atención, de cuño público y controlada por el Estado, de forma que el proceso de implementación y efectivación de la gestión descentralizada alcanza 5.136 de los 5.507 municipios brasileños, lo que corresponde a 93,28\% de ese total, abarcando 90,85\% de la población del país. En la actualidad se encuentra en vigencia el programa Comunidad Solidaria (propuesta de tipo compensatoria), que busca articular recursos financieros y humanos, fuerzas gubernamentales, empresariales y de la sociedad civil, concentrando acciones en seis componentes: reducción de la mortalidad infantil, apoyo a la enseñanza primaria, desarrollo urbano, desarrollo rural, generación de ingreso y calificación profesional.

El balance expuesto anteriormente podría ser el símbolo del gran esfuerzo que el gobierno y el pueblo brasileño ha hecho para cumplir su Agenda Social, de tal forma que el país ha sido señalado, incluso, como un gran laboratorio de experiencias sociales. Contradictoriamente, la dirección política de inserción en el mercado globalizado continúa apuntando hacia la profundización de las desigualdades y de la exclusión social, económica, política y moral de gran parte de la población, trastocando las fuerzas de transformación en un camino inverso a los esfuerzos de cambio y ampliación de la ciudadanía. Como bien se ha preguntado Cohn (1999), «¿Cómo podemos monitorear las políticas de generación de empleo cuando la política macroeconómica está creando desempleo al por mayor?». La misma autora señala como principal causa de esa contradicción, la concentración en la pobreza, como primeros auxilios para la atención a las heridas creadas por los cambios en la dinámica de los procesos de globalización económica. Existe una creencia hegemónica implícita que domina hoy al gobierno, ésta es que las fuerzas del mercado se encargarán de hacer justicia por medio del crecimiento económico, y mientras ello no ocurra, las políticas sociales fragmentadas, focalizadas, discontinuas, deben cumplir el papel de amortiguadores de las presiones sociales. La discusión planteada anteriormente revela que se trata sencillamente de un «anzuelo político». Sólo la conciencia de la centralidad de los problemas sociales podrá contrarrestar el movimiento de exclusión y darle rumbo al país, llevando su desarrollo a favor de su propio pueblo.

Llegado a este punto es necesario plantearse una pregunta: ¿cómo invertir en la superación de las desigualdades? El Banco Mundial ha sugerido que sin transferencia de ingresos no puede haber crecimiento. Hace poco tiempo atrás, no obstante, muchos economistas defendieron la tesis de que la concentración de ingresos favorece el ahorro interno y que la aceleración del ritmo de crecimiento económico disminuirá la pobreza. Hay otros estudiosos, sin embargo, que defienden la idea de que se puede hacer una interferencia directa del Estado para cambiar la clave que señala cada vez más el crecimiento de la desigualdad. Existen entre los planificadores que trabajan en el ámbito macrosocial, la creencia de que la clave de las políticas redistributivas es la ampliación de los niveles educativos. Barros (1999) está a favor de esta tesis, demostrando que la desigualdad educativa sigue el mismo ritmo de las desigualdades sociales en general, y que los países que lograron elevar los niveles escolares de su población consiguieron al mismo tiempo disminuir sus diferencias internas de apropiación de la riqueza. Ello tendría lugar por el hecho de que el valor que la sociedad le atribuye al nivel educativo disminuiría con la expansión del acceso y de los resultados del mismo y se elevaría con el progreso tecnológico.

Es posible que al menos en parte esta última idea sea más que un nuevo mito. El déficit del nivel educativo brasileño es uno de los peores de América Latina: en 1996 el número medio de años de estudio era de 5,1 entre los hombres y 4,9 entre las mujeres; también aquí persisten las diferencias regionales, pues en el nordeste la media es de 3,3 años y en el sur es de 5,7. Según algunos investigadores, al país le sería posible erradicar la pobreza aplicando entre el 3 y el 4\% de su ingreso nacional a una política de tal envergadura, empero, la mejor equidad de ingresos se obtendría a través de la universalización del acceso escolar. 
Barros (1999) argumenta que la escolaridad en sí misma aumenta la productividad individual, pero su gran retorno se da en el aumento de la productividad económica, en el balance del acceso a los bienes sociales y en la relativización del valor educación en la apropiación de los salarios y del ingreso. Esto lo ejemplifica a través del caso de Colombia, que en los últimos años invirtió sistemáticamente en los niveles educativos y obtuvo una mejoría sustancial en la distribución del ingreso y la reducción de la pobreza. De la misma forma que Corea, que en 1960 tenía los mismos índices educativos del Brasil, hoy tiene un patrón europeo y ha logrado un avance sustancial en los procesos redistributivos del ingreso.

Es posible que desde el punto de vista técnico, la inversión en educación como directriz política constituya la apertura de un canal hacia la construcción de la equidad y de la justicia social; no obstante, podemos estar construyendo un nuevo mito, concentrando una estrategia, cuando la dirección de puntos esenciales de la política macroeconómica continúa señalando una visión monetarista y concentracionista del desarrollo en toda la década anterior.

El propio Banco Mundial en su Informe sobre el desarrollo mundial (1999) sostiene que ningún factor tomado de manera aislada ha demostrado garantizar los cambios estructurales hacia la equidad.

En una conferencia dictada el 18/07/99 en la UnCTAT (Conferencia de las Naciones Unidas sobre el Comercio y el Desarrollo), siguiendo el cambio de discurso de todos los órganos multilaterales vinculados a las Naciones Unidas, John Toye, ex director del Instituto para el Desarrollo de la Universidad de Sussex, habló sobre la necesidad de «nacionalizan» la agenda de la lucha contra la pobreza, demostrando lo limitado del poder de las organizaciones internacionales para intervenir en ella. Así, colocó la superación de la pobreza y las desigualdades como producto de la decisión de las elites locales. Recordó la «Ley de los Pobres» en Inglaterra en 1640 , cuya motivación fue la convicción de la unidad de destino de las clases sociales. Señaló las sublevaciones violentas y la inestabilidad política postrevolución francesa registrada por Víctor Hugo en Los miserables. Rememoró los 20.000 fusilamientos ocurridos en la Comuna de París. En fin, llamó la atención hacia la movilización social ocurrida en Europa por el temor de las epidemias y de las pestes, originadas en las sórdidas casas miserables de la ciudad.

En un importante trabajo de investigación sobre las elites, Pereira (1999) señala que en Brasil todos, sin importar la clase social, quieren disminuir la pobreza y la desigualdad y «disminuir la deuda social». No obstante, cuando se trata de tomar acciones son sobre todo las elites las que se escurren, responsabilizando a los gobiernos, al sistema político y al congreso nacional. Tal vez en ausencia de las epidemias y de las insurrecciones del pasado, la única motivación que podrá movilizar a la elite brasileña será la «epidemia» del crimen, que, a pesar de castigar especialmente a los más pobres (como la peste), no descarta a nadie.

Tendemos a creer que los movimientos políticos y sociales tradicionalmente volcados a los problemas de las poblaciones tendrán que retomar para sí el rumbo y el sentido del desarrollo sustentado, pensándolo en su totalidad y en su complejidad, y al mismo tiempo colocando el problema social como centro de la discusión, sin crear una contradicción con el desarrollo económico y sin someter el movimiento político al tecnicismo dominante.

Así, como propone Cohn (1997), el avance del debate aquí esbozado reside en la viabilidad política de la transformación de enfoque, en el que la evaluación del desarrollo no sea sólo el de la producción y de la prosperidad, sino del enriquecimiento de la vida humana que de ella se origina, del cual el acceso y el resultado de la educación son fundamentales. Citando a Doyal \& Gough (1994:97), Cohn hace un llamado ético relativo al nuevo momento histórico que vivimos: «Si los seres humanos tienen realmente la capacidad de alterar la historia, la tarea es persistir en los esfuerzos de realizar los cambios que son condiciones necesarias para la liberación humana - la satisfacción de las necesidades de salud y de autonomía del mayor número posible de seres humanos en el nivel más elevado que sea sustentable». Para eso, Benevides (1991) recuerda que es necesario salir del modelo clásico de representación 
política en América Latina y también en Brasil, donde prevalece el sentido teatral de encontrarse coyunturalmente deprimidos. Deberán ser los pregoneros de un cambio de enfoque y de mentalidad en los procesos redistributivos, tratando las desigualdades como el problema y no como resultados frente a los cuales la sociedad sólo puede aplicar remedios temporales. La clave técnica no puede sustituir la representación del poder frente al pueblo, por el contrario el desafío está en construir la representación del pueblo frente al poder, haciendo énfasis en la ampliación de la participación y de las prácticas sociales que posibiliten cada vez más la inclusión, de género, de raza, etario, de pluralismo religioso, de clase y de segmentos sociales.

Terminando este texto vuelvo al tema de la salud, articulándolo al debate de la pobreza, de las desigualdades y del desarrollo sustentado:

- Existe una articulación de las condiciones generales de producción y de reproducción en la configuración de mayor o menor exposición a los agravios de salud;

- No hay fatalidad en el cuadro de morbimortalidad de ninguna sociedad. Para todos los problemas existe un espacio de intervención social y de intervención del sector, que deben ser combinados para la generación de resultados positivos duraderos;

- La salud colectiva depende de cambios sociales combinados con cambios subjetivos que alcancen hábitos, costumbres y modos de vida, y el sector salud, por la presencia universal en la sociedad, tiene un papel fundamental en los procesos positivos de transformación;

- Existe la urgente necesidad de repensar los marcos tradicionales de educación y salud, ampliando su referencia con las teorías y experiencias existentes de participación y control social, de comunicación social y de nuevas teorías de aprendizaje y de psicología social, que permitan aumentar el potencial de integración de la población en el camino de los cambios, de forma tal que éstas estén a su favor.

En fin, el sector salud, como sector profundamente sensible a la realidad social en general, necesita reafirmar su compromiso en el contexto político, al mismo tiempo que no puede obviar la preparación científica y tecnológica de nuestros países como parte de la construcción de la calidad de vida y de la ciudadanía de la población a la que sirve.

\section{REFERENCIAS BIBLIOGRÁFICAS}

Arendt, H., 1980. Origens do totalitarismo. Sao Paulo: Companhia das Letras.

Banco Mundial, 1999. Relatório sobre o desenvolvimento mundial. Washington: Banco Mundial.

Barreto, M.L. \& Carmo, H., 1995. Mudanças em padrões de morbimortalidade: conceitos e métodos. En: Velhos e novos males da saúde no Brasil (C.A. Monteiro), pp. 7-32 Sao Paulo: Hucitec/Nupens.

Barros, R.P., 1999. Análise do Programa Social do Governo. Cadernos do Observatónio,1(0):111-124.

Bastos, F.J. et al., 1995. A epidemia de AIDs no Brasil. En: Os muitos brasis (M.C. de Souza Minayo, org.), pp. 245-268. Sao Paulo: Hucitec/ Abrasco.

Behm, H. et al., 1970. Mortalidad infantil en Chile: tendencias recientes. Cuadernos Meil. Social, 11 (3):5-13.

Benevides, M.V., 1991. A cidadania ativa: referendo, plebiscito e iniciativa popular. Sao Paulo: Ática.

Bermúdez, M., 1995. Análisis de la situación de salud según condiciones de vida en el municipio Libertador. Epid. 95 Resumos. Salvador de Bahía: Abrasco.

Brasil, 1995. Relatório Nacional Brasileiro (relatora general: Amélia Cohn). Cumbre Mundial para el Desarrollo Social. Copenhague.

Breilh, E. S.; Granda, E. et al., 1990. Deterioro de la vida: un instrumento para análisis de prioridades regionales en lo social y la salud. Quito: Cooperación Editora Nacional.

Cenepr, 1998. Consolidado anual da distribuição de casos notificados de agravos e doenças infecciosas e parasitárias, 1997. Informe Epidemiológico do SUS, 7 (1):105-113.

Cepal, 1998. Panorama social de América Latina. Santiago de Chile: Cepal. 
Chadwich, E., 1945. Report on the Sanitary Condition of Labouring Population of Great Britain: 1842. Chicago: Aldine Pub. Co.

Chor, D. et al., 1995. Doenças cárdio-vasculares: panorama da mortalidade no Brasil. En: Os muitos brasis (M.C. de Souza Minayo, org.), pp. 57-86. Sao Paulo: Hucitec/Abrasco.

Cohn, A., 1997. Desenvolvimento social e impactos na saúde. En: Condições de vida e situação de saúde (R.B. Barata, org.), pp. 77-95. Río de Janeiro: Abrasco.

Cohn, A., 1999. Uma avaliação sobre o estado dos compromissos do Brasil. Cadernos do Observatório, 1 (0):23-30.

Doyal, L. \& Gough, I., 1994. O direito à satisfação das necessidades. Lua Nova, 33:97-121.

Duchiade, M.P., 1995. População brasileira: um retrato em movimento. En: Os muitos brasis (M.C. de Souza Minayo, org.), pp. 14-56. Sao Paulo: Hucitec/Abrasco.

Engels, F., 1975. A situação da classe trabalhadora na Inglaterra. Porto: Educação. Afrontamento.

Escorel, S., 1998. Vidas as léu: uma etnografia da exclusão social. Tesis de Doctorado, Brasilia: Facultad de Sociología, Universidad de Brasilia.

Frederiksen, H., 1969. Feedbaks in economic and demographic transition. Science, 166:837847.

Ibase, 1999. Observatório da cidadania no Brasil. Cadernos do Observatório, 1:35.

IPEA/FJp/IbGe/Pnud, 1998. Desenvolvimento humano e condiçoes de vida: indicadores brasileiros. Brasilia: Trena Triângulo Editora Nacional.

Koifman, S., 1995. Incidência de câncer no Brasil. En: Os muitos brasis (M.C. de Souza Minayo, org.), pp. 143-176. Sao Paulo: Hucitec/ Abrasco.

Lalonde, M., 1978. A new perspective of the bealth of canadians: a work document. Otawa.

Loureiro, S., 1990. Desigualdade social, doença e morte. En: Congresso De Epidemiologia da Abrasco, Memorias, 1 (sp). Campinas.

Machado, J.M.H. \& Minayo Gómez, C., 1995. Acidentes de Trabalbo: concepções de dados. En: Os muitos brasis (M.C. de Souza Minayo, org.), pp. 117-142. Sao Paulo: Hucitec/ Abrasco.

Mckeown, T., 1979. The role of medicine: dream, mirage and nemesis? Oxford: Basil Blackwell.

Mello Jorge, M.H., 1998. Como morrem nossos jovens. En: Jovens acontecendo nas trilhas das políticas públicas (E. Berquó, org.), pp. 209292. Brasilia: CNPD.

Monteiro, C.A., 1995. Velhos e novos males da saúde no Brasil. Sao Paulo: Hucitec/Nupens.

Núñez, N., 1994 Perfiles de mortalidad según condiciones de vida en Venezuela. En: Qualidade de vida: compromisso bistórico da epidemiologia (Comissão de Epidemiologia, org.), pp. 199-217. Belo Horizonte: Coopmed/Abrasco.

Omran, A.R., 1971. The epidemiologic transition. The Milbank. Memorial Fund .Q, 3:509-583.

Paina, J., 1997. Abordagens teórico-conceituais em estudos de condições de vida a saúde: notas para reflexão e ação. En: Condição de vida e saúde (R.B. Barata, org.), pp. 7-30. Río de Janeiro: Abrasco.

Pereira, E. R., 1999. A visão das elites sobre a pobreza e a desigualdade. Seminário Nacional do IPEA.

Roque, A. \& Corrêa, S., 1999. A agenda do ciclo social no Brasil: impasses e desafios. Cadernos do Observatório, 1 (0):11-21.

Rosen, G., 1980. Da polícia médica à medicina social. Río de Janeiro: Graal.

Sabroza, P. et al., 1995. Doenças transmissíveis: ainda um desafio. En: Os muitos brasis (M.C. de Souza Minayo, org.), pp. 177-244. Sao Paulo: Hucitec/Abrasco.

Santos, W.G., 1999. Cidadania e justiça. Río de Janeiro: Campus.

Souza, E.R. \& Minayo, M.C. S., 1995. O impacto da violência social na saúde pública do Brasil: década de 80. En: Os muitos brasis (M.C. de Souza Minayo, org.), pp. 87-116. Sao Paulo: Hucitec/Abrasco.

Towsend, P. \& Davidson, N., 1982. Inequalities in health. The Blach Report. Nueva York: Penquim Books.

Traducción a español: antropólogo Júlio de Freitas Taylor 


\section{GLOBALIZACIÓN, POLÍTICAS NEOLIBERALES Y SALUD}

Asa Cristina Laurell ${ }^{*}$

\section{INTRODUCCIÓN}

Este texto tiene como propósito examinar algunas formas específicas bajo las cuales la globalización impacta la salud de los trabajadores. Como punto de partida del análisis se sostiene que la expresión concreta más relevante de la globalización en la región latinoamericana es la instrumentación del proyecto neoliberal en la mayoría de estos países. Este proceso significa una reorganización integral de la sociedad y no sólo un cambio en la política económica. Este puede asumir distintas modalidades nacionales, pero en todos los casos está basado en los principios del mercado y el individualismo. La nueva organización de la sociedad requiere de una profunda reestructuración del Estado, que significa un nuevo tipo de intervención, mas no su retiro, y que se manifiesta en el terreno legal, en las políticas y en las instituciones de bienestar social.

Con este punto de partida el acercamiento a la problemática "globalización / salud de los trabajadores" se hace a través de la reforma del Estado. Hemos elegido este enfoque porque lleva al análisis de un conjunto de políticas, particularmente las laborales y de salud y seguridad social, que redefinen las relaciones entre el trabajo y el capital y transforman profundamente las condiciones de existencia de los trabajadores y, por tanto, su salud. Como es obvio, este enfoque es sólo uno de los varios posibles (Lee, 1998) pero tiene la ventaja de definir un ámbito analítico que abarca los procesos económicos, políticos y sociales. No se pretende incluir una medición directa del impacto en las condiciones de salud de los trabajadores, cuya concreción involucra problemas teórico-metodológicos y técnicos de difícil resolución.
Con base en estas consideraciones, en este ensayo se abordarán los siguientes temas:

- Una reflexión sobre los términos del debate sobre la globalización en el contexto del proyecto neoliberal;

- El impacto de los programas de ajuste y cambio estructural sobre el empleo y el salario y las repercusiones de éstos en los sistemas de seguridad social, ya que es una cuestión central tanto para comprender su crisis actual como para formular alternativas de solución;

- La reforma laboral que, por un lado, permite comprender las transformaciones en las condiciones del trabajo, y por el otro, es causa y condición de los cambios en la concepción de la seguridad social;

- La nueva concepción del seguro social vista a la luz de la constitución de un nuevo patrón de acumulación y de un modo específico de satisfacer las necesidades sociales;

- Algunas consideraciones para pensar las alternativas a la reforma social neoliberal que salvaguarden los derechos sociales y la responsabilidad social del Estado.

\section{LA GLOBALIZACIÓN Y EL PROYECTO}

\section{NEOLIBERAL}

En el debate sobre las alternativas de política económica y social, la globalización se ha convertido en un punto de referencia casi obligada. Detrás de este hecho está la suposición de que las nuevas tendencias de la economía globalizada imponen una serie de restricciones a los Estados nacionales que se

Maestría en Medicina Social, Universidad Autónoma Metropolitana-Xochimilco, México DF. E-mail: claurell@cueyatl.uam.mx. 
traducen en la reducción de sus márgenes para tomar decisiones soberanas, no sólo sobre la conducción de la economía, sino también sobre cómo satisfacer las necesidades sociales de la población (Navarro, 1999). Es decir, se asume el mecanicismo económico propio de la doctrina neoliberal.

Por ello, no se define con precisión qué es aquello que se denomina globalización, ni se explicitan sus significados más profundos en cuanto expresión de una nueva relación de fuerzas donde dominan los grandes intereses financieros (Valenzuela, 1990). Al contrario, se percibe la globalización como un proceso evolutivo económico, casi natural, en el cual la fuerza del mercado se impone como el principio organizador al nivel mundial, facilitada por la revolución tecnológica e informática. Esto ha llevado al derrumbe de las fronteras nacionales, la liberación de los flujos de capital y la interconexión de los procesos productivos; situación que, a su vez, exigiría el fortalecimiento de los cuerpos de decisión supranacionales y sistemas de seguridad integrados y bajo mando único. Aunque la caracterización del proceso tenga muchos elementos de verdad, resulta tergiversada al no reconocerse que está causada por una serie de decisiones políticas correspondientes a intereses específicos y no por una fatalidad económica (Navarro, 1998)

Este proceso vertiginoso de integración asume formas diferentes en distintas regiones del planeta que asimismo expresa relaciones de fuerza, no sólo entre los agentes económicos sino también entre naciones. De esta manera, la integración económica europea significa la libre movilidad tanto del capital como del trabajo y una agenda social común para los Estados miembro, aunque esta comunidad se rodea de un muro hacia el oriente y el sur. Por su parte el Tratado de Libre Comercio de América del Norte, la punta de lanza de la integración del bloque regional del continente americano, ha desmontado las barreras a las mercancías y los flujos de capital al tiempo que su socio dominante, EEUU, construye bardas electrificadas y custodiadas para detener a los inmigrantes y mantener a los trabajadores foráneos en la ilegalidad.

En el terreno más acotado de las políticas laborales y sociales son frecuentes dos tipos de reflexiones. Aquellas que, tomando la globalización neoliberal como un hecho irreversible, esgrimen una serie de argumentos para modificar estas políticas para adecuarlas a la nueva situación. Las otras que, entendiendo la globalización como una nueva relación de fuerzas, examinan su impacto en las políticas en función de los intereses de los actores económicos emergentes.

El argumento central, esgrimido a favor de un cambio en la política laboral hacia formas más flexibles, es la necesidad de hacer más competitivas las empresas nacionales en el mercado internacional mediante el abaratamiento de la mano de obra. Esto se lograría reduciendo el salario directo o el indirecto, o sea, las prestaciones sociales, lo que involucra especialmente el seguro social. Respecto a las políticas sociales se argumenta la incompatibilidad entre la apertura de mercados y la existencia de un monopolio estatal de financiamiento y prestación de los servicios y beneficios sociales. Es decir, la apertura al mercado externo obligaría a la promoción interna de la competencia. En esta misma línea de argumentación se inscribe la necesidad de uniformar las políticas sociales con las de los principales socios comerciales para constituir condiciones homogéneas de competencia.

La segunda línea de reflexión explora las implicaciones de la liberalización económica como un recurso de poder para plantear exigencias y ejercer presión en el terreno de las políticas laboral y sociales. Aunque no hay evidencias empíricas para demostrar una recomposición sustancial de la inversión productiva entre los países desarrollados y subdesarrollados, la mera posibilidad de que pueda ocurrir a raíz de la liberalización ha permitido a los empresarios imponer sus condiciones a los trabajadores, tanto en los países centrales como en los periféricos, y justificar la llamada reforma laboral. En el terreno de la salud y seguridad social los tratados de libre comercio han fortalecido a dos poderosos actores económicos, que son la industria aseguradora y el tradicional complejo médico-industrial, ambos grandes empresas multinacionales. Sin embargo, para que éstos puedan tener una plena expansión la sola apertura del mercado es insuficiente, ya que requieren de políticas estatales específicas para constituir y 
garantizar el mercado nacional a través de la reforma de salud y seguridad social (Laurell, 1997).

El debate latinoamericano sobre la "globalización" refleja una realidad donde en la práctica ésta es equivalente al proyecto neoliberal y sus distintas vertientes de ajuste estructural y reforma del Estado. Ante esta realidad se puede adoptar dos posiciones distintas. Una es la propia de los exponentes de este proyecto y los hacedores de sus políticas. La otra es la de sus críticos, que se distinguen no sólo por sus cuestionamientos del proyecto sino también por no considerarlo una fatalidad. Sin embargo, independientemente de la posición que se toma ante este proyecto, existen pocas dudas sobre su vigencia y la necesidad de estudiarlo como un hecho fundamental de la realidad.

\section{LAS REPERCUSIONES DEL AJUSTE}

\section{ESTRUCTURAL SOBRE EL EMPLEO, EL SALARIO}

\section{Y LAS INSTITUCIONES DE SEGURIDAD SOCIAL}

Es un hecho empíricamente constatable que la aplicación de los programas de ajuste y cambio estructural han llevado al estancamiento o la disminución del empleo formal y el correlativo crecimiento de las actividades denominadas informales (Laurell, 1999). Debe señalarse que la denominación "informal" es imprecisa y encubre fenómenos de distinto índole, como son la sustitución de empleos fijos con prestaciones sociales por empleos temporales sin prestaciones; el trabajo a domicilio; el comercio ambulante; etcétera. En este contexto cabe además recordar que la medición del desempleo en América Latina tiene serias deficiencias, tanto por razones técnicas como por la necesidad de la población de desarrollar alguna actividad que le reporta ingresos en ausencia de un sistema comprensivo de protección contra la pérdida del salario. En efecto, sólo ocho países de América Latina y el Caribe tienen algún tipo de seguro de desempleo, que en todos los casos se caracteriza por una cobertura no-universal, una vigencia reducida en el tiempo y una compensación baja (Inter-American Development Bank, 1996). Esta situación explica la simetría entre el decrecimiento o estancamiento del empleo formal y el crecimiento del empleo informal.
Aunque existe consenso respecto al impacto negativo sobre el empleo de los programas de ajuste y cambio estructural, algunos expertos lo consideran un fenómeno pasajero mientras que otros argumentan que tiene carácter estructural (Valenzuela, 1997). Esta última posición está apoyada en una serie de evidencias que demuestran que las causas del impacto negativo están íntimamente relacionadas con las principales políticas del ajuste estructural. La más importante es la brusca apertura externa instrumentada en todos los países de la región, que ha repercutido fuertemente en las actividades productivas en los sectores primario y secundario. A ello se añaden la inestabilidad y la pronunciada heterogeneidad del crecimiento económico que han caracterizado a la mayor parte de los países (Inter-American Development Bank, 1996); situación que se refleja en la evolución negativa del PIB per cápita. Estos problemas, junto con la reducción del gasto público, la concentración del ingreso y su caída para la mayoría de las familias, han provocado la contracción del mercado interno, que a su vez frena el crecimiento económico. De esta manera se ha constituido un círculo vicioso donde el empleo resulta una de las variables macroeconómicas más afectadas.

El segundo problema que tiene efectos directos sobre el bienestar social es la depresión salarial mediante la imposición de los llamados "topes salariales". Esta política ha sido uno de los mecanismos típicos para instrumentar el ajuste fiscal pero se está prolongando por tiempo indefinido. La caída salarial y el estancamiento del empleo llevan necesariamente al desfinanciamiento de los seguros sociales, ya que sus ingresos disminuyen al tiempo que sus obligaciones se mantienen fijos o incluso, en el caso de las pensiones, crecen. La dinámica específica depende de las modalidades del seguro en cada país pero se deriva del hecho de que el monto de la cuota obrero-patronal disminuye al ser proporcional al salario y/o porque las aportaciones estatales decrecen a raíz del recorte del gasto social.

El desfinanciamiento de los sistemas de seguridad social en América Latina tiene una diferencia específica con el de los sistemas universales en los países desarrollados, ya que en ellos se combina la disminución de los ingresos a causa del desempleo con el incremento en los egresos por el pago de los 
seguros de desempleo. Sin embargo, en ambos casos los problemas de fondo están en la profunda reestructuración del mercado de trabajo y una nueva distribución del excedente entre salarios y ganancias, a favor de estas últimas.

\section{LA REFORMA LABORAL}

La reforma laboral y la reforma de la seguridad social son partes sustantivas de la reforma neoliberal del Estado y tienen como denominador común la supresión de derechos sociales: el derecho al trabajo y a la seguridad social. Son, de esta manera, elementos importantes de la reorganización social global cuyo sustento conceptual-ideológico es el libre mercado y el individualismo. En ambos casos el propósito es abaratar la mano de obra, o sea recuperar la tasa de ganancia para impulsar la acumulación, aunque la justificación explícita sea incrementar la competitividad de las empresas nacionales en el mercado mundial. A partir de estas reformas se establece una nueva relación entre el capital y el trabajo y una nueva distribución de responsabilidades entre el Estado y los privados en la satisfacción de las necesidades sociales que implica una nueva definición de cómo acceder a los beneficios y servicios así como de su tipo y cantidad.

Aunque la llamada reforma laboral constituye una parte fundamental de la agenda neoliberal, para 1996 sólo se había instrumentado formalmente mediante los cambios legales correspondientes en Argentina, Chile, Colombia, Guatemala, Panamá y Perú; situación que revela las dificultades políticas para imponerla. Sin embargo, es necesario señalar que se ha avanzado de facto en la reforma por varias vías sin cambiar la legislación. Por ejemplo, en México se ha firmado una serie de "pactos" entre las organizaciones empresariales y sindicales sobre productividad, nueva "cultura laboral", etcétera. La otra vía, y tal vez la más importante, es una renegociación de los contratos colectivos, que significa la pérdida de derechos adquiridos y la redefinición de las normas de trabajo, las condiciones de contratación, la materia de trabajo (de la Garza, 1999).

Los elementos centrales del nuevo modelo laboral son, por un lado, la contratación individual y, por el otro, la flexibilización de la relación laboral. El tránsito de la contratación colectiva al contrato individual es clave en la reforma laboral tanto conceptualmente como en términos políticos. De esta manera, el contrato individual corresponde a la idea de que los precios de las mercancías, incluyendo el de la fuerza de trabajo, deben estar regidos por el mercado. En esta visión el contrato y la negociación colectivas distorsionan el libre juego de las fuerzas del mercado, ya que introducen elementos extraeconómicos, y por tanto ilegítimos, en la fijación del salario (directo e indirecto) y respecto a las condiciones de uso de la fuerza de trabajo. Resulta significativo que para el neoliberalismo las organizaciones sindicales - las corporaciones - son, junto con el Estado, los principales obstáculos a una economía sana y competitiva (Guillén, 1992). El debilitamiento de la contratación colectiva y de la negociación obrero-patronal del salario, las prestaciones y las normas de trabajo tiene implicaciones políticas más allá de lo laboral, ya que persigue desarticular las organizaciones de los trabajadores y con ello la representación colectiva de sus intereses. En esta misma lógica se inscriben las restricciones al derecho de huelga, que tienen por objeto reducir el poder de los trabajadores basado en su acción colectiva.

La flexibilización del trabajo tiene conceptualmente dos vertientes distintas aunque en la práctica pueden confluir. Una se refiere esencialmente al precio de la fuerza de trabajo y la otra a las reglas para su uso. La primera vertiente tiene como palanca central la supresión de la estabilidad en el empleo y la eliminación de los derechos derivados de ésta. La flexibilización de las formas de contratación y la legalización del contrato eventual o de prueba abre además la puerta a otras formas de precarización del trabajo, como son la subrogación o contratación de tareas con terceros, el trabajo a domicilio sin contrato o a destajo, etcétera. Otra forma de flexibilización de la relación laboral con impacto sobre el precio de la fuerza de trabajo es la anulación de la indemnización obligatoria por despido y la relación de su monto con la antigüedad. Otro propósito central de la reforma laboral es generalizar el pago por hora trabajada con premio por productividad individual en sustitución del salario 
base con el pago adicional por horas extras, trabajo nocturno y trabajo durante días feriados. Es decir, se busca no sólo individualizar el pago sino además hacerlo estrictamente equivalente al tiempo de trabajo realizado, independientemente de las circunstancias bajo las cuales se realiza. Respecto al salario indirecto, el abaratamiento de la mano de obra se centra en la disminución del costo del seguro social o el llamado impuesto sobre la nómina y de otras prestaciones, como por ejemplo vacaciones, educación, etcétera.

El segundo tipo de flexibilización se refiere, como ya se señaló, a una redefinición del uso de la fuerza de trabajo. Los temas de reforma laboral en este terreno son la polivalencia del trabajador y la supresión de la definición de tareas y normas de trabajo en los contratos colectivos. El sentido profundo de esta vertiente de la reforma laboral es la redefinición de las relaciones de poder dentro del centro de trabajo, ya que incrementa el control patronal sobre el uso de la fuerza de trabajo. Esta pérdida de recursos de poder por parte de los trabajadores se añade al debilitamiento de su forma básica de organización, que es el sindicato.

Las características de la reforma laboral señalan varios efectos posibles, directos e indirectos, sobre la salud de los trabajadores. Es, de esta manera, uno de los mecanismos utilizados para lograr una reducción salarial; reducción que, en la actualidad, define importantemente el deterioro de las condiciones de vida. Otro elemento a destacar es que este nuevo modelo laboral incrementa sustancialmente las situaciones de estrés vividas por los trabajadores y relacionadas con la inestabilidad en el empleo, la presión sobre el individuo para incrementar su productividad, el bajo control sobre la tarea y el desempleo. Existe una literatura científica amplia respecto a los distintos efectos adversos sobre la salud asociados con la amenaza de perder el empleo y con el desempleo mismo que sólo en una parte están mediados por la pérdida del ingreso (Lin et al., 1995; Bartley, 1994). A estas situaciones patógenas se añaden además los problemas derivados de la precarización del trabajo y sus repercusiones sobre las condiciones de trabajo. Es de esperar que éstas empeoren, con un incremento de las cargas físicas, químicas, fisiológicas y psíquicas en el proceso laboral.
Otro efecto de la reforma laboral sobre la salud es que la individualización del contrato, y por tanto de las prestaciones, es uno de los sustentos de la reforma de la seguridad social que, como se verá, conlleva una nueva estratificación en el acceso a los servicios a partir de la diferenciación de los trabajadores en función de sus aportaciones.

\section{LA REFORMA DE LA SEGURIDAD SOCIAL}

Los gobiernos justifican la necesidad de reformar la seguridad social con varios argumentos (Laurell, 1997). El primero es su crisis de cobertura y calidad provocada por el desequilibrio financiero que, en esta visión, se debe a problemas demográficos, epidemiológicos y de ineficiencia administrativa. Sin embargo, no se menciona más que colateralmente el problema de fondo, que es, como ya se vio, la caída del empleo y del salario. El segundo argumento es la afirmación, nunca comprobada, de que el pago de cuotas obrero-patronales o, lo que es lo mismo, el "impuesto sobre la nómina" impide la expansión del empleo, ya que induciría a los empresarios a no contratar trabajadores y a éstos a no aceptar un empleo formal (sic). Sería, entonces, necesario desligar el seguro social de la relación laboral y buscar formas individualizadas de aseguramiento.

Para comprender el contenido de esta reforma es preciso explicitar que sus propósitos se inscriben en la lógica del proyecto neoliberal global: contribuir a la reproducción ampliada del capital abaratando la mano de obra con una disminución de la cuota patronal y transformando los beneficios y servicios sociales en un ámbito directo de acumulación (Laurell, 1995). En este contexto la seguridad social obligatoria y pública es clave porque abarca los fondos de pensiones y las principales instituciones de salud. La parte más importante de la reforma involucra, por ello, estos dos ámbitos y se ha instrumentado o está agendada en la mayoría de los países de la región latinoamericana. Así, se han llevado adelante en Chile, Perú, Argentina, Colombia, Uruguay y México (Inter-American Development Bank, 1996), mientras que las iniciativas de reforma han topado con una fuerte resistencia en América Central, Bolivia, Ecuador y Brasil. 
Casi todos los programas de reforma están directa o indirectamente conducidos y frecuentemente financiados por el Banco Mundial (Paul y Paul, 1995) y su receta básica está expuesta en Invertir en Salud (World Bank, 1993) y en Envejecimiento sin crisis (World Bank, 1994). La experiencia chilena, iniciada en 1981, es además un punto de referencia sobresaliente. Estas reformas mueven el esquema básico de la seguridad social del financiamiento y prestación de servicios públicos a la administración privada; de un seguro integral a seguros separados por cada contingencia especifica; de la solidaridad al individualismo; de la redistribución y derechos iguales para los asegurados a la equivalencia entre la prima y los serviciosbeneficios.

Aunque las pautas son semejantes, existen algunas importantes variaciones nacionales en dos aspectos. Uno consiste en introducir medidas que, en principio, tienden a suavizar la pérdida de derechos o incluso ampliarlos a nuevos grupos, como en los casos de Uruguay y Colombia. El otro involucra mecanismos que tienen el propósito de corregir las más evidentes "fallas del mercado" para contener costos en los servicios de salud, como en los casos de Colombia y México. Las variaciones nacionales en la aplicación de la reforma, obviamente, también obedecen a la configuración previa de las instituciones de seguridad social (Laurell, 1999).

La primera reforma, y la más radical, es la de los sistemas obligatorios de pensiones, que involucra el control sobre enormes fondos financieros. Típicamente esta reforma abandona el sistema de fondos colectivos bajo administración pública o sindical con una pensión conocida y adopta el sistema de cuentas de capitalización individual manejados por administradoras privadas (AFP, Afore, etc.), usadas para contratar la pensión con compañías de seguro privadas. Es decir, la solidaridad intergeneracional y entre trabajadores sanos y discapacitados se elimina, ya que las pensiones son equivalentes al ahorro individual $y$, en consecuencia, de un monto desconocido.

Este esquema de pensiones significa la transferencia más grande de fondos públicos a grupos financieros privados nacionales o transnacionales que jamás se ha dado en América Latina. Para ilustrar su tamaño se puede mencionar que los AFPs chilenos controlaron fondos equivalentes al 40\% del PIB en 1995 (Banamex, 1996) y se estima que las Afores mexicanas acumularán fondos equivalentes al 25\% del PIB en diez años (Laurell, 1997). El control sobre esta enorme cantidad de capital confiere a estos agentes financieros un poder económico sin precedentes y consecuentemente un poder político que sólo se puede regular parcialmente vía la legislación (Ruiz-Tagle, 1996).

Adicionalmente, el negocio de las pensiones es muy atractivo, ya que la administradora de fondos cobra una comisión que, por ejemplo, en Chile y México corresponde a entre el 15\% y 30\% de la cuota depositada (Instituto Mexicano del Seguro Social, 1995; Ruiz-Tagle, 1996). La forma de cobro de la comisión tiende además a transferir los riesgos del mercado financiero a los trabajadores asegurados (Laurell, 1997).

Las administradoras privadas son, por otra parte, más ineficientes que las públicas porque tienen altos gastos en comercialización y su razón de ser es la ganancia (Beattie y McGillivry, 1995; Banamex, 1996). Esta es una de las razones por las cuales los expertos en la materia se oponen a los sistemas privados de capitalización individual (Bonilla, 1995; López, 1995; Ruiz-Tagle, 1996; Hazas, 1996).

Para viabilizar esta reforma es indispensable la intervención estatal directa, no sólo en el ámbito legal sino también mediante el compromiso de subsidiar la privatización del sistema de pensiones con recursos fiscales. Este "costo de transición" es una condición absoluta e inevitable en el cambio del sistema de fondos colectivos al de capitalización individual. Su monto depende del diseño específico de la reforma —en México se estima entre 1 a $2 \%$ del PIB anualmente (Laurell, 1997) y en Chile en 3,5\% (Ruiz-Tagle, 1996)_e invariablemente tendrá que ser pagado durante por lo menos medio siglo. Al representar esta cantidad una parte considerable del gasto social público, los gobiernos se ven obligados a recortar otros programas sociales a fin de mantener el equilibrio fiscal, una de las principales prioridades del ajuste.

Mientras que los grupos financieros son los ganadores de la reforma, los contribuyentes noasegurados y los trabajadores asegurados son los 
perdedores. Los primeros pierden porque están obligados a subsidiar el sistema, a pesar de que no les representa ninguna ventaja. Los trabajadores asegurados pierden porque su futura pensión es incierta y probablemente baja, ya que depende de su ahorro individual acumulado; ninguno de los componentes de éste -el monto y el número de contribuciones semanales, la comisión de la administradora y la tasa de interés devengadapuede estimarse con certidumbre para el período de una vida laboral (Beattie y McGillivray, 1995; Du Boff, 1997; Ruiz-Tagle, 1996; Bonilla, 1995; Lacey, 1996; Kurczyn, 1996; Lo Vuolo, 1996). La principal incertidumbre concierne a la tasa de interés promedio de los mercados financieros. Incluso los expertos más optimistas y comprometidos con el nuevo esquema estiman una tasa de interés real del orden de 4 a $5 \%$, mientras que expertos más moderados pronostican una tasa de entre 2 y 3\%, basando sus cálculos en evidencias históricas (Bonilla, 1995; Du Boff, 1997; Ruiz-Tagle, 1996; Gillion y Bonilla, 1992; Bustos Castillo, 1993). Con una contribución del orden de $12 \%$ del salario pagado durante 40 años y restando las comisiones, una tasa de interés promedio de 5\% correspondería a una pensión de entre 16\% y 37\% del salario anterior a la jubilación, dependiendo de la carrera salarial del trabajador (Hazas, 1998).

El último argumento de los creyentes en la reforma de pensiones es que ésta es positiva porque el gran incremento en el ahorro interno dará por resultado un crecimiento económico rápido, más empleos y salarios más altos. Sin embargo, esto es un asunto polémico. No está claro, por una parte, si el ahorro forzoso vía pensiones produce un incremento del ahorro nacional o sólo un cambio en las proporciones entre el ahorro privado y el público. El desahorro público implicado en el "costo de transición" puede, en efecto, provocar una baja en la inversión pública con efectos negativos sobre el crecimiento. Por la otra, no existen evidencias empíricas consistentes para probar una relación causal entre la tasa de ahorro interno, inversión y crecimiento del PIB (Gillion y Bonilla, 1992; Kurczyn, 1996). Considerando que la mera oferta de recursos financieros no genera automáticamente una demanda de crédito para actividades productivas, resulta comprensible que el incremento del ahorro interno no necesariamente provoque crecimiento de cara a un mercado interno contraído a causa de las políticas de ajuste (López, 1995).

La reforma pensionaria es un ejemplo gráfico de la intervención directa del Estado a fin de crear mercados totalmente nuevos en bencficio de grupos de interés particulares, en este caso de los grupos financieros. Lo que solía ser una preocupación social y una responsabilidad pública se ha convertido en un terreno de los negocios privados. No es fortuito que el Banco Mundial considere como los grandes éxitos de la reforma pensionaria chilena la ampliación del mercado de capitales, el crecimiento de la industria de los AFPs y la renovación de la industria de seguros (Lacey, 1996).

La otra parte importante de la reforma de la seguridad social se refiere a los servicios de salud e involucra, generalmente, la transformación de todo el sistema de salud, o sea, de los servicios prestados por el seguro social, los servicios públicos asistenciales y los servicios privados. Este proceso de reforma tiende a ser más lento que el de pensiones, por dos razones. Una es que, a diferencia del sistema de pensiones, que en esencia consiste en transferir fondos a la administración privada con fines de lucro, esta reforma involucra la administración de fondos de salud y la prestación de servicios que en una parte no es rentable. La otra es que esta reforma necesariamente conlleva una reorganización institucional profunda que plantea problemas administrativos complejos y afecta un número importante de empleados.

Por ello, los arreglos institucionales previos del sistema de salud son cruciales, ya que determinan en gran medida la modalidad y el proceso de la reforma en cada país. Las características que condicionan la reforma son: el grado de vigencia del derecho a la salud; la cobertura de población de la seguridad social y de los servicios asistenciales públicos; la organización de la seguridad social, particularmente su papel en el financiamiento y la prestación de los servicios, así como su fragmentación o unidad; y el poder y maduración de los seguros y servicios médicos privados. Estos elementos explican, por ejemplo, por qué el proceso de reforma y los nuevos arreglos institucionales en Chile son distintos a los de Argentina 
o México, ya que estos tres países difieren en los aspectos mencionados y la reforma se dio bajo condiciones políticas bastante diferentes (Laurell, 1999).

Aun así llama la atención que los elementos fundamentales de las reformas son muy similares. De conformidad con los principios básicos de la política social neoliberal, buscan constituir al seguro y servicios de salud en un ámbito de acumulación de capital. Sin embargo, la reforma tiende a establecer un sistema dual con un subsistema para los asegurados con un componente mercantil fuerte y con participación directa del sector privado y, dado que la atención a los pobres generalmente no es negocio, un subsistema asistencial para los no-asegurados (Laurell, 1997; Tetelboin, 1996).

La instrumentación del subsistema mercantil requiere de la intervención estatal directa para inducir la mercantilización y, eventualmente, la privatización de la gestión de fondos y la prestación de servicios. Este proceso ha asumido formas diferentes en América Latina pero se construye invariablemente sobre cinco pilares básicos, que son: la separación entre el financiamiento, la prestación y regulación de los servicios; el fortalecimiento de los esquemas de prepago con el propósito de garantizar un mercado estable y promover la administración comercial de los fondos de salud; el costeo de los actos médicos como paso necesario para mercantilizarlos y definir el contenido y costo de los planes o paquetes de salud; la conversión de las clínicas y hospitales públicos en unidades autónomas con gestión empresarial; y la introducción de la libertad de elección de los usuarios de su gestor de fondos y/o prestador de servicios. Estas operaciones abren al mercado tanto los fondos de salud como las instalaciones del seguro social obligatorio. Adicionalmente se ha incrementado sustancialmente el subsidio fiscal estatal al seguro de salud obligatorio para reducir la cuota patronal (Laurell, 1997; Cárdenas, 1996).

Algunos países, por ejemplo Chile, han constituido dos subsistemas aparentemente separados, uno privado (las IsAPres) y otro público, donde los individuos optan por uno u otro. Este modelo es altamente susceptible a prácticas de "sclección adversa", ya que las IsAPres eligen como sus clientes a aquellos que cotizan alto y tienen bajo riesgo de enfermar y dejan al sistema público a aquellos que pagan poco y se enferman mucho (World Bank, 1993). Como resultado, las IsAPREs son un gran negocio y concentran los recursos financieros y técnicos, mientras que el sistema público tiene una sobrecarga de pacientes y mucho menos recursos. A pesar de que el subsistema ISAPRE atiende a una minoría de la población, impone la lógica básica al sistema en su conjunto (Vergara, 1997; Tetelboin, 1996).

Otros países, por ejemplo Colombia y México, han preservado o constituido un organismo o fondo público que recauda las contribuciones al seguro social y las aportaciones estatales, establece mecanismos de contención de costos y transfiere recursos financieros a los distintos gestores de salud, públicos o privados. Los gestores contratan los servicios de sus "clientes" con los prestadores y/o los ofrecen en sus propias instalaciones, con personal propio (Cárdenas, 1996; Londoño y Frenk, 1996; World Bank, 1998).

Ambos modelos comparten la característica de convertir la gestión de los fondos de salud en la actividad central que subordina la prestación directa del servicio a una nueva lógica. Esto significa que las compañías privadas de seguros, generalmente ligadas a los grandes grupos financieros, son el poderoso actor emergente en el campo de salud, al igual que en EEUU, con repercusiones bastante negativas sobre la cobertura, la calidad, los costos, la práctica médica y la equidad (Bodenheimer, 1995; Navarro, 1997). Es significativo que las aseguradoras, las organizaciones de administración de la salud y las grandes empresas hospitalarias que están penetrando en el nuevo mercado de salud son estadounidenses o sus socios locales (Laurell, 1997).

Una segunda característica común es la definición de una gran variedad de planes de salud con primas y copagos diferentes, con o sin un plan básico obligatorio. El resultado es una nueva estratificación en el acceso y la calidad de los servicios que no existía en la seguridad social obligatoria, donde todos los asegurados tenían los mismos derechos, con independencia del monto de su contribución (Laurell, 1999). La lógica mercantil y los nuevos arreglos financieros eliminan, de esta manera, la solidaridad entre los asegurados y tienden a reducir derechos. 
Dado que el seguro obligatorio de salud no tiene una cobertura universal en la mayoría de los países de la región, se requiere de servicios de salud asistenciales. La intención de la reforma de salud es (re)organizarlo bajo los principios de los programas para los pobres, es decir, focalización, descentralización y costo-eficiencia. De esta manera, los gobiernos centrales han descentralizado los servicios de los ministerios de salud a los estados, provincias o municipios y reducido su responsabilidad financiera a la transferencia de fondos sólo para un "paquete básico o esencial de salud". Este paquete, dirigido a la población pobre no-asegurada, incluye algunas intervenciones de salud pública y diez a quince acciones clínicas ambulatorias, altamente costoeficientes (medido en Avads), más restringidos que los servicios anteriormente prestados por el Estado a los pobres.

La política dual de la reforma en salud -la mercantilización del financiamiento y la prestación del servicio y la asistencia pública selectiva- revierte la tendencia histórica hacia la cobertura universal de servicios integrales de salud. Significa, además, una redistribución de los recursos sociales dedicados a salud favorable a los prestadores y aseguradoras privados. La reducción de la responsabilidad colectiva y/o pública en el campo de la salud ocurre además en medio de un proceso de empobrecimiento de la absoluta mayoría de la población, pobre desde antes. Y por último, no existe ninguna evidencia sólida para pensar que la política propuesta podrá cumplir sus promesas de equidad, eficiencia y calidad, en vista de que los hechos empíricos apuntan en la dirección contraria (Salmón, 1990; Bodenheimer, 1995; Tetelboin, 1996; Rajs, 1995; Diderichsen, 1995; Dahlgren, 1994; Health Policy Network, 1995).

Los efectos negativos de la reforma de la seguridad social se agravan, además, por la reforma laboral, con sus consecuencias de inestabilidad y precarización del empleo. Ocurre así porque el nuevo modelo de privatización, individualización y equivalencia impedirá al trabajador alcanzar una pensión suficiente, ya que es de esperar que tendrá períodos significativos sin cotizar durante su vida laboral, lo que contrasta con el derecho de la administradora de sus fondos de cobrar continuamente sus servicios. Sufrirá, además, períodos de descobertura de servicios de salud, ya que el nuevo esquema difícilmente le permitirá cotizar cuando no tenga un empleo formal.

\section{Algunos elementos para Pensar}

\section{ALTERNATIVAS A LA REFORMA SOCLAL}

\section{NEOLIBERAL}

Ante este panorama complejo, ¿existe algún otro camino, o tendrán razón aquellos que sostienen que estas reformas no sólo son necesarias sino la única opción viable en el contexto de la globalización? Para empezar a responder a esta pregunta hay que subrayar que la construcción de un sistema de satisfacción de necesidades sociales tiene como condición ineludible una política de empleo y de ingresos. Uno de los ejes de la política social en la mayoría de los Estados de bienestar es, por ello, una activa política de generación de empleos con una remuneración razonable, donde el seguro de desempleo es el último recurso ante el eventual fracaso de ésta (Esping-Andersen, 1990). Aunque el empleo tienen una relación directa con el crecimiento económico, hoy resulta evidente que el mero crecimiento es insuficiente para resolver el problema del desempleo. De allí la necesidad de desplegar una política específica al respecto (Zepeda y Alarcón, 1996).

De la misma manera ningún modelo de seguro social, sea éste público, cuasipúblico o privado, es sostenible, y mucho menos universalizable, en ausencia de niveles suficientes de empleo y salario (Laurell, 1996). Es así debido a que ambos constituyen la base necesaria de su financiamiento, sea por la vía de los impuestos o por la vía del pago de una cuota o prima. Un modelo que individualiza y privatiza el seguro, no resuelve el problema de la protección social de la población. Sólo legaliza la desprotección de los que no están en condiciones de pagar o no pagan lo suficiente $y$, en el mejor de los casos, los convierte en objetos de una asistencia social mínima y selectiva. Es decir, priva de sus derechos sociales a los ciudadanos y constituye dos nuevas categorías de individuos: los clientes y los sujeto de asistencia.

Para pensar las alternativas al proyecto social neoliberal es necesario recordar el hecho de que una determinada política distributiva depende de la decisión 
política respecto a qué proporción de la riqueza socialmente producida debe destinarse a la protección social y sobre las formas institucionales para administrarla. Esto viene al caso porque, con excepción de los países cuyo producto interno bruto es insuficiente para satisfacer las necesidades básicas de sus habitantes, la cuestión de la redistribución es tan o más importante que el crecimiento (Boltvinik, 1996). Es, por tanto, crucial analizar las prioridades que rigen la asignación de los recursos fiscales y su recaudación, ya que, vista en esta perspectiva, la "escasez" de recursos para los programas sociales resulta bastante relativa en la absoluta mayoría de los países latinoamericanos.

Otra consideración, soslayada en el discurso técnico-pragmático, es que la política social, como toda política, surge de ideas sobre cuáles son las necesidades sociales y qué "debe" hacer la sociedad a través de la acción estatal para satisfacerlas en función de valores y normas sociales, como por ejemplo igualdad, universalidad, no-discriminación, dignidad humana. Este "deber ser" ciertamente se matiza por el "poder hacer", que depende de las instituciones, capacidades y recursos existentes. Sin embargo, estamos ante un proceso dinámico donde las normas o la moralidad social y política no sólo generan recursos, capacidades e instituciones, sino además las características de estas últimas son un elemento sustancial en la formación de los valores sociales (Rothstein, 1994).

En este contexto cabe recordar que la valoración de una política tendría que hacerse juzgando su idoneidad o su capacidad para alcanzar los propósitos que la orientan. Esto requiere de la explicitación y definición, no sólo de objetivos programáticos inmediatos, sino de los objetivos sustantivos que están cercanamente relacionados con los valores sociales arriba mencionados. Esto resulta importante actualmente porque hay bastante ambigüedad en el uso de conceptos como equidad, universalidad, necesidades humanas, etcétera (Funsalud, 1994). La evaluación de las políticas tiende, además, a centrarse no en su eficacia sino en su eficiencia, que sólo abarca el aspecto de uso de recursos.

Una última consideración para fundamentar una propuesta alternativa a la neoliberal es de orden empírico-histórico. Resulta, de esta manera, posible comprobar, con base en los estudios comparativos entre países, que ciertas políticas sociales han demostrado más eficacia y eficiencia que otras. En particular, la garantía universal de los derechos sociales de todos los ciudadanos y la satisfacción de la necesidad humana sólo han sido posibles con mecanismos amplios de solidaridad instrumentados por instituciones públicas y financiados con recursos públicos (Esping-Andersen, 1990).

A diferencia de Estados Unidos, en América Latina los derechos al trabajo y a la seguridad social están basados en la idea de los derechos sociales y contribuyeron a socializar éstos como valores sociales compartidos. Surgieron de un pacto entre el Estado, empresarios y sindicatos, y aunque con frecuencia no llegaron a ser una realidad, repercutieron en la ampliación de las políticas de bienestar para grupos no asegurados (Vilas, 1995). No existen elementos de peso para suponer que el valor social de los derechos sociales haya perdido vigencia en nuestras sociedades o haya sido sustituido por los valores del mercado y el individualismo. Es más, el discurso dominante evade la cuestión de los derechos al trabajo y a la seguridad social y se centra en la eficiencia. La justificación de la reforma laboral es, por ello, necesaria para incrementar la competitividad, el crecimiento económico y la generación de empleo. Igualmente pone en entredicho la eficiencia de la forma estatal y pública de la seguridad social y su capacidad de generar bienestar social. Es decir, no ataca toda forma del seguro social sino sus elementos públicos, colectivos, solidarios y redistributivos.

Este conjunto de consideraciones viene al caso porque, si se asume el principio de los derechos al trabajo y a la seguridad social, estamos ante la oportunidad y la necesidad de avanzar a su cumplimiento universal, y exigible como parte de los compromisos de un nuevo pacto social. Pasa por un debate amplio sobre valores sociales; sobre las responsabilidades y derechos colectivos; sobre las prioridades sociales y económicas; sobre la eficacia de distintas políticas de creación de empleo; sobre la idoneidad de los distintos modelos de seguridad social para alcanzar el propósito de proteger a la población contra las contingencias de la vida. Pasa, en suma, por la construcción de otro proyecto nacional y de una nueva alianza social que lo viabilice. 
La ruptura del pacto social de los años de posguerra plantea la urgencia de forjar otro cuyo contenido específico dependerá de la alianza social que lo sustenta. Los sujetos de esta alianza, con certeza, serán distintos a los de la anterior. Sin embargo, para que este pacto tenga viabilidad necesita satisfacer dos condiciones. Una es que se (re)constituyan sujetos sociales colectivos con representaciones auténticas y con capacidad de negociar la satisfacción de sus intereses, aunque sea subordinadamente. La otra es que no excluya a numerosos grupos o incluso a la mayoría de la población, ya que requiere como mínimo garantizar a todos "un lugar en este mundo".

\section{REFERENCIAS BIBLIOGRÁFICAS}

Banamex, 1996. Administradoras de fondos de retiro: reforma en México y los ejemplos chileno $\mathrm{y}$ argentino. Examen de la situación económica de México, 884:102-114.

Bartley, M., 1994. Unemployment and ill health: understanding the relationship. Journal of Epidemiology and Community Health, 48:333-37.

Beattie, R. \& McGillivray, W., 1995. Una estrategia riesgosa: reflexiones acerca del informe del Banco Mundial "Envejecimiento sin crisis". Revista Internacional de la Seguridad Social (3-4).

Bodenheimer, T., 1995. The industrial revolution in health care. Social Justice, 22(4):26-42.

Boltvinik, D. 1996. Algunas tesis y reflexiones sobre la pobreza en México. Bases para una política para su superación. En: Hacia una Politica Social Alternativa (A.C. Laurell, org). México DF: Fundación F. Ebert.

Bonilla, A., 1995. Reformas de los sistemas de pensiones. En: Reunión Internacional de Expertos en Seguridad Social, Memorias. México DF: Centro de Desarrollo Estratégico para la Seguridad Social.

Bustos Castillo, R., 1993. Analysis of a national private pension scheme: the case of Chile International Labour Review, 133:3.

Cárdenas, M., 1996. La reforma de la seguridad social colombiana: entre la competencia y la solidaridad. En: La seguridad social en América
Latina: ¿reforma o liquidación? (J. Esignia \& R. Díaz, coords.). Caracas: Nueva Sociedad.

Dahlgren, G., 1994. Framtidens sjukvardsmarknader vinnare och förlorare (Los mercados de salud del futuro - ganadores y perdedores). Estocolmo: Natur och Kultur.

De La Garza, E., 1999. Modelos de producción, estrategias empresariales y relaciones laborales. En: Estrategias de modernización empresarial en México, flexibilidad y control sobre el proceso de trabajo (De La Garza, E., comp.). México DF: Rayuela.

Diderichsen, F., 1995. Market reforms in health care and sustainability of the welfare State: lessons from Sweden. Health Policy, (32):141-153.

Du Boff, R., 1997. The welfare State, pensions, privatization: the case of social security in the United States. International Journal of Health Services, 27:1-23.

Esping-Andersen, G., 1990. The three worlds of welfare capitalism. Princeton: Princeton University Press.

Funsalud, 1994. Economía y salud. México DF: Funsalud.

Gillion, C. \& Bonilla, A., 1992. Analysis of a national private pension scheme: the case of Chile. International Labour Review, 131:2.

Guillén, H., 1992. El proyecto social de Milton Friedman: el regreso al laisseq-faire. Investigación Económica, 202:277-309.

Hazas Sánchez, A., 1996. Futuro del sistema pensionario de los trabajadores sujetos a la nueva ley del IMSS. En: Alternativas de Reforma de la Seguridad Social (M.L. Mussot, coord.), pp. 153-198. México DF: Universidad Autónoma Metropolitana-Fundación F. Ebert.

Hazas Sánchez, A., 1998. Comunicación personal.

Health Policy Network, 1995. In practice: the NHS market in the United Kingdom. Public Health Policy, 16:452-491.

Instituto Mexicano del Seguro Social, 1995. Diagnóstico. México DF: IMSS, mimeo.

Inter-American Development Bank, 1996. Economic and social progress in Latin America. Baltimore: Johns Hopkins University Press. 
Kurczyn, S., 1996. Reforma del sistema de pensiones mexicano: principales aspectos macroeconómicos. Comercio Exterior, 46:741-754.

Lacey, R., 1996. La reforma de la jubilación en América Latina: los retos y el papel del Banco Mundial. Comercio Exterior 46: 683-691.

Laurell, A.C., 1995. La lógica de la privatización en salud. En: Política de Saúde: o público e o privado (C. Eibenschutz, ed.), pp. 31-48. Río de Janeiro: Fiocruz.

Laurell, A.C., 1996. La política social del pacto posrevolucionario y el viraje neoliberal. En: Hacia una política social alternativa (A.C. Laurell, coord.), pp. 15-32. México DF: IERD-Fundación F. Ebert.

Laurell, A.C., 1997. La reforma contra la salud y la seguridad social. México DF: ERA.

Laurell, A.C., 1999. La política de salud en el contexto de las políticas sociales. En M. Bronfman y R. Castro, coords.), pp. 239-252. Salud, cambio social y politica. Perspectivas desde América Latina. México DF: Edamex.

Lee, K., 1998. Globalization and bealth policy. Londres: London School of Hygiene and Tropical Medicine, mimeo.

Lin, R. J.; Shah, C. P. \& Svoboda, T., 1995. The impact of unemployment on health. Canadian Medical Association Journal, 153(5): 529-540.

Lo Vuolo, R., 1996. Reformas previsionales en América Latina: el caso argentino. Comercio Exterior, 46: 692-702.

Londoño, J.L. \& Frenk, J., 1996. Pluralismo estructurado: hacia un modelo innovador para la reforma de los sistemas de salud en América Latina. Boletin Salud y Gerencia, 15:5-28.

López, A.C., 1995. El ahorro interno en los planes de ajuste estructural. En: Reunión Internacional de Expertos en Seguridad Social, Memorias. México DF: Centro de Desarrollo Estratégico para la Seguridad Social.

Navarro, V., 1997. Neoliberalismo y estado de bienestar. Barcelona, España: Ariel.

Navarro, V., 1998. Neoliberalism, "globalization", unemployment, inequities and the welfare
State. International Journal of Health Services, 28(4):607-683.

Navarro, V., 1999. The political economy of the welfare State in developed capitalist countries. International Journal of Health Services, 29(1):1-50.

Paul, S. \& Paul, J., 1995. The World Bank, pensions, and income (in)security in the global South. International Journal of Health Services, 25:697726.

Rajs, D., 1995. Políticas de salud y organización del sector salud en Chile. En: Política de saúde: o público e o privado (C. Eibenschutz, org.). Río de Janeiro: Fiocruz.

Rothstein, B., 1994. Vad bör Staten göra? (¿Qué debe hacer el Estado?). Estocolmo: SNS Förlag.

Ruiz-Tagle, J., 1996. El nuevo sistema de pensiones en Chile: una evaluación preliminar. Comercio Exterior, 46:703-709.

Salmon, J.W. (ed.), 1990. The corporate transformation of bealth care. Amityville: Baywood Publishing Company.

Tetelboin, C., 1996. Neoliberalismo y sistemas de salud. La experiencia cbilena, 1973-1994. Tesis de doctorado, México DF: Universidad Iberoamericana.

Valenzuela, J.C., 1997. Opciones de desarrollo. En: El futuro económico de la nación (J.C. Valenzuela, org.). México DF: UNAM-Diana.

Vergara, P., 1997. Chile's free-market reform. International Journal of Health Services, 27(2):207-215.

Vilas, C., 1995. Estado y políticas sociales después del ajuste. Caracas: Nueva Sociedad.

World Bank, 1993. Invertir en salud. Washington DC: World Bank.

World Bank, 1994. Envejecimiento sin crisis. Nueva York: Oxford University Press.

World Bank, 1998. Mexico: Health System Reform. Documento no publicado.

Zepeda, E. \& Alarcón, D., 1996. Macro-economía y política social: hacia una estrategia de desarrollo redistributivo. En: Hacia una política social alternativa (A.C. Laurell, coord.). México DF: IERD-Fundación F. Ebert. 


\section{Participación SOCIAL, DERECHOS HUMANOS Y SALUD: PROCURANDO COMPRENDER LOS CAMINOS DE LAS CLASES POPULARES}

Victor Vincent Valla

\section{INTRODUCCIÓN}

La discusión que en los últimos años se ha venido desarrollando en Brasil sobre participación popular, ha contribuido a la creación de una especie de estereotipo: el hacer explícitas las reivindicaciones a través de las entidades representativas de la sociedad civil de cara a los órganos, agencias o servicios del Estado responsables de las políticas públicas en el área social.

Ciertamente se trata de un cuadro deseable, pero la nueva coyuntura nacional e internacional de los últimos quince años ha creado obstáculos para que las clases populares y sus aliados desarrollen su propia búsqueda de resolución de problemas por esta vía. El peligro del estereotipo de que la participación popular sea vista de esa forma estimula la construcción de la siguiente imagen: si la correlación de fuerzas no se conforma de la manera mencionada anteriormente, la participación popular no existe.

Este artículo trabaja bajo la premisa de que las clases populares buscan sistemáticamente formas de resolver sus problemas y en la medida que las propuestas clásicas no sean viables, serán descubiertos otros caminos para intentar solucionar sus demandas; o en palabras de Starn (1991), para las clases populares no existe la pasividad, incluso en los períodos de calma.

Lo importante, entonces, es que se le presta atención a las acciones y fallas de los miembros de esas clases con la intención de comprender sus estrategias, sin buscar descubrir si las iniciativas se corresponden o no con nuestras concepciones acerca de lo que es la participación popular.
Hay en discusión dos campos de preocupaciones acerca de los pobres que viven en las áreas periféricas de las grandes ciudades brasileñas: los de la salud y los de los derechos humanos, así como cuáles son las alternativas que las clases populares producen ante los obstáculos creados frente a estos dos campos. En este sentido, el presente trabajo representa un ejercicio de "ajuste de los binoculares" (Cunha, 1995) en tanto reconocimiento de que "la crisis de comprensión es nuestra” (Martins, 1989).

\section{REVISANDO EL DEBATE CLÁSICO SOBRE LA}

\section{PARTICIPACIÓN POPULAR}

Antes de discutir los tortuosos caminos que deben atravesar las clases populares para expresar sus ideas acerca de la participación popular, revisemos la forma en que el término se ha definido en los últimos años.

El concepto de participación popular posee una estrecha relación con la educación, pues en su definición se hace explícita la presencia de las clases populares y la de los mediadores (profesionales, técnicos, políticos, militantes, educadores populares, líderes religiosos). Por ejemplo, ¿đde quién vendrían los subsidios para hacer explícitas sus demandas? ¿Cómo se entiende normalmente el movimiento de información entre ambos grupos? Por ello la participación popular no se explica por sí misma, y cuando alguien la define, define al mismo tiempo su manera de comprender qué es la educación y qué es la sociedad.

Profesor del Departamento de Endemias Samuel Pessoa, Escuela Nacional de Salud Pública de la Fundación Oswaldo Cruz, egresado de la Maestría en Educaçión de la Universidade Federal Fluminense y presidente del Centro de Estudios e Investigaciones de la Leopoldina. E-mail:valla@ensp.fiocruz.br. 
Frecuentemente la discusión y la práctica de la participación popular se circunscriben a una concepción determinada: la relación de la sociedad civil con los gobiernos con miras al uso del dinero público. Sin duda, se trata de una concepción esencial en la construcción de ésta en cuanto categoría, pero la nueva coyuntura, que promueve la discusión de los fenómenos de la globalización y de las políticas (neo) liberales, puede también promover el nacimiento de nuevas perspectivas sobre participación popular.

La participación popular es un concepto de uso universal, es decir, es un fenómeno que se expresa en todas las sociedades, pero en América Latina, con los grandes niveles de desigualdad de ingresos y de condiciones de vida, así como el acentuado grado de autoritarismo de los gobernantes hacia los ciudadanos, este concepto tiene un significado especial.

A pesar de que las definiciones del término puedan variar, todas tienden a relacionarse con la capacidad que tiene el Estado de recaudar impuestos y distribuirlos en forma de servicios públicos. Todas las fuerzas de la sociedad brasileña "participan" en la disputa por el dinero público. Sin embargo, el término participación popular se refiere tradicionalmente a las clases populares; es decir, el 60 a 70\% de la población que sobrevive exclusivamente de su trabajo diario y que depende, en gran parte, de las inversiones que realiza el Estado para reproducir su fuerza de trabajo (educación, salud, transporte, saneamiento básico, etc.) (Valla y Stotz, 1991).

Las dificultades de recaudación son múltiples; algunas veces fuera del control de las autoridades, otras veces creadas por ellas mismas o con su propia anuencia. Es común que determinado gobierno no recaude lo suficiente parà cubrir sus gastos porque muchos ciudadanos alteran sus contribuciones o porque, en virtud del alto índice de desempleo, el mercado informal crece y se generan pocos impuestos. "De la renta tributaria brasileña, 34\% no paga impuestos por evasión o por declaración fraudulenta" (Rossi, 1999:1-2). Es más común, sin embargo, que la recaudación redistribuida beneficie en demasía algunos sectores de la sociedad.

Recientemente "el gobierno (federal) perdonó parte de la deuda de (empresarios) que se apropiaron indebidamente de recursos descontados de la nómina a los trabajadores. Personas que cometieron un delito" (Gaspari, 1999:8). En la actualidad, veintidós estados brasileños han acumulado deudas tan grandes que sería necesario gastar todo lo que recaudan en un año para poder saldarlas (Rodrigues, 1998).

Todo gobierno destina el dinero público al consumo colectivo y a la infraestructura industrial. El consumo colectivo se relaciona con los servicios necesarios para la reproducción de la fuerza de trabajo, principalmente de las clases populares: saneamiento, luz, salud, educación, transporte público. $\mathrm{La}$ infraestructura industrial se refiere a aquellas inversiones necesarias para el funcionamiento de la propia sociedad: autopistas, vías férreas, fábricas, represas, puentes, etc. (Valla y Stotz, 1991).

Es difícil usar el dinero público para el "bien común", porque las fuerzas organizadas de la sociedad lo disputan, incluso los grupos de capitales nacionales e internacionales. Como es bien sabido, en América Latina existe a menudo una relación íntima entre esos grupos con los gobiernos federales, estatales y municipales, fenómeno que se expresa con mayor claridad en los períodos electorales. La disputa por las inversiones de la infraestructura industrial casi siempre se da a espaldas de los gastos relacionados con el consumo colectivo, perjudicando de esa manera la calidad de vida de grandes sectores de la población, especialmente de las clases populares.

El actual gobernador de Río Grande do Sur ilustra esto con el siguiente ejemplo: "El gobierno que nos precedió (...) vendió las dos principales empresas públicas (...) recibiendo cinco millardos de reales, que, sin embargo, no fueron utilizados para la salud, educación, seguridad social o incluso para pagar la deuda, sino para cubrir el déficit operativo de un millardo por año, resultante éste de una política de renuncia fiscal". La "renuncia fiscal" se refiere a la política del gobierno de no tomar en cuenta impuestos que deben pagarse, por ejemplo los de una fábrica extranjera que se instale en Brasil (no pagar por el terreno, estar exento de impuestos por 20 años, etc.).

El término políticas públicas se refiere a la participación del Estado en el montaje de la infraestructura industrial necesaria para la 
superconcentración de actividades productivas en las grandes metrópolis brasileñas (Moisés, 1985). En este proceso, que se viene desarrollando desde los años treinta, surgieron "contradicciones urbanas", es decir, la necesidad, por una parte, de la intervención del poder estatal para garantizar la constante y creciente reproducción capitalista y, por otro, suplir con servicios de infraestructura a las enormes masas de población que hicieron aumentar la llamada "urbanización por expansión de las periferias".

Tal vez una de las principales contradicciones de este proceso fue la poca capacidad o el pequeño interés del capital en invertir en aquello que creía le ofrecería poco lucro en lo inmediato. Surge así la noción del 'Estado como 'proveedor' de toda la población (...) y así, (capaz de) resolver la problemática urbana, que parecía crecer permanentemente" (Moisés, 1985). La noción de participación popular ha sido vista como parte integrante de este proceso.

En la medida en que los gobiernos no proporcionan dinero público para inversiones en los servicios públicos o para la creación de más empleos, se crea lo que se conoce como una "deuda social", principalmente con las clases populares.

En el conjunto de discusiones que desde hace algunos años se ha venido intensificando sobre el rumbo técnico y político del Sistema Nacional de Salud, se ha destacado con frecuencia la participación popular. Ese intenso uso del concepto se encuentra, sin embargo, marcado de ambigüedades que expresan las diferentes perspectivas con las que se utiliza el término.

El tono vago y difuso con el que esa propuesta aparece en los textos oficiales, al lado de su frágil normalización, tiende a concentrarla en manos de los técnicos y de la burocracia gubernamental.

Para tener una mejor comprensión del sentido de la participación popular, es interesante situar brevemente algunas de sus definiciones.

De forma general, la participación social comprende las múltiples acciones que las diferentes fuerzas sociales desarrollan para influir en la formulación, ejecución, fiscalización y evaluación de las políticas públicas y los servicios básicos en el área social (salud, educación, vivienda, transporte, saneamiento básico, etc.). El sentido más corriente del término participación, más allá de la participación popular aquí destacada, es el de modernización, integración de grupos "marginalizados" y "trabajo en grupo" (Valla et al., 1996).

El término modernización tiene el sentido de superar los atrasos tecnológicos y culturales de una sociedad determinada. Equivale al desarrollo de nuevas formas de producir y consumir, de innovaciones tecnológicas (por ejemplo discado directo, robots industriales, cajeros automáticos en los bancos, televisión por cable, teléfonos celulares) y culturales (por ejemplo el divorcio, hábitos de comidas rápidas, adquisición de electrodomésticos), que estarían introduciendo profundos cambios en la sociedad, en los cuales la población, como un todo, debería participar.

Un ejemplo más actual de la propuesta de promover la participación social vía modernización, fue el enorme gasto de dinero público (un millardo de reales) hecho por la Alcaldía de Río de Janeiro para producir una mejoría visual de la ciudad de Río de Janeiro, a través del proyecto Rio Cidade. Esta empresa no contempló el saneamiento básico de una gran parte de las favelas como tampoco las causas de las crecidas de las aguas. (Refiriéndose nuevamente al término "renuncia fiscal", un comentario frecuente en las calles era si la escogencia de determinadas urbanizaciones y la reparación de las aceras en éstas no guardaba relación con el interés de instalar los cables de una compañía de televisión por cable).

Esta modalidad de la participación social contempla también que la población tenga la sensación de que participa de algo que no necesariamente disfruta y sobre lo que no tiene control. La mejora de vida de la población sería una consecuencia de esa modernización. La realidad brasileña no confirmó ese presupuesto: no hay indicaciones de que esas innovaciones hayan permitido una mayor participación.

La propuesta de la integración de los grupos "marginalizados" parte del principio de que la mayoría de la población, debido a la pobreza, se encuentra "fuera" de la sociedad. Es como si no disfrutar de los productos y servicios básicos fuese consecuencia de la ignorancia y de la pasividad por parte de esas 
poblaciones "marginales", o para utilizar un término más actual, de esos excluidos. Es decir, que están "fuera", de una u otra forma, por su propia culpa, por lo que necesitan ser "animados", "incentivados", "instruidos" para poder participar de los beneficios del progreso económico y cultural. Esa concepción tiene profundas raíces en la sociedad brasileña, y desde hace muchos años viene inspirando innumerables programas gubernamentales y religiosos.

Ese tipo de participación enmascara el hecho de que los llamados "excluidos" siempre han estado dentro de la sociedad, aunque participando de forma muy desigual de la riqueza. La "integración" que se busca debería, entonces, pasar necesariamente por garantizar empleos, mejores salarios y servicios básicos.

Otra forma de participación social muy utilizada es la del "trabajo en grupo". Se trata de un pedido, de una invitación a la población, principalmente la que vive en los barrios periféricos y en las favelas, para realizar - con su trabajotiempo de ocio y, algunas veces, dinero, acciones y obras que son responsabilidad del gobierno.

En gran parte, los gobiernos brasileños, tanto el federal como los estatales y municipales, actúan de una manera autoritaria, $\mathrm{y}$ toman decisiones unilaterales sobre la calidad y la cantidad de los servicios básicos. A pesar de esto, cuando se dan cuenta de que su acción es ineficaz y no puede resolver un determinado problema (como el dengue o el cólera, por ejemplo) los gobiernos exhortan a la población a participar en el combate y la erradicación del mal a través del "trabajo en grupo".

Merece, sin embargo, más atención de los estudiosos de las clases populares, la insistencia de éstas en participar en el "trabajo en grupo". Desde hace años, los mediadores de la clase media señalan las pérdidas de dinero y de energía en este tipo de prácticas; empero, las poblaciones pobres continúan haciendo lo que un salario más digno o un gobierno más popular podrían facilitar.

Es posible que se encuentre presente en la lógica y en la experiencia de los pobres brasileños la idea de que "no se puede confiar en las promesas de los gobiernos". Es posible también que el "trabajo en grupo" en los barrios refleje valores comunes de solidaridad y reciprocidad.

Pese a no ser muy comunes en Brasil, a excepción de algunos gobiernos municipales, existen algunas experiencias de "trabajo en grupo" en los que la población asume tareas que en realidad serían de los gobiernos. Se trata de los llamados "gobiernos populares", donde las reformas sociales que benefician principalmente a las clases populares consumen más dinero del que normalmente se recauda. En estas situaciones, la confianza de la población en el proyecto de gobierno hace que el "trabajo en grupo" sea utilizado en labores como la alfabetización de jóvenes y adultos, la vigilancia de las condiciones de salud por agentes populares y la seguridad en barrios populares.

Normalmente el concepto de participación popular se diferencia de las formas hasta aquí discutidas, por tratarse de una participación política de las entidades representativas de la sociedad civil en órganos, agencias o servicios del Estado responsables por las políticas públicas en el área social.

La contradicción presente en esta forma de participación está en que si, por una parte, legitima la política del Estado frente a la población, por otra, ésta representa un canal para que las entidades populares disputen el control y destino de las partidas públicas.

En realidad no todos tienen acceso al dinero público, aunque todos estén obligados a contribuir con sus impuestos para que exista el dinero público. La propuesta de participación popular se coloca justamente en el camino contrario de ese estado de cosas.

Aun así, en el campo de la participación popular existen diferencias importantes, pues el grado de participación de las clases populares en la formulación de las propuestas a ser reivindicadas no es del todo clara. Es posible, por un lado, la construcción de una propuesta por parte de un grupo de profesionales o intelectuales que buscan la adhesión de las clases populares; por otro, también se admite la presencia de las clases populares en la propia construcción de la propuesta, lo cual frecuentemente entra en contradicción con lo que los mediadores contemplan.

Hay un debate que se viene desarrollando en Brasil acerca de si esos problemas se constituyen en 
el obstáculo para la evaluación, por ejemplo, de la reforma sanitaria brasileña en el campo de la salud. La cuestión es si las dificultades que se han enfrentado con la implantación de esa reforma no se relacionan con el hecho de que la propuesta de la Reforma Sanitaria fue elaborada, en gran parte, en las universidades y en los despachos de políticos progresistas.

\section{NuEVOS DESAFÍOS PARA LA PARTICIPACIÓN}

\section{POPULAR}

Los grandes cambios que han ocurrido en los últimos años - la caída del muro de Berlín y el consiguiente fin del socialismo real, la victoriosa ola neoliberal y el proceso de globalización que se instaura hoy en el mundo- ejercieron un profundo papel en la manera de pensar sobre las clases populares, como también en relación con la salud.

Posiblemente uno de los temas más cuestionados se refiere a las formas a través de las cuales las sociedades se transforman. Mientras que las revoluciones o rebeliones siempre han sido una excepción - y no una regla - como forma de lucha, otras maneras de enfrentamiento pueden darse a partir de movimientos y resistencias más sutiles.

Aunque menos dramáticos, esos movimientos pueden servir para minar la legitimidad política de diferentes sistemas de explotación y al mismo tiempo para indicar, de manera más precisa que las confrontaciones directas, el sistema de creencias de las clases populares (Serulnikov, 1994). Tal vez el gran viraje, el principal cambio de óptica con relación a los trabajos que son desarrollados con las clases populares, se refiera a la comprensión que se tiene de la manera como las personas de esas clases piensan y perciben el mundo.

En 1996, varios políticos e intelectuales se reunieron en Ciudad de México, con el apoyo de la Organización de las Naciones Unidas (ONU), para debatir el siguiente problema: ¿Cuál es el proyecto de reforma del Estado y de desarrollo económico alternativo a la economía y la política hegemónicas actualmente en América Latina? Independientemente de su origen político, la gran mayoría de los participantes señaló que los gobiernos federales tienden a aplicar medidas semejantes: privatizaciones salvajes; políticas compensatorias para los pobres, sin, no obstante, pretender incluirlos en la sociedad formal; reducción de la capacidad inductora y reguladora del Estado y socialización de las eventuales pérdidas del capital financiero.

Los participantes del debate llamaron la atención hacia lo que tal vez sea la principal contradicción del proceso de globalización: si, por una parte, cada política de ajuste conlleva a un aumento de la pobreza y del desempleo en cada país, por otra, la lógica de la globalización está lejos de ofrecer una solución, pues exige la inversión de grandes masas de capital concentradas para integrar la economía dentro de los patrones competitivos pautados por la revolución digital-informática; $y$, finalmente, la constatación de que los grandes medios de comunicación tienden a reforzar esas medidas con una nueva cultura despolitizante, que busca convencer a la sociedad de que el proceso de globalización no deja otra salida que la de resignarse a la "exclusión social” como algo inevitable (Genro, 1996).

Stotz (Valla y Stotz, 1997) señala que las empresas transnacionales - en un número cada vez mayor, por efecto de las fusiones e incorporaciones pasaron a imponer sus intereses en todos los rincones del planeta, involucrando asuntos como el grado de protección de las economías nacionales, el ámbito de la intervención directa del Estado en la economía, los límites para el endeudamiento público en función de los gastos sociales, etc. Sin embargo, es claro que los sacrificios impuestos a la mayoría de las poblaciones que viven sólo de su trabajo no tiene la contrapartida de las economías en crecimiento - al menos a tasas equiparables con la de las poblaciones y con garantía de bienestar y mejora en el ingreso. El mundo del trabajo está hoy constreñido, por una parte, por el desempleo estructural y, por otra, por la precarización del trabajo. La situación en los países en desarrollo es más dramática porque las políticas, las instituciones y los servicios de protección social - que nunca fueron muy eficaces y difícilmente tenían carácter universalestán siendo revisadas, eliminadas o limitadas.

Los efectos negativos creados por la apertura de los mercados extranjeros, la privatización de las empresas públicas y el consecuente aumento del 
desempleo son conocidos en toda América Latina. A continuación presentamos algunos datos recientes para demostrar cómo el proceso en desarrollo continúa produciendo víctimas. Entre 1994 y 1998, aumentó en $47 \%$ el número de habitantes en favelas en la ciudad de Sao Paulo. "Las víctimas del desempleo fueron empujadas hacia las favelas, las casas de vecindad o, hasta el límite, hacia la exclusión total — simbolizada por las invasiones de áreas periféricas y la construcción de viviendas precarias aisladas" (Toledo, 1999:3).

En la misma época, aunque hubiese aumento del ingreso para toda la sociedad, el 10\% más pobre aumentó su ingreso en un $24 \%$ (de 43 reales a 54 reales), mientras el 10\% más rico aumentó su ingreso en un 34\% (de 1793 reales a 2460 reales) (Toledo, 1999:3).

Como resultado de la gran desnacionalización de las empresas brasileñas, se triplicó la remesa de lucros hacia el exterior. En 1994, de los casi 29 millardos de reales invertidos, 21 millardos fueron utilizados para la compra de industrias brasileñas. " $\mathrm{La}$ desnacionalización indiscriminada va a presionar la balanza de pagos y está colocando el país en una posición de total subordinación" fue el resultado de la evaluación realizada por Roberto Nicolau Jeha, de la Federación de Industrias del Estado de Sao Paulo (FiesP) (Canzian, 1999:1-13).

En un intento de coronar todo ese proceso de globalización, la Organización Mundial del Comercio promovió una reunión en Seattle, Washington, en diciembre de 1999, llamada por quienes la propusieron "la Rueda del Milenio", y por sus críticos, como el "Robo del Milenio". "(...) trata de todo lo que se hace en el comercio, desde la venta de fresas hasta las competencias públicas, pasando por el control o no de las inversiones externas y llegando a la liberalización del transporte aéreo" (Rossi, 1999:1-2). Investigadores atentos que acompañaban los preparativos para esa reunión estimaban que los resultados para Brasil podían ser los siguientes: destrucción de la agricultura familiar, regresión de Brasil a exportador de productos tropicales, imposición de los transgénicos, explotación predatoria de la Amazonia, privatización de los sistemas de salud y asistencia social, control extranjero de los recursos hídricos, subordinación del Derecho brasileño a los intereses del capital transnacional, reducción de los derechos laborales, precarización del trabajo, disminución de la enseñanza pública y profundización del desempleo y de la exclusión social (Tautz, 1999).

Parece importante tener en cuenta que las medidas sobre participación popular y el Sistema Único de Salud (SUS) aprobadas durante la octava Conferencia Nacional de Salud y en la Ley Orgánica de Salud, coinciden en el tiempo con la elección de Fernando Collor de Melo y la aceleración de la incorporación de la sociedad brasileña al proceso de globalización.

Por una parte, las medidas aprobadas, principalmente en lo que se refiere a la creación de los Consejos de Salud, fue ciertamente un avance; por otra, el rígido pero contradictorio control fiscal ejercido por el gobierno federal — sea en atención a las exigencias del Fondo Monetario Internacional o sea para gastos del dinero público, como por ejemplo pagar la deuda externa o salvar bancos privados en problemas-y, consecuentemente, a través de los estados y municipios, genera un ambiente de penuria y control.

De acuerdo con Pinotti, "Brasil recibe 130 millardos de reales por concepto de impuestos y paga 70 millardos de reales por servicios de la deuda (...) el país debería limitar el pago de la deuda al 20\% de los impuestos. Más de eso significa pagar la deuda con sangre" (Biancarelli, 1999:4). Así, las autoridades cuentan con estos límites para ignorar las reivindicaciones de los sectores organizados de la sociedad civil de carácter popular.

La situación económica es tan grave que recientemente la prensa brasileña anunció que el Banco Mundial, la Cepal y un ideólogo del "Consenso de Washington" consideran que el gobierno brasileño llevó las orientaciones del FMI y del Banco Mundial al extremo: "Brasil es un antiejemplo para los países emergentes" (Aith, 1999:2-5); "La apertura no reduce la pobreza, señala Bird" (Schwartz, 1999:2-1); "El país pierde con el neoliberalismo, dice la CePAL" (Santos, 1999:2-1); "Consenso de Washington 'fue demasiado lejos', dice su ideólogo" (Canzian, 1999:1-13).

Hay una clara contradicción con relación a la crisis de la salud en Brasil. Aunque exista una evidente 
caída en la calidad de vida en grandes sectores de las clases populares, una vasta infraestructura de unidades de asistencia conjuntamente con tecnologías como la de la terapia de rehidratación oral (suero casero) hacen que menos niños mueran antes de completar el año, y que más adultos sobrepasen los 65 años. Incluso así, aunque Cuba y Brasil gasten aproximadamente 100 reales por habitante en salud, "La mortalidad infantil en Cuba es de 8 por cada mil nacidos vivos. En Brasil, es de es de 50 a 60 por cada mil nacidos vivos. La mortalidad materna en Cuba es de 7 por 100.000. La nuestra es de 220 por 100.000" (Biancarelli, 1999:4-4).

Justamente porque las condiciones de higiene y alimentación son mínimas, los consecuentes problemas de salud gastan todavía más los recursos disponibles para el área de salud pública. En el caso de Brasil, este cuadro se ve agravado por los bajos salarios y las precarias condiciones de trabajo ofrecidos a los profesionales de la salud, llevando de esta manera a muchos de ellos a abandonar el servicio público.

En este sentido, uno de los efectos más perniciosos del mal funcionamiento de los servicios públicos en Brasil es lo que se conoce como "culpabilización de la víctima". Existe una imagen, construida en torno a las condiciones de vida y de trabajo de la población trabajadora, que justifica en parte la precariedad de los servicios públicos para esos sectores de la sociedad.

Se acusa a los padres de un niño deshidratado de no preocuparse de los cuidados que el niño requiere, se culpa al niño de clase popular de no "aprender" en la escuela por no esforzarse, se explica el accidente sufrido por el obrero como resultado de su falta de atención o se culpa a la madre cuyo hijo murió de meningitis de no haberse percatado de los síntomas a tiempo. La individualización de la culpa resulta en la explicación de una práctica colectiva (Valla y Stotz, 1996).

La inoperatividad, la ausencia o la irresponsabilidad de las instituciones sociales (que conllevan a accidentes de trabajo, enfermedades infectocontagiosas y fracaso escolar, entre otras cosas) acaban siendo justificadas por el lugar donde se vive, el bajo salario en el empleo, el nivel de escolaridad y la falta de información.
Una de las justificaciones para la culpabilidad de las víctimas es la descalificación del saber popular. Así, el monopolio del saber técnico, sea médico o de otro tipo, coloca en un segundo plano el saber acumulado de la población trabajadora, cuando asume la escolaridad formal como parámetro para ser competente.

Pero la "descalificación" de la clase trabajadora también pasa por la construcción de una imagen del "bruto", del "desposeído", del "nulo", afirmando, además, que familia pobre es "igual a enfermedad". Esa imagen propagada del trabajador, del pobre, tiene, por un lado, el resultado de borrar las diversidades dentro de las clases populares. Por otro, busca infantilizar a los mismos trabajadores, llamándolos "mentirosos" cuando alegan problemas de salud, "apáticos" cuando demuestran desinterés en los salones de clase, o acusándolos de "no comprender" los consejos de prevención contra enfermedades como el dengue, la malaria y la meningitis (Valla y Stotz, 1996).

El fenómeno de la culpabilización de la víctima se ve agravado frecuentemente por la llamada "dictadura de la urgencia". La falta de inversiones en la infraestructura de consumo colectivo hace que grandes sectores de la población vivan en un estado de emergencia permanente, donde las emergencias, la "urgencia", suscitan consejos preventivos de las autoridades a un ritmo continuo.

En este sentido, el "no cumplimiento" de los consejos, por las razones señaladas anteriormente, acaba colocando el peso de la responsabilidad sobre las víctimas de las emergencias. Cuando las epidemias de dengue y cólera se hacen presentes, las autoridades recurren a los consejos de mantener tapados los recipientes de agua o de agregar en el agua unas gotas de cloro. Cualquier protesta contra el sistema de abastecimiento de agua es excusada por la urgencia. La discusión del tratamiento y distribución de agua es postergada para "después".

$\mathrm{Si}$, por una parte, el acceso a los servicios de salud es uno de los principales problemas, por otra, su resolución es llevada a un segundo plano. Un problema de salud que afecta a millones de brasileños, por ejemplo, son las múltiples expresiones de salud mental, cubriendo una gama de síntomas que van 
desde eso que la clase media llama "ansiedad" a lo que las clases populares llaman "nervios". Datos recientes, provenientes de Argentina, indican que más del $50 \%$ de los medicamentos consumidos por la población son psicofármacos (Bermann, 1995:115). Cabe preguntarse si aunque el sistema de salud en Brasil funcionara satisfactoriamente, sería posible atender todos esos casos adecuadamente.

En algunos Consejos de Salud, sobre todo en Río de Janeiro, la demanda por el acceso a la asistencia médica es tan grande, que casi nunca hay tiempo para discutir problemas relacionados con el medio ambiente y el control de las epidemias y endemias (Valla, 1998).

\section{REACCIONANDO CON ALTERNATIVAS A LA INSATISFACCIÓN CON LOS SERVICIOS DE SALUD}

En un país de población empobrecida como la de Brasil, surgen con cierta facilidad ideas como la de que preocuparse por agrotóxicos en la alimentación es un lujo de los países industrializados, donde el hambre crónica es poco visible (Falcão, 1999:3). De la misma manera, ¿cómo cuestionar la deforestación de la Amazonia, si el derribar árboles, incluso de manera ilegal, es la forma que tienen muchos de paliar el desempleo? ¿Cómo preservar el medio ambiente en las grandes ciudades, si el valor del suelo urbano más barato se encuentra justamente en las áreas de preservación ecológica? Es en estos lugares que los pobres buscan su vivienda porque los grandes espacios vacíos continúan en manos de particulares o de los gobiernos.

La pregunta que se hace con relación a los servicios de salud es: ¿por qué discutir formas alternativas de lidiar con la salud cuando una gran parte de las clases populares todavía no tiene una atención satisfactoria en los locales de salud pública?

Ese tipo de razonamiento termina tomando la miseria de los pobres para justificar la falta de supervisión por parte de los gobernantes, y de esta forma hacer natural la injusticia y la falta de democracia en Brasil.

Lo que se discute es la satisfacción de las necesidades básicas de las clases populares de cara a un modelo de Estado crecientemente incapaz de cumplir esa obligación. En las ideas que se presentan, existe la preocupación de discutir, particularmente, con los mediadores de la educación popular y con los profesores de las escuelas públicas los límites del sistema de salud pública hegemonizado por el paradigma biomédico. En este sentido, se propone discutir las formas alternativas de lidiar con la salud y las condiciones de vida de las clases populares: ¿¿cuáles son los caminos que las clases populares recorren de cara a los estrechos límites impuestos por el sistema de salud pública y cuál es el papel de los mediadores de la educación popular y profesores de las escuelas públicas en comprender las contradicciones de ese proceso?

Los graves problemas de desempleo y la pobreza creciente indican los límites del actual sistema de salud. Hay un cuestionamiento que se difunde entre los profesionales de la salud: si la manera en la que se estructura la atención en salud en Brasil es capaz de lidiar con lo que algunos llaman "sufrimiento difuso presentado por las clases populares". Algunos profesionales estiman que casi el $60 \%$ de las consultas tratan problemas psicosomáticos, donde el tiempo necesario para atender a cada paciente está reñido con la relación eficiencia-eficacia (Valla y Stotz, 1996).

Lo que se discute es la capacidad real del Estado brasileño, tal como está estructurado en la actualidad, de satisfacer las demandas que las clases populares vienen presentando. "Hacer lo mejor posible" en cada unidad de salud del país es ciertamente importante, pero no necesariamente toma en cuenta un gran sector de la población que ya no se presenta a las unidades de salud. Tampoco toma en cuenta si todas las quejas presentadas se solucionan de forma satisfactoria (Vasconcelos, 1998:47).

A la luz de este telón de fondo, se propone inicialmente discutir algunas de las ideas que señalan las formas alternativas de enfrentar la salud, procurando demostrar cómo éstas se restringen, en gran parte, al ámbito de las clases alta y media.

Cuando se habla de formas alternativas de enfrentar la salud, esto se refiere tanto a las terapias que buscan resolver las quejas de salud por procedimientos que no son biomédicos, como a diversas actividades de solidaridad y apoyo social que puedan traducirse, de manera intencional o no, en 
mejoras a la salud. En esta parte del texto, el término "formas alternativas de enfrentar la salud" será sustituido por el término "salud alternativa".

La discusión sobre la salud alternativa surge en el siguiente contexto: ¿se trata solamente de una crisis de recursos, o se trata también de una discusión acerca de los límites del modelo biomédico? Habiendo más tiempo y recursos, ¿habría condiciones de lidiar con los problemas psicosomáticos, o es también un asunto de perspectiva?

Cuando se habla de un "problema de perspectiva", se refiere a las crecientes críticas a la eficacia del modelo biomédico. Se trata de un conjunto de preocupaciones que incluyen cuestiones como la de "mucho de lo que tiene que ver con la salud en la actualidad no se relaciona estrictamente con la medicina". Otra es que los éxitos de la medicina frente a las enfermedades infecciosas no tiene su equivalencia cuando se trata de enfermedades crónicas. Una tercera se relaciona con la dificultad de la medicina en reconocer el papel que tienen los hombres en crear condiciones sociales que son en sí mismas agentes de enfermedad. Los mejores estimados son que el sistema médico hegemónico corresponde a $10 \%$ de los índices para medir el estado de salud de una persona. El otro $90 \%$ se refiere a factores sobre los cuales los médicos no tienen control: fumar, ejercicio, ansiedad, condiciones sociales y medio ambiente (Waldovsky, 1977:1; Foss \& Rothenberg, 1987:81).

Muchas de las críticas al modelo biomédico se derivan de la propuesta que señala que no hay separación entre el cuerpo y la mente del hombre. La biomedicina tiene su origen en la física newtoniana y en el dualismo cartesiano y asume que la comprensión del cuerpo viene del conocimiento sólo de sus partes y de cómo ellas se relacionan entre sí (Foss y Rothenberg, 1987:21). Las dificultades de las propuestas de las medicinas holista y psicosomática en superar el dualismo cuerpo-mente en la biomedicina están relacionadas con lo enraizado de esa propuesta en la experiencia occidental (Kirmayer, 1987:58).

La cuestión, entonces, no es si la salud alternativa constituye una "ayudita" ante la crisis que se presenta en el sistema de salud brasileño, sino, más bien, si la propia crisis no está señalando otras alternativas para enfrentar muchos de los problemas de salud de la población.

Muchas de las propuestas de salud alternativa se basan en la categoría de "apoyo social". Se define como cualquier información, hablada o no, y auxilio material, ofrecidos por grupos y personas que ya se conocen, que conllevan a efectos emocionales y comportamientos positivos. Se trata de un proceso recíproco, es decir, que genera tanto efectos positivos para quien lo recibe como para quien ofrece el apoyo, permitiendo de esta manera que ambos tengan una sensación de coherencia de vida y un mayor sentido de control sobre sí mismos. De ese proceso se aprende que las personas se necesitan las unas a las otras.

En esencia, el debate en torno a la cuestión del apoyo social se basa en investigaciones que señalan su papel en el mantenimiento de la salud, en la prevención de la enfermedad y como forma de facilitar la convalecencia. Una de las principales premisas de la teoría es que el apoyo social ejerce efectos directos sobre el sistema inmunológico, actuando como un tapón al aumentar las defensas contra el estrés (Minkler, 1985:305; Cassell, 1976a:122; Cassell, 1976b:641; Valla, 1998:160).

En momentos de mucho estrés, el apoyo social contribuye a mantener la salud de las personas, pues desempeña una función mediadora. Así, permite que éstas contemplen la posibilidad de enfermar como resultado de determinados eventos en la vida, como por ejemplo la muerte de alguien en la familia, la pérdida de la capacidad de trabajar o el desalojo de la casa donde se ha vivido desde hace muchos años.

Cassell formula la hipótesis de que los lugares de alta densidad poblacional no necesariamente aumentan la susceptibilidad a la enfermedad por efecto de la densidad en sí misma. Una sensación de no poder controlar su propia vida junto a la sensación de aislamiento pueden relacionarse con el proceso salud-enfermedad. La propuesta del apoyo social sugiere que las consecuencias de esas sensaciones no necesariamente alcanzan de la misma manera a todas las personas afectadas. Algunos estudios han demostrado que los apoyos de determinadas organizaciones sociales pueden influir de manera beneficiosa al proporcionar factores de protección contra la aparición de enfermedades, ofreciendo 
mejoras en la salud física, mental y emocional (Cassell, 1974:1041). Se trata de la noción de empowerment, es decir, un proceso mediante el cual los individuos, grupos sociales y organizaciones pasan a adquirir mayor control sobre sus propios destinos (Minkler, 1985:304-305).

En este sentido, involucrarse con la comunidad puede ser un factor psicosocial significativo para mejorar la confianza personal, la satisfacción con la vida y la capacidad para enfrentar problemas. La participación popular puede reforzar el sistema de defensa del cuerpo y disminuir la susceptibilidad a la enfermedad.

Como puede percibirse a través de la propuesta del apoyo social, se discute una forma de lidiar con la relación salud-enfermedad que presupone una unidad entre cuerpo y mente. Una parte importante de la teoría del apoyo social es que las enfermedades tienen su origen en un desequilibrio emocional. $\mathrm{Al}$ respecto la doctora $\mathrm{Hu}$ Pao Yu, de Río de Janeiro, trabaja sobre la perspectiva de que cada órgano del cuerpo humano está íntimamente relacionado con una emoción determinada. Por ejemplo, el pulmón con la tristeza, el hígado con la irritabilidad y los riñones con el miedo. Así, afirma que las enfermedades surgen porque inicialmente las emociones interfieren de forma perjudicial sobre los órganos (Ivanissevich, 1995:30; Minkler, 1985:305).

Hasta donde sabemos, existe poco material escrito o de carácter audiovisual sobre salud alternativa disponible para las clases populares. Lo que se encuentra disponible son materiales relativamente frecuentes en los grandes diarios. Cuando se analiza el contenido sobre salud en estos periódicos, generalmente se trata de temas dirigidos a los lectores de clase media y alta. Las clases populares no son lectores sistemáticos de la gran prensa y, en particular, de los diarios como la Folha de São Paulo y el Jornal do Brasil, donde aparecen la mayoría de los artículos sobre salud alternativa.

Tanto los médicos y atletas como los ejecutivos, comienzan a adherirse a la idea de que las técnicas orientales de relajación producen efectos benéficos para la salud. Comprobaciones científicas han demostrado la contribución de esas técnicas en el combate contra las enfermedades relacionadas con problemas cardiovasculares, estrés, insomnio y ansiedad. Las técnicas de introspección y meditación frecuentemente traen como resultado una relajación entre seis y ocho veces mayor que durante el sueño, haciendo que el consumo de oxígeno disminuya hasta en un $60 \%$. El resultado es un aumento de la energía física y un declive en la producción de cortisol, considerada la hormona del estrés, que cuando es producida en exceso deprime el sistema inmunológico y sus células de defensa (Parcias, 1998:1).

Durante la meditación las células trabajan de manera más eficiente y saludable, eliminando las impurezas del organismo y creando resistencia a los estímulos del medio ambiente, aliviando de esa manera el estrés y bajando los niveles de colesterol y la tensión arterial. De igual manera, la meditación ayuda a disminuir la pérdida de lactato de la musculatura, pues la pérdida de esa sustancia resulta en un aumento de la ansiedad (Parcias, 1998:2).

De una manera semejante a otros investigadores, McEwen (1998) supone que el estrés se relaciona con reacciones del cuerpo humano a las agresiones de orden físico y psíquico, perjudicando de esta forma su estabilidad. Esto puede ser provocado por un ritmo de trabajo excesivo y frustrante como también por una acumulación sistemática de pequeñas irritaciones de la vida cotidiana.

El estrés acciona las hormonas, es decir, las sustancias químicas que van hasta el torrente sanguíneo para defender el organismo humano. La repetición excesiva de la producción de esas hormonas representa problemas de salud para la persona. "Carga alostática" es el nombre que McEwen le da al conjunto de indicadores de estrés. Esa carga es el precio que paga el organismo para adaptarse al estrés. Cuanto más alta es la carga, más posibilidad de sufrir enfermedades cardiovasculares como también un mayor declive mental y físico. McEwen sugiere el ejercicio y la dieta moderada como las mejores formas de terminar los círculos viciosos de alimentación, bebidas alcohólicas y cigarrillos a los que induce el estrés (McEwen, 1998:175; Bonalume Neto, 1998:15).

Va en aumento el número de cardiólogos que le dan mucha importancia al apoyo social. El 
doctor Dean Ornish afirma que la intimidad, el apoyo emocional y las relaciones sociales son tan importantes como el ejercicio y las dietas prudentes. Por su parte, Daniel Goleman percibió en sus investigaciones que los ancianos víctimas de ataques al corazón logran sobrevivir más tiempo en la medida que cuentan con el apoyo emocional de dos o más personas, y que la depresión aumenta cinco veces más las posibilidades de muerte después de un ataque cardíaco (Ventura, 1998:1).

Una investigación realizada en Tel Aviv demostró que el número de infartos aumentó tres veces cuando el gobierno de Iraq indicaba la inminencia de un ataque aéreo.

El psicoanalista y psiquiatra Carlos Garrido Pereira alerta hacia las pruebas que demuestran que las personas competitivas, ansiosas y centralizadoras son más susceptibles a las enfermedades cardíacas, y recomienda como una de las salidas, que las personas sean menos competitivas y actúen de manera franca y abierta en las relaciones cotidianas (Ventura, 1998:2).

Según Henrique Figueiredo, jefe del Servicio de Salud Mental del Hospital de Laranjeiras en Río de Janeiro, con frecuencia la baja autoestima hace que las personas sean ansiosas, influyendo así en sus hábitos alimentarios y haciendo que presten poca atención a su estado de salud. La depresión baja las defensas inmunológicas, facilitando de esa manera la aparición de enfermedades. Figueiredo agrega otros datos sobre el estrés: causa la liberación de adrenalina y cortisol, haciendo así que el corazón lata más deprisa, provocando tensión en las arterias y contribuyendo a que la sangre se haga más espesa. El consumo de oxígeno aumenta, y en consecuencia, la tensión arterial (Ventura, 1998:3). En contraposición, el placer está relacionado con la relajación, pues hace que el cuerpo libere endorfina, un revigorizante natural que crea una sensación de bienestar en el cuerpo.

Garrido recomienda la práctica del acto de soltarse. Señala que lo que se habla es visto generalmente como más importante que el propio acto de hablar. Así, cuando algo no se dice o no se reclama, es como si el cuerpo acumulara un veneno que un día saldrá de otra forma: diarrea, impotencia o infarto.
La cardióloga Lígia Barros llama la atención hacia el peligro de "tragar sapos", haciendo que el acto de sufrir sin soltarse traiga como resultado una acumulación de tensiones que a la larga podrían generar problemas de salud (Ventura, 1998:2-3).

En su libro Love and Survival, Ornish comenta que en una investigación realizada en Estados Unidos, algunos voluntarios recibieron el virus de la gripe a través de una inyección. Sin embargo, no todos se enfermaron. Aquellos que se encontraban con al menos seis o más personas durante la semana se enfermaron cuatro veces menos que los voluntarios que se encontraban con sólo dos amigos. Un resultado que recuerda las afirmaciones de Cassell (Sekles, 1998:2).

La ruptura de las redes sociales está ocasionando que haya más aislamiento y depresión. Así, el sentido de comunidad tiene que ser descubierto de otras formas. El profesor Sylvio Coutinho, de la Universidad Abierta de la Tercera Edad/ Universidad de Sao Paulo, promueve un curso de pintura que ha indicado mejoras en la salud de los participantes. Estimulando la actividad motora y la autonomía de la actividad física, los alumnos afirman que se sienten parte de un grupo y que son capaces de hacer amistades. Hubo una mejora en la percepción de sí mismos y en la autoestima (Sekles, 1998:2).

\section{LAS CLASES POPULARES, SUS CONDICIONES DE}

\section{VIDA Y LA SALUD ALTERNATIVA}

Bermann (1995:115) llama la atención hacia el efecto ideológico que posee el término "estrés". Normalmente la discusión de ese término se desarrolla en torno al resultado y no en torno al proceso en sí mismo, lo cual es más importante. Tratar sólo los síntomas transmite la ilusión de que el problema está en el malestar que la persona siente cuando busca asistencia; de esta manera no es visto como parte de un proceso más largo que acaba produciendo el malestar (Stotz, 1996:44-45). En este sentido, esconde el desgaste del trabajo excesivo al que el trabajador se somete para no perder el empleo, como también los horarios irregulares que impone 
el trabajo precario y tercerizado. Quien no tiene un empleo fijo, relacionado con sus intereses, difícilmente escapa del mercado informal y de un "trabajo frustrante". Un trabajo frustrante para las clases populares no se trata de una "mala escogencia", sino, casi siempre, de una "única escogencia" por causa de las pocas ofertas del mercado.

Aunque no se pretende negar los procesos de estrés que le ocurren a los miembros de la clase media y alta, se quiere, al mismo tiempo, llamar la atención hacia el hecho de que las clases populares en las grandes ciudades tienden a sufrir un proceso de estrés mucho más intenso. La concejal Jurema Batista, de Río de Janeiro, pregunta si existe remedio para la tensión arterial alta cuando el helicóptero de la Policía Militar sobrevuela la favela buscando miembros del narcotráfico. Para la clase media, las pequeñas irritaciones mencionadas por McEwen (1998) pueden traducirse en un atascamiento en el tránsito, pero para el poblador de la favela, se trata frecuentemente de la falta continua de agua o las caídas de tensión en el voltaje y el consecuente daño a los electrodomésticos.

Una de las propuestas para el combate contra el estrés es la de la introspección y la meditación. Aunque teóricamente la práctica de la meditación no sea imposible en cualquier circunstancia, ciertamente un lugar relativamente espacioso y quicto facilita la concentración. Normalmente, el período de meditación más corto, una hora, se divide en dos partes: media hora para escuchar una lectura para realizar el paso de la calle a la sala de meditación y media hora de la meditación en sí misma. Una tarea difícil para quien transita lo que Chuai (1990:80-81) llama el "camino estrecho", es decir, una vida de poco dinero, espacio y tiempo libre.

En un país en el que los servicios de salud están tan moldeados por el modelo biomédico, difícilmente las actividades propuestas en el área de la salud alternativa provienen del sector público, exigiendo de esa forma algún tipo de pago. Aunque no sea imposible que las actividades de apoyo social sean desarrolladas en una unidad de salud pública grupos de discusión, relajación muscular o meditación-, los profesionales de la salud más críticos afirman que ese tipo de actividad es vista por muchos colegas como formas de "huir del trabajo".
El estrés causado por lo que muchos profesionales llaman "superexcitación del organismo" tiene su raíz en un estilo de vida en el que la persona está expuesta sistemáticamente a agresiones de orden físico y psíquico. De esta forma, el "susto continuo" arroja grandes cantidades de adrenalina en la sangre por un largo período de tiempo. Nuevamente, la causa puede ser la pérdida de 100 mil reales en la bolsa de valores, así como una amenaza de guerra entre policías y traficantes o la pérdida del "rancho" durante una lluvia fuerte.

Lo que importa en esta discusión es que un gran sector de las clases populares está expuesto a lo que se conoce como "un estado de emergencia permanente" (Valla y Stotz, 1996:121). La gran prensa tiende a definir el término "emergencia" como un acontecimiento pasajero —una falla de luz o una crecida de las aguas, por ejemplo. Una vez que el agua deje de cubrir los automóviles o que la luz eléctrica regrese, para la gran prensa termina la emergencia. Pero las condiciones de vida para muchos pobladores de la favela indican un estado de emergencia permanente: distribución irregular del agua, dificultad en el acceso a las unidades de salud, exposición permanente a las balas "perdidas" y sobrevivir a través del mercado informal en proceso de saturación.

Las recomendaciones que $\mathrm{McEwen}$ hace sobre una dieta moderada y prudente, así como las del ejercicio físico sistemático, encuentran obstáculos relacionados no solamente con las condiciones de vida, sino también con cuestiones de índole cultural. De cualquier manera, jugar fútbol los domingos en la tarde no parece corresponderse con la idea del ejercicio físico sistemático; que se sepa, no está muy desarrollada en Brasil la discusión acerca de lo que sería una dieta moderada y prudente para las clases populares, tomando en cuenta los costos y los problemas culturales.

Incluso así, McEwen recuerda que esas recomendaciones no son suficientes en muchos casos, si no hay como actuar en la causa inmediata del problema, pues el estrés posee causas sociales complejas, que no pueden ser resueltas por la medicina, como la pobreza, las malas condiciones de trabajo y la contaminación ambiental. McEwen 
recuerda que las investigaciones mostraron que mientras más pobre es una persona, peor es su salud, sin importar si ella tiene acceso o no a un tratamiento médico (McEwen, 1998:177; Bonalume Neto, 1998:15).

Laurell (1987:70) le da mayor complejidad a la categoría de "carga" utilizada por McEwen. A través del ejemplo de la salud del trabajador, clasifica las cargas en diversos tipos: física, química, biológica, mecánica, fisiológica y psíquica. Cuando discute sobre la sobrecarga y subcarga psíquica, se refiere a situaciones de tensión prolongada: por una parte, la conciencia de peligro del trabajo, los altos ritmos de trabajo; por otra, la pérdida de control sobre el trabajo por estar subordinado a la máquina (Bosi, 1979:23), la descalificación del trabajo por la separación de su concepción y ejecución y el parcelamiento del trabajo, que conlleva a la monotonía y a la repetitividad. Como puede verse, condiciones de trabajo que difieren poco de las condiciones de vida de las clases populares.

Las recomendaciones de Garrido tienen poco que ver con la vida cotidiana de las clases populares. ¿Cómo ser menos competitivo y ansioso en un mundo donde las ofertas de trabajo formal están rápidamente decayendo y donde el mercado informal se está saturando? Asumir una postura abierta y franca se relaciona muy poco con un sector de la población que emplea como forma de sobrevivencia un lenguaje permeado de "doble código", donde "decir y desdecir" en la misma frase es algo constante (Martins, 1989:115).

Garrido y Barros llaman la atención hacia la importancia del "soltarse" y del no "tragar sapos", pues así, en vez de expulsar el veneno del cuerpo, hace que éste se acumule y sea expulsado de otras formas. Pero ¿qué puede significar "tragar sapos" o "soltarse" para las clases populares? Soltarse al momento puede conllevar a varios problemas para las clases populares: puede significar perder el empleo, sea en la fábrica, sea como empleada doméstica. En una cultura machista, soltarse en el momento, o sea "no tragar sapos", "no llevar los problemas para la casa", puede desencadenar un enfrentamiento con un final incierto.

\section{PROCURANDO COMPRENDER LAS ACCIONES Y} HABLAS DE LAS CLASES POPULARES COMO LA
BÚSQUEDA DE ALTERNATIVAS: AMPLIANDO LAS CONCEPCIONES SOBRE PARTICIPACIÓN POPULAR

Si el abordaje de la participación popular presentado al comienzo de este trabajo continúa siendo adecuado como punto de partida para comprender las desigualdades de la sociedad brasileña, desde el punto de vista de quien se preocupa en desarrollar trabajos con las clases populares la participación es un asunto, en palabras de Nunes (1989), "resuelto de antemano". Pues se torna "ocioso (...) preguntarse sobre la génesis y el significado del contenido de las reivindicaciones sociales, porque ya sabemos a priori que éstas son el resultado indefectible de la dinámica global de la ciudad capitalista y que expresan equipamientos necesarios para la reproducción de la fuerza de trabajo y, por tanto, para la reproducción del capital (...) Desde este punto de vista, quien sufre las necesidades no tiene un papel activo en determinarlas como tal (...) Las respuestas a esas preguntas no pueden salir de 'conceptos sin vida'. Deben ser investigadas (...) Se vuelven prácticamente puntos de partida absolutos para los procesos de reivindicación urbana de las clases populares, a las cuales están obligados a responder".

Desde el punto de vista de Cunha (1995), es como si las clases populares sólo se organizaran y reivindicaran si existiera lo que se él llama "un vacío de Estado". En esta perspectiva, las clases populares no tienen una autonomía propia, sus movimientos estarían necesariamente asociados a un Estado que no cumple con sus obligaciones, y en segundo lugar, a los mediadores, que perciben cuáles son las reivindicaciones "correctas".

Para algunos que se dedican al estudio de las clases populares hay una tendencia, por formación académica o por orientación política, de hacer una lectura del habla y de las acciones de las clases populares según la categoría "carencia". Si la pobreza y la miseria se prestan a reforzar el uso de esta categoría, algunos intelectuales piensan que tal lectura puede empobrecer sus análisis. Llaman la atención hacia otra categoría - la de "intensidad"-, que trae 
dentro de sí la idea de "iniciativa", de "lúdico", de "autonomía" (Saidon, 1991; Almeida, 1995).

Rodrigues (1992) señala como ejemplo de la idea de "intensidad" el caso de los "surfistas" de los trenes de Río de Janeiro. Por la categoría "carencia", el pasajero estaría encima del tren o por falta de dinero o porque el tren está lleno. Entrevistas posteriores han demostrado que el "surfista" podía pagar el pasaje y que había lugares disponibles en el tren escogido.

La dificultad de que los mediadores comprendan lo que dicen los miembros de las clases populares está relacionada más con su postura — la dificultad de aceptar que las personas "humildes, pobres, pobladores de la periferia" sean capaces de producir conocimiento, de organizar y sistematizar pensamientos sobre la sociedad- que con problemas técnicos, como por ejemplo lingüísticos.

En realidad, esa discusión -que, ciertamente, no es nueva en el campo de la educación popular- se trata de las dificultades que los profesionales y los políticos tienen para interpretar a las clases populares, y de que la "crisis de interpretación es nuestra” (Martins, 1989), así como también en la idea de "iniciativa". La cuestión de la "iniciativa" señala hacia la relación profesional/clases populares, y el hecho de que muchos trabajen con la perspectiva de que la "iniciativa" es parte de la tradición de los mediadores, y que la población falla en este aspecto, haciendo que esta última sea vista como pasiva y apática (Valla, 1986).

Toda propuesta de los sanitaristas presupone la "prevención" como principal categoría, pues la propia idea de prevención implica una mirada hacia el futuro. Pero podría ser formulada como hipótesis de que estos sectores de la población conducen sus vidas con la categoría principal de "provisión". Con eso quiere decirse que el recuerdo del hambre y de las dificultades de sobrevivencia enfrentadas en el pasado, hacen que la mirada se vuelque hacia el pasado y la preocupación sea la de proveer el día de hoy, por tanto con una idea de "acumulación". Así, la propuesta de "prevención" estaría en conflicto directo con la de "provisión".

El gran poder de síntesis de Antonio Gramsci (1977) ya había señalado el hecho de que “(...) el elemento intelectual 'sabe', pero no siempre comprende y mucho menos 'siente".

Satriani ofrece la idea de que la cultura popular, para afirmarse en este mundo del vencedor, utiliza la duplicidad, el doble código "(...) el afirmar y el negar, el obedecer y el desobedecer" (Martins, 1989); "el ajuste a los valores dominantes y su rechazo; interpretaciones lúcidas combinadas con ilusiones en apariencia alienadas" (Evers et al., 1985); "un inconformismo profundo (...) bajo una capa de fatalismo" (Chaui, 1990). Un estilo de vida que "se manifiesta en el lenguaje metafórico, en la teatralización que pone en boca de otro la palabra del sujeto enmudecido" (Martins, 1989).

Martins (1989) sugiere que la cultura popular "debe ser pensada como (...) conocimiento acumulado, sistematizado, interpretativo y explicativo (...) teoría inmediata". En este sentido, lo que parece absurdo para el profesional puede tener una lógica clara para la población.

Aunque algunos mediadores sean más atentos, respeten más a las personas pobres de la periferia, los muchos años de educación clasista y prejuiciada hacen que el papel de "tutor" predomine en su relación con las clases populares.

La discusión de la educación como parte del proceso de participación popular está más relacionada con las ideas del educador Paulo Freire (1974), que ve la educación como un diálogo entre educadores y educandos, oponiéndose a la idea de repaso de informaciones de los mediadores a las clases populares, entendiendo que los dos grupos desempeñan los papeles de educadores y educandos.

Las categorías de "atraso" e "ignorancia" no se aplican en términos comparativos; toda sociedad, en el pasado y en la actualidad, posee una pluralidad de sujetos, pero con inserciones diferentes según sean sus relaciones con el capital (Starn, 1991).

La búsqueda de un denominador común para comprender el habla y las acciones de las clases subalternas conlleva a subestimar hechos y a interpretaciones simplistas. Cada nuevo movimiento, no importa donde ocurra, debe ser visto como único y como un proceso de construcción y creación de identidad de grupo. 
En este sentido, una protesta no sería sólo una reacción contra las fuerzas externas, sino también un movimiento emergente de un conjunto de circunstancias singulares e históricamente específicas. Al mismo tiempo, acompañar la construcción de la identidad política de un determinado movimiento requiere que se evite la utilización de categorías preestablecidas, tales como hegemonía versus contrahegemonía; revolución versus reforma; cooptación versus enraizamiento en las bases; falsa conciencia versus comprensión correcta, pues pocas son las experiencias donde las posibilidades de transformación radical sean visibles. La mayoría de los movimientos posee implicaciones múltiples, en las que el desafío al gobierno se mezcla con la admiración de las autoridades municipales y el desdén por los burócratas locales. Difícilmente una manifestación de las clases populares es de oposición o de servicio al poder, y por estas razones, debe ser vista como singular y dinámica, con su identidad propia (Starn, 1991).

Tanto para los trabajadores rurales como para los grupos de la población que habitan en las periferias de las grandes ciudades, insertas de manera informal en el mercado, la "resistencia cotidiana" es un indicador de sus formas de organización. La falsa deferencia, la evasión, el trabajo lento, son comportamientos que indican el reconocimiento de los altos costos de la protesta abierta. Tiene sentido la frase de Gramsci (1977): “(...) la historia de los grupos sociales subalternos es necesariamente disgregada y episódica (...)”.

Las categorías "apatía" y "desorganización", que se atribuyen a las clases populares que no forman parte de la sociedad civil de carácter popular, escamotean una realidad que es opuesta. Una gran parte de la población de los barrios periféricos y favelas participa de algún tipo de organización (escuela de samba, equipo de fútbol, iglesia) que si, por una parte, no demuestra un discurso articulado políticamente, por otra, indica relaciones cohesionadas y sistemáticas.

La propia sobrevivencia de grandes sectores se debe en gran parte a su "iniciativa" de vivir, pues es frecuente la postura de intelectuales y profesionales de que la iniciativa es un atributo de ellos, incluso "reconociendo que me gustaría que no fuese así". La imagen de pasividad es ilusoria, y si no es vista así, necesariamente coloca la concepción de acción e iniciativa sólo del lado de los mediadores (Valla, 1986).

Cuando a la discusión de los problemas de comprensión de las clases populares por parte de los mediadores se agrega la evaluación de la coyuntura, el resultado puede indicar la necesidad de un nuevo abordaje de la participación popular. Al lado de la perspectiva del "vacío de Estado", se formula la hipótesis de que el Estado no sería el único punto de referencia para el desarrollo de prácticas vinculadas con la participación popular. Es posible que otras formas ya estén siendo construidas por grupos sociales pertenecientes a las clases populares. El desempleo estructural, el trabajo precario y la consecuente caída de la recaudación de impuestos señalan los problemas de acceso a los servicios y de su resolución. De acuerdo con Chaui (1990), es muy probable que las clases populares tengan una enorme lucidez sobre su situación social y que esa lucidez indique pocas esperanzas de una mejoría significativa. Si es cierta la premisa de que las clases populares evalúan su realidad a partir de sus vivencias, entonces es posible que algunos de sus problemas de salud se resuelvan por vías a las que los mediadores califican tradicionalmente como "alienantes" o "asistencialistas".

En todos los países del mundo industrializado, y en muchos países en desarrollo - y en este caso Brasil es un ejemplo sin par-, hubo un énfasis en la privatización de la asistencia médica junto con su especialización y tecnificación, trayendo como resultado una medicina menos humana y una vida más "medicalizada" (Cox, 1995; Luz, 1996).

Luz (1996) señala la insatisfacción de sectores de todas las capas sociales de Brasil con los servicios de salud, trátese de servicios públicos o privados. Mientras las clases medias buscan soluciones, por ejemplo, en la homeopatía, la meditación, el yoga, las terapias con cristales y con flores, cabe preguntarse qué significa el extraordinario crecimiento de la presencia de las clases populares en las iglesias de todas las religiones, principalmente en las evangélicas y pentecostales (Barros y Silva, 1995; Mariz y Machado, 
1994; Valla, 1997b). Maris y Machado (1994) observan que la falta de apoyo institucional en esta época de cambios sociales intensos, hace que esas iglesias ofrezcan un "potencial racionalizador", es decir, un sentido para la vida. Asimismo, estos autores comentan la frágil presencia de los partidos políticos, asociaciones y del propio Estado de bienestar entre los pobres y que las religiones ofrecen "algunos grupos de soporte alternativo (...) y crean motivaciones para resistir a la pobreza".

Es esta insatisfacción lo que empuja a las personas a buscar alternativas. Teóricamente no hay nada que impida que esas mismas alternativas existan en el servicio público, pero no se trata sólo de un problema de inversión, existe la necesidad de ver la relación salud-enfermedad desde otra perspectiva. Todo eso cobra sentido cuando recordamos que "(...) los sectores populares mantuvieron sobre los problemas relacionados con la salud una cosmovisión próxima a la tradicional, en la medida en que (...) no separan al hombre de la naturaleza, el cuerpo del alma" (Luz, 1996:275).

Dentro de una perspectiva de una educación popular transformadora, es necesario distinguir entre las propuestas de salud colectiva "individualizantes" de las clases media y alta y los caminos colectivos de las clases populares, creados a partir de sus condiciones de vida.

Ciertamente, los caminos alternativos recorridos por las clases populares para aliviar sus problemas de salud son diversos. Tanto por el problema de la relación cuerpo-mente, como por la perspectiva del apoyo social, el camino de la espiritualidad y de la religión parece ser una de las trayectorias principales (Valla, 1998:166).

La cuestión señalada anteriormente acerca del "tragar sapos" y de "soltarse" puede ofrecer una pista para comprender mejor el "uso" que las clases populares hacen de las iglesias, especialmente de las iglesias que desarrollan cultos donde el gritar y el cantar alto es una constante (Cox, 1995:109-110).

Finkler (1985) realizó un estudio sobre los 500 centros espirituales y los 5 millones de fieles en México. Al respecto, señala el éxito de las "curas espirituales (...) con sufrimientos crónicos de una forma que la biomedicina no es capaz de igualar (...) atenúan el dolor, cuando no lo eliminan, y ayudan a las víctimas de sufrimiento a hacer más tolerables y significativas sus vidas". Este autor (Finkler, 1985:84) habla de "símbolos emocionalmente densos que son derivados de la experiencia colectiva de aquellos que sufren". Así, cabe preguntarse si la propia colectividad presente en esos espacios no se relaciona con la discusión acerca del apoyo social, presentada anteriormente.

En su estudio sobre la Asamblea de Dios, Neves (1984) señala la multiplicidad de concepciones de cura para quien no posee condiciones de vida y de trabajo que permitan que sean examinadas otras alternativas.

Cabe a los mediadores de la salud popular y a los profesionales de la salud y de la educación reivindicar un sistema de salud que incorpore formas alternativas de lidiar con la salud, sea a nivel nacional o de manera experimental en algunas unidades de salud. Al mismo tiempo, es necesario acompañar las experiencias aisladas de salud alternativa desarrolladas por y para las clases populares. En tercer lugar, se deben proponer discusiones en los partidos políticos, sindicatos, iglesias y entidades de tipo asociativo; pero, principalmente, como parte de los pensa de estudios de ciencia y salud de las escuelas públicas, como una forma de demostrar que existen otras maneras de pensar el problema de la relación salud-enfermedad.

En realidad, lo que se discute es cómo las clases populares se apropian de formas de enfrentar sus problemas de salud cuando las propuestas biomédicas no les satisfacen. Parece, sin embargo, que no es tan importante un juicio de antemano acerca de los caminos escogidos por las clases populares, sino, más bien, conocer el porqué de esos caminos. Ello quizás sea la tarea de la educación popular: investigar esos caminos que parecen señalar hacia una vida "más tolerable y significativa".

Los desacuerdos entre las relaciones de los gobiernos con las clases populares organizadas no significan que la participación popular carezca de sentido dentro del juego político. A pesar de su retracción, el Estado continúa concentrando grandes sumas de dinero público, que debe ser disputado para 
la mejora en la atención de la salud de las clases populares.

El hecho de que algunos líderes religiosos utilizan sus iglesias como forma de enriquecimiento personal o de asegurar votos para sus candidatos, no puede ser una explicación satisfactoria para tanta búsqueda. Se debe buscar una explicación que relativice la participación de los pastores: posiblemente en lo que Finkler (1985) llama "símbolos emocionalmente densos que se derivan de la experiencia colectiva de aquellos que sufren".

Llegado a este punto, cabe realizar una unión con la teoría de apoyo social. La propuesta del apoyo social sugiere que los problemas sociales no afectan a todas las personas de igual manera. Algunos estudios han demostrado que los apoyos de determinadas organizaciones sociales pueden influir de manera beneficiosa, en tanto proporcionan factores de protección contra la aparición de enfermedades, ofreciendo mejoras en la salud física, mental y emocional (Cassell, 1974:1041).

En momentos de mucha tensión el apoyo social contribuye a mantener la salud de las personas, pues desempeña una función mediadora. Al proponer la cuestión del apoyo social, no se busca tan sólo una solución puntual para los llamados "excluidos", sin embargo, se incluye en la propuesta la siguiente pregunta: ¿no merece tal propuesta ser considerada por sus propios méritos? ¿No serviría como una especie de trampolín para revisar la salud como problema médico? Por una parte, el apoyo social ofrece la posibilidad de realizar la prevención a través de la solidaridad y del apoyo mutuo; por otra, permite abrir una discusión sobre el control del destino de los grupos sociales y sobre la autonomía de las personas de cara a la hegemonía médica, gracias a la "nueva" concepción del hombre como unidad (Tognoni, 1991; Valla, 1996).

Si unimos esas consideraciones a las de Luz (1996) acerca de que “(...) los sectores populares mantuvieron sobre los problemas relacionados con la salud una cosmovisión próxima a la tradicional, en la medida en que (...) no separan al hombre de la naturaleza, el cuerpo del alma", es posible que se llegue a conclusiones inesperadas. Vasconcelos (1997) comenta que esa aparente alienación de las clases populares puede estar señalando dimensiones de la existencia coherentes con las preocupaciones del movimiento holístico, pues significan la búsqueda de formas de organización social, de vivencias más profundas de valores como la solidaridad, el apoyo mutuo, el control autónomo de la propia vida, el placer y la espiritualidad. Al contrario de la alienación, podemos estar presenciando un movimiento de bases de reconstrucción social menos centrado en la transformación de la estructura política del aparato de Estado y más volcada hacia el fortalecimiento de las redes de solidaridad de la sociedad civil.

\section{¿EL CAMPO DE LOS DERECHOS HUMANOS}

\section{INCLUYY A LAS CLASES POPULARES?}

La democracia presenta la propuesta de que los derechos individuales (humanos) de cada ciudadano sean respetados, pero esa propuesta solamente tendría sentido si todos los ciudadanos tuvieran pleno acceso a los servicios básicos.

Los derechos humanos se tornan difíciles de ser respetados en la medida en que los derechos sociales tienen en Brasil una expresión material frágil. ¿Cómo garantizar el derecho de ir y venir, por ejemplo, si el transporte colectivo no existe (obligando a largas caminatas a pie) o es extremadamente precario, con horarios irregulares, pocos autobuses, precios altos, etc.? ¿Cómo garantizar el derecho a la salud, si gran parte de la población no tiene acceso al saneamiento básico? El dinero que gastan los gobiernos para el consumo colectivo está lejos de ser suficiente para proporcionar a toda la población todo lo que la Constitución garantiza, perjudicando así el ejercicio pleno de los derechos humanos.

En realidad, intentar responder estas preguntas, es decir, comprender la relación entre la población y las partidas públicas, es hablar de ciudadanía. Pero discutir sobre ciudadanía en Brasil constituye un problema, pues la idea que ha sido divulgada es la de una ciudadanía propia de países desarrollados, de Estados Unidos, de Europa Occidental. Todos hemos oído hablar de esos países donde todo el mundo tiene agua en su casa, tiene red de cloacas, puede con confianza tomar agua del grifo, donde el 
peatón sabe que los choferes están obligados a detener sus vehículos cuando baja de la acera.

Hay muchas maneras en las que la violencia de los derechos humanos afecta a las clases populares en América Latina. En este trabajo ello puede ser percibido a través de la débil presencia de los derechos sociales, una amplia y permanente violación de los derechos humanos: la declaración fraudulenta de impuestos por parte de los miembros de las clases altas, inversiones de los gobiernos que sólo benefician a las clases más adineradas, servicios de salud deficientes y políticas compensatorias que mantienen a los pobres lejos del ejercicio de la ciudadanía.

Es posible que una de las principales formas de violar los derechos humanos de las clases populares en América Latina sea a través de la violencia que se desarrolla en los barrios periféricos de las grandes ciudades. Se trata de las atrocidades cometidas en los barrios populares como resultado de los enfrentamientos entre las fuerzas de represión y los miembros del comercio del narcotráfico. Incentivado por el desempleo estructural e ignorado de una forma disfrazada por el gobierno y una gran parte de los miembros de las clases altas y medias, ese problema difícilmente será resuelto por los propios afectados. De forma distinta a otros problemas que enfrentan los pobres — falta de agua, falta de acceso a la escuela y a los puestos de salud, por ejemplo-, la propia reivindicación contra la violencia es respondida con más violencia y frecuentemente con la muerte.

Por una combinación de intereses convergentes con los niveles nacional e internacional -el incentivo al turismo, la venta de armas y el comercio de drogas - hay incluso un gran silencio en los grandes diarios sobre la existencia de esa forma de violación de los derechos humanos.

Últimamente, la prensa brasileña ha destacado las acciones de tortura practicada por efectivos policiales en las propias delegaciones de los estados de Sao Paulo, Minas Gerais y Pará. Existen grabaciones en las que puede escucharse al secretario de Defensa Social del estado de Pará diciendo: "Nosotros agarramos al sujeto cayéndole a golpes al tipo como un loco". El oficial comandante del quinto batallón de la Policía Militar Metropolitana de Sao Paulo fue despedido de su cargo por haberle dicho a los soldados que "maleante y urna es lo mismo", es decir, una forma de recomendar el asesinato de quienes cometan crímenes (Magalhães, 1999). Tres promotores del Ministerio Público en el estado de Minas Gerais que procesaban demandas de torturas a presos fueron amenazados por efectivos policiales con armas en la mano. El carro oficial utilizado por los promotores había sido desvalijado, además de rayado con obscenidades y vaciados sus cauchos. La investigación promovida por los promotores buscaba datos no sólo relacionados con la acusación de tortura, sino también con el hecho de que había 378 presos en una celda con capacidad de 80 (Santiago, 1999:4-1).

Desde 1995 ha sido registrado el aumento de homicidios en la periferia de Sao Paulo. En 1998, la violencia en los barrios periféricos superó seis veces a la del área central de la ciudad, acusando más de 5000 asesinatos durante el año, es decir, aproximadamente 430 por mes (Correa, 1999). El día 16 de octubre de 1999, se cometieron 10 asesinatos en apenas 7 horas. Con esas dos matanzas, la Gran Sao Paulo registró 60 matanzas durante el año 1999, representando más de 200 muertes (Navarrete, 1999:3-3).

Otro ejemplo de violencia contra las clases populares se refiere a la fuga de casi 500 menores de la Fundación Estatal de Bienestar del Menor (FEBEM) en Sao Paulo. Las fugas se debían al hacinamiento y al maltrato de los adolescentes por funcionarios que usaban capuchas. Durante el tumulto, después de la fuga, algunos padres de los adolescentes presos pelearon contra los funcionarios y varios familiares de los presos fueron heridos con perdigones de goma disparados por la policía (Losano, 1999:4-5).

Difícilmente la resolución de esos problemas ocurrirá sin la emergencia de la organización, la articulación y las denuncias de la sociedad civil que, en gran parte, no sufre esas violencias, pero nota su existencia como tal vez la principal injusticia de la actualidad en el continente.

\section{ConClusión}

El dramatismo de la nueva coyuntura se revela a través de aparentes desacuerdos en las negociaciones entre los gobiernos y las organizaciones populares en lo referente a las reivindicaciones más básicas de salud y seguridad. El desconcierto de los mediadores puede 
ser un indicativo de la necesidad de mirar y ver las clases populares a través de otras categorías, tales como "intensidad", "vacío de Estado", "desempleo estructural" y "solidaridad".

La poca confianza de las clases populares en la eficacia de los políticos y de la política, conjuntamente con un decreciente mercado de trabajo, puede estar señalando a los mediadores la necesidad de "descubrir" otras formas de participación popular. Es probable que el "descubrimiento" por parte de algunos investigadores y mediadores de amplias redes de apoyo mutuo entre las clases populares y formas de solidaridad que coinciden con la búsqueda de sobrevivencia sean, en realidad, caminos que las clases populares han venido transitando durante mucho tiempo.

Posiblemente los mediadores en el campo de la participación popular y de la salud tengan ante ellos un nuevo desafí: ¿cómo leer y comprender el habla y los movimientos de las clases populares como manifestaciones de participación popular, sin obviar todo el trabajo construido hasta ahora en los consejos y asociaciones populares? En el espíritu dialógico de Paulo Freire y de la afirmación de Martins de que "la crisis de comprensión es nuestra", tal vez sea necesaria una nueva disponibilidad de los mediadores con relación a las clases populares. De comprender las implicaciones de estas manifestaciones de solidaridad y apoyo mutuo como formas de organización popular, y al mismo tiempo procurar descubrir las posibles contribuciones de estas iniciativas para los sindicatos, partidos y consejos populares.

Milton Santos (1996) ha dicho que la "reconstrucción de Brasil" pasa por la creencia de que la "verdad" está con los pobres, y en este sentido, quien se interesa en acompañar a las clases populares en sus caminos para resolver sus problemas de salud y seguridad, debe entender lo que el mismo Santos llama la acción creativa de los "hombres lentos en sus espacios urbanos opacos".

\section{REFERENCIAS BIBLIOGRÁFICAS}
Aith, M., 1999. Brasil é contra-exemplo para emergente. Folba de São Paulo, 16 de septiembre: $2-1$.

Almeida, A.L., 1995. Por um tema menor: democracia e participação ativa (o medo e a luta produzindo relaģões democráticas na escola pública). Tesis de maestría, Niteroi: UFF.

Barros \& Silva, F., 1995. Pesquisadora vê democracia religiosa. Folha de São Paulo, 26 de diciembre:1-6.

Bermann, S., 1995. Trabajo precario y salud mental. Córdoba, Argentina: Navajo Editor.

Biancarelli, A., 1999. Pinotti vê "incompetência" na saúde. Folba de São Paulo, 11 de octubre:4-4.

Bonalume Neto, R., 1998. Pesquisa revela "mapa" do estresse. Folha de São Paulo, 15 de enero:114-15.

Bosi, E. (org.), 1979. Simone Weil. A condição operária e outros estudos sobre a opressão. Río de Janeiro: Paz e Terra.

Canzian, F., 1999. "Consenso de Washington" foi longe demais, diz seu ideólogo. Folha de São Paulo, 03 de octubre:1-13.

Cassell, E.J., 1974. An epidemiological perspective of psychosocial factors in disease etiology. American Journal of Medicine, 64:1040-1043.

Cassell, E.J., 1976a. The healer's art. Nueva York: J.P. Lippincott Company.

Cassell, E.J., 1976b. The nature of suffering and the goals of medicine. New England Journal of Medicine, 11:639-645.

Chuai, M., 1990. Notas sobre cultura popular. En: Cultura e democracia (M. Chuai, edt.), pp. 6183. Sao Paulo: Cortez.

Corrêa, S., 1999. Violência na periferia de SP cresce seis vezes mais que na área central. Folha de São Paulo, 13 de septiembre:4-1.

Cox, H., 1995. Fire from heaven. The rise of Pentecostal Spirituality and the reshaping of religion in the twentyfirst century. Nueva York: Addison-Wesley.

Cunha, M.B., 1995. Parque Proletário de Grotão e outras moradas: saber e história nas favelas da Penha. Tesis de maestría en Educación, Niteroi: UFF.

Evers, T.; Muller-Plantenberg, C. \& Spessart, S., 1985. Movimentos de bairro e Estado: lutas na esfera da reprodução na América Latina. En: Cidade, povo e poder (J.A. Moisés, org.). Río de Janeiro: Paz e Terra. 
Falcão, D., 1999. Metade das crianças do país sofre de anemia. Folha de São Paulo, Caderno Cotidiano, 09 de marzo: 3.

Fernandes, R.C., 1994. Privado porém público. O terceiro setor na América Latina. Río de Janeiro: Relume Dumará.

Finkler, K., 1985. Spiritualist bealers in Mexico. Successes and failures of alternative therapentics. Nueva York: Praeger.

Foss, L. \& Rothenberg, K., 1987. The second medical revolution. From biomedicine to infomedicine. Boston: New Science Library/Sambhala.

Freire, P., 1974. Pedagogia do oprimido. Río de Janeiro: Paz e Terra.

Gaspari, E., 1999. Quem paga imposto fez seu eterno papel, o de bobo. Folha de São Paulo, 10 de octubre: $1-8$.

Genro, T., 1996. O enigma do México. Folha de São Paulo, 25 de febrero: 1-3.

Gramsci, A., 1966. Concepção dialética da história. Río de Janeiro: Civilização Brasileira

Gramsci, A., 1977. Appunti sulla storia delle classi subaltermi. Il Risorgimento. Roma: Editori Riuniti (citado por: Martins, José de Souza, 1989. Dilemas sobre as classes subalternas na idade da razão. En: Caminhando no chão da noite. Sao Paulo: Hucitec).

Ivanissevich, A., 1995. Mulher faz negócio da China. Jornal do Brasil, 3 de diciembre: 30.

Kirmayer, L.J., 1987. Mind and body as metaphors: bidden values in biomedicine.

Laurell, A.C., 1987. Para el estudio de la salud em su relación com el proceso de producción. En: Taller Latinoamericano de Medicina Social. Asociacion Latinoamericana de Medicina Social, Memorias, pp. 61-94. Medellín.

Lock, M. \& Gordon, D. (orgs.), 1988. Biomedicine examined, pp. 57-94. Boston: Kluwer Academic Publishers.

Losano, A., 1999. 500 menores fogem de Febem em SP. Folha de São Paulo, 13 de septiembre: 5-4.

Luz, M.T., 1996. A arte de curar versus a ciência das doenças. Sao Paulo: Dynamis.
Magalhães, M., 1999. Promotora arquiva denúncia de tortura. Folha de São Paulo, 11 de octubre: 4-1.

Mariz, C.L. \& Machado, M.D.C., 1994. Pentecostalismo e a redefinição do feminino. En: Pentecostes e nova era: fronteiras, passagens (L. Landim, org.). Río de Janeiro: Instituto Superior de Religião, Série Religião e Sociedade, 17/1-2.

Martins, J.S., 1989. Dilemas sobre as classes subalternas na idade da razão. En: Caminhada no chão da noite (J.S. Martins, org.). Sao Paulo: Hucitec.

Mcewen, B.S., 1998. Protective and damaging effects of stress mediators. The New England Journal of Medicine, 338 (3):171-79.

Minkler, M., 1985. Building supportive ties and sense of community among the inner-city elderly: The Tenderloin Outreach Project. Health Educational Quartely, 12:303-314.

Moisés, J. A., 1985. O Estado, contradições urbanas e movimentos sociais. En: Cidade, povo e poder (J.A. Moisés, org. ). Río de Janeiro. Paz e Terra.

Navarrete, G., 1999. Chacinas fazem 10 mortos em 7 horas. Folha de São Paulo, 16 de octubre: 3-3.

Neves, D.P., 1984. As "curas milagrosas" e a idealização social. Niteroi: UFF/ CEUfF-Pro-Ed.

Nunes, E., 1989. Carências urbanas, reivindicações sociais e valores democráticos. Lua Nova. Revista de Cultura e Politica, 17:75-92.

Parcias, C., 1998. Meditação controla o estresse. Jornal do Brasil, Suplemento Vida, 10 de mayo: 1-2.

Rodrigues, F., 1998. Dívida de vinte e dois estados supera receita. Folha de São Paulo. 11 de enero: I-6.

Rodrigues, J.C., 1992. Ensaios em antropologia do poder. Río de Janeiro: Terra Nova.

Rossi, C., 1999. Começa o jogo do século. Folha de São Paulo, 07 de octubre: 1-2.

Saidón, O., 1991. As loucas da Praça de Maio: carência ou intensidade? Tortura Nunca Mais, Boletim Informativo do Grupo Tortura Nunca Mais/RJ, 3: 8.

Santiago, C.H., 1999. Promotor apura tortura e é ameaçado. Folha de São Paulo, 13 de octubre: $4-3$. 
Santos, C., 1999. País perde com liberalismo, diz Cepal. Folha de São Paulo, 16 de septiembre: 2-5.

Santos, M., 1996. Natureza do espaço. Técnica e tempo. Razãa e emoção. Sao Paulo: Hucitec.

Schwartz, G., 1999. Abertura não reduz pobreza, diz Bird. Folba de São Paulo, 16 de septiembre: 2-1.

Sekles, F., 1998. Amor e intimidade prolonga a vida. Jornal do Brasil, Caderno Vida, 26 de abril: 2 .

Serulnikov, S., 1994. When looting becomes a right: urban poverty and food riots in Argentina. Latin American Perspectives, 21: 69-81.

Starn, O., 1991. Reflexiones sobre rondas campensinas, protesto rural e nuevos movimientos sociales. Lima: IEP Ediciones.

Tautz, C., 1999. Rodada do milênio ou robada do milênio? A Terceira Conferência Ministerial da Organização Mundial do Comércio. Discusión celebrada en la Escola Nacional de Saúde Pública, Fundação Oswaldo Cruz, 06 de octubre.

Tognoni, G., 1991. Epidemiologia comunitária. Salud Comunitária,1:3-9.

Toledo, J.R., 1999. Desigualdade aumenta entre os mais ricos e os mais pobres da Grande SP. Folba de São Paulo, 29 de septiembre: 3-1.

Valla, V.V. \& Stotz, E.N., 1991. Participação popular e saúde. Petrópolis: Centro de Defesa dos Direitos Humanos / Centro de Estudos e Pesquisas da Leopoldina.

Valla, V.V. \& Stotz, E.N., 1997. Apresentação. En: Participação popular, educação e saúde: teoria e prática (V.V. Valla \& E.N. Stotz, orgs.), pp. 7-10. Río de Janeiro: Relume Dumará.

Valla, V.V., 1986. Educação e favela. Políticas para as favelas do Rio de Janeiro, 1940-1985. Petrópolis: Vozes/Abrasco.

Valla, V.V., 1996. A crise de interpretação é nossa. Procurando compreender a fala das classes populares. Educaşão e Realidade, 21: 177-190.

Valla, V.V., 1997. A construção desigual do conhecimento e o controle social dos serviços de educação e saúde. En: Participação popular, educação e saúde. Teoria e prática (V.V. Valla \& E.N. Stotz, eds.). Río de Janeiro: Relume Dumará.
Valla, V.V., 1998. Apoio social e saúde: buscando compreender a fala das classes populares. En: Educação popular hoje (Costa, M.V., org.), pp. 151-180. Sao Paulo: Loyola.

Valla, V.V., 1998. Movimentos sociais, educação popular e intelectuais: entre algumas questões metodológicas. En: Intercultura e movimentos sociais (R.M. Fleuri, org.). Florianópolis: Mover/NUP.

Valla, V.V.; Assis, M. \& Carvalho, M., 1996. Participação popular e os serviços de saúde: o controle social como exercício da cidadania. En: Educação, saúde e cidadania (V.V. Valla \& E.N. Stotz, orgs.), pp. 87-98. Petrópolis: Vozes.

Valla,V.V. \& Stotz, E.N., 1996. As respostas do movimento popular ao "estado de emergência permanente". En: Educação, saúde e cidadania (V.V. Valla \& E.N. Stotz, orgs.), pp. 99-122. Petrópolis: Vozes.

Vasconcelos, E.M., 1997. Comentários sobre o trabalho, apoio social e saúde: buscando compreender a fala das classes populares. En: Apoio social e saúde: buscando compreender a fala das classes populares (V.V. Valla, coord.). Trabalho apresentado no Intercâmbio do GT Educação Popular, AnPed, João Pessoa.

Vasconcelos, E.M., 1998. Educação popular como instrumento de reorientação das estratégias de controle das doenças infecciosas e parasitárias. Cadernos de Saúde Pública, suplemento 2, Vol. 14:39-58.

Ventura, M., 1998. Amar protege o coração. Jornal do Brasil, Caderno Vida, 28 de enero:1.

Waldovsky, A., 1977. Doing better and feeling worse: the politics of pathology of health policy. Daedalus, 106:1.

Weiss, R., 1995. Meditação combate hipertensão. Jornal do Brasil, 03 de diciembre:28.

Werner, S.A., 1994. Participação social em saúde: a experiência do Conselho Municipal de Saúde de Niterói. Tesis de maestría, Río de Janeiro.

Traducción a español: antropólogo Julio de Freitas Taylor. 


\section{SALUD Y PUEBLOS INDíGENAS: LOS DESAFíOS EN EL CAMBIO DE SIGLO}

Esther Jean Langdon *

\section{INTRODUCCIÓN}

Hablar sobre salud y pueblos indígenas no es una tarea fácil, debido a las grandes diferencias entre los países de América Latina y a la situación de los pueblos indígenas que forman parte de estos Estados pluriétnicos. En algunos países, la población indígena es demográficamente mayoritaria, o por lo menos representa una proporción de la población total lo suficientemente significativa como para ejercer una influencia potencialmente importante en la identidad nacional, en la cultura y en la política del país. En otros países, constituye una minoría, en términos numéricos y étnicos, y podemos observar bastante variación en la situación que tienen los pueblos indígenas frente a las sociedades nacionales. Finalmente, la política indígena, y específicamente las políticas de salud indígena, varían de Estado en Estado, no sólo en cuanto a la elaboración de los principios que guían la legislación, sino también en la ejecución de estos principios por parte de las instituciones encargadas de atender las necesidades y demandas de los indios.

Pese a esta diversidad, podemos reconocer algunos desarrollos históricos y ciertas tendencias compartidas por los países latinoamericanos respecto a los derechos y a la noción de la autenticidad de la cultura indígena. Estas tendencias están expresadas en las directrices emitidas por organizaciones internacionales, tales como la ONU, la Oṛganización Internacional del Trabajo, la UNESCO, etc., y se reflejan diferencialmente en las legislaciones y constituciones de cada país.

Podemos examinar como ejemplo los Principios sobre la Tolerancia aprobados por la
UNESCO en 1995. Específicamente puede ser citado el artículo 1, que define tolerancia como "el respeto, la aceptación y el aprecio de la riqueza y de la diversidad de las culturas..." (UNESCO, 1997:11) y el artículo 2, que declara la necesidad de que los Estados acepten y respeten "el carácter multicultural de la familia humana" (UnEsCo, 1997:13). Asimismo, de particular interés para la salud indígena es el artículo 3.3, en el cual puede leerse:

...es preciso adoptar medidas, donde hagan falta, para garantizar la igualdad en dignidad y derechos de los individuos y grupos humanos. A este respecto se debe prestar especial atención a los grupos vulnerables socialmente desfavorecidos para protegerlos con las leyes $y$ medidas sociales en vigor, especialmente en materia de vivienda, de empleo y de salud; respetar la autenticidad de su cultura y sus valores... (UNESCO, 1997:14. Destacado mío).

El reconocimiento de los derechos indígenas y el carácter pluricultural de los Estados está también presente en la Convención 169 sobre Pueblos Indígenas y Tribales en Países Independientes, aprobada en 1989 por el 85\% de los Estados miembros de la Organización Internacional del Trabajo (OIT). Este documento "fue el primer instrumento jurídico internacional concebido específicamente con el objeto de salvaguardar los derechos indígenas" (Luz, 1995:102).

Lo más significativo de esta Convención es la eliminación del carácter integracionista que caracterizó a la Convención original, y el reconocimiento de que la diversidad étnico-cultural de los pueblos indígenas debe ser respetada en todas sus dimensiones, reforzando sus derechos e incluyendo aspectos tales como empleo, educación y salud, entre otros. La

Antropóloga, Universidad Federal de Santa Catarina, Brasil. E-mail: jean@cfh.ufsc.br. 
Convención anterior, adoptada en 1957, señalaba como principal objetivo la integración gradual de los indios a sus sociedades nacionales y designó a los pueblos indígenas como colaboradores en la aplicación de los mecanismos dirigidos a su propia protección e integración.

La Convención 169 revierte este principio. Aparte de reivindicar la garantía de los derechos de ciudadanía y formular directrices sobre varios aspectos de la calidad de vida, esta última Convención también sustituye la noción de la eventual colaboración de los pueblos indígenas por su participación activa en las medidas y decisiones gubernamentales y legislativas que los afecten directamente.

Los cambios entre la primera Convención sobre Pueblos Indígenas y Tribales en Países Independientes (1957) y la segunda, aprobada en 1995 , son testimonio del surgimiento de movimientos indígenas y del impacto que éstos han tenido en toda América Latina. En los años cincuenta, los indios formaban una minoría étnica y cultural, dominados y excluidos de las ideologías nacionales (Guss, 1994). La presencia de poblaciones indígenas en los diversos países fue ignorada y/o casi invisible en las legislaciones, en los censos nacionales y en las actividades de las instituciones gubernamentales, como por ejemplo los ministerios de salud.

$\mathrm{El}$ indio fue visto como un obstáculo para el progreso de los países, lo cual justificaba la ideología de la integración. Si los movimientos indígenas y la formación de asociaciones políticas evidencian el crecimiento de la resistencia y la afirmación de la identidad étnica (Turner, 1991), la ausencia de éstas, cinco décadas antes, sugiere que los pueblos indígenas, en su mayor parte, no habían llegado a formar una conciencia del poder político de su identidad étnica.

Hubo resistencia, en forma de conflictos entre indios y blancos, y a lo largo del siglo surgieron, además, varios héroes de la lucha indígena, tales como Quintín Lame de Colombia (Castrillón, 1973), pero, prácticamente, se observó una total ausencia de organizaciones indígenas o indios ocupando cargos políticos. Sólo en los últimos veinte años del siglo $\mathrm{XX}$, los movimientos indígenas comenzaron a organizar y dar voz a su identidad y a sus demandas y en varios países los indios están siendo elegidos para ocupar cargos públicos.

No está dentro de los objetivos de este trabajo analizar estos movimientos y los cambios en el liderazgo indígena y el concepto de "indio" e identidad étnica (Guss, 1994; Jackson, 1995a, 1995b; Brown, 1993). No obstante, no podemos ignorar que hubo un crecimiento significativo en la formación y en las actividades de las asociaciones indígenas, que influyeron en alguna medida en los cambios realizados en los documentos nacionales e internacionales, dando reconocimiento a los derechos indígenas. A pesar de que estamos lejos de ver gozar al indio de una ciudadanía plena en una sociedad sin prejuicios y explotación, el surgimiento de la identificación y resistencia étnica como una fuerza política significativa en la actual América Latina tiene consecuencias importantes en las políticas de salud indígena y en el papel de los científicos sociales vinculados a la investigación o al desarrollo de proyectos en esta área.

Después de la segunda guerra mundial, época que marca generalmente el inicio del campo de la antropología médica, la antropología y las ciencias sociales en general visualizaron el fenómeno de contacto entre el indio y la sociedad nacional como un proceso de "aculturación", apoyando así, implícitamente, la visión de que este contacto tendría como resultado la asimilación del indio por parte de la sociedad nacional. Otra noción vigente en aquella época, que también reflejó esta idea, fue la de la distinción entre "indios integrados" y "no integrados". Específicamente en el área de la salud, el antropólogo interpretó su papel como el de un mediador entre los pueblos indígenas y los profesionales de la salud, señalando los aspectos negativos de la cultura nativa con el fin de modificar las prácticas o da1 r a conocer los obstáculos culturales que los proyectos de desarrollo en salud tendrían que enfrentar. ${ }^{1}$

Hoy, en el cambio de siglo, la situación del indio es bastante diferente. La composición pluriétnica

1 Respecto a este punto, véase Bonfil (1966) para una crítica acerca del papel del antropólogo. 
de los Estados latinoamericanos no puede ser negada. Los indios están organizándose, exigiendo sus derechos y afirmando su identidad. Los problemas relativos al poder, la etnicidad y la fricción interétnica siguen dominando las discusiones sobre la relación del indio con la sociedad que lo rodea. La resistencia étnica y la organización de asociaciones indígenas están lejos de alcanzar plenamente sus objetivos y el proceso para garantizar los derechos del indio no ha sido fácil ni siempre pacífico.

Podemos evidenciar la violencia en todas partes, en eventos tales como la reciente rebelión en Chiapas, la "masacre de Navidad" en Bolivia (Orellana Aillón, 1998) o la violencia del gobierno peruano contra los movimientos indígenas (Brown, 1991). No obstante, las asambleas gubernamentales en toda América Latina están siendo forzadas a reformar sus legislaciones, reconociendo los derechos indígenas y estableciendo como principio el respeto a la especificidad cultural de sus pueblos indígenas.

Así, para analizar el problema de la salud de los pueblos indígenas en América Latina y el papel de las ciencias sociales en la investigación y en otras actividades en el campo de la salud, es necesario considerar el surgimiento de la etnicidad como factor central en la historia de los indios durante las últimas décadas de este siglo, y como factor de confrontación con los gobiernos latinoamericanos, exigiendo una reformulación de la política y de la provisión de servicios de salud para los pueblos indígenas. El surgimiento de la etnicidad también exige que las ciencias sociales repiensen y reorienten sus teorías y sus actividades prácticas en este campo de la salud indígena.

A la luz de estas consideraciones, y para estimular un debate sobre la situación específica de los países, pretendo examinar la política de la salud indígena en Brasil durante los últimos quince años, las actividades de los científicos sociales y los desafíos que éstos enfrentan, particularmente en la antropología. Todo ello en un contexto en el cual, a partir de 1986, la legislación sobre salud indígena tiene entre sus objetivos no sólo el de garantizar los derechos al acceso a los servicios de salud, sino también el respeto y el reconocimiento de los saberes indígenas y la participación de la comunidad en los programas de salud.

He escogido Brasil por varias razones. Una, por ser èl caso que mejor conozco. He acompañado activamente conferencias y simposios sobre políticas de salud indígena, proyectos de servicios de salud indígena preparados por organizaciones gubernamentales y no gubernamentales, y también he participado en investigaciones sobre salud indígena en el sur de Brasil. Pero, aún más importante, a mi manera de ver, Brasil es un buen punto de partida para una discusión, porque demuestra la complejidad del asunto y los desafíos que todavía deben ser enfrentados en este cambio de siglo. Además, la situación del indio en Brasil posee características comunes con otros países latinoamericanos.

\section{BRASIL：LA SITUACIÓN INTERÉTNICA}

En Brasil, el indio constituye una minoría, tanto numérica como étnicamente. La población indígena constituye aproximadamente el 0,2\% de la población brasileña (Ricardo, 1995:46), es decir, se estima en unas 200.000 personas, aunque no hay datos exactos sobre el tamaño de la población. Además de ser pocos desde el punto de vista numérico, en comparación con la población total, se caracterizan por una multiplicidad de grupos y lenguas. Como en toda América, no hay una cultura indígena única; la mayor parte de los pueblos indígenas brasileños pertenecen a microsociedades. El 40\% de los 206 pueblos, o sea 83 grupos, tienen una población de hasta 200 individuos, y cerca del $77 \%$ de los pueblos indígenas brasileños cuentan con una población de hasta mil individuos (Ricardo, 1995:46).

Los grupos indígenas se encuentran en varios estados de contacto: en un extremo existen grupos aislados o semiaislados, que sufren todavía el impacto de la violencia y de las enfermedades de contacto, y en el otro, los indios que están en constante contacto con la población no india. Estos grupos de contacto sufren constantemente de una 
situación sanitaria que caracteriza a los grupos pobres en general: alta incidencia de desnutrición, tuberculosis, problemas de salud bucal, parásitos, alcoholismo, alta mortalidad infantil, baja expectativa de vida, etc. Hoy en día existe una gran preocupación ante la posibilidad de que el SIDA pueda convertirse en una epidemia que amenace la supervivencia de los pueblos indígenas en los próximos años. ${ }^{2}$

\section{LEGISLACIÓN}

La Constitución Federal de 1988 está considerada una de las más avanzadas en lo referente a la cuestión indígena. Dedicó un capítulo a los derechos indígenas, asegurando sus "derechos originarios sobre las tierras que tradicionalmente ocupan", y reconoció su organización social, costumbres, lenguas, creencias y tradiciones. A pesar de que la Constitución está lejos de garantizar en la práctica estos derechos y de que han surgido varias tentativas de modificarla y reducir las tierras ya demarcadas, el capítulo dedicado a los indios, reconociendo la autenticidad de su cultura y sus derechos sobre las tierras que ocupan, fue fruto "de un fuerte movimiento de los líderes indígenas y de sus organizaciones, además de diferentes ONGs, entidades científicas, iglesias, etc." (Santos, 1995:104).

\section{ORGANIZACIÓN DE LOS SERVICIOS DE SALUD}

Después de la aprobación de la Constitución Federal, el movimiento indígena nacional se fragmentó temporalmente, pero esto fue seguido por la formación de asociaciones indígenas más locales, que en la actualidad representan grupos importantes en la expresión política de identidad étnica. En 1995, setenta y una organizaciones indígenas fueron registradas en notarías públicas (Ricardo, 1995:52-53), todas formadas en las dos últimas décadas. Varios grupos indígenas "emergentes" surgieron también del anonimato en los últimos años, no porque hayan estado aislados y hayan sido descubiertos recientemente, sino porque sólo ahora resolvieron salir de su invisibilidad y manifestar su identidad, reclamando sus derechos en una sociedad que tradicionalmente discrimina al indio.

La Constitución de 1988 formó parte de la redemocrartización del país. En esta misma década hubo una reforma del sistema de salud, implantándose el Sistema Único de Salud, que otorgó más responsabilidad y poder a las municipalidades. Frente a esta reforma, en 1986 se realizó la Primera Conferencia Nacional de Protección a la Salud del Indio, que tenía como objetivo evaluar la situación de salud de los indios y crear una política efectiva para las poblaciones indígenas frente a la municipalización de la salud.

Hasta esta Primera Conferencia no existía una política sobre salud indígena y nunca llegaron a establecerse servicios de atención a la salud del indio realmente adecuados. Antes de la creación del Servicio de Protección a los Indios (SPI) hubo una atención ocasional a la salud por parte de los misioneros, y fue a partir de 1910, con la creación del SPI, que se inició una intervención más acentuada del Estado de un modo general. Uno de los objetivos del SPI era precisamente el de atender los problemas de salud indígena.

Muchos grupos indígenas fueron salvados del exterminio total gracias a ese servicio. Sin embargo, la "pacificación de las tribus hostiles ocasionó la diseminación del hambre, de las enfermedades y de la desintegración, convirtiendo a los indios en parte del grupo más miserable de los segmentos marginales de la sociedad" (Costa, 1989:68). Los servicios de salud del SPI fueron esporádicos y desorganizados. No se conservaron datos sistemáticos sobre las condiciones de salud, y en muchos casos ni siquiera se levantaron. El Servicio Nacional de Tuberculosis (SN'T) atendió, en parte, la salud indígena durante la época del SPI y en 1956 el Servicio de Unidades Sanitarias Aéreas (SUSA) se unió al SNT para atender a las poblaciones indígenas aisladas. No obstante, los indios menos aislados, con mayor contacto con la sociedad nacional, no fueron atendidos por esos servicios.

2 Las tasas de SIDA en el mundo son más altas entre los pobres y el tercer mundo. Según Connors y McGrath (1997), 95\% de los casos de SIDA se encuentran entre los pobres, los marginados, los discriminados y los del tercer mundo, factores que caracterizan a la mayor parte de los pueblos indígenas. 
Con su creación, en 1967, la Fundación Nacional del Indio (FunAI) estableció sectores orientados a atender específicamente los problemas de salud existentes entre los indios. Lamentablemente, el funcionamiento de estos servicios, sea por falta de recursos o por falta de una preparación adecuada de sus funcionarios, terminó siendo inadecuado. La FunAi estableció puestos de salud dentro de las áreas indígenas, a fin de atender las necesidades de salud primaria; tal atención fue reforzada por un equipo itinerante de médicos que visitaban las áreas con poca frecuencia.

En teoría, el 90\% de los problemas de salud debían ser resueltos en el propio Puesto Indígena. Los casos más difíciles, que precisaran diagnósticos o tratamientos sofisticados, debían ser remitidos a los hospitales locales o a los servicios del Ministerio de la Salud, con quien la FunaI mantenía convenios (INAmPs rural, Secretarías de Salud de los estados, Funrural, Sucam e Inam). Finalmente, los casos más serios debían ser dirigidos a las Casas del Indio en el Centro Regional.

Este sistema, sin embargo, no fue satisfactorio, efectivo ni adecuado, por la poca preparación de los servicios, lo que se tradujo en una atención desorganizada e ineficaz. En la mayoría de los casos, los profesionales de la salud en el ámbito local no fueron adiestrados adecuadamente (Costa, 1989).

Así, en la época de la Primera Conferencia Nacional de Protección a la Salud del Indio la situación de atención al indio se caracterizaba por la ausencia de una red eficiente de asistencia, de una infraestructura adecuada en las áreas y de profesionales preparados para trabajar con la especificidad cultural de los pueblos indígenas; tampoco existían datos sobre la situación epidemiológica de los grupos y ninguna institución se encargaba de centralizar las informaciones sobre salud indígena. Peor aún, la Funal, llena de problemas e incapaz de atender las necesidades de salud de los indígenas, pretendía abandonar los problemas relativos a la educación y la salud de los indios con el fin de atender exclusivamente la demarcación de tierras. ${ }^{3}$
Los participantes de la primera conferencia fueron indios representantes de las asociaciones indígenas, funcionarios de la FunAI y del Ministerio de la Salud, antropólogos, médicos y miembros de las organizaciones no gubernamentales que trabajaban junto a las comunidades indígenas. De la conferencia resultaron dos principios generales: a) la necesidad urgente de la implantación de un subsistema específico, con la creación de una agencia para ese fin, vinculado al gestor del SUS, que garantizara al indio el derecho universal a la salud; b) el respeto a las especificidades culturales y prácticas tradicionales de cada grupo, recomendando el acompañamiento de antropólogos en los programas de salud y la participación de las comunidades en la planificación de los servicios. Estos principios fueron incorporados por la Asamblea Nacional Constituyente en 1988, que creó el Sistema Único de Salud, y garantizó a los pueblos indígenas el derecho a la atención integral y diferenciada con relación a la salud.

\section{A) Modelo de ATENCIÓN DiferenCiAdA}

La garantía en la Constituyente del derecho indígena a la atención integral y diferenciada de la salud, se justifica por la vulnerabilidad de los indios en términos de su situación de salud y de su especificidad étnica. Con su pacificación, grupos enteros fueron exterminados o casi exterminados como consecuencia del contacto con las enfermedades europeas.

Las enfermedades siempre representaron el primer factor de disminución de las poblaciones indígenas. La historia de nuestras relaciones con los indios es, en gran parte, una crónica de matanzas y sobre todo, de epidemias (Ribeiro, 1982:208).

Factores como la marginación, la pérdida del territorio, los cambios ambientales, las consecuentes pérdidas de las técnicas tradicionales de subsistencia y la explotación por parte de la sociedad dominante, contribuyen a una situación de salud muy precaria.

3 Comunicación oral de Marcos Antonio Guimarães, jefe, para el momento, del Sector de Salud de FUNAI en el Simposio sobre Salud Indígena del Indio y el Sistema Unico de Salud, 26-27 de octubre de 1989, Río de Janeiro. 
Sus condiciones sanitarias en general no son satisfactorias. Entre otros problemas se destacan: el predominio de enfermedades endémicas, como la tuberculosis, la malaria, la parasitosis y los frecuentes ataques epidémicos provocados por virus; también puede encontrarse una alta tasa de enfermedades por carencias, siendo que en algunos de ellos hay un alto grado de desnutrición; daños psíquicos que originan una alta incidencia del alcoholismo; salud bucal precaria; malas condiciones de saneamiento básico... (Miranda et al., 1988:25).

Catorce años después de la Primera Conferencia y de la legislación subsecuente, en la práctica los servicios de salud están lejos de solucionar la situación general de la salud indígena. Los decretos 23 de 1991 y 1141 de 1994, que tienen como objetivo delegar las responsabilidades institucionales para la organización de los servicios de salud del indio, no lograron establecer un modelo de atención adecuado para resolver los problemas agudos. Así, la salud del indio continua siendo pésima. Su vulnerabilidad frente al HIV/sIDA evidencia las condiciones de pobreza, discriminación, dominación y mala salud que continúan padeciendo en la actualidad.

El fracaso en atender las necesidades de salud se debe, en gran parte, a los problemas de desarrollo de los servicios adecuados, que son diferenciados y al mismo tiempo forman parte del SUS. Las soluciones propuestas por los decretos sobre salud indígena de 1991 y 1993 se tradujeron en profundos problemas referentes a la creación, administración, financiamiento y ejecución de los servicios de salud. Estos problemas se resumen, principalmente, en una estructura burocrático/administrativa demasiado confusa y complicada, caracterizada por la falta de definición de competencias y responsabilidades en la creación de proyectos y servicios, y por los conflictos de intereses entre las instituciones involucradas.

La Segunda Conferencia de Salud Indígena fue realizada en 1993 para debatir este problema de la organización de los servicios. A pesar de que las conclusiones de la Conferencia nunca han sido publicadas, su recomendación para la creación de Distritos Sanitarios Especiales Indígenas, como base del modelo asistencial para garantizar una atención particularizada, ya comenzó a ser discutida. Un principio fundamental en el establecimiento y funcionamiento del Distrito Sanitario es la participación de la comunidad en las actividades y prioridades establecidas (Mendes, 1995).

Un elemento nuevo en la política y en las actividades relacionadas con la salud indígena fue la creación del Programa Nacional de ETS/sIDA, fundado en 1995 con recursos internacionales. En 1996 el programa centró su atención en las poblaciones indígenas, consideradas como poblaciones vulnerables frente a ETS/SIDA.

Este programa, independiente de otras entidades nacionales encargadas de la salud indígena (FUNAI, FNS), realizó un ciclo de conferencias y financió proyectos en todos los estados para el adiestramiento de multiplicadores en las comunidades indígenas. Ahora, en su segunda fase, el programa está financiando proyectos relacionados con el problema del alcoholismo en las comunidades indígenas. Por haber dedicado mayores recursos financieros para la salud indígena que la FunaI o la FNS, este programa ha promovido una gran parte de las actividades relacionadas con esta área en los últimos años. No obstante, sus actividades dependen de la organización de los servicios de salud indígena existentes, dificultando su éxito.

A partir de marzo de 1998, la Comisión de Salud Indígena (COSAI), vinculada al Ministerio de la Salud, inició la implantación de Distritos Sanitarios Indígenas a través de la realización de conferencias regionales y estatales para informar a los profesionales de la salud y a las comunidades sobre la organización de estos distritos. En este momento, sería prematuro evaluar esta nueva fase en la organización de la salud indígena y prever si la formación de distritos sanitarios va a resolver los problemas que tanto han perjudicado la implantación de los servicios de salud para los pueblos indígenas.

Entre los problemas más crónicos podemos citar la falta de recursos financieros adecuados, de planificación y de definición clara de las competencias de las instituciones encargadas de los servicios de salud (Fundación Nacional de Salud, Funat, Departamentos Municipales y Estatales de Salud y organizaciones no gubernamentales); la ausencia de 
un sistema de recolección y registro de datos epidemiológicos; unos procedimientos demasiado burocratizados para reaccionar a los problemas urgentes e irrupciones de enfermedades epidémicas; la necesidad de garantizar la participación de las comunidades en la planificación de los servicios de salud y la pésima situación sanitaria de las comunidades indígenas. Hasta ahora el problema de control social, fundamental para el concepto de Distrito Sanitario, tampoco ha sido resuelto.

\section{B) RESPETO A LAS ESPECIFICIDADES CULTURALES Y}

\section{PRÁCTICAS TRADICIONALES}

Los principios de la Primera Conferencia y la legislación subsecuente no sólo exigen que la nación asegure la salud del indio, en el sentido de mejorarla y de garantizar el acceso a los servicios adecuados, sino también el respeto a su especificidad cultural y el reconocimiento de sus saberes. Esto último implica una comprensión profunda y un respeto auténtico a la vida indígena y a sus saberes.

Teóricamente no debe haber falta de respeto o conflicto entre los dos sistemas médicos, el de los indios y el de los profesionales de la salud. Como he argumentado anteriormente, los indios reconocen generalmente la eficacia de la biomedicina, y comúnmente hay una relación de complementariedad entre las dos medicinas en la búsqueda del tratamiento (Langdon, 1988, 1991; Langdon y MacLennan, 1979). No obstante, evaluando mi experiencia de varios años investigando y colaborando en actividades relacionadas con la salud del indígena, veo ciertos obstáculos de difícil resolución para que un verdadero respeto al saber indígena sea una realidad.

Me gustaría explorar aquí esos obstáculos que imposibilitan la realización plena del principio del respeto a los saberes indígenas, y las implicaciones para la práctica de los antropólogos en el área de cuidados de la salud entre poblaciones indígenas.

En el primer momento, el respeto a la especificidad cultural se refiere a considerar al indio como un ser humano igual, relativizando sus hábitos, costumbres y creencias y entendiendo que éstas provienen de una cultura diferente, con valores y conocimientos diferentes. Roberto Da Matta afirma que nuestra atención hacia las sociedades tribales debe estar fundamentada en el intercambio igualitario de experiencias humanas (1987:13). No obstante, muy pocas veces se evidencia el respeto mutuo en el día a día de los servicios de salud, los cuales se caracterizan normalmente por la fuerte presencia de relaciones jerarquizadas y por la ignorancia.

Es frecuente escuchar a los profesionales de la salud manifestando prejuicios comunes contra los indios, caracterizándolos o condenándolos como personas sucias, ignorantes en lo referente a las nociones sobre salud y enfermedad, como pacientes desobedientes, con mucha resistencia a las indicaciones del tratamiento e, incluso, incapaces de comprenderlas. En general, las intervenciones en el área de la salud son realizadas sin el debido respeto al conocimiento de la cultura del grupo, y de esta forma, los profesionales expresan actitudes etnocéntricas y realizan sus prácticas sin reconocer cómo la especificidad cultural del grupo puede influir en el buen desempeño de su trabajo.

De esta manera, es importante que la formación de los profesionales que trabajan con la salud indígena dedique suficiente tiempo a la comprensión en profundidad del concepto antropológico de relativismo y también al concepto de cultura. El profesional de la salud debe estar familiarizado con la naturaleza del sistema indígena de salud y con la idea de que sus prácticas forman parte de su cultura, entendida como un sistema simbólico compuesto de valores, representaciones y significados interrelacionados. Se hace necesario señalar que los indios también han desarrollado conocimientos y saberes sobre salud, y como en el caso de nuestra biomedicina, estos saberes componen su sistema de salud, definiendo qué es enfermedad y qué es salud, qué causa las enfermedades y qué las cura, y qué significa curación.

Las respuestas culturales para estos conceptos de salud y enfermedad son diferentes de los que tiene la biomedicina y se traducen en nociones, valores y expectativas diferentes según la etnia de que se trate. El primer paso para realizar los principios de una legislación sobre salud indígena es el reconocimiento de que estas diferencias son legítimas y forman parte de un sistema cultural de salud, y de que no se trata, 
en ningún caso, de supersticiones o de fragmentos de un pensamiento menos evolucionado.

Un segundo paso, el más difícil de realizar, según creo, es el de la relativización de los saberes; más aún, relativizar nuestra medicina. La biomedicina, término que usamos para designar nuestra medicina, debe ser vista también como un sistema cultural y no como la única ciencia, la ciencia de la verdad. La biomedicina es un sistema de conocimiento basado en la observación empírica que ha logrado desarrollar terapias altamente técnicas y eficaces frente a ciertos estados biológicos. Su enfoque principal, en el sentido estricto, es el de la biología humana, la fisiología o la fisiopatología, que ven la enfermedad como un proceso biológico universal y cuya concepción del cuerpo es básicamente mecánica y cartesiana.

Pese a que resulta imposible hablar de una medicina indígena, en general los sistemas indígenas de salud son más holistas y pueden ser caracterizados como sistemas chamánicos, en los cuales la enfermedad y la salud forman parte de un sistema cosmológico, y los factores físicos, sociales y espirituales interactúan en el proceso de salud/ enfermedad y curación. Esto se traduce en un sistema de salud basado en principios epistemológicos muy diferentes a los de la biomedicina. Ambos sistemas conocen el mundo y construyen sus saberes con ópticas diferentes acerca de lo que es verdadero e indiscutible.

Es peligroso caracterizar ambos sistemas de medicina como opuestos. Bajo ningún concepto intento reforzar las viejas ideas que plantean que la medicina indígena es básicamente mágica. ${ }^{4} \mathrm{~A}$ mi juicio, caracterizar la medicina indígena como mágica es un error etnocéntrico que formó parte de la historia de la antropología durante muchos años. En la práctica, los indios siguen un proceso terapéutico no muy distinto del nuestro.

Al principio de una enfermedad buscan identificar los síntomas, hacen un diagnóstico temporal que orienta la elección de la terapia y luego evalúan el éxito del tratamiento escogido (Langdon, 1994). Esto es, fundamentan sus primeras observaciones y evaluaciones en los cambios de los síntomas. Con tales fines han desarrollado una ciencia de fitoterapia y técnicas de parto, cirugía y otras que son análogas a las técnicas de la biomedicina, cuya eficacia puede ser reconocida por nuestra medicina. Muchas de estas técnicas han sido - o pueden serincorporadas a los servicios de salud.

No obstante, el sistema indígena tiene una noción de curación más amplia que la biomedicina. Mientras esta última define la curación como ausencia de síntomas de enfermedad, para los sistemas indígenas la curación se aproxima más al concepto inglés de "heal", de origen griego, que significa totalidad. Así, "heal" para los sistemas indígenas significa restauración del bienestar, y en los casos de enfermedades graves que amenazan la vida, este bienestar requiere la restauración de las relaciones amenazadas por la enfermedad y no sólo la ausencia de esta última.

La búsqueda del tratamiento chamánico está guiada por la necesidad de descubrir la causa última de la enfermedad y explicar su significado (Buchillet, 1991; Langdon, 1991; Evans-Pritchard, 1978). Por ello, ambas medicinas pueden ser vistas como complementarias - la búsqueda de la biomedicina, por su eficacia técnica en los procesos biológicos del cuerpo, y la de la medicina indígena para dar una explicación acerca del porqué de la enfermedad. El acto de relativizar, en este caso, requiere que el profesional de la salud reconozca la presencia, la legitimidad y la necesidad de los especialistas indígenas de salud, particularmente de los chamanes, cuyas prácticas terapéuticas no tienen analogías con las de nuestra medicina. Estos buscan fuera del cuerpo biológico para entender y curar la enfermedad.

Pero, subyacente al problema del respeto a los saberes indígenas, hay todavía problemas que deben ser resueltos y cuya solución no es fácil. Toda intervención médica implica un cambio de comportamiento — sea el uso de remedios o los esfuerzos de cambiar los hábitos que bajo la óptica de la biomedicina contribuyen a la mala salud. Así, una tarea común de los antropólogos vinculados a

4 Para algunas discusiones sobre chamanismo, véase Buchillet, 1990; Langdon, 1996; Lobo-Guerrero, 1991; Reichel-Dolmatoff, 1983; Hildebrand, 1983. 
proyectos en el área de la salud es la de evaluar las prácticas nativas a la luz de sus consecuencias para la salud, identificando las que son dañinas, neutras o beneficiosas (Foster \& Anderson, 1978), con la idea de que las dañinas deben ser eliminadas, permitiendo sólo las que no causan daños.

Es necesario enfatizar que en tales casos el antropólogo está realizando una tarea subordinada, "colocándose al servicio de las concepciones hegemónicas de la medicina legitimada" (Minayo, 1991:234). En éste, la biomedicina mantiene la posición de paradigma universal y único sobre el problema de la salud. Estamos juzgando la eficacia de la medicina indígena según nuestra comprensión de la salud, según nuestra cultura. Sin desvalorizar la alta tecnología de la biomedicina y su éxito en el tratamiento de ciertas enfermedades y síntomas físicos, la posición de la biomedicina como la única medida eficaz es, a final de cuentas, una actitud etnocéntrica. Esto es particularmente cierto si ignoramos todas las investigaciones que demuestran la eficacia de la cura ritual.

Digo etnocéntrica porque hay tres conceptos clave que marcan la diferencia entre la biomedicina y la medicina indígena, y éstos necesitan ser reconocidos por la biomedicina para que relativice su propio saber frente a los saberes indígenas. Estas nociones son: la curación, la eficacia y la realidad biológica de la enfermedad. Hace mucho que la antropología ha contribuido a la discusión sobre las causas psíquicas y socioculturales de las enfermedades (O’Nell \& Selby, 1978), así como a la discusión de la eficacia de los sistemas de curación (Frank, 1974; Csordas, 1983; Kiev, 1964; Lévi-Strauss, 1975; Turner, 1967).

En los últimos tiempos, con los nuevos descubrimientos en medicina, sobre todo en el campo de la neurobiología y neuroinmunología, es posible plantear un abordaje interdisciplinario que avance en el conocimiento de la enfermedad (Ornstein \& Sobel, 1987; Laughlin, McManus \& D’Aquili, 1990). Sería todavía mejor si fuese un abordaje intercultural en el que la medicina sea relativizada y los saberes de la medicina indígena fuesen tratados como ciencia para redefinir los conceptos de eficacia y curación.

Para que esto sea una realidad, los profesionales de la salud tienen que reconocer las limitaciones de su medicina, relativizándola y admitiendo que existen otros sistemas de medicina con saberes sobre salud, que por sus diferencias epistemológicas no sólo deben ser respetados sino también comprendidos como capaces de hacer una contribución al conocimiento.

\section{Pensamientos finales}

Este trabajo no pretende ser exhaustivo sobre las problemáticas de la salud de interés para los científicos sociales y profesionales de la salud. Debemos también pensar en otros temas, como las investigaciones sobre fitoterapia y sus implicaciones para la discusión sobre derechos de propiedad intelectual (Chaparro Beltrán, 1993; Terena, 1993); el papel del agente indígena de salud; la ética de la investigación biomédica en poblaciones indígenas; el impacto del neoliberalismo en los servicios públicos de salud, entre otros.

Para concluir, quiero volver a la discusión sobre etnicidad. Para pensar la situación de salud de los pueblos indígenas es necesario reconocer que los datos epidemiológicos, la organización y calidad de los servicios de salud y las relaciones entre los profesionales de la salud y las comunidades indígenas están, en gran parte, determinados por el contexto de las relaciones interétnicas.

Este contexto interétnico se caracteriza por relaciones jerarquizadas en dos sentidos. En el primero de ellos tenemos la relación de jerarquía que caracteriza las relaciones interétnicas en general, la posición del indio frente al blanco en la sociedad. El segundo sentido se refiere a la jerarquía entre los saberes, en el cual la cultura de la biomedicina se coloca como hegemónica y superior a los otros saberes, dificultando la plena realización del principio de respeto a los saberes y prácticas indígenas.

\section{REFERENCIAS BIBLIOGRÁFICAS}

Bonfil, G., 1966. Conservative thought in applied anthropology: a critique. Human Organization, 25:89-22.

Brown, M., 1991. Beyond resistance: utopian renewal in Amazonia. Ethnobistory, 38 (4):388-413. 
Brown, M., 1993. Facing the State, facing the world: Amazonia's native leaders and the new politics of identity. LHomme: la remontée de l'Amarone (C. Lévi-Strauss et al., orgs.), XXXIII (126-128):307-326.

Buchillet, D. 1990. Los poderes del hablar. terapia y agresión chamánica entre los indios Desana del Vaupes brasilero. En: Las culturas latinoamericanas a través de sus discursos, pp. 319 354. Quito: Abya-Yala.

Buchillet, D., 1991. A antropologia da doença e os sistemas oficiais de saúde. En: Medicinas tradicionais e medicina ocidental na Amazônia (D) Buchillet, org.), pp. 21-44. Belém: MpEG/ CEJup/UEP.

Castrillón Arboleda, D., 1973. El indio Quintín Lame. Bogotá: Ediciones Tercer Mundo.

Chaparro Beltrán, F., 1993. Las riquezas naturales de la Amazonia y la propiedad intelectual. En: Memorias del I Simposio Salud y Población Indigena de la Amazonia (E. Estrella y A. Crespo, orgs.), Vol. II, pp.245-260. Quito: Impretec.

Connors, M.M. \& McGrath, J.W., 1997. The known, unknown and unknownable in AIDS research in anthropology. Anthropology Newsletter, 38(3):1-5.

Costa, D.C., 1989. Política indigenista e assistência à saúde. Ciência Hoje, 10 (55):68-73.

Csordas, T., 1983. The rhetoric of transformation in ritual healing. Culture, Medicine and Psycbiatry, 7:333-375.

Da Matta, R., 1987. Relativizando: uma introdução à antropologia social. Río de Janeiro: Rocco.

Evans-Pritchard, E.E. 1978 [1937]. Bruxaria, oraculos e magia entre os Aqande. Río de Janeiro: Zahar Editora.

Foster, G. \& Anderson, B., 1978. Medical Anthropology. Nueva York: Wiley.

Frank, J., 1974. Persuasion and Healing. Nueva York: Schocken Books.

Guss, D., 1994. Re-imaginando la comunidad imaginada: la política de la diversidad cultural en América Latina y el Caribe. En: Teoría y politica de la construcción de identidades y diferencias en América Latina y el Caribe (D. Mato, ed.). Caracas: Editorial Nueva Sociedad.

Hildebrand, M. (von), 1983. Cosmovision y el concepto de enfermedad entre los Ufaina. En: Medicina, shamanismo y botánica (FunCOL, orgs.), pp. 48-63. Bogotá: Funcol.

Jackson, J., 1995a. Culture, genuine and spurious: the politics of indianness in the Vaupes, Colombia. American Ethnologist, 22 (1):3-27.

Jackson, J., 1995b. Preserving indian culture: shaman schools and ethno-education in the Vaupes, Colombia. Cultural Antbropology, 10:3.

Kiev, A., 1964. Magic, faith and bealing. Nueva York: The Free Press.

Langdon, E.J. \& MacLennan, M.D., 1979. Western biomedical and Sibundoy diagnosis: an interdisciplinary comparison. Social Science and Medicine, 13B:211-220.

Langdon, E.J. (org.), 1996. Xamanismo no Brasil: novas perspectivas. Frorianópolis, SC: UFSC.

Langdon, E.J., 1988. Saúde indígena: a lógica do processo de tratamento. Revista de Saúde em Debate, número especial:12-15.

Langdon, E.J., 1991. Percepção e utilização da medicina ocidental dos índios Sibundoy e Siona no sul da Colômbia. En: Medicina tradicional e medicina ocidental na Amazônia (D. Buchillet, org.). Belem: Museu Goeldi.

Langdon, E.J., 1994. Representações de doença e itinerário terapêutico entre os Siona da Amazônia colombiana. En: Saúde e povos indigenas (R.V. Santos \& Carlos Coimbra, orgs.), pp. 115-142. Río de Janeiro: Editora Fiocruz.

Laughlin, Jr. C.D.; McManus, J.; D'Aquili, E.E.G., 1990. Brain, symbol and experience. Boston: Shambhala, New Science Library.

Lévi-Strauss, C., 1975. A eficácia simbólica. Antropologia Structural I. Río de Janeiro: Tempo Brasileiro.

Lobo-Guerrero, M., 1991. Incorporación del shamán indígena en los programas de salud: reflexiones sobre algunas experiencias en 
Colombia. En: Medicinas tradicionais e medicina ocidental na Amarônia (D. Buchillet, org.), pp. 267-279. Belem: CejuP.

Luz, L., 1995. Convenção 169 da OIT -um instrumento de defesa dos direitos indígenas. En: A temática indígena na escola (A. Lopes da Silva A., org.), pp. 102-104. Brasilia: MEC/MARI/Unesco.

Mendes, E.V. (org.), 1995. Distrito sanitário: o processo social de mudanca das práticas sanitárias do Sistema Único de Saúde. Río de Janeiro: Hucitec/Abrasco.

Minayo, M.C. (de S.), 1991. Abordagem antropológica para avaliaçao de políticas sociais. Cadernos de Saúde Pública, 25(3):233238.

Miranda, J.A. (N. de); Hautequestt (de), A.F. \& Costa, D.C., 1988. A tuberculose no índio. Saúde em Debate, enero: 24-25.

O’Nell, C. \& Selby, H.A., 1978. Sex differences in the incidence of susto in two Zapotec pueblos: an analysis of the relationships between sex role expectations and a folk illness. En: Health and the buman condition (M. Logan \& Hunt, org.). Massachusetts: Duxbury Press.

Orellana Aillón, L., 1998. La "Masacre de Navidad". Un fragmento de la violencia estatal y resistencia popular en Bolivia. Nueva Sociedad, 153:104-119.

Ornstein, R. \& Sobel, D., 1987. The healing brain. Nueva York: Simon \& Schuster.

Reichel-Dolmatoff, R., 1983. Conceptos indígenas de enfermedad y de equilibrio ecológico: los Tukano y los Kogi de Colombia. En: Medicina, shamanismo y botánica (FUNCOL, orgs.), pp. 19-27. Bogotá: FunCOL.

Ribeiro, D. 1982. Os indios e a civilização. Río de Janeiro: Vozes.

Ricardo, C.A., 1995. "Os índios" e a socio diversidade nativa contemporânea no Brasil. En: $A$ temática indígena na escola (A.L. da Silva \& L.D.B. Grupioni, orgs.), pp. 29-60. Brasilia: MEC/ UNESCO.

Santos, S.C. (dos), 1995. Os direitos dos indígenas.
En: A temática indigena na escola (A.L. da Silva \& L.D.B. Grupioni, orgs.), pp. 87-105. Brasilia: MEC/ UnEsCO.

Terena, J., 1993. Derechos de propiedad intelectual y su aplicación para las comunidades indígenas. En: Memorias del I Simposio Saludy Población Indígena de la Amazonia (E. Estrella y A. Crespo, orgs.), Vol. II, pp. 261-268. Quito: Impretec.

Turner, T., 1991. Da cosmologia à história: resistência, adaptação e consciência social entre os Kayapó. Cadernos do Campo, 1:68-83.

Turner, V., 1967. The forest of symbols. Ithaca, N.Y.: Cornell University Press.

Unesco, 1997. Princípios sobre a Tolerância. Sao Paulo: USO/FLlCh.

Traducción a español: antropólogo Júlio de Freitas Taylor Colaboración: Laura Pérez Gil 
III

ESPACIO, AMBIENTE Y SALUD 


\section{Desigualdades ESPACIALES DEL BIENESTAR Y LA SALUD EN AMÉRICA LATINA. PROBLEMAS ÉTICOS Y METODOLÓGICOS}

Luisa Iñiguer Rojas*

Muy probablemente, la preocupación más general de los seres humanos es por su bienestar, acrecentada por las urgencias del mundo actual. El tema del bienestar es uno de los menos investigados explícitamente, mientras conceptos y formas para su medición, relativamente más recientes, como calidad de la vida, calidad del medio ambiente, necesidades básicas insatisfechas, línea de pobreza o desarrollo humano, atraen progresivamente la atención de un número cada vez mayor de profesionales e instituciones.

Al margen de su contenido relativo o temporal y de su dudosa dualidad objetivo-subjetiva, el bienestar se limita hoy para algunos grupos poblacionales a la satisfacción de las necesidades más elementales de subsistencia, mientras para otros representa la satisfacción de las necesidades y aspiraciones más elevadas de autorrealización (Iñiguez, 1992:2) y en todas las naciones, incluyendo las más ricas, se han generado notables variaciones espaciales del bienestar humano.

Surgidas inicialmente de la distribución desigual de condiciones y recursos naturales, de las pugnas para poseerlos o del desconocimiento u olvido de las "necesidades de la naturaleza", no quedan ya dudas de que las más importantes desigualdades del bienestar y la salud en el mundo son, más que resultado de relaciones disarmónicas entre los hombres y la naturaleza, expresión del deterioro progresivo de las relaciones entre los hombres; reales inequidades sociales.

La América Latina es un concepto geográfico cultural, propuesto con objetivos de integrar los estados americanos influenciados por España, Portugal y Francia, generalizado a partir de 1856 (Núñez, 1980:20). La denominación de América Latina y el Caribe se ha hecho frecuente, incluyendo las Antillas no latinas. En una naturaleza extraordinariamente diversa, con un elevado potencial de recursos naturales, han sido construidas sociedades profundamente desiguales e inequitativas, en procesos que se agudizan a fines de siglo.

El presente trabajo examina el significado teórico-metodológico del espacio-territorio en la aprehensión o medición de las desigualdades espaciales del bienestar y la salud en Latinoamérica y el Caribe. Se aproxima a los procesos naturales y humanos que diferencian internamente la región, como marco de discusión del significado de la unidad y escala territorial de medición de las desigualdades, tomando como eje inicial las divisiones espaciales construidas socialmente sobre condiciones naturales - biofísico-ambientales y las divisiones territoriales, como límites políticoadministrativos de poder.

Mediante la selección de indicadores sociales básicos, evidencia las diferentes formas de "conocer" según la heterogeneidad intra e interterritorial, incluyendo las fuentes de limitaciones de los sistemas de información sanitaria, que comúnmente no rebasan los atributos individuales de los "casos" o son tan incompletos cuanto sean los recursos humanos e infraestructurales del sector salud.

Trata por tanto de repensar y privilegiar el dónde, como problema metodológico y ético. 


\section{LA DIVERSIDAD NATURAL Y LAS DIVISIONES}

\section{IMPUESTAS POR LA NATURALEZA}

El determinismo geográfico, y más recientemente el determinismo ambiental, aún se esgrimen como esenciales fuentes de las desigualdades territoriales, económicas y sociales. Si bien es cierto que la diversidad natural, en términos cuantitativos y cualitativos de sus recursos, impone ciertos límites y restricciones para que los procesos productivos ocurran, las legítimas causas de las desigualdades económicas y sociales están sobre todo explicadas por la propia esencia del sistema capitalista.

La heterogeneidad intra $e$ inter Estados fue objetivamente construida, sirviendo de fundamento para las posteriores e inestables estratificaciones en territorios atrasados o adelantados —o más actualmente, zonas luminosas, con alto contenido de ciencia tecnología e información; o zonas opacas, con escasa o nula incorporación de estos elementos-, que imponen desigualdades de nuevo tipo, por sus efectos sobre los procesos productivos y sociales. Desigualdades de nuevo tipo, por sus efectos sobre los procesos productivos y sociales - la geografía de desigualdades (Santos 1997:57).

Una primera división del territorio latinoamericano, de acuerdo a los rasgos más generales de la evolución paleogeográfica, reconoce cuatro grandes unidades estructurales: México, Centroamérica, Sudamérica y los arcos de islas del Caribe. Con la más amplia distribución latitudinal de tierras del mundo, de 30 grados norte a 55 grados sur aproximadamente, se distinguen amplias diferencias de relieve y de redes hidrográficas, donde destacan las unidades ecogeográficas de la Cuenca del Amazonas, la más extensa del mundo, y de la Cordillera de los Andes, la cadena montañosa más larga del planeta.

Es otra división particular de América Latina aquella que distingue del resto de su territorio las áreas geográfic̀as donde formas de equilibrio endogenético o exogenético de la naturaleza provocan históricamente desastres sociales y humanos, exclusivamente denominados "desastres naturales", que degradan en proporciones trágicas el bienestar y la salud de la población hasta la actualidad.
A las erupciones volcánicas y sismos de variada intensidad y frecuencia se integran períodos de lluvias extremas por el paso de ciclones tropicales u otras situaciones meteorológicas, en contraste con intensas y prolongadas sequías. El Istmo Centroamericano, Caribe, oeste y nordeste de la América del Sur son las áreas geográficas donde estos procesos se manifiestan de forma más regular, y exponentes tradicionales de la pobreza latinoamericana.

Los yacimientos minerales, metálicos y no metálicos, los grandes potenciales hidrológicos e hidrotécnicos, la elevada biodiversidad y los variados recursos turísticos, entre otros, tienen una distribución resultante de la historia paleogeográfica, que diferencian internamente la región según el potencial de recursos naturales, sus condiciones de explotación y protección. La división de América Latina, considerando su diversidad de componentes biofísico ambientales, aportaría un mosaico de oportunidades de desarrollo que sería diferente en cuanto a los diferentes tipos de recursos, pero no necesariamente desigual en el ritmo y nivel de desarrollo de los territorios. Esto es lo que Bret llama igualdad dentro de la diferencia (Bret, 1997:208).

\section{FRAGMENTACIÓN DEL TERRITORIO Y HETEROGENEIDAD}

\section{TERRITORIAL}

La superposición de límites creados por la división político-administrativa del planeta, sobre un espacio natural diversificado, creó compartimentos muy desiguales, de forma que la fragmentación de los territorios condicionaba en primera instancia la desigualdad espacial de componentes de las condiciones de vida, el bienestar y la salud de los hombres. En los casos en que la conducción política y las dimensiones lo permitieron, las fragmentaciones procuraron la diversidad natural intraterritorial como factor inductor del desarrollo económico. El trazado de fronteras políticas condujo a la siguiente paradoja: colocada como garantía de igualdad jurídica entre los Estados, la soberanía sobre los recursos naturales aumentaba la desigualdad económica entre los hombres (Bret, 1997:208).

En cierta complicidad con las condiciones y recursos naturales y permanentes incomprensiones y 
conflictos, las divisiones territoriales iniciadas hace algo más de 30 mil años fueron construidas y sobrepuestas en nuestra región, con la relativa estabilización de sus primeros pobladores llegados por el estrecho de Bering, por el Pacífico, desde África o cualquier otra de las rutas discutidas (PNuma, Aeci \& Mopu, 1990).

A mediados del siglo $\mathrm{XV}$, los europeos encuentran a estos pueblos organizados en dos imperios, a su vez fragmentados en provincias, con una desigual distribución de la población y la mayor densidad en los centros imperiales en altas montañas, reconociendo las ventajas productivas y la capacidad de protegerse, incluso de epidemias. La población se ha estimado entre los 50 a 100 millones de hombres en el momento del encuentro con los pueblos europeos, o sea superior o similar a la de Europa de entonces. La variación de las densidades de población entre 1 a 14 $\mathrm{km}^{2}$ y el uso del suelo, demuestran el impacto localizado de la ocupación humana en este período.

La consolidación de estos imperios, como en otros, estuvo marcada por intensos desajustes ambientales, formas de organización y funcionamiento social de confrontación y sojuzgamiento, pero también con relaciones armoniosas entre algunos grupos y de éstos con la naturaleza de manera focal.

Las ventajas numéricas o de conocimiento del "teatro de operaciones" fueron factores irrelevantes en la rápida aniquilación de estos imperios y el establecimiento de los rotundos procesos de conquista y colonización. Varios elementos concurren en la explicación de tan sorprendentes hechos, entre ellos se citan las pugnas internas entre los indígenas, factores morales, las crisis sanitarias desencadenadas (PNUMA, Aeci \& Mopu, 1990:65) y hasta el inconsciente de estos grupos, como cómplice de la dominación (Acanda, 1997:4). El resultado más conmovedor fue el colapso demográfico resultante de los procesos de conquista-colonización.

La Independencia, 300 años más tarde, daba paso a una nueva división territorial que, consolidada a fines del siglo XIX, fragmentaba a América Latina en dieciocho naciones, desiguales en dimensiones y cantidad de población. Guerras civiles y conflictos fronterizos caracterizaron entonces la etapa de implantación del capitalismo en este Nuevo Mundo.
La simple contemplación del mapa de las Américas demuestra la compactación de Norteamérica, en contraposición a la intensa fragmentación de América Central y de América del Sur, a excepción de la América portuguesa, unida en un único Estado, el brasileño, venciendo la extensión y elevada diversidad natural y humana para permanecer casi milagrosamente como un solo país. Esta división permaneció prácticamente estable en el siglo xx a escala de países-Estados, aunque con fragmentaciones frecuentes en unidades políticas inferiores. La población fue ampliando su distribución en la región, con excepción de áreas relativamente reducidas, aquellas permanentemente heladas o de aridez extrema, observándose en la actualidad las más altas densidades en capitales y las más bajas en paisajes poco transformados donde operan regulaciones antropológicas, como en la Cuenca del Amazonas o en extensos latifundios con oleadas periódicas de emigrantes, asociadas frecuentemente a la ocurrencia de eventos naturales, tales como sequías, inundaciones y terremotos entre otros.

\section{LAS DESIGUALDADES TERRITORIALES Y}

\section{ESPACIALES DEL BIENESTAR Y LA SALUD EN}

\section{AmÉrica LATINA. UnA APROXIMACIÓN}

La diversidad natural y ambiental se conoce en las verdaderas unidades geográficas de su expresión, mientras los indicadores sociales y de salud se registran en unidades político-administrativas. Una observación poco usual de la distribución geográfica de la población latinoamericana obviando las divisiones entre países, permite apreciar en la actualidad la elevada concentración en capitales y regiones metropolitanas. La comparación de esta distribución con la reconstruida como hipótesis en el período precolonial demuestra la condicionalidad ejercida por la diversidad natural, principalmente en sus más extensos ecosistemas, las selvas amazónicas y la Cordillera Andina. La elevada concentración de la población de los grandes imperios se expande y sustituye por las más elevadas densidades de población en capitales y regiones metropolitanas de países sudamericanos, centroamericanos o en islas del Caribe. 
Los mayores contrastes en la cantidad de población entre los países de la región se observan en Brasil, con más de 165 millones de habitantes, y Panamá con 2 millones (OPS, 1998). Si incluyéramos al Caribe en este análisis, aparecería Anguila con 8 mil habitantes. Estas diferencias están reguladas tanto por la extensión superficial como por condiciones ecológicas extremas, en íntima relación con factores de la evolución histórica.

La observación general de indicadores de salud y bienestar en la región, tomando las informaciones del primer quinquenio de las décadas del cincuenta a la del noventa, evidencia la mejoría progresiva de indicadores, a excepción del empeoramiento en el 1990-95 del PNBpc y de la población en pobreza (tabla 1). ser muy específicos, como la división según su inserción en tratados, bloques económicos, potencialidades para la cooperación intra e interregional y otros. En ambos casos estas agregaciones permiten una primera aproximación a las desigualdades internas de la región.

Dada la posibilidad de hallar información referida a problemas de salud e indicadores demográficos y socioeconómicos en una misma fuente, adoptaremos convencionalmente la división frecuentemente utilizada por la Organización Panamericana de la Salud, que divide América Latina en siete "subregiones": México, Caribe latino, Istmo Centroamericano, Área Andina, Brasil y Cono Sur, incluyendo el Caribe no latino.

\section{América Latina y el Caribe. Indicadores seleccionados / Tabla 1}

\begin{tabular}{|lrrrrr|}
\hline Indicadores/año & $50 / 55$ & $60 / 65$ & $70 / 75$ & $80 / 85$ & $90 / 95$ \\
\hline Tasa bruta de mortalidad & 15,0 & 12,0 & 9,4 & 8,0 & 6,8 \\
Tasa de mortalidad infantil & 120 & 90 & 75 & 60 & 45 \\
Esperanza de vida al nacer & 51 & 57 & 62 & 66 & 69 \\
Médico por 10.000 hab. & - & 5,8 & $<7,0$ & $>11$ & $>15$ \\
PNB/hab. (USD 80) & 950 & 1200 & 1550 & 2160 & 1950 \\
Pobreza (\%) & 60 & 51 & 40 & 35 & 42 \\
Agua potable (\% de casas) & 41 & 49 & - & 65 & 75 \\
\hline
\end{tabular}

Fuente: Guerra de Macedo (1997).

Al respecto ha ido destacando el mejoramiento mantenido de indicadores en la última década, con diferencias entre países y entre grupos humanos de un mismo país (OPS, 1998). Los Estados de América Latina han sido convencionalmente agrupados por organismos e instituciones regionales $\mathrm{o}$ internacionales a partir de integraciones supranacionales, que tienen en cuenta criterios histórico-geográficos. Otras agrupaciones se han construido a partir de indicadores demográficos, económicos o socioculturales, con diversos objetivos, llegando a
Uno de los indicadores más empleados, el Producto Nacional Bruto per cápita (PNBpc), identifica para América Latina y el Caribe cinco estratos, que revelan la amplitud de las desigualdades internas en la región. Los vecinos Estados de Puerto Rico y Haití, en el Caribe latino, presentan los valores extremos de PNBpc, con 7 mil USD y 250 USD respectivamente. Incluyendo el Caribe no latino las brechas se ampliarían: Islas Caimán, también Estado vecino, registra un PNBpc de 26 mil USD. En el grupo I de países con más altos valores de este indicador sólo se 
encuentran islas del Caribe no latino, mientras en el grupo II, además de otras de las islas de este agregado, se localizan dos países del Cono Sur (Argentina y Uruguay) y uno del Caribe latino (Puerto Rico).

El resto de los países del Cono Sur se ubican en el grupo III (Chile) y IV (Paraguay), con aproximadamente 2500 USD de diferencia. Los valores extremos se sitúan en Argentina con 8030 USD y Paraguay con 1690 USD. De forma similar, Puerto Rico, en el Caribe latino, con 7 mil USD en el grupo II, se separa del resto de los países de su agregado, que se ubican en el IV grupo, con valores aproximados de 1500 USD. Los valores más bajos de este indicador se observan en el Área Andina. La mayoría de sus países se localizan en el IV grupo, con valores PNBpc entre 1000 y 2000 USD. Las excepciones son Venezuela y Bolivia, que marcan las más intensas desigualdades dentro de esta agregación, con 3020 USD (III) y 800 USD respectivamente. Los países del Istmo Centroamericano se fragmentan en dos agregados: Panamá y Costa Rica con PNBpc entre 2610 y 2750 USD, distanciados del resto, que se ubica en los grupos IV y V, donde Nicaragua alcanza el segundo valor más bajo del PNBpc entre los países de América Latina y el Caribe, con 380 USD.

A pesar de las excepciones comentadas, una relativa homogeneidad interna es apreciada en el interior de las subregiones consideradas. El PNBpc, al igual que otros indicadores económicos similares, tiene un valor aproximado y significados diferentes en el bienestar y la salud de las poblaciones, ya que están regulados tanto por los avances sociales que los respectivos Estados hayan conseguido en los diferentes períodos históricosociales, como por las condiciones para el mantenimiento de estos logros. Por ejemplo, la notable superioridad del PNBpc de Brasil en relación con Costa Rica contrasta con las ventajas de este último país en diferentes indicadores sociales, de escolaridad, salud o saneamiento básico.

Incorporando otro de los indicadores más usados para revelar las desigualdades del bienestar - la proporción de población en condiciones de pobreza (línea de pobreza)-, aparecen con los valores extremos Guatemala (con 75,2\%) y Uruguay (con 7\%). En el grupo de países andinos se aprecia una relación directa entre el PNBpc y la proporción de población en condiciones de pobreza (40-70\%), a excepción de Colombia, con un valor considerablemente inferior $(17,7 \%)$. En el Istmo Centroamericano se presenta la misma regularidad que la observada para el PNBpc; Panamá y Costa Rica se agregan con aproximadamente $30 \%$ de su población en situación de pobreza, distantes del resto, con valores de alrededor del 50\% hasta el 75\% valor más crítico entre el total de países latinoamericanos.

Informaciones demográficas destacan al Caribe y al Istmo Centroamericano con la menor proporción de población de la región, y mientras las tasas de crecimiento poblacional del Caribe son las más bajas, el Istmo Centroamericano exhibe las más altas de la región. Aquí destaca Honduras con el más elevado crecimiento medio $(2,8$ por 100 habitantes) y Haití con 2,0 por 100 habitantes en el período 1993-1998, reflejo de la conocida concordancia entre precariedad de condiciones de vida y elevado crecimiento.

El grado de urbanización en estas subregiones presenta proporciones similares y próximas a las de América Latina en su conjunto (74,8\%), a excepción de los países comprendidos en el Istmo Centroamericano, con la mayor ruralidad, seguida del Caribe latino y no latino, con $61,0 \%$ y $62,4 \%$ respectivamente. Destacan varias islas de las Antillas Menores y Haití con menos del 30\% de población urbana. Es el Cono Sur el más urbano $(84,8 \%$ ), alejándose Paraguay con $54,6 \%$.

La observación integrada de los indicadores según las divisiones consideradas destaca el Istmo Centroamericano y el Área Andina como los más próximos y desiguales al resto de las divisiones, y el Cono Sur, como el más distante, con la mayor urbanización, los más elevados valores de PNBpc y la menor proporción de población en situación de pobreza (tabla 2). 
VARIACIÓN DE INDICADORES SELECCIONADOS Según divisiones de América Latina y el CARibe / Tabla 2

\begin{tabular}{|c|c|c|c|c|c|}
\hline Grupo de países & $\begin{array}{l}\text { Pob. } 1998 \\
\text { (millones) }\end{array}$ & $\begin{array}{l}\text { Pob. urbana } \\
1998(\%)\end{array}$ & $\begin{array}{l}\text { Crec. anual } \\
(\%) \text { 1993-98 }\end{array}$ & $\begin{array}{l}\text { PNBpc } \\
\text { (USD) } 1996\end{array}$ & $\begin{array}{l}\mathrm{PP} \\
(\%) 1996\end{array}$ \\
\hline México & 95 & 74 & 1,7 & 3300 & 39 \\
\hline Istmo Centro. & 34 & $40-64(47)$ & $1,7-2,8(2,5)$ & $380-2750$ & $27-75$ \\
\hline Caribe latino & 30 & $33-77(62)$ & $0,5-2,0(1,3)$ & $590-7000$ & $28-65$ \\
\hline Caribe no latino & 7 & $0-100(61)$ & $0,0-4,2(1,0)$ & $590-26000$ & Ind* \\
\hline Área Andina & 105 & $61-87(74)$ & $1,3-2,4(1,9)$ & $800-3020$ & $18-70$ \\
\hline Brasil & 165 & $(80)$ & 1.3 & 3640 & 27 \\
\hline Cono Sur & 59 & $55-91(85)$ & $0,6-2,6(1,4)$ & $1690-8030$ & $7-25$ \\
\hline
\end{tabular}

Fuente: OPS (1998: Vol. 1).

* Información no disponible

Las desigualdades extremas entre los Estados que integran las subregiones consideradas se observan en el Caribe (latino y no latino), determinadas por las diferencias histórico-políticas de la evolución económica y social, tal vez condicionadas por las pequeñas dimensiones y relativamente baja cantidad de población de los países que lo integran. Todo ello permite la lectura más precisa del funcionamiento económico y sociocultural, según las influencias de países europeos o de Estados Unidos de América, mantengan o no la dependencia de ellos.
La diferenciación por subregiones de algunos de los indicadores presentados y otros seleccionados entre los problemas de salud de la región destacan el Área Andina y Brasil con las situaciones más desfavorables. De forma similar a lo anteriormente observado, los contrastes más agudos se observan en el Caribe. Costa Rica y Panamá se separan del Istmo Centroamericano, Paraguay del Cono Sur y Colombia y Venezuela del Área Andina, con tasas muy inferiores (tabla 3).

\section{AMÉRICA LATINA Y EL CARIBE.}

INDICADORES DE MORTALIDAD Y MORBILIDAD SELECCIONADOS / TABLA 3

\begin{tabular}{|c|c|c|c|c|c|c|c|c|}
\hline $\begin{array}{l}\text { Subre/ } \\
\text { Indicadores }\end{array}$ & $\begin{array}{c}\text { MI } \\
1997 \\
/ 1000 \mathrm{nv} \\
\end{array}$ & $\begin{array}{c}\text { Ev. años } \\
1997\end{array}$ & $\begin{array}{c}\text { Inc de TB } \\
(*)\end{array}$ & $\begin{array}{c}\text { Médicos/ } \\
10000 \text { hab } \\
1997\end{array}$ & $\begin{array}{l}\text { Mort. } \\
\text { C. ext. } \\
(* *)\end{array}$ & $\begin{array}{c}\text { Mort. } \\
\text { Acc. tránsito } \\
(* *)\end{array}$ & $\begin{array}{c}\text { Mort. } \\
\text { homicidio } \\
(* *)\end{array}$ & $\begin{array}{l}\text { Inc. } \\
\text { sida } \\
(* * *)\end{array}$ \\
\hline México & 23,4 & 75,6 & 22,2 & 18,64 & 67,3 & 16,8 & 19,5 & 44,2 \\
\hline $\begin{array}{l}\text { Caribe } \\
\text { latino }\end{array}$ & $7,9 / 74$ & $56,3 / 80,6$ & $5,9 / 91,4$ & $0,8 / 53,0$ & - & - & - & 24,9 \\
\hline $\begin{array}{l}\text { Caribe no } \\
\text { latino }\end{array}$ & $0 / 26$ & $68,1 / 80,4$ & $1,1 / 20,8$ & $4,9 / 19,7$ & 49,0 & 10,3 & 8,7 & 246,2 \\
\hline $\begin{array}{l}\text { Istmo } \\
\text { centro }\end{array}$ & $11,8 / 47$ & $70 / 79,3$ & $4,6 / 71,8$ & $8,3 / 16,7$ & 75,6 & 19,0 & 21,1 & 80,5 \\
\hline $\begin{array}{l}\text { Área } \\
\text { Andina }\end{array}$ & $22 / 59$ & $63,4 / 75,8$ & $54 / 174,2$ & $9,3 / 23,6$ & 106,1 & 21,4 & 51,9 & 29,0 \\
\hline Brasil & 39,8 & 71,3 & 54,2 & 12,7 & 86,4 & 26,8 & 30,1 & 100,2 \\
\hline Cono Sur & $13 / 20,9$ & $72,1 / 78,4$ & $21,9 / 43,3$ & $10,9 / 37,0$ & 59,2 & 15,0 & 6,2 & 46,7 \\
\hline
\end{tabular}

Fuente: OPS. 1998

(*) Tasa /100.000 habitantes (1994-1996); (**) Tasa /100.000 habitantes (1994); (***) Tasa /1.000.000 habitantes (1996) 
La heterogeneidad interna de las subregiones es particularmente apreciable en el Caribe latino. De 7,9 a 74 por 1000 nacidos vivos y de 80 a 56,3 años de esperanza de vida al nacer, demuestran el agudo contraste entre los éxitos de la salud pública cubana y la dramática situación de su vecino Haití. Sin duda, las medias que menos informan sobre las realidades internas de las subregiones son las de los gigantes de Brasil y México, observados con un único valor, comprobadas sus diferencias históricas internas y su ampliación en la década de los noventa. Por ejemplo, la tasa de mortalidad infantil en Brasil presenta una relativa homogeneidad en las regiones centro-oeste, sudeste y sur, alejadas de las regiones del norte y sobre todo del nordeste. Las tasas por estados varían entre $84,2 / 1000$ nacidos vivos en Alagoas, en la región nordeste, a 21,6/1000 nacidos vivos en Río Grande del Sur.

Al margen de las múltiples causas que en los diferentes países explican la reemergencia de la tuberculosis, no quedan dudas de que su incremento se asocia al deterioro de dimensiones de las condiciones de vida en la última década.

La tasa de incidencia de tuberculosis para América Latina y el Caribe en 1996 fue de 47,6 por 100 mil habitantes, con notables diferencias intra e inter subregiones. El Área Andina aparece con el mayor número de enfermos entre su población. Se exceptúan nuevamente Venezuela y Colombia, con tasas muy inferiores y próximas. Brasil, el Caribe latino y el Istmo Centroamericano superan la tasa media de la región, destacándose en el Caribe latino bajas tasas en Cuba y Puerto Rico, mientras Santo Domingo y Haití superan o se aproximan a 90 por $100 \mathrm{mil}$ habitantes (OPS, 1998).

La interpretación de la diferenciación geoepidemiológica de la mortalidad por causas externas es compleja, especialmente en causas particulares, como el suicidio y el homicidio, donde operan determinantes psicosociales. La más alta proporción de muertes por causa externas en la región corresponde a diferentes tipos de accidentes, aproximadamente el $40 \%$ de los cuales son de tránsito de vehículos de motor. La proporción de estas defunciones sobre el total varía de 10 a 20\%, sólo superada por el Área Andina con 27\% del total.
Para el año 1994 la tasa de la región fue de 69 por 100 mil habitantes, mientras la más alta tasa correspondió al Área Andina y sólo el Cono Sur y el Caribe no latino presentaron tasas inferiores a la regional. Cabe resaltar que las tasas de mortalidad por accidentes de tránsito de vehículos de motor y la de homicidios fueron exactamente iguales $(18,4$ por 100 mil habitantes), y mientras la tasa de homicidios duplicó la de accidentes en el Área Andina, en el Cono Sur sucedió exactamente lo contrario, como expresión de dinámicas sociales contrastantes, en íntima asociación con las diferencias en los patrones de poblamiento.

La tasa de incidencia anual de SIDA (año 1996) presenta otro patrón de diferenciación geográfica entre las subregiones. Según el registro de casos, el Área Andina es ahora, por primera vez en los indicadores que hemos observado, la de situación más favorable, con una tasa de 24,9 por 1 millón de habitantes, cuando la media de la región es de 62,5 por 1 millón de habitantes. No ha de desconsiderarse, en el caso de los países del Área Andina, la posible influencia de elevados subregistros .El Caribe no latino, en situación favorable en la totalidad de los indicadores anteriormente analizados, alcanza ahora la tasa más elevada, con 246,2 por 1 millón de habitantes, seguido de Brasil y del Istmo Centroamericano, que duplica la tasa del resto de las subregiones.

Otras informaciones dan cuenta de las desigualdades interestatales entre los países de la región, tales como la situación de las viviendas. Según estadísticas comparadas para diferentes años (entre 1981 y 1993), en los países que contienen el 96\% de la población latinoamericana los porcentajes de viviendas adecuadas variaban entre $83,3 \%$ para Uruguay y $20,1 \%$ en Nicaragua. Los mayores déficit cuantitativos se registran en Nicaragua, El Salvador y Bolivia, donde entre el 25 y el $45 \%$ de las viviendas totales se consideran irrecuperables (OPS, 1998).

Una última consideración sobre las divisiones político-administrativas y las desigualdades del bienestar y la salud se refiere a organizaciones territoriales antiguas, de cierto modo reordenadas ahora como "reservas", donde habitan los descendientes de los primeros pobladores de nuestra región. En la prolongada historia de consolidación 
de las desigualdades en América Latina, se resalta la diferenciación de la composición "étnica o racial" de su población, hecho éste ligado permanentemente al tema de las inequidades.

Los grupos de población indígena y sus espacios de reproducción no cuentan con informaciones precisas y sistemáticas sobre condiciones de vida y salud, aunque se aceptan dentro de los más marginados en la sociedad latinoamericana, con elevados índices de analfabetismo, desempleo, necesidades básicas insatisfechas y pobreza en general. De los aproximadamente 40 millones de indígenas en la población latinoamericana, cerca del 90\% se localiza en cinco países: México con la mayor población, seguido de Perú, Bolivia y Ecuador en el Área Andina y Guatemala en Centroamérica. Con las más altas proporciones de población indígena en población total se identifican Bolivia y Guatemala, con 71 y 66 $\%$ respectivamente.(OPS, 1998).

En varios países se han destacado los valores siempre inferiores en la esperanza de vida de las poblaciones indígenas en relación con la población general. En algunos estudios de grupos han sido reveladas profundas desigualdades, como en Honduras, donde se ha calculado en 39 años la esperanza de vida de los hombres del pueblo lenca, en tanto la esperanza de vida para los hombres en población general alcanza los 65,4 años (OPS, 1998).

No pocas interrogantes levantan las observaciones hasta aquí realizadas sobre la forma en que "conocemos" por medias de contextos territoriales de elevada heterogeneidad interna de condiciones de vida de las poblaciones y de notables iniquidades en el acceso a sistemas de atención a la salud. A esta visión tradicional y de utilidad para "cierto" nivel de conocimiento, deberán progresivamente incorporarse otras observaciones más precisas de carácter complementario.

La afirmación de que los índices e indicadores nacionales medios calculados por habitante permiten reflejar a grandes rasgos el nivel de desarrollo alcanzado y el grado de bienestar de la población de un país (Buzúev, 1991:10), es una verdad estrictamente estadística, que a su vez enmascara radicales diferencias internas de la vida de la población.

\section{LA UNIDAD GEOGRÁFICA DE MEDICIÓN Y LOS}

\section{DENOMINADORES POBLACIONALES}

Los Sistemas de Información en Salud, partiendo de la notificación de enfermedades u otros eventos de salud a nivel individual, integran las informaciones en sucesivas unidades políticoadministrativas. Disuelven por tanto los verdaderos espacios - territorios en que se producen los daños a la salud, espacios de prioridad para intervenir con eficiencia, efectividad y equidad. Se pueden así conocer los casos sin conocer la incidencia (Rose, 1985). A ello se integra la escasa incorporación en el sistema de notificaciones -incluyendo las compulsorias u obligatorias - de variables o indicadores sobre las condiciones vida del individuo y sus ambientes de reproducción, que complementen los datos estrictamente clínicos o biológicos, para interpretar la producción de uno u otro problema de salud, como rezago de la "medicina biologicista".

En la mayor parte de los Sistemas de Información Sanitaria de la mayoría de los países se evidencia la mala calidad o ausencia de datos socioeconómicos de los individuos (Regidor 1997:788), por lo que "los signos vitales sociales" no pueden conocerse. Al respecto se ha planteado la necesidad de reconocer las desigualdades, las clases, la decadencia regional o la fragmentación social, como agentes patógenos centrales de análisis de la salud pública, hechos que requieren de una revisión de la conceptualización de la colecta de datos y de los métodos de interpretación (Levins, 1998:25).

La heterogeneidad interna de las unidades de medición no es un tema nuevo, pero sí insuficientemente ponderado, o al menos resuelto. Se necesita encontrar "unidades genuinas" de las formaciones sociales (Samaja, 1994), para que de forma complementaria a las establecidas se profundice en el conocimiento y la efectividad de las acciones en salud.

En íntima asociación con lo anteriormente planteado, el denominador poblacional para el cálculo de tasas se obtiene por agregación de la población que tributa a los diferentes niveles del sistema de atención. En el primer nivel, la unidad está generalmente definida por el Sector Salud, como el 
área de salud en Cuba o el área de "abrangencia" de las unidades de salud en Brasil. A partir de esta unidad, los casos y las poblaciones se agregan sucesivamente en unidades político-administrativas superiores, tales como distritos, cantones, municipios, provincias, departamentos o estados, hasta la nación o país.

La información resultante de estas sucesivas agregaciones no sólo impide la aprehensión de las desigualdades, sino que dificulta la definición de prioridades de intervención que fundamente el ejercicio de la equidad de grupos en espacios poblacionales concretos. Debe insistirse en que un problema de salud, y en general un problema social, sólo es un problema con relación a un conjunto social, a un espacio y a un tiempo determinado (OPS, 1990).

Una propuesta prometedora es la del análisis de la situación de salud según condiciones de vida, operacionalizadas en las dimensiones económicas, ecológicas, biológicas y de conciencia-conducta en unidades tales como territorio-población, o espaciopoblación, con objetivos de fundamentar la estructuración de los subsistemas de intervención (Castellanos, 1992). La exploración que de esta propuesta han realizado algunos países, augura la inserción progresiva de este enfoque en la vigilancia y gestión y especialmente en los Sistemas de Información en Salud, al menos en las unidades político-administrativas inferiores.

Unidades independientes de las políticoadministrativas han sido también definidas en investigaciones de la transmisión y difusión de enfermedades, tales como patobiocenosis y nosoáreas. Encaminadas a revelar las desigualdades e inequidades en América Latina se han utilizado unidades socioespaciales (Blanco \& Saenz 1991) y corepidemas (Breilh \& Granda, 1991). La propuesta de organización de los Sistemas Locales de Salud (SiLOS) (OPS, 1990) asume entre sus objetivos la identificación de unidades territoriales locales (Paganini \& Chorny, 1990).

Se acepta que las estadísticas generales de un país y los valores medios esconden sensibles diferencias (George, 1973:59), pero poco se ha avanzado en introducir en los Sistemas de Información Nacionales o Regionales los datos que nos permitan mirar la realidad con los dos ojos abiertos. No deja de ser paradójico que sean reconocidas las profundas desigualdades e iniquidades que se despliegan en el contexto latinoamericano, e infrecuentemente se disponga de informaciones para revelarlas y documentarlas, a no ser por investigaciones puntuales o temporalmente irregulares.

Como fue expuesto en este propio trabajo, algunos países de la región se apartan de las subregiones donde se agrupan, por sobre la contigüidad y la relativa homogeneidad de sus contextos geográficos. A este hecho se integra la heterogeneidad espacial interna de los países, para corroborar las limitaciones de las informaciones a este nivel territorial. Tanto dentro de los países como en diferentes agregados de ellos, existen condiciones para mejorar el conocimiento de la distribución de problemas de salud, con o sin mapas. Establecer como rutina el conocimiento de la distribución geográfica de problemas de salud, según las más amplias desigualdades ambientales y de condiciones de vida de la población, o sea de grupos en espacios poblacionales, no necesariamente precisa de un "mapa", y constituye una documentación de importancia para la racionalidad de las políticas públicas y de salud.

Consideramos, por tanto, necesario iniciar un proceso que permita cambiar paulatinamente la forma de expresar indicadores económicos, demográficos, sociales y de salud, y elaborar métodos que posibiliten análisis alternativos con las nuevas informaciones producidas, de forma que generen conocimientos más reales sobre la distribución geográfica de problemas de salud y se aproximen a la medición de las desigualdades e iniquidades en la región.

Como ejemplo de la viabilidad de este proceso puede citarse el reconocimiento de la diferenciación interna de los países de la región, considerados en el tomo II de la publicación Salud en las Américas (OPS, 1998), dedicado a la situación de salud de los diferentes países que componen la región:

Argentina expone que las áreas donde se concentra la pobreza corresponden a las provincias del norte y del nordeste y a los cinturones periurbanos, mientras Bolivia destaca la existencia de tres regiones metropolitanas que concentran el $36,2 \%$ de la 
población y una distribución de población según grandes regiones: los llanos, los valles interandinos y el altiplano y Cordillera de los Andes, que con sólo el $25 \%$ del área total del país concentra el $45 \%$ de su población.

Por su parte Chile argumenta la elevada cantidad de población residente en zonas urbanas $(84,7 \%)$, más del $60 \%$ de ella, concentrada en tres regiones metropolitanas, el 39,8\% en la región metropolitana de Santiago. Paraguay resalta la similar proporción de la población rural y la urbana en el país y la división de éste en dos grandes regiones convencionales: la occidental de llanura árida y la oriental, muy poblada y rica. En Ecuador se llama la atención a la división del territorio del país en las zonas de Costa 50\%, Sierra 45\%, Amazonas 4,6\%, 0,1\% en islas, declarando el $61,0 \%$ de su población urbana. Nicaragua divide su territorio en tres regiones altamente diferenciadas: la del Pacífico, Central y Atlántico, con variaciones de la proporción de población en pobreza de 5 a $45 \%$ del total.

En ningún caso estas divisiones en regiones o zonas, que presentan la heterogeneidad interna del país, se retoman al informar sobre los problemas de salud de los respectivos países, a pesar de que ellas aseguran diferencias del ambiente biofísico y psicococial, así como de las condiciones de vida de la población, que distinguirían diferenciales en los procesos de producción de enfermedades.

No obstante lo apuntado, la publicación por la OPS de indicadores básicos por países en los últimos cuatro años y el fomento de la producción de materiales similares con informaciones subnacionales, apoyadas fundamentalmente por los ministerios de Salud y la Organización Panamericana de la Salud, ofrece potencialidades para penetrar en el problema analizado. Por ejemplo, el material publicado en 1998 por países como Venezuela, Ecuador, Perú y Brasil permite observar las diferencias intraregionales e interprovinciales o departamentales. En este último país, además de informaciones agrupadas por regiones geográficas y estados, se incluye los indicadores básicos para sus regiones metropolitanas.

La obtención de información de salud para estas divisiones reconocidas por los países, requiere de agregaciones al menos a nivel de unidades políticoadministrativas y de nuevas informaciones a ser incluidas como campos en las bases de datos existentes, proceso que actualmente puede ser agilizado con el auxilio de los SIG.

La posibilidad de reconocer las diferencias geográficas de la salud de la población existe para los Sistemas de Salud de cualquier país, y constituye en general un recurso poco explorado. La disponibilidad de medios tecnológicos preocupa menos que la posibilidad de contar con recursos humanos motivados y entrenados para tales fines. Así, las informaciones de salud pudieran estar referidas al menos a sus grandes divisiones de modos de vida, urbanos y rurales, o también a las grandes diferencias que expresan la vida en las regiones metropolitanas y del interior del país. Al igual que el interior rural, podría conocerse la ocurrencia de problemas de salud según los patrones de población dispersa o concentrada, que facilitarían el conocimiento de la difusión de las enfermedades; o los lugares de intensos o débiles flujos poblacionales, donde se localizan o no vectores de desarrollo o reanimación económica, asumiendo la importancia de la movilidad poblacional, tanto para la identificación de problemas prioritarios o emergentes como para las necesarias respuestas del sector.

En diferentes instancias del sector salud de numerosos países de la región se han dado pasos firmes en los últimos años hacia la obtención de "tecnologías" encaminadas a este objetivo, pero tal vez menos atención han recibido los necesarios cambios en los sistemas de información, que deberían comenzar a incluir códigos (campos) que permitan una aproximación a los espacios de producción de los problemas de salud de los territorios. La georeferenciación de estos problemas permitiría responder a la necesaria pregunta de ¿dónde? Son acometidos hombres o mujeres, de tal o cual grupo de edades (¿de dónde?).

Podría ser un hecho común conocer la información de la vida y la salud de cualquier país latinoamericano, al menos dividido en dos estadísticas, la de la metrópoli o regiones metropolitanas y el resto del país o de la población urbana y rural, o de reales divisiones espaciales tales como metrópolis o grandes ciudades, espacios favorecidos por inversiones, agropecuarios, 
industriales, turísticos y otros, verdaderos polos de desarrollo y aquellos donde por décadas no se producen inversiones significativas ni en el plano económico ni en el social, reinos de la inamovilidad.

Al interior de los países se trabajaría en la aprehensión de la coexistencia de las más agudas desigualdades sociales, con diferentes expresiones cuantitativas, particularmente agudas en el caso de las periferias de las grandes ciudades. ¿Cuántos de los países latinoamericanos disponen de informaciones sistemáticas del bienestar y la salud que den cuenta de la profunda segregación que los aqueja?

\section{LA CALIDAD Y PARCLALIDAD DE LAS INFORMACIONES.}

\section{¿QUÉ PARTE CONOCEMOS?}

Los registros primarios sobre enfermedades y muertes son generados por personal directamente relacionado con los servicios en el sector salud. La cobertura de médicos en América Latina y el Caribe en 1997 variaba de 1,8 a 53,1 médicos por $10 \mathrm{mil}$ habitantes (tabla 3), lo que sugiere que el acceso físico y social a la atención médica es profundamente desigual. En la ausencia o escasez de notificaciones de enfermedades o muertes en un territorio, está el efecto de la insuficiente cobertura de recursos humanos en salud, y en numerosas ocasiones los análisis de la diferenciación espacial de enfermedades evidencia el "silencio epidemiológico". La coincidencia espacial entre precariedad de la cobertura de servicios e inaccesibilidad social conduce al conocimiento más incompleto sobre la intensidad de los problemas de salud en la unidad territorial primaria de medición y las sucesivas unidades de agregación. Observando el indicador de subregistros de mortalidad en la región, se aprecia que en algunos estados éstos alcanzan cifras que superan el 50\%, como en Honduras (OPS, 1998). En otros casos hasta el conocimiento de los subregistros está limitado por carencias técnicas o incluso impedimentos políticos para su cálculo. A esta situación se suma la proporción de muertes por causa mal definidas. Para 1997, Brasil alcanzó un 15,1\%, en tanto en algunos de sus estados estas cifras oscilaron entre el 40 y el 50\%, como en Paraiba y Alagoas (RIPSA, 1998). En la provincia boliviana de Tepacán sólo un 11\% de la población tiene acceso a los servicios de salud (OPS, 1998), por tanto, las informaciones de esta provincia pueden considerarse absolutamente insuficientes.

La extensión de la medicina privada, concretamente en espacios urbanos, se constituye en una adicional limitación. En general los flujos de estas informaciones hacia los sistemas estadísticos municipales son parciales, especialmente para algunas entidades nosológicas. Las campañas de inmunización en programas alternativos de atención móvil o de movimientos de agentes comunitarios como soluciones paliativas a la carencia de recursos humanos e incluso el mejoramiento de condiciones higiénicosanitarias, indican avances localizados en regiones y lugares, expresiones de voluntades y coyunturas sociopolíticas en los diferentes territorios.

\section{Distribución geográfica. MAPAS y Sistemas de Información Geográfica en SALUd}

La distribución geográfica de problemas de salud o de componentes del Sistema adquiere tal importancia, que se ha estimado que el $80 \%$ de las necesidades de información de quienes toman decisiones o definen políticas está relacionado con una ubicación geográfica (Williams, 1987). El creciente interés por los mapas se asocia al desarrollo de las tecnologías automatizadas para su elaboración, las cuales posibilitan el manejo de grandes volúmenes de información georeferenciadas. Como resultado de ello se asiste a un vertiginoso desarrollo de los Sistemas de Información Geográfica (SIG), y la proliferación de eventos y literatura sobre estos temas.

Los Sistemas de Información Geográfica en Salud (SIGSA) o en epidemiología (SIG-epi) se califican como herramienta de apoyo en el análisis de situación de salud, en la vigilancia, planeamiento y evaluación de intervenciones en el Sector Salud (Castillo \& Salgado, 1996). La preocupación por el incremento de la utilización de los mapas en la literatura médica y de salud pública en general fue expuesta hace mas de 10 años por Cliff y Hagget (1988), científicos de amplia producción en el área de la geografía médica. Esta preocupación, compartida por algunos geógrafos latinoamericanos vinculados al sector salud, se fundamenta en el poder de atracción de estos recursos. 
Los mapas están permanentemente amenazados por la reproducción de las deficiencias de la información bioestadística, por el oscurecimiento de las verdaderas distribuciones al asumir valores generales o promediados en unidades heterogéneas, así como por la incorporación de errores de redacción cartográfica

Estos hechos pueden enmascarar evidencias, sugerir falsas concentraciones o pistas incorrectas en la interpretación y toma de decisiones en uno u otro problema de salud. Así, la vuelta a los mapas prioriza el manejo de softwares y secundariza o no toma en consideración las implicaciones teóricometodológicas de la espacialidad de los problemas de salud. Se corre por tanto el riesgo de que muchos productos, incluyendo aquellos elaborados para los servicios de salud, no sean aprovechados para producir análisis de problemas o para aportar nuevas ideas, y los procesos técnicos se adelanten a la creación y a la teoría (Dosse, 1994:359).

Pudiera considerarse también un riesgo su empleo exclusivo como ilustración, o como fin en lugar de como medio. La verdadera geografía médica empieza cuando la cartografía de la enfermedad o la muerte acaba (Sáenz de la Calzada, 1956). La elaboración de los mapas precisa del conocimiento cartográfico y estadístico mínimo, para reducir o eliminar los eventuales errores e imprecisiones que se observan en la actualidad y ampliar las potencialidades de su utilización.

Existe una tradición de representación cartográfica de las enfermedades, poco conocidas por los profesionales de salud que desarrollan en la actualidad los Sistemas de Información Geográfica en Salud; también es frecuente que se desconozca la existencia de la geografía médica o de la salud y la cartografía médico-geográfica, tanto por profesionales de las ciencias de la salud, como de las ciencias geográficas. Mapas y atlas de enfermedades fueron publicados en países europeos desde el siglo XIX. El desarrollo de mapas de morbilidad y mortalidad a los inicios del aquel siglo, se asocia a la difusión del cólera en la India, Eurasia y Norteamérica. No obstante, su importancia ha sido secundaria y su incorporación más incidental que central en los informes epidemiológicos (Cliff, 1988).
El surgimiento de la epidemiología se asocia a los mapas, a pesar de que su empleo por los epidemiólogos ha sido generalmente incidental. La representación que Snow hiciera sobre la distribución del cólera en ciudades inglesas se reconoce como una de las primeras pruebas de la importancia del análisis del lugar en la interpretación de las enfermedades (Snow, 1854). El lugar está incluido entre los componentes esenciales de los estudios epidemiológicos y varios de los conceptos y términos básicos, antiguos y nuevos, se apoyan en él, tales como epidemias, endemias o enfermedades emergentes. En libros de epidemiología se observa que los conceptos de endemia o epidemia incluyen el lugar de forma imprecisa, y se refieren a un área geográfica, comunidad, región, localidad, que para la geografía tienen diferentes implicaciones teórico-metodológicas. En otros casos se alude a la alteración de la espacialidad de una enfermedad, en el caso de la epidemia o a una enfermedad espacialmente localizada en el caso de la endemia, sin precisarse si el espacio es considerado desde el punto de vista geométrico, como sinónimo de área o superficie, o definido por las peculiaridades de su construcción social o cualquier otro significado.

\section{CONSIDERACIONES FINALES: UN INICIO}

El camino de fragmentaciones y divisiones que el mundo tomó, que las sociedades tomaron, no fue por consenso; tal vez nunca aconteció nada en este mundo por consenso. De las imposiciones de las minorías a las grandes mayorías resultaron los desajustes que hoy presenciamos. El poderío y el dominio de las tierras y sus recursos fueron siempre conducidos por conquistas y colonizaciones, y con muy débiles o inexistentes sentimientos de colaboración. Son estos grandes hechos que facilitaron un mundo y una región que hoy sorprende por sus distancias y sus proximidades, contrarias a la geografía convencional. Imaginando el siglo XXI, el director general de la UNESCO, planteó al respecto: "Los déficit éticos me parecen más graves a largo plazo que los presupuestarios" (Mayor, 1998).

Las sucesivas divisiones socioespaciales han colocado en planos de ventajas o desventajas de crecimiento económico y social a lugares, naciones y 
regiones, con el consecuente empobrecimiento progresivo de extensos espacios poblacionales (opacos), donde el tiempo detenido y carente de opciones de mejoramiento de la vida contrasta con los espacios de mayor crecimiento económico y social (luminosos). Sobre la diversidad natural se sobreimpusieron las desigualdades sociales intra e interestados y dentro de ellas fueron construidas ya trágicas inequidades $\mathrm{Si}$ en el mantenimiento o recrudecimiento de la marginalidad y la pobreza de grupos poblacionales en América Latina intervienen también la desigual distribución de los recursos naturales o la ocurrencia de eventos naturales extremos, no es sólo por designios de la naturaleza. Ella impone condiciones que pueden ser obviadas o minimizadas por determinaciones sociales; lo natural se aloja o refugia hoy en los intersticios de lo social (Santos, 1997:106).

Podemos considerar que la cuestión regional en América Latina es la de formas espaciales contradictorias, resultantes de la organización y reorganización territorial de los procesos sociales dominados por las relaciones capitalistas (Coragio, 1988:61). Una asimilación de los recursos permanentemente dependiente de las voluntades de los dominadores, de la condición de colonia, neocolonia o repúblicas independientes, o libres asociadas, condujeron a la consolidación de desigualdades, mantenidas por la capacidad peculiar de subsistencia de los productos históricos y sobre todo porque los sectores desheredados están estrictamente subordinados a un orden social compulsorio que mantiene incólume la estructura social. En América Latina, más desigual que la distribución de recursos o de beneficios económicos (o sociales), es la distribución del poder (Ribeiro, 1978:76).

La distribución geográfica de enfermedades, muertes y del bienestar de las poblaciones latinoamericanas, es una geografía de las desigualdades que parece desafiar el valor de la contigüidad geográfica, de la distancia física o hasta de las condiciones ecológicas. En esa otra geografía, la verdadera, como siempre en complicidad causal con la historia incluyendo la que actualmente construimos-, Panamá y Costa Rica se separan del Istmo Centroamericano y Paraguay se aparta del Cono Sur, aproximándose a los países andinos y centroamericanos. Haití se aleja de sus vecinos países del Caribe, y se aproxima al otro lado del Atlántico y al hemisferio sur, como un fragmento de cualquiera de los más sufridos países africanos. Mientras, Venezuela y Colombia se alejan de su subregión de pertenencia, recordando la historia de Nueva Granada.

También se aproximan al otro lado del Atlántico al norte de la Europa occidental, o a Norteamérica, algunas Islas del Caribe con las ventajas climáticas del trópico. Gran Caimán o Puerto Rico exhiben indicadores favorables de bienestar y salud, mientras en la vecina isla de Haití apenas si podemos hablar de subsistencia.

Se separan en nuestras ciudades latinoamericanas los contiguos barrios del más dramático tercer mundo de los del primer mundo, con la agravante de que la proximidad física los obliga a una coexistencia que genera sueños de aproximación alcanzables por cualquier vía. Tal vez más trágico aún sea observar, a modo de "ovnis", suntuosas residencias dentro de la más absoluta precariedad de vida de los sertones brasileños. En barrios de ciudades, incluso capitales de estados latinoamericanos "ruralizadas", que en ocasiones son llamadas lastimosamente "invasiones", se expresan hábitos de la vida rural más precaria, contiguos y distantes de los artificios más modernos de la vida urbana.

Son escasas las informaciones que permitan profundizar en las desigualdades espaciales del bienestar y la salud en América Latina, e inexistentes las que posibiliten su observación sistemática. Las vías son aún insuficientes, a pesar del creciente uso de indicadores e índices tales como extrema pobreza, miseria, necesidades básicas insatisfechas (NBI) o desarrollo humano (IDH) y el vertiginoso desarrollo de los Sistemas de Información Geográfica con la vuelta a los mapas.

Las influencias de la posición y situación geográfica, el régimen climático, los componentes del fondo y la dinámica ambiental, las diferencias en el abasto de recursos naturales o la ocurrencia de eventos naturales, pueden influenciar las asustadoras desigualdades e iniquidades de Estados de América Latina y del Caribe, pero sólo como integrantes de la trama causal de factores que intervienen en la conducción histórico-política de estos territorios, 
donde también puede incluirse el ejercicio de la solidaridad por parte de otros países de la región o del mundo.

Conocemos que los problemas de salud se producen socialmente y el estado de salud de la población es resultado de condicionantes y determinantes sociales-ambientales-biológicos, debidamente modelados y ampliamente divulgados. Mientras, medimos en unidades políticoadministrativas que obstaculizan la recuperación del marco teórico o los traicionan, sesgando tanto el conocimiento más real de su intensidad o frecuencia, como las posibilidades de interpretación de los procesos que les dan origen, y en consecuencia, la efectividad de las acciones de control, eliminación o erradicación.

Urge privilegiar la íntima relación entre la diversidad natural y las desigualdades e inequidades construidas y reconstruidas en el espacio que nunca es inocente (Briceño, 1974) y —asumiéndolo como cómplice involuntario - intentar nuevas agregaciones, conformar otras divisiones complementarias a las existentes, para que la producción de nuevos conocimientos incrementen nuestra intranquilidad.

Diseñemos nuevos mapas, que revelen con la realidad y el rigor que se necesita, la diferenciación geográfica de la vida humana en nuestra América Latina, como herramienta de acción para las transformaciones necesarias. Estos se aproximarán a los propuestos por Peet (1993:64): “que muestren un mundo y (una región) despertando de una pesadilla, al final de la prehistoria y saliendo para la aurora de una verdadera historia humana".

Enfrentemos la urgente tarea de encontrar formas de revelar, con la profundidad necesaria, la trama que argumenta la distribución desigual del desarrollo, de condiciones y calidad de vida, de la salud y el bienestar humano - la geografía de las desigualdades que posibilite construir una geografía de la solidaridad-y preguntémonos si faltan métodos, procedimientos metodológicos, congruencia o más valor.

\section{REFERENCIAS BIBLIOGRÁFICAS}

Acanda, J.L., 1992. Inconsciente y dominación: un aporte del etnopsicoanálisis al estudio de la Conquista. Convenio, 1:1-6.

Bret, B., 1997. A partilha do território e a desigualdades frente ao desenvolvimento: um problema de geografía política. En: $A$ Geografia politica do desenvolvimento sustentável (B. Becker \& M. Miranda, orgs.), pp. 208227. Río de Janeiro: UFRJ.

Briceño León, R., 1974. Hacia una teoría materialista del espacio. Caracas: Escuela de Sociología, Universidad Central de Venezuela. Mimeo.

Buzúev, A., 1991. Las desigualdades económicas de las naciones. Moscú: Progreso.

Castellanos, P.L., 1991. Perfiles de salud y condiciones de vida: una propuesta operativa para el estudio de las iniquidades en salud en América Latina. En: Anales del I Congreso Iberoamericano de Epidemiología. Granada.

Castillo, C. \& Salgado, E., 1996. Uso de los sistemas de información geográfica en epidemiología. Boletín de la Organización Panamericana de la Salud, 17:1-6.

Castro, J., 1972. Geopolítica del hambre. Madrid: Guadarrama.

Cliff, A.D \& Hagget, P., 1992. Atlas of disease distributions. Cambridge: Blackwell.

Coraggio, J.L., 1988. Territorios en transición. Crítica a la planificación regional en América Latina. Quito: Ciudad.

Dietrich, P.H., 1989. Sistema de la naturaleza. La Habana: Editorial de Ciencias Sociales.

Dosse, F.A., 1994. Convidada de ultima hora: a Geografia desperta para a epistemologia. En: Historia del estructuralismo do ano de 1967 a nossos dias, pp. 347-359. Campinas: EnsaioUnicamp.

Engels, F., 1979. Dialéctica de la naturaleza. La Habana: Editora Política.

George, H., 1966. Progreso y miseria. Nueva York: Robert Schalkenbach Foundation.

George. P., 1972. Geografía del consumo. Barcelona, España: Oikos Tau, Colección ¿Qué sé? Nº 86. 
George. P., 1973. Geografía de las desigualdades. Barcelona, España: Oikos Tau, Colección ¿Qué sé? N 148.

Guerra de Macedo, C., 1997, Notas para una história recente da saùde pública na América Latina. Brasilia: OPS/OMS.

Iñiguez, R.L., 1992. Geografia del bienestar. Experiencias y proyección. Primer Taller Científico del Centro de Estudios de Ciencias Naturales, Memoria. La Habana: Mimeo.

Iñiguez, R.L., 1996. Lo socioambiental y del bienestar humano. Revista Cubana de Salud Pública, 22 (1):29-36.

Iñiguez, R.L., 1998. Geografía y salud. Experiencias y alternativas en América Latina. Cadernos de Saùde Pública, 4:705.

Levins, R., 1998. Looking at the whole: toward a social ecology of health. Kansas Health Foundation, 1-27

Mayor, F., 1998. Imaginar y construir el siglo XXI. El Correo Unesco, noviembre:?.

Ministerio de Salud, 1999. Indicadores básicos de salud. Cuba: Ministerio de Salud.

Minsa-OPS/OMS, 1999. Situación de salud en Venezuela. Indicadores Básicos. Caracas: MINSA-OPS/ OMS.

Núñez, J.A., 1990. Nuestra América. La Habana: Pueblo y Educación.

OPS, 1990. Organización y gestión participativa en los SILOS, 109 (5 y 6). Washington DC: OPS.

OPS, 1997. Boletín Epidemiológico, 18 (4). Washington DC: OPS

OPS, 1998. Informe del director. Washington DC: OPS.

OPS, 1998. La salud de las Américas. Washington DC: OPS, Publicación Científica $N^{\circ} 569$.

OPS/OMS, 1997. Situación de salud en Ecuador. Indicadores Básicos por provincias. Washington DC: OPS.

OPS/OMS, 1998. Indicadores básicos 1998. Washington DC: HDP/HDA 01.

Paganini, L.L. \& Chorny, A.H., 1990. Los sistemas locales de salud: Desafíos para la década de los noventa. Boletín de la OPS, 109(56):436-450.
Peet, R., 1993. Mapa do mundo no fim da história. En: Fím de século e globalização (M. Santos, M.A de Souza, C.F. Scarlato \& M. Arroyo, orgs.). Sao Paulo: Hucitec-Anpur.

Pnuma, Aeci \& Mopu, 1990. Desarrollo y medio ambiente en América Latina y el Caribe. Una visión evolutiva. Madrid: Mopu.

Regidor, E., 1997. Investigación y acción sobre desigualdades en salud. Medicina Clínica, 108:784-790.

Ribeiro, D., 1978. O dilema de América Latina. Petrópolis: Vozes.

RIPSA, 1998. Indicadores e dados básicos. Brasilia: Ministerio da Saúde, OPS/OMS.

Rose, G., 1985. Individuos enfermos y poblaciones enfermas. Journal of Epidemiology, 14:32-38.

Sáenz de La Calzada, C., 1956. Los fundamentos de la geografía médica. Boletín de la Sociedad Mexicana de Geografía y Estadística, LXXXI (1):168.

Samaja, J., 1994. Vigilancia epidemiológica de los ambientes en que se desarrollan los procesos de reproducción social. Sexto Congreso Latinoamericano y Octavo Congreso Mundial de Medicina Social, Memorias. México DF.

Santos, M \& Arroyo, M., 1997.Globalização, regionalização: a proposta de Mercosul. Caderno Técnico, 24.

Santos, M., 1989. Espacio y método. París: Ediciones Publisud.

Santos, M., 1997. A natureza do espaço. Sao Paulo: Hucitec.

Smith, D., 1980. Geografía humana. Barcelona, España: Oikos Tau.

Smith, N., 1988. Desenvolvimiento desigual. Río de Janeiro: Bertrand Brasil.

Snow, J., 1990. Sobre a maneira de transmissão da cólera. Salud en Debate, 33.

Williams, R.E., 1987. Selling a geographical system to goverment policy makers (citado por: Castillo, C., 1996. Uso de los sistemas de información geográfica en epidemiología. Boletín de la Organización Panamericana de la Salud, 17:1). 


\title{
CALIDAD DE VIDA, SERVICIO PúBLICO Y DESARROLLO URBANO EN VENEZUELA
}

\author{
Esther Elena Marcano *
}

Las frecuentes informaciones y programas de opinión que en los distintos medios de comunicación dan cuenta del estado de los servicios públicos, son indicios de que la precariedad de éstos en Venezuela ha afectado la calidad de vida de un importante sector de la población, denotando, además, tal grado de deterioro, que podría atentar contra la totalidad de la salud pública si no se les atiende con seriedad y urgencia.

No ha sido producto del azar el significativo número de casos de dengue hemorrágico registrados en Caracas a finales de 1997 y 1998, tampoco la proliferación de enfermedades de tipo respiratorio. Estos hechos, registrados tanto en instituciones sanitarias públicas como privadas, alertan sobre las inadecuadas condiciones de saneamiento de las ciudades venezolanas. La falta de adecuación de las políticas públicas de agua y saneamiento a las demandas crecientes de necesidades de dichos servicios, origina la conformación de un hábitat insalubre que degrada la calidad de vida en la ciudad.

Las llamadas de previsión hechas a la ciudadanía por el Ministerio de Sanidad y Desarrollo Social (MsDs) orientadas a la eliminación de los depósitos de agua, pasan por alto que en las ciudades el servicio de agua potable no es continuo y por lo tanto una buena parte de la población continuará manteniendo depósitos de agua en las viviendas para el consumo diario. ¿Cómo puede resolver el usuario los dos problemas? ¿Sufre de dengue o se queda sin agua? Si se indaga más en el asunto, se encuentra que la falta de un servicio de agua continuo es motivo para el robo de los utensilios instalados como depósitos de basura en las calles por municipios o residentes, luego transformados en depósitos para almacenar el agua en las viviendas, con lo cual las calles se quedan sin recipientes y los desperdicios esparcidos por doquier.

Hacer un breve recorrido por la historia de los servicios públicos en Venezuela puede llevarnos a comprender las relaciones sucesivas entre desarrollo urbano, calidad de vida y servicio público.

\section{CONCEPTOS Y PRÁCTICAS PÚBLICAS}

La calidad de vida se concibe como la satisfacción de las necesidades de una población dentro de sus posibilidades de disponer de servicios públicos en un entorno social lo suficientemente próximo, que permita acceder a ellos y utilizarlos en condiciones de equidad. Si bien las necesidades de una población conducen a unas demandas para su satisfacción, las respuestas obedecen a las decisiones asumidas por el Estado en la distribución de los bienes y usos urbanos. Lo que significa que existen políticas de organización de la vida cotidiana que llevan a definir niveles sociales de calidad de vida por acceso al salario y a los servicios públicos.

Por otra parte, la teoría acuña a los servicios públicos un gran valor, tanto para la eficacia productiva de la economía como para el mantenimiento de la cohesión social. Se necesitan buenos transportes, una buena distribución de energía, una eficiente red de comunicaciones, una población sana, para hacer funcionar cualquicr actividad productiva. Igualmente, la incorporación a una red es necesaria para mantener la cohesión social; por el contrario, la falta de incorporación aparece como una exclusión (Stoffaës, 1995:21).

Otros autores, como Rivero (1994), centran la importancia en el aspecto social. Este autor

Socióloga de la Universidad Central de Venezuela, doctora en Urbanismo de la Universidad de París. Actualmente es investigadora en el Se Urquitectura y Urbanismo de la Universidad Central de Venezuela. E-mail: emarcano@,urbe.arq.ucv.ve. 
plantea que la finalidad del servicio público es "la satisfacción de una necesidad de interés general". Junyent se inscribe dentro de la misma visión cuando sostiene que por "servicios públicos se entiende a menudo aquella prestación que debe ofrecer la administración pública para satisfacer una determinada demanda colectiva" (Stoffaës, 1995:21).

Autores latinoamericanos, como Cuervo et al. (1988), refiriéndose a la Teoría del Servicio Público como ideas "afines y complementarias" de la intervención del Estado benefactor, sostienen que "el servicio se orienta a la satisfacción de necesidades sociales y no meramente económicas; su rentabilidad sólo puede estimarse en términos difícilmente cuantificables, como son los del bienestar colectivo. Estrictamente hablando, no puede excluir a ningún asociado, ni siquiera por medio del mecanismo de los precios o en razón de la capacidad económica de los individuos" (Cuervo et al., 1988:84).

En esta última conceptualización se asume que el Estado es directamente responsable de proveer los servicios públicos a la sociedad. La cuestión a resolver es quién paga los costos.

El proceso de urbanización y la organización de la vida cotidiana que ello lleva consigo, está ligado en las ciudades latinoamericanas al papel que juega el Estado nacional en la reestructuración del capitalismo mundial. Venezuela no escapa a esta generalidad. El proceso de urbanización que se desarrolla en América Latina a partir de la postguerra fortaleció su papel como base necesaria para el desarrollo de la política de sustitución de importaciones, cuyo eje prioritario se encontraba en la industria automotriz.

La Venezuela petrolera tenía la primera condición para el desarrollo de dicha política, sólo faltaban eliminar los obstáculos que impedían poner en práctica la modernización del país. Las contradicciones de este proceso moderno se reflejan posteriormente en la importación de alta tecnología y el empobrecimiento de las mayorías expresado en el deterioro de sus condiciones de vida y de salud, proceso que se explica a continuación.

\section{LA NOCIÓN DE SERVICIO PÚBLICO EN VENEZUELA}

La visión del servicio público ha jugado un papel cardinal en el proceso de desarrollo urbano del país, cuya evolución se tratará de simplificar a continuación, destacando los momentos históricos donde el desarrollo urbano y su relación con servicio público y calidad de vida adquiere mayor significación.

La definición de servicio público que se encuentra en Venezuela en el proceso de desarrollo urbano, viene referida fundamentalmente al aspecto normativo y legal, entendiéndose por servicio público "prestaciones legalmente obligatorias a cargo del Estado o de un ente público, que deben ser realizados en forma regular y continua, ya sea a través de los organismos de la Administración, ya sea bajo su control, dirección y vigilancia" (Ministerio de Justicia, 1963:269) (resaltado nuestro).

Esta conceptualización ha ido cambiando en la práctica a medida que la urbanización avanza, alejándose de la concepción arriba indicada y creando, por el contrario, condiciones de pérdidas consecutivas de la calidad de vida de la población, que se puede establecer según períodos históricos arbitrarios, tomados para facilitar la comprensión del tema.

\section{ANTES DE 1936. LA INGENIERÍA SANITARIA:}

\section{POLÍTICA DE ESTADO}

El concepto de servicio público en Venezuela nace ligado a la ingeniería sanitaria y tiene como finalidad resguardar la salud pública amenazada por las epidemias. No se podría olvidar toda la importancia que adquirió en el país la lucha contra el paludismo, durante los procesos de exploración y explotación del petróleo a partir de 1920. Para entonces, se requería sanear el espacio sometido al proceso económico, y por ende mantener una población sana para el desarrollo de la producción petrolera. Este interés no era sólo del gobierno nacional: las empresas internacionales, concesionarias del Estado venezolano para la explotación petrolera, estaban interesadas en mantener sanos a sus 
trabajadores, muchos de ellos afectados por la malaria. Esto explica que en 1926 llegue al país una misión cívico-militar de la Fundación Rockefeller para asesorar a las autoridades del país en la lucha contra la fiebre amarilla (Castellanos, 1982:81). Era tan importante el hecho, que el ingeniero jefe de la Misión de Ingeniería Sanitaria de la Fundación, Thorndike Saville, fue nombrado jefe de Servicios de Ingeniería Sanitaria del país entre 1926 y 1927 (Castellanos, 1982:82), con lo que la salud y el saneamiento ambiental adquirían importancia internacional en el país.

La legislación del momento estableció el marco jurídico e institucional necesarios para que las funciones de saneamiento se cumplieran. El articulado de la Ley de Sanidad de 1931 expresa en su artículo primero que el Servicio de Sanidad Nacional estaba a cargo del Ministerio de Salubridad y de Agricultura y Cría y en su artículo $4^{\circ}$ le asigna al ingeniero sanitario las siguientes atribuciones:

1) Inspeccionar las instalaciones y procedimientos empleados en la provisión de aguas para el consumo bumano, informar al Ministerio de Salubridad y Agricultura y Cría acerca de las modificaciones o reparaciones que deben hacerse o de los procedimientos que deban adoptarse para mejorar aquéllos en resguardo de la salubridad publica.

2) Estudiar los procedimientos modernos más adecuados para el tratamiento de las aguas contaminadas (cloacas), basuras, desperdicios...

3) Informar al Ministerio... acerca de los trabajos de canalización drenaje, desagües y otros que sea necesario ejecutar a fin de evitar la formación de pozos, lagunas y estancamientos de agua que favorezcan el desarrollo de larvas de mosquito o la reproducción de gases perjudiciales a la salud (República de Venezuela, 1931) (resaltado nuestro).

El Ministerio de Salubridad y de Agricultura y Cría asume entonces los servicios de provisión de agua potable, cloacas, desagües y basuras, con el objetivo de preservar la salud pública. De lo que se desprende que la ingeniería sanitaria no podía separarse del contexto social y político de la Venezuela de comienzos de siglo, al contrario, la política de salubridad es coherente con el objetivo del Estado venezolano del momento: establecer las condiciones necesarias de higiene pública para que el naciente modelo petrolero pudiera instalarse.

\section{Entre 1936-1942. Adecuación DEL SERVICIO}

PÚBLICO AL DESARROLLO URBANO

Controlado el brote de malaria, resuelta la fase de exploración y explotación e iniciada la fase de exportación petrolera, la política del servicio de agua y saneamiento toma otro sendero: servir al proceso de urbanización y adecuarse a la producción industrial, que comienza a imponerse en el país a partir de la década de los cuarenta y que va a reflejarse con mayor intensidad en los años cincuenta y sesenta. Es así como, resuelto el problema de la salubridad, el Estado venezolano asume con propiedad el servicio público, con el precepto de interés general, y lo norma en la Ley de Sanidad Nacional de 1942.

En la ley se especifica la potestad del Estado en la materia, cuando en su artículo $2^{\circ}$ expresa que "...la suprema dirección del Servicio de Sanidad de la República le corresponde al Ejecutivo Federal, quien la ejercerá por órgano del Ministerio de Sanidad y Asistencia Social, y al efecto se declara de interés público para la salubridad general la coordinación y cooperación de la nación de los Estados y de las Municipalidades, en materia de servicios_sanitarios" (República de Venezuela, 1942) (resaltado nuestro).

Esta ley podría considerarse como pionera de la descentralización, no sólo por lo arriba indicado, sino porque, además, en el artículo $5^{\circ}$ prevé incluso el financiamiento de esta actividad: "Para la coordinación y cooperación de los servicios sanitarios, los Estados y las Municipalidades, aportarán los fondos que requieran conforme a los convenios que se celebren al efecto con el Ejecutivo Federal" (artículo $5^{\circ}$ ) y en el artículo $3^{\circ}$ la Ley se refiere a que "El servicio de Sanidad comprende todos los ramos de la higiene pública y de la higiene social".

\section{ENTRE 1943-60. Agua y SANEAmiento SE}

\section{ASUMEN COMO SERVICIOS DE GESTIÓN PÚBLICA}

Un año después de haberse proclamado la Ley de Sanidad y las Normas Sanitarias de 1942, el Estado 
mantiene la concepción de que el servicio de agua y saneamiento es de interés general. Profundiza esta posición tomando la responsabilidad directa del servicio, para lo cual crea, en 1943, una empresa pública - Instituto Nacional de Obras Sanitarias (INOS) - mediante la cual asume la gestión del servicio de agua. Este instituto fue creado con las funciones de "constitución, conservación y administración de los acueductos y cloacas del país".

A partir de entonces, las autoridades empiezan a considerar que el problema del agua y el saneamiento en la ciudad capital requería de una organización técnica adecuada, que posibilitara un manejo más efectivo de los acueductos y que tomara en cuenta el crecimiento futuro de la población.

\section{ENTRE 1960-1976. Se SUSTITUYE EN LA PRÁCTICA}

\section{LA GESTIÓN DEL SERVICIO Y SE ACOGE LA POLÍTICA DE}

\section{INFRAESTRUCTURA}

El desarrollo del modelo petrolero produjo, necesariamente, cambios en el aparato político institucional, a fin de dar respuesta al proceso de acumulación que se instauraba. En el agua y saneamiento se diversifican las funciones de la empresa pública para intervenir en estos servicios y es así como el reglamento del Inos de 1962 limita la injerencia de este instituto al medio urbano, mientras que el medio rural se circunscribe al Servicio de Malariología del Ministerio de Sanidad y Asistencia Social. Además, al Inos se le asignan nuevas atribuciones, tales como la construcción de toda la infraestructura que tiene que ver con el agua y el saneamiento, "...de toda clase de obras relacionadas con la captación, conducción, tratamiento y distribución y de aquellas relacionadas con ...la evacuación y tratamiento de aguas residuales" (INos, 1962, cit. Marcano et al., 1991:77).

A partir de entonces, la gestión del servicio para la cual fue creada el INos en 1943 comienza a ser sustituida, durante este período, por la construcción de las grandes obras de embalse, transporte, redes y plantas de tratamiento, asumida en la práctica como prioridad de la institución. La gestión del servicio queda así minimizada por la construcción de las grandes obras. La ingeniería civil juega un papel fundamental en las decisiones tecnológicas de ese momento, mientras que la ingeniería sanitaria, otrora fundamental para el control de la salud pública, pierde importancia y sus funciones se reducen.

De tal manera que a partir de ese momento la visión del servicio público se centra primordialmente en la construcción de grandes estructuras físicas y de infraestructuras como asiento institucional de los servicios. Esta política no es exclusiva del servicio de agua y saneamiento, igual política se aplica al transporte, donde lo prioritario pasa a ser la construcción de infraestructura vial y no el diseño de una política de transporte masivo de pasajeros. En este período se construyeron también las grandes redes hospitalatias y de educación.

Esta visión del desarrollo urbano priorizando la construcción de infraestructuras, de la gran obra pública como símbolo urbano de poder político, deja minimizada la vieja concepción del servicio de saneamiento como gestión pública; le quita poder político a la ingeniería sanitaria para dársela a la ingeniería civil. Ello expresa cómo se había cambiado la visión del servicio y cómo se había insertado la concepción de infraestructura en la obra pública como prioridad en la visión del desarrollo urbano de la política del Estado venezolano.

\section{ENTRE 1976-1990. CRISIS DE LA GeSTIÓN PÚBLICA}

El abandono de la gestión pública de los servicios de agua y saneamiento provoca su crisis. A fines de los años setenta, la crisis de funcionamiento del servicio de agua se expresaba fundamentalmente en la capital: períodos de escasez y simultáneas búsqueda de salidas que resolvían sólo momentáneamente la situación, para caer en una práctica sistemática de falta frecuente de agua en la ciudad.

En lo institucional, la crisis se reflejaba en la disparidad entre el presupuesto del Inos y sus problemas administrativos y financieros. En los años ochenta, el Inos absorbía el 83\% de los préstamos internacionales otorgados a este sector; sin embargo, 
la gestión del servicio presentaba serios problemas administrativos y financicros caracterizados por unos costos administrativos excesivamente elevados, un precio político del agua y una gestión distorsionada.

Para ilustrar el caso, los gastos comerciales, administrativos y de supervisión y de gerencia del Inos Metropolitano pasaron de 14\% en 1973 a 23\% en 1980 y siguió su tendencia expansiva en 1990 (Limardo, 1984; Marcano, 1993). Los costos indirectos sufrieron un aumento del $37 \%$ en el mismo período. La diferencia entre $\mathrm{m}^{3}$ producido y $\mathrm{m}^{3}$ fracturado era del 43\% entre 1973 y 1980, pero la distancia era superior entre agua facturada y agua cobrada, que llegó en 1990 al 88\% (INOs, 1990, cit. Marcano, 1993:177). A esto se sumaban frecuentes reorganizaciones internas del Inos Metropolitano, sin resultado alguno.

Esta crisis del Instituto Nacional de Obras Sanitarias significó para la población un descenso tanto en la frecuencia de recepción del servicio como en su calidad, lo cual se tradujo en menos agua para la población, mayor cantidad de sectores populares y medios sin agua y aumento del número de viviendas no conectadas a cloacas. La salubridad pública, por carencias y deficiencias en el servicio sanitario, tomó un camino crítico.

Este proceso empieza a detectarse ya en la década de los ochenta, lo que indicaba signos de agotamiento en el modelo de desarrollo de Venezuela. La caída de los precios petroleros, la fuga de capitales y la suspensión de créditos por parte de la banca internacional, planteaban realizar profundas transformaciones en el modelo de desarrollo del país. Los servicios públicos han sido un sector profundamente tocado por este cambio. Se introducen en la discusión pública términos como calidad en la prestación de servicios públicos, eficiencia en su administración, productividad, privatización y nuevos financiamientos, en referencia a los servicios públicos. A fines de los ochenta y comienzos de los noventa, las modalidades de gestión de los servicios públicos entra en una nueva fase.

Problemas administrativos graves en la conducción institucional, una tarifación sin cobranza y una abultada nómina de personal, son algunos de los problemas que marcaron la crisis del servicio en el período y que dieron paso a un cambio en la gestión del servicio de agua y saneamiento.

\section{CAMbio del modelo de GeStión. \\ DESCENTRALIZACIÓN Y PRIVATIZACIÓN}

La crisis del modelo de desarrollo de la década de los ochenta exige una reestructuración del Estado para su adaptación a los nuevos tiempos. Las políticas de privatización y descentralización forman parte de este proceso; son mecanismos que intentan reducir la intervención del Estado, tanto en lo económico como en lo social, el incremento de la eficiencia de la administración pública y una apertura democrática hacia las regiones. Este proceso se inicia en 1989 con la descentralización del poder político y se concreta en 1993 con la firma del Acuerdo Nacional para la descentralización, fijando un plazo de tres años para llevar a cabo la transferencia de servicios entre la nación y cada entidad federal (De La Cruz, 1994:237).

Con el proceso de descentralización, el gobierno central, que tradicionalmente había mantenido una intervención directa en la producción y gestión de gran parte de los servicios públicos, cambia su política hacia un intento de redefinición de su papel en la sociedad venezolana, tendiente a la transformación económica mediante la reestructuración de aquellas actividades que se mantenían en manos del Estado. En materia de servicios públicos, se trataba no sólo de eliminar las empresas del Estado, sino de realizar transferencias hacia el sector privado de servicios tradicionalmente manejados por aquél. Este paso significativo tenía como objetivo principal, además de las transferencias de competencia desde el poder central a las regiones y municipios, la introducción de cambios en el financiamiento de los servicios, que hasta esa fecha se habían mantenido a cargo del presupuesto nacional.

La privatización de la Compañía Nacional Teléfonos de Venezuela (CANTV), en 1989, inicia el camino del cambio de gestión de los servicios públicos, le siguió el agua y el saneamiento.

El cambio de modelo de gestión del servicio de agua ha implicado varios ensayos: reorganización del InOS en 1986, que radicó en una desconcentración interna del instituto, consistente en la creación de unos 
"entes desconcentrados" que sustituyeron a las direcciones regionales de los estados por regiones hidrológicas, que seguían actuando sin autonomía. Adicionalmente, el intento frustrado de privatización del Acueducto Metropolitano y por último, la conformación de empresas hidrológicas.

El fracaso de privatización del Acueducto Metropolitano dio origen a la reestructuración de Hidrocapital (responsable del acueducto en la región capital), mediante el decreto $N^{\circ} 2513$ del 1/9/92. Otros decretos se suceden, entre ellos el decreto 2786 del 27/1/93, que declara de primera necesidad los servicios de acueductos y de recolección, tratamiento y disposición de las aguas residuales en todo el territorio nacional, con lo cual el Estado intenta volver, en el texto por lo menos, a su condición de Estado benefactor que vela por la salubridad pública (resaltado nuestro). La resolución del 24/2/93 establece nuevas tarifas del servicio. Además, se crearon dos agencias para la conservación de las cuencas del río Tuy y del lago de Valencia.

Las empresas hidrológicas, actual forma de organización del servicio de agua y saneamiento en todo el país, surgen por la transformación del viejo Instituto Nacional de Obras Sanitarias en una empresa matriz, Hidrológica Venezolana C.A. (Hidroven). Esta transformación fue iniciada en 1991, con la liquidación del $90 \%$ de los trabajadores y la creación de once empresas operadoras repartidas en las regiones del país. Sin embargo, el informe del ministro del Ambiente al gabinete económico el 13 de enero de 1993, reseñaba que los recursos para el abastecimiento de agua habían disminuido en más de un $30 \%$ con respecto al año 1992, brecha que esperaba cubrirse con el aumento de las tarifas. Este déficit se situaba en 11.000 millones de bolívares (aproximadamente 110 millones de dólares para la época) para los gastos mínimos de operación de las hidrológicas en 1993. Para la misma fecha, el presidente de Hidrocapital, ingeniero De Viana, en entrevista a Radio Capital decía que el costo real de un $\mathrm{m}^{3}$ de agua era de Bs. 40 y la brecha entre costo de producción y costo de venta Bs. $34 \mathrm{Bs} . / \mathrm{m}^{3}$, cifras que harían difícil resolver la brecha con el aumento de la tarifa (entrevistador Temístocles Rojas, 13/1/ 93). Dos funcionarios y dos opiniones distintas sobre el mismo tema.

\section{CONCLUSIONES}

Si bien la administración pública en su Doctrina Administrativa (Ministerio de Justicia, 1963:269) considera que el servicio público constituye una prestación legal obligatoria a cargo del Estado o de un ente público, que debe ser realizado en forma regular y continua, en la práctica, con la intervención del Estado, tal doctrina se aleja mucho de su postulado. En el caso del servicio de agua y saneamiento, el suministro se da de forma irregular y discontinua, con una distribución desigual según los distintos sectores de la población y un saneamiento arcaico, dejado muchas veces a cargo de la naturaleza, con las consecuencias de deterioro de la salud y del hábitat residencial.

Aunque la ingeniería sanitaria marcó un hito en el desarrollo urbano del país, fundamentalmente en el control de la salud pública, en el proceso de urbanización su importancia fue sustituida por la ingeniería civil. En consecuencia, la preservación de la salud pública en materia de agua y saneamiento fue dejada de lado para darle prioridad a la obra pública, sustituyéndose, en este proceso de desarrollo urbano, de modernidad, el papel del ingeniero sanitarista por el del ingeniero civil y/ o constructor.

El proceso de modernización de Venezuela fue desarrollado mediante la concepción de que el costo de los servicios públicos en materia de construcción, operación y mantenimiento de la infraestructura estuviese a cargo del Estado, igualmente la dotación y administración del servicio. Esto fue posible por la confluencia de dos grandes factores: un Estado con una alta renta petrolera y una concepción de gobierno sustentada en el populismo. El deterioro del modelo, iniciado en la década de los ochenta, cambia las reglas de juego. El Estado empieza a abandonar su inversión en el sector y cede la prestación y administración de los servicios a empresas privadas, con lo cual la población asume los costos de los mismos, pagando un alto precio por un mal servicio.

Si bien en 1943, con la creación del Instituto Nacional de Obras Sanitarias, el Estado asume el agua y saneamiento como su responsabilidad, al asignarle a este instituto funciones de construcción de grandes obras desvirtúa su función de agente gestor del agua 
y saneamiento urbano y lo convierte en ente concentrador de empleo clientelar, lo que permitía, por un lado, responder a la política populista del gobierno mientras que por el otro, se abandonaba el control de la salud pública.

La crisis del servicio, el deterioro de la salud pública por la carencia del servicio y/o la mala calidad y la irregularidad en la frecuencia del suministro llevan a tal deterioro de la calidad de vida, que hace crisis. Las consecuencias de este deterioro se manifiestan en la presencia de grandes masas de población sin conexión a las redes de agua (30\%) y cloacas $(70 \%)$, afloramiento de enfermedades producidas por el agua, tales como dengue, cólera, diarreas, parasitosis, y la reaparición del paludismo, que había sido exterminado en la década de los cuarenta. La descentralización y la privatización se ensayan como salida a dicha crisis, soluciones que en la práctica no se consolidan a pesar de las decisiones tomadas.

Estas salidas presentan sus dificultades. En Venezuela, la privatización responde a una política de inserción del país en el mercado mundial de gestión y operación de los servicios públicos, que busca la participación de nuevos actores en el proceso, la eficiencia administrativa, un manejo más comercial de las empresas y una recuperación de los costos que permita "una contribución para la inversión futura" (CEPAL, 1990). Implantar este modelo ha sido difícil. Los servicios públicos tradicionalmente han conformado un espacio central de concentración del empleo clientelar y algunos de ellos, como el agua, la educación y la salud, han jugado un papel fundamental en la distribución de la renta petrolera, en el sentido de haber sido asumidos por la población como un derecho a recibir el servicio de manera gratuita.

Otros problemas a resolver vienen dados por la disparidad existente entre salario mínimo y tarifas de servicios públicos, dentro de un proceso inflacionario alto. Las altas tarifas alcanzadas por el servicio de electricidad y el servicio telefónico no se compaginan ni con la calidad del servicio ni con un salario mínimo situado en Bs. $120.000 /$ mes ( $\$ 180$ / mes). Por ejemplo, en los tres últimos años, la renta básica residencial de CANTV ha sufrido un incremento de $639 \%$ y la empresa no cuenta con un equipo confiable para medir los impulsos telefónicos; además, el número de teléfonos instalados es de 12 por 100 habitantes, cuando se previeron 20 por 100 para 1997 (Ramos, 1998). Los frecuentes apagones de la electricidad de Caracas indican las deficiencias del servicio, mientras que el aumento progresivo de las tarifas llevó a la decisión del gobierno nacional a su congelación, en abril de 1998, por el resto del año, mediante acuerdo aprobado por el Congreso Nacional.

Por otra parte, debe tomarse en cuenta que una de las dificultades para llevar a cabo los objetivos de modernización del Estado está en que en el país la descentralización de los servicios públicos está afectada por la estructura clientelar del gobierno central, armada por los partidos tradicionales y trasladada a regiones y municipios con la política descentralizadora. Los nuevos gobiernos regionales tendrán que cambiar esta vieja visión para poder enfrentar las necesidades y respuestas de la población por unos servicios de calidad. Es el reto y la salida para una gestión urbana que les permita ejercer y mantener el poder en beneficio de las mayorías.

Respecto a la gestión municipal, si bien la Ley Orgánica de Régimen Municipal le otorga a los municipios la potestad de delegar la gestión de los servicios a empresas públicas o privadas, su práctica ha estado constreñida al Servicio de Aseo Urbano y Domiciliario, mientras que servicios como el agua y el saneamiento aún continúan con una intervención fuerte de la administración central, a pesar de la existencia de las hidrológicas regionales. Si bien estas empresas han sido reestructuradas y han mejorado su eficiencia, carecen de un modelo alterno de financiamiento, recurriendo todavía al Estado para resolver parte de sus dificultades. Servicios como la electricidad han sido, desde su inicio, de gestión privada, el municipio interviene poco.

Por último, si lo fundamental de la sociedad que hoy se intenta construir es dar respuestas adecuadas a las demandas de las necesidades sociales, estados y municipios - en relaciones directas con la población- se encuentran en el compromiso político de aumentar la cobertura y calidad de los servicios, lo que se revierte en un aumento del gasto público local. Siendo así, tanto al gobierno regional como al municipal le corresponde definir el rol de proveedor 
de las condiciones para que esas necesidades sean resueltas. Establecer adecuadas relaciones entre el gobierno municipal y los ciudadanos en cuanto a la provisión y mantenimiento de los servicios, conlleva a incorporar nuevos actores y a establecer claramente las condiciones entre la gestión urbana y los residentes de la ciudad. Esto significa un cambio en las reglas del juego entre organización institucional y colectividades locales, lo que implica, entre otras acciones, buscar nuevas formas jurídicas para la operación de los servicios públicos y nuevas formas de funcionamiento que permitan elevar la calidad de vida de la población.

\section{REFERENCIAS BIBLIOGRÁFICAS}

Castellanos, P.L., 1982. Notas sobre el Estado y la salud en Venezuela. Cuadernos Sociedad Venezolana de Planificación, 5:69-158.

Cepal (Comisión Económica para América Latina y el Caribe), 1990. Abastecimiento de agua potable y saneamiento ambiental en América Latina y El Caribe con posteridad a la carta de Punta del Este. Caracas: ONU.

Cuervo, M.; Jaramillo, S.; González, J. \& Rojas, F., 1988. Economía política de los servicios públicos: una visión alternativa. Bogotá: CINEP.

De La Cruz, R., 1994. Finanzas públicas y descentralización: la teoría inacabada del federalismo fiscal. En: Federalismo fiscal: el costo de la descentralización en Venezuela, pp.199-305. Caracas: Copre-Pnud.

Limardo, C., 1984. Informe costos y precios del agua. Caracas: IU/FAU/UCV.

Marcano, E.E., 1993. La crisis del agua en Caracas: elementos para el análisis de la política urbana. Caracas: Consejo de Desarrollo Científico y Humanístico, Universidad Central de Venezuela.

Marcano, E.E.; Foley, J.; Benaiges, A.; Semeco, A.; Rojas, T; Pacheco, C.; Leal, A; Valdez, N., 1991. Los servicios urbanos en las ciudades venezolanas. Modos de gestión y de organización. Agentes urbanos que intervienen y formas de Intervención. $1^{\circ}$ etapa Barquisimeto. Informe de Investigación presentados al Consejo de
Desarrollo Científico y Humanístico de la Universidad Central de Venezuela, Caracas: Instituto de Urbanismo, Facultad de Arquitectura y Urbanismo.

Ministerio de Justicia, 1963. Doctrina administrativa Dictámenes de la Consultoría Jurídica 1959-1963. Caracas: Ministerio de Justicia (citado por A. Brewer Carías, 1971. Aspectos institucionales del transporte y tránsito en el área metropolitana de Caracas. Caracas: Fondo Editorial Común, p.79).

Poletto, A., 1997. Aspectos estratégicos de la privatización en Venezuela. En: Privatización en Venequela. Caracas: La Estrella, Serie Debates.

Ramos, A., 1998. Conferencia presentada ante el Postgrado de Planificación Urbana, mención Politicay Acción Social Local. Caracas: Instituto de Urbanismo, Facultad de Arquitectura y Urbanismo, Universidad Central de Venezuela.

República de Venezuela, 1931. Reglamento de la Ley de Sanidad Nacional. Gaceta Oficial N $N^{\circ} 17.512$. Caracas.

República de Venezuela, 1942. Ley de Sanidad Nacional. Gaceta Oficial $N^{\circ}$ 20.846. Caracas.

República de Venezuela, 1962. Normas para el proyecto de construcción, reparación y reformas de edificios. Caracas: Ministerio de Sanidad y Asistencia Social.

Rivero, J., 1994. Les deux finalités du service public industriel et commerciel. Cabiers Juridiques de l'Electricité et du Gas, junio: 44-48.

Stoffaës, Ch., 1995. Services publics, question d'avenir. París: Odele Jacob. 
VIOLENCIA Y DROGAS EN LA SALUD PÚBLICA 


\section{LA VIOLENCIA DESDE LA PERSPECTIVA DE LA SALUD PÚBLICA}

Rodrigo Guerrero*

\section{INTRODUCCIÓN}

Se estima que en las Américas mueren anualmente cerca de 140 mil personas de manera violenta. Para muchos países la violencia es la primera causa de muerte en la población general, y en casi todos es la primera causa de Años de Vida Saludable Perdidos (Avisas). Se estima que el 14\% del Producto Interno Bruto de la región se pierde por la violencia. La violencia y la inseguridad ocupan el primer lugar en la preocupación ciudadana en la casi totalidad de los países. Paradójicamente, a pesar de la gran importancia del problema, apenas recientemente se ha comenzado a tocar el tema en foros internacionales y, más recientemente, las agencias bilaterales de crédito han comenzado a financiar intervenciones orientadas a la prevención en algunos países.

Violencia es un término que se utiliza para significar una gran variedad de situaciones, y por esta razón se generan muchas controversias y confusiones. Por otro lado, la violencia puede ser mirada desde la perspectiva de diferentes profesiones y con intereses distintos. Las ciencias sociales y del comportamiento miran la violencia desde el ángulo del agresor, y su motivación fundamental se orienta a buscar los factores que llevaron a cometer el acto violento. Las ciencias jurídicas y penales se orientan a estudiar la naturaleza del hecho y la forma de sancionarlo. Las ciencias de la salud, hasta hace poco tiempo, se habían limitado a atender a las víctimas de la violencia, sin preocuparse mucho por la prevención. Cada una de estas perspectivas posee una terminología propia y es, a veces, fuente de confusión. Un hecho aparentemente sencillo de clasificar, como el homicidio, tiene diferentes interpretaciones. Así, por ejemplo, las ciencias jurídicas y penales excluyen aquellos casos en los que la muerte fue producto del uso legal de la fuerza (si ocurrió por causa del enfrentamiento con las fuerzas de la ley o producto de la aplicación de la pena de muerte, en los países en donde existe). Para la salud pública, todas las muertes se contabilizan como homicidios.

En este trabajo se pretende presentar el enfoque de salud pública aplicado al estudio y diseño de estrategias preventivas para el caso de la violencia.

\section{LA VIOLENCIA Y LA SALUD PÚBLICA}

Héctor Abad Gómez, un ilustre y visionario salubrista colombiano, planteó la violencia como el principal problema de la salud pública colombiana desde comienzos de la década de los cincuenta. La violencia como un problema de salud pública es una idea relativamente nueva, escribió en 1985 Everett Koop, el "surgeon general" de Estados Unidos (Koop, 1989). El mismo Koop declaró, en 1992, la violencia como una emergencia de salud pública para Estados Unidos. En 1993, los ministros de Salud de las Américas, reunidos en el Consejo Directivo de la Organización Panamericana de la Salud, decretaron que la violencia era prioridad de salud pública en las Américas (OPS, 1993); a su vez, la 49ª Asamblea Mundial de la Organización Mundial de la Salud aprobó una resolución similar (WHO, 1996).

Al contrario de lo que se piensa generalmente, la salud pública y la epidemiología no son ciencias que estudian únicamente las enfermedades infecciosas. La epidemiología es una parte de la salud pública que se dedica a estudiar las causas de la enfermedad, y si bien en una etapa temprana estuvo centrada en

Médico egresado de la Universidad del Valle, Cali, Colombia. PhD en Epidemiología por la Universidad de Harvard. Actualmente labora en la Fundación Carvajal, Cali, Colombia. E-mail: guerrerr@norma.net. 
las enfermedades producidas por agentes infecciosos, posteriormente se aplicó a las enfermedades producidas por agentes químicos o del ambiente físico y más recientemente a aquellas de naturaleza social (Guerrero, González \& Medina, 1981).

\section{CONCEPTO DE CAUSALIDAD EN LA SALUD}

\section{PÚBLICA}

Una contribución muy importante de la salud pública al estudio de la violencia es la forma de abordar el concepto de causalidad Para la epidemiología, la causalidad se interpreta siempre en términos de probabilidad. Esto quiere decir que para un determinado factor ser considerado causa, basta solamente con que su presencia aumente (o disminuya, si el factor previene) la enfermedad. En términos más precisos, se habla de causa cuando existe una asociación directa, para diferenciarla de las asociaciones indirectas, o aquellas donde dos factores aparecen asociados entre sí debido a que ambos dependen de un factor común (Guerrero, González \& Medina, 1981).

Aun en ausencia de un factor considerado como causal, la enfermedad puede seguirse presentando debido a que pueden existir otros factores que producen el mismo efecto o, al menos, uno muy similar. Esta característica, llamada multicausalidad, es especialmente aplicable al caso de la violencia, donde una variedad de factores producen un efecto muy similar. Por esta razón, es mejor hablar de violencias en vez de violencia, y más que buscar la causa única de la violencia, es mejor buscar los diversos factores que la producen o se asocian con ella.

Este concepto puede entenderse mejor con el ejemplo de la tuberculosis. Existe un factor llamado "bacilo tuberculoso" que caracteriza la enfermedad; sin embargo, su sola presencia no asegura que la enfermedad se produzca. De hecho, sólo unas pocas de las personas que se exponen al bacilo desarrollan la enfermedad. Para que la tuberculosis se desarrolle es necesario, además de la exposición al bacilo, la presencia de otros factores, tales como un sistema inmunitario deficiente, desnutrición y hacinamiento. La epidemiología llama a estos factores "factores de riesgo". La importancia de ellos, desde el punto de visto práctico, radica en que la incidencia de tuberculosis se puede disminuir, tanto disminuyendo la exposición al bacilo como mejorando el estado nutricional o el sistema inmune.

El caso de la enfermedad cardiovascular (ECV) tiene una analogía de especial aplicación al caso de la violencia. Se sabe que la ECV es causada por la acumulación de grasas en las arterias del organismo, por un proceso metabólico propio de cada persona, regulado genéticamente. Como tal, el factor genético es, al menos por el momento, imposible de controlar. Pero también se sabe que hay otros factores de riesgo, tales como la dieta, el consumo de cigarrillo, la falta de ejercicio físico, el estrés, etc., que pueden aumentar el riesgo de desarrollar la ECV. El modificar estos factores de riesgo ha sido la única forma de controlar la ECV y con esta estrategia se han logrado resultados muy importantes.

La violencia se puede analizar de manera similar. Se puede decir que en la especie humana hay un factor genético que impulsa a la agresión, a la agresividad, y que la especie humana comparte con otras especie inferiores (gráfico 1). Sobre el impulso a la agresión se ha comenzado a conocer mucho recientemente. Se han identificado los sitios anatómicos donde se asienta y se empieza a conocer la naturaleza de los mediadores químicos, neurotransmisores, que permiten su expresión. Sin embargo, por el momento, estos conocimientos no han llegado todavía a tener consecuencias prácticas; pero la experiencia ha mostrado que también existen otros factores que permiten o impiden que la agresividad se manifieste como un comportamiento violento. Dada la incapacidad de alterar el factor genético, la mejor alternativa para el control de la violencia es trabajar sobre sus factores de riesgo. En esta presentación se discutirán algunos de los factores de riesgo de la violencia más importantes.

\section{LA ESTRATEGIA DE LA SALUD PÚBLICA PARA}

\section{SITUACIONES DE CAUSA DESCONOCIDA}

La salud pública y la epidemiología han diseñado una estrategia sencilla y práctica para abordar el manejo de enfermedades cuya causa se desconoce. En general la estrategia está compuesta de cinco etapas: 
1. Definir claramente el problema o enfermedad en cuestión.

2. Estudio de las variables descriptivas (quién, dónde, cuándo) y de los factores de riesgo asociados con el problema.

3. Planteamiento de hipótesis explicativas y diseño de posibles intervenciones.

4. Evaluación de los resultados obtenidos, y

5. Rediseño de las intervenciones a la luz de los resultados.

\section{DeFinición DE VIOLENCIA}

Existen múltiples formas de definir la violencia. La violencia se puede definir según la persona que la sufre: en violencia contra los niños, la mujer o el anciano; según la naturaleza de la agresión: en física, psicológica, sexual, etc.; según el motivo o razón aparente: en política, racial, etc.; según el sitio donde ocurre: en doméstica o del ambiente del trabajo, urbana, rural, etc.

Una categoría de violencia que merece destacarse, por razón de su importancia práctica, es la de violencia intencional o no intencional. En la primera categoría caen todos aquellos actos donde existe la voluntad de ocasionar daño. Dentro de la segunda, caen los tradicionalmente llamados "accidentes". Es preferible utilizar el término violencia no intencional al de accidentes, que comúnmente se asocia con actos imprevisibles o producto de la mala suerte.

Otra categoría que merece especial mención, por su extraordinaria frecuencia y por sus implicaciones sociales, es la violencia que ocurre en el hogar: la violencia doméstica, que puede ser contra la mujer, la infancia o el anciano. La violencia doméstica, la que ocurre alrededor del ambiente del hogar, tiene dos grandes categorías: la violencia contra la mujer y la violencia contra el menor. A pesar de la dificultad de medir estas violencias - ya que involucran componentes sicológicos, sexuales, físicos y hasta abandono- y de la escasez de estudios, toda la evidencia sugiere que son muy prevalentes y que están en aumento. Un estudio reciente estima que el número de niños maltratados en EEUU aumentó de 1,4 a 2,8 millones entre 1986 y 1993 (Shalala, 1996).
Un estudio realizado en Chile mostró que en uno de cada cuatro hogares del área metropolitana de Santiago, la mujer es agredida por su pareja y que en $60 \%$ de los hogares se vive violencia, en sus diversas formas, dentro de la pareja (Larraín, 1996).

\section{FACTORES DE RIESGO PARA LA VIOLENCIA}

A continuación discutiremos algunos de los factores de riesgo más conocidos, dando especial énfasis a aquellos donde la evidencia empírica ha corroborado la teoría.

\section{Alcohol}

Se sabe que el consumo de alcohol produce cambios metabólicos importantes en el organismo, especialmente en algunos de los neurotransmisores que intervienen en la violencia (Pihl \& Peterson, 1993). Por otro lado, se sabe que el consumo desmedido de alcohol se asocia con casi todas las formas de violencia, especialmente cuando su consumo es episódico y se da en ciertos ámbitos culturales (Parker, 1993). Coleman y Straus (1983) encontraron que las tasas de violencia contra la mujer eran 15 veces mayores en aquellos hogares en donde se informaba de alcoholismo del marido. Una revisión de cinco estudios de homicidios mostró que entre 47 y 68\% de las víctimas habían consumido alcohol (Murdoch, Pihl \& Ross, 1990), y otros estudios han mostrado elevados niveles de consumo de alcohol entre los agresores o victimarios (García \& Vélez Cano, 1992). Los datos provenientes del programa Desepaz en Cali, Colombia, indican que el $56 \%$ de los homicidios ocurren en los tres días del fin de semana, y una cuarta parte de ellos ocurren el día domingo (Espitia \& Velasco, 1999). Igualmente, se observa un incremento desproporcionado de homicidios en los días de celebraciones especiales, como el día de la madre, la época de Navidad, la noche de año nuevo, los triunfos deportivos, etc. Este comportamiento, junto con la observación de que la mayoría ocurren en horas de la noche, refuerza la asociación con el consumo de alcohol, conocido como factor de riesgo en otras latitudes (Mark, Rosenberg \& Fenley, 1991). J.L. Londoño (1996) encontró una correlación significante entre la incidencia de alcoholismo y las tasas de 
1. Definir claramente el problema o enfermedad en cuestión.

2. Estudio de las variables descriptivas (quién, dónde, cuándo) y de los factores de riesgo asociados con el problema.

3. Planteamiento de hipótesis explicativas y diseño de posibles intervenciones.

4. Evaluación de los resultados obtenidos, y

5. Rediseño de las intervenciones a la luz de los resultados.

\section{DEFINICIÓN DE VIOLENCIA}

Existen múltiples formas de definir la violencia. La violencia se puede definir según la persona que la sufre: en violencia contra los niños, la mujer o el anciano; según la naturaleza de la agresión: en física, psicológica, sexual, etc.; según el motivo o razón aparente: en política, racial, etc.; según el sitio donde ocurre: en doméstica o del ambiente del trabajo, urbana, rural, etc.

Una categoría de violencia que merece destacarse, por razón de su importancia práctica, es la de violencia intencional o no intencional. En la primera categoría caen todos aquellos actos donde existe la voluntad de ocasionar daño. Dentro de la segunda, caen los tradicionalmente llamados "accidentes". Es preferible utilizar el término violencia no intencional al de accidentes, que comúnmente se asocia con actos imprevisibles o producto de la mala suerte.

Otra categoría que merece especial mención, por su extraordinaria frecuencia y por sus implicaciones sociales, es la violencia que ocurre en el hogar: la violencia doméstica, que puede ser contra la mujer, la infancia o el anciano. La violencia doméstica, la que ocurre alrededor del ambiente del hogar, tiene dos grandes categorías: la violencia contra la mujer y la violencia contra el menor. A pesar de la dificultad de medir estas violencias - ya que involucran componentes sicológicos, sexuales, físicos y hasta abandono- y de la escasez de estudios, toda la evidencia sugiere que son muy prevalentes y que están en aumento. Un estudio reciente estima que el número de niños maltratados en EEUU aumentó de 1,4 a 2,8 millones entre 1986 y 1993 (Shalala, 1996).
Un estudio realizado en Chile mostró que en uno de cada cuatro hogares del área metropolitana de Santiago, la mujer es agredida por su pareja y que en $60 \%$ de los hogares se vive violencia, en sus diversas formas, dentro de la pareja (Larraín, 1996).

\section{FACTORES DE RIESGO PARA LA VIOLENCIA}

A continuación discutiremos algunos de los factores de riesgo más conocidos, dando especial énfasis a aquellos donde la evidencia empírica ha corroborado la teoría.

\section{ALCOHOL}

Se sabe que el consumo de alcohol produce cambios metabólicos importantes en el organismo, especialmente en algunos de los neurotransmisores que intervienen en la violencia (Pihl \& Peterson, 1993). Por otro lado, se sabe que el consumo desmedido de alcohol se asocia con casi todas las formas de violencia, especialmente cuando su consumo es episódico y se da en ciertos ámbitos culturales (Parker, 1993). Coleman y Straus (1983) encontraron que las tasas de violencia contra la mujer eran 15 veces mayores en aquellos hogares en donde se informaba de alcoholismo del marido. Una revisión de cinco estudios de homicidios mostró que entre 47 y $68 \%$ de las víctimas habían consumido alcohol (Murdoch, Pihl \& Ross, 1990), y otros estudios han mostrado elevados niveles de consumo de alcohol entre los agresores o victimarios (García \& Vélez Cano, 1992). Los datos provenientes del programa Desepaz en Cali, Colombia, indican que el 56\% de los homicidios ocurren en los tres días del fin de semana, y una cuarta parte de ellos ocurren el día domingo (Espitia \& Velasco, 1999). Igualmente, se observa un incremento desproporcionado de homicidios en los días de celebraciones especiales, como el día de la madre, la época de Navidad, la noche de año nuevo, los triunfos deportivos, etc. Este comportamiento, junto con la observación de que la mayoría ocurren en horas de la noche, refuerza la asociación con el consumo de alcohol, conocido como factor de riesgo en otras latitudes (Mark, Rosenberg \& Fenley, 1991). J.L. Londoño (1996) encontró una correlación significante entre la incidencia de alcoholismo y las tasas de 
homicidio en varias regiones del mundo. Según el estudio de las autopsias de Cali, mencionado en la obra citada, un $25 \%$ de las víctimas estaban intoxicadas con alcohol. Resultados similares, aunque con una proporción mayor de intoxicación en las víctimas, han sido informados para Medellín (García \& Vélez Cano, 1992) y para toda Colombia (Mora et al., 1994).

\section{Armas DE FUEGo}

El incremento en las tasas de homicidio de Estados Unidos observado en los últimos años, se debe al aumento de los homicidios producidos por armas de fuego, ya que los producidos por otras causas han permanecido constantes (The Carter Center, 1994). Según el mismo estudio del Centro Carter, mencionado en la referencia anterior, se ha observado que el $80 \%$ de los homicidios de jóvenes en Estados Unidos son producidos por armas de fuego. Estudios realizados en otras partes han permitido identificar la proliferación de armas de fuego como un factor de riesgo, especialmente por cuanto tornan más letal la agresión y, por eso, recomiendan la restricción en la venta y el porte de las mismas (Sloan et al., 1988). Se ha demostrado que la posesión de un arma de fuego incrementa 2,7 veces el riesgo de muerte para los integrantes del hogar (Kellerman et al., 1993).

Según el citado informe del Instituto de Medicina Legal de Colombia, en 1994 el 80\% de los homicidios de Colombia fueron ocasionados con armas de fuego. Cifras idénticas se muestran para Cali y Medellín. Una información de la Policía Metropolitana de Bogotá muestra que el 31,3\% de las armas incautadas en la Comisión de Delitos habían sido vendidas por la Industria Militar de Armamentos y que un 20\% de ellas estaban amparadas por un permiso legal (Alcaldía Mayor de Santafé de Bogotá, 1996). Según estos datos de la Alcaldía de Bogotá, en 1994 se expidicron 156.283 permisos para portar o tener armas de fuego en esa ciudad. Si a esta cifra se suman las armas cortopunzantes y las de fuego que no están amparadas legalmente, se puede deducir fácilmente que esta ciudad tiene una proliferación extraordinaria de instrumentos letales de agresión.

\section{Cultura De la Respuesta VIOLENTA AL}

\section{CONFLICTO}

Un volumen importante de publicaciones revela que el comportamiento violento se comienza a gestar desde la temprana infancia, y que las prácticas y creencias acerca de la educación de los hijos favorecen o dificultan el comportamiento violento del adulto (Slaby et al., 1995). Las diversas sociedades tienen patrones culturales más o menos violentos para la solución de sus conflictos. Así, por ejemplo, en algunos países la solución del conflicto rara vez llega a la violencia, mientras que en otras partes la solución violenta aparece legitimada. Baron y Straus observaron una relación entre el homicidio y un índice de "violencia legítima", que refleja diferentes normas culturales en diferentes estados de EEUU (Baron \& Straus, 1988). El establecimiento de una cultura del honor ha sido postulada como causa explicativa de los altos niveles de violencia en los estados del sur de EEUU (Cohen \& Nisbett, 1994). Un estudio sobre actitudes y normas culturales mostró que el $40 \%$ de los ciudadanos de Río de Janeiro aprueban, o al menos entienden, a quien manda a matar al violador de su hija (Piquet-Carneiro, 1997). La pérdida de la influencia reguladora de la Iglesia Católica, que con sus diez mandamientos era la norma de convivencia ciudadana, ha sido postulada como una de las razones de los altos índices de violencia en Colombia (De Roux, 1996). Los movimientos guerrilleros prevalentes en América Latina y el narcotráfico también han contribuido, sin duda, a legitimar la violencia y a establecer patrones de respuesta violenta al conflicto.

Conocer las actitudes hacia el comportamiento violento en sus diferentes modalidades fue el objeto de un estudio multicéntrico patrocinado por la Organización Panamericana de la Salud, realizado en varios países del continente (OPS, 1996). Este estudio permitirá ver la correlación entre los diferentes comportamientos violentos y las actitudes de la sociedad, y permitirá diseñar estrategias educativas para modificar positivamente esas creencias culturales. 


\section{IMPUNIDAD E INEFICACIA DE LA JUSTICIA Y}

\section{DE LA FUERZA POLICLAL}

La selección de la respuesta a una ofensa se ve influida por las actitudes relativas hacia otras estrategias posibles (Deutsh, 1993). La percepción ciudadana de la inoperancia del sistema judicial y la poca credibilidad de la policía, son otro factor de riesgo que creemos está operando en muchas partes de la región de las Américas, porque llevan a la aplicación de la justicia por la propia mano, es decir, a la legitimación de la violencia. Los datos de DesEPAZ en 1983 mostraban que en únicamente el $6 \%$ de los homicidios de Cali se lograba identificar al agresor. Datos de Bogotá y Medellín mostraban resultados similares. Si se tiene en cuenta que sólo una pequeña parte de aquellos agresores identificados será finalmente sancionada, podemos ver que la bajísima probabilidad de castigo puede estimular el comportamiento agresivo.

\section{VIOLENCIA EN LOS MEDIOS MASIVOS DE}

\section{COMUNICACIÓN}

Para la Sociedad Norteamericana de Sicología no existe duda de que el despliegue de violencia en los medios de comunicación estimula el comportamiento violento, especialmente en jóvenes (Donnerstein, Slaby \& Eron, 1994). Y, además, se asocia con bajo rendimiento escolar, angustia, temor, depresión y aislamiento emocional (Bell \& Jenkins, 1991). Existen múltiples ejemplos de comportamiento delictivo moldeado de acuerdo con los comportamientos observados en el cine y la televisión. El inusitado despliegue de violencia por parte de los medios, especialmente de los programas de noticias, contribuye a estimular el fenómeno de la violencia y a percibir el entorno de manera que estimule a algunos a tomar la justicia por sus propias manos. Frente a la controversia sobre el papel de los medios de comunicación, es necesario insistir que el despliegue de la violencia en los medios es un factor de riesgo, cuyo efecto se suma a los mencionados anteriormente. Dicho de otra manera, no es que los medios de comunicación sean la causa única de la situación de violencia que se observa en las Américas, sino que el despliegue desproporcionado que se hace de la violencia contribuye a incrementarla.

\section{ViOLENCIA ENTRE PANDILLAS (GANGS)}

$\mathrm{El}$ análisis de los homicidios muestra que éstos ocurren predominantemente en varones, jóvenes y muchas veces en menores de edad. Estados Unidos posee las tasas de homicidios más altas entre los países económicamente desarrollados, y una parte muy importante de ellos se debe a los homicidios de jóvenes, los cuales aumentaron un 47\% entre 1980 y 1994 (U.S. Department of Justice, 1996).

Según los datos citados anteriormente del Instituto de Medicina Legal de Colombia, en este país los homicidios afectan predominantemente a los hombres jóvenes, entre 15 y 34 años, con una relación de 13 hombres por cada mujer. Aun cuando la información disponible sobre los agresores es muy escasa, la poca existente parece indicar que éstos tienen las mismas características demográficas de las víctimas. Esto es, son hombres jóvenes, provenientes de estratos socioeconómicos bajos (García \& Vélez Cano, 1992).

En algunos casos, como en Estados Unidos, una gran parte de la violencia homicida es producida por las pandillas juveniles (llamadas maras en Centroamérica). En la ciudad de Los Angeles, California, Estados Unidos, por ejemplo, el porcentaje de homicidios atribuido a pandillas fue de $43 \%$ para el año 1994 (mientras que en 1979 había sido 18\%) (Hutson et al., 1995).

A pesar de la gran complejidad del problema de la violencia juvenil, la evidencia aportada por varias investigaciones permite concluir que existe una relación clara entre problemas de la infancia y la niñez y la criminalidad de los jóvenes, ocasionada por una relación defectuosa entre la familia y los padres con el niño, futuro criminal (Wright \& Wright, 1995). Entre los factores de riesgo para la violencia juvenil se han identificado: familias inestables, padres abusadores o alcohólicos y fallas en la educación afectiva de los niños (Protrow-Smith, 1991); la exposición a violencia física y sexual en los medios de televisión; consumo de alcohol y drogas; y deserción escolar y desempleo juvenil (Guerrero, 1996a, 1996b). Los programas que 
buscan controlar la violencia se han orientado hacia el control de los diversos factores de riesgo. Una experiencia exitosa en el manejo de la violencia juvenil es la desarrollada por Slaby, basada en el desarrollo de un curriculum especial diseñado para enseñar a los jóvenes violentos otras formas de responder a la agresión (Slaby, Wilson-Brewer \& Dash, 1994). El programa Desepaz, de la ciudad de Cali, ha utilizado el empleo de los jóvenes a través de microempresas como estrategia para controlar la violencia juvenil (Guerrero et al., 1994).

\section{Pobreza, DESIGUALDAD SOCIAL Y}

\section{MARGINALIDAD}

En Estados Unidos las tasas de homicidio, para todas las razas, son 2,5 veces mayores en los niveles socioeconómicos bajos que en los altos (Baker et al., 1992). Los datos del programa Desepaz de Cali muestran, igualmente, una tasa más elevada de homicidios entre los niveles socioeconómicos bajos (Guerrero et al., 1994). Sin embargo, en otros estudios, con datos a nivel nacional, no se ha podido encontrar una asociación entre los niveles de pobreza y las tasas de homicidio (Londoño, 1996). Desde 1973 hasta 1993 la pobreza en Colombia, medida bien por necesidades básicas insatisfechas o por ingreso, ha venido disminuyendo. A pesar de la aparente contradicción, posiblemente basada en problemas metodológicos, no parece haber duda de que la violencia intencional urbana se presenta con mayor frecuencia en los grupos socioeconómicos más bajos (Guerrero, 1996a). Los pobres son a la vez agresores y agredidos. Para algunos, más que la pobreza absoluta, lo que importa es la pobreza relativa, la cual lleva a una sensación de rechazo, frustración e incapacidad y produce una "angustia flotante libre" que facilita la agresión (Ramey, L., citado en ProtrowSmith, 1954).

La asociación entre pobreza y violencia es de difícil interpretación, dado los múltiples factores de carácter social y educativo que se asocian con la pobreza. Junto con los bajos ingresos los pobres sufren de deprivaciones de carácter múltiple, las cuales pueden ser factores de violencia. Lo único claro parece ser que la erradicación de la pobreza y de las desigualdades deben ser parte integral de cualquier programa de lucha contra la violencia.

\section{DISEÑO DE INTERVENCIONES Y EVALUACIÓN}

El éxito de la aplicación de la estrategia de salud pública radica en diseñar las intervenciones a partir de una identificación correcta de los factores de riesgo. No sobra insistir sobre este aspecto fundamental porque los factores de la violencia pueden ser diferentes de un lugar a otro o, al menos, tener una importancia relativa distinta. La contribución de la violencia de pandillas a la criminalidad urbana en EEUU es mucho mayor que en la mayoría de las ciudades de América Latina. Por otro lado, la presencia de grupos guerrilleros urbanos, que es importante en algunas ciudades colombianas, no lo es en muchas otras partes de la misma región. No existe una receta única que sea aplicable en todos los lugares.

Finalmente, para completar la aplicación de la estrategia, se hace necesario diseñar mecanismos de evaluación que permitan conocer si las intervenciones diseñadas se están aplicando correctamente (indicadores de desempeño) y si están produciendo los resultados esperados (indicadores de resultado). Es preciso reconocer las dificultades de evaluar procesos sociales complejos, donde es muy difícil tener las condiciones apropiadas para un experimento, pero es necesario insistir en la importancia y necesidad de la evaluación de resultados.

Una evaluación de la política de restricción en el porte de armas de fuego implantada en Cali durante 1994 durante fines de semana seleccionados, mostró una reducción significativa en los homicidios por armas de fuego mientras que no se observaron cambios en los homicidios producidos por otros medios (Villaveces, Espitia \& Kellermann, 1994). Es posible, sin embargo, que la reducción observada pudiera haber sido causada por otras razones, como mayor presencia policial en las calles o mayor cuidado de la población ante el despliegue de medios que acompañaban la medida. En el caso de Bogotá, el conflicto entre las Fuerzas Armadas y la Alcaldía sobre quién tenía la facultad de controlar las armas, provocó una situación durante la cual la ley de porte de armas no pudo aplicarse durante un período. Una 
evaluación posterior de esta situación mostró un incremento en homicidios por armas de fuego durante el levantamiento de la medida, con lo cual se reforzó la validez de la hipótesis.

En el caso del consumo de alcohol, y desde el punto de vista de la prevención, se ha podido constatar que medidas como la restricción en la venta de alcohol en sitios públicos, leyes semisecas o leyes zanahorias, en Colombia, han mostrado su efecto benéfico en Cali, y más recientemente en Bogotá (Centro de Referencia Nacional sobre Violencia, 1996). En un estudio de los 48 estados contiguos de Estados Unidos para el período 1979-1988, se correlacionaron las tasas de criminalidad con el consumo de alcohol (cerveza, vino y licores destilados) y los impuestos a la cerveza, y se encontró que un incremento del $10 \%$ en los impuestos de la cerveza reduciría las tasas de homicidios en $0,3 \%$, la de violaciones en 1,32\%, la de agresiones en un $0,3 \%$ y la de asaltos a mano armada en un $0,9 \%$ (Cook \& Moore, 1993).

Unas aplicaciones de la estrategia de salud pública en la prevención de la violencia y la promoción de la convivencia ciudadana a nivel nacional la han constituido los créditos del Banco Interamericano de Desarrollo para Colombia (CO0231) y Uruguay (UR0118). En ambos casos se ha partido de un diagnóstico de la situación realizado a partir de estudios epidemiológicos y se han diseñado estrategias que abarcan varios de los factores de riesgo identificados. En ambos casos también se ha puesto especial cuidado en el desarrollo de criterios de evaluación (yardsticks) que permitirán evaluar los resultados.

\section{BREVE ANÁLISIS EPIDEMIOLÓGICO DE LA}

\section{VIOLENCIA COLOMBIANA}

En el gráfico 2 se muestran las tasas de homicidio en Colombia. Hay varias observaciones importantes que pueden hacerse. Una primera observación de importancia es el notar que los puntos más bajos del gráfico están alrededor de 20/100.000, tasa que sería considerada como "epidémica" en muchos países del mundo. Dicho de otra manera, la tasa de homicidios más baja observada durante el período en cuestión sería alarmantemente alta en otras partes.

A título de hipótesis pensamos que el alto nivel de base pueda ser explicado por el establecimiento en Colombia de una cultura de la respuesta violenta ante el conflicto (De Roux, 1994). Colombia tiene una larguísima lista de guerras civiles y una muy vieja trayectoria de movimientos guerrilleros, que pueden haber ido estableciendo en la sociedad la tendencia a solucionar los conflictos a la fuerza y no a través del diálogo y la concertación. Sin embargo, si bien esta hipótesis podría explicar el alto nivel de base, no parece ser suficiente para explicar la elevación drástica que se observa al comienzo de la década de 1980. Los cambios culturales evolucionan de una manera mucho más lenta.

La hipótesis explicativa de esta elevación por la urbanización creciente, no está sustentada por los datos. La más grande concentración urbana del país, Bogotá, tiene una tasa menor que la de Medellín y Cali. Ciudades intermedias como Manizales, Cúcuta y Bucaramanga tienen tasas alrededor de 100, mientras que ciudades pequeñas como El Dovio, El Aguila y Toro, en el Valle del Cauca, están alrededor de 300 homicidios/100.000 habitantes. Sale de toda consideración y merece explicación diferente la tasa de 800/100.000 registrada para Apartadó (Suárez \& Ospina, 1995).

El incremento de la pobreza es otra de las hipótesis explicativas de la violencia esgrimida con bastante frecuencia. Sin embargo, los datos disponibles tampoco parecen explicar el aumento. La pobreza en Colombia desde 1973 hasta 1993, medida bien por necesidades básicas insatisfechas o por ingreso, ha venido disminuyendo (Pérez Piñeros, 1995). La hipótesis de la pobreza tampoco coincide con la comparación del nivel de ingreso per cápita con las tasas de violencia de las diferentes regiones de Colombia, donde puede verse que las más pobres no son las más violentas. Otras hipótesis explicativas, como son la proliferación de armas de fuego o el consumo de alcohol, ambos conocidos factores de riesgo para la violencia, tampoco parecen haber aumentado en forma tan dramática en los últimos años como para poder explicar el extraordinario aumento observado desde los años ochenta. La 
hipótesis de que los colombianos son violentos por naturaleza, esto es, por razones genéticas, de ninguna manera podría explicar un cambio tan acelerado como el observado desde 1980. La hipótesis genética tampoco serviría para explicar las extraordinarias variaciones que existen entre las ciudades colombianas.

El cambio más llamativo en la sociedad colombiana ocurrido en los últimos quince años es la aparición del tráfico de drogas y el crimen organizado, como fenómenos de importancia que han afectado todas las esferas de la vida nacional y, quizás por eso, deba considerarse como la mejor hipótesis explicativa del incremento. Los datos del programa DesepAz en Cali parecen sugerir que el gran efecto del narcotráfico es indirecto, esto es, afectando las diversas formas de funcionamiento de la sociedad, destruyendo el capital social, y no exclusivamente a través de la violencia que los narcotraficantes ejercen directamente. Es necesario recordar, sin embargo, lo mencionado arriba acerca de la multicausalidad de la violencia.

\section{CONCLUSIONES}

La gran bondad del enfoque de salud pública radica en su aproximación empírica, basada en la observación de los hechos para tratar de deducir de ellos las reglas o principios generales. Otra bondad especial del enfoque de salud pública es su enfoque práctico, orientado a la prevención, a través de la identificación y control de los factores de riesgo operantes en un momento dado y en una situación específica. Para el caso de la violencia es claro que no existe una solución única, sencilla, para resolver este complejo problema. Los factores de riesgo son diferentes en cada entorno, y si bien es cierto que muchos de ellos son comunes, su contribución ponderada puede ser diferente. Para hacer las cosas mas dificiles, no todos los factores de riesgo son susceptibles de manejo. Tratándose de complejos problemas sociales y culturales, no es probable una respuesta pronta, aun en el caso de que las intervenciones planteadas sean las correctas, y debemos por lo tanto prepararnos para plazos medianos y largos durante los cuales se debe continuar trabajando.

El mejoramiento de la justicia y de la policía son componentes fundamentales de la solución de la violencia tal como se aprecia en muchas ciudades de América Latina, pero no deben ni pueden convertirse en el único mecanismo de respuesta. Un análisis reciente sugiere que los mecanismos represivos y punitivos tradicionales se vuelven insuficientes cuando los niveles de violencia y homicidios pasan de un cierto nivel. Colombia y la mayoría de los países de América Latina parecen haber pasado hace tiempo ese umbral.

Pero por encima de todo, es necesario darle a la violencia la importancia y prioridad política que el problema merece y lograr que los gobernantes se comprometan a controlarla. Solo así se podrán movilizar los recursos y las voluntades de todos los ciudadanos, requisito sin el cual es imposible resolver el problema.

\section{REFERENCIAS BIBLIOGRÁFICAS}

Alcaldía Mayor de Santafé de Bogotá, 1996. Plan Desarme (folleto). Bogotá: Alcaldía Mayor de Santafé de Bogotá.

Baker, S.; O’Neill, B.O.; Gisnburg, M.J. \& Li, G., 1992. The injury fact book. Oxford, NY: Oxford University Press.

Baron, L. \& Straus, M.A., 1988. Cultural and economic sources of homicide in the United States. The Sociological Quarterly, 29 (3):371-390.

Bell, C.C. \& Jenkins, E.J., 1991. Traumatic stress and children. Journal of Health Care for the Poor and Underserved, 2:175-185.

Centro de Referencia Nacional sobre Violencia, 1996. Evaluación de la efectividad de las medidas de control adoptadas en Santafé de Bogotá en 1995. Boletin CRNV, 6 (Bogotá: Instituto Nacional de Medicina Legal y Ciencias Forenses).

Cohen, D. \& Nisbett, RE., 1994. Self-protection and the culture of honor. Explaining southern violence. Personality and Social Psychology Bull, 20(5):551-567.

Coleman, D.H. \& Straus, M.A., 1983. Alcohol abuse and family violence. En: Alcobol, drug abuse and aggression (E. Gottheil, K.A. Druley, T.E. Skoloda \& H.M. Waxman, eds.). Springfield IL: Charles C. Thomas. 
Cook, P.J. \& Moore, M.J., 1993. Economic perspectives on reducing alcohol-related violence. En: Alcobol and Interpersonal violence: Fostering multidisciplinary perspectives. Rockville, MD: U.S. Department of Health and Human Services National Institute of Health. National Institute of Alcohol Abuse and Alcoholism, Research Monograph 24.

De Roux, F., 1996. Etica pública y ética religiosa. Conferencia Interamericana sobre Sociedad, Violencia y Salud, Memorias. Washington DC: Organización Panamericana de la Salud.

De Roux, G., 1994. Ciudad y violencia en América Latina. En: Ciudad y violencias en América Latina (A. Concha, F. Carrión \& G. Cobo, eds.). Quito: Programa de Gestión Urbana, Serie Gestión Urbana vol. 2.

Deutsh, M., 1993. Educating for a peaceful world. American Psychologist, 510-517

Donnerstein, E.; Slaby, R.G. \& Eron, L.D., 1994. The mass media and youth aggression. Reason to Hope. A psychological perspective on violence and youth. Washington, DC: American Psychological Association.

Espitia, V.E. \& Velasco, P.C., 1999. Atlas de las muertes violentas en Cali 1993-1997. Cali: Consejería para el Desarrollo, la Seguridad y la Paz / Alcaldía de Santiago de Cali.

García, H.I. \& Vélez Cano, C.H., 1992. Caracterización de la muerte violenta por homicidio en Medellín en la década de los ochenta. Tesis de maestría, Medellín: Facultad Nacional de Salud Pública, Universidad de Antioquia.

Guerrero, R., 1996a. Epidemiología de la violencia en la región de las Américas. El caso de Colombia. Trabajo presentado en la Segunda Conferencia Anual del Banco Mundial para el Desarrollo en América Latina y el Caribe. Bogotá.

Guerrero, R., 1996b. La violencia como problema de salud pública. La experiencia colombiana. Conferencia Interamericana sobre Sociedad, violencia y salud, Memorias. Washington DC: OPS.
Guerrero, R.; Concha, A.; Alvarez, A.A. et al., 1994. Programa de desarrollo, seguridad y paz, Desepaz. Estrategias de la Alcaldía de Cali para enfrentar la inseguridad y la violencia. En: Ciudad y violencias en América Latina (A. Concha, F. Carrión \& G. Cobo, eds.). Quito: Programa de Gestión Urbana.

Guerrero, R.; González, C.L. \& Medina, E., 1981. Epidemiología. Bogotá / Caracas: Fondo Educativo Interamericano S.A.

Hutson, H.R.; Anglin, D.; Kyriacou, D.N. et al., 1995. The epidemic of gang-related homicides in Los Angeles County from 1979 through 1994. JAMA, 274(13): 1031-1036.

Kellerman, A.L. et al., 1993. Gun ownership as a risk factor for homicide in the home. NEJM, 329: 1084-1091.

Koop C.E., 1989. Injury prevention: meeting the challenge. A report of the National Committee for Injury Prevention and Control. Oxford, Nueva York: Oxford University Press.

Larraín, S., 1996. Violencia familiar y la transmisión de pautas de comportamiento social. Trabajo presentado en el encuentro de reflexión Hacia un Enfoque Integrado de Desarrollo: Etica, Violencia y Seguridad Ciudadana. Washington DC: Banco Interamericano de Desarrollo.

Londoño, J.L., 1996. Violencia, psychis y capital social. Trabajo presentado en la Segunda Conferencia Anual del Banco Mundial para el Desarrollo en América Latina y el Caribe. Bogotá.

Mark, L.; Rosenberg, M. \& Fenley, A. (eds.), 1991. Violence in America: a public bealth approach. Oxford, New York: Oxford University Press.

Mora, R.; Sánchez, M.D.; Suárez, G.I. \& Hernández, W.H., 1994. Reporte del comportamiento de las lesiones fatales en Colombia, 1994. Bogotá: Centro de Referencia Nacional sobre Violencia, Instituto Nacional de Medicina Legal y Ciencias Forenses.

Murdoch, D.; Pihl, R.O. \& Ross, D., 1990. Alcohol and crimes of violence: present issues. International Journal of the Addictions, 25(9): 1065-1081. 
Organización Panamericana de la Salud, 1993. Resolución XIX, aprobada en la XXXVII Reunión del Consejo Directivo. Washington DC: OPS.

Organización Panamericana de la Salud, 1996. Actitudes y normas culturales sobre la violencia en ciudades seleccionadas de la región de las Américas. Proyecto Activa. Washington DC: OPS, División de Salud y Desarrollo Humano.

Parker, R.N., 1993. The effects of context on alcohol and violence. Alcobol Health \& Research World, 17 (2): 117-122.

Pérez Piñeros, M.J., 1995. La situación social en Colombia. Planeación y Desarrollo, 26(3): 85 123.

Pihl, R.O. \& Peterson, J.B., 1993. Alcohol, serotonin and aggression. Alcohol Health \& Research World, 17 (2): 113-116.

Piquet-Carneiro L., 1997. Estudio sobre las normas culturales y actitudes respecto a la violencia en Río de Janeiro (comunicación personal).

Protrow-Smith, D., 1991. Deadly consequences: bow violence is destroying our youth and a plan to begin solving the problem. Nueva York: Harper Collins.

Protrow-Smith, D., 1954. Deadly consequences. Nueva York. Harper Collins.

Shalala, D.E., 1996. Informe a los empleados del Departamento de Health and Human Services sobre el National Incidence Study. Washington DC: National Center on Child Abuse and Neglect.

Slaby, R.G.; Roedell, W.C.; Arezzo, D. \& Hendrix, K., 1995. Early violence prevention. Tools for teachers of young children. Washington, DC: National Association for the Education of Young Children.

Slaby, R.G.; Wilson-Brewer, R. \& Dash, K., 1994. Aggressors, victims and bystanders: tbinking and acting to prevent violence. Newton, MA: Education Development Center.

Sloan, J.H. \& Kellerman, A.L. et al., 1988. Handgun regulations, crime, assaults and homicide. NEJM, 319:1256-1262.
Suárez, G.; Ospina, C.F. \& Duque, M., 1995. Homicidio colectivo en la hacienda Las Tortugas, Apartadó. IQCB, 1(5):32-34.

The Carter Center, 1994. The report of the Carter Center Consultation on the crisis of children and firearms. Not Even One. One Copenhill, Atlanta GA: The Carter Center.

U.S. Department of Justice, 1996. Jwenile offenders and victims: 1996 update on Violence. Washington DC: U.S. Department of Justice, National Center for Juvenile Justice.

Villaveces, A.; Espitia, V.E. \& Kellermann, A., 1994. Effect of a disarmament strategy on homicides in Cali, Colombia. Cali: mimeo.

World Health Organization, 1996. Resolucion WHA 49.35, aprobada por la $49^{\circ}$ Asamblea Mundial de la Salud. Ginebra: WHO.

Wright, K.N. \& Wright, K.E., 1995. Family life, delinquency and crime: a policymaker's guide. Washington DC: U.S. Department of Justice, Office of Juvenile Justice and Delinquency Prevention. 
Violencia Urbana

FACTORES DE RIESGO

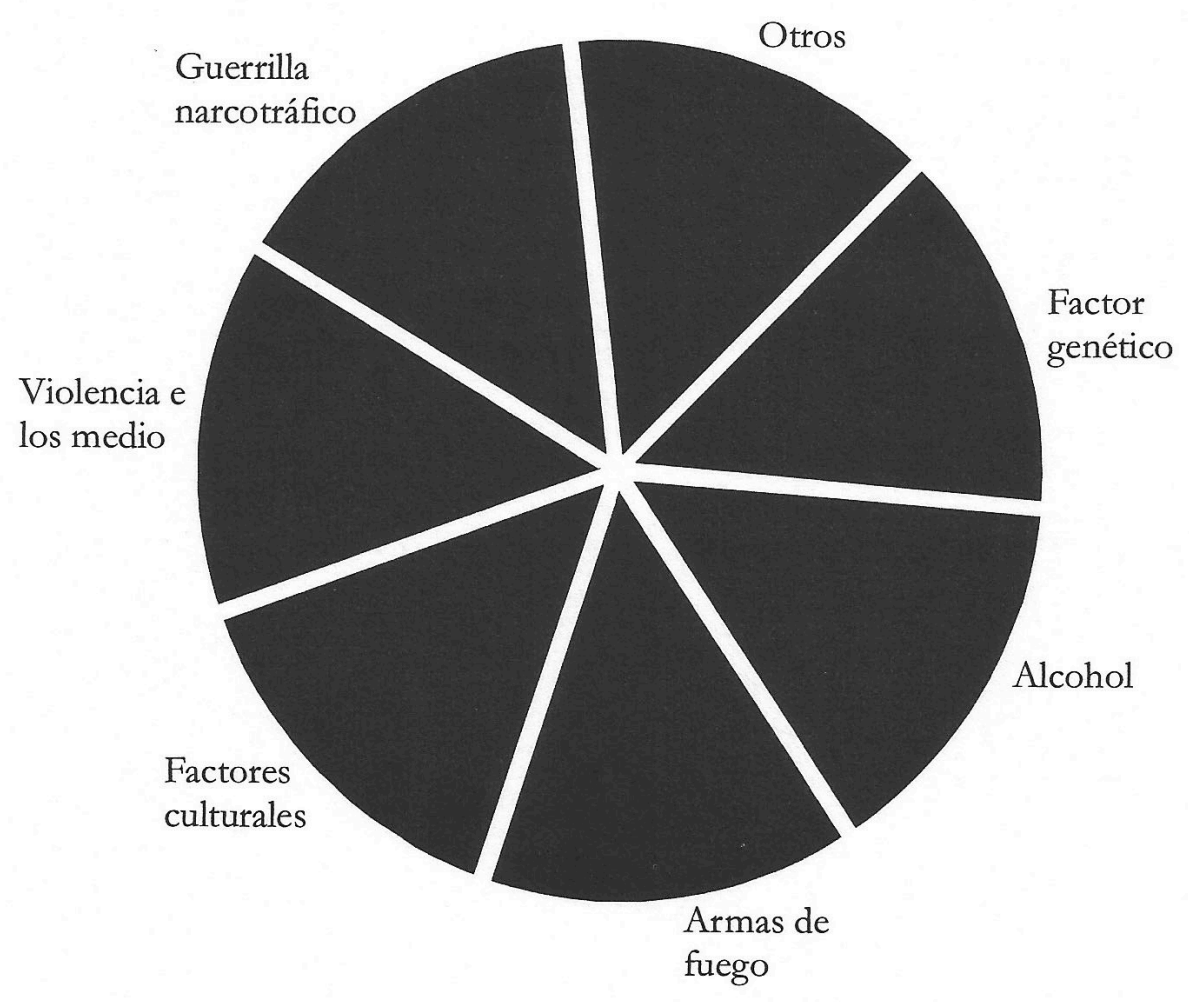

TASAS de Homicidios en Colombia

1938-1995

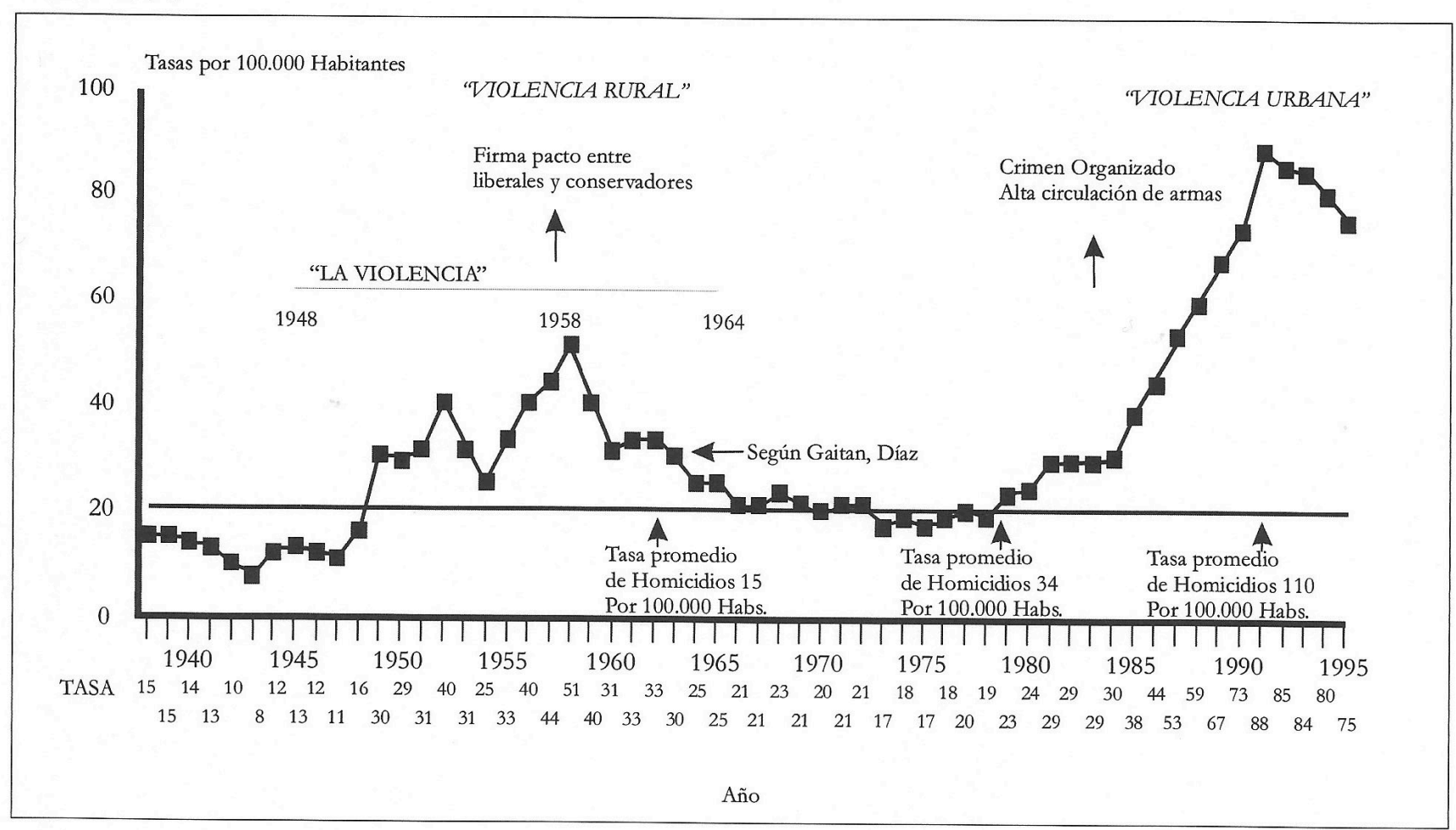

Fuente: DANE (1938-1990). Gaitan F. y Diaz J. - Planeación Bogotá. POLICIA NACIONAL (1991-1995) 


\title{
LAS VIOLENCIAS, LA SALUD PÚBLICA Y LA CIUDADANÍA
}

\author{
Magally Huggins C.
}

\section{INTRODUCCIÓN}

Una cita de Daniel Levine (1996) que anota Héctor Silva Michelena al analizar las políticas sociales en Venezuela en los años ochenta y noventa, sirve para introducir este trabajo:

Hoy día (la época dorada) parece un sueño. El excepcionalismo ha sido reemplazado por lo que muchos en Venezuela llaman la latino americanización de su país. Junto con la declinación económica, la inflación, los vaivenes monetarios que crean la obsesión por el dólar, el colapso institucional, la decadencia política y el resurgimiento de la política personalista. El crecimiento del crimen, la violencia civil, conspiraciones y golpes militares, esta latinoamericanización de Venezuela ha reemplazado el orgullo y las esperanzas del futuro por la desesperación, la ira sin propósito, y por un sentimiento de traición (Levine, 1996, citado por Silva Michelena, 1999:93-94).

Silva Michelena introduce la cita anterior señalando que "Levine ya había visto que la 'tacita de plata' que los venezolanos pensábamos que éramos, se hacía pedazos ante una realidad que, cual alquimista invertido, transformaba esos pedazos de un metal precioso en restos de metales viles" (Silva Michelena, 1999:93-94).

Las violencias son expresiones del trabajo del alquimista; las maneras en que ellas han venido presentándose e interactuando a través de las últimas dos décadas han sido claramente detectadas por el termómetro de lo social. La violencia criminal, quizás la fresa que adorna el postre (para decirlo coloquialmente), es lo que más vemos, aunque no sea el único y más negativo de los indicadores de ese trabajo de antialquimia.
Voy a tratar de acercarme a los que serían - a mi manera de ver- el proceso, los ingredientes principales de la mezcla que el alquimista invertido ha utilizado en su pócima envilecedora. La violencia del desmoronamiento institucional de la democracia venezolana de los últimos años; la violenta impunidad; la violenta exclusión social y política, y la devaluación de la vida, todos ellos sazonados por un toque permanente de noticias sensacionalistas, han generado un estado de inseguridad colectiva que se traduce en miedo, desesperanza y pérdida de sentido de futuro.

\section{AlgunAS PRECISIONES NECESARIAS}

Nuestra primera precisión es que partimos de una concepción de violencia que incluye no sólo aquellos actos en los cuales los actores que participan - ya sea como sujeto activo o pasivo- pueden ser identificados como personas concretas. Compartimos la posición que sostiene que existen situaciones sociales que son - porque implican la acción de una fuerza sobre determinados sujetos que los saca de su estado natural y que produce en ellos/as un daño- formas de violencia en las cuales los actores no pueden ser personalizados y, por lo tanto, su intención manifiesta no existe, ya que se expresan a través de procesos políticos, económicos o sociales que actúan excluyendo a una población - no a una persona determinada-, ejerciendo sobre ella lo que conocemos como violencia estructural.

Esta, a su vez, se convierte en un elemento fundamental que potencia el desarrollo de las múltiples expresiones de la violencia, al articularse con las características concretas de los/as individualidades que se construyen en esta atmósfera, aumentando la probabilidad de que en estos sectores se genere un

Psicóloga social egresada de la Universidad Central de Venezuela y Magister en Criminología de la California State University. Profesorainvestigadora del Centro de Estudios del Desarrollo (CENDES) de la Universidad Central de Venezuela. E-Mail: magalyhuggins@,cantv.net. 
número cada vez más elevado de acciones violentas, de actores concretos, contra sujetos pasivos determinados.

Algunas exclusiones pueden ser vividas como individuales, pero esto no elimina su calidad de fenómeno colectivo que afecta a muchas personas o a un sector de la población, que son violentadas por acción u omisión de las instituciones del Estado, responsables de garantizar los derechos fundamentales de todos y todas. De esta manera, también articulamos la violencia estructural o sistémica con la violación de los derechos humanos, por omisión de la acción inmediata y oportuna de las instituciones del Estado.

Otra precisión necesaria es sobre qué entendemos por salud pública. Tomamos la definición de Saúl Franco, quien la define como

la situación y sensación de bienestar colectivo, los respectivos conocimientos sobre su naturaleza, determinantes, manifestaciones y funcionamiento, $y$ las consiguientes prácticas sociales y estatales para garantizarlo (Franco, 1995:32).

Queremos centrarnos básicamente en la primera parte de la definición anterior, ya que para nosotros es el elemento fundamental cuando hablamos de la relación entre violencia y salud pública. La situación y sensación de bienestar colectivo es quizás lo primero que se deteriora frente a los problemas que las violencias generan en una comunidad determinada. Particularmente, cuando la violencia delictiva se produce en las ciudades en donde las condiciones de vida se han venido deteriorando violentamente, como en nuestro caso, el clima de la vida cotidiana, su atmósfera, se vuelve densa, viscosa; las inseguridades se potencian y no hay ninguna posibilidad medianamente coherente de sentirse parte de una situación o sensación de bienestar colectivo. Como dice el mismo autor,

Si la salud pública es una cierta situación de bienestar colectivo y la consiguiente sensación de desarrollo y disfrute de la vida de las personas y sus diferentes colectivos, la violencia es una fuerza de signo contrario. Ella dificulta o impide el adecuado funcionamiento orgánico, descompone la estructura individual y social, y amarga e imposibilita la vida (Franco, 1995:24).
$Y$ éste es el sentido que queremos dar a este trabajo. No es sólo el problema de la violencia delictiva y su secuela de muertos e incapacitados el problema de la violencia en los países latinoamericanos, y no podemos entenderla desde sí misma. Su complejidad como fenómeno y su estruendosa presencia en la vida cotidiana no son sólo un hecho, un dato fáctico que debemos interpretar y entender desde la ciencia; son también un complejo entramado sociopolítico que se articula con las dinámicas propias del conflicto social en cada uno de nuestros países.

Sobre la base de lo anterior, planteamos que desde los años ochenta la salud pública en Venezuela está confrontando un marcado y continuo proceso de deterioro debido a la desposesión de los derechos más elementales a que la democracia política vigente ha sometido a las mayorías del país, desde el derecho a la vida hasta el derecho a ser —o sentirse - parte de un colectivo con derechos sociales, económicos, políticos, civiles, es decir, humanos. El derecho a la felicidad ha sido boicoteado por el deterioro marcado del llamado estado de derecho, por la impunidad, por la exclusión social, por la pérdida de legitimidad de un orden político en donde "el Estado ha perdido su capacidad y su autoridad para pautar y mediar los conflictos sociales y que, en consecuencia, no sólo el uso de la fuerza sino también la decisión sobre la vida de las personas quedan al arbitrio de otros poderes y esquemas valorativos" (Franco, 1995:26).

Hagamos una revisión de los elementos del contexto de la pérdida de la situación y sensación de bienestar colectivo. El orden de presentación no sigue un criterio jerárquico del impacto que cada uno de estos procesos ha tenido y tiene sobre la salud colectiva. Sostenemos que de acuerdo a las coyunturas sociopolíticas y económicas, estos procesos ganan o pierden relevancia en la construcción social de la inseguridad, de la desprotección y del desamparo colectivo.

\section{IMPUNIDAD, ILEGALIDAD E ILEGITIMIDAD DEL ESTADO}

Si bien las violencias en sus más agudas expresiones son un problema común en América 
Latina, existen diferencias en las dinámicas de cada país que merecen ser consideradas.

Luis Gómez C. afirma que "una particularidad del Estado social venezolano ha sido la relativa abundancia de recursos con la que ha contado, provenientes en lo fundamental de los impuestos a la exportación petrolera" (Gómez, 1997:285). Esta particularidad marcó la forma como se administró la riqueza, así como la forma en que se organizaron las instituciones del Estado y la cultura venezolana. La renta del petróleo permitió un determinado modelo de desarrollo (rentista) en el cual, por su riqueza, el Estado era el principal actor económico. De él dependieron, y aún dependen en mayor o menor grado, los empresarios; las fuentes de trabajo más importantes estaban en sus manos, lo cual nos convirtió en trabajadores por excelencia de la administración del Estado. El desarrollo de la democracia representativa, sustentada en la renta petrolera y la obediencia militar, fue un proceso facilitado por la presencia de partidos fuertes, populistas, que poco a poco cooptaron todos los procesos de mediación entre el Estado, la renta petrolera y la población. En Venezuela la expresión papá Estado se hizo realidad.

Podríamos decir que hasta comienzos de los años ochenta, la mayoría de la población venezolana percibía una estabilidad político-social que de alguna manera significaba que todos y todas accedíamos al beneficio de la renta petrolera. Los menos, directamente, en dinero constante y sonante; los más, a través del acceso a la educación, la salud, el trabajo remunerado en el sector formal de la economía o como empleados públicos.

Venezuela, la tacita de plata de la democracia latinoamericana, vivía desde 1958 en un estado de derecho fundado en un consenso sobre la libertad política de todos y todas, y la igualdad de participación de los ciudadanos. Éramos un sistema político en el cual venezolanos y venezolanas, a través del voto elegíamos a nuestros representantes políticos, con muy bajos índices de abstención, ${ }^{1}$ y en el cual se confiaba en la legalidad y legitimidad de las instituciones que conformaban el Estado.
Para comienzos de la década de los ochenta, aun los menos beneficiados podían acceder a la educación y aspirar a mejorar su calidad de vida, vía la meritocracia. La mayoría de los venezolanos y venezolanas de hoy somos producto de esta Venezuela democrática, más del 60\% menores de 50 años para el año 2000, y por ende demócratas en el sentido de la vida. Pero, la impunidad socavó las bases de ese sentido de democracia en la población.

Luis Gómez C. establece cuatro problemas centrales del proceso venezolano de deslegitimación del sistema político:

1. Se generalizó la percepción de un grave déficit de justicia, tanto en el sentido general de "justicia social" y equidad como en el sentido más preciso e institucional, definido por la capacidad que debe tener una sociedad de contar con un poder judicial eficaz e independiente.

2. El tema de la concentración del poder en pocas manos, tanto en el seno del sistema político como en el de la sociedad civil. Dicha concentración es cada vez más criticada, y su presencia denunciada tanto en las estructuras organizativas de los actores sociales y políticos, como en la organización jerárquica y territorial del Estado.

3. Los dos factores anteriores se combinaron, en el discurso crítico de los actores sociales, como explicaciones de la creciente importancia y visibilidad de la corrupción en todos los espacios institucionales y niveles de decisión. En efecto, dado el hecho generalmente reconocido del estrecho control del sistema judicial por las jerarquías partidistas, la lucha contra la corrupción aparecía como estructuralmente condenada al fracaso.

4. Finalmente, y como síntesis de los problemas señalados, se destaca la cuestión del Estado y de su rol en la sociedad, dada su creciente incapacidad para hacer frente a las responsabilidades económicas y sociales que había asumido en los años de crecimiento y consolidación democrática (Gómez, 1995:104-105).

1 No porque el voto fuera obligatorio, lo cual era y sigue siendo, sino por el profundo sentimiento de participación democrática que significa acudir a las urnas electorales. 
Lo anterior nos habla de un proceso complejo que solapadamente fue construyendo el desencanto. $\mathrm{Si}$ bien este proceso degenerativo de la institucionalidad ha teñido todos y cada uno de los espacios de la vida colectiva y las instancias gubernamentales, la percibida y sentida como más impactante para el colectivo es la del sistema de justicia. Por la corrupción interna de sus miembros a todo nivel, tanto los que hacen el trabajo limpio (jueces) como los que hacen el trabajo sucio (policías). La politización interna lo ha convertido en un apéndice de los principales partidos políticos tradicionales que nombran y destituyen jueces, o los mandan voluntaria o involuntariamente- de vacaciones o transitoriamente fuera del tribunal, para que un juez accidental produzca la sentencia esperada. La penetración del narcotráfico y la impunidad generalizada en todas las circunscripciones judiciales (civil, penal, mercantil, tributario, laboral, militar, etc.) ha destruido la credibilidad en sus decisiones, produciendo un sentimiento de que todos son culpables aunque se demuestre lo contrario, especialmente en cuanto a juicios políticos, a banqueros y otros altos funcionarios, independientemente de que esta culpabilidad no sea jurídicamente sancionada.

La importancia de la percepción de impunidad sobre la salud pública en Venezuela ${ }^{2}$ viene dada por varias razones. Primero, la incidencia de la violencia delictiva. Las cifras de mortalidad por homicidios en el país han mantenido un proceso creciente en los últimos años, particularmente en las principales ciudades. "Mientras que la tasa nacional de homicidios se incrementa dos veces y media entre 1986 y 1996 , en el área metropolitana de Caracas, en ese mismo período, se incrementa más de cuatro veces" (Sanjuán, 1997:17). ${ }^{3}$ De acuerdo al Ministerio de Sanidad según las partidas de defunción, la tasa de muertes por homicidios en 1996 asciende a 14,9 por 100.000 habitantes, lo cual implica 5,98 años de vida potencialmente perdidos por 1.000 habitantes de $1 \mathrm{a}$
70 años (MSAS, 1996). Quizás lo más impactante sea la avasallante presencia de varones jóvenes entre los muertos y los victimarios de la violencia delictiva. Estos datos son confirmados por las diferentes investigaciones hechas en el país, con variaciones numéricas derivadas de las diferentes fuentes ${ }^{4}$.

Esta realidad del incremento de los homicidios en Venezuela se une al incremento de otros delitos, como lesiones personales, arrebatón, robo y hurto de vehículos, etc. Sin embargo, son los homicidios los que se han convertido en centro de la inseguridad de los venezolanos y las venezolanas, puesto que su incremento y la manera como son presentados y manejados a través de los diferentes medios de comunicación, hacen de éstos una presencia o riesgo constante y generalizado en la percepción de la colectividad.

Sin embargo, es de hacer notar que sigue siendo, como en años anteriores, primordialmente una violencia intraclase; básicamente en los barrios, entre miembros de las comunidades aledañas o de las mismas comunidades. Esta violencia ha variado cualitativamente. Es más cruel el ensañamiento y la muerte por pertenencias de poco valor o por no tener nada de valor. Se mata de manera directa sin que medien otras alternativas. También ha aumentado la presencia de acciones violentas asociadas a delitos contra la propiedad, tales como robo/lesiones y robo/violación ${ }^{5}$.

Desde el punto de vista de la salud pública, un delito que ha aumentado entre los años ochenta y los noventa, y que produce un gran deterioro dentro del grupo familiar, son las lesiones personales. Éstas generan la principal morbilidad por violencia, que deteriora la calidad de vida de un grupo familiar ante la presencia de la pérdida de capacidades de trabajo, de interacción cotidiana en la comunidad, y dentro del grupo familiar, por las graves secuelas físicas y psicológicas que producen y los costos económicos,

2 Si bien existen diferencias entre las áreas rurales y urbanas, es de recordar que Venezuela es un país eminentemente urbano, el cual para el año 2000, según el CELADE, tendrá el $82 \%$ de la población en las principales ciudades, en las cuales se manifiesta, de manera creciente, la misma situación de inseguridad con pocas variaciones significativas.

3 Sin embargo, los datos del MSAs no reproducen este crecimiento. Mientras la mortalidad general — de acuerdo a los certificados de defunción - se mantiene estable, la tasa de homicidios por 100.000 habitantes casi se duplica entre 1986 y 1996.

4 Según el MSAs entre 1986 y 1995 el 40\% de los muertos por violencia estaban entre los 15 y 24 años.

5 Esta afirmación se desprende de los datos de la Policía Técnica Judicial. 
que pueden llevar a la desesperación a una familia debido a la poca capacidad adquisitiva de los ingresos frente al costo de la salud. Recordemos que los lesionados son en su mayoría jóvenes varones que pueden quedar incapacitados de muchas maneras, y cuya incorporación posterior a la vida útil como minusválidos es casi imposible en nuestro país, por no haber condiciones institucionales y por el índice creciente de desempleo, especialmente entre los jóvenes.

Quiero hablar ahora de otro tipo de delitos, que si bien aparecen en las estadísticas policiales con una incidencia moderada porque generalmente no son denunciados, son particularmente destructivos de la seguridad ciudadana. Ante ellos, la respuesta propuesta desde las instancias institucionales es que las mujeres se encierren en sus casas, que es el lugar de donde nunca debieron salir. Me refiero a los delitos mal llamados contra las buenas costumbres y el buen orden de las familias. Entre 1983 y 1997 éstos oscilan entre un 3 y un 6 por ciento del total de los delitos conocidos por la Policía Técnica Judicial (PTJ). Sin embargo, sabemos que la violación, el más violento de todos estos delitos, es reconocida como el delito que tiene una mayor cifra negra en el mundo en cuanto a denuncias policiales. Su tasa de ocurrencia conocida para el Distrito Federal presenta un incremento de 21,9 en 1985 a 27,3 por 100 mil en 1994 (Ocei/Pnud/Fnuap, 1997:199).

Estos delitos tienen una carga de inseguridad que socialmente se proyecta al futuro de manera oprobiosa. La cultura sexista y la discriminación de las mujeres en nuestra tradicional visión judeocristiana de la vida hace que las víctimas de estos delitos sean consideradas culpables aun siendo inocentes, y si son niñas, la culpa será de las madres o los padres que no supieron cuidarlas. Esta visión de la violación, compartida socialmente en Venezuela, deja a estas víctimas sumidas en una enorme soledad y desprotección, en la vivencia de un absoluto desamparo.

Sabemos lo destructivo que es para un grupo familiar un acto delictivo de este tipo, ya que con frecuencia son cometidos por personas conocidas, en el contexto de relaciones en la comunidad o aun dentro del grupo familiar, y que por lo general, quedan encubiertos por la duda. Sus consecuencias pueden ser letales porque pueden llevar no sólo al suicidio de la víctima, al homicidio - de ella o el victimariopor parte del esposo que se siente engañado o ultrajado, el padre o algún otro miembro masculino del grupo familiar, sino que también desorganiza la vida de relaciones de toda la familia y en particular de la pareja y produce generalmente el abandono o el divorcio, y lo que es más grave aún, es frecuente la presencia del embarazo por violación. Esto, en un país en donde el aborto no existe legalmente para estas mujeres victmizadas.

Éstas son también consecuencias de la violencia que afectan la salud pública, que han pasado desapercibidas durante años, quizás por la presencia evidente del sexo como instrumento en estos delitos y por la discriminación de género, ya que sus víctimas fundamentalmente son mujeres.

Una segunda razón de la percepción de impunidad se refiere a la eficiencia de la acción policial. Según información del Cuerpo Técnico de Policía Judicial, en promedio, durante los últimos quince años (1983-1997) la PTJ concluye y pasa a los tribunales el $45 \%$ de los casos que conoce. Es decir, que se van acumulando casos no resueltos a los cuales no se les da respuesta. Esos casos concluidos, por lo general, incluyen detenidos. Los autores del 55\% de los casos restantes quedan sin intervención de la policía. Esto nos explica la alta incidencia de múltiples delitos o amplio historial que cada delincuente apresado posee, como indiciado cuando es detenido por un delito, pero también nos habla de la ineficiencia policial.

Como es de esperar, la mayoría de los delitos (un promedio de 68,3\%) que conoce la PTJ son delitos contra la propiedad, siendo en 1987 el 78,3\% y el más bajo $59,2 \%$ en 1992; pero solamente el 50\% de esos casos son concluidos y remitidos a los tribunales. En cuanto a los delitos contra las personas, constituyen en los últimos quince años el 16\% de los delitos conocidos por la PTJ y solamente se concluye en promedio el 30,6\%, y no siempre con detenidos $(22,8 \%)$. Esto nos indica que, más allá del uso que los medios de comunicación hacen de la epidemia delictiva en el país, lo que parecería estar sucediendo es que la acción policial represiva prevista por el Estado para dar respuesta a los delitos contra la vida y propiedades de la gente es absolutamente ineficiente. 
Otros datos interesantes son los relativos a los sancionados por la Ley de Salvaguarda del Patrimonio Público entre 1988 y 1997, en particular corrupción de funcionario, peculado y soborno. En promedio, en diez años éstos constituyen solamente el $0,01 \%$ de los casos conocidos y el $0,06 \%$ de los casos concluidos y remitidos a los tribunales. Podemos así constatar que la percepción común de inseguridad jurídica, por la falta de atención a los casos que atentan contra nuestra seguridad, debido a la impunidad de los autores de los mismos, es en buena parte un reflejo de la realidad.

Algo similar sucede con los delitos contra la Ley de Sustancias Estupefacientes y Psicotrópicas. De acuerdo con los datos de la PTJ, entre 1988 y 1997 estos delitos constituyen en promedio el 3,6\% del total de casos conocidos, y sólo el $9 \%$ de ese porcentaje es concluido y remitido a tribunales.

Como vemos, no son tantos los delitos conocidos por la PTJ como los que suponemos debido a la información que circula en los medios de comunicación. No sólo por la amplia cobertura que reciben en demostración de la eficiencia policial (sic), sino también en el estilo que se utiliza para las noticias de sucesos, que permiten que sean percibidos más que cualquier otra noticia delictiva en los medios.

Sin embargo, quiero señalar que los medios de comunicación no solamente informan - como es un derecho nuestro y de los actores massmediáticos sobre la problemática de la violencia, sino que también participan en su construcción como forma de relación e instrumento válido en la resolución de conflictos. La violencia que proyectan los medios masivos de difusión dejó de ser la última alternativa ante los conflictos de la vida cotidiana, y pasó a ser la forma natural de resolución.

La violencia hace al héroe, ya no solamente al villano. Devalúa la justicia institucional y el Estado como único proveedor legítimo y legal de la misma, puesto que nunca sabemos si ese héroe violento es un representante legítimo de la justicia o no. Si lo es, su actuación solamente sirve para reforzar la impunidad de la violencia de los cuerpos policiales (incluyendo la policía política y la militar), pues su actuación violenta no responde a los cánones legales sino a lo que cada persona temerosa o victimizada desearía que suceda: aniquilar al delincuente.

Un tercer elemento importante en la percepción de la impunidad deslegitimadora del sistema político venezolano es la selección clasista de los chivos expiatorios. Como decíamos en 1996 (Huggins, 1996:43-44), los delitos contra nuestra propiedad cometidos por delincuentes de cuello blanco nunca llegan a los tribunales penales, sino a tribunales especiales. Quienes los cometen, nunca son sentenciados; para ellos no hay consideración de violentos, ni de delincuentes, ni de 'malos'. Ellos tienen leyes especiales, se fugan del país antes de que los juicios se concreten, o simplemente, tienen la protección de clase y de la moral clasista que los ampara, por ser del bando de los que tienen el poder.

Los policías, guardias nacionales o militares no son sentenciados por ningún tipo de delito, salvo que ellos sean de muy bajo rango, o al menos inferior al de sus víctimas. Cuando cometen delitos contra los bienes del Estado -o mejor dicho, de todos nosotros-, la condena no llega tampoco hasta ellos. Esta doble moral, cada vez más descarada en su ejercicio, también es fuente de corrupción y de violencia en el resto de la población desprotegida, desposeída de sus derechos y agredida, violentada por estos personeros del estatus.

Esta selección clasista ha permitido que quienes van a las cárceles venezolanas sean chivos expiatorios que pierden su condición de seres humanos dentro de los infiernitos" judiciales. Los "desechables", en palabras de Saúl Franco. Esto se puede entender desde dos aspectos. Primero, la selectividad de la acción policial hacia determinados sectores de la sociedad y cierto tipo de delitos. No queremos decir que los autores de homicidios no deban ir a la cárcel y que la mayoría de ellos no sean de clase baja, lo que queremos decir es que los delincuentes como los banqueros de la crisis del año 94, no deberían ser excluidos de las sanciones previstas en las leyes y de la persecución que sufren otros autores de delitos.

6 Infiernitos son llamados en el argot judicial aquellos lugares de castigo que llevan al paroxismo la injusticia y la arbitrariedad del castigo en las prisiones: incomunicación, hacinamiento en espacios mínimos y sin ventilación y servicios públicos, son las celdas de castigo de las prisiones venezolanas. 
Las leyes están hechas a favor del patrón, decía una canción de los años sesenta, y esto aún es así porque siguen fuera de las leyes penales aquellos delitos que son cometidos por personas de alto estatus social y económico. La propuesta de penalización de algunos delitos financieros junto con la despenalización del aborto, son algunas de las razones por las cuales el proyecto de Código Penal de 1984 no ha sido discutido en el Congreso de la República. Esta selección de los perseguidos no sólo nos ratifica quiénes son los malos y cuáles son las conductas malas, sino también indican a la población quiénes son los protegidos por la ley y por qué.

La segunda lectura de la selección de chivos expiatorios es que los perseguidos por la policía y sometidos a las prisiones venezolanas, incluso sin sentencias definitivas, son solamente un sector de los que corresponden a los llamados delincuentes comunes, y sobre éstos se centra toda la condena pública. Para ellos, hay exceso de violación de derechos pues son los que simbolizan la acción de la justicia contra los delincuentes. Ellos no son considerados humanos ni tratados como tales. De allí el lamentable estado de las prisiones venezolanas, consideradas entre las peores del mundo.

Allí se va a sobrevivir, si es posible. Su repetitivo ciclo de violencia interna y el para nadie importante número de muertos que en él se genera, evidencian que la vida de los que están adentro, no vale nada. Allín no se resocializa a nadie, allí se va a la cuarentena antes de la muerte, porque muchos de los que de ellas salen años después, han perdido hasta el sentido de la vida. No saben realmente para qué o por qué sobrevivieron (Huggins, 1996:46).

Y esta realidad carcelaria tiene también un sentido para la comunidad. Detrás de sus muros están los malos, y la angustia colectiva refrenda que allí el tratamiento sea lo más inhumano posible. Por ello, el que las prisiones sean no sólo un lugar de segregación sino también de sufrimiento, es aceptado como una manera de castigar a los de adentro y permitirnos un sentido de seguridad a los que estamos afuera. Por tanto, cuando se producen los motines, las muertes dentro de los penales venezolanos, no se protesta por la violación de los derechos humanos y, por el contrario, se considera que los que lo hacen solamente se preocupan por los derechos de los presos entiéndase los malos - y se olvidan de los derechos humanos de las víctimas de ellos. "En algunas circunstancias, la violación de los derechos de ciertos grupos no es percibida como tal, principalmente cuando el grupo es extraño, representa una amenaza o tiene un estatus inferior" (Cardia, 1994:28).

El retardo procesal, y por ende el hacinamiento de la población reclusa, es una de las violaciones de derechos humanos a los presos que motiva los constantes motines penitenciarios. Según ProvEA, para septiembre de 1997 la proporción entre los reclusos a la espera de una sentencia y los condenados era de $68,6 \%$ y $31,1 \%$ respectivamente, para una población total de 25.511 reclusos. Durante 1996, 207 presos fueron asesinados y 1.133 resultaron heridos, cifras levemente inferiores a las de 1995, cuando se registraron 239 muertes violentas y 1.241 heridos. Del total de 283 decesos contabilizados entre octubre de 1996 y septiembre de 1997, en 59 casos la responsabilidad recae en agentes del Estado (ProveA, 1998:107). Basta recordar los sucesos del 26 de octubre de 1996, cuando a través de los televisores pudimos presenciar - hasta el cansancio- la impactante imagen de 25 internos de La Planta calcinados dentro de su pabellón. "Otros diez meses después, 30 reclusos del Centro de Reeducación Agropecuario El Dorado, estado Bolívar, murieron a manos de compañeros de celda frente a la inacción de los efectivos militares" (PRoveA, 1988:114). Así, vemos como el sistema de justicia no cumple las funciones de rehabilitación que teóricamente le corresponden, sino que, por el contrario, potencia la rabia y el sentido de devaluación de la vida de quienes se encuentran en las cárceles, confirmándoles además que no hay vuelta atrás en la carrera delictiva de cada uno de ellos. De ahora en adelante los delitos serán más crueles; los cometidos por ellos, porque no hay vuelta atrás, como dijimos antes, y para los que se incorporan al mundo delictivo, porque la expectativa ante la violencia del sistema de justicia puede simplemente significar que cualquiera sea el crimen la pena será la misma. No hay mucho que perder.

En el desamparo de los presos, la colectividad no reacciona indignada ante estas masacres, sino que por el contrario empieza a pensar que mientras menos haya, mejor. Este proceso de exclusión moral de los 
seleccionados como chivos expiatorios para drenar nuestra rabia frente a la impunidad de la violencia y la injusta justicia, es un problema que se está generalizando en el continente. Como señala Nancy Cardia, refiriéndose a una masacre de presos en Brasil por la Policía Militar y a la reacción de las personas entrevistadas por los medios de comunicación apoyando la acción policial:

Esta ausencia de indignación en la aceptación de las violaciones del derecho a la integridad física por parte del Estado es a nuestro entender un síntoma muy peligroso para la construcción de una sociedad democrática. Sugiere la existencia de una ciudadanía frágil que ignora la relevancia de la defensa del derecho a la integridad física como condición de acceso a los derechos sociales, económicos, políticos y laborales. Revela además que puede estar en curso en esta sociedad un proceso colectivo de desactivación de los mecanismos de autocontrol moral (ProveA, 1988:16).

Esta realidad que nos plantea la autora se convalida con el silencio ante la violación de los derechos humanos de los más pobres. La muerte de los jóvenes en los barrios no sólo es obra de la delincuencia sino que también encubre dentro de ella la acción violatoria del derecho a la vida de parte de miembros de los cuerpos de seguridad del Estado.

Según el Programa Venezolano de EducaciónAcción en Derechos Humanos (Provea), la participación de agentes de los cuerpos de seguridad del Estado venezolano en violaciones al derecho a la vida aumentó de manera significativa, de 69 casos identificados entre octubre 1988/septiembre 1989 a 151 casos entre octubre 1996/septiembre 1997. Asimismo se ha hecho significativa la participación de los nuevos cuerpos policiales de los estados y municipios en estas acciones. Entre octubre de 1996 y septiembre de 1997 se consignaron 69 casos cometidos por miembros de las policías estatales y 15 por las policías municipales, es decir, el 55,6\% del total. Lo mismo sucede con las violaciones al derecho a la integridad personal; de los 526 casos de penas crueles, inhumanas y degradantes registrados por Provea en el mismo año, estas policías cometieron
241, o sea el $45,8 \%$, y el mayor número de heridos: $48(=40,3 \%)$ de los 119 casos registrados.

Esta es otra realidad, el cuarto elemento que coadyuva a la construcción social del miedo, ya no a los delincuentes sino a los miembros de los cuerpos policiales. Es expresión común en nuestro país que en las barriadas de las principales ciudades venezolanas se les teme tanto como a los malandros, a pesar de que lo esperado es que los cuerpos de seguridad no actúen como delincuentes en un estado de derecho. Lo que se espera en los barrios cuando llega la policía es muerte indiscriminada e injusticia generalizada. Desprotección, miedo e inseguridad es lo que se siente hoy frente a los agentes de seguridad policial. Así, la represión desatada en los barrios, que se supone va dirigida a proteger a la ciudadanía, se ha convertido en un factor de potenciación de la violencia, tanto de los delincuentes como de los habitantes de los barrios que son acosados por la policía y, sin derecho a juicio, considerados delincuentes por ser jóvenes y pobres.

Para concluir este punto sólo quiero reseñar una experiencia personal. Durante los últimos dos años, la Alcaldía de Chacao ${ }^{7}$ colocó una alcabala en la avenida Francisco de Miranda (recientemente fue eliminada) que se dedicaba a bajar de los carros de transporte público a los jóvenes trigueños, pobres, que venían en ellos. Recordemos que Chacao es paso obligatorio del oeste-centro hacia el este de la ciudad. Esta arbitrariedad humillante de parte de los policías de Chacao rara vez se traducía en arresto de algún joven, puesto que luego de ser bajados del carro, colocados contra la pared, cacheados en plena vía pública y chequeados los documentos, la mayoría eran nuevamente enviados a continuar su ruta en el transporte público, ya que no presentaban antecedentes $y$, generalmente, eran jóvenes estudiantes o en su mayoría trabajadores que iban de regreso al hogar.

Así, la impunidad contra los pobres en todas sus expresiones de parte de los cuerpos policiales, la injusta justicia que sanciona a los más pobres y absuelve a los más ricos y la precaria condición de las prisiones y cárceles venezolanas, han coadyuvado a la pérdida, no sólo de legitimidad de la democracia

7 Este es el municipio más rico de los cinco que conforman a la ciudad de Caracas y su área metropolitana. 
venezolana, sino también a su pérdida de legalidad, entendida ésta como,

el principio de acuerdo al cual todos los órganos del Estado, o sea, todos los que ejercen un poder público, se considera que actúan dentro del ámbito de las leyes, salvo en casos excepcionales establecidos expresamente, y legalizados también por el hecho mismo de haberse establecido expresamente (Bobbio et al., 1991:861).

El Estado venezolano ha fracasado al no "poner fin a la dispersión del poder armado en manos de particulares" (Vilas, 1996:5).

En síntesis, la pérdida de legitimidad y la ruptura de la legalidad al amparo de la corrupción del sistema de justicia y de la no aplicación de la justicia a todos por igual, genera un sentimiento de inseguridad y se constituye a su vez en caldo de cultivo, como dicen en el argot de la salud pública, de expresiones de violencias que radicalizan el sentimiento de desesperanza y desamparo que se desarrolla desde finales de los años ochenta en nuestro país. Veamos ahora el otro caldo de cultivo que, a mi manera de ver, ha afectado la situación y sensación de salud de los venezolanos y venezolanas de este fin de siglo.

\section{LA EXCLUSIÓN SOCLAL}

Paralelamente a este proceso de inseguridad jurídica, la exclusión se estaba consolidando de manera paulatina. La primera evidencia estaría en la consolidación y crecimiento de los barrios caraqueños y de las principales ciudades del país, en donde se hacinaron miles de venezolanos y venezolanas que buscaban acceder a la renta petrolera traducida en beneficios sociales. La escasez de vivienda se convirtió en un problema crónico y se construyeron en zonas de difícil acceso, sin condiciones sanitarias y de servicios públicos, pero cercanas a los centros del poder. Estos contingentes humanos se hicieron dependientes del sistema de la palanca a fin de poderse colocar en el trabajo, especialmente vía partidos políticos, ya que la capacitación laboral era escasa. Este sistema se convirtió en la referencia obligatoria para todos los sectores sociales, llegando el clientelismo y la corrupción a ser un instrumento generalizado de relaciones en los espacios políticos, económicos y sociales.

A la vez, en un país que construyó sus expectativas de bienestar viendo hacia el norte, con patrones de país desarrollado, el consumismo de las clases medias creció aparejado con la calidad de vida a que accedían: apartamento propio en urbanizaciones, hijos en colegios privados, más de un vehículo en la familia, viajes al exterior y apartamento vacacional en la playa, mujeres que no trabajaban por necesidad sino por desarrollo personal y esposos cuyos sueldos permitían mantener el nivel de vida del grupo familiar. Los sectores populares accedían sólo a niveles muy básicos de consumo pero las expectativas fueron estimuladas cada vez más por la publicidad y por el contraste cada vez mayor entre los niveles de opulencia de los sectores más poderosos del país y el consumismo desbordado de los sectores medios, frente a la marginalización cada vez mayor de aquéllos.

Nuestro proceso de modernización durante los últimos años generó espacios de participación vía descentralización y la incipiente organización de la sociedad civil; sin embargo, estos procesos no pudieron servir de contención ante la crisis del modelo económico y político evidenciada en la década de los ochenta, marcada por la deuda externa (acrecentada al incorporar la deuda privada como responsabilidad del Estado venezolano), por las políticas de ajuste y por las presiones del mercado internacional sobre la economía nacional. Los procesos de cambio del modelo económico y político de país rentista — rico - a país con grave crisis económica, se tradujeron en cambios violentos en las políticas distributivas del ingreso nacional, afectando la calidad de vida de la población. El crecimiento acelerado de la informalización y el desempleo en el sector formal, la caída del valor adquisitivo del salario, la profundización y feminización de la pobreza, la inflación creciente

8 Sistema informal a través del cual la única manera de obtener un trabajo, un beneficio social o cualquier derecho es a través de alguien con acceso a los canales de toma de decisión. Esto deteriora los sistemas formales de acceso a los derechos y beneficios sociales y abre paso al clientelismo político como 'pago al favor recibido'. 
aparejada con la crisis bancaria y las altas tazas de interés, echaron por tierra los proyectos y estilos de vida de una gran parte de la población.

La clase media se vio en un acelerado proceso de empobrecimiento que la obligó a generar alternativas de supervivencia, que en este caso buscaban mantener el estilo y nivel de vida, con una marcada angustia ante la amenaza de pérdida de estatus. Esto ha generado un gran descontento que se ha traducido en búsqueda de alternativas de distribución del mermado ingreso petrolero, con expresiones de rechazo hacia las políticas dirigidas a los sectores más desposeídos y, positivamente, una limitada pero creciente participación en organizaciones de la sociedad civil. Por otro lado, los sectores populares han visto profundizarse su pobreza. En 1994 FundACREDESA informaba que la situación de las mayorías del país era realmente aguda y de consecuencias a largo plazo.

Para 1990 el 78,19\% de las familias están en situación de pobreza en el país al considerar a) profesión del jefe de familia; b) nivel de instrucción de la madre; c) principal fuente de ingreso de la familia y d) condiciones de la vivienda. De estas el 40,34\% está en situación de pobreza crítica, es decir, viven en el nivel absoluto de privación y requieren de atención inmediata (estrato V), y el $37,85 \%$ lo constituyen aquellas familias de pobreza relativa, que no implica el nivel absoluto de privación (Acosta y Huggins, 1998:19).

Este proceso de profundización de la pobreza se acompañó de una pérdida de las esperanzas de ascender en el estatus, rompiéndose planes y proyectos de mejorar la calidad de vida a través del trabajo y la educación de los hijos. Los tradicionales canales de ascenso se trancaron aún más para los jóvenes de los sectores populares, la oferta de trabajo no los asimila y los salarios a los cuales tienen acceso no permiten alcanzar los mínimos bienes gratificantes que se venden a través de los medios de comunicación, la publicidad y los centros comerciales.

Estamos entonces hablando de un marcado proceso de exclusión social. Progresivamente, al profundizarse y ampliarse la pobreza, en nuestro país fue creciendo el número de familias que quedaron fuera del acceso a activos productivos, a créditos, a educación de buena calidad y, consiguientemente, a ingresos adecuados. Estas exclusiones se refuerzan mutuamente y conducen a 'círculos perversos', que dejan a extensos grupos humanos sin capacidades básicas de funcionamiento" (Kliksberg, 1999:37).

Obviamente esto reduce el acceso a la ciudadanía a esos sectores, puesto que, como sostiene el autor, junto a los derechos civiles y políticos un ciudadano debe tener derechos sociales. Su falta significa exclusión y es, en definitiva, un atentado a derechos humanos básicos (Kliksberg, 1999:37). El Índice de Desarrollo Humano de Venezuela afirma que para 1994 “... .la situación social y económica, entendida como la calidad de vida y las opciones que debe tener la gente para acceder a una vida digna y plena, ha desmejorado" (Ocei/Pnud/FnuAP, 1997: 42).

Esta marcada pérdida de la calidad de vida está acompañada por procesos de tipo psicosocial que se expresan en pérdida de la valoración personal, al vivir como individual el fracaso en la búsqueda de trabajo o de mejorar los ingresos necesarios para la sobrevivencia del grupo familiar. Esto se traduce a su vez en un sentimiento de desempoderamiento, es decir, de merma en la capacidad de asumirse actor y desplegar acciones y estrategias individuales $\mathrm{y} / \mathrm{o}$ colectivas que faciliten el acceso a los medios de vida socialmente reconocidos como valiosos.

Es decir, que la exclusión social se traduce en lo personal-individual en un cierre de oportunidades.

Otras veces la exclusión parece ser un proceso que además de impedir el acceso a bienes y servicios no crea ninguna perspectiva para superar esa situación; un ciclo que no se soluciona y que no tiene visos de cambiar. Eso sería la exclusión y no la pobreza; esto es, que la exclusión aparece cuando la pobreza no tiene perspectiva de superarse permitiendo la inserción en un nuevo ciclo de consumo (Fleury, 1999:74).

En síntesis podemos acordar con Sonia Fleury que

la exclusión tiene una dimensión que es cultural; no es un problema que puede ser medido como un atributo individual. La exclusión parece ser 
algo vivido dentro de una comunidad sociopolítica, se es excluido de los derechos sociales, de las instituciones, pero más que todo se la excluye de la condición humana, de la condición básica de pertenencia a esa comunidad (Fleury, 1999:75).

El Banco Mundial caracteriza la exclusión como "un proceso a través del cual individuos o grupos se hallan total o parcialmente excluidos de la participación económica social o política en su sociedad" (Kliksberg, 1999:37). En nuestro caso, la exclusión social se ha venido radicalizando, siendo muy marcado su impacto en la calidad de vida y en la sensación de la población de bienestar y pertenencia a un proyecto común. Algunos datos del Informe de Desarrollo Humano en Venezuela en 1997 nos permiten ver esta tendencia, todavía en proceso de profundización:

De un IDH de 0.8536 (alto desarrollo) en 1991, el país pasa a tener tres años después, en 1994, un IDH de 0.7921, lo cual es un descenso significativo, medido en ingreso, logro educativo y longevidad ( $p$. 42). La brecha entre las entidades regionales de mayor a menor Desarrollo Humano lejos de reducirse se ha ensanchado y la tendencia se incrementa, a pesar de que las de mayor desarrollo también han descendido (p.46). Desde el punto de vista de la población, el deterioro marcado de los servicios de salud, sobre todo en el área metropolitana de Caracas, ha llegado a convertirse en un indicador de la desesperanza que embarga a los distintos sectores sociales, particularmente aquellos más necesitados (p.98)... Las consecuencias más dramáticas del proceso inflacionario que ha padecido nuestro país en estos últimos años son el alza desmedida de los precios de los bienes y servicios de primera necesidad, representados por los costos mensuales de las canastas de consumo ( $\mathrm{y}$ la intensificación de la pobreza) (p.147) (OCEI/PNUd/FNUAP, 1997).

Obviamente, esta exclusión social es, en términos de salud pública, un caldo de cultivo de la desesperanza, la desprotección y el desamparo, pero también de la rabia, el descontento y la necesidad de búsqueda de alternativas, sea cuales sean las que puedan ser implementadas. Esta sensación de sálvese quien pueda y de supervivencia individual se convierte en otro elemento de inseguridad ante la pérdida de valoración del otro y de propuestas colectivas de participación que generen mayor solidaridad y encuentro.

Así vemos como la violencia delincuencial, con sus cifras ascendentes, se convierte en la forma más visible de expresión de la verdadera problemática que la contiene: impunidad, exclusión y pérdida de legitimidad y legalidad del sistema democrático. Todo ello contenido y conviviendo con formas hasta ahora negadas y encubiertas de violencia, que la han socializado y construido como una alternativa válida de resolución de conflictos y de convivencia.

Podríamos decir que no puede haber una sensación de bienestar colectivo cuando sobre lo visible de las deformaciones de las prácticas sociales de vida se encubre una violencia cultural, dañina y destructiva de los lazos más básicos de convivencia. Me refiero a la violencia doméstica, la que se sufre día a día en los hogares y que sólo desde algunos años, gracias a las prácticas de las organizaciones de mujeres, se ha hecho visible en nuestro país. Los actos de violencia doméstica casi siempre se presentan combinados (violencia física, psicológica o sexual), manteniendo un patrón que hace que no sean casuales sino, por el contrario, constituyen una dinámica de convivencia que establece la rutina del miedo y la desconfianza. El miedo, fundamentalmente a la muerte y a la agresión contra las hijas e hijos, genera en la mujer una serie de alternativas de sobrevivencia que, por lo general, disminuyen su propia capacidad de autodeterminación. La violencia dentro del hogar es de graves consecuencias en la construcción social de los ciudadanos y ciudadanas.

Es lógico pensar que una familia no democrática, como es la familia tradicional en nuestros países, sometida a situaciones económicas y sociales de profundización de la pobreza y de exclusión social y que, además, tiene la violencia como elemento cotidiano en su dinámica, no puede ser punto de partida en la construcción de las y los ciudadanos que necesitamos para transformar las actuales condiciones de vida y convivencia violentas en América Latina y, mucho menos, para ser actores y actoras centrales en un nuevo modelo de desarrollo. Dentro de una familia cuya dinámica gira frecuentemente en torno a la violencia de género, se está socializando también una forma de relación entre 
los sexos; es decir, la dominación de género, la discriminación de la mujer y una determinada distribución del poder entre hombres y mujeres.

Así se construye una sociedad no democrática y, dentro de ella, todas las formas de expresión de la violencia tendrán su espacio, dependiendo — para hacerse más o menos visible y hacernos más o menos intolerantes- de cómo se muevan en el contexto las diferentes fuerzas que las potencian. Ellas están en permanente interacción, y aun cuando no queramos verlo, el enfrentamiento resolutivo en búsqueda de una convivencia armónica entre hombres y mujeres, todos y todas, los y las ciudadanas de diferentes estatus y espacios de participación, no logrará éxito a través de más políticas represivas que no llegan a afectar la dinámica de producción que se mantiene entre las diferentes violencias en nuestro país.

\section{EL MIEDO A LA VIOLENCIA: PROBLEMA DE}

\section{SALUD PÚBLICA}

La violencia delictiva facilita la construcción del miedo, facilita la búsqueda de la seguridad personal sin importar la seguridad de los otros, aísla e individualiza, y convierte en privado lo que es un problema público. Pero también es parte activa en la construcción de la necesidad de más violencia: la violencia encubierta de protección de parte del Estado, disfrazada, intolerante, discriminadora; la violencia de la impunidad y la persecución de unos no necesariamente peores que los no perseguidos. Esa respuesta, pedida a gritos por una comunidad desamparada, no resuelve sino que potencia el problema.

Potencia la inseguridad y la percepción de pérdida de control de la situación y sensación de bienestar, porque se articula consciente o inconscientemente con nuestras otras vivencias de exclusión. Las respuestas son diferentes en los seres humanos, pero siempre hay respuesta. Los suicidas responden a la desarticulación de su vida quitándosela, y éste es también un acto de violencia contra sí mismos y contra los otros inmediatos; así como también son violencia los linchamientos y otras formas de bacer justicia por las propias manos, como los homicidios cometidos por mujeres maltratadas o por hijos cansados de la violencia impune del padre o padrastro contra la madre. Como señala Carlos Vilas, "El producto final de todo esto es un ambiente generalizado de inseguridad y de incertidumbre, donde la mayoría de la gente expuesta a él no sabe qué esperar del mañana, salvo más inseguridad e incertidumbre" (Vilas, 1996:32).

Así, la violencia delictiva, la violencia intrafamiliar o doméstica, la violencia de género en todas sus otras expresiones, la violencia policial, la violencia de la exclusión social y de la impunidad del sistema de justicia, todas ellas y muchas más son la cara de una moneda. La otra cara es el miedo, la desesperanza, el desamparo que las violencias producen. Ambas caras de la moneda son fundamentales a la hora de entender la relación entre la violencia y la salud pública.

El miedo al delito es una construcción social que, si bien tiene relación con el problema real, es básicamente construido hacia determinados delitos, hacia determinados delincuentes, hacia determinados costos y consecuencias del delito. La percepción es moldeada por una ideología del delito que nos lleva a aceptar una visión sesgada y a dejar de lado otras inseguridades igualmente dañinas, descompensadoras de la vida en sociedad y con altos costos para la vida, la salud y la convivencia social. Nos lleva a una visión sesgada de quiénes son las personas más propensas a convertirse en víctimas y las que serán los posibles victimarios. Como afirma Esther Madriz,

A través de estas representaciones de las víctimas inocentes un complejo conjunto de imágenes, temas, conceptos y códigos son introducidos en nuestro subconsciente, ayudándonos a construir una versión compartida de la realidad social que nutre nuestras fantasías y ansiedades. Estos temas de los medios de comunicación masivos nos enseñan los delitos a temer más, las personas a temer, dónde o cuándo tener miedo, quién es más propenso a ser una víctima y quién es una víctima inocente y una culpable (Madriz, 1997:84, traducción nuestra).

El miedo genera una sensación insana, altamente cargada en lo emocional, que nos polariza y separa entre buenos y malos. Esta visión es extremadamente peligrosa porque crea barreras a partir de estas identidades sociales. 
La creación de los ilegales, los que están fuera de la ley, o los otros, reúne a los miembros de una sociedad en una convicción común, que dirige su desaprobación en contra de los que están fuera de los límites sociales. El miedo es un componente muy importante en la creación de los ilegales: debemos temerles porque ellos son peligrosos, o demonios, o sólo amenazantes para "nosotros". La producción de este miedo es vital, no solamente para organizar el consenso acerca de los temas buenos o malos, sino también para estimular el desarrollo de medidas represivas para castigar o erradicar a los ilegales (Madriz, 1997:96, traducción nuestra).

Sobre esta construcción se sustenta la ausencia de indignación por las muertes continuas en las prisiones; se sustenta el mensaje que recibimos de los muros de las cárceles, mientras más altos y con alambres de púas y garitas muy cercanas unas a otras y con guardias nacionales, mejor. Sobre esta construcción se sustenta la selección permanente de las escenas que nos muestran los noticieros de la televisión, madres que lloran la muerte de un hijo o hija e imploran por una justicia que sabemos nunca llega. Además, si el muerto es un joven de barrio marginal, moreno o negro, pensamos que probablemente no merece esa justicia, ya que los hijos siempre son inocentes para la madre.

El miedo nos lleva a generalizar y estereotipadamente sentimos miedo ante cualquier joven con la apariencia del muchacho de barrio, pobre y con los rasgos físicos propios del mestizaje venezolano. Simplemente olvidamos que la mayoría de la población se le parece y que el $80 \%$ de los venezolanos es pobre. Si bien los que hacen daño por la violencia delictiva son pocos dentro de ese total, preferimos cruzar la calle, alejarnos de él, porque es mejor prevenir que lamentar. Los estigmatizamos y humillamos por pobres, no por delincuentes.

Y aquí, nuevamente, debemos recordar la importancia del papel de los medios de comunicación, los juegos computarizados, etc. La ciencia y la tecnología comunicacional ha avanzado mucho, pero los malos siguen siendo los malos de siempre para nuestros países: negros, indios, mulatos y siempre pobres.
Como Gregg Barak (1994) sostiene, con muy pocas excepciones, la clase trabajadora casi ha desaparecido del mundo de los comerciales y los programas de televisión. Consecuentemente, hay tres "clases creadas por los medios": los ricos, la clase media y la clase criminal. La última es consistentemente presentada como fuera de control, indisciplinada, carente de cualidades humanas básicas, diferente de "nosotros" (Madriz, 1997:102, traducción nuestra).

Un ejemplo del uso de los medios lo vivimos recientemente. El jueves 22 de abril de 1999, tres días antes del referéndum para la Asamblea Constituyente, leímos en los medios de comunicación impresos: Primera evaluación del Plan de Seguridad Ciudadana. El índice de criminalidad ba descendido $20 \%$ en Caracas.

Estamos tratando el aspecto delictivo como un todo. Estamos hablando de las distintas clases de delitos, homicidios, robo de vehículos, arrebatones, atraco a mano armada, asalto a las entidades bancarias... "Aprovecho a los medios de comunicación para pedirle a la comunidad que en verdad nos ayude porque la lucha no es solamente de los cuerpos de seguridad, sino que todo ciudadano debe estar inmerso en ese esfuerzo, que es la creación de los comités regionales, municipales y hasta vecinales. Cada oficial de policía y de la GN debe convertirse en un verdadero líder dentro de la comunidad donde presta sus servicios"... (Delgado M., 1999:D-5).

En sólo 22 días el Plan ya produce resultados en la ciudad de Caracas en relación con los delitos señalados. Posteriormente, el domingo en el mismo diario encontramos la siguiente información: "En un mes, decreció en 16 entidades. Indice delictivo aumentó en 8 estados durante Plan de Seguridad'.

Hay satisfacción entre los coordinadores del Plan Nacional de Seguridad Ciudadana. Según las estadísticas de la PTJ, el índice delictivo se redujo en casi $15 \%$ en un mes y una semana que lleva ejecutándose el operativo en todo el país. Sin embargo, el General Francisco Belisario Landis, coordinador del Plan, mostró su preocupación porque de los 24 estados, en 8 subió el índice de criminalidad, aunque en 16 entidades las estadísticas son satisfactorias... (Guerrero, 1999:D-8). 
Ambas informaciones nos llevan a seguir de cerca el proceso, puesto que si bien los datos son elocuentes, no podemos suponer que en poco tiempo los índices delictivos se alteren de manera estable. Lo importante a destacar en este trabajo es la forma como se condiciona la información. Evidentemente, los objetivos políticos del gobierno y las fuerzas policiales hacen que la información se presente como un éxito a pesar del poco tiempo de las acciones. Segundo, enfatizan los logros de la acción de control represivo al demostrar la acción policial como eficaz ante la exigencia de seguridad de parte de la ciudadanía. Tercero, enfatizan la participación de la Guardia Nacional como cuerpo activo en la seguridad en las comunidades.

Pero es evidente la forma tendenciosa como el medio presenta la información en el segundo artículo. En lugar de resaltar en el titular la noticia principal, que es la disminución de los delitos en 16 entidades federales, selecciona la información negativa de los 8 estados en donde el índice aumentó. Resalto este punto para evidenciar que la construcción de la opinión pública viene dirigida por el medio, el cual selecciona la forma y contenidos de la información de manera de insertarla en una posición sobre el tema que responde a los intereses del medio y no a los de la comunidad.

Un último ejemplo lo tomamos del mismo diario El Nacional: "Drama pasional conmocionó a vecinos de Caricuao. Hombre se suicidó luego de matar a su compañera de dos disparos". Esta noticia viene acompañada de una foto de la pareja amorosamente abrazada.

Las víctimas involucradas en el episodio fueron identificadas como Olga M., de 58 años de edad, quien laboraba como secretaria en la presidencia del Instituto Nacional del Deporte; y Pedro J.P., de 32 años, sin oficio conocido (...) La pareja, que había cumplido hace poco 10 años de concubinato, venía afrontando problemas graves y esa noche tuvieron una fuerte discusión. Pedro, quien al parecer era adicto a las drogas, el alcohol y las armas, tomó su revolver calibre 38 y una escopeta y disparó dos veces contra Olga M. (... ) A pesar de la insistencia de los funcionarios para que Pedro J.P. se entregara, nada resultó (...) Cuando los directivos del BAE intentaban ingresar al apartamento, se escuchó una detonación. Todo había terminado. P. disparó el revolver en su contra (Luna N., 1999:D-8).

Lo que quiero resaltar en esta noticia es básicamente que el delito cometido contra Olga no es presentado como tal sino como un drama pasional. El orden del titular dirige la atención no al hecho de haber matado a su compañera sino al hecho de que el hombre se suicidó. Así vemos como se escamotea el sentido de homicidio al hecho y se convierte en un drama porque ambos eran una pareja. En este caso, todos los medios resaltaron el hecho de que era un concubinato y no un matrimonio legalmente constituido entre una mujer 26 años mayor que el hombre.

En síntesis, se magnifican algunos delitos considerados horrendos y se minimizan delitos graves que no caen dentro del estereotipo del delito, el delincuente y la víctima que contiene la ideología correspondiente. Se resalta la presencia de alcohol o drogas como causas del hecho y no como precipitantes de acciones que se presentan aisladamente o como última etapa de un proceso de violencia, particularmente si es de género. $\mathrm{Al}$ autor del delito se le presenta como un malo siempre, las 24 horas del día los 365 días del año, es decir, no humano. Se maneja la temática delictiva como un problema de familias con relaciones complejas, ya sea parejas fuera de lo considerado "normal", incompletas, con padres ausentes y madres inestables o que no cumplen bien su función de socializadoras de los valores fundamentales de la convivencia social. En síntesis, se convierte un problema social en privado, familiar o de patologías.

\section{A MANERA DE CIERRE}

Hablar de violencia y salud pública es hablar de dos enemigas encontradas. La presencia de la primera en sus múltiples formas de expresión, es negar el logro de la segunda. Las posibilidades de construcción de esta última pasan por políticas de Estado que no se conformen con bajar los índices de criminalidad en nuestros países, sino que propicien políticas de distribución de los ingresos del Estado de manera equitativa. 
(...) la mejor equidad creará también condiciones más favorables para el fortalecimiento y desarrollo del capital social. El mismo comprende aspectos como los valores compartidos, el grado de asociatividad de una sociedad, sus capacidades para promover concertaciones, sinergias, construir redes, el clima de confianza mutua entre sus componentes, las normas sociales, las instituciones... El mejoramiento de la equidad favorecerá aspectos cruciales, entre otros, el clima de confianza, y creará condiciones objetivas más favorables para una participación más intensa de la población en organizaciones de base de la sociedad civil (Kliksberg, 1999:33).

Obviamente, será una manera de acercarnos a la salud del colectivo, al disfrute de un estado de bienestar compartido. Esto sólo será posible por la acción concertada de múltiples actores sociales y no a través de decisiones desde arriba. Construir ciudadanía pasa por participar realmente y no sólo como ejecutores de las decisiones de otros. Rescatar el valor de la vida pasa por rescatar el derecho a tener derechos, como afirmara Hanna Arendt. Para ello es necesario asumir la lucha por la legalidad, porque es dentro de un Estado democrático donde se puede pensar en reconvertir la dictadura de las violencias, particularmente de aquellas que se convierten en la negación de la ciudadanía y desposesión de derechos fundamentales, porque desaparece el sujeto. Y como señala Carlos Vilas refiriéndose a los más excluidos, a los pobres estructurales, "No se pueden violar derechos que no se cree que existan, o que ya se olvidó que existen" (Vilas, 1996:35).

\section{REFERENCIAS BIBLIOGRÁFICAS}

Acosta, N. \& Huggins C., M., 1998. Venezuela: diagnóstico y prospectiva sociopolitica. Caracas: Cendes, UCV.

Bobbio, N.; Matteuci, N. \& Pasquino, G., 1991. Diccionario de política. Madrid: Siglo XXI.

Cardia, N., 1994. Percepción de los derechos humanos: ausencia de ciudadanía y la exclusión moral. En: A ciudadania en comstru̧ão: uma reflexão transdisciplinar (M. París \& M.J. Spink, orgs.), pp. 15-56. Brasil: Cortez.
Franco A., S., 1995. Violencia, ciudadanía y salud pública. Cuadernos Médico Sociales, 71:23-38.

Gómez Calcaño, L., 1995. Crisis de legitimidad e inestabilidad política en Venezuela. Revista Venezolana de Economía y Ciencias Sociales, 23:103-164.

Gómez Calcaño, L., 1997. La redefinición del Estado social: el caso de Venezuela. En: El cambio del papel del Estado en América Latina (M. Vellinga, coord.). México DF: Siglo XXI.

Huggins C., M. 1996. Una reflexión en torno a la violencia en Caracas. Revista Venezolana de Análisis de Coyuntura, II(2):39-58.

Kliksberg, B., 1999. Inequidad en América Latina: un tema clave. En: Política social: exclusión y equidad en Venequela durante los años noventa (L. Alvarez, H. del Rosario y J. Robles, coords.), pp. 27-72. Caracas: Fonvis/CENDES/ILDIS/ Nueva Sociedad.

Msas (Ministerio de Sanidad y Asistencia Social), 1996. Anuarios de Epidemiología y Estadística Vital. Caracas: Msas.

OCEI/Pnud/Fnuap, 1997. Informe sobre indice y entorno del desarrollo bumano en Venezuela 1997. Caracas: OcEI/PNUd/FnUAP.

Provea (Programa Venezolano de Educación-Acción en Derechos Humanos), 1988. Informe anual. Situación de los derechos bumanos en Venezuela. Caracas: ProveA.

Sanjuán, A.M., 1997. La criminalidad en Caracas: percepciones, realidades objetivas y políticas. Trabajo presentado en el Seminario sobre Violencia Criminal Urbana. Río de Janeiro: BID.

Santos A., T., 1997. Repensando la violencia desde la criminología. Espacio Abierto, 6(1):29-44.

Silva Michelena, H., 1999. La política social en Venezuela durante los años ochenta y noventa. En: Politica social: exclusión y equidad en Venezuela durante los años noventa ( $\mathrm{L}$. Alvarez, H. Del Rosario y J. Robles, coords.), pp. 85-114. Caracas: Fonvis/CENDES/ ILDIS/Nueva Sociedad. 
Vilas, C., 1996. Violencia política, legitimidad y fragmentación social (o el difícil matrimonio entre democracia y capitalismo en América Latina. Foro Violencia y Políticas Públicas. Caracas: Cendes.

\section{ARTÍCULOS DE PRENSA}

Delgado M., Y., 1999. El índice de criminalidad ha descendido $20 \%$ en Caracas: primera evaluación del Plan de Seguridad Ciudadana. El Nacional, abril 22:D-5.

Escalona, V., 1999. Aumentó índice delictivo en primer trimestre del año. Muertes violentas, lesiones personales y hurto de vehículos encabezan las estadísticas. El Universal, abril $27: 4-1$.

Guerrero, S., 1999. Índice delictivo aumentó en 8 estados durante Plan de Seguridad. En un mes, decreció en 16 entidades. El Nacional, mayo 9:D-1.

Luna N., R., 1999. Hombre se suicidó luego de matar a su compañera de dos disparos: drama pasional conmocionó a vecinos de Caricuao. El Nacional, abril 22:D-8. 


\section{EL CONSUMO DE DROGAS COMO PROBLEMA DE SALUD PÚBLICA: DESAFÍOS PARA LA INVESTIGACIÓN Y LA FORMULACIÓN DE POLÍTICAS}

Julio Bejarano *

\section{INTRODUCCIÓN}

La problemática del consumo indebido de drogas y el tema de la drogadicción son instancias históricas relativamente recientes, pese a que el consumo de sustancias en general se ha vuelto una constante psicosocial y antropológica cuya extensión temporal es milenaria. Los problemas asociados al abuso de sustancias nunca antes tuvieron la importancia sanitaria (ni política) que se les confiere hoy en día, aunado al hecho de que los mismos trascienden al individuo para afectar a grupos familiares y a comunidades. En diferentes países estos hechos son concebidos como problemas de salud pública, cuya atención se establece como prioritaria.

A la par del fenómeno del consumo de sustancias y de la drogadicción, y también de reciente data, se presenta el narcotráfico, término que desde la década de los ochenta expresa diversas facetas del comercio ilícito de cocaína. Visto desde una perspectiva más amplia, la comercialización de las drogas, sean éstas lícitas o ilícitas, se introduce como un elemento de mercado que suele generar distorsiones y provocar desestabilización en distintos niveles, no sólo económicos sino políticos y judiciales.

La preocupación en torno al tema de las drogas en el nivel internacional se inaugura parcialmente con el comienzo del siglo $\mathrm{XX}$, al celebrarse la primera conferencia internacional sobre estupefacientes en la ciudad de Shanghai en 1909, la cual fue sucedida por el primer tratado de control de drogas: la Convención Internacional sobre el Opio, firmada en La Haya en el año 1912. Desde esa época hasta la actualidad se ha producido una gran cantidad de legislación, buena parte de ella bajo los auspicios de Naciones Unidas (la Convención Única sobre Estupefacientes de 1961, la Convención sobre Drogas Psicotrópicas de 1971). Estos instrumentos han tenido por finalidad la reducción del consumo de drogas mediante la aplicación de fuertes restricciones a la oferta. De fecha más reciente es la Convención contra el Tráfico Ilícito de Drogas (1988), cuyo interés primordial ha sido limitar y reprimir las actividades de los traficantes de drogas. No obstante, el marco internacional en el cual se desarrollan estos instrumentos es considerado por los expertos en la materia como rígido, en virtud de que la política criminal usualmente se establece desde el derecho internacional. Esta circunstancia explicaría la extraordinaria semejanza de las leyes antidrogas de los diferentes países latinoamericanos, las cuales muchas veces, en especial hasta mediados de la década de los ochenta, han sido más el resultado de imposiciones de los países centrales que de acuerdos internacionales acordes con la realidad de cada nación.

Las diversas convenciones e instrumentos legales para enfrentar el problema del consumo y el tráfico de drogas corren de modo paralelo con la instauración de modelos y enfoques particulares orientados a concebir y entender el problema de la farmacodependencia. Así, la instauración del modelo ético-jurídico, antes de la primera convención de Naciones Unidas, concebía la droga como sinónimo de peligrosidad y al toxicómano como un delincuente. El modelo médico sanitario, de amplia difusión en los países de América, tuvo sus orígenes con las primeras proclamas internacionales a comienzos de la década de los sesenta, de manera

Médico. Director del Instituto sobre Alcoholismo y Farmacodependencia, Costa Rica. E-mail: julio_bejarano@hotmail.com. 
que el discurso comenzó a variar: el consumidor dejaba de ser visto como delincuente para ser asumido como un enfermo. Otros modelos han surgido desde entonces; sin embargo, la influencia de los sucintamente citados antes aún es importante y de un modo u otro definen en buena medida las actividades de prevención, tratamiento y represión. Esta diversidad de enfoques, estrategias y modelos revela, ante todo, la creciente preocupación de la mayor parte de los gobiernos del orbe por enfrentar adecuadamente los problemas relacionados con el consumo y el abuso de drogas. Sin embargo, no están exentas de dificultades. Prueba de ello son los limitados éxitos que es posible registrar desde cualquiera de las vertientes o aproximaciones al fenómeno de la producción y el consumo indebido de sustancias.

La emergencia, a mediados de la década de los ochenta, de una transnacionalización del discurso y la legislación sobre las drogas, especialmente la cocaína, ha provocado, en unos países más que en otros, que la atención sobre los problemas relacionados con el alcohol, el tabaco y los psicofármacos se haya desviado del cauce que tenía hasta el primer quinquenio de la década de los ochenta. Por ello, este trabajo busca establecer un balance entre los elementos de discusión y el análisis sobre el consumo de sustancias lícitas y aquellas de producción, distribución y consumo al margen de la ley, junto a algunas consecuencias sociales.

Al mismo tiempo, se describen algunas características de la investigación sobre drogas, sus principales problemas, las dificultades existentes en relación con la formulación de políticas y la articulación entre los sectores que se ocupan directa o indirectamente del problema.

\section{LAS DROGAS COMO PROBLEMA DE SALUD}

\section{públicA. Perspectiva general}

Aunque no siempre se dispone de estimaciones confiables, la magnitud de los problemas derivados del consumo indebido de drogas como el tabaco, el alcohol, la mariguana, la cocaína y las drogas psicotrópicas se encuentra debidamente documentado desde hace varios años en algunos países. Un informe relativamente reciente (WHO, 1996) sitúa los costos de la atención en salud y la pérdida en productividad en 125 billones de dólares sólo en EEUU. A esto debe agregarse un importante subregistro en centros hospitalarios y una atención tardía de las secuelas, y más tardía aún cuando tiene lugar como consecuencia del problema primario de consumo, generalmente alcohol y tabaco.

Estimaciones del NiaAa (National Institute on Alcohol Abuse and Alcoholism) y el NiDA (National Institute on Drug Abuse) (1998) revelan que al consumo excesivo de alcohol y al alcoholismo corresponde un $60 \%$ de los costos. Una comparación con las estimaciones de costos generadas en 1985 revela que una década después las relacionadas con el alcohol son $42 \%$ superiores y $50 \%$ más elevadas para otras drogas. No obstante, debe considerarse que la mayor parte del incremento en los costos que se adjudican al alcohol es atribuido a cambios en la metodología empleada en los estudios más recientes, en los cuales no se subestima el impacto del abuso de alcohol, como aparentemente sucedió en 1985. La variación en los costos por abuso de drogas ilícitas obedeció a un cambio real reflejado en un incremento en los ingresos a salas de emergencia de hospitales y otros gastos, tales como aquellos correspondientes al sistema de justicia.

Las consecuencias sobre la salud y otros efectos de la ingestión excesiva de alcohol se encuentran mejor documentadas que las que atañen a otras drogas. Diversos autores han dado cuenta de estos problemas, en especial acerca de sus implicaciones económicas (Maynard, 1993; Rice et al., 1991).

El costo del abuso de alcohol y el alcoholismo fue estimado en EEUU, para 1990, en US\$11.142 millones, suma que no contiene la gama de delitos no registrados (Rice, 1993).

Aunque no se dispone de información semejante para los países latinoamericanos, la figura 1 pone de relieve el papel que corresponde al alcohol en la generación de eventos traumáticos en algunas salas de emergencias de un grupo de países seleccionados. 
DisTRIBUCIÓN PORCENTUAL DE LOS SUJETOS INGRESADOS A SALAS DE URGENCIA DE ALGUNOS PAÍSES SELECCIONADOS, SEGÚN CRITERIO MÉDICO, SOBRE LA RELACIÓN ENTRE EL EVENTO TRAUMÁTICO Y EL CONSUMO DE ALCOHOL Y DROGAS, 1998 / FIGURA 1

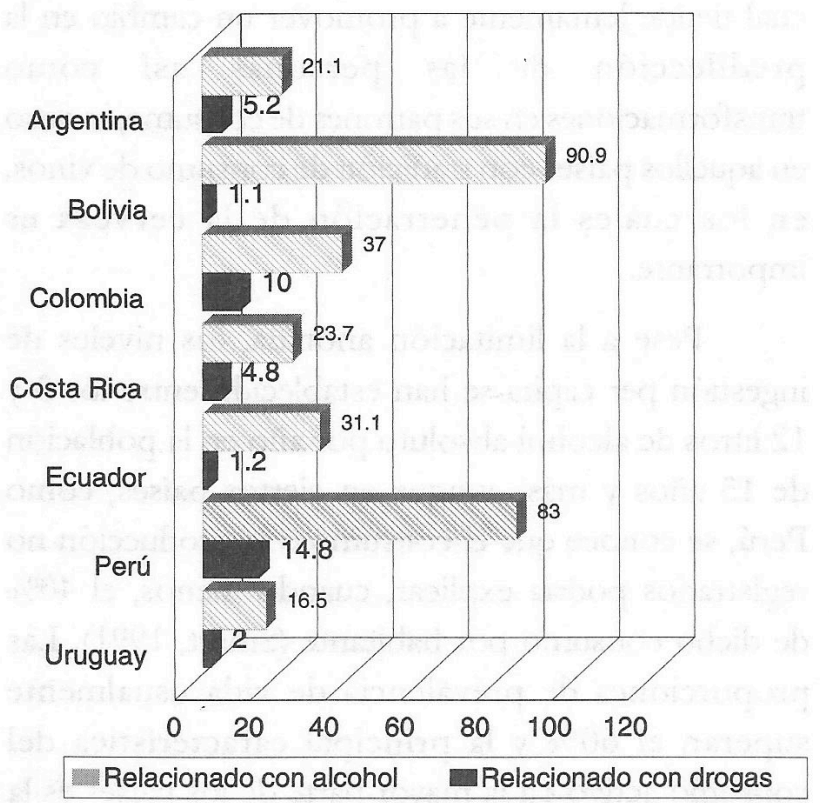

Fuente: CICAD/OEA (1998b)

En lo que a tabaco respecta, se conoce que ocasiona el 30\% de todas las muertes por cáncer, el $87 \%$ de los decesos por cáncer de pulmón y el $82 \%$ por enfermedad pulmonar. Asimismo, ocasiona el $21 \%$ de los fallecimientos por enfermedad cardiovascular crónica (Single et al., 1996). En el nivel mundial, cada año el número de muertes relacionadas con el fumado se estima en 3 millones de individuos. De estas muertes, 500 mil ocurren en EEUU, 34 mil en Canadá y 100 mil en Latinoamérica.

La industria tabacalera, movida por el afán de lucro, busca la creación de nuevos mercados en áreas sensibles (v. gr. países en desarrollo) alrededor del mundo (Asia, África, Europa Oriental, América Latina y el Caribe). Es evidente que las compañias que producen el tabaco buscan la creación de mercados futuros entre la gente más joven y el mantenimiento de la adicción entre los fumadores activos. $\mathrm{Ha}$ sido altamente efectiva la publicidad orientada a que la mujer, y los jóvenes en general, fumen, y lo hagan de una manera cada vez más precoz.
El efecto de la difusión del tabaquismo en las sociedades industrializadas en los años cuarenta y cincuenta se aprecia hoy en día de modo claro: cerca de $20 \%$ de las muertes son atribuibles al consumo de cigarrillos. A esto se agregan los datos del Banco Mundial relativos a las pérdidas económicas netas como consecuencia de esta práctica (Barnum, 1993), los cuales son reveladores del impacto del tabaquismo: US\$200.000 millones al año. La mitad de este total corresponde a países en desarrollo, lo cual sugiere que los efectos sobre estas sociedades son considerablemente más deletéreos que en las desarrolladas.

Existen, en el otro extremo, desigualdades relacionadas con las ventajas que países como EEUU y Canadá han logrado en el campo de la prevención y la formulación de políticas basadas en información científica relevante y actualizada y en las recomendaciones de organismos internacionales. Países como los citados anteriormente han reducido de modo significativo los problemas derivados del tabaquismo, en tanto no sucede lo mismo con la mayor parte de los países en vías de desarrollo. Las transformaciones en las normás sociales y la implementación de acciones educativas en salud pública, como parte integral de campañas antitabaco de gran envergadura, explican estos cambios. La mayor parte de los países de América Latina, y muchos otros en el mundo, por el contrario, no han logrado la generación de políticas y planes de salud y educación específicos, más allá de esfuerzos puntuales en la promoción de espacios libres de humo e información para el público.

Hoy día se sabe que los fumadores presentan una tasa de mortalidad tres veces más alta que la de quienes no fuman. Se estima que en el mundo existen unos 1.100 millones de fumadores (esto quiere decir que fuma una de cada tres personas mayores de 15 años). Si los indicadores de prevalencia e incidencia persisten para los próximos años, el número de muertes por problemas atribuibles al tabaco será de unos 500 millones de personas. Es posible que un $50 \%$ fallezca en edad madura, lo cual implica que en promedio se perderán de 20 a 25 años de vida. $70 \%$ de las muertes relacionadas con el tabaco ocurrirán en países en vías de desarrollo 
Por otra parte, el impacto social y los costos del abuso de las sustancias ilegales no ha sido objeto de estimaciones como las que se han realizado para el alcohol y el tabaco. En las naciones latinoamericanas esta ausencia es particularmente notoria. La información disponible en EEUU de Norteamérica (NiDA Media Advisory, 1998) indica que más de la mitad de dichos costos se relaciona con la generación de delitos asociados con el consumo de drogas. Los mismos incluyen además la pérdida en productividad de las víctimas de crímenes y el encarcelamiento de los ofensores y otros costos, como daños a la propiedad, accidentes de tránsito, muertes prematuras y otros. Durante el primer quinquenio de la década de los noventa los costos directos e indirectos del abuso de drogas en EEUU fueron del orden de los US\$71 billones (The National Foundation for Brain Research, 1992). No existen estimaciones para el nivel mundial, pero una aproximación conservadora que incluya costos directos e indirectos del abuso de drogas podría rondar los US $\$ 150$ billones.

\section{El CONSUMo De DRogas. Características}

\section{FUNDAMENTALES}

\section{A. EL ALCOHOL}

Una primera consideración en torno al tema del consumo de drogas en la subregión remite a la ingestión de bebidas alcohólicas. Y un elemento sobresaliente se refiere a la ausencia relativa de información confiable que permita determinar las características reales de la producción y, consecuentemente, de la ingesta per cápita en los países, así como sus patrones de consumo. Estas dificultades son de orden metodológico y se agravan por la inexistencia de registros, o la baja calidad de éstos. El volumen de la producción clandestina, el contrabando de licores y otros, suelen ser muy difíciles de registrar. A esto se agrega la escasa cantidad de estudios nacionales y, consecuentemente, la imposibilidad de comparación entre éstos. No obstante lo antes citado, desde principios del siglo XX el alcoholismo como problema social y de salud pública ha sido reconocido ampliamente por la mayor parte de los países como uno de sus principales problemas, pero no ha alcanzado la conmoción pública que de modo permanente se ha producido alrededor de las sustancias ilegales.

Un rasgo distintivo de la producción de bebidas alcohólicas en la subregión se relaciona con el auge que se observa en la producción cervecera, la cual tiende lentamente a promover un cambio en la predilección de las personas así como transformaciones en sus patrones de consumo, incluso en aquellos países con tradición de consumo de vinos, en los cuales la penetración de la cerveza es importante.

Pese a la limitación anotada, los niveles de ingestión per cápita se han establecido entre los 3 y 12 litros de alcohol absoluto por año en la población de 15 años y más, aunque en ciertos países, como Perú, se conoce que el consumo o la producción no registrados podría explicar, cuando menos, el 40\% de dicho consumo por habitante (Smart, 1991). Las proporciones de prevalencia de vida usualmente superan el $60 \%$ y la principal característica del consumo activo en la mayor parte de los países es la búsqueda de la embriaguez, observándose en la mayor parte de las naciones una tendencia creciente en grupos cada vez más jóvenes por obtener rápidamente los efectos farmacológicos del alcohol.

La información sobre morbimortalidad atribuible al alcohol, en las Américas, revela características sumamente preocupantes, que ubican el problema de abuso de bebidas alcohólicas como el más importante, en conjunto con la ya de por sí dramática situación atribuible al tabaquismo.

\section{B. EL TABACO}

En efecto, la problemática del daño atribuible al consumo de tabaco constituye hoy en día una fuente de enorme preocupación para los gobiernos. Aunque en nuestros países los niveles de consumo son menores que en las sociedades industrializadas, el problema del tabaquismo en la mayor parte de las sociedades reviste características epidémicas (Murray \& López, 1996; OMS, 1995).

Las prevalencias generales de consumo rondan cifras superiores a 30\%: 35\% en Costa Rica (Bejarano et al., 1996), 32\% en Paraguay (Míguez y Pecci, 1991), 
57,2\% en Perú (Ferrando, 1990), 45\% en Colombia (Rodríguez et al., 1993), según los reportes de diferentes estudios publicados a finales de los ochenta e inicios de los noventa. No obstante, algunas estadísticas revelan disminuciones en el consumo activo, dadas las medidas de control impuestas en la mayor parte de los países. En América Latina la situación muestra signos de gravedad desde décadas anteriores. Los niveles de prevalencia en la década de los setenta y ochenta, por ejemplo, han oscilado entre 30 y $40 \%$. Una encuesta de 1991, patrocinada por la OPS en ocho ciudades (OPS, 1992), reveló niveles de consumo superiores en varones de los países del Cono Sur, los cuales sobrepasaban al $40 \%$ de la población adulta.

Por otra parte, la industria tabacalera y el comercio internacional han creado cada vez mayores espacios para el cabildeo y el debilitamiento de las medidas de salud pública, frente a posturas gubernamentales que subestiman los efectos nocivos y los costos sociales del tabaquismo, al presentar ideas promisorias para las empresas y el fisco, así como el argumento de que la industria genera empleo.

\section{LOS PSICOFÁRMACOS}

El consumo indebido de psicofármacos, fundamentalmente benzodiacepínicos, se encuentra entre las conductas menos estudiadas, pero cuyos alcances van más allá de la descripción e implicaciones de sus efectos para situarse como un problema que atraviesa la industria farmacéutica, la formación médica, la educación preventiva y la presencia de imposiciones y controles (según se conoce, en algunos países los psicofármacos son de venta libre). En Costa Rica, por ejemplo, el uso indebido de benzodiacepínicos "alguna vez en la vida" pasó de 0,88\% en 1990 a 2,2\% en 1995 (Bejarano et al., 1996). Países como Bolivia (CIECC, 1992) y Colombia (Rodríguez et al., 1993) sitúan el consumo de "alguna vez" (incluyendo la ingestión por prescripción) en $5 \%$ y $4,1 \%$ respectivamente. Como aspectos relevantes dentro del uso indebido de medicamentos tranquilizantes cabe indicar una edad más tardía de iniciación, la mayor prevalencia de consumo en el sector femenino de la población y, dentro de éste, su ubicación en los grupos de menor nivel de escolaridad.

\section{LAS SUSTANCLAS ILEGALES}

Finalizamos este apartado con algunas observaciones en torno al consumo de sustancias ilegales - mariguana, cocaína y "crack", con una brevísima mención de la PBC (pasta básica de cocaína) y el basuco.

En general, y pese a la dificultad de establecer comparaciones, el consumo de mariguana en Latinoamérica muestra una relativa estabilidad a lo largo de los años. Se trata de la droga ilícita de consumo "alguna vez", más frecuentemente reportada en Centroamérica entre 1991 y 1996 (NIDA, 1998). Los indicadores de prevalencia de vida en la década de los noventa para países como Colombia, Bolivia, Paraguay y Costa Rica oscilan entre $3 \%$ y 5,3\%, en tanto que Chile (ConACE, 1995) reveló un $12,9 \%$ en su última encuesta nacional.

La situación del consumo de cocaína indica que las proporciones son menores que las de mariguana, aunque desde los años ochenta los hallazgos en encuestas de hogares revelan una tendencia al alza. Los estudios las sitúan entre 0,3\%, como fue el caso de México (CONADic, 1994) a inicios de los noventa, y $0,9 \%$, tal el caso de Costa Rica en 1995 (Bejarano et al., 1996).

En relación con el consumo de "crack", la principal característica por mencionar es su acelerada evolución. En Costa Rica no se registró consumo en la encuesta de hogares de 1990, mientras que en 1995 un $0,4 \%$ de la población aceptó haberlo consumido alguna vez en la vida (Bejarano et al., 1996). En países de Sudamérica las drogas que podrían equipararse al "crack" (por ser formas baratas de consumo de cocaína) son la PBC y el basuco. En el caso de la PBC, un reporte de Perú reveló una prevalencia de vida de 5,6\% en 1993 (Rojas, 1994), en tanto en Colombia el consumo de basuco "alguna vez en la vida" fue referido por un 1,5\% de la población nacional encuestada (Rodríguez, 1997).

En general, los niveles de consumo de drogas ilícitas obtenidos tradicionalmente mediante encuestas de hogares son relativamente bajos, razón por la cual ha sido necesario explorar en otras poblaciones, como las de personas sin residencia fija, deambulantes, las detenidas en centros de reclusión y otras. La 
experiencia en investigaciones en poblaciones específicas, en especial con metodología cualitativa, es limitada en la subregión. No obstante, algunas experiencias concretas llevadas a cabo en Centroamérica —entre 1992 y 1996 se llevó a cabo el Proyecto de Vigilancia Epidemiológica del Consumo de Drogas en los países de Centroamérica, Panamá y República Dominicana, auspiciado por la CICAD/OEA - han permitido ampliar el espectro de conocimiento en relación con el consumo de sustancias. De esta forma, en varios países los datos obtenidos mediante encuestas de hogares se complementan con los hallados en salas de emergencia, centros de tratamiento y centros de detención, observándose una muy significativa diferencia, que sugiere la importancia de consolidar el esfuerzo investigativo en diferentes sectores poblacionales.

\section{LA INVESTIGACIÓN SOBRE LA OFERTA Y LA}

\section{DEMANDA DE DROGAS}

La investigación en materia de oferta y demanda de drogas producida en el ámbito latinoamericano ha mostrado una tendencia creciente en los últimos años. Sin embargo, los niveles de producción son muy distintos entre los países.

En lo que a oferta se refiere, generalmente los datos son recopilados por instancias gubernamentales, como la policía, los Consejos de Drogas y otras vinculadas con servicios de inteligencia. Usualmente, los datos sobre decomisos, detenciones y otros derivados del orden represivo, se presentan a las autoridades políticas superiores, se difunden por los medios y permiten la toma de decisiones. Sin embargo, en la mayor parte de los países la confiabilidad de la información no siempre es aceptable debido a problemas metodológicos diversos. $\mathrm{La}$ Comisión Interamericana para el Control del Abuso de Drogas (CICAD) ha realizado un esfuerzo importante al promover la publicación de estadísticas sobre la oferta de drogas a partir de la información que le aportan los países (CICAD/OEA, 1998); no obstante, sólo algunos, como Chile, Venezuela, Colombia y Perú, han efectuado análisis comparativos y críticos con fundamento en este tipo de información.
Acerca del conocimiento producido en relación con la demanda de drogas, hoy en día existen francas diferencias entre los países de la subregión y una serie de variaciones a lo largo de los años. Por ejemplo, a finales de la década de los setenta México y Costa Rica eran pioneros en el desarrollo de investigación epidemiológica sobre consumo de alcohol (Menéndez, 1998). En los últimos años dichos países, además de Colombia, Chile y Perú, están desarrollando, comparativamente, una producción cada vez mayor. Esta multiplicación del trabajo científico en el campo de las drogas está muy relacionada con el tema de la cocaína, es decir, el impacto que ha ejercido el tráfico internacional, cierta masificación del consumo en las sociedades industrializadas y la presión directa o indirecta que se ha generado para el desarrollo de estudios sobre consumo de sustancias ilegales, básicamente cocaína en sus diferentes formas (clorhidrato, pasta, "crack").

Este fenómeno fue característico de los diferentes países durante los primeros años de la década de los ochenta y ha implicado un desplazamiento, más o menos considerable, del interés por investigar los problemas asociados con consumo de bebidas alcohólicas y sobre las sustancias lícitas en general, constituyéndose en una barrera de primer orden al limitarse la comprensión y la toma de decisiones alrededor de problemas de salud pública tan importantes como el abuso de alcohol y tabaco.

Otro elemento por destacar dentro del ámbito investigativo tiene que ver con los tipos de investigación realizados en los noventa. En esto cabe mencionar algo que no escapa a nadie: la preeminencia de diseños de corte positivista, en especial de estudios transversales que tienen como base el método de encuesta. De ellos es posible dar cuenta de aspectos muy positivos. De hecho, son parte (o deberían serlo) de los fundamentos para hacer la prevención y generar teoría al respecto. Sin embargo, presentan, como cualquier procedimiento metodológico, limitaciones que últimamente han generado discusiones y polémicas semejantes a las que tenían lugar en los años sesenta y setenta, cuando se aplicaban al estudio de otros fenómenos.

Ciertamente, aunque la investigación así concebida prevalece en nuestros países, no es privativa 
de éstos. Una revisión de las aplicaciones que recibió el DAPA (siglas que corresponden al Comité Revisor de Investigaciones en Epidemiología y Prevención, que reporta al National Institute on Drug Abuse, NIDA) en 1992, y que se considera típica de todas las aplicaciones revisadas por éste, reveló que prácticamente la mitad de las solicitudes estaban centradas en temas epidemiológicos, $38 \%$ en cuestiones preventivas, $14 \%$ en estudios sobre el lugar de trabajo y $3 \%$ en otros tópicos. Un replanteamiento de este tipo de procedimientos y el desarrollo de opciones de aproximación a la realidad que busquen una mejor comprensión del fenómeno del consumo de drogas resulta una tarea prioritaria para la generación de un conocimiento que se traduzca en decisiones y en acciones que produzcan un impacto cada vez mayor en sociedades cambiantes, donde los problemas sociales y económicos imponen día con día desafíos de mayor envergadura.

Además, los tipos de investigación varían, muchas veces, de acuerdo con la asignación presupuestaria otorgada a ellos. En países desarrollados sobresalen diseños mucho más onerosos que los que es posible llevar a cabo en los nuestros, aunque esto no se debería considerar como una limitación en sí misma; el problema esencial de las naciones latinoamericanas consiste en que la asignación de recursos para este tipo de estudios, y en general para investigaciones en salud, es realmente escasa.

El liderazgo y el apoyo financiero y técnico de la Organización de Estados Americanos - por conducto de la Comisión Interamericana para el Control del Abuso de Drogas-y de la Organización Panamericana de la Salud han sido determinantes en el logro de experiencias comunes de investigación. Las experiencias orientadas al desarrollo de sistemas uniformes de registro de información sobre drogas han sido un recurso valioso para todos los países. El Proyecto de Vigilancia Epidemiológica del Consumo de Drogas en Centroamérica, Panamá y República Dominicana, que se llevó a cabo entre 1992 y 1996, permitió formar y consolidar, pese a diferentes adversidades de orden logístico, equipos de investigación en siete países. Más recientemente, el Sistema Interamericano de Datos Uniformes sobre consumo de Drogas (Siduc) de la CicAd/OEA
(1998) involucra un número mayor de países, generando datos comparables sobre la demanda de drogas en diversos escenarios (salas de urgencia, centros de tratamiento, etc.).

En lo que respecta a las poblaciones de estudio, en la actualidad un número mayor (aunque siempre limitado) de países realizan encuestas en poblaciones nacionales, las cuales se constituyen en recursos valiosos aunque persisten los problemas de comparabilidad de los datos entre países y muchas veces en el interior de cada nación.

Hoy en día se reconoce la urgencia de realizar estudios en poblaciones infantiles escolarizadas, no escolarizadas y en riesgo social, sobre el tema de las percepciones y el consumo de drogas en el lugar de trabajo y sobre prevención específicamente.

La mayor parte de los países del continente han efectuado investigaciones en poblaciones de estudiantes, generalmente de enseñanza secundaria. En este grupo de población los hallazgos sobre consumo de alcohol, tabaco y tranquilizantes siempre provocan preocupación en los investigadores. Por sobre todo resaltan las edades tempranas en que tiene lugar el inicio del consumo de alcohol y tabaco, así como la tendencia generalizada a la práctica de la embriaguez. Los hallazgos que hemos realizado en Costa Rica, salvo escasas excepciones, son semejantes a los encontrados en los países de América Latina. Es posible afirmar que mucho de lo que se ha encontrado en esta población en relación con las prácticas de consumo, no sólo de drogas, está estrechamente vinculado con los cambios que se están operando en la visión que el joven tiene del mundo, debido principalmente a su exposición a un cúmulo de influencias que le llegan a través de los medios de comunicación colectiva. Influencias que parecieran introducir elementos que afectan sus valores, sus creencias, y promueven estilos de vida consumistas que estimulan el individualismo y una débil conciencia crítica acerca del entorno, además de las importantes transformaciones que ha experimentado la estructura y dinámicas familiares durante los últimos años en la mayor parte de la sociedad latinoamericana.

La figura 2 ilustra la situación de consumo anual de mariguana y cocaína en estudiantes de educación secundaria de tres países seleccionados. 
Prevalencia anual de Consumo mariguana y cocána en ESTUDIANTES DE EDUCACIÓN SECUNDARIA DE TRES PAÍSES SELECCIONADOS / FiguRA 2

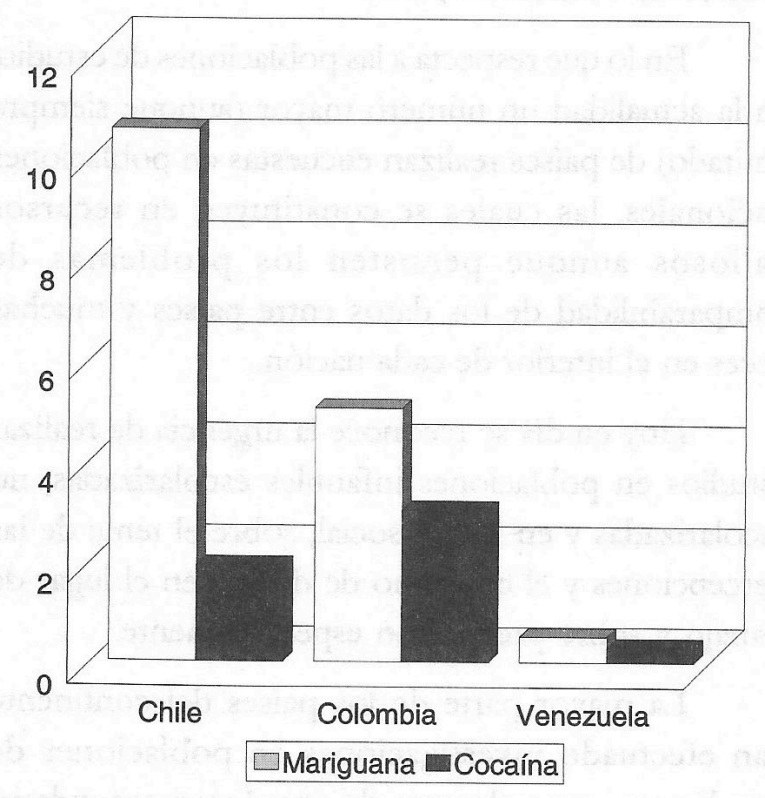

Fuente: CICAD/OEA (1998b).

También ha sido motivo de inquietud la influencia que pudiera tener este conjunto de transformaciones sobre las creencias o fundamentos espirituales de los jóvenes, en virtud de que se ha podido comprobar en ellos el significativo papel que le corresponde al componente espiritual como protección frente al consumo y al abuso de drogas.

Si bien en los años ochenta algunos países les concedieron más importancia, en los noventa fue relativamente escasa la producción de conocimiento en las denominadas poblaciones de alto riesgo (por ejemplo los niños y adolescentes que trabajan y viven en la calle, las personas internadas en centros de reclusión, etc.). Acerca de los niños trabajadores de la calle, un reciente informe de UNICEF (1998) destaca la existencia de 73 millones de individuos en el nivel mundial, y prácticamente todos se concentran en América Latina, África y Asia. En el subcontinente trabaja uno de cada cinco niños, constituyéndose entonces en un grupo de interés al cual no se ha concedido la importancia que amerita.

Por otra parte, sobra destacar la relevancia del tema de género, la problemática de la discriminación contra la mujer, las relaciones en medio de las dificultades sociales del subcontinente y las transformaciones culturales y el empleo de sustancias psicoactivas. Pese al limitado número de investigaciones sobre el tema del consumo de drogas en la mujer, hoy se considera que ésta es un área prioritaria de intervención, pues si bien las diferencias entre el consumo masculino y femenino son muy importantes, los patrones de ingestión y de abuso de tabaco, alcohol y benzodiacepínicos en la mujer mostraron signos de transformación constante en los noventa y evidencia la necesidad de reflexión en la mayor parte de los países. La determinación de las condiciones de riesgo y protección para el consumo de drogas se considera actualmente en Latinoamérica y el Caribe como un tema de investigación prioritaria (OEA, 1996b).

\section{APLiCACIONES DE LA INVESTIGACIÓN. Principales PROBLEMAS Y RETOS ACTUALES}

Podemos intentar generalizar al área latinoamericana algunas dificultades en relación con la aplicación de los resultados de investigaciones a campos específicos de la prevención, el tratamiento o la represión. Primeramente, existe en los países una carencia de directrices (¿políticas?) explícitas de investigación y, frente a esa falta de lineamientos, también una ausencia de orientaciones generales de investigación y de posibles relaciones con las políticas de prevención, tratamiento y rehabilitación.

Al no existir directrices, también es evidente la ausencia de prioridades de investigación. En general, la investigación pareciera responder a intereses aislados, muy particulares de personas o grupos, al no existir un marco general que comprenda y oriente el quehacer investigativo. Cuando en 1994 intentamos establecer prioridades de investigación en el Instituto sobre Alcoholismo y Farmacodependencia de Costa Rica, se hizo una búsqueda en una gran cantidad de instituciones nacionales y varias extranjeras, y resultó imposible encontrar una sola priorización de necesidades.

El problema de la falta de comunicación entre los investigadores y quienes trabajan en prevención, es sumamente importante. Se observa muy poca coordinación entre unos y otros. 
En un nivel más amplio se encuentra el problema de la relación entre la investigación y la formulación de políticas. $\mathrm{Al}$ respecto cabe indicar que ambos son procesos de naturaleza distinta, y es esto lo que en primera instancia genera tensión entre ambas. El conocimiento es poco utilizado por quienes formulan políticas, básicamente por aspectos de credibilidad o falta de comprensión sobre los aspectos metodológicos de la investigación, por la distancia existente entre la esfera de la investigación y la de la política y por las múltiples restricciones burocráticas existentes en los niveles de diseño de políticas de la mayor parte de los países (Walker, 1992).

Un problema adicional, relacionado indirectamente con lo anterior, es el de la interdisciplina, la cual ha sido una ausencia notable. Esta carencia es producto, parcialmente, de la tradición positivista antes citada y de la hegemonía médicosanitaria en el campo de las drogas, la cual se ha reflejado reiteradamente en la ausencia de coordinaciones multisectoriales y multidisciplinarias fructíferas que fuercen el reconocimiento de los límites de los enfoques parciales. No obstante, en varios países la situación muestra avances notables en esta materia, en virtud del fuerte impulso otorgado a la coordinación interinstitucional e intersectorial.

Además de lo anterior, es posible observar concepciones inapropiadas en relación con la investigación. En el nivel de la administración pública y en otros niveles existe una inclinación a concebirla, no como una inversión o al menos una necesidad, o como algo que va a orientar, a definir y a ayudar a la toma de mejores decisiones, sino como algo caro, de dudosa utilidad o una estrategia superflua. Definitivamente, no se le otorga el valor que usualmente se le asigna en los países de más desarrollo y quizá sea esa asignación de valor en la que se asientan muchas de las diferencias en cuanto al éxito de los programas, sin importar su signo. Sin embargo, cabe destacar que ésta constituye una tendencia general que muestra signos de recuperación paulatina.

\section{OTROS PROBLEMAS COMUNES}

De modo paralelo o como resultado de lo anterior, también se ha podido detectar la presencia de otros problemas, aunque algunos de ellos pudieran no ser aplicable a todos los países.

Primero, una coordinación deficiente entre sectores que tienen relación con el tema de las drogas. En ese sentido cabe destacar, en primer lugar, la pobre coordinación que existe entre las instancias que previenen y las que hacen tratamiento. También entre las primeras y las que desarrollan la investigación. Un ejemplo de lo anterior se encuentra en el Proyecto Subregional de Prevención del Consumo de Drogas de la Organización de los Estados Americanos, el cual finalizó en 1996: de los cuatro componentes básicos, el que estaba más aislado en todos los países era el de investigación.

Otro problema relevante se relaciona con la divulgación o accesibilidad de los resultados. Tiene que ver con el tema de las prioridades y las concepciones en torno a la investigación. Generalmente la información, la mayor parte muy valiosa, no se publica o se disemina escasamente. En el caso de Costa Rica y algunos otros países latinoamericanos, sólo desde épocas recientes se hacen esfuerzos técnico-financieros para una divulgación de cierta envergadura.

De menor peso son quizás los problemas asociados con el empleo de lenguaje técnico. Sin embargo, en ocasiones puede constituirse en una seria dificultad, pues limita el acceso al conocimiento de los técnicos, los profesionales, el personal de base de las instituciones y organizaciones, los políticos y el público en general.

También es posible hallar la presencia de resistencias de diverso signo en diferentes sectores y países. Según se ha podido observar, en la gente que desarrolla la acción, los preventores, existiría una posible inclinación a minimizar la relevancia que tienen las investigaciones, precisamente porque ellos no han participado en los estudios, o porque los datos contrastan con su propia percepción del fenómeno que están abordando. Además, la mayor parte de los técnicos y profesionales presentan dificultad para saber cómo emplear la investigación y a veces se confía más en la intuición y los buenos propósitos a la hora de formular un plan de acción. Este es un asunto delicado, pues romper las resistencias quizás pase por promover y facilitar una mayor participación de las 
personas que están directamente actuando en el campo, en la escuela, en la comunidad, en el lugar de trabajo y, ¿por qué no?, de las que son potenciales destinatarias de los planes.

En suma, no resulta infrecuente que observemos caminos separados, que ante todo fomentan un inadecuado empleo de los recursos y un impacto débil de los programas de prevención o de tratamiento.

Todo lo anteriormente expuesto pone de manifiesto que la investigación, las políticas y la acción no siempre van de la mano. A veces el divorcio es franco. De nuevo, la falta de definiciones o directrices en materia de investigación, pero además en tratamiento y prevención, ha hecho que ésta se desarrolle de manera segregada de los planteamientos preventivos. La ausencia de políticas de investigación es un problema muy generalizado y debieran desarrollarse sin duda alguna, no sólo por los investigadores, o por quienes usualmente definen las políticas, sino mediante la conjunción de esfuerzos en todos los sectores.

\section{ELEMENTOS PARA LA DISCUSIÓN}

El consumo de drogas es un problema social que tiene serias implicaciones para la salud pública. Sin embargo, es infrecuente que los diferentes Estados hagan tal clase de reconocimiento y que, consiguientemente, doten a las instituciones de las herramientas para enfrentarlo. Esto explica en parte la diversidad de líneas de acción que se observa en cada país, la ausencia de enfoques teóricos coherentes con la realidad de cada nación y una débil articulación entre los entes que directa o indirectamente se relacionan con el tema. Por otra parte, y pese a que en los países de América Latina se produce conocimiento relevante en la materia, no siempre este conocimiento se emplea para la formulación de políticas.

Aunque estos problemas tendrían posibilidades de solución diferentes en cada país, es posible considerar un número limitado de ellas, como se expone de seguido.

En primer lugar, pareciera relevante el establecimiento de directrices $y$, mejor aún, políticas de investigación y evaluación que se deriven de una priorización de necesidades en cada país. Esta tarea tal vez podría originarse desde los Consejos Nacionales de Drogas, instancias por excelencia para este tipo de cometido, o desde alguna autoridad técnico-política superior, junto a los planes nacionales de prevención, pero estimulando a la vez una amplia participación, con el objeto de que haya un acuerdo, claridad y consenso acerca de lo que existe por hacer en esta materia. Asimismo, es sumamente importante desarrollar coordinación, es decir, una vía de comunicación efectiva entre quienes hacen la prevención y el tratamiento y quienes investigan. Decimos coordinación efectiva porque a veces es posible efectuarla, pero con resultados deficientes.

Cabe aquí destacar el papel que debería conferirse a la investigación en centros de tratamiento, los cuales tienen una presencia significativa y creciente en los países latinoamericanos. La investigación en pacientes con problemas de adicción no ha sido concebida como una acción prioritaria. Es por ello que, desde este ámbito, es poco lo que se ha producido. Existe una franca necesidad de intercambio de experiencias sobre estrategias y modelos de intervención particulares que promuevan alternativas de recuperación válidas, de bajo costo y con una eficacia relativamente alta.

Es importante también que haya una mayor socialización del conocimiento para que los profesionales, el personal de base, la gente que trabaja directamente en prevención, o los llamados a prevenir, dispongan del conocimiento oportunamente. No se trata únicamente de poner a disposición la investigación local, sino también la investigación foránea, para poder ayudar a definir nuevas vías de producción de conocimiento.

$\mathrm{Y}$, por último, mayor participación. En este sentido, pareciera absolutamente conveniente que la gente que trabaja en actividades de prevención y tratamiento, propiamente dichos, participe en la investigación, y que para ello tenga un conocimiento profundo de lo que se desea investigar, que conozcan cuál es el conocimiento disponible y cuál es el que debe producirse dentro de cada comunidad, en el sistema educativo y en el lugar de trabajo.

En un nivel más general, cabe mencionar que la participación de la sociedad civil en la generación 
de políticas públicas en varios de los países de la subregión es limitada, y todavía más limitada cuando se trata de políticas relativas al tema de las drogas. La formulación de políticas permanece bajo el control de un número reducido de individuos que posiblemente no reconoce la importancia de una mayor participación. La organización de las comunidades a partir de la instancia de las municipalidades pareciera constituir hoy en día una estrategia adecuada para la identificación de las necesidades comunitarias y la búsqueda de soluciones.

Como asuntos de salud pública, y por ende como problemas sociales de gran complejidad, el consumo y el abuso de drogas requieren de un abordaje de amplia participación que suprima del imaginario social la idea de que la represión (en sentido amplio), o los enfoques centrados en la droga, sin más, constituyen las únicas alternativas de solución frente al problema. Cobra aquí una especial importancia el papel del sector salud, a partir del cual se ha organizado en diferentes países el abordaje del problema. Se trata de un sector salud efectivamente vinculado con otros sectores, como el educativo y de justicia, entre otros.

La posibilidad de promover y desarrollar proyectos bajo un enfoque o perspectiva multinacional en las materias que hemos discutido pareciera ayudar a la solución de los problemas discutidos y a asegurar el logro de los propósitos comentados en este trabajo.

\section{REFERENCIAS BIBLIOGRÁFICAS}

Anicama, J. (ed.), 1994. Drogas, violencia y ecología (Memoria del VI Seminario Internacional sobre Drogas). Lima: CEDRO.

Barnum, H., 1993. Priorities for controlling the global economic impact of tobacco. En: Proceedings for the all Africa on tobacco or bealth (D. Yach \& D. Harrison, eds.). Zimbabwe.

Bejarano, J.; Carvajal, H. \& San Lee, L., 1996. Consumo de drogas en Costa Rica. Resultados de la Encuesta Nacional de 1995. San José, Costa Rica: IAFA.

CICAD/OEA, 1998a. Resumen estadistico, Vol. I. Washington DC: CICAD.
CicAd/OEA, 1998b. Resumen estadístico, Vol. II. Washington DC: CICAD.

Ciecc, 1992. Estudio de prevalencia del consumo de drogas en Bolivia. Encuesta Nacional de Hogares, 1992. La Paz: Development Associates, Inc.

CONACE, 1995. Estudio nacional sobre consumo de drogas. Santiago de Chile: CONACE.

CONADIC, 1994. Programa contra la farmacodependencia, 1992-1994. México DF: Conadic.

Del Olmo, R., 1988. La cara oculta de la droga. Bogotá: Editorial Temis.

Ferrando, D., 1990. Uso de drogas en las ciudades del Perú. Lima: Cedro.

Ghodse, H., 1995. Drugs and society. European Conference on Health Society and Alcohol, París, 12-14 december.

Maynard, A., 1993. Is it helpful to measure the social costs of alcohol use? Yartic Nenusletter, 2.

Menéndez, E. (ed.), 1988. Aportes metodológicos y bibliográficos a la investigación del proceso de alcoholización en América Latina. México, DF: Editorial Casa Chata.

Míguez, H. \& Pecci, C., 1991. Estudio nacional sobre salud mental y bábitos tóxicos en el Paraguay. Asunción: Comité Paraguay-Kansas.

Murray, C. \& López, A., 1996. The global burden of desease. Harvard University Press.

NiDA Media Advisory, 1998. Economic costs of alcohol and drug abuse estimated at $\$ 256$ billion in the US. Http://www.nida.nih.gov/MedAdv/ 98/MA-513.html.

NIDA, 1998. Current trends in drug use worldwide. Notes, 13 (2).

Organización de los Estados Americanos, 1996a. Educación preventiva integral contra el uso indebido de drogas. Nuevos desafíos en Centroamérica, Panamá y Repuiblica Dominicana. Nueva York: Ciecc/OEA.

Organización de los Estados Americanos, 1996b. El impacto del abuso de drogas en la mujer y la familia. Informe final y ponencias, tomo I. Montevideo: IIN. 
Organización Mundial de la Salud, 1995. Tabaco. Día Mundial sin Tabaco (boletín informativo).

Organización Panamericana de la Salud, 1992. La adicción al tabaco. Washington, DC: OPS, Sinopsis Informativa 2/92.

Rapaka, R., Makriyannis, A. \& Kuhar, M. (eds.), 1991. Emerging technologies and new directions in drug abuse research. Washington DC: National Institute on Drug Abuse, Research Monograph 112.

Rice, D., 1993. The economic cost of alcohol and drug abuse and mental illness. Alcobol Health and Research World, 17:10-11.

Rice, D.; Kelman, S. \& Miller, L., 1991. The economic cost of alcohol abuse. Alcohol Health and Research World, 15 (4):307-315.

Rodríguez, E. et al., 1993. Estudio nacional sobre consumo de sustancias psicoactivas en Colombia. Bogotá: DNE.

Rodríguez, E., 1997. Consumo de sustancias psicoactivas en Colombia, 1996. Bogotá: DNE/CEIS.

Rojas, M., 1994. Análisis comparativo de las tendencias de consumo de drogas en el Perú: Un perfil del consumidor desde una perspectiva epidemiológica. En: Drogas, violencia y ecología (Memoria del VI Seminario Internacional sobre Drogas) (J. Anicama, ed.). Lima: CEDRO.

San Lee, L., 1997. Compilación sobre algunos indicadores de alcohol y drogas, 1996. San José, Costa Rica: IAFA.

San Lee, L. et al., 1998. Factores de riesgo y factores protectores en el medio universitario. Cartago, Costa Rica: ITCR.

Single, E. et al., 1996. The costs of substance abuse in Canada. Ottawa: Canadian Center on Substance Abuse.

Smart, R., 1991. Consumo de alcohol: tendencias mundiales. Foro Mundial de la Salud, 12(1):106-110.

The National Foundation for Brain Research, 1992. The cost of disorders of the brain. Washington

DC: Lewin-ICF.
UNICEF, 1998. Estado mundial de la infancia, 1997. Ginebra: UNICEF.

US Department of Health and Human Services, 1994. Eight special report to the US Congress on Alcohol and Health. NIH Publication, $N^{\circ}$ 94-3699.

Walker, H., 1992. La investigación en la formulación de políticas. En: $O E A$, comunicación contra las drogas. Quito: Ediciones Ciespal.

World Health Organization, 1996. Health professional education on psychoactive substance use issues. WHO/PSA/96.16. Ginebra:WHO. 


\section{V}

\section{LA PERSPECTIVA SUBJETIVA DE LA SALUD}




\section{EXPERIENCIAS DE AFLICCIÓNY Y TRATAMIENTO EN EL ÁMBITO RELIGIOSO}

Miriam Cristina Rabelo y Paulo César Alves*

\section{INTRODUCCIÓN}

El presente trabajo se propone realizar un análisis de los abordajes terapéuticos desarrollados en el marco del pentecostalismo, el espiritismo y el candomblé. Para ello, se discuten casos de personas con problemas relacionados con el campo de la salud mental que estuvieron o están en tratamiento en cada uno de estos universos religiosos, procurando comparar las diferentes posibilidades de reorientación del cotidiano abiertas por la participación religiosa. Conviene destacar que, dada la propia complejidad del tema, este trabajo no pretende producir conclusiones definitivas, sino solamente formular algunos problemas para su reflexión.

El artículo se inicia con una discusión más general que busca aclarar el abordaje adoptado y precisar algunos conceptos. Posteriormente, se presentan datos relacionados con los grupos religiosos estudiados, así como los casos de personas que fueron tratados en dichos contextos. Este material es el producto de una investigación, todavía en desarrollo, sobre la experiencia de tratamiento y cura en el ámbito de los tres sistemas religiosos anteriormente mencionados. ${ }^{1}$ La conclusión busca delimitar un marco comparativo de carácter más general y formular algunos problemas para estudios posteriores.

\section{EL TRATAMIENTO RELIGIOSO Y LA RECONSTRUCCIÓN DE LA COTIDIANIDAD:}

\section{ALGUNOS PROBLEMAS INICIALES}

En el estudio de los procesos de tratamiento dentro de los grupos religiosos, se destacan dos problemas básicos: los modos a través de los cuales la experiencia de la enfermedad es reconstruida en el dominio religioso y las formas a través de las cuales la experiencia religiosa de curación es absorbida y repercute en la cotidianidad.

Veamos el primer punto. En general, los análisis convergen en el reconocimiento de que los sistemas religiosos ofrecen una interpretación de la enfermedad que la inserta en un contexto más amplio de relaciones entre lo humano y lo sagrado. La terapéutica religiosa es vista como un intento por producir una reorientación más general del comportamiento, llevando al enfermo a situarse según nuevas formas frente a los otros y frente a sí mismo (Csordas, 1983).

Estudios sobre los procesos terapéuticos desarrollados dentro de los grupos religiosos tienden a resaltar el papel de los rituales en la transformación de la experiencia de la aflicción (Geertz, 1978; Turner, 1967, 1969, 1974, 1975; Tambiah, 1979; Kapferer, 1979a, 1979b, 1991). Los rituales encierran un dominio especial de acción que rompe con los parámetros de la vida cotidiana y exige de quienes participan en ellos un diálogo especial con el mundo de los dramas y aflicciones cotidianas, representándolo desde nuevas

PhD en sociología por la Universidad de Liverpool (Inglaterra). Profesores del Departamento de Sociología y del Programa de Postoraduación en Ciencias Sociales de la Universidad Federal de Bahía (UFBA). Investigadores/fundadores del Núcleo de Estudios en Ciencias Sociales y Salud (ECSAS), UFBA. E-mail: alves@e-net.com.br.

1 Se trata de la investigación "Doença Mental, Religião y Sociabilidade” (Enfermedad mental, religión y sociabilidad), coordinada por la Dra. Miriam Cristina Rabelo, con apoyo del CNPq (Conselho Nacional de Desenvolvimento Científico e Tecnológico). Esta investigación forma parte de las actividades del ECSAS. 
versiones y perspectivas, a veces sorprendentes y profundamente desconcertantes.

Tomando como punto de partida el concepto de encuadre (frame) trabajado por Goffman (1986), podemos decir que en los rituales cada encuadre es construido mediante el uso combinado de distintos medios: música, baile, discurso hablado, iluminación, modos de ocupación y delimitación del espacio. Los cambios en las formas de presentación de estos medios son utilizados a veces para indicar una mutación en el encuadre propuesto; es decir, funcionan como metamensajes que le señalan al actor que la situación debe ser interpretada con otros nuevos parámetros.

La sucesión de encuadres en un ritual delinea muchas veces una narrativa compleja; el recurso de la narrativa parece ser particularmente importante para la realización del trabajo terapéutico por dos razones básicas: primero porque el desarrollo de una historia trae en sí misma y anuncia después de su inicio la posibilidad de una solución o desenlace típico. Segundo, porque en su mismo desarrollo la trama hace emerger el personaje (o personajes), revelando identidades en el flujo de los eventos que se suceden. Por ello, narrar la enfermedad en un contexto de terapia religiosa consiste en algo mucho más complejo que su mera explicación: implica abrir un camino para su resolución en el curso del cual la enfermedad y el enfermo pueden ser profundamente redefinidos.

Llegado a este punto nos hemos visto en la necesidad de desarrollar mejor la idea de transformación de la experiencia, ya implícita en las consideraciones anteriormente expuestas. Argumentamos que ésta no puede ser adecuadamente entendida como adquisición de nuevas ideas, representaciones o esquemas interpretativos que, una vez internalizados, le dan una nueva orientación a la acción. La experiencia de tratamiento que se desarrolla en los rituales atañe directamente al cuerpo y no al intelecto: en ella parece cobrar una importancia primordial la incorporación gradual en contextos de sonidos, movimientos, colores y olores. No obstante, ello no quiere decir que en tanto enfermos o meros espectadores de un ritual, apenas reaccionemos a los diversos estímulos a los que somos sometidos a lo largo del performance. Los modos por los cuales respondemos a estas solicitudes del medio sobrepasan, con mucho, una dimensión de sentido; por ejemplo, que se constituyan en parte de una actividad interpretativa — la posibilidad de que sea tocado o movido en una dirección determinada por el ritmo de la música, los pasos del baile, el juego de colores, el sonido o el movimiento, depende de que esos elementos formen para mí parte de una situación. Es a todo esto, y no a la suma de estímulos sino a cierto modo de articularlos, a lo que respondo.

Así, para dar cuenta de los modos de incorporación en los rituales es apropiado hablar de procesos imaginativos. Tratar los procesos imaginativos desarrollados durante los rituales es justamente tratar de entender cómo los participantes se involucran y se asumen mientras sus encuadres se generan.

Sartre (1983) asume la imaginación como una actividad de síntesis, que organiza varios elementos (un conjunto dado de formas, sombras y colores; podríamos decir también de movimientos, olores y sonidos) en una situación en la cual el objeto representado se hace súbitamente presente. Uno de los análisis más penetrantes de Sartre sobre la imaginación, se encuentra en su descripción de un espectáculo de personificación. En principio, argumenta, en cuanto espectadores, percibimos los elementos que componen la escena y los tomamos como signos a ser interpretados: son elementos que remiten a categorías típicas de personas y acciones. Como signos, los trazos personales del actor desaparecen para representar cualidades generales. Estamos aquí en el nivel del pensamiento abstracto, nos orientamos frente a una situación típica y la interpretamos como una escena de imitación, pero todavía no nos transportamos imaginariamente hacia el universo que ella delimita. Es sólo cuando nos vemos emocionalmente involucrados que esa transposición se opera.

En el argumento de Sartre la cualidad afectiva que le damos al objeto/personaje imitado se transpone luego al actor: en este momento, tenemos frente a nosotros ya no a un mimo que representa a un personaje conocido sino a la presencia misma de ese personaje invadiendo la escena. Es este sentido afectivo "el que realiza la unión sintética de los 
diferentes signos, es lo que anima su cristalizada aridez, lo que le da vida y cierto espesor. Es lo que, dándole a los elementos aislados de la imitación un sentido indefinible y la unidad de un objeto, puede pasar como la verdadera materia intuitiva de la conciencia de imitación. Finalmente, lo que contemplamos en el cuerpo de la imitadora es ese objeto como imagen: los signos reunidos por un sentido afectivo, es decir, la naturaleza expresiva" (Sartre, 1983:48-49).

Dos puntos importantes deben ser tomados en cuenta si queremos abordar el papel de la imaginación en los procesos terapéuticos. En primer lugar, la imaginación se desarrolla en contextos que presuponen procesos de reorientación mutua: descansa en un campo de significados compartidos, insertándose en él y comunicando a través de él mismo ciertas posibilidades de ser; ello sólo es posible -y he aquí nuestro segundo punto- porque el sujeto de la imaginación no es una mente, conciencia o subjetividad soberana, sino el sujeto/cuerpo de la acción, comprometido con otros en una actividad —ritual— que es fundamentalmente pública.

La imaginación es una forma de compromiso corporal, es una comprensión lograda con los sentidos; con el campo unificado de todos los sentidos que conforman el cuerpo. La experiencia de aquellos que se someten a tratamientos religiosos puede incluir imágenes que van más allá de las puramente visuales, en las que cualquier otro de los sentidos ejerce el dominio, o incluso combinaciones de éstos, como cuando, por ejemplo, a la imagen táctil o a la sensación de presencia física de un personaje sagrado están asociadas, de forma solidaria, imágenes olfativas y auditivas (cierta cualidad de olor y sonido relacionados con el personaje).

En la imaginación se produce un sentido de sintonía entre cuerpo/sujeto y situación en la que, por una parte, las sensaciones, estados de ánimo e intenciones esbozadas por el primero parecen devenir de una situación preexistente, en medio de una determinada estructura de sentido, y por otro lado, la propia situación parece reflejar directamente la perspectiva del sujeto. Extendiendo ese argumento, podemos decir que la imaginación está bastante próxima de lo que Merleau Ponty (1994) describió como modo de comprensión en el que la significación termina por devorar los signos, rompiendo las fronteras, características del pensamiento intelectual, entre ambos dominios. Así, podemos decir que es en la posesión como modalidad singular de imaginación que la fusión entre sujeto y situación, significación y signo, tiende a realizarse plenamente.

A partir de esta formulación del concepto de imaginación, podemos encontrar una mediación entre los contextos colectivos de acción delimitados por el ritual y la constitución de la experiencia de los participantes en esos contextos. Tratando de integrar el análisis de los encuadres a la discusión sobre imaginación podemos formular dos puntos importantes: 1) Identificar los procesos de transformación de los encuadres a lo largo de los performances nos lleva hacia los modos por los cuales el ritual puede reorientar el comportamiento de los individuos, guiándolos a través de límites que poseen un sentido compartido; 2) recuperar la noción fenomenológica de imaginación conduce a la idea de que el compromiso de los individuos dentro de los encuadres propuestos en un ritual, no está orientado por una actitud de conocimiento (conforme puede indicar la noción de esquema interpretativo) sino por una inmersión en la situación, que en gran parte se logra a través de los sentidos. Así, la eficacia de la historia que se teje en el ritual depende de que su público pueda al mismo tiempo encarnar al personaje y continuar su cotidianidad, también como narrador, de la trama que fue iniciada en el mundo de la práctica religiosa.

En este punto nos encontramos frente al problema de las relaciones entre el contexto religioso del tratamiento y el mundo de la vida cotidiana. De cierta forma todo tratamiento religioso, así como toda forma de conversión religiosa, busca inculcar un nuevo conjunto de hábitos en el paciente/ miembro futuro (Bordieu, 1977; Turner, 1984; Csordas, 1993), de tal manera que el proyecto religioso (de hombre sano y/o converso) se vuelva una guía permanente para la vida cotidiana, sin necesidad de ser interpretada intelectualmente.

Aunque pudiéramos plantearnos algunas de las principales formulaciones desarrolladas en el ámbito de la sociología y la antropología de la religión para 
comprender los procesos de transformación de la vida cotidiana desencadenados por la participación religiosa, difícilmente estaríamos en capacidad de producir un análisis que sea capaz de explicar el problema en toda su complejidad. Hemos preferido aquí explorar apenas un ángulo del problema: ese que se relaciona con los "pasajes" o saltos que los miembros de una religión continuamente deben realizar entre el mundo de la vida cotidiana y el mundo de la participación religiosa, en tanto distintas regiones de sentido.

Partiendo de una idea de W. James, Schultz (1973) señala que nuestras experiencias se desarrollan según diferentes y finitos ámbitos de sentido, cada uno con un acento de realidad que le es propio: el mundo de los sueños, del arte, de la fantasía, de la ciencia, de la religión, de la vida cotidiana, etc. De todas estas regiones de sentido, el mundo de la vida cotidiana constituye para nosotros la realidad última o paramétrica. Según Schultz y Luckmann (1973), en tanto cada una de estas regiones encierra un sentido particular de la realidad, el paso de una hacia otra no puede darse sin la sensación de salto. No obstante, lo que podía ser visto como un problema en una determinada región de sentido, desaparece como problema al ingresar a otra región; pero, a pesar de que el problema sea neutralizado, puede ser retomado a la luz de las estructuras de sentido propias de la región en la que se ingresa.

Las experiencias de incorporar el oricha, ser habitado por el Espíritu Santo o entrar en sintonía con los otros espíritus tiene su sentido definido en un ámbito de la realidad muy particular: el ámbito de la religión. Cuando sus protagonistas (re)ingresan al mundo de la vida cotidiana, sienten que tales experiencias pierden la fuerza y la profundidad de la cual se habían revestido cuando estaban siendo vividas en el ritual, no tienen cómo sustentarlas integralmente fuera del ámbito de la realidad de la cual forman parte; a muchos les queda sólo la sensación de que se trata de experiencias incomunicables a través del lenguaje ordinario. A pesar de esto último, la referencia a estas experiencias reaparece continuamente en la vida cotidiana: éstas son aludidas, descritas, comentadas, evaluadas; objeto de risas o materia de discusión en torno a su significado; base legitimadora para ciertas exigencias y roles o fuente de nuevos lazos.
En gran medida, todas esas acciones se logran a través de narrativas — sean historias formales para la instrucción de una platea silenciosa o relatos elaborados colectivamente en el contexto de conversaciones ordinarias.

A través de estas narrativas, la apertura que la experiencia religiosa efectúa en el día a día está llena de problemas propios de ese dominio de la realidad, interconectada con acciones, proyectos e intereses que conforman la vida cotidiana. El efecto de esto no se limita a remodelar la experiencia religiosa según las estructuras de sentido del mundo del sentido común, sino también permitir que la experiencia religiosa sirva de guía a la acción cotidiana. Las historias contadas sobre experiencias vividas en el universo religioso conectan narrativas ejemplares tejidas en los mitos y puestas en escena en los rituales junto con la esfera de los dramas y preocupaciones diarias, ofreciendo de esta manera pistas para una exploración activa del contexto de la vida cotidiana.

Veamos ahora cómo pueden esos puntos ayudarnos a entender experiencias de enfermedad y tratamiento en el candomblé, el pentecostalismo y el espiritismo.

\section{El CANDOMBLÉ}

El candomblé es una religión fundamentada en la búsqueda del encuentro con lo sagrado a través del fenómeno de la posesión; una religión fuertemente marcada por los rituales. Es a partir de la práctica ritual que el devoto se familiariza con la cosmología y aprende su lugar dentro de una compleja red de relaciones entre lo divino y lo profano. El ritual busca restablecer la unidad perdida entre el aiê - el mundo físico, la tierra- y el orun, el mundo sobrenatural de las entidades divinas u orichas.

Operando en un movimiento contrario al del ritual — que busca reconstruir la antigua unión entre el aiê y el orun—, la enfermedad aparece, la mayoría de las veces, como señal de la "falta" de unión, de un desorden en las relaciones de un individuo con lo sagrado. Aunque estas relaciones no representen directamente la causa de la aflicción, constituyen el telón de fondo a partir del cual tanto puede descubrirse un cuadro de debilidad como puede ser 
(re)construido un estado de protección, seguridad o equilibrio.

En la perspectiva de muchos miembros del candomblé, las causas de las enfermedades pueden ser de tipo físico/material o espiritual — de las cuales se ocupan preferiblemente los terapeutas religiosos. En la práctica, los dos tipos tienden a combinarse. Tal como señala Teixeira, en el candomblé la enfermedad nunca se ve como mera manifestación física sino más bien "siempre supone una dimensión magico-religiosa" (1996:11). Así, aunque puedan tratar síntomas físicos con el uso de un amplio recetario de hierbas medicinales, los padres y madres de santo ${ }^{2}$ nunca actúan sólo sobre la dimensión física de la enfermedad.

En el candomblé, se señalan una serie de situaciones típicas como causa de la enfermedad (Barbara, 1998; Caprara, 1998). Ésta puede expresar los designios o la voluntad del oricha, y es posible que sea un pedido de la divinidad para asentarse de manera correcta. Según los relatos de los miembros, algunas veces aparecen enfermedades que la medicina oficial no logra curar y que se resuelven con el ingreso efectivo del enfermo al culto, es decir, con la iniciación. La locura es una de las formas privilegiadas en las que se produce el llamado del santo. Una vez que el oricha ocupa el cuerpo o se asienta, se producen una serie de obligaciones rituales que unen al devoto a su santo y al terreiro. ${ }^{3}$ El no cumplimiento de estas obligaciones rituales es considerado generalmente como causante de enfermedades.

Algunos devotos suponen que cuando el oricha es dejado a un lado, éste castiga a quien tenga la osadía de hacerlo, trayéndole toda suerte de infortunios, otros miembros suponen que sólo se aparta dejando a su hijo sin protección. Hay menos referencias como causantes de enfermedad a las situaciones que remiten a la bajada ${ }^{4}$ del santo equivocado, cuando en la iniciación no baja el oricha que de hecho es el "dueño" de la cabeza de quien va a iniciarse, sino otro. Este tipo de situaciones sugiere una falla de parte del padre o madre de santo en la identificación del oricha (hecha a través de los caracoles), ${ }^{5}$ aunque algunos miembros señalan que existen casos en el que ese oricha se "esconde" detrás de otro oricha, dificultando el trabajo del especialista religioso.

Además de los orichas, también los eguns, espíritus de los muertos, o incluso otros humanos (vivos), pueden producir una enfermedad. El recostamiento ${ }^{6}$ describe la situación de interferencia de los eguns, cuya influencia trae serios problemas al cuerpo, originándole enfermedad y sufrimiento. El hechizo señala la posibilidad y la capacidad que tienen ciertas personas de interferir en el bienestar de los otros. Se dice (usualmente a través de comentarios o como "chisme") que algunos padres y madres de santo se especializan en la realización de trabajos para causar infortunio, si así le es solicitado por sus clientes.

En el origen de toda enfermedad - no importa cual sea su causa más inmediata - existe una situación de vulnerabilidad. Eștas indican que el cuerpo está “abierto", pudiendo perder su axe, energía vital, y recibir energías negativas. El cuerpo abierto, según hemos observado, conlleva a un desequilibrio o ruptura en las relaciones entre el individuo y las entidades o fuerzas sagradas. La revelación de las causas se da por medio de la adivinación, en el encuentro privado de la madre de santo con el cliente, para realizar la lectura de los caracoles. El tratamiento puede conllevar desde la utilización de remedios a base de plantas hasta, incluso, la iniciación dentro de la misma religión.

Comprender el contexto que conduce a la enfermedad y a la salud requiere comprender las relaciones entre lo humano y lo divino establecidas en la religión, en la cotidianidad del terreiro y en los contextos rituales. En el candomblé se considera que

2 "Pai de santo" y "mae de santo", figuras terrenas más importantes en el candomblé, especies de sacerdotes (N.T.).

3 Espacio de tierra plano y largo, al aire libre o no, donde se realiza el ritual del candomblé o de la umbanda (N.T.).

4 Usamos el término "bajada", comúnmente utilizado en el español de Venezuela para referirse a la posesión momentánea de un cuerpo por parte de una entidad divina o no, en el original portugués el término utilizado es "assentamento", literalmente asentamiento (N.T.).

5 En portugués "buzios", caracoles usados como oráculo en muchas religiones de origen afro, también conocidos en español como "cauris" (N.T.).

6 Utilizamos el término "recostamiento", usado en la santería afrocubana, pues describe la misma situación de término portugués "encosto", utilizado en el candomblé (N.del T.) 
cada individuo pertenece a un determinado oricha, el cual es dueño de su cabeza. Los orichas a los que se le rinde culto en un terreiro corresponden a modelos generales, cada uno de ellos asociado a ciertos elementos naturales, los colores, los días y los tipos de sacrificio, además de poseer ciertos trazos de personalidad que los distinguen, tal como puede verse a través de los mitos.

Este modelo general se diferencia por un conjunto de cualidades específicas del oricha, que "son partes o segmentos de su propia biografía mítica o representaciones de lugares en los que se les rinde o ha rendido culto de esa manera" (Prandi, 1991:123). Asimismo, el oricha o la cualidad de oricha se desdobla en el oricha específico de cada persona, único e intransferible, que se fija en la cabeza u ori. El oricha es una energía, no puede ser visto - lo que puede verse es el oricha particular de cada persona. El oricha individual tiene su grito propio o ilá, que se hace conocido y apreciado en el terreiro. Éste es el único que posee un erê — cualidad infantil del oricha. El erê es distinto al oricha, le gusta hablar mucho y hacer bromas tal como un niño y con frecuencia provoca confusiones en la vida cotidiana del terreiro.

En la iniciación, los novicios son mantenidos en estado de erê, especie de trance incompleto, y de esta manera se les expone a varias enseñanzas de la religión. Ademas del oricha dueño de su cabeza, la persona tiene varios orichas, los cuales deben ser "bajados" en una serie de rituales que se realizan según el tiempo de iniciación que se tenga dentro de la religión. Entre éstos se encuentra Exu, el mensajero de los dioses y los humanos, señor de los caminos y las encrucijadas. Se trata de una divinidad trickester, tenida como amoral, y que fuera del dominio "erudito" (en el cual es de suma importancia la fidelidad al modelo africano) se le asocia con el diablo cristiano. Exu es una divinidad múltiple: cada oricha posee un exu que le sirve de esclavo.

Las alianzas con los orichas se construyen y refuerzan a través de la construcción de acuerdos dentro del terreiro, donde domina una fuerte jerarquía. Como la familia, el terreiro acoge, protege, produce alimento y da de comer a todos, pero lo hace conforme a una jerarquía de respeto y subordinación, que se desdobla y segmenta en varios niveles. $\mathrm{La}$ cotidianidad del terreiro es siempre un ir y venir de mujeres atareadas, ropas blancas extendidas o para ser planchadas, trabajo duro en la cocina, preparación para las fiestas y promesas (obrigações), todo bajo la mirada vigilante del padre o madre de santo. No es raro que la persona que se encuentra en estado de aflicción sea acogida dentro de esa dinámica de la casa, pasando algunos días en el terreiro y comprometiéndose con la cotidianidad del trabajo, la conversación, los comentarios y el ir y venir de gente. Es en el contexto de estas relaciones que se fortalecen los lazos entre el devoto o fiel y los orichas.

En el candomblé, el hijo de santo es visto como una multiplicidad construida con la ayuda de los orichas (Augras, 1983; Goldman, 1989). La iniciación es el momento crítico y primordial de ese proceso; allí el fiel se retira del mundo de las acciones y certezas de la vida cotidiana para aprender los modos de ser de la religión. A su regreso el devoto o fiel renace como hijo de un determinado oricha.

Algunos autores han señalado la importancia central que tiene el sonido en el proceso de identificación con el santo que ocurre en la iniciación (Segato, 1995; Barbara, 1998). Podemos decir que para el devoto, el toque del oricha marca una situación que de manera gradual va adhiriéndose a su cuerpo: a ese toque responderá en las ceremonias sagradas, a través de un compromiso imaginativo que sobrepasa los límites de una experiencia sensorial autocontenida y que, a su vez, envuelve al cuerpo como un todo. Es de esta manera que va a vivenciar la posesión.

En la experiencia del hijo (a) de santo, la música y el baile están estrechamente ligadas. La posesión envuelve un cambio radical en el cuerpo, que pasa a ser tomado por el oricha. Es sobre todo a través del baile que el oricha se manifiesta, que la posesión modela a éste en el cuerpo. El baile es profundamente estilizado y expresa las características del oricha, además de contar elementos de su historia (Bastide, 1973; Augras, 1983; Segato, 1995).

Los orichas no son las únicas entidades que descienden sobre el cuerpo de los ficles; como ya hemos señalado, existen los erês, entidades infantiles, juguetonas y desordenadas, que no han sido socializadas. A pesar de ser también un oricha, exu goza de un posición especial en el candomblé, y su 
incorporación —bastante rara en los terreiros más tradicionales - tiende a ser descontrolada y violenta. En la umbanda y los terreiros menos africanizados, exu se desdobla en personajes ligados a los malandros y al submundo. Aunque externos al universo de las religiones africanas, existen también los caboclos, espítitus nacionales que describen tipos o personajes importantes en la historia brasileña: el indio, vaqueros, marinos, pescadores.

Los orichas y caboclos difieren bastante en su manera de comportarse y relacionarse con el mundo humano: mientras los primeros son altivos y distantes, comunicándose sobre todo a través del baile (y por tanto de la música que reproduce su identidad sonora particular), los caboclos son más cercanos, conversan, dan consejos, trabajan ejerciendo actividades curativas; en general, les gusta beber, fumar y muchas veces tomar cuerpos de forma violenta y descontrolada. Existen algunas similitudes importantes entre los caboclos y los erês: ambos expresan la dimensión de lo carnavalesco, de la ruptura con las fronteras rígidas a través del humor y de la sustitución de la formalidad y la distancia por los riesgos e incertidumbres advenidos de las relaciones entre prójimos (Wafer, 1991).

Estas diferencias son vividas por los devotos también como experiencia de posesión bastante distintas; en varios terreiros se hacen fiestas particulares para los caboclos. Según algunos adeptos del candomblé, cuando los caboclos descienden mantienen a la persona en estado de semiinconsciencia durante un cierto tiempo: incapaz de controlar el cuerpo - a los caboclos les gusta jugar y manipular con cierta dosis de violencia- pero de cierto modo todavía capaz de presenciar, como espectador, ese movimiento de sentir o sufrir las sensaciones muchas veces de dolor- que provoca. La posesión por el oricha, al contrario, implica, al menos idealmente, pérdida total de la conciencia. Otra diferencia expresa la intensidad y descontrol que se siente en el momento de la incorporación: mientras que la bajada de los caboclos tiende a ser más fuerte y descontrolada, la incorporación del oricha es más amena (Teles dos Santos, 1995).

$\mathrm{Al}$ adentrarse en el mundo del candomblé el devoto pasa a experimentar en los rituales posibilidades nuevas y diferentes de ser que puede descubrir y explorar en cada nuevo performance. Según Prandi: "en la iniciación... el hijo de santo deja modelar sus yo sagrados, cuya validez social, sin embargo, sólo tiene sentido dentro del grupo religioso. Al unirse al grupo, su yo social pasa por consiguiente a contar con una enriquecedora expansión a través del proceso ritual de multiplicación y yuxtaposición de sus yo sagrados" (1991:182). Para los devotos los performances no sólo recrean o reactivan el tiempo mítico, sino que pasan a formar parte por sí mismos de una historia. Esta es la historia en la que gradualmente se revelan peculiaridades del oricha o del caboclo de cada uno - un modo particular y singular de bailar, y en el caso de los caboclos, también de comunicarse, de expresar y desarrollar preferencias frente a la audiencia- y en las que se muestran diferentes momentos o fases en la relación de las entidades con sus carnales. Se trata de una historia que, construida en los performances, muchas veces se expande fuera de los límites del ritual, ocupando la vida del terreiro. Así, caboclos, erês e incluso orichas se mezclan de vez en cuando en la cotidianidad de la vida de santo, trayendo revelaciones, realizando hazañas o simplemente impregnando el aire de su gracia. De la misma manera, también se expande hacia el mundo privado de los sueños, en el que las entidades muestran a sus devotos nuevas facetas de su personalidad, les envían avisos y les revelan deseos que deben ser cumplidos. Según Segato (1995), la valoración de los sueños en el candomblé cumple una doble función: por una parte permite que el sueño pueda entiquecer, y así reavivar, el mito, señalado por las características del oricha determinado; por otro lado, permite que el mito integre la propia identidad.

A continuación pasamos a una rápida presentación de una historia de enfermedad y tratamiento en el candomblé.

\section{LA HISTORIA DE RITINHA}

Habitante de un barrio pobre de Salvador de Bahía, Ritinha es una mujer negra de 28 años, madre de dos hijos pequeños. Cuando era adolescentes estuvo internada en un hospital psiquiátrico, considerada como loca. Hoy en día pertenece al terreiro de José Lins y ha ingresado por iniciativa propia a la carrera de madre de santo. Su caboclo, 
Boiadeiro (vaquero), consulta y hace trabajos y Ritinha ha promovido dos sesiones con el caboclo en su casa.

Ritinha creció en medio del candomblé: su madre era hija de santo y frecuentaba activamente un terreiro en el barrio. Cuando ésta murió Ritinha, todavía niña, se va a vivir con una tía pentecostal; enseguida comienza a tener ataques, que las personas califican de epilepsia. Las crisis se hacen frecuentes, con convulsiones y rigidez física, sin que nadie identificara su origen - los exámenes médicos no confirmaron el diagnóstico de epilepsia. Para su tía se trataba de "cosas del diablo", manifestación que ella combate golpeando a la sobrina para expulsar al demonio. Al poco tiempo, las crisis impiden que Ritinha trabaje, no logra mantenerse en ningún empleo. En esta trayectoria cada vez más personas coinciden con la hipótesis de la locura, hasta que al fin la tía decide internarla; para ese momento Ritinha tenía apenas 15 años.

Gracias a la intervención de su padre, Ritinha es dada de alta en el hospital después de una semana de internada. Ritinha es llevada al candomblé de José Lins, terreiro relativamente pequeño y sin gran fama, en el que ella va a incorporarse. Según ella misma relata, asistió a una fiesta y sólo despertó tres meses después, ya iniciada. El candomblé le produce un reencuadre de su experiencia de aflicción interpretada como el llamado del santo.

Ritinha es hija de Obaluaê, el oricha que retiene el poder de la enfermedad y de la cura. Más comúnmente relacionado con enfermedades de la piel, también se le identifica con ataques epilépticos, que algunos padres y madres de santo consideran una enfermedad típica de Omolu/Obaluaê (Caprara, 1998). Caracterizada por movimientos espasmódicos, la danza de ese oricha parece elaborar una analogía con el ataque epiléptico. No obstante, más que establecer una asociación lógica o a nivel de representaciones entre la realidad sagrada y la realidad médica, opera como metáfora encarnada, transformando los términos de la analogía y modificando radicalmente la experiencia de la aflicción. En otras palabras, la metáfora aquí no propone simplemente una analogía entre términos distintos - por un lado la aflicción de Ritinha (sus ataques constantes) y, por el otro, el modelo mítico de Obaluaê-, actúa en el sentido de borrar o disolver lo mejor posible las fronteras que los separan.

Los ataques de Ritinha guardan relación con Obaluaê: en el contexto ritual son transformados en el modo de expresión típico de ese oricha. Además de Obaluaê, Ritinha tiene una fuerte unión con su caboclo Boaideiro y con su erê, Soldadinho. La dimensión vivida de la posesión guarda una "cualidad" propia que Ritinha describe a la luz de una metáfora que se encuentra en el dominio de las relaciones amorosas: "Tú dice, a ti te gusta un muchacho... (tá bien). Ahí tú tás con ese muchacho, te acuesta con ese muchacho, ahí cuando tú tás con él, te tás sintiendo fuerte, ¿no? Cuando él se va tú te siente así... sola, te siente así abandoná, te siente vacía... así es que yo me siento cuando ese caboclo se va, es así que yo me siento".

Los problemas en la vida de Ritinha no terminan con la iniciación; durante mucho tiempo mantiene una postura ambivalente frente a la religión, sea aproximándose, sea buscando marcar una distancia. Cuando busca apartarse del candomblé es castigada por el santo. Uno de sus conflictos con el candomblé -y fueron muchos- le trajo consecuencias desastrosas. Ritinha cuenta que no quería estar más dentro de la secta, pero no lograba apartarse. Iba al candomblé, incluso sin querer. Cierta vez, había una fiesta en la calle pero también había una en el terreiro de José Lins. Ella decidió ir a la primera, pero en el camino es poseída por Boiadeiro, éste la lleva para el monte, hace que se rasgue la ropa y se cubra con hojas de cansancio (cansanção). Así, llega al terreiro para experimentar todavía más sufrimiento, el caboclo le da una palmada lanzándola violentamente contra el piso y haciéndole golpear la cabeza contra la pared. Al final de la fiesta el estado de Ritinha era tan lamentable que José Lins decide mantenerla en el erê, para que pueda recuperarse sin mucho dolor. Por fin, ella termina por desistir en su lucha contra su destino del candomblé.

Ritinha relaciona los acontecimientos de su vida con el santo. No logra mantenerse en un empleo por más de un año pues siempre pasa algo que la saca del trabajo. Dice que esa es la voluntad del santo, que no quiere que ella trabaje para otros, sino con él. Conversando con nosotros a principios de 1998 nos 
explicaba que tenía el cargo de madre de santo, y que necesitaba asumirlo. Con el pasar del tiempo, empieza a tomar en serio su proyecto en el candomblé. Comienza a consultar, leer los caracoles a clientes eventuales y hacer trabajos de "limpieza".

Generalmente, trabaja con Boiadeiro. Una amiga le asiste en esa empresa, Marina, que vive en el barrio y se hace llamar "madrina" del caboclo. Marina administra todo cuando Ritinha está trabajando. Ritinha señala, con cierto disgusto, que Boiadeiro no permite que le cobre a los clientes: parte de su misión es pasar un tiempo atendiendo gratis. Sin embargo, siempre entra algún regalito de los clientes satisfechos, lo que le permite comprar los materiales para la sesión (tabacos, esencias, etc.) y reservar algo para su casa y sus hijos. Boiadeiro no cobra, pero pide cerveza: él y Marina son capaces de tomarse una caja completa después de un servicio. Ritinha está molesta porque el caboclo y su amiga se divierten bebiendo y nunca sobra un poco para ella.

El comportamiento de Boiadeiro es, en gran medida, contradictorio con el comportamiento esperado por una madre de familia. Además de ser aficionado a la fiesta y la bebida, el caboclo no le demuestra afecto a los hijos de Ritinha, por el contrario, las travesuras de éstos le sacan de sus casillas. Cierta vez, muy molesto con la presencia de uno de los niños, que entorpecía las consultas, Boiadeiro le dio un golpe tan fuerte que lo mandó al otro lado de la sala.

En el mes de abril Ritinha dio la primera sesión en su propia casa, bastante pequeña y todavía en construcción. La segunda sesión ocurrió en mayo, ya más organizada en términos de infraestructura material. La pequeña sala se llenó de gente, en su mayoría mujeres. El evento fue considerado exitoso; la realización de una próxima sesión dependería de que Ritinha recaudase los fondos suficientes para comprar los tambores.

El Boiadeiro de Ritinha no es solamente un personaje mítico de la historia individual, privada. Éste forma parte de la vida cotidiana y de la historia de mucha gente, de cuya vida participa como consejero, pretendiente e, incluso, compañero de farra. Muchas mujeres tienen relaciones en secreto con Boiadeiro y han establecido una relación que, aparentemente, no necesita de la mediación de Ritinha. Ocurre lo mismo con Soldadinho, el erê que Ritinha incorpora. La relación de Ritinha con esas entidades parece proporcionarle acceso a un conjunto variado de experiencias y relaciones sociales, a partir de las cuales su vida se compone y recompone en tanto una trama de múltiples caminos y posibilidades.

\section{El pentecostalismo de la iglesia Dios es} AMOR

El pentecostalismo es un movimiento propio del protestantismo, que resalta la experiencia única y transformadora del Espíritu Santo en la vida de los fieles. El pentecostalismo de la iglesia Dios es Amor - fundada por David Miranda en 1960 en Sao Paulo- representa la segunda fase del movimiento pentecostal en Brasil y está marcado por una doctrina pautada en la observación de principios morales bastante rígidos.

Para los pentecostales, muchas enfermedades tienen causas espirituales, son el resultado de la influencia del mal y pueden ser tomadas como amenaza e incluso invasión del cuerpo por entidades demoníacas. Es posible que tales influencias maléficas sean desencadenadas por la acción de otros — a través de la hechicería o incluso por medio del mal de ojo. Sin embargo, la producción de la enfermedad apunta hacia dos situaciones básicas. En el primer caso remite a un estado de vulnerabilidad: cierto modo de vida que contraría o se aparta de los principios divinos; la enfermedad es, en este caso, sólo un elemento más que compone el cuadro general del pecado. En el segundo caso representa una prueba impuesta por Dios para examinar a sus fieles, sin que necesariamente haya existido un estado previo de debilidad moral.

Se hace necesario, llegado a este punto, comprender mejor la visión del mundo pentecostal. En primer lugar, ésta se asienta en una oposición rígida entre el bien y el mal; se trata, en última instancia, de planes discontinuos e irreconciliables. El individuo sólo comparte el poder sagrado al aliarse definitivamente al plano del bien (Brandão, 1980; Fernandes, 1982). La iglesia ofrece un espacio alternativo que debe sustituir los "placeres del mundo" por el placer de las prácticas y celebraciones religiosas, 
en las que se cultivan los dones del Espíritu Santo. Así, busca constituirse en un subuniverso contrapuesto al medio circundante.

En el contexto de la religión, el paso de la aflicción a la cura se mueve a través de un espacio ético: librarse de la enfermedad es dejar el plano del mal y transportarse hacia el universo ordenado de los fieles. Esa es la dinámica de la conversión, que se yergue como el momento de cambio profundo en la vida. De esta manera, curar no es parte de un proyecto más amplio de liberación que involucra una reorientación de la vida según los principios de la fe. La cura de la enfermedad es una gracia concedida por Dios, una señal de que es preciso y posible cambiar, un aviso de que el cambio requiere de una vigilia continua sobre el comportamiento y, por lo tanto, sobre el cuerpo. Éste debe fortalecerse para cumplir su papel de templo del espíritu.

Entre los pentecostales, el creyente es un vector para la acción del Espíritu Santo, convirtiéndose en una especie de "locus" y agente del Divino. Para el pentecostal, ser habitado por la divinidad significa poder ser usado por Dios en cualquier momento para la manifestación de su poder; también significa que una de las más importantes ocupaciones del creyente es la de cuidar con celo el cuerpo para hacer de él un templo en el que el Espíritu Santo pueda habitar. Es necesario cuidar de la casa. El cuidado del cuerpo, sin embargo, no se define en términos de lo que ordinariamente llamamos prácticas de salud: es más que todo una empresa moral. De esta empresa se origina un estado de fuerza y protección que se hace sentir en todas las dimensiones de la vida y que es una fuente de salud, prosperidad, armonía en las relaciones familiares, éxito y bienestar en el trabajo, etc. Para los pentecostales el Espíritu Santo posee una dimensión real y concreta, actúa en sus cuerpos.

La presencia activa del Espíritu Santo está fuertemente cultivada en iglesias como Dios es Amor. Construida ritualmente, se desdobla a partir de un conjunto de encuadres que funden el poder divino con el cuerpo de los fieles y los modela según la dinámica de este poder. Conviene analizar mejor algunos de los encuadres centrales del culto, entre los cuales se destaca la oración.
Este es el momento en que el culto crece en dinámica e involucra con mayor intensidad a los fieles; está constituido básicamente de oraciones individualizadas pero que siguen frases repetidas y preparadas que piden la "victoria" y las "bendiciones de Dios". Las oraciones se inician en un tono más bajo que va creciendo y tomando el ambiente. El pastor o el obrero (a) que está en el púlpito, profiere su oración: sus palabras al principio son claras, pero al poco tiempo se confunden, distinguiéndose apenas un ritmo acelerado que alcanza su punto más bajo cuando nuevamente se destacan frases como Gloria a Dios, Gracias Jesús. Éstas vuelven enseguida a desvanecerse bajo el fondo de muchas voces.

El efecto de esta sobreposición de voces y oraciones es, en primer lugar, crear un espacio totalmente lleno por el poder divino; una ola de poder que se expande y no deja de tocar a nadie. Pero también presenta ese poder como algo que se multiplica y singulariza en cada uno de los presentes, haciendo de cada cuerpo una morada.

Cuando la profusión de voces se confunde y entrelaza en un ritmo acelerado llegamos al auge de la oración. Llantos, gritos, saltos, personas temblando de los pies a la cabeza. Algunos fieles comienzan a temblar como en un acceso de risa, otros giran sobre el eje de su propio cuerpo, dando la impresión de que terminarán cayéndose. A veces se balancean de un lado a otro, llorando y produciendo chillidos finos y prolongados. Están manifestando el Espíritu Santo. Para los fieles esa es una experiencia de profunda alegría. Es como ser tomado por un sentimiento que no puede contenerse pero que es, en el fondo, un sentimiento positivo: "Cuando se tiene el corazón abierto al señor el Espíritu Santo toca y hace que la persona sienta una alegría tan grande que ella no logra controlarse. Es como un corrientazo, la gente queda como borracha. ¿La persona cuando está borracha no se pone mareada? Sólo que cuando se está borracho del Espíritu Santo la persona está consciente, sabe qué es lo que pasa a su alrededor".

Existen, específicamente, dos dones del Espíritu Santo que se manifiestan durante el culto, usualmente entre pastores y obreros: la glosolalia y la revelación. El primer don, el de hablar en lenguas extrañas, tiende a ocurrir en el contexto de la propia 
oración, transformando súbitamente las palabras del pastor en señal directa del Espíritu Santo. Cuando ello ocurre se produce una intensificación de la propia oración. El segundo guarda características opuestas a la glosolalia: mientras en ésta el espíritu se revela como pura espontaneidad y el sentido de las palabras se remite directamente al campo de poder que instauran, en la revelación se tiene un discurso claro y estructurado que requiere una interpretación literal. Aquel que tiene ese don se convierte en emisario de la voluntad de Dios de conceder una gracia a uno de los fieles.

Esta gracia recae sobre un aspecto de la vida del fiel que es súbitamente puesto al descubierto o revelado al pastor u obrero (a) durante el culto. Puede que se trate de un problema que está afligiendo a una persona, como también puede tratarse de una falta cometida, pues son muchas las posibilidades de falta o de desvío a la moral de la iglesia. Al recibir una revelación el pastor usualmente comienza diciendo: "Hay alguien aquí que..." y describe cierto comportamiento o estado, pidiendo inmediatamente que la persona se haga presente para recibir la gracia (que en el caso de faltas, es el perdón divino). Usualmente alguien se pone de pie y va hasta el púlpito, acompañado por las plegarias de los demás, arrodillándose para ser bendecido.

Como la glosolalia y la manifestación del Espíritu en los fieles, la revelación atestigua el poder de Dios; sin embargo, señala otra faceta de ese poder. En las dos primeras es un poder que "suelta" o deconstruye el cuerpo, rompiendo los controles cotidianos que operan sobre él. La espontaneidad y la relativa libertad están marcadas por ese poder. En la revelación, por otra parte, se trata del poder que vigila y disciplina, que reconstruye el cuerpo según el orden divino. En ambos casos se tiene un poder único, que se singulariza y desdobla en los cuerpos para reconstruirlos como su casa.

La fuerza no es sólo vivida en el culto sino continuamente testificada. Los fieles van al frente para contar su testimonio: contar a los hermanos cómo Dios ha actuado en sus vidas. Los testimonios tienen una forma muy semejante, comienzan hablando de las privaciones, las dificultades para conseguir dinero o pagar deudas, conflictos en la familia y problemas de salud. Posteriormente, resaltan la imposibilidad de resolución inmediata o satisfactoria del problema y el drama vivido por todos aquellos involucrados. A partir de allí, se describe el agravamiento de este cuadro o la proximidad sentida de un desenlace negativo, frente al que sus protagonistas deciden dejar el caso en manos de Dios. Así — concluyen - cuando todo parece estar perdido, la resolución del problema viene casi siempre de manera inesperada e inexplicablemente, comprobando la acción milagrosa del Señor.

\section{LA HISTORIA DE DOÑA LOURDES}

Doña Lourdes es una señora de aproximadamente 70 años. Viuda, madre de 10 hijos, vive en el nordeste de Amaralina con las dos hijas más jóvenes. Sufre de los nervios ${ }^{7}$ desde hace muchos años y en el pasado la dolencia constituía un caso bastante grave, intimamente relacionada con la enfermedad de su hija menor, hoy de 34 años.

La historia de la nerviosidad de doña Lourdes comenzó con el nacimiento de esta hija. Una fuerte bomba con las que se celebra el día de San Juan es lanzada a su ventana, asustando a ella y a la bebé, y provocándole un dolor de cabeza insoportable.

Este acontecimiento divide la vida de doña Lourdes en dos períodos bastante distintos. En el primero era la madre dedicada, amamantaba a sus hijos con placer, vigilaba con celo su bienestar y siempre les confeccionaba las ropas para las principales fiestas del año. En el segundo pierde el ánimo de vivir y muestra una total indiferencia hacia la casa y la hija pequeña. El estado de nerviosismo del que se ve presa coloca así en jaque los elementos centrales de su propia identidad. Este es un momento

7 Hemos traducido la palabra portuguesa "nervoso", por la expresión "sufrir de los nervios", "nerviosismo" o "nerviosidad", comúnmente usada entre los grupos de menos recursos urbanos o rurales en América hispana. Al igual que el término "nervoso", el "sufrir de los nervios" puede describir ciertos cuadros de patologías mentales, no representados socialmente como tales o como un eufemismo - o negación- de éstos (N.T.). 
tan difícil en su vida que doña Lourdes llega a pensar incluso en el suicidio.

La enfermedad de la hija, también atribuida a los daños causados por la bomba de San Juan, aunque sólo venga a manifestarse seis años después, hace bastante difícil para Lourdes superar su problema nervioso. A la preocupación viene a agregársele posteriormente la muerte del marido, que deja a doña Lourdes bastante abatida. El alivio para la enfermedad de doña Lourdes comienza a sentirse cuando ingresa al pentecostalismo. En esa época sufría también de mareos muy fuertes y por ese motivo fue llevada por una vecina a la iglesia cuadrangular. Allá se convirtió en creyente y vivió una mejoría de su nerviosidad y de sus mareos. Después de sufrir dos paros cardíacos y una cirugía de emergencia, doña Lourdes fue llevada a conocer la iglesia pentecostal Dios es Amor.

Según sus relatos, ella vivió una revelación: el pastor le dijo que tenía un problema grave en el corazón y que Dios escogió aquel día para darle un corazón nuevo. A partir de entonces dejó de usar los remedios para el corazón; dice haber quedado completamente curada. También mejoró bastante su nerviosidad con las visitas frecuentes a la iglesia Dios es Amor. Explica que todavía siente nervios pero ya no se trata del estado paralizante que vivía en el pasado.

Doña Lourdes considera que la iglesia Dios es Amor tiene una doctrina más pura y verdadera que las otras, sus miembros llevan una vida totalmente volcada a agradar al Señor. Como una fuerte señal de ese cambio ella recogió toda la ropa y objetos sagrados del candomblé, que fueron usados cuando fue tratada por una madre de santo, y los quemó en plena calle a la vista de todos. Se trata de un primer paso para la verdadera purificación de su casa; pero esa purificación exige la conversión de la familia, hecho que Lourdes todavía no ha podido producir. En su relato subraya la idea de que la purificación del cuerpo y la purificación de la casa - es decir, la transformación de ambos en receptáculos del Señor - forman parte de un solo proceso que estará siempre incompleto mientras una de esas dimensiones no se realice.

En la búsqueda de la purificación de la casa (y de la familia), doña Lourdes ya no tiene en su casa los tres televisores de los que era dueña y el radio sólo se sintoniza en los programas de Dios es Amor. Ya ha logrado convertir a dos hijas, y los otros miembros de su familia, a pesar de no frecuentar la iglesia, acostumbran a escuchar sus prédicas con cierta reverencia. Las visitas a la iglesia sólo son impedidas por la debilidad que le aqueja de vez en cuando. La debilidad del cuerpo que doña Lourdes experimenta es sentida por ella como un impedimento para realizar plenamente su ideal de convertirse en un recipiente para la manifestación del poder de Dios; por ello todavía no ha sido bautizada en el Espíritu Santo, que "es algo purísimo, finísimo", no accesible a todo el mundo. Cierta vez, estuvo muy cercana a recibir el espíritu: "Sentía aquella cosa fuerte, yo taba en el culto y aquella oración tan poderosa (yo taba más fuertecita en aquella época) entonces aquella oración tan poderosa me fue llenando y yo iba quedándome así, con el cuerpo temblando, y aquella alegría... Yo todavía estoy sintiéndome alegre pero no sé si es porque yo toy así débil, toy volviéndome vieja, mi médica dice hasta que tengo anemia".

Aunque todavía sienta nervios y no haya alcanzado el don de ser llenada por el Espíritu Santo, doña Lourdes considera que su vida tiene un nuevo rumbo: "yo no soy parte de este mundo, no miro las cosas mundanas, no veo televisión, prácticamente vivo la santidad, procuro vivir como mi Señor manda. Hoy yo soy una cristiana y gracias a Dios toy feliz en la iglesia Dios es Amor".

\section{EL ESPIRITISMO}

El espiritismo es una religión basada en la doctrina del médium francés Alain Kardec. Establecido en Brasil a finales del siglo pasado, congrega una clientela preponderantemente de clase media. La doctrina espírita elabora la oposición entre bien y mal siguiendo un esquema evolucionista -en el marco de una línea continua de evolución, el mal corresponde a los niveles inferiores de existencia.

En el abordaje espírita la enfermedad señala en primer lugar el estado de desarrollo espiritual del enfermo; es señal de debilidad moral que debe ser corregida. Este estado se refiere no sólo a las acciones del individuo en esta vida, sino que puede remitir a una situación proveniente de reencarnaciones pasadas. 
En algunos casos la enfermedad resulta directamente de la interferencia de espíritus menos desarrollados, "inoportunos", a los que se les hace fácil introducirse en el cuerpo de quienes se encuentren más vulnerables.

Aquí es necesario entender algunos elementos de la doctrina espírita. Al espírita se le revela el mundo por medio de dos planos, el espiritual y el material (Cavalcanti, 1983; Droogers, 1989; Greenfield, 1992). $\mathrm{El}$ primero es el mundo invisible de los espíritus en proceso de continua evolución, a lo largo del cual se puede venir a tener existencias encarnadas, en el ámbito del mundo material. La llave de esta evolución, según señalan los espíritas, está en una vida dedicada al bien y el amor al prójimo, ideal que se encuentra resumido en el principio de la caridad. El espírita debe remodelar y regular su vida de acucrdo a este ideal. Más que un simple acumular de buenas acciones, ello implica un control reflexivo sobre sí mismo y sobre el cuerpo para que el espíritu pueda evolucionar.

La formación del espírita está, de hecho, regida por una serie de prácticas de reflexión y vigilancia del cuerpo, tendientes a lograr una postura equilibrada frente a la vida. Evolucionar es imprimir de manera consciente, en el ejercicio del libre arbitrio, una nueva dirección a la vida y a las relaciones con los otros, según los principios morales establecidos en la doctrina. El control de sí mismo se evidencia en el equilibrio, en una actitud tranquila y serena frente a la vida.

Esta postura también es fundamental en la misma mediumnidad; se describe en términos de una comunicación de energía, el médium no es poseído sino que canaliza energía. Este proceso de canalización requiere dos realizaciones básicas por parte del médium; por una parte, el (la) médium debe estar abierto para captar o canalizar la energía del espíritu, es decir, establecer una sintonía con la cualidad energética que dicho espíritu emana. Sin embargo, no puede dejarse poseer por esa energía, sobre todo cuando se trata de un espíritu inferior. Debe estar siempre atento a no perder el control sobre sí mismo pues de no hacerlo pondría en peligro la actividad terapéutica que involucra el adoctrinamiento de los espíritus inoportunos u obstructores. Es en el juego entre la apertura hacia el otro y el control de sí mismo que reside el ejercicio correcto de la mediumnidad.
Tal como ya ha sido señalado, el ejercicio de la mediumnidad es parte integrante de la actividad terapéutica desarrollada en cualquier centro espírita. Ésta se desarrolla en un contexto organizado según modelos asistenciales: el centro es una institución que presta servicios tanto a los visitantes frecuentes como a los ocasionales. En este sentido existe una clara división entre quienes trabajan en él y quienes van a buscar tratamiento. Al entrar, el cliente llena una ficha describiendo sus síntomas, en la cual le serán agregados los datos de todos los terapeutas y los tratamientos específicos por los cuales pasará, siendo usada cada vez que realice un nuevo ingreso al centro.

Inmediatamente después del triaje inicial, el paciente es enviado a una entrevistadora, con quien establecerá una relación de carácter más privado, dentro de los cánones de una consulta. Es, justamente, la entrevistadora quien indicará al paciente los tratamientos a los que debe someterse y es también a ella a quien el paciente regresará después de terminar cada uno de ćstos. Muchos de estos tratamientos se construyen con base en un conjunto de imágenes tomadas del dominio de la práctica biomédica, lo que refuerza la definición del centro espírita como institución asistencial.

El tratamiento conlleva tanto a medidas sobre el enfermo como, en los casos de obstrucción, una acción dirigida al espíritu causante de la aflicción. Éste consiste fundamentalmente en una empresa de corte pedagógico: es necesario enseñar a la persona en estado de aflicción - y, en los casos de obstrucción, también a los espíritus inferiores - a aprender y a adoptar, gradualmente, una postura correcta frente a la vida, una actitud serena, equilibrada y responsable. Se trata de abrir caminos a un proceso de evolución moral. Lo más importante para conservar la salud es mantener una conducta acorde con las pautas de la doctrina espírita, como una forma de no predisponerse al acercamiento de los espíritus considerados inferiores. Mantener la vigilancia contra los comportamientos y pensamientos inferiores permite que no se entre en sintonía con los espíritus que todavía están poco evolucionados.

El enfermo necesita ser fortalecido espiritualmente, debe ser instruido —a través de las charlas que se dictan en las sesiones doctrinarias, de 
las conversaciones con su entrevistador y de los grupos de reflexión y estudios que se organizan en el centroa progresar moralmente, lo que incluye, además de las virtudes cristianas de la caridad y amor al prójimo, el autocontrol, la disciplina y el estudio (es decir, perfeccionamiento en la doctrina). El progreso moral está acompañado por el fortalecimiento de las energías por la imposición, ritual en el que, a través de las manos de quien realiza la imposición (pase) - el terapeuta-, se lleva a cabo una transferencia de energías positivas hacia el cliente. ${ }^{8}$

La organización de la imposición expresa muy bien el ideal espiritista. Al comienzo se tiene generalmente un ambiente de penumbra en el que se escucha una música suave de fondo, acompañada por el habla pausada y lenta de uno de los médium, quien da a los presentes instrucciones de mantener silencio y relajarse, cerrar los ojos y descruzar los brazos y las piernas. Este ambiente no es exclusivo de la imposición, la luz azul y la música suave pueden estar presentes en varios tipos de situaciones, como el comienzo de la sesión doctrinaria y de la sesión mediúmnica. En la sala de imposición, donde las personas son llevadas individualmente o en grupos pequeños, todos deben mantenerse concentrados, con los ojos cerrados, mientras quienes realizan las imposiciones se acercan colocando y moviendo lentamente las manos sobre la cabeza y alrededor del cuerpo de cada uno.

En lo referente a la acción de los espíritus "obstructores" - desarrollada en el contexto de la sesión mediúmnica o de desobstrucción-, ésta no difiere mucho del tratamiento que se le da a los encarnados que sufren con su interferencia. Estas entidades causantes de aflicción son también tratadas con cortesía, como si fuesen niños que necesitan ser enseñados a comportarse de manera apropiada, además de motivársele a sustituir la acción destructiva, causante de la enfermedad, por una acción constructiva y benéfica. Al curar al enfermo, los terapeutas espíritas procuran también contribuir al progreso moral de las entidades responsables de la enfermedad. El tratamiento de curación debe buscar llevar a los espíritus menos desarrollados hacia estadios superiores de existencia.

Las sesiones de espiritismo están usualmente restringidas a los médium del propio centro, por lo cual no se permite la presencia a los pacientes. La sesión se inicia cuando a uno de los médium (o médium de incorporación) se le manifiesta el espíritu que se aloja en el cuerpo del enfermo; a partir de allí, se inicia un diálogo entre el médium encargado de adoctrinar y el espíritu, cuyo contenido es claramente pedagógico: éste debe ser persuadido de cambiar su conducta, a fin de permitir que el enfermo en cuyo cuerpo se aloja, pueda recuperar su bienestar.

La conversación informal se convierte en el modo de comunicación por excelencia para la construcción del escenario de la curación; mientras el médium y el espíritu conversan, otros participantes (médium de apoyo) oran en voz baja. El cambio gradual en la actitud del espíritu, de abierto rechazo al diálogo hasta una creciente sensibilización a las palabras del médium, durante las sesiones (que pueden ser varias), redefine el contexto de la enfermedad.

\section{LA HISTORIA DE LANA}

Lana tiene 34 años, vive con su esposo y con dos hijas, en una casa del interior del nordeste de Amaralina. El problema de Lana, según ella misma señala, es de tipo "nervioso". Su experiencia de aflicción está rodeada de un sentimiento de proximidad de la muerte, que la lleva a la desesperación y a la angustia. Para Lana su "nerviosidad" se fue desarrollando a partir de las dificultades de la vida: hija de una familia pobre, fue abandonada por su primer compañero con cuatro hijos pequeños, a los cuales tuvo que criar sola, sujeta a una rutina de trabajo extremadamente pesada para poder sostener a sus hijos y su hogar. Peor que todo eso fue la pérdida de un hijo de siete meses. El itinerario terapéutico de Lana incluyó visitas continuas a médicos - principalmente psiquiatras y neurólogos-, además de breves pasos por un centro de candomblé y por iglesias pentecostales. Lana

8 Muchos médium manifiestan sentir el paso de su energía moviendo la de los clientes durante la imposición o pase. Un médium del centro donde se realizó la investigación relató que cuando la persona que está recibiendo la imposición está muy "cargada", siente como si el paciente tuviese una costra de protección oscura a su alrededor que impide el "paso de la energía". 
utilizó tranquilizantes durante mucho tiempo, aunque siempre le incomodaban los efectos incapacitantes de ese tipo de drogas.

Hay además otro elemento que Lana identifica en el origen de su estado, ella cree poseer un poder especial para curar y realizar predicciones. El hecho de no utilizar este potencial es, desde su punto de vista, una de las causas de su problema nervioso. Según ella misma explica, su vida ha estado marcada por toda una serie de acontecimientos que señalan la presencia de ese poder. Dos caboclos, un indio y un africano, le aparecen siempre que necesita ayudar a alguien. Cuenta, además, que en el momento en que éstos se presentan siente mucha ansiedad; una vez que se van no logra recordar nada.

La experiencia de Lana, entonces, está directamente vinculada con su proyecto de ser terapeuta. Estrechamente relacionado con su potencial para curar se encuentra la experiencia de los "choques" o "corrientazos" que ella siente en el cuerpo, para los cuales encuentra una explicación en el espiritismo. Estos choques, nos dice, ocurren por no estar haciendo uso de su poder para ayudar a la gente, siendo así una señal más de ese poder.

Desde la óptica de Lana el espiritismo le ofrece la posibilidad de convertirse en una terapeuta espírita. Lana ha encontrado en la terapia espírita la solución a sus problemas y visita regularmente un centro grande, situado en la frontera entre el nordeste de Amaralina y Pituba, urbanización de clase media cercana al nordeste. La cura dentro del espiritismo para ella parece relacionarse con la posibilidad de una mejoría general de su vida, incluso en términos financieros.

En el centro espírita, Lana participa en las sesiones de pase, asiste a las conferencias, frecuenta las sesiones con el Hermano Palminha - un espíritu médico que se incorpora a uno de los médium del centro- y tiene encuentros regulares con una entrevistadora, con quien charla acerca de su problema. En uno de esos encuentros, al principio de su tratamiento, la entrevistadora le dijo a Lana que su "escaparate estaba muy desarreglado". Para poner las cosas en orden Lana debía manejarse de acuerdo con los preceptos de la doctrina espírita; ello exige una disciplina que Lana no cree tener en este momento.
El pase, según Lana, es algo capaz de curar a cualquier persona con problemas: "al tú tomar el pase con fe, cerrando los ojos, tomándolo con fe, tú... cambias ¿̇me entiendes? Tú logras sacar los pies del suelo, logras salir... de ti... ir para donde tú quieras ¿verdad?".

Lana percibe entre los miembros del centro una postura tranquila, que asocia directamente a la educación, lo cual se traduce en otro elemento distintivo del universo de clase media del que tanto gusta. Esta postura tranquila está estrechamente relacionada con otro elemento del ethos de clase media: la centralidad de la idea de control de sí misma que aparece en la serie de consejos y enseñanzas que Lana recibe de los terapeutas espíritas. Uno de éstos señala la importancia de que ella se haga independiente, que asuma las riendas de su vida. Otro campo sobre el cual buscan intervenir los terapeutas del centro se refiere a las experiencias de incorporación vividas por Lana. Haciendo énfasis en la importancia de tener control sobre el propio cuerpo, le instruyen para evitar la pérdida de conciencia y la entrega de sí misma al poder de los guías.

Esta propuesta no es aceptada del todo por Lana, que siempre se ha enorgullecido de su poder espiritual y que, según insiste, siempre ha sido beneficiada por sus guías. Por ello, su entusiasmo por el espiritismo ha, de alguna manera, decaído en los últimos meses.

Lana pasó algún tiempo sin visitar el centro, aunque cuando su problema nervioso se agravó volvió al tratamiento del Hermano Paulo, esta vez encaminada también en un grupo de crecimiento espiritual. Dice sentirse bastante serena después del tratamiento, lo que se expresa en su tono de voz, lento y pausado. La participación en el grupo de crecimiento es vista por Lana con mucho entusiasmo, porque parece señalar un camino alternativo en su proyecto de ser terapeuta.

\section{Algunos comentarios a guisa de CONCLUSIÓN}

Al discutir los abordajes, las enfermedades y la curación en el candomblé, el pentecostalismo y el espiritismo, hemos descrito varios contextos 
en los que se define, desdobla y redefine la experiencia de personas con problemas relacionados con la salud mental. Partimos de dos problemas básicos, que conviene retomar: la reconstrucción de la experiencia de la enfermedad dentro del dominio religioso y la absorción de la experiencia básica de la cura en el mundo de la vida cotidiana.

Un primer elemento a ser considerado se refiere a la caracterización de los encuadres más amplios ofrecidos por la religión. Estos encuadres definen los espacios y las formas propias de sociablidad en los cuales se inserta el enfermo al ingresar en el grupo, a partir de los cuales se desarrolla su experiencia de cura.

En el candomblé observamos la fuerza y la vitalidad de las redes de relaciones constituidas en torno al terreiro como eje. Tales relaciones se superponen y refuerzan vínculos ya existentes de parentesco y vecindad, que remiten a encuadres definidos a partir del plano de la casa y de la familia. Este punto ya ha sido señalado por varios estudiosos de las religiones afrobrasileñas; como la familia, el terreno acoge, protege, produce alimentos y da de comer a todos, siguiendo una jerarquía de alianza y subordinación, que se desdobla y segmenta en varios niveles.

En la iglesia Dios es Amor, observamos también la importancia de las relaciones creadas en torno a la iglesia: los miembros se tornan hermanos con el bautismo, introduciéndolos de una cierta manera a una nueva familia. No obstante, a diferencia del candomblé, el encuadre aquí propuesto está regido en varios aspectos por una lógica distinta y alternativa al modelo de familia. La casa es sustituida por la iglesia, que constituye también cierto espacio burocrático; la cotidianidad doméstica de la casa se transforma en la imagen del trabajo serio y dedicado de las obreras.

En este sentido, la iglesia ofrece un espacio en el que las relaciones de pertenencia al grupo - las distintas actividades que congregan los fieles: cadenas de oración, evangelización en la calle, reuniones de grupos de jóvenes, grupos de señoras, etc.- deben asumir un papel central en la organización de la cotidianidad.
De las tres vertientes religiosas, es el espiritismo la que más se aparta de los encuadres construidos según las reglas de la familia. Aquí el modelo de casa parece ser sustituido por el modelo de la institución burocrática. El centro es el lugar de servicio, del ejercicio de la caridad para sus dirigentes y médium. Para quienes lo frecuentan en busca de curación o de alivio al sufrimiento puede constituirse con mayor facilidad en una alternativa de atención.

La inserción del enfermo/fiel en uno de estos encuadres $-\mathrm{y}$ en los modos de sociabilidad que delimitan - se desdoblará en una serie de interacciones a lo largo del tiempo, muchas de ellas de carácter ritual. Es en el contexto del ritual - y de los encuadres menores propuestos en su interiorque el enfermo probará y afirmará nuevas formas de enfrentarse a la aflicción, a los otros y a sí mismo. Aquí encontramos grandes diferencias entre las tres religiones y los tipos de experiencia que proporcionan a sus miembros.

En el candomblé, el restablecimiento de la salud está construido ritualmente como creación, reproducción y fortalecimiento de lazos con las entidades sagradas. Reafirmada con la iniciación, la relación del individuo con su santo, y también con erê, el exu o caboclo que manifiesta, reconstruye la identidad como un diálogo de muchas voces, al recolocar el cuerpo como diferentes voluntades y modos de ser en el mundo. Los encuadres rituales crean posibilidades y permiten el desarrollo de una experiencia de "otros" irrumpiendo en el cuerpo. Esta experiencia del otro - lo cual al principio es tan sólo la imagen que se ve, el orixa que es admirado en las fiestas - es construida paso a paso y aprendida fundamentalmente con los sentidos. La posesión implica una manera de compromiso en el universo de las imágenes sagradas en el que las distinciones sujeto-objeto, observador-observado, signosignificado se desvanecen temporalmente y pierden su utilidad de guía para la acción.

La importancia de los sentidos en la construcción de esa experiencia, así como el sentido de alteridad que ella instituye, se desprende de las propias descripciones de los miembros. La imagen de "convertirse en el santo", usada frecuentemente para describir la posesión, señala tanto la dimensión 
encarnada de ser poseído como el hecho de que lo que está en juego es el manejo del cuerpo por "otro". No es casual que para los adeptos del candomblé la posesión implica, en su forma más legítima, la pérdida total de la conciencia.

Al celebrar la llegada de los orichas y de los caboclos a través de la posesión, el ritual permite la experiencia radical de una identidad múltiple. En él la narrativa del yo es una narrativa encarnada y pública: tejida por el cuerpo y compartida con otros, que la presencian y se involucran en ella. No obstante, esa identidad múltiple no se vive sólo en el contexto ritual, aunque allí encuentre su posibilidad de expresión más radical: rebasa bajo distintas formas los límites de lo cotidiano.

En las historias que los adeptos del candomblé elaboran y continuamente rehacen se resalta la acción de los otros —orichas, exus, erês, caboclos- que se exhiben y conmueven pero también (principalmente en el caso de los tres últimos) transgreden, se divierten, castigan, hacen sufrir y hacen curar en el cuerpo del sujeto. La vida narrada y, por añadidura, la identidad, se transforma en un diálogo, cuyos personajes arrojan nuevos puntos de vista y descubren nuevas alternativas en el contexto vivido.

Es necesario detenernos en el análisis de las implicaciones de esas narrativas cuando son efectivamente incorporadas a la vida cotidiana del enfermo. Como ya hemos señalado, el restablecimiento de la salud dentro del candomblé no es una empresa moral - no implica corrección o perfeccionamiento moral-, aunque pueda representar cambios significativos en la vida de los fieles. ¿En qué consisten estos cambios? Una primera aproximación sociológica a este problema apunta hacia la legitimidad que el candomblé puede conferir a comportamientos poco usuales o divergentes de los patrones socialmente aceptados. Ello, sin lugar a dudas, sugiere a título de hipótesis una mayor apertura de la religión a los comportamientos desviados exhibidos por individuos con problemas relacionados con la salud mental. Sin embargo, para entender la dimensión terapéutica del candomblé, así como de cualquier otra religión, se hace necesario ir más allá del establecimiento de correlaciones exteriores.
Tal como algunos estudiosos han mostrado (Goldman, 1989; Birman, 1995), ello implica un esfuerzo analítico para reconstituir la lógica interna de la religión y del juego de identidades que ella pone en acción. Siendo un camino poco explorado, implica también un movimiento rumbo a la comprensión de la experiencia de las personas que buscan tratamiento y constituyen los clientes o miembros de la religión. El ingreso al candomblé no sólo le da cierta legitimidad a los comportamientos ya descritos anteriormente. Narrar al yo como múltiple, sin duda retira la responsabilidad y la culpa que tenga el yo singular de eventos y experiencias que no encajen con los patrones vigentes - como por ejemplo la enfermedad mental-, distribuyéndola y suavizando su peso. Desvía el foco de atención del individuo hacia los contextos relacionales que su cuerpo delimita y expresa: el llamado o castigo del santo, por ejemplo. Empero, no sólo conduce a una mejor aceptación - por parte del sujeto y de los otros con quienes convive - de la ambigüedad o contradicción que cada uno encierra en su comportamiento, sino que también conduce a la exploración activa y legitimada de nuevas y alternativas maneras de ser en el mundo.

El caso de Ritinha es un ejemplo paradigmático de este hecho: en Boiadeiro Ritinha descubre y se compromete en un mundo público de trabajo y fiesta, lo que establece una distancia frente a la esfera doméstica del cuidado de los niños y de la casa, a lo cual como Ritinha tiene un acceso limitado.

En el pentecostalismo de la iglesia Dios es Amor, la enfermedad y la cura son parte fundamental de liberación y fortalecimiento en el poder de Dios. A diferencia del candomblé, la curación aquí es una empresa moral. Se da entonces un movimiento opuesto al que opera en el candomblé en lo que se refiere a la construcción del individuo curado, adepto a la religión. Mientras el candomblé construye al individuo como múltiple - enseñándolo a conocer y convivir con el otro que se encarga de él-, el pentecostalismo lo construye como uno en el Señor. No multiplica el yo, sino que lo fortalece como parte de una trama sagrada y colectiva, que es la iglesia. Separa toda experiencia de alteridad como algo fuera de la iglesia y fuera del yo. 
A través de una sucesión de encuadres, el ritual crea una ola de poder sagrado que envuelve a los fieles, llenando todo el espacio de la iglesia. Los cánticos y la oración en gran medida logran ese hecho, construyen la presencia divina como una nueva cualidad o efecto sonoro que se destaca de la superposición de muchas voces, sin que ninguna de ellas salga de manera aislada. Se trata así de un poder moral que es, en primer lugar, colectivo, pero que al mismo tiempo se singulariza en cada uno, que hace de cada cuerpo su morada.

Los fieles no oran al unísono, cada uno se entrega con fervor a su oración individual mientras ve cómo gradualmente desaparece en medio de un tornado de muchas voces y oraciones. Es sólo en este instante, cuando es casi imposible discernir la parte de cada uno en la producción del evento, que de nuevo la perspectiva individual puede destacarse. Este es el momento en el que el Espíritu Santo se manifiesta.

La imagen dominante es la de hacer del cuerpo una morada. Esta imagen - y el tipo de experiencia que ella resume - tiene características bastante peculiares. El cuerpo habitado por el Espíritu tiembla, se contornea, salta y gira, es tomado por movimientos espontáneos, desordenados. Es señal de un poder que rompe las reglas de este mundo y que puede desafiarlas sin miedo. Expresa, en este sentido, el ideal pentecostal de ruptura con lo mundano, pero también es un cuerpo que se purifica y se disciplina para transformarse en una casa en la que el Espíritu pueda habitar, expresando la búsqueda pentecostal de reconstrucción activa y ordenada del mundo a partir de lo sagrado.

Ser habitado señala en primer lugar la idea de que se es un vaso, morada o receptáculo de lo divino. No evoca la alteridad radical implicada en la experiencia de incorporar el oricha. Para los fieles, la experiencia del Espíritu Santo no involucra la pérdida total de la conciencia - no se trata de ser tomado por otro, sino ser uno en él. Remite a la necesidad de ser llenado por el poder divino pero además a la necesidad de hacerse lo suficientemente sólido y fuerte para abrigar ese poder. En este sentido depende, al menos en parte, de una toma de posición por parte del sujeto, de una decisión de liberarse y de dejar que Dios realice milagros en su vida.
Ello queda bastante claro en el modelo narrativo que el ritual propone para la reconstrucción de la experiencia. Este tiene como una de sus características más sólidas el contraste entre dos formas de existencia: un pasado de ignorancia, pecado y sufrimiento y un presente de rectitud y fuerza en el Señor. En el ritual emergen dos estrategias narrativas básicas para construir y mantener vivo ese modelo genérico: el testimonio y la revelación. En el primero se tiene el descubrimiento de la miseria en la que el fiel es llamado a describir el contexto de miseria, enfermedad o depravación en el que vivía antes de convertirse y, después de dado ese paso, las continuas gracias que ha recibido del Señor.

Los individuos desviados de la sociedad criminales, alcohólicos, prostitutas, homosexuales y enfermos mentales - encuentran así abiertas las puertas de la iglesia y al procurar la posibilidad de ingreso no necesitan ocultar su identidad. Su historia personal es tomada como un hilo más de una trama divina; también ésta va a comprobar el poder que Dios posee de operar maravillas en la vida.

Hacia esa dirección convergen las biografías de aquellos que ingresaron a la iglesia. Si difieren en cuanto al contenido específico de la vida anterior a la conversión, respecto a vicios, enfermedades, ofensas y fracasos vividos, tienden a ser semejantes en cuanto al rumbo que van a tomar con la entrada en la iglesia. Allí la diferencia se transforma en unidad, los comportamientos asumen un patrón, son emblemáticos del ser creyente. La revelación cumple un papel importante en el mantenimiento de ese patrón: busca guiar de manera más directa las historias individuales, colocando de vuelta en el camino a aquellas que por ventura se descarrilaron.

Incorporado en la vida cotidiana, en las conversaciones y encuentros que conforman la rutina diaria, este modelo narrativo ofrece un medio para la organización de la experiencia, no sólo en tanto eventos transcurridos sino posiblemente también como eventos que se viven y se procura controlar. No obstante, una vez más es necesario ir más allá de la constatación de que la religión abre la puerta y acoge a los desviados para entender a qué modalidades de experiencia les da acceso. Las narrativas ejemplares tejidas en los cultos orientan tanto la identificación de 
elementos importantes de la situación que se vivió como una exploración activa de la situación que se vive. La experiencia de doña Lourdes es en este sentido bastante ilustrativa.

Doña Lourdes reorganiza su vida de acuerdo con la narrativa pentecostal: su manera de ser refleja el ideal de la iglesia Dios es Amor, busca agradar a Dios. Las marcas de distinción que exhibe en su cuerpo como creyente y que ve reflejadas en los otros miembros, la separan radicalmente de todo lo mundano, al tiempo que le señalan hacia el poder que circula en la iglesia. La posibilidad de compartir ese poder y de ser orientada por él orienta su comportamiento, su relación con la enfermedad y con los otros. No se trata, sin embargo, de un movimiento que individualiza. La experiencia que tiene doña Lourdes del Espíritu Santo muestra cuán fuertemente imbricados están el cuerpo individual y el cuerpo social. Mientras su casa, que funciona como una metáfora para la familia, no sea purificada y vuelta a hacer a partir de los principios sagrados, ella misma no puede convertirse en una morada perfecta para el señor, de aquí su compromiso militante: la quema de los objetos rituales del candomblé en plena calle y la lucha incansable por convertir a los hijos y nietos.

El espacio que la "morada del espíritu" circunscribe no es primero y fundamentalmente el espacio del sujeto individual sino el espacio moral de la iglesia y, tal como lo demuestra Doña Lourdes, de la familia. Por otro lado, ese espacio moral no puede ser abstraído del espacio físico del cuerpo.

La solidez de la morada que cada fiel pentecostal anhela ser no sólo depende de una incuestionable fuerza moral sino también de un cuerpo saludable. Doña Lourdes se juzga ya muy débil y consumida por la edad para alojar al Espíritu - su cuerpo ya no puede ser una morada segura para algo tan excelso o, lo que es lo mismo, no tiene la fuerza necesaria para resistir una experiencia tan intensa. Esta percepción no nos lleva al sentido de una identidad minusválida, disminuida, sino, lo que nos parece, al reconocimiento de límites en el proyecto radical de santificación propuesto por la iglesia.

En el espiritismo la enfermedad y la curación se sitúan en un marco de desarrollo espiritual. La enfermedad señala potencialmente una espiritualidad poco desarrollada todavía y por tanto una situación de debilidad moral. El tratamiento tiene, como ya hemos dicho, una dimensión fundamentalmente pedagógica. Así, junto a medidas terapéuticas directas, como la cirugía espiritual o la desobstrucción, enseña un patrón de comportamiento pautado en el sentimiento y la práctica de la caridad.

Varios de los encuadres de interacción en un centro espírita se desarrollan según el modelo de enseñanza, desde la sesión doctrinaria y la entrevista, hasta la sesión de desobstrucción. De esta manera, sus participantes se diferencian de acuerdo con el grado de conocimiento y progreso moral: hay quienes educan y hay quienes aprenden, aunque un cambio de encuadre pueda implicar para los sujetos singulares un movimiento de un papel hacia otro. En la construcción de esos encuadres domina el recurso del discurso hablado y particularmente de prácticas discursivas de cuestionamiento, consejo, argumentación y convencimiento, lo que refuerza la idea de una instancia pedagógica.

Si en el espiritismo la relación terapeutapaciente está, por decirlo de alguna forma, incluida en un encuadre mayor definido por la relación educador-educando, es preciso recordar que la pedagogía espírita no se resume a la transmisión de reglas o refuerzo de principio morales. Partiendo de la idea de que la debilidad remite a la falta de claridad para regir la propia vida, se trata de una pedagogía que busca colocar al individuo en el camino de la perfección de sí mismo, transformarlo, a partir del ejercicio racional de la disciplina y el autocontrol, en un sujeto consciente capaz de asumir con responsabilidad el curso (evolutivo) de su existencia.

Esta búsqueda de afirmación de un dominio individual autónomo aparece no sólo en el contenido de la enseñanza espírita sino también en la forma en la que el cuerpo se involucra en los rituales. Hay una preponderancia de lo verbal y de la postura corporal de relajamiento y apertura para las palabras. Incluso en el pase y en la cirugía espiritual, la intervención es alrededor del cuerpo sin tocarlo. Hay cierto respeto al cuerpo del individuo, en el sentido de que no se realiza una confrontación directa. Si lo comparamos con el pentecostalismo y el candomblé, en el que el contacto con el cuerpo del otro tiene un papel muy importante 
en varios momentos del ritual, tal vez podamos afirmar que en el espiritismo el espacio que los cuerpos ocupan tiene mayor circunferencia, como si una redoma invisible separara cada cuerpo de los demás.

Estos son también temas que rigen la experiencia de la mediumnidad. La imagen que define el trance mediúmnico para los espíritas es la de la comunicación. En la medida en que comunicarse con un espíritu desencarnado involucra un movimiento estratégico para la apertura hacia el otro sintonización con la calidad de energía que él emanay la seguridad de sí mismo como polo del diálogo, exige del médium un control y una disciplina bastante desarrollados. En este sentido, el trance mediúmnico contrasta tanto con la pérdida y multiplicación del yo en el candomblé como con la entrega de sí mismo en el Espíritu operada en los cultos pentecostales. Regido por una postura controlada, es una experiencia legitimada e incentivada sólo entre quienes desempeñan estadios superiores de desarrollo espiritual. Aquellos que, como hemos explicado anteriormente, expresan mejor el ideal del individuo autónomo: equilibrados, serenos, racionales.

En el universo del espiritismo Lana está inserta en un programa de desarrollo espiritual. Para ella se destaca en primer lugar el tono general de la propuesta espírita: en el centro todo parece expresar un ideal de serenidad, desde la organización de los espacios terapéuticos - la música suave de fondo, la atmósfera de penumbra, los paisajes naturales de los afiches colocados en las paredes - hasta la postura general de los médium - habla pausada, tono de voz más bajo, movimientos tranquilos, argumentos ponderados. La postura del espírita es la de una distancia vigilante: involucra una actitud de calma reflejada frente a la situaciones problemáticas — tal como Lana lo percibe- que es bastante distinta del compromiso militante de los creyentes y del desarrollo del mundo entre los adeptos del candomblé.

Esta atmósfera delinea el contexto en el que se propone y se trabaja la narrativa de Lana. La imagen del "escaparate desarreglado" es el elemento central de esa narrativa, en la medida que al mismo tiempo describe un estado general de cosas en el presente y anticipa un desdoblamiento de este estado en el futuro. Condensa en cuanto imagen varios significados. En primer lugar, es bastante expresiva del proyecto espírita de evolución mediante una acción ordenadora de la vida por parte del sujeto; plantea, además, la necesidad de una práctica disciplinada y racional para mantener el orden instaurado - el escaparate arreglado. Por último, establece la perspectiva o identidad de un sujeto/personaje. Se trata de una identidad procesal, en vías de desarrollo: diferente de la experiencia identitaria en el candomblé, que es plural y, por tanto, marcada de manera constante por un sentido de ambigüedad e imprevisibilidad; pero también distinta de la identidad pentecostal, fundada en la fuerza inequívoca y no ambigua de la iglesia, casa por excelencia del Espíritu Santo.

Se trata de un proyecto de curación (e identidad) que es, en gran medida, ajeno al universo cultural de las clases trabajadoras. Refleja un ethos individualista, un ideal de progreso y diferenciación, como ya ha sido señalado por algunos estudiosos del espiritismo. Lana está, al mismo tiempo, atraída por este ideal - éste integra su proyecto de ascenso social_ y fuertemente limitada por él en su demanda de acceso legítimo al poder sagrado. El relato de su experiencia en el espiritismo, marcada por fuertes oscilaciones entre el compromiso serio y el casi abandono, resalta un elemento primordial en el proceso de incorporación a la cotidianidad de las experiencias tejidas en la esfera de la religión: resalta el papel de los hábitos, intereses y planes de la vida cotidiana, delimitando el campo de sentido a partir del cual se puede dar esa incorporación.

$$
* * *
$$

Comparando los abordajes a la enfermedad y a la curación establecidas en el candomblé, el pentecostalismo y el espiritismo, se destaca enseguida las fuertes diferencias entre los encuadres y las imágenes que cada uno de ellos propone para reconstruir la vivencia de la aflicción. Sin duda, existen modalidades de experiencias distintas asociadas a las imágenes religiosas de convertirse en el santo o incorporar al oricha, ser habitado por el Espíritu Santo y entrar en comunicación con los espíritus desencarnados. Nuestro argumento fue el de que esas modalidades de experiencia se construyen a partir de un compromiso del cuerpo - como campo unificado 
de los sentidos - en el universo de las imágenes que componen los encuadres rituales.

A lo largo de este trabajo buscamos abordar el problema de cómo tales experiencias religiosas abren espacios en la cotidianidad: sugerimos que las narrativas que las religiones ponen en movimiento se constituyen en recursos importantes en ese proceso; sin embargo, como también hemos señalado, el papel de esas narrativas en la transformación de la experiencia de la aflicción no es el de dar legitimidad a las identidades, inclinaciones o proyectos previamente existentes pero imposibilitados de ser asumidos en condiciones ordinarias: es, más bien, el de abrir caminos hacia una exploración activa de las nuevas formas de ser en el mundo.

\section{REFERENCIAS BIBLIOGRÁFICAS}

Augras, M., 1983. O duplo e a metamorfose. A identidade mítica em comunidades nagô. Petrópolis: Vozes.

Barbara, R.S., 1998. A terapia musical no candomblé. Salvador de Bahía: Textos do Núcleo de Estudos em Ciências Sociais em Saúde, Faculdade de Filosofia e Ciências Humans, Universidade Federal da Bahia. Mimeo.

Bastide, R., 1973. Cavalos dos Santos (esboço de uma sociologia do transe místico). En: Estudos afro-brasileiros (R. Bastide). Sao Paulo: Perspectiva.

Birman, P., 1995. Fą̧er estilos, criando gêneros. Possesão e diferenças de gênero em terreiros de umbanda e candomblé no Rio de Janeiro. Río de Janeiro: Relume Dumará/UERJ.

Bourdieu, P., 1977. Outline of a theory of practice. Cambridge: Cambridge University Press.

Brandão, C. R., 1980. Os deuses do povo. Sao Paulo: Brasiliense.

Caprara. A., 1998. Médico ferido: omulu nos labirintos da doença. En: Antropologia da saúde: traçando identidade e explorando fronteiras (P.C. Alves \& M.C. Rabelo, orgs.). Río de Janeiro: Relume Dumará/Fiocruz.

Cavalcanti, M.L. de C., 1983. O mundo invisivel: cosmologia, sistema ritual e noşão de pessoa no espiritismo. Río de Janeiro: Zahar.
Csordas, T., 1983. The rhetoric of transformation in ritual healing. Culture, Medicine and Psychiatry, $7: 333-375$.

Csordas, T., 1993. Somatic modes of attention. Cultural Anthropology, 8 (2):135-156.

Csordas, T., 1994. The sacred self: a cultural phenomenology of charismatic healing. Berkeley: University of California Press.

Droogers, A., 1989. The enigma of the metaphor that beals: signification in an urban spiritist bealing group. Washington DC: Annual Meeting of the American Anthropological Association. Mimeo.

Fernandes, R.C., 1982. Os Cavaleiros do Bom Jesus. Sao Paulo: Brasiliense.

Geertz, C., 1978. A interpretação das culturas. Río de Janeiro: Zahar.

Goffman, E., 1986. Frame analysis: an essay on the organization of experience. Boston: Northeastern University Press.

Goldman, M., 1989. A construção ritual da pessoa: a possessão no candomblé. En: Candomblé: desvendando identidades (C.E.M. Moura, org.). Sao Paulo: EMW Editores.

Greenfield, S.M., 1992. Spirits and spiritist therapy in southern Brazil: a case study of an innovative, syncretic, healing group. Culture, Medicine and Psychiatry, 16 (1):2352.

Kapferer, B., 1979a. Introduction: ritual process and the transformation of context. Social. Analysis, 1:3-19.

Kapferer, B., 1979b. Entertaining demons. Social Analysis, 1:108-152.

Kapferer, B., 1991. A celebration of demons: exorcism and the aesthetics of healing in Sri Lanka. Oxford: Berg Publishers Limited.

Merleau-Ponty, M., 1994. Fenomenologia da percepscão. Sao Paulo: Martins Fontes.

Prandi, R., 1991. Os candomblés de São Paulo. Sao Paulo: Hucitec.

Sartre, J.P., 1983. The psychology of imagination. Londres Methuen \& Co. 
Schutz, A. \& Luckmann, T., 1973. Las estructuras del mundo de la vida. Buenos Aires: Amorrortu.

Schutz, A., 1973. Collected Papers I: the problem of social reality. La Haya: Martinus Nijhoff.

Segato, R.L., 1995. Santos e daimones: o politeísmo afrobrasileiro e tradição arquetipal. Brasilia: Editora UnB.

Tambiah, S., 1979. A performative approach to ritual. Proceedings of the British Academy, LXV:113169.

Teixeira, M.L.L., 1996. Representações da [lou]cura em terreiros de candomblé. XX Encontro Anual da Anpocs. Caxambu: mimeo.

Teles dos Santos, J., 1995. O dono da terra: o caboclo nos candomblés da Babia. Salvador de Bahía: Editora Sarah Letras/Programa A Cor da Bahia.

Turner, B., 1984. The body and society. Oxford: Basil Blackwell.

Turner, E., 1992. Experiencing ritual. Philadelphia: University of Pennsylvania Press.

Turner, V., 1967. The forest of symbols. Ithaca, NY: Cornell University Press.

Turner, V., 1969. The ritual process. Chicago: Aldine.

Turner, V., 1974. Dramas, fields and metaphors. Ithaca, NY: Cornell University Press.

Turner, V., 1975. Revelation and divination in ndembu ritual. Ithaca, NY: Cornell University Press.

Wafer, J., 1991. The taste of blood. spirit possession in bra:ilian candomblé. Philadelphia: University of Pennsylvania Press.

Traducción a español: antropólogo Jútio de Freitas Taylor 


\section{REPRESENTACIONES SOCIALES ACERCA DE LA SALUD Y LA ENFERMEDAD: UNA PUESTA AL DÍA}

Ana Lia Kornblit*

La teoría de las representaciones sociales se inscribe en el modelo del construccionismo en psicología social, que enfatiza tres aspectos (Elejabarrieta, 1991):

a) El carácter productor y no sólo reproductor del conocimiento en la vida cotidiana;

b) La naturaleza social de ese conocimiento, que se genera a partir de la comunicación y la interacción entre individuos, grupos e instituciones;

c) La importancia del lenguaje y de la comunicación en cuanto a la creación de la realidad, por una parte, y como marco en el que la realidad adquiere sentido, por otra.

El carácter productor y no meramente reproductor de las representaciones sociales es un elemento central de la teoría de Moscovici (1961), quien la lanzó retomando el concepto de Durkheim (1898). Para este último existe un tipo de pensamiento social en cuanto a su elaboración y a su función, que da lugar a lo que él denominó "representaciones colectivas", a partir de las cuales se conforman, en su conceptualización, las representaciones individuales.

Según el principio del objetivismo de los hechos sociales, desarrollado por el autor de El suicidio, las representaciones colectivas se imponen a las personas, a los ojos de las cuales poseen una objetividad similar a la de los hechos naturales. Para Moscovici, en cambio, y en esto coincide con los teóricos del construccionismo, las representaciones sociales no son sólo reproductivas, a partir de formas de conciencia que la sociedad impone a los individuos, sino que implican la producción y elaboración por parte de estos últimos de diferentes parámetros sociales.
En su obra inicial, El psicoanálisis, su imagen y su público, Moscovici (1961) había señalado tres aspectos constitutivos del concepto:

1. No hay una única representación social de algo (en ese caso el psicoanálisis), sino muchas. Ellas difieren en cuanto a su contenido y en cuanto a las actitudes que desencadenan en función de las afiliaciones socioeconómicas, políticas, religiosas, etc., de los individuos que las sustentan.

2. El proceso representacional no se da en el vacío social. Esto explica que un mismo objeto pueda dar lugar a diferentes representaciones. Estas se vincularán con los valores y patrones de conducta del grupo de que se trate.

3. La transformación del objeto en su representación (en ese caso de la teoría psicoanalítica a su representación por parte de las personas legas) se efectúa a través de dos movimientos complementarios:

a) ciertas informaciones son seleccionadas $y$ retiradas de su contexto;

b) dichas informaciones son concretizadas en imágenes.

De estas propiedades de las representaciones sociales se desprende que para que pueda hablarse de su existencia, ellas deben referirse a un objeto social, que no es cualquiera, sino que debe reunir ciertas condiciones: debe tratarse de un objeto social tal que despierte a la vez perspectivas conflictivas y cierto grado de consenso; que revista importancia para la vida cotidiana de los sujetos y que se establezcan en torno a él mensajes comunicativos. 
Si se tratara de un objeto social sobre el que no existieran perspectivas diferentes, surgidas de afiliaciones grupales también diferentes, este objeto - por otra parte difícil de imaginar en nuestras sociedades - no daría pie al surgimiento de representaciones sociales acerca de él, como tampoco lo haría un objeto - también difícil de imaginar- sobre el que no existieran comunicaciones cruzadas, ni aquel dotado de cierta intrascendencia para la vida de las personas. Nada de esto ocurre con la salud y la enfermedad, que se han convertido en objetos de diversas y fecundas investigaciones en este campo.

Es sobre los aspectos simbólicos, más que cognitivos, de los objetos sociales —en el caso que nos ocupa, la salud y la enfermedad- sobre los que se construyen las representaciones sociales. Esto implica introducir la dimensión del sentido atribuido por los sujetos a los hechos sociales. Si bien el sentido tiene sus raíces en las condiciones estructurales en las que se desarrolla la vida de los sujetos, no puede pensarse en una relación determinística entre ambos. El sentido denota un "plus", más allá de sus condicionamientos objetivos, que está dado por elementos de la historia personal y grupal, que en ocasiones trasciende estas barreras para adquirir alcances generacionales o comunitarios más amplios. Este sentido al que aludimos es socialmente elaborado y compartido, por lo menos grupalmente, y tiene un aspecto "práctico", en cuanto a que orienta la acción y en cuanto a que se trata de un saber que da cuenta de algún aspecto vinculado con las actividades de las personas en la vida cotidiana.

El conocimiento implícito en las representaciones sociales es un "conocimiento de sentido común" que se construye a partir de las experiencias vividas por los sujetos, así como a partir de las informaciones y modelos recibidos a través de la tradición y la comunicación social.

A nivel metodológico las representaciones sociales son versátiles. Ellas pueden ser tomadas como variables dependientes (Di Giácomo, 1987), en cuyo caso muestran el estado y la evolución de la cultura (incluyendo en ella los valores) y de las elecciones de los sujetos con respecto al objeto social en estudio. Pueden ser analizadas también como variables independientes, para mostrar las semejanzas y diferencias inter e intragrupales.

En el primer caso el relevamiento de datos se hace a través de métodos de encuesta, con cuestionarios o entrevistas. En el segundo caso se trata de analizar las estructuras alrededor de las cuales se cristalizan los sistemas de representaciones que diferencian a grupos de personas, para lo cual se estudian los campos semánticos que configuran dichas representaciones, a través de métodos de asociaciones de palabras.

La naturaleza de las representaciones sociales hace que no puedan ser investigadas exitosamente mediante un método único y que se recomiende usar para su estudio diferentes métodos, reconociendo las ventajas y limitaciones de cada uno.

Los estudios empíricos acerca de la salud y la enfermedad constituyen algunos de los trabajos más importantes desarrollados tomando como base el modelo de las representaciones sociales. Hay que recordar que el estudio pionero de Moscovici, que marcó el inicio del desarrollo de la escuela en 1961, versó sobre la inscripción de un modelo terapéutico, el del psicoanálisis, en el imaginario social francés de la época. A partir de dicho trabajo el itinerario de las representaciones sociales en el campo de la salud está jalonado por otros dos importantes hitos: el trabajo de C. Herzlich a fines de la década de los sesenta, en el que realiza una tipología de las representaciones sociales acerca de la salud, y el de D. Jodelet, a fines de los ochenta, sobre las representaciones sociales acerca de los enfermos mentales en una comunidad rural del centro de Francia. En la trayectoria marcada por estos trabajos pioneros se inscriben otros estudios que han concurrido a delimitar un campo en el que las dimensiones más importantes son:

- Las representaciones sociales de la salud y la enfermedad como metáfora de la relación individuo-sociedad.

- Las representaciones sociales como teorías folk sobre la salud y la enfermedad.

- Los contenidos de las representaciones sociales de la salud.

- Los contenidos de las representaciones sociales de la enfermedad. 
- La cuestión del género y las representaciones sociales sobre la salud y la enfermedad.

- Las representaciones sociales acerca del origen de la enfermedad.

- Las representaciones sociales acerca de enfermedades tipo (por ejemplo la enfermedad mental y el SIDA).

- Las representaciones sociales acerca de la medicina y el saber médico

Desarrollaremos cada una de estas dimensiones ejemplificándolas, cuando sea posible, con estudios empíricos llevados a cabo sobre cada una de ellas.

\section{LAS REPRESENTACIONES SOCIALES DE LA}

\section{SALUD Y LA ENFERMEDAD COMO METÁFORA}

\section{DE LA RELACIÓN INDIVIDUO-SOCIEDAD}

Ya Susan Sontag (1977) había planteado con gran clarividencia que la enfermedad es una metáfora a través de la cual hablamos de la sociedad y de nuestra relación con ellạ. El malestar corporal es identificado con la agresión social, interpretada como aquello que potencialmente lo provoca. El individuo se atribuye a sí mismo la responsabilidad de los hechos positivos de su vida y atribuye al exterior la responsabilidad de los hechos negativos. Desde esta visión la enfermedad es engendrada por una causalidad externa, nunca por una condición propia del individuo. Esta representación remite a la visión rousseauniana de las relaciones entre el hombre y la naturaleza de fines del siglo XVIII, por la que el proceso de civilización conduce necesariamente a la degradación de la vida natural, originando el malestar y la enfermedad. Se trata de una visión crítica de la sociedad y nostálgica de la historia, en la que el individuo es caracterizado como una víctima de las presiones sociales, que imprimen sobre él las cicatrices de los daños a la salud. Esta última queda entonces identificada con el pasado rural y bucólico, contrapartida de la ciudad con su ambiente polucionado, al que se agregan los males de la comida "desnaturalizada" (enlatada y química), el ruido y el ritmo acelerado de la vida urbana.

La oposición salud/enfermedad replica la oposición individuo/sociedad, dice Herzlich (1969), de modo tal que se transcriben sobre el plano de la explicación de lo biológico las visiones del mundo más amplias. Esto es lo que muestra por ejemplo el estudio llevado a cabo por D. Jodelet (1984) acerca de las representaciones sociales del cuerpo, en el que expone cómo éste es percibido como una metáfora de la historia del sujeto y como un continente a través del cual se expresan los conflictos del individuo con la sociedad.

\section{LAS REPRESENTACIONES SOCLALES COMO TEORÍAS FOLK ACERCA DE LA SALUD Y LA}

\section{ENFERMEDAD}

La teoría de las representaciones sociales describe ciertos mecanismos específicos que intervienen en su formación: la objetivación y el anclaje.

El primero se refiere a las transformaciones que sufren los objetos de conocimiento hasta que entran a formar parte de las representaciones sociales. Tales transformaciones abarcan la organización de los elementos que configuran el campo de significaciones de una representación alrededor de un núcleo figurativo - la parte más estable de la representación - que se constituye en imágenes, a través de la transformación de los diferentes contenidos conceptuales relacionados con el objeto.

Este proceso hace que los sujetos se forjen una visión más concreta del objeto representado, dado que sus características asumen rasgos figurativos y no abstractos. Remite, pues, a la característica del pensamiento social por el que se hace posible la concretización de lo abstracto. Se produce así la transformación icónica de conceptos abstractos, que devienen en una visión simplificada y fáctica de ellos, lo que permite la asimilación de novedades, así como su comunicación. Esto implica, como dijimos antes, una dinámica de selección y descontextualización de elementos informativos, que decodificados y recodificados son adaptados a esquemas de pensamiento previos. Pero estos elementos son apropiados por los sujetos sobre una base a la vez simbólica y cognitiva, lo que hace posible su estructuración sobre líneas jerárquicas que privilegian algunos aspectos en desmedro de otros. 
Además del proceso de objetivación, el segundo mecanismo básico que describe Moscovici en relación con la constitución de las representaciones sociales es, como dijimos, el anclaje. A través de este mecanismo la información nueva acerca de un objeto es integrada a nuestros esquemas de pensamiento, enraizándola en una red de significaciones previas. Esto es lo que ocurre por ejemplo con la incorporación de los conocimientos científicos por los legos, que los asimilan hasta convertirlos en saber de sentido común compartido.

El anclaje denota que las representaciones no se inscriben sobre una tábula rasa. Por el contrario, se trata de un proceso por el que el objeto representado se enraiza en un sistema de pensamiento ya constituido y preexistente. El anclaje articula las tres funciones básicas de la representación: la función cognitiva de integración de la novedad, la función de interpretación de la realidad y la función de orientación de la conducta. Esta dinámica es clave en la generalización de sentido en el marco de las identidades y posiciones sociales de los sujetos que lo forjan.

Las concepciones de las personas comunes acerca de la enfermedad y de la salud constituyen teorías subjetivas compartidas culturalmente, con implicaciones prácticas, que abarcan las ideas acerca de qué es la salud, cómo se la conserva y cómo se la picrde, los esquemas explicativos que se aplican a las distintas enfermedades, las ideas sobre la evolución de la enfermedad y del tratamiento, las opiniones sobre los médicos y las instituciones, sobre la eficacia de los medicamentos y otras terapéuticas, etc.

La relevancia específica de las representaciones sociales como enfoque respecto de la salud y la enfermedad es el hecho de que ellas apuntan a comprenderlas no sólo como asuntos individuales, sino tomando en cuenta la influencia de lo social sobre las personas y comprendiendo el conocimiento lego como socialmente construido.

El pensamiento lego acerca de las enfermedades y su posible distancia con respecto al modelo médico es una variable crucial en relación con el seguimiento de las indicaciones terapéuticas provenientes del sistema de salud.

\section{LOS CONTENIDOS DE LAS REPRESENTACIONES}

\section{SOCIALES SOBRE LA SALUD}

En su trabajo de 1969 Herzlich describe tres representaciones sociales acerca de la salud que están vigentes en nuestras sociedades:

- La salud como vacío, caracterizada como ausencia de enfermedad, en la que la salud es una cualidad de la persona (alguien es sano).

- La salud concebida como reservorio, caracterizada como la salud orgánico-biológica, en la que ella es una condición temporal (alguien tiene salud).

- La salud como equilibrio, caracterizada como bienestar físico y psíquico, que debe buscarse y mantenerse (alguien hace lo necesario para lograr y/o mantener dicho equilibrio).

En una investigación realizada por la autora en Argentina sobre concepciones acerca de la salud "ideal" en jóvenes escolarizados de 15 a 18 años (Kornblit, 1995), se halló que ellas configuran una tipología en la que el sí mismo se percibe como pura corporeidad, como pura "mentalidad" o como integración cuerpo-mente.

En la población estudiada las respuestas se dividen en forma proporcional entre los que plantean el criterio de la salud orgánica (34\%), los que plantean el criterio de la salud mental (25\%) y los que plantean el criterio de la salud como "integración cuerpomente" (41\%).

En consecuencia, para más de la mitad de los jóvenes encuestados subsiste la disociación cuerpomente, quedando la idea acerca del estado de salud ideal asociada a uno u otro de los términos, con exclusión del otro.

La mayor frecuencia con que las mujeres identifican el estado de salud ideal con la "salud mental" no implica una menor involucración de su parte con respecto al cuerpo. Como se sabe, tanto muchos hombres como mujeres jóvenes protagonizan en la actualidad lo que se ha llamado el "retorno al cuerpo" (Melucci, 1989), en el que éste aparece como pieza clave en la búsqueda de identidad. 
El cuerpo ha dejado de ser algo "dado", a menudo el asiento inconveniente e inadecuado del sí mismo, para convertirse en un lugar de interacción con los conocimientos "reflexivamente organizados" —en el sentido de Giddens (1991) — de los expertos que se ocupan de sus diferentes aspectos.

Sin embargo, a pesar de la jerarquización de "lo corporal", observable en muchas expresiones juveniles, persiste en un cierto porcentaje de los casos, en especial para las mujeres, el hecho de relacionar "lo psíquico" con el estado de salud ideal, lo que corre paralelo con la mayor inversión de las mujeres en la esfera afectiva.

Así, el "estar bien" remite a sentidos diversos para los jóvenes, dependiendo de los estilos de vida ${ }^{1}$ que asuman, pero se hace evidente que para muchos de ellos existen esferas de preocupaciones que pueden coexistir sin interferirse mutuamente. Pueden estar obsesivamente preocupados por la imagen del cuerpo, pero también hacer depender su bienestar emocional de la esfera afectiva.

Otra dimensión del "estado de salud ideal" se refiere a la consideración de la ausencia de síntomas o de enfermedades, criterio de definición de la salud considerado "negativo", no en el sentido valorativo sino en términos de cómo se construye la definición.

Por el otro lado, cabe que el concepto se construya de modo "positivo", apuntando a la realización de conductas saludables. En este último caso el estado de salud ideal se define por la búsqueda activa de aspectos saludables, como alimentarse bien, realizar deportes, cuidarse en general, y al mismo tiempo, evitar conductas riesgosas para la salud, como fumar, beber en exceso, consumir drogas, etc.

Más de un tercio de los jóvenes caracteriza la salud como "ausencia de enfermedad". Los restantes adhieren a una concepción más activa de la salud, ya sea en términos de la adopción de conductas saludables (41\%) o en términos de la evitación de conductas de riesgo (21\%).
Estos dos grupos configuran un perfil de jóvenes más abiertos al discurso de la prevención, que reconocen la etiología múltiple de la mayor parte de las enfermedades y la importancia de una actitud activa con respecto al cuidado de la salud (y en este aspecto las mujeres son amplia mayoría), y un perfil de jóvenes que mantienen una actitud más pasiva con respecto al cuidado de la salud, para quienes la integración cuerpo-mente no es una realidad vigente. Obviamente, estos últimos constituyen el grupo más preocupante, en términos de la ideología de la promoción de la salud.

Puede decirse, pues, que existe entre buena parte de los jóvenes encuestados una conciencia de la necesidad de adoptar una posición activa en relación con el logro de un buen estado de salud.

En un estudio llevado a cabo en Francia, J. Pierret (1985) categorizó las representaciones acerca de la salud en:

- La salud-enfermedad, referida a la experiencia vivida de la salud como opuesta a enfermedad;

- La salud como producto, que pone en relación el estado corporal con los determinantes sociales que posibilitan o no la satisfacción de las necesidades básicas;

- La salud como instrumento, referido a la salud como un bien personal gracias al cual se puede trabajar;

- La salud en relación con las instituciones, que corresponde a la acción de los poderes públicos en el campo de la salud pública.

En la mencionada investigación sobre las representaciones sociales de los jóvenes acerca de la salud, realizada en Argentina, el análisis de los datos referidos a las asociaciones entre los términos relacionados con la salud permite señalar que los jóvenes encuestados ponen el acento en las dos primeras representaciones mencionadas, probablemente porque aún no han experimentado

\footnotetext{
1 La noción de "estilo de vida" y su utilización en las ciencias sociales reconoce — según Giddens - dos orígenes distintos. Para algunos deriva de la obra de Adler, de quien fue tomada por los "radicales" estadounidenses en la década de los sesenta, y luego por los publicistas. Para otros, en cambio, deriva de Max Weber, quien la desarrolló en su explicación acerca del "estilo de vida" puritano. El concepto no es asimilable, pues, como han creído ver algunos sociólogos, a una mera descripción en términos de consumos individuales.
} 
en sus historias de vida la evidencia de la salud como bien necesario en relación con la capacidad laboral, ni han palpado la dimensión institucional de la salud. Para ellos la salud es sobre todo una noción ligada al equilibrio físico o psíquico, o un estado al que se otorga una valoración afectiva.

Puede decirse, de acuerdo a lo anterior, que la polisemia del término salud reenvía a explicaciones sociológicas complejas en las que intervienen los valores culturales, compartidos por un grupo en un momento dado, así como a las características materiales de la existencia de las personas.

Por otra parte, el concepto de salud incluye un conjunto de entidades que suelen ser ajenas a la medicina y que operan como símbolos condensados que se relacionan con una amplia variedad de experiencias propias de una cultura o de un sector de la población.

En el mencionado estudio sobre jóvenes se analizaron los conceptos que ellos asocian más comúnmente con la salud, no sólo con relación a entidades corporales o psíquicas, sino también en cuanto a imágenes asociadas con otras áreas de la vida.

Aplicando la técnica del análisis factorial a las palabras marcadas por los jóvenes como preocupantes en relación con la salud a partir de una lista de 92 palabras, éstas resultaron agrupadas en doce factores, que hemos denominado:

Factor 1: problemas corporales

Factor 2: problemas sociales

Factor 3: la cotidianidad actual

Factor 4: situaciones críticas

Factor 5: enfermedades mortales

Factor 6: ideales

Factor 7: sexualidad y procreación

Factor 8: esparcimiento

Factor 9: incapacidades

Factor 10: política y represión

Factor 11: problemas psíquicos

Factor 12: adicciones
Según la frecuencia con que fueron marcados, estos factores fueron agrupados en tres categorías:

\section{Factores que concitan mayor preocupación:}

Factor 12 (adicciones) 77,7\%

Factor 5 (enfermedades mortales) $74,2 \%$

Factor 6 (ideales) $\quad 70,4 \%$

\section{Factores que concitan una preocupación media:}

Factor 3 (la cotidianidad actual) $\quad 64,2 \%$

Factor 2 (problemas sociales) ～63,4\%

Factor 7 (sexualidad y procreación) 56,9\%

Factor 9 (incapacidades) $\quad 52,5 \%$

Factor 4 (situaciones de riesgo) $\quad 49,9 \%$

\section{Factores que concitan menor preocupación:}

Factor 1 (problemas corporales) 42,9\%

Factor 8 (esparcimiento) $\quad 32,7 \%$

Factor 11 (problemas mentales) 29,7\%

Factor 10 (política y represión) 18,8\%

Analizando estos datos puede verse que el perfil de preocupaciones de los jóvenes pasa en primer lugar por lo que ellos perciben como las patologías actuales de mayor gravedad: las adicciones, el SIDA y el cáncer.

Significativamente, junto a estas preocupaciones surgen como importantes para ellos ciertos valores que configuran lo que podríamos denominar los ideales juveniles actuales: la felicidad, la belleza, la amistad.

Estas preferencias marcan fuertes diferencias con los que presumiblemente fueron los valores o ideales de los jóvenes de las generaciones de los sesenta y setenta, más orientados a ideales o problemáticas sociales.

Si bien estas últimas temáticas concitan una preocupación "media" en cl estudio que estamos comentando, aparecen con un puntaje algo menor al que se asigna a las temáticas ligadas a lo que llamamos "cotidianidad": los ámbitos familiar y escolar.

Es también llamativo que el factor marcado en último lugar sea el que agrupa a la política, la policía 
y los militares, cuya agrupabilidad es por demás elocuente con respecto a los contenidos a los que los jóvenes asocian la política. Parecería a este respecto que la herencia de los años de dictadura militar sufridos en Argentina ha dejado una impronta tal en ellos que no ha podido borrarse aún, tras más de quince años de gobiernos democráticos.

El hecho de que los "problemas corporales" sean marcados como factor que entra en la categoría de "menor preocupación" señala también una diferencia con respecto a las características descripciones del perfil adolescente que aparecen en los textos de psicología evolutiva tradicionales.

En todo caso, las temáticas corporales que les preocupan algo más son las relacionadas con la "sexualidad y la procreación" (categorización intermedia en la escala de factores preocupantes).

El estudio permitió categorizar a la población estudiada en cuatro perfiles de jóvenes:

1) Los "organicistas", preocupados por el cuerpo y su funcionamiento (alrededor del 24\% de la muestra).

2) Los "sobreadaptados", preocupados por su realidad social inmediata (la escuela, la familia), y por "ideales" de corte individualista (alrededor del $57 \%$ de la muestra).

3) Los "preocupados por problemáticas sociales e individuales" (alrededor del 49\% de la muestra).

4) Los "jóvenes preocupados por las situaciones de riesgo de los jóvenes", como el consumo de drogas y las situaciones críticas de la vida en esta etapa etaria (alrededor del $41 \%$ de la muestra). ${ }^{2}$

\section{CONTENIDOS DE LAS REPRESENTACIONES}

\section{SOCIALES ACERCA DE LA ENFERMEDAD}

Los trabajos de Herzlich y Pierret (1988) y de Páez et al. (1987), entre otros, han permitido subrayar que el núcleo de la representación social de la enfermedad está anclado en la percepción de que el sujeto sufre un "ataque" por parte del ambiente externo, que destruye su capacidad como ser actuante. La enfermedad siempre aparece como un estado deficitario, como "un estar peor que antes", siendo ese pasado ideal algo que se quiere recuperar.

En su estudio de 1969, Herzlich describe también tres tipos de representaciones sociales acerca de la enfermedad:

- La enfermedad "destructora", caracterizada por el hecho de que el sujeto se siente/es excluido socialmente, al mismo tiempo que depende de otros; el enfermo vive su condición como una violencia que se ejerce sobre él, viéndose reducido a la inactividad.

- La enfermedad "liberadora", vivida como ruptura con las presiones sociales, de modo que ella ofrece nuevas posibilidades de vida y libertad; la enfermedad es un modo de defensa contra las exigencias sociales.

- La enfermedad como "oficio", que implica la lucha activa del sujeto en pos de la salud, a partir de la aceptación de su condición de enfermo; la enfermedad implica en este caso una situación de aprendizaje, como ocurre en las enfermedades crónicas que requieren la participación activa del sujeto en su terapéutica.

Por otra parte, y atendiendo a la producción intelectual acerca de la enfermedad, Laplantine (1989) afirma que los sistemas de representaciones sobre ella, estudiados por los diferentes autores, se construyen alrededor de tres ejes:

- La enfermedad en tercera persona (a la que alude el término en inglés disease), que comprende el análisis que la medicina hace del síntoma y de su etiología, lo que relega a un segundo plano la relación de la enfermedad con lo psicológico y con lo social. Este conocimiento se postula como "objetivo" e impregna en mayor o menor medida las representaciones sociales acerca de las enfermedades.

- La enfermedad en segunda persona (a la que alude el término en inglés sickness), que comprende el enfoque del médico clínico, del homeópata, del psicólogo, en el desarrollo de sus prácticas.

- La enfermedad en primera persona (a la que alude el término en inglés illness), que implica el análisis

2 El tipo de respuestas con que se construyeron los datos (elecciones múltiples) hace que el total supere el 100\%. 
de los sistemas interpretativos forjados en el entrecruzamiento de la subjetividad de los que padecen la enfermedad y de los terapeutas, en la medida en que ellos proceden de la misma cultura que la de los enfermos.

Otro aspecto que Laplantine toma en cuenta en relación con los contenidos de las representaciones sociales acerca de la enfermedad es su caracterización como una entidad exógena que penetra por efracción en el cuerpo de un individuo, siendo la curación la aniquilación de un enemigo con el que no hay que transar, o, por el contrario, como disfunción. En este último caso la terapéutica se concibe como una acción reguladora que otorga prioridad a las potencialidades del sujeto enfermo. Se alientan especialmente las reacciones de defensa del organismo. La medicina occidental ha privilegiado en general el primer modo de comprensión de la enfermedad, que es concebida como lo opuesto a la salud y no como una condición en la que la salud está potencialmente presente, aspecto subrayado por la medicina oriental y otros modelos médicos no hegemónicos, como la homeopatía.

\section{LA CUESTIÓN DEL GÉNERO Y LAS}

\section{REPRESENTACIONES SOCIALES ACERCA DE LA}

\section{SALUD Y LA ENFERMEDAD}

Los numerosos estudios que han analizado las diferencias de género en relación con las representaciones sociales acerca de la salud y la enfermedad coinciden en señalar que las mujeres son vistas como sostenedoras de todo aquello que se relaciona con la salud en la vida cotidiana y también de todo lo referente a su recuperación cuando ella se ha perdido.

Así, las mujeres son percibidas como:

- Proveedoras de la salud, es decir, responsables de establecer un medio doméstico favorable a la salud.

- Negociadoras de la salud, es decir, responsables de transmitir las actitudes y comportamientos necesarios para mantenerse en buen estado de salud por parte de los miembros del grupo familiar.
- Mediadoras de la salud, es decir, de establecer el contacto con el sistema profesional de salud.

Es interesante señalar que el criterio de evitar conductas de riesgo como característica de la salud es adoptado, en el mencionado estudio llevado a cabo en Argentina con jóvenes, en mayor proporción por las mujeres, quienes parecen tener así una mayor conciencia acerca de la propia responsabilidad en la conservación de la salud, coincidiendo con lo descrito en la bibliografía respecto del rol femenino en la familia, en cuanto a velar por las acciones vinculadas con la salud de todo el grupo (Graham,1984).

En la misma investigación surgieron también diferencias significativas por sexo: los varones parecen estar más preocupados por lo orgánico, ya que las únicas palabras que marcan en mayor proporción que sus pares femeninos, como indicadores de sus preocupaciones en torno a la salud, son: estatura, oído, dientes, fatiga, apetito, sueño y respiración.

Las mujeres, por su parte, no muestran preocupación por lo orgánico, salvo en lo que se refiere a lo fisiológico, en especial relacionado con la sexualidad, dado que marcan más palabras como pubertad, transformación del cuerpo, menstruación, anticoncepción, embarazo, parto y aborto.

A su vez, las mujeres muestran una gama sumamente diversa de preocupaciones que asocian con la salud. Les preocupa lo psicológico, lo cognoscitivo, lo afectivo y lo recreativo.

Las patologías psicosociales, como divorcio, suicidio, delincuencia, desocupación, violencia, guerra y hambre, también son asociadas a la salud por las estudiantes femeninas, así como las enfermedades mortales (SIDA, cáncer, muerte), su prevención y la medicina.

Amor y amistad son dos palabras que tienen que ver con proyecto de vida, que las mujeres en mayor proporción que sus pares masculinos asocian con la salud. Esto muestra la vigencia de la importancia que las jóvenes asignan a las relaciones interpersonales.

Por último es interesante señalar que las tres palabras donde hay mayor diferencia entre mujeres y varones son: prevención de enfermedades, futuro y familia, lo que denota la mayor posibilidad de las jóvenes de trascender el momento presente. 


\section{REPRESENTACIONES SOCIALES ACERCA DE ENFERMEDADES TIPO}

De los estudios realizados acerca de las representaciones sociales de enfermedades específicas hemos elegido exponer dos casos: la enfermedad mental y el sIDA.

\section{REPRESENTACIONES SOCIALES ACERCA DE LA}

\section{ENFERMEDAD MENTAL}

En los últimos años de la década de los ochenta D. Jodelet investigó las representaciones sociales acerca de la enfermedad mental y de los enfermos mentales por parte de los habitantes de una comunidad rural del centro de Francia. La circunstancia de que en ella se había realizado la experiencia de ofrecer como hogares sustitutos para enfermos mentales, a cambio de una retribución, algunas de las casas de los habitantes del lugar, torna este estudio más interesante, dado que se puede considerar que las representaciones sociales de estos campesinos sobre el tema han sido "reforzadas", o quizás modificadas, a partir de su contacto directo con los enfermos.

Jodelet afirma que este proceso puede describirse según los ejes a partir de los cuales se forman las representaciones sociales: el anclaje y la objetivación. Por un lado, a través del anclaje, el enfermo y la enfermedad se inscriben en la red de significaciones y en un cuadro cognitivo preexistentes. Este saber es instrumentalizado al aplicárselo a la gestión del trato cotidiano con los enfermos. A través de la objetivación, el concepto de enfermedad mental se reifica y se inscribe en la materia sanguínea y humoral. El saber se esquematiza, subrayándose ciertos aspectos, como la falta de afectividad y de voluntad de los enfermos.

Las representaciones sociales acerca de estos últimos resultan en una devaluación de sus personas que lleva a formas abiertas y sutiles de rechazo, interponiéndose reglas que los alejan en el contacto cotidiano (no comer juntos, ubicarlos en las habitaciones más distantes de las ocupadas por los miembros de la familia, etc.).
Jodelet afirma que este trabajo muestra, además, cómo la asimilación de las percepciones acerca de los enfermos a creencias enraizadas en la tradición puede pervertir el sentido de ciertas prácticas terapéuticas y de progreso científico, si no se trabaja previamente en el sentido de su modificación.

Puede decirse que la característica intrínseca de las representaciones sociales acerca de la enfermedad mental es su definición como lo diferente a uno mismo, siendo esta diferencia evaluada negativamente. Esto marca una diferencia con respecto a las representaciones sociales de los enfermos físicos, que son caracterizados como débiles y necesitados, pero no necesariamente distantes. Esto está dado por la percepción de que su situación podría ser la propia, de lo que surge una actitud de comprensión y de empatía hacia ellos.

De lo anterior se desprende que a la dimensión salud/enfermedad mental se yuxtapone la de normalidad/desviación, que remite a la oposición entre identidad y otredad, entre similaridad y diferencia.

Es interesante señalar que esta yuxtaposición es posible de ser modificada, como lo prueba la mayor tolerancia a los enfermos mentales que se observó en Italia tras la ley que clausuró las instituciones manicomiales y preconizó un modelo psicosocial acerca de la enfermedad mental.

\section{LAS REPRESENTACIONES SOCIALES ACERCA DEL SIDA}

Los primeros estudios sobre representaciones sociales del SIDA (Jodelet, 1989; Páez et al., 1991a, 1991b) pusieron de manifiesto que en su constitución se recurría a antiguas teorías sobre el contagio por los humores corporales o sobre la enfermedad como castigo, así como la existencia de dos clusters de representaciones sociales: el "liberal" y el "conservador".

El primero ve al SIDA como menos contagioso que el segundo y rechaza su identificación con los grupos de riesgo. El segundo atribuye la causa de la enfermedad a la crisis social y moral actual y la liga a grupos marginales socialmente.

Una segunda "generación" de estudios sobre las representaciones sociales del SIDA tienen como 
objetivo poner en evidencia los principios organizadores que estructuran las representaciones acerca de la enfermedad, a través del análisis de qué asociaciones semánticas se realizan con el concepto SIDA. Ejemplos de este tipo de trabajos son los realizados en Francia por Morin y Vergès (1992).

El estudio de los términos más frecuentes asociados a una palabra estímulo es un muy buen indicador de los referentes privilegiados por los sujetos en torno a un objeto social, en este caso el SIDA. Tal enfoque permite integrar el tema del SIDA en un discurso que va más allá de los modos de transmisión de la infección y de los modos de protegerse de ella, enmarcándolos en una visión más abarcativa del mundo social en el que surgen.

A partir de la coocurrencia de palabras se construyen "nubes léxicas" que muestran los contenidos semánticos principales ligados al tema en estudio.

Los pasos seguidos para el análisis de las representaciones sociales sobre el SIDA han sido puntualizados por Páez et al. (1992):

1. Exțraer las dimensiones más importantes de esta representación para una población determinada, mediante métodos que analizan la coocurrencia de creencias, como el análisis factorial de correspondencias o el escalamiento multidimensional. Los estudios realizados hasta ahora en este sentido muestran que la dimensión más importante de las representaciones sociales con respecto al SIDA es la que se refiere a la distancia social aceptada con los que padecen la enfermedad o son seropositivos.

Este eje comprende en un polo las personas que consideran que el virus es fácilmente transmisible por contactos casuales y que mantienen una pronunciada distancia social con los infectados. En el otro polo se incluyen las personas que no consideran que la enfermedad sea fácilmente transmisible y que no temen la interacción con los sujetos infectados.

2. Analizar las asociaciones entre las respuestas a las indagaciones acerca de las creencias de las personas sobre el SIDA a través de la técnica del análisis de clusters permite entender la lógica de la representación y consecuentemente construir una tipología de las representaciones sociales acerca del
SIDA. El análisis realizado de este modo permitió identificar dos tipos fundamentales de creencias:

a) el tipo conservador-corporativista

b) el tipo liberal

El primero adjudica a los enfermos la culpabilidad y la responsabilidad de haberse contagiado. Esto deriva en enojo hacia ellos y genera pocos deseos de ayudarlos, reacciones que no se encontraron cuando se identifica una causa no controlable por el sujeto, como una transfusión de sangre.

El segundo define el SIDA como una enfermedad infecciosa que no se basa en un estilo de conducta y que no exige medidas de aislamiento ni de coerción social dirigidas a los infectados.

3. Analizar la función social de las representaciones mediante técnicas estadísticas, como el análisis discriminante o la regresión múltiple entre los indicadores del grado de acuerdo individual con las puntuaciones factoriales y los indicadores de estatus social y posición ideológica.

Se vio de este modo que las personas de mayor edad relativa, de bajo nivel educativo y de ideología conservadora correspondían en mayor medida al cluster conservador.

Del mismo modo se puso en evidencia que las personas con actitudes negativas ante la homosexualidad sostenían creencias incorrectas con respecto al SIDA y actitudes discriminatorias hacia los enfermos.

4. Relevar la distribución de los elementos cognitivos sobresalientes que entran en la estructuración de la representación social sobre el SIDA, a través de evocaciones o asociaciones de ideas y de la utilización de tareas de clasificación de ítems que conducen a la atribución de significaciones en el campo semántico del SIDA.

Aplicando estos instrumentos, Morin y Vergès (1992) identificaron tres principios generadores de construcción del universo semántico del SIDA:

a) Los atributos médicos y el componente de transmisión de la enfermedad;

b) La personalización de las vivencias despertadas por el SIDA, específicamente en cuanto a las asociaciones vinculadas con el miedo; 
c) Los componentes "sociales" en cuanto a las categorías identificatorias de los enfermos vinculadas a la diferencia y a la marginación.

5. Relevar la estructura de la representación sobre el SIDA distinguiendo entre el núcleo de dicha representación y los elementos periféricos, a través de las técnicas del análisis de frecuencia de las asociaciones y del análisis de su rango de ocurrencia.

Morin y Vergès (1992) encontraron en una investigación sobre las representaciones sociales acerca del SIDA en jóvenes franceses escolarizados, realizada con la técnica de evocación de palabras, que los dos temas figurativos que más aparecieron en las respuestas a sus preguntas fueron "la muerte" y "la enfermedad". Para dichos autores esto es el reflejo reificado de la noción de "enfermedad mortal", difundida por los medios a partir del discurso médico. De hecho, los jóvenes que mencionaban los dos términos juntos, en el sintagma "enfermedad mortal", habían tenido más contacto con instituciones médicas.

El siDA tiene, pues, para los jóvenes franceses, una significación central doble: enfermedad y muerte, de la que tanto la sèxualidad como la prevención resultan elementos periféricos.

A través de otra técnica de recolección de datos - la asignación diferencial de rasgos, que ayuda a mostrar la estructuración del objeto-, los mismos autores obtienen resultados semejantes a los obtenidos en una investigación realizada en Argentina (Kornblit et al., 1997): el cáncer es un referente esencial en la cognición del SIDA.

Esta "objetivación" del SIDA como cáncer puede verse como una respuesta a las incertidumbres y temores despertados por la enfermedad. El acercar el sIDA al cáncer es así una posibilidad paradójica de "pensar lo impensable", porque lo presenta como una enfermedad grave, con respecto a la cual el cuerpo médico ha transmitido la idea de que, en algunos casos, es curable. En este proceso, “...las representaciones del SIDA y del cáncer se neutralizan recíprocamente, cuando, gracias al SIDA, el cáncer deviene una enfermedad menos terrorífica y más banal, y cuando, gracias al cáncer, el SIDA deviene una enfermedad grave que no es más que provisoriamente incurable" (Morin y Vergès, 1992:70).
La asociación entre cáncer y SIDA muestra también que el horizonte de la enfermedad se construye en torno a lo inevitable e incurable, o sea en torno a la enfermedad-destino, en términos de Herzlich y Pierret (1988), y no en torno a lo prevenible. Éste es, pues, un importante hallazgo a la hora de repensar la direccionalidad de los mensajes preventivos, que han acentuado hasta ahora en términos racionales la naturaleza evitable de la enfermedad.

La teoría de las representaciones sociales ha sido también aplicada al análisis del reconocimiento y recuerdo de los mensajes preventivos (Echabarría y Páez, 1989), a partir del reconocimiento de que las desviaciones en el recuerdo actúan como mecanismos para garantizar la estabilidad de las representaciones preexistentes. Este hallazgo pone en tela de juicio las campañas preventivas basadas exclusivamente en la difusión de información.

Según Páez et al. (1992) el enfoque de las representaciones sociales pone el acento sobre el hecho de que ellas están ligadas a la memoria colectiva, y más aún, que esta última constituye su núcleo. Estos autores recuperan los trabajos de Halbwachs (1950) y de Bartlett (1973) sobre la memoria colectiva, que plantean el carácter social y construido de la memoria individual. Así, los niveles elevados de reacciones emocionales a la evocación de hechos personales importantes del pasado se asocian con niveles altos de repetición social en el pasado.

"La memoria es social porque las personas comparten sus recuerdos y los recuerdan juntos" (Páez et al., 1992) y porque nuestros puntos de referencia para nuestras evocaciones están por lo general definidos socialmente (fiestas, acontecimientos sociales, ceremonias).

Probablemente el SIDA activa recuerdos de epidemias y catástrofes pasadas y de cómo las personas reaccionaron frente a ellas. En Argentina, por ejemplo, la epidemia que los adultos especialmente pueden recordar es la de parálisis infantil, que afectó a la población en la década de los cincuenta. La convicción generalizada de que pronto surgirá una vacuna contra el SIDA puede vincularse a la rápida aparición de las vacunas Salk y Sabin para la 
parálisis infantil en aquellos años. En este aspecto, el SIDA no se asocia con el cáncer, al que sólo es parangonado en términos de la gravedad de ambas enfermedades.

Se ha planteado también que las personas anclan sus representaciones con respecto al SIDA como enfermedad recientemente aparecida en sus representaciones acerca de las enfermedades infectocontagiosas que conocen.

En un estudio llevado a cabo por Páez et al. (1991a) se vio que las personas utilizan en general sus conocimientos sobre los mecanismos de transmisión de las enfermedades infantiles comunes como base de su apreciación acerca de las vías de contagio del SIDA. Esta sería la explicación acerca de por qué está tan difundida la creencia de que el SIDA se contagia por la saliva o el contacto físico.

En otra investigación llevada a cabo también por Páez et al. (1991b) se vio que las personas encuestadas tenían ya en 1988 un conocimiento bastante exacto de los mecanismos de contagio del SIDA, junto a una subvaloración de su riesgo personal de contraer la enfermedad y a una ausencia de medidas preventivas correctas. Resultados similares se han encontrado en Argentina (Petracci, 1995; Kornblit et al., 1997).

Los estudios sobre representaciones sociales en torno al SIDA permitieron confirmar el rol de las representaciones sociocognitivas con respecto a las prácticas sociales, aun cuando no se desconoce el hecho de que la interacción entre las prácticas y las representaciones es compleja.

Morin y Vergès (1992) plantean que a nivel de la población general se ha dado un fenómeno de autonomización relativa de las representaciones del SIDA en relación con la hegemonía del discurso médico. Las primeras devienen componentes estructurados y específicos del mundo construido por los diferentes subgrupos poblacionales.

En cuanto a quiénes se percibe como más expuestos a la enfermedad, en un estudio realizado en Argentina (Kornblit et al., 1997), frente a las alternativas: bomosexual, bisexual y heterosexual, el 20\% de las personas encuestadas percibe como más expuestos a los homosexuales. El 69 \% afirma que es indistinto.
El discurso acerca de que el virus puede ser contraído por "cualquier persona" ha prendido en mayor medida en la ciudad de Buenos Aires, el más cosmopolita de los núcleos urbanos estudiados, y el porcentaje de personas que contestan de este modo es mayor también entre los que tienen un amigo o conocido muerto de SIDA.

Los así llamados "grupos de riesgo" son visualizados por la mayoría de la población como difusores de la enfermedad, pero no como blancos actuales privilegiados de la infección. No ocurre lo mismo con respecto a la categoría "jóvenes", a la que al menos la mitad de la población adjudica mayor riesgo de infección.

Como vemos, la producción de trabajos en torno al SIDA realizados desde la perspectiva de las representaciones sociales ha sido amplia, y ello se debe al carácter inusual de la enfermedad, en cuanto a su brusca aparición a comienzos de la década de los ochenta, lo que determinó un fenómeno hasta entonces inédito: la construcción simultánea de conocimientos científicos sobre ella y la construcción que de ella hicieron los medios, que la transmitieron en sus orígenes como una enfermedad limitada a los "grupos de riesgo". La impronta que esta definición dejó en el imaginario social no puede ser fácilmente transformada, a pesar de los esfuerzos de las campañas comunicacionales posteriores que se realizaron en casi todos los países. Esta circunstancia creó una condición privilegiada para el desarrollo de estudios desde el modelo de las representaciones sociales, que confirmaron la vigencia de lo postulado por dicho modelo en cuanto a la construcción de los objetos sociales, en este caso la enfermedad SIDA.

\section{LAS REPRESENTACIONES SOCIALES ACERCA DEL} ORIGEN DE LA ENFERMEDAD

Según Moscovici (1992), la pregunta inescapable que las personas se formulan cuando se enferman es: ¿por qué yo? Esta pregunta muestra la creencia implícita de que existe un encadenamiento causal para cada hecho particular, que lo produce. El segundo contenido ideacional que aparece en ocasión de una enfermedad es la responsabilidad del sujeto 
en lo que le sucede, la idea de culpabilidad, de una falta moral cometida (por ejemplo el no haberse cuidado suficientemente), que redunda en la aparición de la enfermedad.

Para este autor estas preguntas son indicadoras de la existencia generalizada de una mentalidad prelógica, en virtud de la cual se asocian rasgos sin relación entre sí en correlaciones falaces, que implican la transgresión de los principios de probabilidad y de correlación. Esto confiere una particularidad a la mentalidad prelógica contemporánea, que se diferencia de la de las culturas arcaicas, en las que lo que se transgrede es el principio de contradicción.

Según nuestra mentalidad prelógica, se supone que si hubiéramos actuado de otra manera las consecuencias hubieran sido diferentes. Este supuesto es acompañado por otro, que se refiere a la cuestión de la necesidad de hacer para controlar la enfermedad. "No se puede no hacer nada". En un aspecto este hacer se relaciona con la obediencia a las prescripciones de la medicina, tanto preventiva como curativa, de ahí el carácter siniestro que reviste la frase: "no hay nada que hacer". Ella arroja al enfermo a un estado en el que queda solo en la lucha contra la enfermedad, librado a sus propias fuerzas, a diferencia del nosotros colectivo y anónimo en el que el "hacer" es asumido por la institución médica, cuando ella visualiza caminos terapéuticos posibles.

\section{REPRESENTACIONES SOCIALES ACERCA DE LA}

\section{MEDICINA Y EL SABER MÉDICO/PSICOLÓGICO}

En su estudio acerca de las representaciones sociales del psicoanálisis Moscovici (1961) insistía en la importancia de la penetración de una teoría científica en el pensamiento común y la transformación que ella puede sufrir a través de este proceso. Es precisamente en torno a los temas vinculados con la salud y la enfermedad donde puede analizarse con más riqueza esta articulación entre el pensamiento común y el científico. Dicho estudio puede realizarse siguiendo dos vertientes: la de la relación entre las representaciones sociales de la enfermedad con la medicina como cuerpo de conocimientos y la de la relación de los individuos portadores de las representaciones sociales con la medicina como profesión.
En el discurso social la salud ocupa un lugar de privilegio, y la valorización que se hace de ella lleva a que se postule una equivalencia entre el estar enfermo y el hacerse curar. La enfermedad no es concebible fuera de su relación con la medicina, pero esto hace que exista un cierto margen de libertad por parte de los individuos en cuanto a las elecciones que realizan en relación con la medicina. Ya no se trata de una relación de entrega del paciente al médico, sino que, por lo menos de parte de los sujetos de las clases medias y altas, se ejerce un cierto filtro con respecto a lo que proviene de la medicina. En ocasiones ésta es homologable a la sociedad represora, por lo que las elecciones se orientan a las medicinas alternativas que ponen en juego recursos homólogos a la naturaleza y a los procesos biológicos que se dan en el ejercicio de la salud.

Por último, para el mismo autor, existen tres modelos epistemológicos que dan cuenta de las enfermedades:

- El modelo biomédico, encarnado en lo que puede denominarse medicina de las especificidades: aislar la etiología específica, diferenciar el cuadro sintomatológico, administrar la terapéutica específica.

- El modelo psi (psicológico, psicoanalítico, psicosomático), que pone el acento en el carácter intrapsíquico del conflicto responsable del síntoma. Aquí es el individuo mismo quien por sus características personales "produce" sus enfermedades. Si bien esta propuesta implica un determinismo causalista, éste es sorteado en las teorías que asumen el carácter holístico de la integración cuerpo-mente.

- El modelo relacional, en el que la enfermedad no es pensada - como en el primer modelo- en términos de "ser", sino en términos de la tercera categoría planteada por Herzlich en su clasificación acerca de los sentidos sociales atribuidos a la salud, en cuanto al equilibrio o desequilibrio, en este caso en relación con el medio. Es la propuesta de la antipsiquiatría, de la terapia familiar sistémica y hasta cierto punto de la epidemiología. En estos casos la enfermedad es imputada al medio ambiente malsano, a la familia, al modo de vida urbano, etc. Nuevamente, el carácter más o menos 
determinista de esta relación depende del modelo que se postula.

Con respecto al "saber médico", se ha producido - especialmente en las enfermedades crónicas - una delegación en los pacientes de ciertos aspectos del tratamiento. Tal como lo expresa Herzlich (1992), en este caso los enfermos ya no son pasivos, sino que son usuarios que han adquirido la maestría de su terapéutica, compartiéndola con los médicos, y aun aventajándolos, dada su praxis cotidiana y el hecho de vivir la enfermedad desde adentro y no como testigos externos, como es el caso de los médicos.

Esto implica el surgimiento de nuevos actores sociales, que a partir del conocimiento de su cuerpo acceden a un espacio social que en épocas anteriores era privilegio de los médicos. Hemos sido testigos así de la creación de grupos de enfermos de diferentes dolencias que se constituyen como actores sociales definidos a partir de la autoayuda, pero que además reclaman con su mera existencia derechos no visualizados hasta ahora. Todo esto implica un nuevo imaginario acerca de la medicina, en el que las relaciones de poder se manifiestan de modos menos jerárquicos y unilaterales.

Laplantine (1989) plantea que las diferentes prácticas terapéuticas vigentes en nuestras sociedades concitan diferentes grados de legitimidad. La biomedicina, por ejemplo, goza de una plena legitimidad. La psicología, el psicoanálisis, la homeopatía, la acupuntura, etc., gozan de una legitimidad parcial. Por último, las prácticas que se sitúan en los márgenes de la cultura oficial, como las de los "curadores", gozan de una legitimidad limitada a quienes buscan sus servicios.

\section{CONCLUSIONES}

A partir de la obra de Moscovici, el modelo de las representaciones sociales se ha convertido en un importante instrumento de la psicología social para entender cómo los grupos sociales se convierten en sujetos activos en la elaboración de "teorías" sobre diversos objetos sociales, por ejemplo la salud, a partir de diversas fuentes de información.
En la medida en que las representaciones sociales son a la vez filtros cognitivos y factores que predisponen a la acción, ellas son poderosas mediaciones en relación con la conducta que desarrollan los sujetos respecto de la salud y la enfermedad. Sin embargo, trabajar con el modelo de las representaciones sociales implica oponerse a una visión mecanicista que ubica las actitudes en el lugar de las causas y las conductas en el de las consecuencias. Propone, en cambio, la hipótesis de que existe una interacción compleja de prácticas y do representaciones en torno a la salud y la enfermedad, de modo tal que ambos elementos se condicionan recíprocamente.

Por otra parte, la medicina debe contextualizarse en el discurso social de la época, y las imágenes de la salud y de la enfermedad que circulan socialmente en un momento determinado son a la vez que derivaciones del saber médico, intermediarias en la absorción que de él hacen los grupos sociales.

El recorridoa por los distintos aspectos ligados a la teoría de las representaciones sociales acerca de la salud y la enfermedad que hemos realizado, sin pretender ser exhaustivo, ha permitido mostrar su valor heurístico en relación con el conocimiento sobre cómo las personas y los grupos construyen socialmente dichos conceptos. Esto posibilita comprender también con mayor profundidad sus prácticas, tanto en relación con la presencia o ausencia del cuidado y mantenimiento de la salud como con la experiencia de la enfermedad, propia o del otro.

\section{REFERENCIAS BIBLIOGRÁFICAS}

Bartlett, F., 1973. Los factores sociales del recuerdo. En: Estudios básicos de psicología social $(\mathrm{H}$. Prohansky \& B. Seidenberg, eds.). Madrid: Tecnos.

Di Giacomo, J.P., 1987. Teoría y métodos de análisis de las representaciones sociales. En: Pensamiento, individuo y sociedad (D. Páez, ed.). Madrid: Fundamentos.

Durkheim, E., 1898. Représentations individuelles et représentations collectives. Revue de Métaphysique et de Morale, VI:273-302. 
Echabarría, A. \& Páez, D., 1989. Social representation and memory: the case of AIDS. European Journal of Social Psychology, 19:543-551.

Elejabarrieta, F., 1991. Las representaciones sociales. En: Psicología social sociocognitiva (A. Echevarría, ed.). Bilbao: Desclée de Brouwer.

Flick, U., 1992. La perception quotidienne de la santé et de la maladie. París: L'Harmattan.

Giddens, A., 1991. Modernity and self-identity. Stanford: Stanford University Press.

Graham, H., 1984. Woman, bealth and the family. Londres: Harvest Press.

Halbwachs, M., 1950. La memoire collective. París: PUF.

Herzlich, C. \& Pierret, J., 1988. De ayer a hoy: construcción social del enfermo. Cuadernos Médico Sociales, 43.

Herzlich, C., 1969. Santé et maladie. Analysis d'une représentation sociale. París: Mouton.

Herzlich, C., 1992. Représentations sociales de la santé et de la maladie et leur dynamique dans le champ social. En: La perception quotidienne de la santé et de la maladie (U. Flick, ed.). París: L'Harmattan.

Jodelet, D. \& Madeira, M., 1998. Aids e representaçoes sociais. Natal: EDUFRN.

Jodelet, D. (comp.), 1989. Les représentations sociales. París: PUF.

Jodelet, D., 1984. The representation of the body and its transformations. En: Social representations (R. Farr \& S. Moscovici, eds.). Cambridge: Cambridge University Press.

Jodelet, D., 1989. Folie et représentations sociales. París: PUF.

Kornblit, A., 1995. Culturas juveniles. Buenos Aires: Instituto Gino Germani.

Kornblit, A.; Giménez, L.; Mendes Diz, A.; Petracci, M. \& Vujosevich, J., 1997. Y el sida está entre nosotros. Buenos Aires: Corregidor.

Laplantine, F., 1989. Anthropologie des sistèmes de représentations de la maladie. En: Les représentations sociales (D. Jodelet, comp.). París: PUF.
Melucci, A., 1989. Nomads of the present. Londres: Hutchinson.

Morin, M. \& Vergès, P., 1992. Enquete sur une représentation en voie d'émancipation: le sida pour les jeunes. Les Cahiers Internationaux de Psychologie Sociale, 15:47-75.

Moscovici, S., 1961. La psychanalyse, son image et son public. París: PUF.

Moscovici, S., 1986. L'ére des représentations sociales. En: L'étude des représentationes sociales (W. Doise \& A. Palmonari, comps.). París: Neuchatel.

Moscovici, S., 1992. La mentalité prélogique des civilisés. En: La perception quotidienne de la santé et de la maladie (U. Flick, comp.). París: L'Harmattan.

Páez, D. et al., 1987. Pensamiento, individuo y sociedad. Madrid: Fundamentos.

Páez, D.; San Juan, C.; Romo, I. \& Vergara, A., 1991a. Sida: imagen y prevención. Madrid: Fundamentos.

Páez, D.; Echabarría, A.; Valencia, J.; Romo, I.; San Juan, C. \& Vergara A., 1991b. Aids'social representations: contents and processes. Journal of Community and Applied Social Psychology, 1:89-104.

Páez, D.; Romo, I.; San Juan, C. \& Vergara, A., 1992. Actitudes, representaciones sociales y prevención en el caso del sida. Papeles del Psicólogo, 3:29-34.

Petracci, M., 1995. Feliz posteridad. Cuatro estudios de opinión pública sobre Sida. Buenos Aires: Letra Buena.

Pierret, J., 1985. Constructions sociales du discours sur la maladie. Prévenir, 11.

Sontag, S., 1977. Illness as metaphor. Nueva York: Farrar, Straus \& Giroux. 


\section{REPRESENTACIONES SOCIALES DE MADRES, MÉDICOS PEDIATRAS Y ENFERMERAS SOBRE EL NIÑO PREESCOLAR Y SU SALUD: UN ESTUDIO DE CASO}

Milagros C. García Cardona*

\section{INTRODUCCIÓN}

Durante los últimos veinte años aproximadamente, Venezuela ha visto transformar su sistema de salud pública, encontrándose que ha habido un aumento en la disponibilidad de infraestructura asistencial. Pero a pesar de tales cambios, lo que ha significado un aumento en la cobertura de atención de salud, los servicios no son utilizados en la medida de lo deseable (MSAS, 1989). Además, desde el punto de vista de los administradores y planificadores de la salud, la accesibilidad al sistema de atención también ha sido considerada un indicador del nivel de salud de las comunidades; accesibilidad que puede ser económica, geográfica o cultural, entre otras.

Para los efectos de la presente investigación abordamos una dimensión de la accesibilidad cultural (Climent, 1988), que condiciona la aceptación de la oferta de atención de salud por parte de la población, estudiando esa accesibilidad cultural a través de lo que la gente dice y hace acerca de su salud, como una forma de conocer cómo piensan y actúan determinados grupos sociales frente a la realidad cotidiana. Partimos del estudio de las representaciones sociales y la salud como elaboraciones socialmente compartidas, asumiendo el concepto de representaciones como una forma de pensary actuar acerca de objetos y hechos reales que ocurren en la vida cotidiana de individuos y grupos (Jodelet, 1986). Para ello se caracterizan las representaciones sociales de un grupo de madres en relación con sus hijos en edad preescolar y en cuanto a su salud tanto física como mental.
Caracterizamos, asimismo, las representaciones sociales de médicos pediatras y enfermeras que atienden consultas de higiene preescolar en un ambulatorio urbano tipo III ("La Carucieña"), de la ciudad de Barquisimeto, estado Lara, Venezuela.

Este ambulatorio, y más específicamente el Programa de Atención al Niño Sano Preescolar, es considerado aquí como un estudio de caso (Glasser y Strauss, 1967), en donde intervienen diferentes actores: las madres usuarias del programa, los médicos que atienden esas madres y las enfermeras que participan de esa atención de salud. Nos apoyamos en las premisas del muestreo teórico como estrategia de recolección de datos, según lo propuesto por Glasser y Strauss, explorando el conjunto de creencias y juicios de valor de madres, pediatras y enfermeras sobre la salud del niño preescolar. Estudiamos además el contexto donde se generan y estructuran las representaciones sociales que acerca del niño preescolar tienen los grupos mencionados, utilizando como referencia la metodología de análisis de contexto de Spink (1994).

Se realizaron entrevistas a profundidad, semiestructuradas, a 10 madres, 2 médicos pediatras y 2 enfermeras comunitarias. Las entrevistas fueron acompañadas del análisis de materiales elaborados por el Ministerio de Sanidad y Asistencia Social (MSAS), la Organización Panamericana de la Salud y la Organización Mundial de la Salud acerca de la atención al niño entre 2 y 6 años (MSAS, 1994). Adicionalmente, se revisaron algunos materiales científicos utilizados por los médicos pediatras acerca del desarrollo infantil.

Socióloga, MSc. en salud pública y MSc. en ciencias sociales. Profesora de la Sección de Ciencias Sociales, Departamento de Medicina Preventiva y Social, Decanato de Medicina, Universidad Centrooccidental Lisandro Alvarado, Barquisimeto, estado Lara, Venezuela. 
El análisis de las entrevistas se realizó utilizando la técnica propuesta por Steinar (1995). Este se llevó a cabo en cuatro fases muy interrelacionadas entre sí y de la siguiente manera: 1 . Se transcribieron las entrevistas, poniendo el énfasis en la situación dialógica creada por la secuencia de preguntas y respuestas y de la funcionalidad del espacio de la entrevista; 2. Seguidamente se elaboraron mapas de asociación. Para ello se requirió pasar todas las entrevistas a columnas (siete en total), las cuales fueron definidas por unidades de sentido.

Las columnas contienen: la Definición, restringida al objeto de asociación: la salud del niño como concepto amplio, y el crecimiento y desarrollo como elementos específicos de esa salud. Las Características, Quién define y Quién promueve comprenden las asociaciones inmediatas o secundarias y la clasificación de las asociaciones, características de la salud, del crecimiento y desarrollo, formas de verificación del crecimiento y desarrollo del niño por parte de la madre. Las Explicaciones, usada para incluir las explicaciones en que la madre abunda cuando quiere ampliar algún concepto. La de Otros, usada para clasificar los contenidos afectivos. $\mathbb{E} 1$ Vínculo, recoge las imágenes, opiniones y experiencias concretas del vínculo con los médicos y enfermeras en sentido estricto y con el ambulatorio en sentido amplio; 3. Posterior a la elaboración de los mapas se realizó un análisis de todas las asociaciones de contenido que compartían las madres, por un lado, y los médicos y enfermeras por otro; 4. Del análisis de los mapas de manera individual se elaboraron luego gráficos de asociaciones, escogiéndose tres de las unidades de sentido contenidas en los mapas, por ser las más inclusivas y relevantes en términos de los objetivos de la investigación: Definición, Quién promueve y $\mathrm{E} 1$ Vínculo. Las otras columnas sirvieron para completar algunos aspectos del análisis del discurso, pero no fueron incorporadas en su totalidad en los gráficos.

\section{QUIÉN PIENSA QUÉ: MAPAS DE ASOCIACIÓN}

\section{A PARTIR DE LAS ENTREVISTAS}

Del estudio de la representación social del niño preescolar y su salud se elaboraron gráficos que puntualizan las relaciones entre elementos cognitivos, las prácticas y las posturas afectivas presentes en el discurso de las madres como informantes principales, y de los médicos y enfermeras como informantes secundarios o de contexto. Abordamos el ámbito de las interacciones cara-a-cara, o territorio del tiempo corto, que es donde se genera la producción de sentido, a través del discurso de los grupos estudiados, haciendo algunas referencias al tiempo vivido o territorio de la socialización para lo cual se introducen citas del discurso de las madres, pediatras y enfermeras. Por último, se aborda el tiempo largo de manera tangencial.

El Gráfico $N^{\circ} 1$ corresponde a las definiciones de salud, crecimiento y desarrollo del grupo de madres entrevistadas. El mismo está centrado en los tres conceptos antes mencionados, mostrando que los conceptos de crecimiento y desarrollo aparecen por un lado como iguales para algunas madres, o significando lo mismo, y por el otro, con significados parecidos para otro grupo de madres. Esta ambigüedad muestra los límites poco definidos de ambos conceptos en la representación de las madres.

Cuando el crecimiento se equipara a desarrollo, éste es circunscrito al tamaño y el peso del niño, asociando su estancamiento o disminución, en términos de medidas, a la presencia de enfermedad en el niño. Cuando el crecimiento se diferencia del desarrollo, este último toma una dimensión independiente relativa y aparece como un concepto más globalizante, discriminando entre el desarrollo físico, y allí se vincula con el crecimiento, y el desarrollo mental, con énfasis en la formación familiar. Aparece también una representación del desarrollo como crecimiento a cierta edad, asociada a la maduración, cambio de forma y voz, diferenciada en hembras y varones.

La salud aparece asociada al crecimiento. Tener salud es crecer, y como consecuencia directa, tener salud es no estar enfermo. Esta primera asociación se complejiza en las asociaciones sucesivas de no estar enfermo, incluyendo allí aspectos afectivos, como no estar triste, alimentación y términos que provienen del discurso médico, tales como "tener la hemoglobina normal y las vacunas". Una de las madres señala: "para mí, estar sano es que ellos tengan 
su hemoglobina normal, que no los vea tristes, con malestar, cuando uno los ve así es que algo les pasa. También es importante una buena alimentación, si un niño no tiene buena alimentación no crece, es un niño deficiente".

Las asociaciones secundarias combinan desarrollo y crecimiento con salud, derivando en desarrollo sano y crecimiento sano. Crecimiento sano vuelve sobre la asociación de salud pero agrega el elemento de la atención materna, requisito básico para crecer sano.
Como las representaciones sociales son estructuras cognitivo-afectivas, al asociarse salud con crecimiento y desarrollo la madre incorpora su práctica como madre, sus principios, valores, estructurando una noción amplia e integral del concepto. Una de las madres dice al respecto: “¿Qué haces tú para que Wilmer se desarrolle y crezca?, atenderlo bien en sus cosas, darle su comida, atenderlo cuando está enfermo y darle cariño para que se sienta animado, así. Yo le doy cariño ayudándolo a crecer, que no se sienta triste, conversar con él, jugar con él,

Gráfico 1. Definición DE SALUD y CRECimiento y

DESARROLLO: LAS MADRES

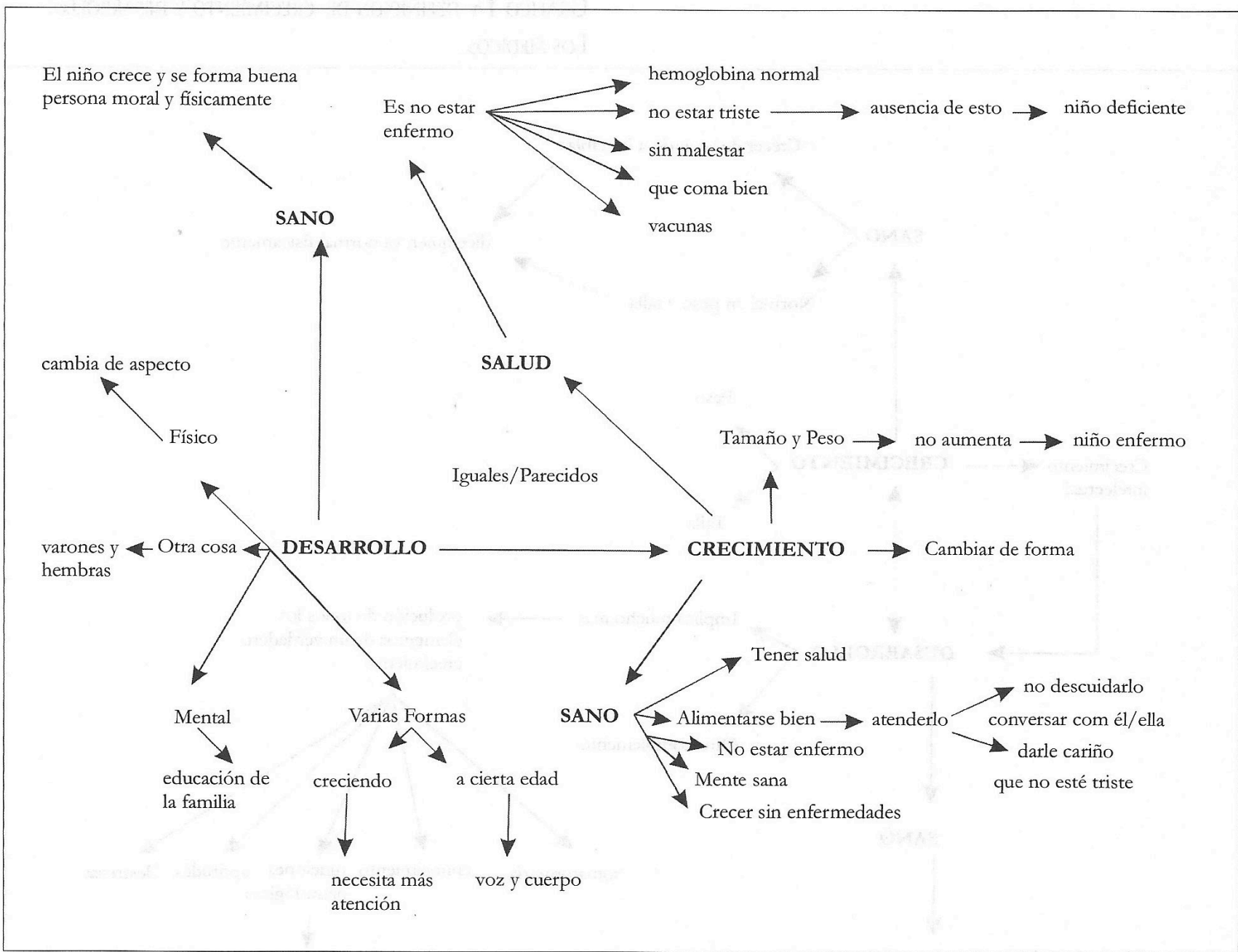


las cosas que uno hace pequeño, ayudarlo para que ese desarrollo vaya creciendo".

Resaltan aspectos como la comunicación con el niño y el cariño. A su vez, el desarrollo sano resulta el concepto más globalizante de todo el gráfico, lo que refleja a su vez el discurso de las madres: desarrollo sano es crecer y formarse buena persona moral y físicamente.

En el caso de los médicos pediatras y enfermeras (gráficos 1ay 1b) respectivamente, para los primeros, el crecimiento se circunscribe exclusivamente a la talla y el peso, de acuerdo a estándares preestablecidos. El establecimiento de escalas de peso y talla desde los años ochenta, marca la práctica médica, imprimiéndole a estos conceptos una cstandarización.
Las enfermeras incorporan una dimensión del crecimiento como proceso, vinculando el desarrollo como una derivación de éste. Aquí se encuentra una similitud con las madres, que equiparan crecimiento con desarrollo. Las enfermeras incluyen los factores condicionantes del crecimiento como parte de la definición, en lo cual coinciden con las madres, sólo que estas últimas no los señalan como factores, son parte intrínseca del concepto.

Gráfico 1A DEFINICION DE CRECIMIENTO Y DESARROLLO:

LOS MEDICOS

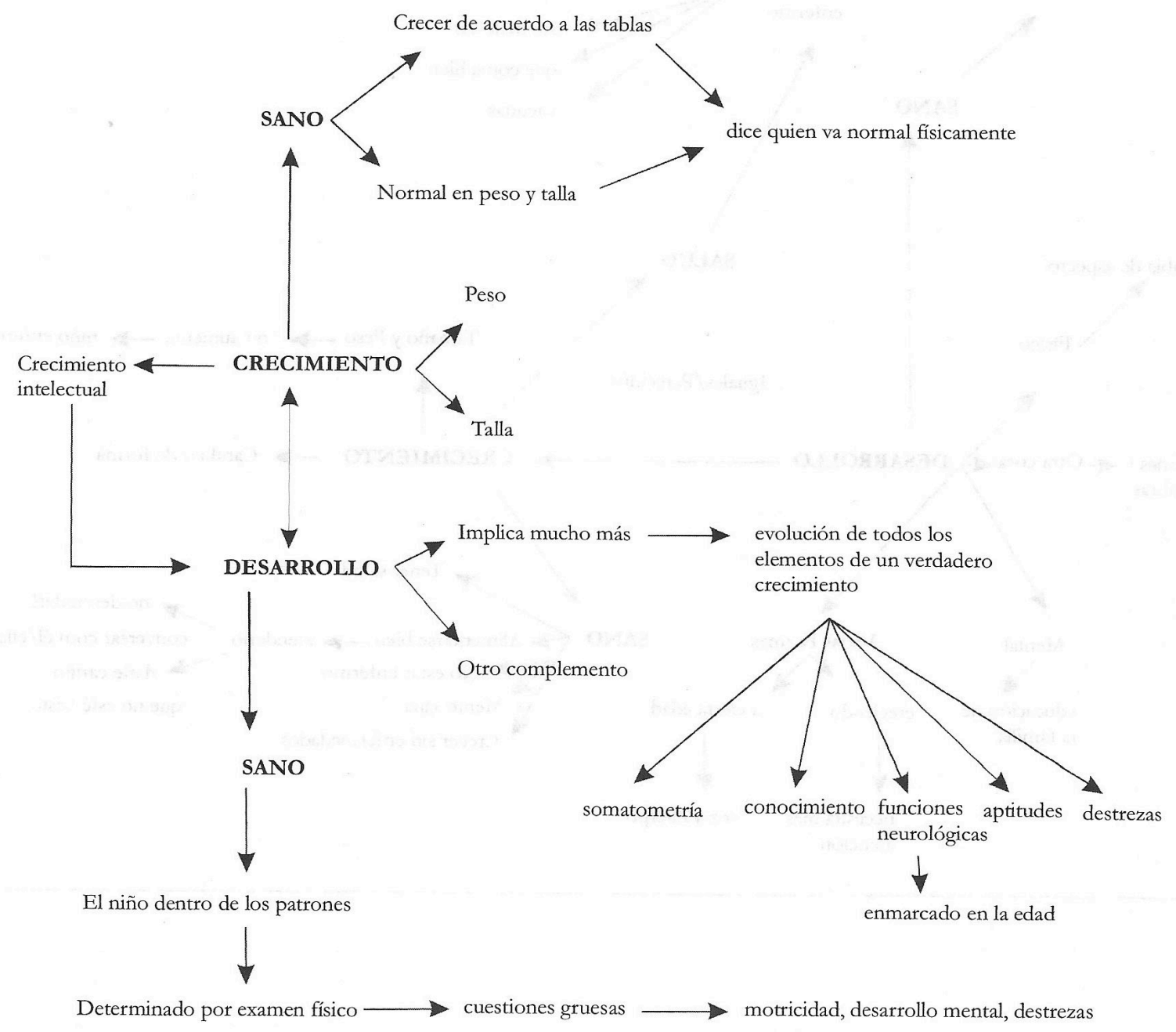




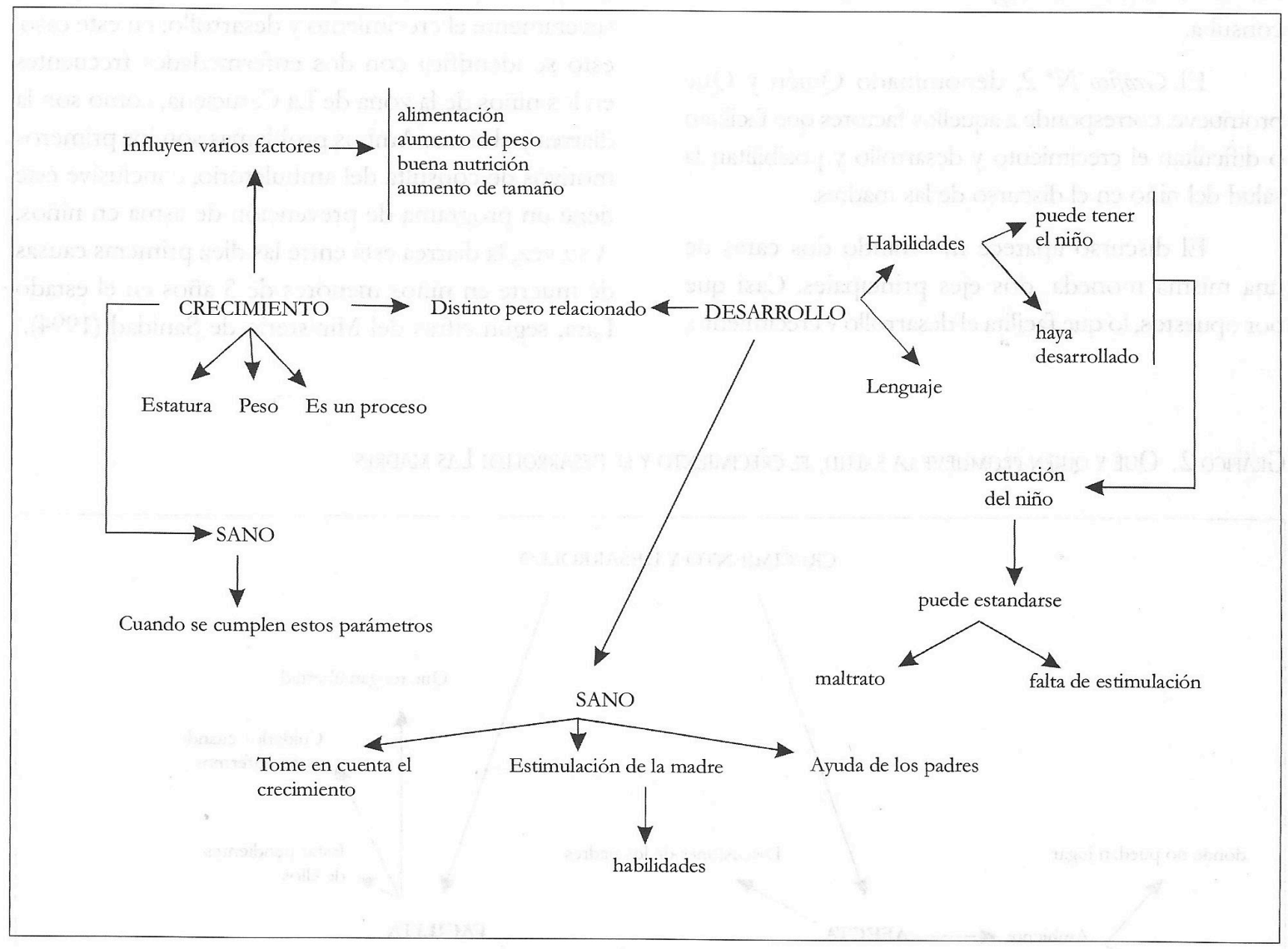

Para los médicos, el concepto de crecimiento está separado de los elementos afectivos, los cuales aparecen en el discurso de manera indiferenciada y probablemente mezcladas con lo ambiental, enfatizando en el peso y la talla. Esto se corresponde con la definición de la medicina acerca del crecimiento: "es el crecimiento de la masa corporal a través de los procesos de hiperplasia e hipertrofia, está íntimamente vinculado a la maduración expresada en la desaparición de funciones o condiciones que nos permiten adaptarnos al medio interno o externo y dar respuestas peculiares a los diferentes estímulos. El crecimiento y desarrollo están programados genéticamente y su mayor o menor expresión o calidad del mismo dependerán de los diferentes factores ambientales que sobre él interactúen" (Herrera, 1996:3).

En cuanto al desarrollo, los médicos lo asocian o bien como un concepto más globalizador, que incluye el crecimiento, o como complemento del crecimiento, aceptando que el desarrollo incluye aspectos físicos, cognitivos y de habilidades. No aparece ninguna asociación con los elementos afectivos vinculados al desarrollo.

Las enfermeras, por su parte, lo asocian con habilidades y lenguaje, con una fuerte influencia del discurso de la psicología del desarrollo, centrado en la adquisición progresiva de habilidades y destrezas observables de acuerdo a la actuación del niño. Incorporan además, un concepto propio de su función asistencial, como lo es la estimulación.

Otra asociación que resalta es el maltrato al niño como elemento perjudicial al desarrollo. Ellas parecen haber incorporado una representación del desarrollo sano y sus límites, muy permeada por su práctica clínica y social en el Ambulatorio de la Carucieña donde se presentan muchos casos de 
maltrato. Aparece como un elemento que se vincula con lo afectivo en el diagnóstico del niño sano en la consulta.

El Gráfico No 2, denominado Quién y Qué promueve, corresponde a aquellos factores que facilitan o dificultan el crecimiento y desarrollo y posibilitan la salud del niño en el discurso de las madres.

El discurso aparece mostrando dos caras de una misma moneda, dos ejes principales. Casi que por opuestos, lo que facilita el desarrollo y crecimiento, cuando no está presente puede limitarlo. La primera asociación que surge es que enfermarse mucho afecta severamente el crecimiento y desarrollo; en este caso, esto se identifica con dos enfermedades frecuentes en los niños de la zona de La Carucieña, como son la diarrea y el asma. Ambos problemas son los primeros motivos de consulta del ambulatorio, e inclusive éste tiene un programa de prevención de asma en niños. A su vez, la diarrea está entre las diez primeras causas de muerte en niños menores de 5 años en el estado Lara, según cifras del Ministerio de Sanidad (1994).

Gráfico 2. Qué y QuIÉN PROMUEVE LA SALUd, EL CRECIMIENTO y el DESARROLLO: LAS MADRES

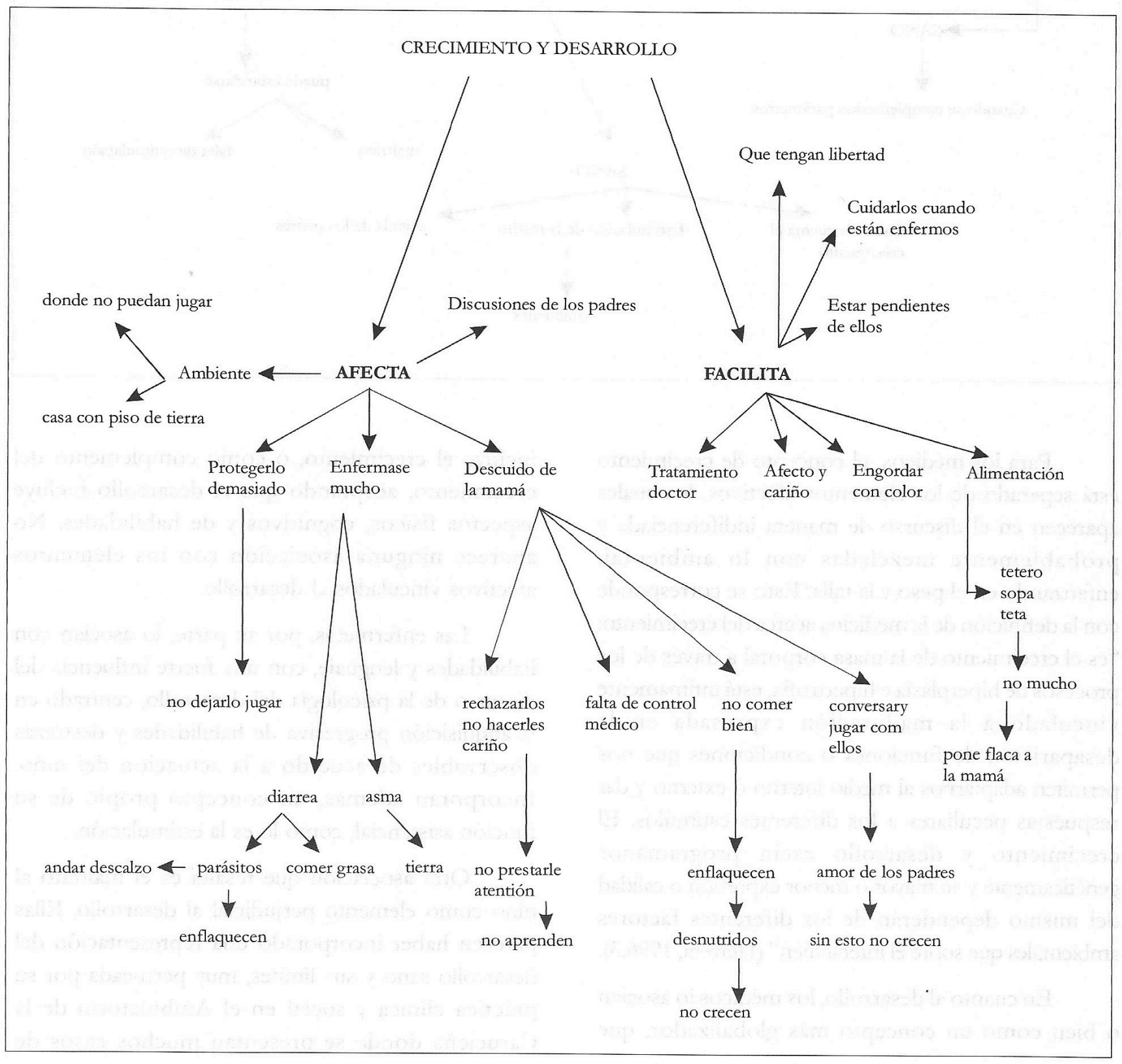


Las diarreas y los parásitos aparecen fuertemente asociados al enflaquecimiento del niño, limitando su crecimiento.

Una segunda asociación que se repite es la idea de que el crecimiento y el desarrollo se pueden afectar por el descuido de la madre. Esta idea del descuido tiene una carga afectiva importante, revelándose valores acerca de lo que debe ser una madre y de las acciones que se espera que ella despliegue para garantizar la salud del niño.

Una idea fuerte que aparece en la mayoría de los discursos es el temor a la desnutrición, reseñada como situación terrible y asociada a la creencia de que estar flaco es algo malo. Una madre refiere: "si el niño no se alimenta bien, es un niño desnutrido, eso debe ser terrible tener un niño desnutrido, por todas las enfermedades que puede adquirir, por todos los problemas en su desarrollo". No comer bien es la causa básica de ese proceso.

Como asociaciones secundarias aparecen: protegerlo demasiado, las peleas de los padres y el ambiente como factores que pueden predisponerlos a que sufran enfermedades o desequilibrios emocionales. Como contraparte, tratarse con el doctor, brindar afecto, engordar y alimentarse, estar pendiente de ellos, cuidarlos cuando están enfermos y ofrecerles un ambiente de libertad, recoge todo lo positivo de los condicionantes del crecimiento y desarrollo.

Es importante señalar que en ambos ejes aparece el contacto con el médico como predisponente o facilitador del crecimiento del niño. Esto parece indicar que las madres reconocen todavía en la atención médica, en la vigilancia del médico, un factor de seguridad en el desarrollo de sus hijos.

En el Gráfico $N^{\circ} 2 a$, los médicos asocian el crecimiento sano y los factores que lo afectan a las enfermedades más frecuentes en los niños preescolares, clasificándolas como respiratorias, gastrointestinales y desnutrición. Coinciden en esta asociación con las madres, donde aparece la preocupación porque el crecimiento se afecta cuando sus hijos se enferman mucho. La coincidencia se da precisamente porque el asma y la diarrea están entre los primeros motivos de consulta en el ambulatorio, apareciendo como primera asociación en ambos grupos.
Como factores básicos que limitan el crecimiento aparecen asociadas la alimentación y las malas condiciones de vida. A pesar de que la alimentación deficiente es una consecuencia de las malas condiciones de vida, en la representación del médico, se asocia las condiciones de vida estrictamente con lo físico ambiental y sanitario. La alimentación vista como factor clave del desarrollo no aparece vinculada en el discurso sobre la desnutrición, como es el caso de las madres. Ella aparece como enfermedad sin vinculación aparente con las condiciones de vida.

Por último, es importante señalar que el discurso de los médicos se centra en los factores negativos o limitantes del crecimiento, manteniéndose, en contraposición a las madres, en el eje de los factores que lo restringen, muy influenciados por el enfoque médico orientado hacia la enfermedad.

En el Gráfico $N^{o} 2 b$ aparecen las asociaciones resultantes del discurso de las enfermeras. Los ejes de la argumentación están en cómo el crecimiento por un lado y el desarrollo por el otro, pueden ser afectados, muy vinculado con los conceptos que manejan las enfermeras sobre ambos aspectos. Las asociaciones, al igual que los médicos, se vinculan más con los factores limitantes del normal desarrollo del niño.

En cuanto al crecimiento, toma relevancia la alimentación, separándola de la nutrición, lo que impresiona como asociaciones diferenciadas aunque no aparecen otras ideas vinculadas. Tamaño y peso se mantienen en el discurso como indicadores de crecimiento, sobre todo las disminuciones y aumentos anormales, según lo estatuyen las pautas establecidas en la literatura (p.e. Alvarez, 1988; Herrera, 1996; MSAS, 1994).

Respecto al desarrollo, retoman las asociaciones derivadas del concepto con relación a la falta de estimulación, el lenguaje como capacidad de comprensión del mundo exterior y el maltrato como anomalía social que conlleva a la desatención del niño. La asociación al ambiente coincide con los médicos, al relacionarlo con el enfoque ecológico condicionante para la aparición de enfermedades. Lo ambiental es visto como saneamiento o más aún, como ausencia de saneamiento adecuado. 
Gráfico 2A. QUE y QUIEN PROMUEVE: LoS MEDICOS

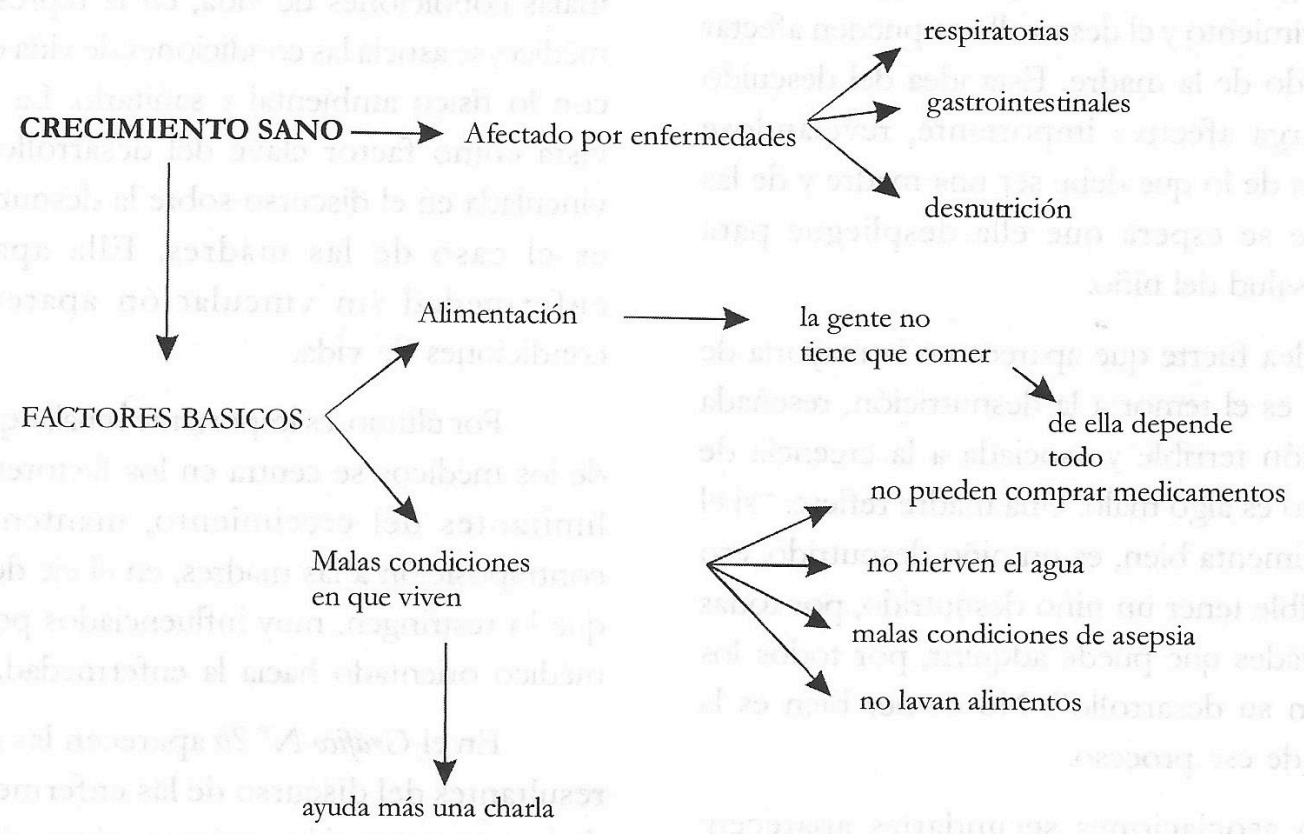

GRÁFICO 2.B QUÉ Y QUIÉN PROMUEVE: LAS ENFERMERAS

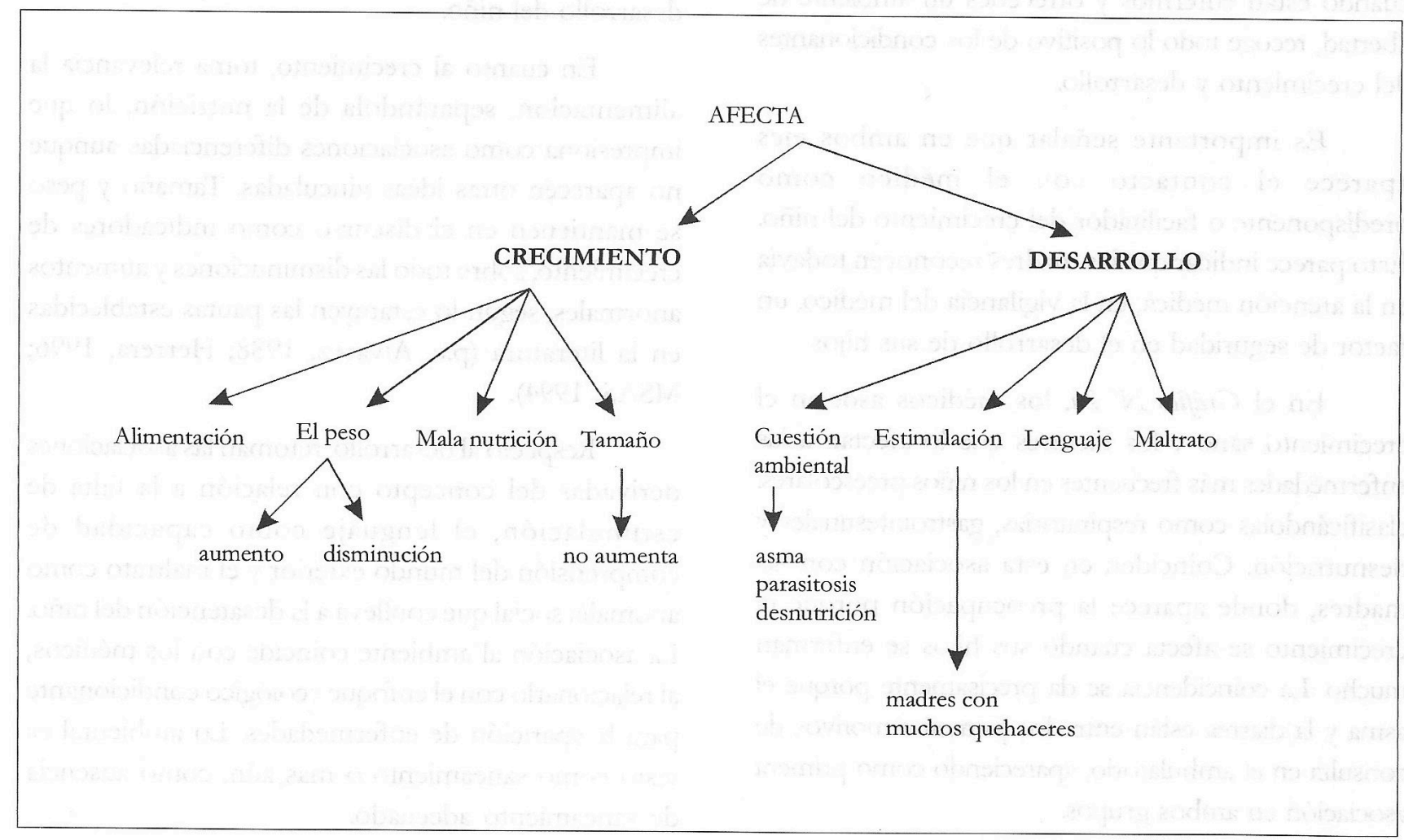


La asociación condiciones de vida, desarrollo y crecimiento es más fuerte y explícita entre los médicos y enfermeras que en el discurso de las madres, lo que hace suponer una dimensión sociológica permeando el discurso médico, no clínico, en contraposición a una dimensión de naturalcza psicosocial de las representaciones de las madres.

La constante del tema de maltrato parece estar indicando fuertes asociaciones entre desarrollo y determinadas condiciones sociales que se dan en el contexto de vida de los pacientes que llegan a la consulta del ambulatorio.
El Gráfico $N^{\circ} 3$, denominado el Vínculo, es una síntesis del discurso de las madres acerca del tipo de relaciones establecidas con los médicos de la consulta de niño sano, las enfermeras y el ambulatorio. El gráfico muestra como aparecen cuatro ejes del discurso.

En el primer eje el centro de las asociaciones es la figura del médico, entendido como un genérico que resume a los médicos que han atendido a su o sus hijos en la consulta de niño sano. Las asociaciones sucesivas reportan una constante que se da en el discurso popular sobre la dificultad para entender las explicaciones que da el médico cuando la madre le solicita alguna aclaratoria sobre algún aspecto de la salud de su hijo.

\section{Gráfico 3. El vínculo. LAS MAdRES}

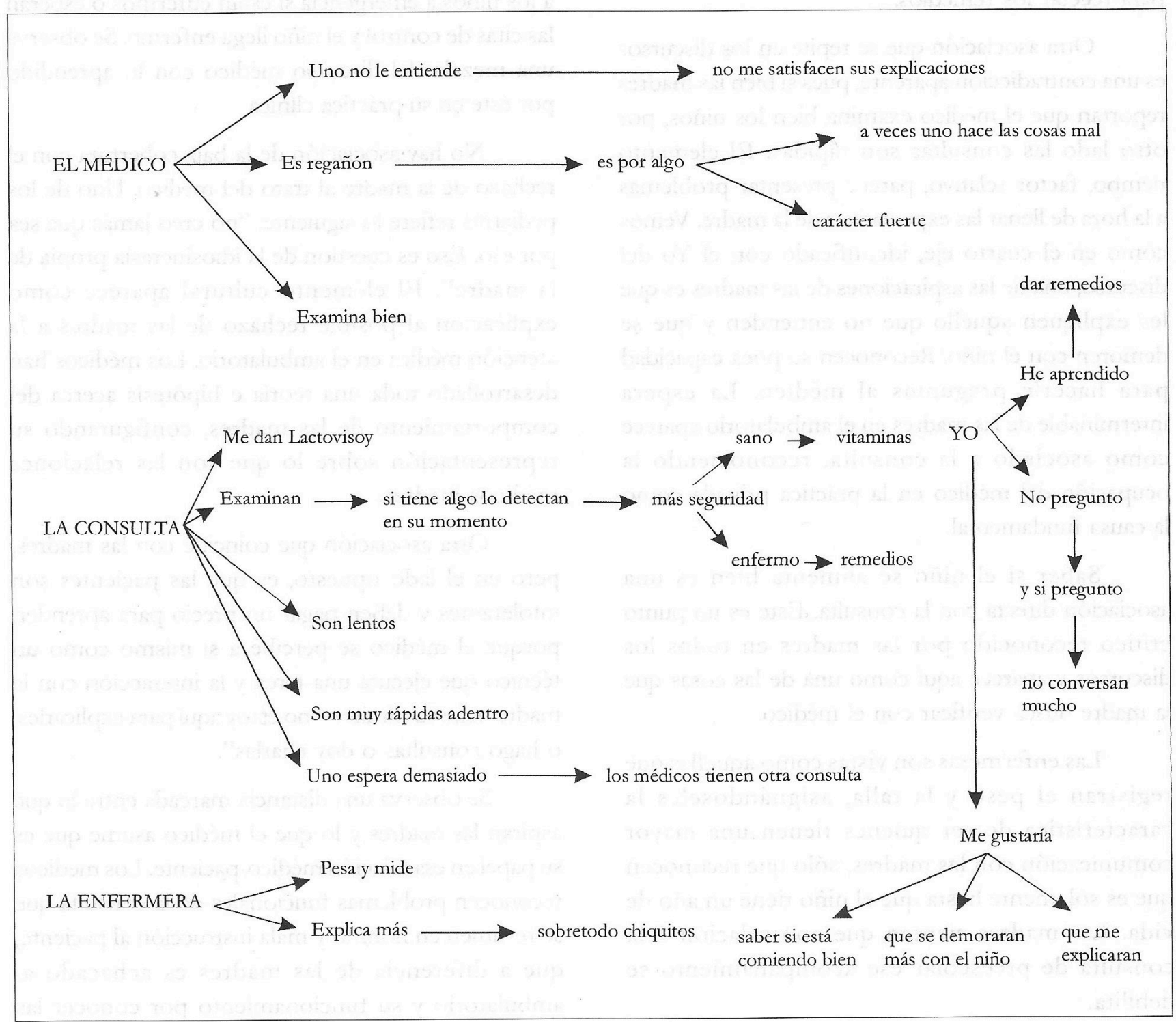


Otra asociación muestra al médico como una persona "regañona", atribuyéndole esa actitud a fallas de la madre, que no obedece lo recomendado por el médico, agregándose a ello características de personalidad del médico que parecen ser aceptadas por algunas de las madres: "Es mejor que sea regañón, así uno no está jugando la pelota con ellos y hace lo que él manda". El médico es visto como competente en términos de que para las madres un médico que examina bien al niño es buen médico. Esta asociación se repite a lo largo de los discursos de las 10 madres entrevistadas.

El segundo eje, la consulta, retoma la idea de la importancia del examen médico como fuente de seguridad, pues si el niño está sano siempre se obtiene alguna recomendación como es el caso de las vitaminas y si está enfermo el médico es el indicado para recetar los remedios.

Otra asociación que se repite en los discursos es una contradicción aparente, pues si bien las madres reportan que el médico examina bien los niños, por otro lado las consultas son rápidas. El elemento tiempo, factor relativo, parece presentar problemas a la hora de llenar las expectativas de la madre. Vemos como en el cuarto eje, identificado con el Yo del discurso, una de las aspiraciones de las madres es que les expliquen aquello que no entienden y que se demoren con el niño. Reconocen su poca capacidad para hacerle preguntas al médico. La espera interminable de las madres en el ambulatorio aparece como asociado a la consulta, reconociendo la ocupación del médico en la práctica privada como la causa fundamental.

Saber si el niño se alimenta bien es una asociación directa con la consulta. Este es un punto crítico reconocido por las madres en todos los discursos y aparece aquí como una de las cosas que la madre busca verificar con el médico.

Las enfermeras son vistas como aquellas que registran el peso y la talla, asignándoseles la característica de ser quienes tienen una mayor comunicación con las madres, sólo que reconocen que es solamente hasta que el niño tiene un año de vida. Las madres sienten que con relación a la consulta de preescolar ese acompañamiento se debilita.
El Gráfico $N^{o} 3 a$, del vínculo, está referido a las asociaciones del discurso médico sobre su relación con las madres-niños en la consulta de niño sano. El gráfico muestra dos ejes: un eje referido a la cobertura de la consulta, centrado en aspectos de funcionamiento del ambulatorio, y un eje de la consulta, en el que aparece la madre como un elemento dentro de ella.

Con relación a la cobertura, la primera asociación que aparece es la madre. El médico señala que es ella la que abandona el control del hijo cuando deja de ser lactante. Clasifica a éstas, por tanto, en dos grupos. Las madres de lactantes, según el discurso del médico, llevan más a los niños pues se enferman más, cosa que el médico comparte a medias con las madres. En contraposición, las madres de niños preescolares, que a su vez son más resistentes, llevan a los niños a emergencia si están enfermos o esperan las citas de control y el niño llega enfermo. Se observa una mezcla del discurso médico con lo aprendido por éste en su práctica clínica

No hay asociación de la baja cobertura con el rechazo de la madre al trato del médico. Uno de los pediatras refiere lo siguiente: "no creo jamás que sea por eso. Eso es cuestión de la idiosincrasia propia de la madre". El elemento cultural aparece como explicación al posible rechazo de las madres a la atención médica en el ambulatorio. Los médicos han desarrollado toda una teoría e hipótesis acerca del comportamiento de las madres, configurando su representación sobre lo que son las relaciones médicos-madres.

Otra asociación que coincide con las madres, pero en el lado opuesto, es que las pacientes son intolerantes y deben pagar un precio para aprender, porque el médico se percibe a sí mismo como un técnico que ejecuta una tarea y la interacción con la madre tiene sus límites: "no estoy aquí para explicarles, o hago consultas o doy charlas".

Se observa una distancia marcada entre lo que aspiran las madres y lo que el médico asume que es su papel en esa relación médico-paciente. Los médicos reconocen problemas funcionales de la consulta que se resumen en horario y mala instrucción al paciente, que a diferencia de las madres es achacado al ambulatorio y su funcionamiento por conocer las 
Gráficos 3A .el VINCULO: Los MÉdICOS

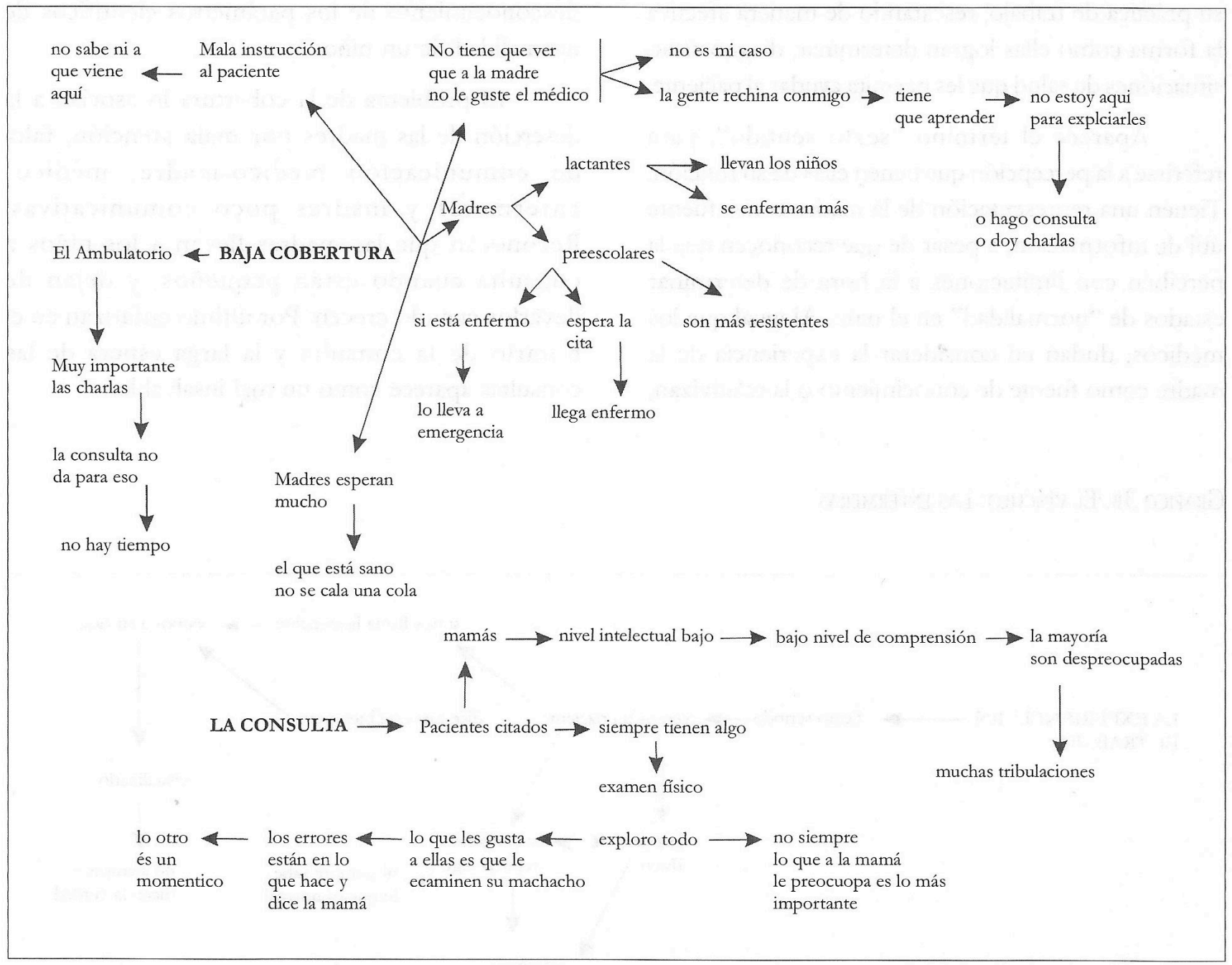

causas "ocultas", que a las madres se les presentan como simple ausencia del doctor por ocupaciones fuera del ambulatorio. Esto parece señalar una falta total de información al paciente sobre el porqué funciona la consulta de la manera como lo hace.

Existe una asociación de prevención y actividades educativas. Los médicos reconocen el papel fundamental de las actividades educativas que realiza el ambulatorio, aunque descartan su participación en ellas, debido a la falta de tiempo. Esto es reforzado por el tipo de tareas asignadas por el programa al médico y la enfermera, profundizando el abordaje biologicista de la atención al paciente.

En el eje de la consulta, no aparece ninguna asociación con los horarios y el tiempo dedicado a los pacientes, a pesar de que las madres señalan como problemáticos esos aspectos. El énfasis se centra en el examen físico y exploración del niño, resaltando la duda por parte del médico acerca de que la madre maneje adecuadamente criterios de normalidad, por lo que la información proveniente de la madre es un insumo aparentemente cuestionado dentro de la rutina de diagnóstico.

Las madres aparecen en el discurso como personas con una baja capacidad de comprensión, lo que se corresponde quizá con el desinterés manifestado por las madres por parte del médico en explicarles y comunicarse con ellas. Habría que profundizar un poco en esta asociación de la despreocupación de las madres pues probablemente se refiera más a la desatención de las medidas sanitarias o a determinados tratamientos, lo que estaría ubicado a cierta distancia de la concepción de atención que manifestaron las madres.

El Gráfico $N^{0} 3 b$ corresponde a las asociaciones de las enfermeras al referirse al vínculo con las 
pacientes. El discurso de las enfermeras se centra en su práctica de trabajo, rescatando de manera afectiva la forma como ellas logran determinar, diagnosticar, situaciones de salud que les permita ayudar al paciente.

Aparece el término "sexto sentido", para referirse a la percepción que tienen ellas de su función. Tienen una representación de la madre como fuente útil de información, a pesar de que reconocen que la perciben con limitaciones a la hora de determinar estados de "normalidad" en el niño. Al igual que los médicos, dudan en considerar la experiencia de la madre como fuente de conocimiento o la relativizan, al asociar no saber lo que es normal al desconocimiento de los parámetros científicos de normalidad de un niño.

El problema de la cobertura lo asocian a la deserción de las madres por mala atención, falta de comunicación médico-madre, médicoenfermeras y madres poco comunicativas. Reconocen que las madres llevan a los niños a consulta cuando están pequeños, y dejan de llevarlos cuando crecen. Por último enfatizan en el horario de la consulta y la larga espera de las consultas aparece como un mal insalvable.

GrÁFico 3B. El VÍNCULO: LAS ENFERMERAS

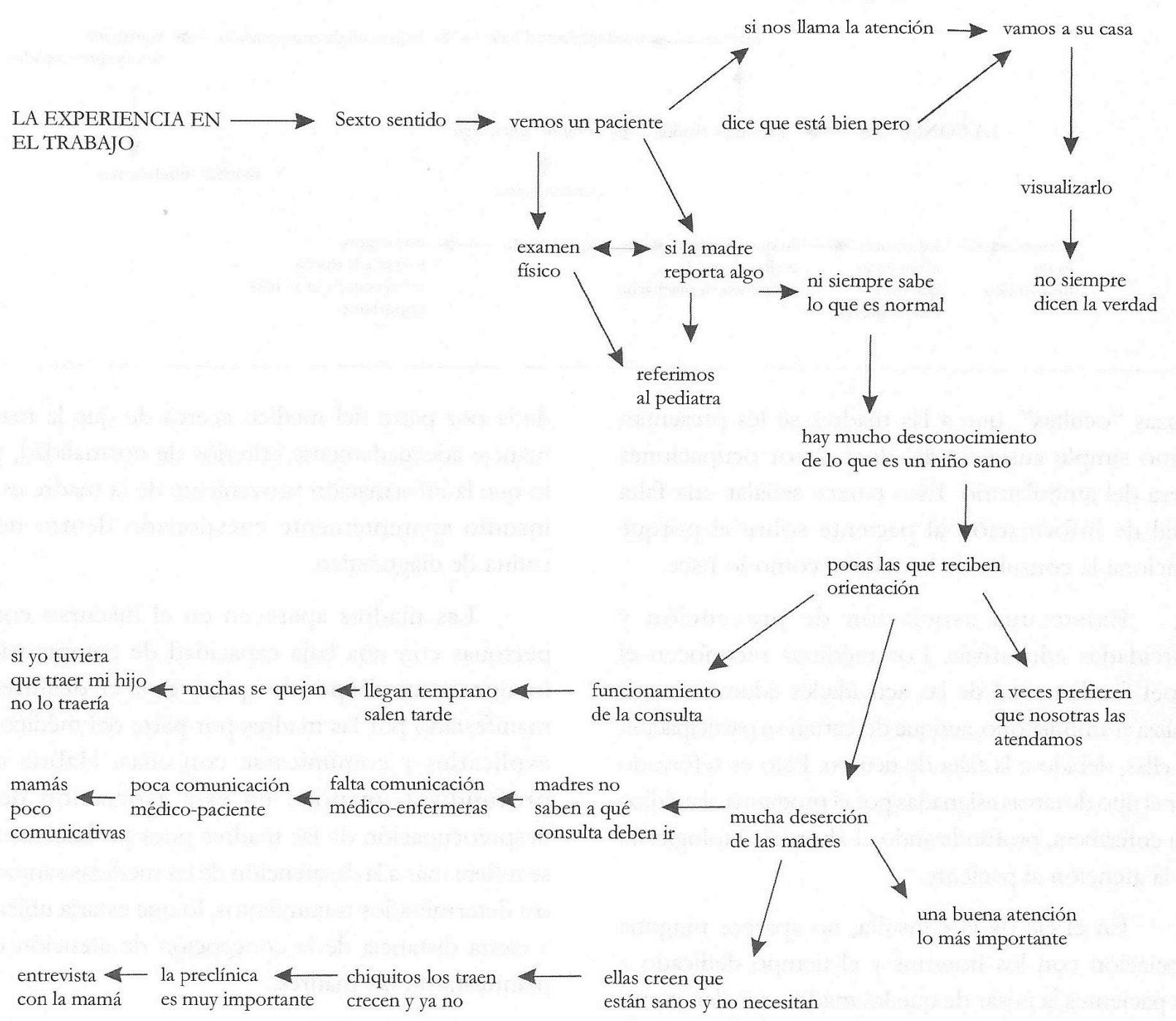




\section{CONCLUSIONES}

1. El análisis del discurso a través de la asociación de ideas evidencia que las madres expresan una representación de la salud del niño preescolar con las siguientes características: a) Está restringida a la ausencia de enfermedad, aunque a través de una reasociación con el término "ausencia de enfermedad" se descubre que se da una ampliación de la representación de la salud, vinculándola con elementos afectivos, la alimentación como factor clave en la salud e incorporando indicadores de salud provenientes del discurso médico, como la hemoglobina normal y la protección por vacunas; b) El crecimiento y el desarrollo aparecen como conceptos vinculados, sin embargo, algunas de las madres separan el crecimiento del desarrollo, ampliándose éste e incorporando toda una dimensión afectiva de la madre, valorizando principalmente el papel de la atención materna en ese proceso; c) Identifican las enfermedades -asma, diarreas, parásitos y desnutrición- y la ausencia de los cuidados de la madre como factores condicionantes de la salud, el crecimiento y el desarrollo. La primera aparece llena de imprecisiones, falta de información, con incorporación de creencias familiares y grupales. La mayoría de las madres no tiene una explicación clara de la causalidad de las enfermedades. Este hecho puede estar condicionando una débil atención y seguimiento por parte de las madres a los niños cuando están sanos.

2. El elemento afectivo del desarrollo, entendido como el cariño y la atención al niño, constituye una constante en la representación de las madres. Este elemento aparece de manera marginal en la representación de las enfermeras y está ausente en la representación de los médicos. Esto puede tener implicaciones prácticas importantes con relación a la atención de salud al niño sano, no existiendo una coincidencia entre los énfasis que establece la madre para seguir el crecimiento y desarrollo de su hijo y los que establece el programa de atención al niño sano preescolar.

3. La alimentación aparece de manera persistente vinculándola con las posibilidades de tener salud y crecer. Las madres reportan recibir escasa o nula información-orientación sobre alimentación. Esto parece ser una consecuencia directa del énfasis puesto por el discurso médico en el seguimiento a los aspectos físicos del crecimiento y desarrollo, por lo que la consulta de niño sano parece estar abordando débilmente lo que tiene que ver con los conceptos y rutinas alimentarias que las madres siguen con sus hijos.

4. En la representación de las madres, el médico aparece como una figura contradictoria. Por un lado es considerado una guía para orientar a la madre; por el otro, es señalado como alguien con poca capacidad de comunicación y de mal carácter. Esta representación parece evidenciar contradicciones en la relación médico-paciente, lo que puede influir en la aceptabilidad de la atención médica, sobre todo la preventiva. El ambulatorio y las consultas de niño sano están referidos a imágenes como demora, largas colas y consultas apuradas, significando una experiencia perturbadora para todas las madres. El desconocimiento aparente de las madres acerca de las causas de todo este proceso, puede estar condicionando fuertemente la asistencia de un número mayor de madres a las consultas. Ellas transmiten su insatisfacción a otras madres, convirticndo el servicio en una realidad rechazada por todas.

5. Los médicos enfatizan en los aspectos físicos del crecimiento y desarrollo, el aumento de peso y talla como indicadores de crecimiento normal, muy vinculado a patrones preestablecidos. La dimensión afectiva del desarrollo no aparece como elemento relevante en el contenido del discurso del médico. Este hecho pudiera estar indicando que el médico ha integrado poco a su conocimiento médico aquellos elementos que provienen de la experiencia con la madre, sobre todo porque vemos que para ella la dimensión afectiva tiene principal relevancia.

6. En la representación del médico sobre su papel en la relación con las madres, éste no se reconoce como un educador permanente, aunque valora el papel del ambulatorio en la educación al paciente. Esta idea puede estar condicionando el que el médico no asuma como práctica rutinaria enfatizar en la comunicación y exploración del punto de vista de las madres. Ellas son vistas por el médico, en mayor medida que por las enfermeras, como entes pasivos y con baja capacidad de comprensión, y como tales, 
no son incorporadas formalmente a la rutina de la consulta, consolidando una distancia entre el médico y la madre y su desmotivación a llevar al niño a no ser cuando está enfermo.

7. El uso de los mapas y gráficos de asociación de ideas ayudaron a comprender cómo se organizan los discursos tanto del investigador como de los informantes, recogidos en un mismo instrumento, ofreciendo ventajas sobre otras técnicas de recolección y análisis de datos donde el investigador no aparece interactuando con sus informantes. Replantea, por tanto, la posición del sujeto en la cuestión del conocimiento; pasa a ser un ente activo construyendo una explicación plausible de los hechos.

\section{REFERENCIAS BIBLIOGRÁFICAS}

Alvarez, G., 1988. Compendio de puericultura y pediatría. Caracas: Ediciones de la Biblioteca de la Universidad Central de Venezuela.

Climent, G., 1988. Factores de riesgo psicosocial y atención de salud. Informe de Avance. Buenos Aires: Conicet.

Glassser, P. \& Strauss, A., 1967. The discovery of grounded theory. Strategy for qualitative research. Nueva York: Aldine.

Herrera, J., 1996. Manejo ambulatorio del paciente pediátrico. Barquisimeto: Ediciones Fundaeduco.

Jodelet, D., 1986. La representación social: fenómenos, concepto y teoría. Buenos Aires: Paidos. p. 475.

MSAS, 1989. VII Congreso de Salud Pública, Memorias. Tomo IV, Caracas: MSAS.

MSAS, 1994. Manual de atención al lactante y preescolar: normas y procedimientos. Caracas: Ministerio de Sanidad y Asistencia Social, Dirección General Sectorial de Salud, Dirección Materno-Infantil.

Spink, M.J., 1994. Desvendando as teorias implicitas: uma metodología de análise das representaçoes sociais. En: Textos en representacoes sociais (S. Jorchelovitch y P. Guareschi, orgs.). Petrópolis: Vozes.
Steinar, K., 1995. The qualitative research interview: a phenomenological and hermeneutical mode of understanding. Journal of Phenomenological Psychology, 14(2):171-195. 
VI

LOS SERVICIOS DE SALUD 


\title{
DESCENTRALIZACIÓN Y PARTICIPACIÓN EN SALUD: NUEVOS APORTES PARA LA DISCUSIÓN
}

\author{
Mario Bronfman * y Cristina Herrera Carnevale **
}

\section{INTRODUCCIÓN}

El objetivo de este trabajo es discutir algunos de los marcos conceptuales que se han propuesto alrededor del tema de la descentralización en el sector salud, para problematizar la relación que frecuentemente se postula entre esta iniciativa gubernamental y la participación de la sociedad civil en la toma de decisiones y/o en la implementación de diversos programas y servicios.

No nos proponemos elaborar un nuevo modelo conceptual sobre la descentralización. Se trata, en cambio, de problematizar las relaciones que teóricamente podrían existir entre los procesos de descentralización - en la forma en que actualmente se conciben y se realizan en América Latina-, el ideal de participación social a ellos asociado y la necesidad de alcanzar metas de eficiencia, equidad y calidad en los programas de salud.

Un marco conceptual útil para esclarecer estas relaciones debe comenzar por revisar qué se entiende por descentralización y por participación y qué relaciones posibles y probables hay entre ambos fenómenos. Las reflexiones que siguen se inspiran en los marcos conceptuales que pueden encontrarse en una amplia literatura sobre descentralización: algunos de ellos se fundamentan en estudios comparativos entre diversos casos de descentralización político-administrativa en varias partes del mundo; otros, en modelos teóricos tomados del derecho administrativo o de la administración pública; $y$, finalmente, otros dan cuenta de las tendencias generales que pueden observarse en la descentralización de los servicios de salud.
El propósito más general de este trabajo consiste en poder ubicar estas iniciativas dentro del complejo panorama de la descentralización como proceso político. Con ello pretendemos aportar elementos para un mejor entendimiento de las oportunidades de acción que la descentralización permite abrir, y de los obstáculos que algunas formas de llevarla a cabo pueden significar para una efectiva participación en favor de la salud de la población.

Como sabemos, la descentralización es una de las estrategias que la política de Reforma del Sector Salud, emprendida en muchos países, utiliza para alcanzar metas en estado de salud, eficiencia, equidad y calidad. Es importante entonces conocer las formas en que esta estrategia - como fenómeno básicamente político- se está llevando a cabo, por las implicaciones que tiene tanto para esas metas como para las formas de participación que permite, o no, desarrollar.

Uno de los puntos de partida de este trabajo asume que no es posible tomar la descentralización como un "hecho" unívoco. Numerosos estudios han mostrado que el término descentralización es polisémico, que se presta a confusiones y que es usado para objetivos políticos dispares y a veces conflictivos (Collins y Green, 1994; González-Block et al., 1989; Torres, 1986, Silverman, 1992, entre otros). Es por este carácter conflictivo y negociado que sostenemos que es posible incidir en el proceso de descentralización a favor de las necesidades de salud de la población, desde esquemas participativos, si es que se logra articular estrategias adecuadas a la realidad de cada contexto político.

\footnotetext{
* Licenciado en sociología por la Universidad de Buenos Aires y doctor en Salud Pública por la Escuela de Salud Pública de la Fundación Oswaldo Cruz, Río de Janeiro, Brasil. Sus áreas de interés son: políticas y sistemas de salud; migración y sidA; métodos de investigación en salud.

** Magister en Ciencias Sociales por la Facultad Latinoamericana de Ciencias Sociales, México. Áreas de interés: investigación cualitativa, mujer y SIDA, salud reproductiva.
} 
En las discusiones alrededor del tema es casi de sentido común asumir que la descentralización entendida como proceso de largo plazo- debería potenciar la participación y la democracia. Algunos analistas van más lejos, entendiendo que la participación es uno de los elementos que permiten verificar si un proceso es efectivamente descentralizador o no, lo que da por descontada la relación positiva que debería existir entre ambos fenómenos (Fuenzalida, 1990; Cabrero y Lira, 1992; Collins y Green, 1994; Gawryszewski, 1993, entre otros). Sin embargo, muchas políticas descentralizadoras que en el discurso favorecen la participación y la democracia, en los hechos no están diseñadas para promoverlas, aun cuando impliquen algún grado de transferencia de responsabilidades del centro a la periferia.

Detrás de esta asociación positiva entre descentralización y democracia se esconde, además, una noción poco cuestionada de participación. En la literatura sobre descentralización suele aludirse a ella como un fin, al tiempo que se argumenta que la participación es el medio más adecuado para lograr eficiencia en la implementación de programas a nivel local. Ambas concepciones pueden ser compatibles, es decir, se puede promover la participación porque además de ser un valor desde el punto de vista ético, también genera beneficios concretos. Sin embargo es importante establecer una distinción entre la participación como medio o como fin, ya que enfatizar uno u otro de estos criterios llevará a evaluar de distinta manera un proceso concreto de descentralización. La mayoría de los que se han comenzado a implementar en América Latina busca, en primer lugar, incrementar la eficacia y la eficiencia de las políticas. Por ello tiende a promover formas de participación más restringidas y funcionales a este fin. Pero también hay casos en los que se privilegia una ampliación de la participación, ya sea por convicción de quienes formulan la política o por presiones sociales. Ello lleva a promover formas más amplias y directas de participación, aun cuando se generen ineficiencias.

En resumen, el presente documento se propone problematizar los conceptos de descentralización y de participación a partir de la literatura relevante y establecer posibles relaciones entre ellos, para una mejor comprensión de los procesos reales de descentralización en salud que enfrentan los países de la región.

\section{EL CONCEPTO DE DESCENTRALIZACIÓN Y SUS}

\section{PROBLEMAS}

En el sentido común la descentralización se identifica como lo opuesto a jerarquía, control burocrático, ineficiencia y corrupción, rasgos que aparecen vinculados al centralismo; por lo mismo, la descentralización se equipara a la idea de "desburocratización" y de cambios en el rol del Estado. Suele confundirse, también, con otros procesos como los de la desconcentración territorial, la democratización o la participación comunitaria.

Pero los acuerdos en la literatura relevante sobre descentralización son escasos. Existe consenso en una definición que entiende la descentralización como transferencia de poder de decisión desde una agencia central a agencias periféricas o "subunidades" y de funciones antes desempeñadas por burocracias centrales, a organizaciones distintas del gobierno central.

La vaguedad de esta definición da lugar a interpretaciones diversas de sus dimensiones principales y, por lo tanto, se presta a confusiones de sentido en las que un mismo concepto puede significar cosas diferentes.

Autores que parten de esta definición general difieren básicamente en relación con sus nociones principales: a) el tipo y grado de poder transferido qué es lo que se transfiere-, y b) el tipo de organización a la que se transfiere ese poder —a quién se lo transfiere.

Una lectura cuidadosa permite distinguir:

a) Una definición amplia de descentralización que abarca cualquier grado y tipo de poder de decisión transferido a cualquier tipo de organización, sea gubernamental o no, y

b) Una definición estricta de descentralización, que hace referencia al traspaso de poderes de decisión del gobierno central a subunidades del Estado 
-típicamente gobiernos locales- con autonomía basada en la Constitución y autoridades que emanan de elecciones locales.

Desde una perspectiva amplia, ${ }^{1}$ los tipos de descentralización pueden incluir desde la desconcentración y la devolución — con base territorial—, hasta la delegación y la privatización - con base funcional- (Rondinelli y Cheema, 1983).

1. En la desconcentración, se trata de transferencia de funciones específicas —es, por lo general, el caso de la prevención en salud-a agencias periféricas de la misma administración central o bien de ministerios sectoriales, sin que los gobiernos locales tengan poder de integración intersectorial. Las agencias que implementan proyectos deben rendir cuentas, en este caso, a las autoridades locales del sector. Un ejemplo de esta modalidad es el de Tailandia, donde las agencias locales del Ministerio de Salud se responsabilizan de implementar los programas nacionales (Mills et al., 1990).

2. En la devolución, en cambio, se trata de la transferencia de poder político para desempeñar distintas funciones a autoridades locales autónomas con bases jurídicas, capacidad de generar recursos materiales y humanos, y poder discrecional de decisión. Aunque son una minoría, en estos casos las agencias que implementan proyectos en un sector son responsables ante los gobiernos locales o provinciales y no ante los ministerios nacionales. El caso de Bolivia se acerca a este tipo, con una devolución al nivel de los municipios (Gobierno de Bolivia, 1998).

3. En la delegación, se trata de la transferencia de algunas funciones -implementar o mantener inversiones en un sector- a entidades autárquicas semiautónomas o paraestatales que se ocupan de proveer un servicio. Ejemplo de esta modalidad en el sector salud son los hospitales de enseñanza en Tanzania y Zambia (Mills et al., 1990).

4. En la privatización, se trata de la transferencia de propiedad y administración de servicios a entidades no gubernamentales, que pueden ser empresas privadas u organizaciones sin fines de lucro. Ejemplo de este último tipo es la gestión de hospitales por parte de organizaciones religiosas en África Central y Oriental, o por organizaciones sin fines de lucro en Estados Unidos y Holanda (Mills et al., 1990). Un ejemplo novedoso lo constituyen las "organizaciones sociales" en Brasil, que se definen como públicas pero no estatales. En ellas el Estado subsidia el inicio de la gestión de los servicios de salud por parte de organizaciones comunitarias, contemplando su progresivo autofinanciamiento (De Souza, 1995; Modesto, 1997).

Una definición estricta abarcaría, en rigor, sólo la devolución, a la que algunos autores llaman "descentralización propiamente dicha" (SSA, citado por Cardozo, 1995). Según esta visión, la transferencia de poderes a subunidades del propio sistema estatal supone hacerlo, siguiendo la definición weberiana, a entidades que detenten el "monopolio de la violencia legitima" en un territorio delimitado (Weber, 1984) o, según la tradición jurídica, "el monopolio de la creación del derecho positivo" (Roversi-Mónaco, 1991).

La definición estricta, en otras palabras, no incluye la desconcentración, la delegación o la privatización, por considerar que la descentralización supone la creación o fortalecimiento de órganos con personalidad jurídica, patrimonio y formas de financiamiento propias, tales como los gobiernos estatales o municipales (Boisier, citado por Modesto, 1997), donde una instancia de gobierno ejerce cierta responsabilidad en favor de otra instancia de nivel superior o inferior, respectivamente. En el primer caso, el gobierno local puede tener autonomía en otras funciones al tiempo que actúa como agente del gobierno central en una función específica. En el segundo, el gobierno central o una paraestatal puede actuar por encargo de gobiernos locales o incluso de beneficiarios, clientes o usuarios.

Además de la existencia de términos diferentes para referirse a similares modalidades de descentralización, se puede constatar también la

1 Nótese que aquí hablamos de definición amplia de descentralización y no de descentralización en sentido amplio, que para algunos autores se refiere al monto de poder transferido (González-Block, 1989). Por otro lado, se ha identificado a las corrientes anglosajonas sobre administración -de las que el modelo de Rondinelli sería uno de los principales exponentes-, con una definición amplia de descentralización semejante a la que aquí mencionamos; por contraste, la literatura francesa -por ejemplo, los trabajos de Boisier- se ajustaría más a una definición estricta de descentralización (Oszlak, 1990). 
utilización de los mismos términos pero con significados distintos, o bien de matices diferentes en un mismo concepto.

También hay autores que, aun adscribiéndose a la definición amplia, excluyen algunos tipos corrientemente usados en ella. Es así como muchos excluyen la desconcentración ${ }^{2}$ por tratarse de la distribución espacial de agencias que trabajan para entes centrales, sin autonomía decisional (Mawhood citado por McGirr \& Smith, 1994; Ortega Lomelín, 1988; Oszlack et al., 1990; Fuenzalida, 1990; Cabrero y Lira, 1992; Cardozo, 1995; Morris y Lowder, 1992; Conyers, 1984, entre otros), mientras que otros toman la devolución en su sentido más extremo, como la separación de estados independientes, lo que no sería, en rigor, un tipo de descentralización (Morris y Lowder, 1992).

El caso más debatido es el de la privatización, que algunos autores llaman "transferencia" (Cardozo, 1995). Autores que parten de diferentes puntos de vista ideológicos (Collins, 1994, Silverman, 1992) la excluyen por considerar que no se ajusta estrictamente a la definición de descentralización. No obstante, hay diferencias entre ellos: para Collins existe un tipo parecido, al que llama introducción de mercados en el sector público, que no es exactamente privatización y que ejemplifica con el caso británico en la actualidad; para Silverman, en cambio, la privatización es uno de los objetivos de las políticas de desarrollo dentro del área de reformas de la política económica, mientras que la descentralización es parte de la reforma política, y muchas veces los objetivos de ambos procesos entran en conflicto.

\section{Problemas CON LAS TIPOLOGÍAS}

Muchas de las confusiones que se generan revisando la literatura especializada, sobre todo la que utiliza definiciones amplias, provienen de que en el concepto de descentralización suelen estar entremezcladas dimensiones de variación que pertenecen a ámbitos distintos: el económico, el político o el administrativo. La consecuencia de esta confusión resulta en proponer la desconcentración, la delegación, la devolución y la privatización como un continuo de menor a mayor descentralización.

Por otra parte, no es lo mismo encontrar tipos "híbridos" (Silverman, 1992), donde se mezclan elementos de la misma dimensión — por ejemplo política-, que superponer procesos que, si bien se dan de forma paralela, no son inherentes a la descentralización, como por ejemplo la reforma y transformación del rol del Estado, el ajuste, el traspaso de servicios al sector privado, la democratización, la desconcentración geográfica, etc. Veamos este problema más detenidamente.

En la literatura sobre descentralización no encontramos en general teorías sino taxonomías, es decir, esquemas ordenados para clasificar y describir una realidad compleja, a partir de conceptos construidos que, eventualmente, podrían formar parte de proposiciones explicativas, como por ejemplo "siempre que hay descentralización aumenta la participación". Las clasificaciones son útiles para poder establecer relaciones de este tipo siempre que se tomen algunas precauciones.

Los términos desconcentración, devolución, delegación, privatización, etc. constituyen una tipología. Esta es una forma menos exigente de taxonomía en la medida en que sus conceptos pueden derivarse de otros (Zetterberg, 1968). Para construir estos tipos se combinan de diversa forma las propiedades que definen al concepto del cual derivan -en este caso el de descentralización-, lo que da por resultado modelos a los que los fenómenos de la realidad pueden acercarse en mayor o menor medida.

Las variables que se seleccionan a tal fin pueden estar inspiradas en casos empíricos, pero no dejan de ser construcciones teóricas y cada autor enfatiza los rasgos que le interesan en función de una problemática específica como, por ejemplo, el desarrollo, la eficiencia administrativa, la legitimidad política, la reforma económica, la democracia, etc.

Sin embargo, en toda tipología debe quedar claro qué tienen en común y en qué se diferencian

2 En la literatura francesa se establece una gran división entre la desconcentración (que en las corrientes anglosajonas suele caracterizarse como "descentralización administrativa") y la descentralización. Sus diferencias no son de grado, ya que en la descentralización se transfiere poder a entidades con distinta personalidad jurídica, mientras que en la desconcentración no (Boisier, citado por Oszlak, 1990). 
entre sí los distintos tipos para formar parte del mismo concepto, lo que implica que las variables básicas elegidas en la definición del concepto de descentralización deben ser las que ordenen los espacios de propiedades que distinguen y caracterizan a los diversos tipos. Si tomamos la definición estricta, una variable será el nivel de gobierno al que se transfiere autoridad, y otra, el grado de autonomía politica transferida. Si tomamos la definición amplia, en cambio, las variables serán el tipo de agente al que se transfieren responsabilidades — para poder incluir cualquier clase de organización, pública o privada- y el tipo de responsabilidad transferida, que puede ir desde diversos grados de poder político, hasta la simple responsabilidad administrativa en algunas tareas asignadas, pasando por la gerencia de servicios que anteriormente eran administrados por el Estado.

Dicho de otro modo, si elegimos la definición estricta de descentralización no podemos incluir en la tipología formas de descentralización que varían con relación al tipo - y no al nivel- de la organización a la que se transfiere el poder, lo que excluiría del esquema a la privatización. Tampoco podríamos incluir aquellas donde se da un traspaso de responsabilidades en la ejecución de tareas sin autonomía decisional sobre políticas, planeación o presupuesto, lo que dejaría fuera la desconcentración. Si, en cambio, elegimos la definición amplia, casi todos los tipos que aparecen en la literatura podrían incluirse en ella.

Sin embargo, la opción de aceptar cualquier tipo como ejemplo de descentralización plantea algunos problemas: a) la descentralización, en este caso, debería dejar de definirse como un fenómeno que ocurre en la esfera política para pasar a ser cualquier situación en la que el sector público transfiere algo a alguien, lo que hace demasiado vaga cualquier definición, y b) los tipos de descentralización que se propongan no deberán clasificarse según variables que, si bien están relacionadas con el fenómeno en cuestión - variables contextuales-, no son las dimensiones básicas de variación elegidas en la misma definición.
Para dar un ejemplo de esto último, si se utiliza la variable motivos de la descentralización, como de manera sugerente lo hacen McGirr et al. (1994), dicotomizándola en motivos "administrativos" o motivos "participativos", deberán quedar más explícitos los criterios elegidos para la elaboración de la tipología resultante. En el esquema que proponen las autoras, la desconcentración y la delegación corresponden a "motivos administrativos" —que podrían traducirse como la búsqueda de mayor eficiencia- mientras que la devolución y la privatización quedan en el rubro de "motivos participativos", que podrían traducirse como búsqueda de mayor democracia (en el caso de la devolución), pero también como búsqueda de mayor competencia y a partir de ella, eficiencia para el sector público (en el caso de la privatización). Como se verá más adelante, las formas de participación resultantes difieren enormemente y a veces no resultan compatibles, ya que detrás de esta variable se agrupan dimensiones distintas de variación que a su vez responden a diferentes objetivos.

A partir de estas consideraciones, se puede poner en duda la idea frecuente de que cuanto mayor sea la competencia en el mercado, mayor será la democratización de un país. Así como la primera se refiere a la participación económica, la segunda tiene que ver con la participación política. La competitividad en el mercado y la participación en las decisiones deben medirse por separado: una, por la ausencia de monopolios y la otra, por la existencia de procedimientos democráticos o por la posibilidad de incidencia de la sociedad civil en la "toma de decisiones vinculantes". No separar las dimensiones política y económica puede llevar a concepciones erróneas, como la que supone que desde el modelo de la desconcentración hasta el de la privatización existe una línea de continuidad, de menor a mayor descentralización.

Lo dicho es de suma importancia para no dar por sentado que ciertos tipos de descentralización por definición son más participativos que otros, o más eficientes que otros, ya que esto deberá comprobarse empíricamente teniendo en cuenta condiciones que son específicas para cada una de estas variables. 


\section{El CaRÁCTER "HÍbRIDO" DE TODO PROCESO DE DESCENTRALIZACIÓN}

De lo anterior se desprende la gran importancia que adquiere el tener una noción clara de la definición de descentralización que estamos utilizando, ya que de ello dependerá la manera en que evaluemos un proceso descentralizador concreto, según los objetivos que más nos interese promover.

Hemos visto algunos de los problemas que surgen al adoptar una definición demasiado amplia de descentralización. Pero una definición demasiado estricta también implicaría dejar fuera de consideración a la mayoría de los casos de la realidad.

Como lo han constatado Vaughan et al. (1984) con relación al sector salud, la descentralización es una cuestión eminentemente política, en tanto tiene que ver con la distribución del poder y la asignación de recursos, y no sólo con una reforma administrativa en la que el control de políticas, planeación y financiamiento pueda seguir estando fuertemente centralizado. En consonancia con esta idea, nuestra postura es más cercana a la definición estricta de descentralización, y no sólo por cuestiones metodológicas - como hemos venido argumentando- sino también porque creemos que si existen posibilidades de incidir de manera participativa en el proceso de descentralización, éstas se ubican en el nivel político propiamente dicho y, más específicamente, en las instancias de decisión que puedan tener un carácter vinculante, como las instituciones democráticas de gobierno, con todo lo débiles que aún puedan ser en nuestra región.

Un proceso de descentralización propiamente tal debe implicar un grado significativo de devolución de poderes a entidades locales con capacidad de decisión política. No obstante, somos conscientes de que en el sector salud una devolución completa no es posible ni deseable. Los autores arriba citados también consideran que cierto grado de centralización es necesario para una distribución más equitativa de los servicios en países con fuertes desigualdades regionales (Vaughan et al., 1984), por lo que en la mayoría de los casos se darán algunos elementos de devolución combinados con otros de desconcentración —o descentralización política y administrativa, respectivamente.
De manera que, flexibilizando un poco la definición estricta, también consideraremos como procesos de descentralización aquellos que combinen grados diversos de devolución con mecanismos propios de la desconcentración o de otros tipos, siempre que quede garantizada la existencia de instancias relativamente autónomas de toma de decisión, que, como veremos, constituyen la modalidad potencialmente más favorable a la participación de los afectados.

Resulta claro, hasta aquí, que estamos utilizando las tipologías propuestas en la literatura pero desde una definición de descentralización que privilegia la dimensión política, y siendo conscientes, a la vez, de su carácter ideal. Dicho esto, se pueden analizar los casos concretos de acuerdo a las variables políticas que hemos escogido. Con respecto a la primera, "qué se transfiere", resultará central, por un lado, el grado y tipo de poder transferido - autoridad política propiamente dicha, alguna responsabilidad en la toma de decisiones o administración de tareas específicas-, y por otro, la autonomía y discrecionalidad de que gozan las autoridades descentralizadas, medida en las funciones en las que toman decisiones y en las líneas formales de rendición de cuentas ("hacia arriba" o "hacia abajo", según la caracterización de A. Mills, 1990). Con relación a la segunda variable, "a quién se transfiere poder", importa conocer los niveles e instancias de gobierno a los que se transfiere autoridad (regional, estatal, municipal, etc.). En este caso también las líneas formales de rendición de cuentas variarán de acuerdo a los particulares arreglos que se den en un sector, entre autoridades locales electas y/o asignadas.

Es importante recordar que en la realidad todos los casos de descentralización son "bíbridos" (Silverman, 1992), que la descentralización es gradual sólo en la dimensión temporal y dentro de cada tipo - de mayor a menor devolución, de menor a mayor desconcentración, etc.- , que no existe un continuo entre los diferentes tipos y que tampoco la relación descentralización/centralización es una dicotomía. Si en lugar de tomar la descentralización como un evento aislado la situamos en su contexto histórico-político, vemos que ella no se opone a la "centralización" en sí, sino a la "sobrecentralización" que ha caracterizado históricamente a la región (Apthorpe y Conyers, 1982). 
La mayoría de los autores constata que en la realidad se dan combinaciones de tipos de descentralización en un mismo país, Estado o sector, conviviendo con funciones que siguen estando altamente centralizadas.

\section{LA DESCENTRALIZACIÓN COMO FENÓMENO} POLÍTICO

Es útil hacer una distinción entre fenómenos de la esfera económica y de la esfera política, y ubicar los procesos de descentralización dentro de esta última, ya que ellos consisten en un reordenamiento de los esquemas de autoridad dentro del ámbito estatal. Descentralizar no es sinónimo de "desestatizar" donde la variable es el mayor o menor grado de intervención del Estado en el desarrollo y, por tanto, en la economía como proveedor de servicios y controlador del mercado. La descentralización se mueve dentro del sector público, y no entre el público y el privado. La confusión entre los conceptos de descentralización y desestatización se debe, en parte, a que los procesos de descentralización política en América Latina se han dado de forma paralela a una mayor liberalización de los mercados y a la transferencia de la propiedad y gestión de diferentes servicios al sector privado.

Pero si bien el Estado se relaciona directamente con la esfera económica, toda vez que mediante su herramienta principal - la planeación - asigna recursos escasos de manera complementaria al mercado, no hay que olvidar aquello que distingue a ambas esferas: la política es el sistema encargado de producir decisiones de carácter vinculante para toda la sociedad, mientras que la economía es la esfera de la producción, intercambio y consumo de bienes y servicios.

Es necesario distinguir también entre una visión jurídica y otra sociológica del Estado. La primera es la que clasifica las formas de gobierno desde el punto de vista constitucional en unitarias o federales - siendo éstas las más "descentralizadas"-, mientras que la segunda da cuenta de una gama de alternativas posibles que combinan elementos de estas categorías polares. Puede existir una amplia devolución de poderes en un esquema jurídicamente centralizado, o centralización de facto en estados formalmente federales.

Partiendo, entonces, de una concepción política y sociológica, distinguimos entre la descentralización política propiamente dicha - transferencia de poderes amplios- y la descentralización administrativa transferencia de responsabilidades diversas para ciertas tareas. Si bien ambas suelen estar presentes simultáneamente en los procesos de este tipo, toda descentralización de funciones administrativas debe ir acompañada de la descentralización del poder político (Oakley, 1990), para evitar una dependencia del nivel central que, con frecuencia, conduce al fracaso de la iniciativa descentralizadora.

En relación con la provisión de servicios públicos, la descentralización política es aquella en la que se transfieren amplias facultades de decisión en múltiples áreas y con mayor poder vinculante, mientras que la descentralización administrativa consiste en la redistribución de responsabilidades de diverso grado en funciones y/o tareas específicas. Como la realidad histórica es dinámica, siempre se dan combinaciones y arreglos cambiantes en cuanto al grado y nivel de los procesos de descentralización. Sin embargo, distintos autores coinciden en señalar que un indicador importante de descentralización política es la medida en que las organizaciones descentralizadas tienen poder de decisión sobre el presupuesto, la gestión de los recursos humanos y la planeación.

Siempre dentro de la esfera política, y a los efectos de adelantar una posible relación entre descentralización y participación, afirmamos que el tipo que más favorece la transferencia de poder de decisión a organizaciones descentralizadas es la devolución, ya que en ella se transfieren facultades a entidades que detentan —en teoría - algún grado de poder político. Por ello, en un sistema democrático, donde las autoridades locales son elegidas por voto popular, habría una garantía mínima de participación - en el plano electoral-y una apertura al eventual acceso de grupos e individuos al proceso de toma de decisiones en la comunidad.

De acuerdo a los criterios de definición que hemos propuesto, la descentralización como devolución puede implicar mayor democracia, siempre que se 
cumpla con sus requisitos básicos a nivel local. Esto es así porque, si bien ningún tipo de descentralización está diseñado explícitamente para promover la participación de todos los actores interesados en los procesos decisorios, la devolución es el tipo de descentralización más abierto a esta posibilidad. Por el momento baste este señalamiento para insistir en que la participación no es un indicador de descentralización, sino una variable diferente cuya relación con la segunda debe enunciarse y ponerse a prueba.

\section{LOS SISTEMAS POLÍTICOS CONTEMPORÁNEOS}

Para tener más claro el panorama de intervención y participación posibles es importante discutir las distintas nociones de democracia que pueden estar presentes cuando hablamos de descentralización y ver la esfera política en nuestras sociedades de una forma más realista. Para ello es útil dejar de pensar en la esfera política como "el Estado" por oposición a "la sociedad civil". En un sistema democrático la esfera política puede verse como compuesta por los cuerpos parlamentarios, la administración y el "público", todos formando parte del Estado, o sistema político (Luhmann, 1987).

La situación histórica actual es producto de una ampliación de la ciudadanía, que progresivamente hizo responsable al "Estado" por la equidad social. Si bien esta situación es problemática y se halla sometida a intensos debates, es vista en general como un logro irreversible.

La ampliación de los derechos - de ciudadanos a políticos y más tarde sociales - fue generando sistemas políticos complejos donde pueden identificarse dos circuitos de poder: uno "oficial", que corresponde al Estado de derecho, y otro "informal" que corresponde al Estado de bienestar (Luhmann, 1987). El primero va del público a los cuerpos parlamentarios y de éstos a la administración según el siguiente flujo: a través del voto se eligen legisladores que, según los intereses de su electorado, discuten y sancionan leyes que luego la administración se encarga de implementar. El circuito alternativo va en sentido opuesto, y funciona en la medida en que las demandas se diversifican e incrementan, representando una sobrecarga para las agendas políticas: el poder ejecutivo controla al legislativo de diversas maneras, éste influye sobre un electorado difícilmente capaz de informarse de todos los temas y de evaluar distintas opciones, a través de las ofertas preestablecidas que los partidos se encargan de preparar, y por su parte el público presiona a la administración, a través de mecanismos informales. Un esquema de esta dinámica puede verse en la figura de abajo.

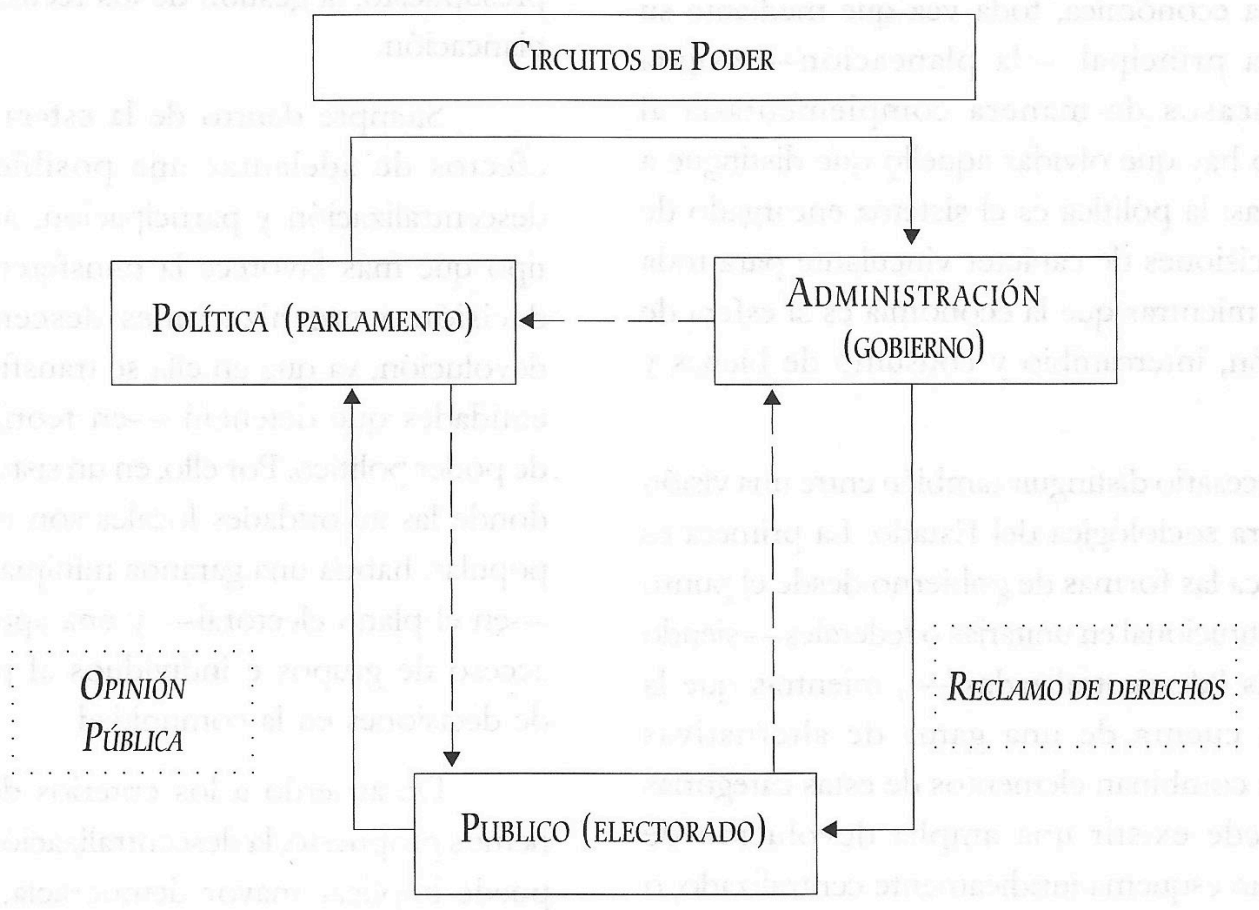


Se trata de las tensiones entre los conceptos de democracia procedimental y democracia social, una falsa opción en la medida en que ambas coexisten de manera conflictiva e incompleta y están arraigadas en nuestras sociedades, no sólo en la cultura política sino también en el propio sistema político. Sin embargo, la primera está asociada hoy a la idea de que el interés público, el bienestar, la eficiencia y la elección del consumidor se dan a través del mercado y del sector privado (eficiente, en contraste con el "Estado" y "la política"), donde las desigualdades son necesarias. La segunda, se asocia más bien al Estado de bienestar, la economía mixta, la equidad y los derechos sociales. ${ }^{3}$

Esta mayor complejidad de la esfera política genera dos tendencias opuestas: burocracia, racionalización y aumento de la comunicación altamente especializada, por un lado, y demanda de mayor participación de la sociedad civil organizada alrededor de temas cada vez más diversos, por el otro. Esto se traduce en una tensión entre fuerzas centralizadoras y "descentralizadoras": la participación estaría mejor garantizada en sistemas donde el poder está descentralizado y los procesos de toma de decisión más cerca de su electorado y comunidad de referencia; pero al mismo tiempo, la lógica actual de la política obliga a optimizar la eficacia decisional y garantizar un nivel mínimo de equidad, lo que resulta más favorecido cuando la planeación está centralmente coordinada.

Un dilema que surge de esto es el de cómo resolver la tensión entre los valores democráticos de la igualdad, por un lado, y del respeto a las diferencias, por el otro. El primero se transforma, en el marco de las políticas públicas, en la búsqueda de equidad, que en el caso específico del sector salud se promueve mediante la universalidad de los servicios, a su vez asegurada a través de una planeación centralizada. El segundo, en cambio, queda mejor garantizado cuando los servicios se adaptan a las demandas y preferencias diferenciadas de las distintas comunidades dentro de la sociedad, ya sean territoriales o de intereses.

Pero convendría también aquí cuestionar la noción de sentido común según la cual la planeación —entendida como decisiones de "arriba hacia abajo" sobre un amplio rango de aspectos de la vida- es lo opuesto de la participación. Hoy en día, las políticas sociales se conciben de manera más participativa, en parte para evitar las críticas al centralismo de las decisiones y en parte para lograr la eficiencia en un contexto de decreciente cantidad de recursos y de crecientes demandas (Bazdresch, 1997). La proposición frecuente de que alguna forma de participación es necesaria para que las decisiones no corran el riesgo de resistencia popular —y en el peor de los casos de fracaso-, ha dado lugar a la noción de "planeación abierta" (Tehranian, 1982). Este tipo de planeación, que contempla la participación de diversos actores interesados en la toma de decisiones, sería un potencial vínculo entre descentralización y participación. En este modelo se privilegia la participación a través de organizaciones de asociación voluntaria, que representan intereses y constituyen canales de comunicación entre la gente y los gobiernos.

\section{LA PARTICIPACIÓN EN UN SISTEMA POLÍTICO}

\section{DESCENTRALIZADO Y COMPLEJO}

En la situación contemporánea arriba esbozada, la participación se amplía y restringe a la vez. Se amplía porque incluye nuevos canales: además de votar, grupos de la sociedad civil se organizan para influir en las decisiones a través de la opinión pública y para crear o promover nuevos derechos, así como para favorecer u obstaculizar los procesos de toma de decisiones en distintas áreas de interés. Se restringe, porque para entrar a la consideración de la política las necesidades deben estar formuladas en el código de la política — ser parte de la opinión pública, ser capaces de transformarse en derechos o trascender a las personas biográficas para convertirse en "temas políticos". Sin este código, las demandas no tienen chance de entrar al circuito político.

Dado este contexto, es importante relacionar las distintas formas de descentralización con las posibilidades y límites de la participación. La participación se asocia con democracia y ejercicio de

3 Aunque excluimos aquí lo que se denomina democracia directa por considerarla altamente improbable en sociedades complejas como las contemporáneas, es preciso señalar que muchos trabajos sobre participación aún tienen tácitamente una idea semejante de democracia. 
las libertades individuales y por lo tanto se considera un valor que se justifica en sí mismo, incluyendo en este proceso distintas formas de organización de la sociedad civil para la búsqueda de intereses colectivos. Sin embargo, el concepto de participación también es polisémico. Además puede verse como fin, o como medio para alcanzar diversos objetivos: educación de la población en una cultura democrática, logro de mayor eficiencia y calidad de servicios, mayor costoefectividad, mayor control del proceso, entre otros (Bronfman y Gleizer, 1994).

La relación entre la noción de participación y la definición estricta de descentralización está dada, principalmente, por la mayor capacidad de pedir y rendir cuentas de las autoridades del nivel local, dado que éstas se eligen democráticamente. En efecto, la definición estricta de descentralización abarca fenómenos cercanos a la devolución, que se caracteriza entre otras cosas por transferir poderes a autoridades electas, y no asignadas por agencias centrales.

Se supone, además, que el proceso democrático se verá estimulado por el hecho de que las organizaciones locales de la sociedad civil se sentirán más involucradas en los procesos de toma de decisión en temas de su interés inmediato. La relación entre ambos tipos de participación (electoral y decisional), sin embargo, no es lineal.

La relación entre la participación y las formas que se derivan de la definición amplia de descentralización, por su parte, se ubica dentro de un rango mayor. En la medida en que esta idea de descentralización incluye la transferencia de funciones y de propiedad a entidades no gubernamentales tanto capitalistas como cooperativas, organizaciones voluntarias, etc.- abarca dos modalidades distintas de participación: a) una mayor influencia de los representantes de la sociedad civil sobre la estructura y gerencia de distintas políticas en su comunidad (igual que en el caso anterior) y b) el aprovechamiento de organizaciones civiles en la generación de ingresos, provisión de servicios o gerencia de recursos. En el primer caso, la dimensión relevante de variación en la participación efectiva estará dada por el nivel de accountability externa a los interesados (cuánto representan o no las necesidades de los afectados por una decisión); en el segundo, por el grado de autoridad interna en la organización civil de que se trate (jerárquica o cooperativa), que será más o menos participativa.

Podemos entonces establecer la siguiente relación:

- Una definición estricta de descentralización, circunscrita a la esfera política, permite una modalidad de participación a la que podemos llamar

1. Capacidad de incidir en los procesos de toma de decisión, ya sea

a) mediante representantes electos de la sociedad civil a través del voto ("circuito oficial de poder"), o bien

b) mediante representantes de grupos diversos de intereses, no electos pero con relaciones informales en la comunidad ("circuito alternativo de poder").

Por otro lado,

- Una definición amplia de descentralización - que incluye ciertos aspectos de la esfera económicapermite dos modalidades de participación

1. Incidir (igual que en el caso anterior), y

2. Reemplazar al sector público en tareas de provisión de servicios, aunque no de toma de decisiones vinculantes. A su vez esta segunda modalidad puede darse

a) a través de organizaciones con fines de lucro o bien

b) a través de organizaciones cooperativas o voluntarias.

La distinción entre éstas se da en el tipo de autoridad dentro de la organización: jerárquica en el primer caso y cooperativa en el segundo, con distintas consecuencias para la eficiencia (más alta en el primer caso, salvo excepciones) y la participación (obviamente más alta en el segundo).

Es importante notar, entonces, que los distintos tipos de descentralización tienen objetivos prioritarios diferentes y formas de participación que son más o menos adecuadas o funcionales a esos objetivos. Su funcionalidad estará determinada, por lo tanto, de acuerdo a las metas específicas del subsistema que se 
esté tomando como referencia: desde el económico se evaluará si la participación es efectivamente un medio para aumentar la eficiencia y la eficacia de las políticas sociales; desde el político, si favorece la gobernabilidad al "desconcentrar" las demandas antes hechas al gobierno central, y si su legitimidad se incrementa porque la gente siente que, en el nivel local, tiene mayores posibilidades de incidir en procesos de toma de decisiones más cercanos a su situación concreta.

Existe consenso internacional sobre el valor de la participación como un fin, pero técnicas insuficientes para evaluar sus resultados, tanto en términos de beneficio para los afectados como de eficiencia o capacidad democratizadora. Por este motivo, aún estamos en el nivel en que no podemos establecer de manera general una relación propositiva entre los conceptos de descentralización y de participación.

Sí en cambio es posible ensayar algunas relaciones entre tipos de descentralización y modalidades de participación, pero en los niveles micro, vale decir, en cada una de las subinstancias de decisión y no en el nivel macroinstitucional. Al hacerlo, hay que tener presente que - lo que es común en sociología - se trata de relaciones interdependientes (pequeños avances en la descentralización pueden provocar pequeños avances en la participación y viceversa), secuenciales (en un proceso de largo plazo donde una sigue a la otra), y además probables y contingentes, lo que podríamos formular con proposiciones del tipo: "tal forma de descentralización está más o menos abierta a tal/es modalidad/es de participación, siempre y cuando intervenga $\mathrm{x}$ variable".

Por otro lado, las variables intervinientes serán distintas según estemos probando una u otra de las variables principales. Por ejemplo, una mayor descentralización - que es una decisión política tomada en el centro- dependerá, entre otras cosas, de una fuerte voluntad política de llevarla adelante y de apoyarla efectivamente, mientras que la participación en ese proceso dependerá de factores como la legitimidad que los actores locales otorguen a las autoridades, su creencia en los beneficios de la política concreta, su capacidad de organizarse y los canales abiertos para ello, entre otros.
Así, según algunos autores, la desconcentración y la delegación no parecen favorecer la participación comunitaria, fundamentalmente porque las autoridades de las agencias a quienes se desconcentra o delega la responsabilidad no son electas sino asignadas, y por lo tanto responden y rinden cuentas al ente central en lugar de dirigirse a la comunidad. Por su parte la devolución parece ser el tipo más potencialmente favorable a la participación, pero requiere, como variable interviniente, la presencia de procesos democráticos a nivel local.

Es desde esta lógica como resultan más comprensibles los tipos híbridos. Así, pueden introducirse elementos democratizadores en un esquema de desconcentración. Ejemplo de ello son algunas modalidades de "comité distrital de salud" -que se componen de funcionarios asignados por el ministerio central y de representantes de la comunidad como autoridades locales, comités de autoayuda, ONG's y cooperativas-, donde el hecho de que algunos sean electos democráticamente y otros asignados favorece un equilibrio entre la rendición de cuentas "hacia arriba" y "hacia abajo".

Es desde esta lógica, también, como vuelve a plantearse el problema de la relación entre participación y algunos tipos contemplados en la definición amplia de descentralización, como la transferencia de funciones al sector no gubernamental o privatización. En efecto, un nivel alto de participación en la esfera económica (reemplazar) requiere como condición un mercado más abierto a la competencia - posibilidad que en la actualidad debe probarse, más aún con los niveles de corrupción que sufre América Latina-, mientras que un nivel alto de participación en la toma de decisiones (incidir) requiere de procedimientos democráticos en la elección de autoridades y/o de niveles altos de organización y movilización de los actores locales, ya que se ha argumentado que la descentralización tiende a reforzar la forma política prevaleciente de dominación en una localidad (Ochoa, 1998). Nuevamente, se trata de dimensiones de variación difícilmente conmensurables, aunque se den de forma paralela.

A la inversa, así como deben encontrarse las condiciones que favorecen u obstaculizan la 
participación, deben tenerse en cuenta también los beneficios y problemas que ella misma genera en sus distintas modalidades, así como sus posibilidades reales en contextos políticos complejos. Uno de los límites intrínsecos de la modalidad "reemplazar" a través de organizaciones voluntarias es la ineficiencia, en la medida en que la necesidad de consensos amplios en ambientes participativos confronta intereses heterogéneos, muchas veces conflictivos, $y$ con ello demora las decisiones. Podría argumentarse en este caso que el valor de la participación en sí supera al de la eficiencia, pero es dudoso que en experiencias con resultados negativos siga habiendo incentivos para participar. En caso de no haber valores cohesionadores fuertes, suelen requerirse mecanismos adicionales que limitan la participación, para que la experiencia tenga éxito.

En el caso de la modalidad "incidir" sucede algo semejante, por lo que no se puede esperar una participación de todos los actores afectados en todas las decisiones, más aún considerando los propios límites de comunicación del sistema político. Con todo, en la actualidad están dadas las condiciones para un estilo de planeación abierto a la participación, lo que será preciso potenciar, siempre que quienes estén involucrados en este proceso acepten los riesgos políticos que implica el tomar y compartir decisiones.

\section{Participación: ¿́legitimación de los PROCESOS DESCENTRALIZADORES?}

Una variable clave que, en teoría, podría mediar entre la descentralización - como política emanada del gobierno-y la participación social a ella vinculada, es el grado de legitimación de que goce la primera. En este sentido, nos preguntamos si la participación alguna de sus variantes- podría considerarse una forma de legitimar al gobierno - y a qué nivel del mismo-, gracias a sus políticas de descentralización, más allá de que los objetivos de cada uno de los actores coincidan o no. Para comprender mejor esta compleja relación, habrá que hacer algunas precisiones.

La teoría política ha definido la legitimidad como la existencia, en una parte relevante de la población, de un grado de consenso tal que transforme la obediencia en adhesión, por lo que la creencia en la legitimidad es el elemento integrante de las relaciones de poder que se encuentran en el ámbito estatal (Levi, 1991). Según este autor, la legitimación es el comportamiento que surge cuando determinados grupos o individuos se dan cuenta de que los fundamentos y fines del poder son compatibles con sus creencias, aceptando las "reglas del juego", más allá de que estén en total acuerdo o no, con las formas concretas de llevarlo a cabo.

En un régimen democrático es clave la creencia en la legalidad de los procedimientos. Pero el proceso de legitimación tiene varios componentes: además de la legitimidad del régimen debe crearse también la legitimidad del gobierno o administración. En un sistema complejo como el que venimos considerando, a los mecanismos de legitimación del Estado de derecho se agregan los propios del Estado de bienestar, vale decir, la creencia por parte de la población de que las políticas sociales emanadas del gobierno realmente la benefician.

Cuando no existe esta creencia, la falta de legitimidad se manifiesta mediante comportamientos "impugnadores" que pueden ir desde el simple rechazo abstracto a las acciones del gobierno, hasta diferentes formas de violencia. La primera de las modalidades es relevante para la pregunta que nos hemos planteado —en qué medida la participación se relaciona con la legitimación de las políticas-, ya que la no-participación puede estar escondiendo un rechazo de esta naturaleza, donde los afectados soportan pasivamente una realidad que no creen posible cambiar.

Por el contrario, cuando el poder es estable y es capaz de cumplir con sus funciones esenciales, ya sea de manera progresista o conservadora, hace valer la justificación de su propia existencia creando el consenso necesario (Levi, 1991). Pero esta situación de legitimidad no implica que necesariamente vaya a estimularse la participación. Se pueden dar estrategias de participación cuyo objetivo sea presionar a administraciones en las que no se cree, pero también formas de participación que respondan a las iniciativas o programas de gobierno en los que sí se cree. En este punto es importante distinguir entre la legitimación del régimen en general, por ejemplo la democracia en el nivel nacional, y la de los regímenes 
locales (Smith, 1985), siendo poco probable que se dé ésta sin aquélla.

De lo que antecede es importante destacar que la legitimación, como proceso por el que se construye la legitimidad, es un fenómeno global que atañe a todo el sistema político y que se compone de múltiples procesos convergentes y relativamente autónomos: la legitimación de la comunidad política - donde la lealtad nacional puede ser un indicador-, la del régimen político - en uno democrático, la aceptación de las reglas del juego-y la del gobierno. Del mismo modo, los actores que participan en cada uno de estos procesos - tanto los que otorgan como los que reciben la legitimidad - también son múltiples.

En este marco, cabría el interrogante acerca de si la descentralización es una medida que legitima al gobierno nacional y/o al local, y cuáles serían los indicadores de tal legitimidad. Hemos adelantado que la creencia en la legalidad de los procedimientos -y podríamos agregar el compromiso político con ella- es una dimensión importante para ciertos sectores. Estos podrían considerar que la participación ciudadana a través del voto en el ámbito local es suficiente para garantizar un mínimo compromiso de los representantes electos hacia los intereses de su electorado, los que en su defecto pueden ser removidos en la siguiente elección. Grupos más movilizados considerarán tal vez fundamental el hecho de que las funciones de planeación y de diseño de políticas - y no sólo las de ejecuciónestén efectivamente descentralizadas, asegurando además su participación en las decisiones. Finalmente, para una gran mayoría de la población, un elemento clave de legitimación será la creencia en los beneficios concretos que la política de descentralización pueda aportar.

A partir de los criterios mencionados podemos identificar distintas formas de participación: 1. a través de representantes electos (circuito formal) o 2. a partir de grupos de interés (circuito informal). Se pueden agregar dos variantes más: 3. la participación de base, organizada por los propios funcionarios a cargo de algún programa gubernamental, sin mediación de otras instancias civiles, o 4. la promovida por otras organizaciones de la sociedad civil. Las cuatro variantes pueden combinarse y coexistir en un contexto particular, y representan distintas formas de "relación entre decisores y afectados" (Oakley, 1990), unas más directas que otras. Lo que no es posible, es establecer relaciones directas entre ellas y el grado de legitimación que estén expresando: en cualquiera se puede mantener una creencia débil o fuerte en las políticas de descentralización, de acuerdo a cualquiera de los elementos legitimadores señalados, es decir la transparencia de los procedimientos o los beneficios generados. Del mismo modo, en cualquiera de las variantes se puede tener una visión de la participación como medio, o como fin.

Al evaluar el grado de legitimidad que pueda tener una política como la descentralizadora, es preciso tener en mente, además, que los procesos de legitimación suelen ser lentos y de largo plazo. Esto es especialmente válido en una región en la que -a diferencia de otras en el mundo - la descentralización, como parte de los procesos de reforma del Estado que siguieron a la crisis de la deuda, provino más de los propios gobiernos que de una demanda social, y donde además las posibilidades de la participación democrática se vieron muy limitadas durante largos períodos.

Los procesos de transición a la democracia en la región fueron acompañados de la defensa de los valores democráticos, o más bien de cierto "clima cultural" que algunos autores denominan de "democraticidad", favorable a la idea de la descentralización (Roversi-Mónaco, 1991). Sin embargo, es importante cuestionar la asociación directa que suele hacerse entre descentralización y democracia. Tal asociación hace de la descentralización el polo "bueno" de una falsa dicotomía donde la centralización, identificada con el autoritarismo, encarna el polo "malo" (RoversiMónaco, 1991), de ahí que la descentralización sea una bandera que encontramos en las plataformas de partidos de la más diversa ideología, pero con diferentes grados de compromiso hacia ella. Si se pone en duda tal dicotomía, puede verse que ciertos valores democráticos — como la igualdad, por ejemplo- pueden ser defendidos también con criterios centralizadores. 
El pluralismo, por su parte, suele ser el valor democrático más claramente asociado con la defensa de la descentralización; pero la clave para que ésta sea un vehículo efectivo de aquél, es que en vez de responder a los intereses de poderes locales no democráticos, reconozca y valorice las "partes" o entes "exponentes" de determinadas fuerzas u organizaciones comunitarias destinadas a ampliar los intereses de los individuos (Roversi-Mónaco, 1991).

De este modo, en la medida que la descentralización ha sido asociada con la democracia sin más, podríamos decir que goza de legitimidad en el nivel de la opinión pública. No obstante, los grupos que acceden a la misma, ya sea para obtener información o para incidir en ella, son limitados. Hay quienes plantean que en una región donde grandes sectores de la población están desinformados, escasamente organizados y con limitaciones para articular de forma efectiva sus demandas políticas, las elecciones libres con sufragio universal como requisito de la democracia, resultan insuficientes (Smith, 1985). Por lo mismo hacen falta mecanismos adicionales para evaluar el grado de legitimidad que las políticas de descentralización puedan tener en estos sectores, ya que, como hemos sugerido, la participación —o su ausencia- no es un indicador suficiente.

Ahí donde existe la participación, ésta puede darse por distintos motivos y asumir formas diversas: puede haber participación porque se desconfía de los procedimientos formales - por ejemplo a través de grupos de presión-, y por lo tanto basarse en una legitimidad débil, como sucede en el caso de muchas organizaciones civiles cuya principal actividad son las campañas de advocacy de temas que consideran de su interés y en los que no sienten que las autoridades y/o partidos políticos estén comprometidos, o bien puede darse otro tipo de participación, precisamente en apoyo a programas o políticas cuya legitimidad se acepta y reconoce. Pero aun cuando la participación no pueda tomarse aisladamente como un indicador de la legitimidad de cierta política, es probable que - de resultar exitosa - conduzca a una mayor legitimación y a la organización de un mayor número de afectados por ella.

\section{DESCENTRALIZACIÓN Y PARTICIPACIÓN EN SALUD}

El sector salud es de interés político en la medida que, en una sociedad diferenciada, debe garantizarse la equidad. Por ello se favorecerán ciertos tipos de descentralización, en general conformando modelos híbridos. En el tipo híbrido se mezclan elementos de los tipos "puros" de descentralización junto con funciones altamente centralizadas. Es importante notar que todos los modelos serán híbridos en el nivel macroinstitucional del sector (en este caso, Ministerio de Salud), encontrándose tipos puros sólo en funciones específicas dentro de niveles subsectoriales, de acuerdo a la estructura de autoridad, por ejemplo planeación, gasto público, programación y gerencia, política fiscal, etc. (Silverman, 1992).

En el sector salud el tipo híbrido más común es una combinación de desconcentración y devolución (Mills, 1994). Éste puede tomar la forma de una devolución a gobiernos locales junto con la permanencia de equipos locales del Ministerio de Salud, o bien una descentralización a cuerpos mixtos, del tipo de los Comités Locales de Salud, con miembros en parte elegidos y en parte asignados. Estos cuerpos a su vez pueden tener poderes amplios (planeación, implementación, control de funcionarios y de presupuesto, recaudación de algunos recursos y establecimiento de algunas regulaciones, siempre bajo el control e instrucciones centrales), o estrechos (coordinación y transmisión de información hacia el centro). Un ejemplo del primer caso serían los Foros de Planeación, que funcionan en sistemas altamente descentralizados y pluralistas, como el que existe en Holanda, y que reúnen a representantes de grupos de pacientes, proveedores de atención, financiadoras, municipalidades y provincias. Un ejemplo intermedio scrían los Comités de Salud, que aunque detenten escasa autoridad directa, por lo general tienen algunas funciones de planeación y sirven para influir en los tomadores de decisiones, tipo al que se acerca el ejemplo de Bolivia. Menores atribuciones tienen los Foros de Consulta, implementados en muchos países de América Latina, que representan básicamente instancias de expresión de la opinión pública y profesional local, pero donde no se rompe la línea de rendición de cuentas hacia arriba. 
El énfasis en el carácter político de la salud pública - como bien público para el que hay que garantizar equidad-implica que la planeación en salud sigue siendo un rol del sector público y que todas las funciones del sector salud - descentralizado o no- deben estar centralmente coordinadas. Es por este motivo que muchos países en desarrollo han intentado descentralizar los procedimientos administrativos, manteniendo un fuerte control centralizado de las actividades legislativas, presupuestarias y de diseño de políticas (Vaughan et al., 1984), con la intención de mejorar la implementación de los programas del gobierno nacional a través de una mayor participación local, sin crear al mismo tiempo mayor desigualdad entre las regiones del país. En consecuencia, en muchos de estos países los elementos de desconcentración han tendido a prevalecer por sobre los de devolución. Los esquemas resultantes suelen tener efectos centralizadores, ya que los ministerios de salud están frecuentemente organizados a lo largo de líneas programáticas verticales; los funcionarios del sector suelen coordinarse más con sus homólogos centrales que con funcionarios locales de otros sectores, o bien con los grupos organizados de la comunidad. El resultado suele ser una insuficiente satisfacción de las necesidades locales, así como la falta de mecanismos de rendición de cuentas (accountability) hacia el electorado y/o la comunidad locales.

De ahí la necesidad de contrabalancear las tendencias centralizantes que se encuentran en los tipos de desconcentración y delegación — que son los más comunes en salud-, ${ }^{4}$ si se busca crear instancias de participación a nivel local. Las fórmulas intentadas han ido en el sentido de promover la integración intersectorial -donde un solo gobernante es responsable de varias funciones y debe rendir cuentas de ellas a la comunidad-y la participación social; tanto la coordinación intersectorial como la creación de instancias de participación - que son elementos más propios de la devolución- rompen la línea formal de rendición de cuentas "hacia arriba" que los caracteriza y permiten una mayor apertura política hacia la comunidad.

\section{Dilemas DE LA DESCENTRALIZACIÓN EN} SALUD

Esos distintos arreglos y combinaciones responden generalmente a un balance entre objetivos contradictorios o conflictivos. Con frecuencia, en la literatura se elabora una lista de "objetivos de la descentralización" o de beneficios que ésta trae, como si todos ellos se dieran de manera conjunta y paralela. En la realidad, sin embargo, hay que distinguir entre objetivos que pertenecen a distintas esferas: en la macroeconómica, por ejemplo el desarrollo; en la financiera, la disciplina fiscal; en la administrativa, la eficiencia organizativa, y en la política, desde la gobernabilidad hasta la participación comunitaria, entre muchos otros.

La combinación de tipos de descentralización por lo general responde a un balance o negociación entre esos objetivos en conflicto. Se presentan dilemas, por ejemplo, entre el criterio económico de la eficiencia y el valor político de la equidad; entre la necesidad de disciplina fiscal —mejor garantizada si hay centralización - y la democracia - mejor promovida si hay descentralización-; entre la defensa de las preferencias individuales y la de los intereses nacionales, entre los más comunes.

El dilema entre participación y eficacia, por ejemplo, se presenta al tener que definir a qué nivel descentralizar, cuanto más pequeña sea la comunidad elegida mayor será la participación, pero esto creará problemas de ineficiencia y de falta de coordinación entre los servicios de salud. Algunas soluciones que se han intentado son: elegir un nivel - por lo general el provincial-, y luego buscar mecanismos adicionales para bajar la instancia de participación a comunidades más pequeñas; o bien establecer una jerarquía de cuerpos gubernamentales de arriba hacia abajo, donde la atención primaria es responsabilidad de los gobiernos municipales, los servicios secundarios de los distritales, las especialidades se coordinan a nivel regional y unos pocos servicios especializados son provistos por el gobierno central (Mills et al., 1990). La forma final que adopte la descentralización

4 La combinación de estos dos tipos es frecuente en América Latina, y puede verse en el ejemplo de México, donde se busca coordinar los servicios que permanecen bajo la jurisdicción del Ministerio de Salud pero administrados por los estados, con la delegación de la salud financiada por la seguridad social a para-estatales. 
en un país dependerá en gran parte de la voluntad y capacidad de imponer valores en la arena política que tengan los diferentes grupos interesados.

Es común que la descentralización se presente como un bien en sí mismo, sin tener en cuenta que si lo es, se debe a que favorece otro tipo de objetivos definidos políticamente. Muchos de estos dilemas están planteados en el nivel internacional, donde también se dan objetivos y valores en competencia. Uno de ellos es el de la eficiencia macroeconómica, objetivo para el cual las entidades financieras internacionales recomiendan a los gobiernos una mayor disciplina fiscal hacia los estados locales, lo que está mejor asegurado con una política centralizadora. Tal política favorece al mismo tiempo el objetivo de la equidad, lo que demuestra el hecho de que muchos gobiernos prefieran el control centralizado de los recursos para no profundizar las desigualdades regionales. Pero al mismo tiempo, entra en conflicto con algunos de los objetivos de la descentralización: la autonomía local, la participación y la posibilidad de pedir cuentas al gobierno — en la medida en que esta posibilidad tiene como requisito que quien recauda y quien gasta los recursos sea la misma entidad.

\section{CÓMO POTENCIAR LA PARTICIPACIÓN}

De las reflexiones anteriores se deriva que una de las estrategias a seguir, si se quiere que los procesos descentralizadores sean también participativos, es el fortalecimiento de mecanismos de participación adecuados a cada arreglo descentralizador. Por ejemplo, abogar por la incorporación de elementos de devolución en esquemas desconcentradores, para contrapesar las tendencias verticalistas de rendición de cuentas y la centralización de decisiones clave, como las relacionadas con el control de recursos y de personal.

Entre las condiciones más importantes para una efectiva participación se han identificado: a) la apertura del "ambiente político", b) capacidades técnicas y organizativas fuertes por parte de las organizaciones civiles, y c) procesos que permitan trabajar juntos a los sectores gubernamental y no gubernamental (Valenzuela et al., 1998).
Siempre desde un punto de vista que enfatiza la dimensión política de la participación - es decir pensando que sus contenidos, procesos y actores deben ser políticos-, consideraremos a los actores identificados en la modalidad que llamamos "reemplazar" (es decir, organizaciones no públicas) sólo en la medida en que estén relacionadas con procesos políticos, como el diálogo para la toma de decisiones o la acción ciudadana en favor de necesidades de salud de la población; es decir, en tanto representen demandas de salud de distintos grupos y actores y no en su papel de proveedores de servicios.

Una implicación de este énfasis en lo político, es que el papẹl de los donadores se verá maximizado si los recursos aportados logran —ademástraducirse en resultados en el código de la esfera política. Uno de ellos es el avance en la adquisición de poder de los actores ubicados en los niveles más bajos de participación, la mayoría de los cuales son las mujeres y sus familias (Valenzuela et al., 1998). Pero, al mismo tiempo, esta adquisición de poder depende en gran parte de la obtención de resultados y beneficios concretos (calidad de servicios, respeto a derechos, etc.), por lo que deberá también evaluarse si la participación, además de los valores que la sustentan, es un medio efectivo para alcanzar metas de salud. Se ha argumentado que puede haber éxito en los servicios de salud sin participación comunitaria (Ugalde, 1987); no obstante, en procesos comprometidos con la democratización - aun en el plano del discurso- existe mayor apertura para algunas formas prometedoras de participación, como la colaboración entre organizaciones civiles e instancias gubernamentales. Si es cierto que las funciones propiamente políticas deben estar en manos de cuerpos legalmente constituidos - como por ejemplo las asambleas municipales-, la participación de organizaciones de la sociedad civil es clave en funciones de control, monitoreo y propuesta de temas a las agendas políticas. Pero la relación entre participación y calidad o equidad, no obstante, debe problematizarse y no darse por sentada.

La participación debe verse como un proceso por el que los interesados de todos los niveles incluyendo beneficiarios o sus representantesadquieren habilidades para dar cuerpo a la 
formulación e implementación de políticas públicas. Una vía para lograr esto es el fortalecimiento de las capacidades técnicas necesarias para que dichos actores se enfrenten a problemas de políticas; otra, la implementación de acciones que faciliten procesos donde los distintos interesados se reúnan en arenas politicas, formales e informales.

Como venimos planteando, el diálogo se da en la esfera política y alrededor de temas políticos. Por eso será importante evaluar las formas de participación posibles y viables en un contexto político concreto, y preguntarse:

- Qué tipo de descentralización se está llevando a cabo en el sector salud;

- Qué objetivos políticos persigue;

- En qué medida favorece la participación;

- Por qué elementos correctivos se puede abogar en el nivel central para que la participación sea efectiva;

- Qué formas de organización civil son posibles en este sistema;

- Qué probabilidades tienen de influir en las decisiones de salud;

- Cuáles son los canales de participación con mayores posibilidades de éxito para lograr metas de salud;

- En qué medida los representantes de la sociedad civil a su vez promueven la participación de las personas directamente afectadas por las políticas;

- Qué grado relativo de fuerza detentan grupos "progresistas" y "conservadores" para incidir en las plataformas partidarias y en la legislación sobre salud y

- Qué capacidades tienen los ciudadanos para convertir sus necesidades de salud en temas políticos, a través de la opinión pública.

Los cambios que puedan detectarse en las relaciones de poder (en especial la adquisición de poder por parte de los grupos antes marginados) serán indicadores de una efectiva participación.

Lo anterior puede permitir detectar aquellos puntos en los que haga falta fortalecer procesos de participación con capacidad de incidir en la arena de las políticas de salud y que involucren la mayor cantidad y variedad de actores interesados posible.

La pregunta entonces será cómo motivar y dotar a estos actores de capacidad de diálogo político, teniendo en cuenta los límites de la participación antes mencionados. Idealmente los actores sociales deberían adquirir valores políticos que favorecieran, por un lado, preferencias electorales acordes a sus intereses (circuito oficial) y por otro, posibilidad de organizarse de acuerdo a intereses específicos con capacidad de advocacy y/o presión (circuito alternativo). Pero hay que recordar que la capacidad de "tener intereses" está desigualmente distribuida y que donde esto no esté garantizado, deberán introducirse elementos que potencialmente favorezcan la participación.

Es probable también que la motivación para participar varíe de acuerdo a la forma en que la opinión pública en una sociedad ha construido los distintos "temas públicos". Aquellos que han sido construidos y son fácilmente percibidos como "peligros" - es decir, producto de causas incontrolables- pueden generar formas más fuertes de reciprocidad social que aquellos percibidos como "riesgos" - que son causados por decisiones voluntarias - ya que al introducir en la gente la noción de vulnerabilidad, el peligro crea la necesidad de solidarizarse con las víctimas reales y potenciales del mismo. A diferencia, por ejemplo, de la planificación familiar, el caso del VIH/SIDA podría ser uno de aquellos temas que transitan de la noción de riesgo (sólo afecta a quienes conscientemente se exponen a él) a la noción de peligro (puede afectar a cualquiera), lo que puede movilizar actores a niveles nacionales, locales y comunitarios y generar mayor compromiso. Esto encierra una contradicción que deberá resolverse: si bien los fenómenos "peligrosos" podrían generar mayor solidaridad social y menor discriminación hacia ciertos grupos que los "riesgosos", una campaña que enfatice una noción de peligro difuso o incontrolable podría opacar la importancia de los elementos de conciencia necesarios para promover cambios de comportamiento, fomentando conductas irracionales.

Algunos problemas frecuentes son la escasa capacidad de diálogo que tienen los distintos actores 
(civiles organizados o no organizados con funcionarios del sector público e incluso legisladores), ya que emplean códigos diferentes de comunicación. Muchos de los límites a la participación surgen de marcos legales inadecuados, por ejemplo, al otorgar pocas o nulas facultades para controlar recursos, $y$ con ellos sostener iniciativas de base en cuestiones de interés de la población. Por lo anterior, algunas recomendaciones pertinentes son las que siguen:

- Concientizar a los actores sobre marcos legales y cuestiones de presupuesto, lo que puede ser un paso para incrementar la capacidad tanto de advocacy como de "pedido de cuentas" a los representantes (electos o no) de la comunidad.

- Transformar las estrategias de confrontación (ya sea de los gobiernos locales hacia los centrales o de las organizaciones civiles hacia las gubernamentales) en estrategias de colaboración, donde cada uno de los actores se apoye mutuamente para fortalecer sus ventajas comparativas. Ciertas funciones son más eficientemente llevadas a cabo por los niveles centrales de gobierno (por ejemplo la planeación y coordinación de los programas de salud) mientras que otras (planificación de los servicios según necesidades locales) resultan más adecuadas si se realizan a nivel local.

- Detectar las ventajas comparativas de distintos actores, a distintos niveles, para fortalecer la colaboración entre ellos, en una estrategia de mutuo apoyo.

Es posible que sin la percepción de que efectivamente existe un proceso participativo a niveles amplios —y no sólo en relación con programas muy específicos - la población quede ajena a los procesos de descentralización. Por ello, siempre teniendo en cuenta el contexto particular de cada caso, se debería promover la descentralización al nivel del municipio, que hasta el momento parece seguir siendo el más favorable a esta percepción (Vaughan et al., 1984).

\section{CONCLUSIONES}

Nuestro propósito en este trabajo fue más el de revisar algunos supuestos comunes en la literatura sobre descentralización que el de ofrecer un nuevo marco conceptual sobre la misma, en su relación con la participación en el sector salud. Con ello obtuvimos una visión más compleja, pero más cercana a los procesos reales. Es así como vimos la necesidad de tener en cuenta que no necesariamente los procesos de descentralización están asociados a variables como democratización, participación, eficiencia, eficacia o gobernabilidad, y que siempre debe negociarse un acuerdo entre metas en conflicto.

Un ejercicio como el que hemos propuesto aquí —el de ver las posibilidades de participación que admite una forma particular de descentralización- facilita la tarea de saber no sólo qué procesos apoyar sino también por cuáles elementos "correctivos" se puede abogar para que la participación sea más efectiva.

También enfatizamos la necesidad de entender la esfera política de manera más amplia de lo que sugieren visiones corrientes, donde "el Estado" es lo propiamente político por oposición a "la sociedad" (tradicionalmente asociada con la esfera económica). Al mismo tiempo advertimos sobre las posibilidades, límites y canales de participación políticamente viables en ese contexto. Señalamos que entre estos clementos debe evaluarse, y en dado caso fortalecerse, la capacidad de los distintos actores interesados y/o afectados para formular temas políticos a partir de necesidades o demandas concretas.

Este énfasis en la importancia de la participación, finalmente, se propone más llamar la atención sobre la necesidad de reconstruir el tejido social de nuestras sociedades, que contribuir a la política de desestatización o privatización de la problemática social de la que el surgimiento de muchas iniciativas de participación social son resultado.

\section{REFERENCIAS BIBLIOGRÁFICAS}

Apthorpe, R. \& Conyers, D., 1982. Decentralization, recentralization and popular participation in developing countries. Towards a framework for analysis. Development and Peace, Vol. 3, autum.

Bazdresch, M., 1997. Política social desde abajo, una mirada complementaria. En: $A$ dos años. La 
politica social de Ernesto Zedillo (E. Valencia Lomelí, coord.). México DF: Red Observatorio Social.

Bronfman, M. \& Gleizer, M., 1994. Participación comunitaria: ¿necesidad, excusa o estrategia? O de qué hablamos cuando hablamos de participación comunitaria. Cadernos de Saúde Pública, 10(1).

Cabrero, E. \& Lira, J.M., 1992. Marco teórico-metodológico para el estudio de politicas descentralizadoras en México. México DF: Cide (documento de trabajo).

Cardozo, M., 1995. Análisis de la politica descentralizadora en el sector salud. Buenos Aires: Asociación de Administradores Gubernamentales / Ministerio de Cultura y Educación.

Collins, C., 1994. Management and organization of developing health systems. Oxford: University Press.

Collins, C. \& Green, A., 1994. Decentralization and primary health care: some negative implications in developing countries. International Journal of Health Services, 24(3).

Conyers, D., 1984. Decentralization and development. a review of the literature. Public Administration and Development, 4:187-197.

De Souza, H., 1995. A caminho do público e da democracia. Folha de Sao Paulo, septiembre.

Fuenzalida Puelma, H., 1990. Sistemas Locales de Salud. Revisión conceptual jurídica. En: Los Sistemas Locales de Salud (OPS, ed.). Washington DC: OPS, Publicación Científica No 519 .

Gawryszewski, V., 1993. Reorganizaçao dos serviços de saúde: Algumas consideraçoes acerca da relaçao entre a descentralizaçao, autonomia local e a participaçao do cidadao. Cadernos de Saúde Pública, 9(2).

Gobierno de Bolivia (Ministerio de Desarrollo Sostenible y Planificación), 1998. Trabajo presentado en el Seminario Internacional Marcos y Politicas para la Participación Cindadana a nivel municipal (intercambio de experiencias entre países del Mercosur, la Comunidad Andina e invitados especiales). Cochabamba, julio.
González-Block, M.A et al., 1989. Health services decentralization in Mexico: formulation, implementation and results of policy. Health Policy and Planning, 4(4).

Levi, L., 1991. Legitimidad. En: Diccionario de politica (N. Bobbio, comp.). México DF: Siglo XXI.

Luhmann, N., 1987. Political theory in the welfare State. Nueva York: De Gruyter.

McGirr, N. \& Smith, J., 1994. The decentralization of family planning programs: selected experience in Asia. Washington DC: Options II Project.

Mills, A., 1994. Decentralization and accountability in the health sector from an international perspective: what are the choices? Public Administration and Development, 14:281-292.

Mills, A.; Vaughan, P.; Smith, D. \& Tabibzadeh, I., 1990. Health system decentralization. Concepts, issues and country experience. Ginebra: WHO.

Modesto, P., 1997. Reforma Administrativa e Marco Legal das Organizagoes Sociais no Brasil. Texto presentado al II Congreso Interamericano sobre la Reforma del Estado y de la Administración Pública, organizado por CLAD-Centro Latinoamericano de Administración para el Desarrollo, Caracas, octubre.

Morris, A. \& Lowder, S. (eds.). 1992. Decentralization in Latin America. An evaluation. Nueva York: Praeger.

Oakley P. 1990. Intervención de la comunidad en el desarrollo sanitario. Examen de los aspectos esenciales. OMS, Ginebra.

Ochoa, H. 1998. La descentralización. Trabajo presentado en el II Taller Latinoamericano de Reformas al sector Salud organizado por El Colegio de la Frontera Sur (Ecosur), San Cristóbal de las Casas, Chiapas, México, octubre.

Ortega Lomelin, R., 1988. El nuevo federalismo. La descentralización. México DF: Porrúa.

Oszlak, O. et al., 1990. Descentralización de los sistemas de salud. El Estado y la salud. En: Los Sistemas Locales de Salud. Conceptos, métodos, experiencias (OPS, ed.). Washington DC: OPS, Publicación Científica No 519. 
Rondinelli, D. \& Cheema, S., 1983. Decentralization and development. Policy implementation in developing countries. Londres: Sage Publications/ UNCRD.

Roversi-Mónaco, F., 1991. “Descentralización (y centralización)". En: Diccionario de politica (N. Bobbio, comp.). México DF: Siglo XXI.

Silverman, J., 1992. Public sector decentralization. economic policy and sector investment programs. Washington DC: World Bank Technical Paper No 188.

Smith, B.C., 1985. Decentraliqation. The territorial dimension of the State. Londres: Allen \& Unwin.

Tehranian, M., 1982. Open planning: the uses of communications in participatory development. Development and Peace, Vol. 3.

Torres, B. (comp.), 1986. Descentralización y democracia en México. México DF: El Colegio de México.

Ugalde, A., 1987. Las dimensiones ideológicas de la participación comunitaria en los programas de salud en Latinoamérica. Cuadernos Médico Sociales, $\mathrm{N}^{\circ} 41$.

Valenzuela, T.; Feranil, I. \& Cross, H., 1998. Improving reproductive health and family planning through participation: three country case studies. The Policy Project (inédito).

Vaughan, P.; Mills, A. \& Smith, D., 1984. District health planning and management: developments required to support primary bealth care. Londres: London School of Hygiene and Tropical Medicine, EPC Publication No 2.

Weber, M., 1984. Economía y sociedad. México DF: Fondo de Cultura Económica.

Zetterberg, H., 1968. Teoría y verificación en sociología. Buenos Aires: Nueva Visión, Cuadernos de Investigación Social, Serie Tratados e Investigaciones. 


\section{TECNOLOGÍAS SANITARIAS EN EL CONTEXTO SOCIAL: UNA REFLEXIÓN BIOÉTICA}

Fernando Lolas Stepke*

\section{DeFinición DE TECNOLOGíA}

Defino tecnología como una técnica o un conjunto de técnicas más un contexto interpretativo que "da sentido" a su aplicación. Fiel a su etimología, desearía rescatar para la voz tecnología el significado de "logos de la técnica", aquello por lo cual el hacer normado y corregible por la experiencia adquiere la jerarquía de un saber-hacer. La tecnología, en verdad, es un hacer (técnica) "informado" por una racionalidad que lo explica, fundamenta y justifica.

La precisión no es trivial. En la medicina contemporánea siguen usándose técnicas antiguas. La palabra, la droga, el bisturí son elementos técnicos que conducen al virtuosismo de la experiencia cuando son bien y reiteradamente usados. Se integran a tecnologías complejas, a complejos de saber-hacer que en ocasiones se institucionalizan. Por ejemplo, el hospital moderno es un conglomerado de tecnologías. El psicoanálisis emplea las técnicas de la palabra en un contexto particular. Los diversos tipos de medicamentos representan formas compactas de tecnologías al servicio de finalidades específicas.

\section{Clasificación de las teCnologías}

Es posible clasificar las tecnologías desde diversos puntos de vista. Por ejemplo, atendiendo a lo que manipulan. Así, hay tecnologías productivas, orientadas a aplicar técnicas que producen "cosas" (objetos, servicios, procesos); las hay simbólicas, que manipulan signos y símbolos; las hay de procedimientos; existen las tecnologías del poder, consagradas a la distribución y administración de éste, y hay tecnologías del "sí mismo" (self), destinadas a la percepción de las personas. En este sentido, podría hablarse de tecnologías de la salud, si la salud pudiera concebirse como un manipulable simple.

Lo cierto es que la salud es un conglomerado de símbolos, rituales, sensaciones, capacidades y poderes. No se reduce a ninguno de estos elementos. Es, por así decir, la "forma" en que ellos se articulan para una persona en un momento determinado. La salud no es 'cosa', es construcción, proceso y aspiración de bienestar.

De allí que sea más aconsejable usar otra forma de clasificación de las tecnologías: atendiendo a aquello a que aspiran quienes las usan, a sus finalidades. La salud, como el bienestar, como la paz, es una aspiración perenne de la humanidad. Igual que otros "estados" deseables, las tecnologías de la salud no son capaces de producirla, sólo facilitan, promueven o favorecen su construcción por parte de las personas. Decir que "se da salud" es un manifiesto sinsentido. Aun gozando de todas las tecnologías posibles, una persona puede no sentirse saludable. Aun teniendo todo lo posible de tener, la construcción de la salud sigue siendo una tarea creativa e individual. De no reconocer su carácter esencialmente subjetivo derivan variedad de erróneas expectativas. Por ejemplo, creer que basta ofrecer recursos para que el estado de salud de la población mejore.

Fuera tal vez recomendable ensayar, para la medicina contemporánea, una muy simple caracterización de sus tecnologías. Es procedente hablar de tecnologías que salvan la vida, de tecnologias que conservan y prolongan la vida y de tecnologías que mejoran la

Médico psiquiatra con formación en medicina psicosomática, Alemania. Profesor titular y director del Departamento de Psiquiatría y Salud Mental, Facultad de Medicina, Universidad de Chile. E-mail: flolas@abello.seci.uchile.cl. 
vida. Obsérvese que, a diferencia de la salud, la vida es un radical menos relativo en lo que a su fundamento biológico concierne. Esto quiere decir que si la salud es construcción esencialmente individual y subjetiva, de la vida puede predicarse un orden descriptivo heterónomo: puede ser determinada o estimada por observadores externos. De allí que la utilidad de esta clasificación de tecnologías sanitarias sea aplicable a la biomedicina más estrictamente "tecnocientífica", si bien ya la categoría de tecnologías que mejoran la vida hace entrar el ámbito valorativo en lo que de otro modo parece un dato inequívoco y neutral.

A las anteriores tecnologías, todas "duras" y relacionadas con equipos e instrumentos, debe agregarse la tecnologia de la administración y la gerencia. En los últimos decenios ésta, no aquéllas, ha determinado más sustantivos cambios en el acceso a recursos y bienes. Es una tecnología tanto más poderosa cuanto que intangible. Parece de sentido común, pero sentido común estilizado por la tecnificación.

\section{Significado DE LAS TECNOLOGías}

\section{SANITARIAS}

La veneración por la técnica no solamente ha influido en el desarrollo de la institución social llamada medicina. La ha transformado por completo. Al integrarse en tecnologías poderosas, las viejas técnicas han sufrido una importante transformación. Sus significados han variado, su valor se ha alterado. La tecnología, de medio se ha convertido en fin. Muchos desarrollos actuales no reconocen como motivación el servicio a las personas o la mejora de su estado de salud. Reconocen como origen, en realidad, la propia dinámica del sistema tecnocientífico, que ya no necesariamente sirve a los fines que lo originaron sino a otros, creados por él mismo. Las nuevas maquinarias se modifican por exigencias cada vez mayores de expertos cuya finalidad es la perfección inherente a su oficio además de la salud y bienestar de las personas. A ello debe agregarse que la "salud" se ha convertido en pretexto comercial, y empresas que dicen dedicarse a ella a veces son negocios lucrativos que la emplean como una materia prima más. La transforman en símbolo de estatus, en "commodity", la exageran y la recubren de servicios accesorios por los cuales puede cobrarse.
Estas consideraciones tienen relevancia al momento de indagar sobre los significados de las tecnologías. Éstos son múltiples. Esa multiplicidad debe tenerse presente en toda evaluación de su impacto. Por ejemplo, la instalación de una nueva tecnología de monitoreo coronario, en la actual medicina de mercado, no siempre responde a un imperativo técnico. Es concebible que éste se acompañe de consideraciones simbólicas y que la asociación con el poder tenga mucho que ver con decisiones relativas a "avances" médicos. Especial significación revisten los aspectos simbólicos de las tecnologías en trances vitales. Un sistema de hidratación parenteral en un enfermo terminal, por ejemplo, despierta asociaciones con la sed y el trato humanitario y en este caso la tecnología no sólo salva la vida sino también contribuye psicológicamente a la sensación de que se hace algo importante por otro ser humano. De modo parecido, algunos avances técnicos no se traducen necesariamente en mejor atención sanitaria global. Acceder a ellos queda limitado por motivos económicos o geográficos. Bajar el "umbral tecnológico" de detección de patologías lleva a rotular de "enfermedades" condiciones asintomáticas que en el pasado no hubieran sido reconocidas como tales. Una prueba determina, por ejemplo, que alguien tiene elevada presión sanguínea y de inmediato esa persona, por los riesgos de su condición, queda rotulada de enferma. Un caso interesante es la evaluación de los lípidos sanguíneos, cuyo resultado obliga a modificaciones del estilo de vida en ausencia de síntomas que pudieran rotularse de amenazadores.

\section{LA PROFESIÓN MÉDICA Y LAS TECNOLOGÍAS}

La tecnificación de la biomedicina es uno de sus rasgos más distintivos. Ese proceso ha creado, literalmente, la profesión médica como profesión tecnológica, depositaria de un saber-hacer único y administradora de la "norma fisiológica", que se equipara a la normalidad. La absorción del ideario técnico significa además la admisión de un saber cosmopolita, neutral y de validez universal, atributos que se identifican con la "ciencia médica".

No siempre se discute con suficiente extensión lo que ello implica. Implica, por lo pronto, una 
racionalidad tecnocrática que evalúa los logros en una comunidad de "expertos" que ya no son los "pacientes". La "salud" de éstos sigue invocándose como el motivo del desarrollo, pero en realidad el investigador de frontera, el diseñador de nuevos equipos o el inventor de artefactos tienen, además de la motivación benefactora, otras relacionadas con el prestigio, el dinero y el poder asociados al desarrollo tecnológico. Sus interlocutores no son sólo los usuarios finales de sus creaciones sino sus pares en la ciencia y la industria.

La dinámica del progreso es más compleja que una simple oferta de servicios para solventar "necesidades". Una discrepancia observable es el divorcio entre el lenguaje de la "oferta" y el lenguaje de la "demanda", evidente en los países avanzados y que dio lugar, sucesivamente, a las "crisis" de la medicina: la que introdujo la psicología y las ciencias sociales y la que introdujo la bioética, por sólo citar dos evidentes. En ambos casos se trató de movimientos rectificadores que intentaban hacer frente a la insatisfacción de las personas con los servicios médicos recibidos y a la necesidad de hacer "humano" el progreso técnico. En ambos casos la filotecnia fue atemperada por la filoantropia, adornada con reminiscencias, probablemente idealizadas, de antiguas prácticas médicas "holísticas" o integrales.

\section{LA "BRECHA EPISTÉMICA" Y LA "ILUSTRACIÓN TECNOLÓGICA"}

La actual situación se caracteriza además por una brecha epistémica. Llamo así a la desigualdad en la información que poseen los expertos y los usuarios de las tecnologías. Es imposible para un profano imaginarse siquiera qué relevancia tiene y cuál es la base conceptual de la resonancia nuclear magnética aplicada al diagnóstico. Distintas audiencias no entienden lo mismo bajo similares palabras y el diálogo es ilusorio, lo que incide sobre materias tan cotidianas como el "consentimiento informado" o la "demanda de atención".

Hay una desigualdad justa en la información, que define los papeles sociales del experto y del profano y hay una desigualdad injusta - una inequidad- que se agrega a ella. En esta segunda forma, lo que todos debieran saber para cuidarse a sí mismos lo ignoran por insuficiente acceso al conocimiento. El conocimiento no sólo es información sino ante todo información organizada y con sentido. La disparidad en el conocimiento hace que las exigencias de las personas sean irreales a veces, inapropiadas otras y queden insatisfechas en numerosas ocasiones.

Sin duda, el uso correcto de las tecnologías exige una "ilustración tecnológica" de las comunidades, no solamente una "humanización" de los expertos y sus técnicas sino también una comprensión más cabal de las tecnologías, sus usos y sus limitaciones. De otro modo, se corre el riesgo de crear falsas esperanzas, pedirle a la tecnología algo que no puede dar e incubar frustración y resentimiento, primero por su inaccesibilidad y luego por su parcial irrelevancia frente a las demandas de la gente. No debe olvidarse que la "eficacia" no es valor absoluto sino relativo y que depende de factores tanto técnicos como simbólicos. Por ejemplo, no toda técnica que produce efectos es una técnica terapéutica. Para rotularla de tal previamente debe identificarse qué permitiría cualificarla en tal sentido. Aunque ello puede ser sencillo en algunos casos, en otros justifica una neta separación entre efectos buscados y efectos laterales, entre beneficios y costos, entre lo deseado y lo producido.

La brecha epistémica llama la atención a que el conocimiento no es una simple acumulación de informaciones sino articulación de éstas en cuerpos significativos, con sentido e interés interpersonal. Saber es participar de un conjunto de personas que otorgan el mismo significado a los signos y símbolos que intercambian. Si bien puede decirse que los elementos para construir conocimientos se encuentran hoy disponibles más fácilmente, el conocimiento en tanto que información articulada es un logro de obtención más difícil, toda vez que involucra dar sentido a lo sabido en un plexo de intereses sociales. Ello implica cualificaciones propias del grupo que corporiza tales intereses. Así, "saber de" SIDA no es lo mismo para un epidemiólogo que para un virólogo y por cierto es diferente para un enfermo. Aun cuando todos tuvieran, aparentemente, la misma "información" (por ejemplo, que el virus exhibe formas mutantes) le darían distinta importancia. La información "significaría" algo distinto para cada uno de ellos. 


\section{"USO APROPIADO" DE LAS TECNOLOGÍAS}

La correcta valoración y el uso "apropiado" de las tecnologías son en realidad procesos sociales más que técnicos. La misma distinción entre medios "ordinarios" y "extraordinarios", que tanto relieve alcanza en el tratamiento de los moribundos, tiene validez según el contexto y la circunstancia y relativiza el concepto de "avance técnico". No todas las mejoras instrumentales pueden considerarse automáticamente avance o progreso si no son empleadas con sentido de la prudencia y la oportunidad. El reto que hoy plantean las tecnologías no es cómo tener más sino cómo tenerlas mejores, esto es, más adecuadas al fin que se supone sirven.

A estas consideraciones, que suponen un empleo de la razón con orientación de prudencia, cabe dar el nombre de Ilustración tecnológica. De no diferente forma, la Ilustración europea significó el uso de la razón para dar cuenta de los usos de la misma Razón. Por sobre todo, significó y significa una confianza en la mente humana universal para abordar los dilemas de las circunstancias y para hacer frente al "caso", siempre distinto y siempre problemático, con principios generales y eternos. El tecnócrata embelesado por los logros de sus artefactos puede necesitar cierta dosis de modestia para limitar la arrogancia. El ciudadano común y corriente precisará algún conocimiento de las limitaciones de las técnicas para moderar el asombro. $\mathrm{Y}$ todos necesitarán reflexionar sobre la equidad y la justicia para adecuar las expectativas a lo que legítimamente puede esperarse.

La conclusión que se impone: no hay tecnologías necesariamente apropiadas a una circunstancia. Puede haber usos apropiados. Definir éstos es materia de conocimiento prudente, de razonable expectativa, de adecuado consenso sobre fines y medios.

\section{Moral y teCnOLOGÍA}

Es un desafío importante posibilitar el consenso sobre los usos. Las diversidades entre los grupos que componen las sociedades contemporáneas no derivan solamente de los distintos conocimientos que tienen o construyen ni del acceso diferente que tienen a las informaciones. Derivan también de las distintas creencias y valores morales que las personas, como miembros de tales grupos, emplean para guiar sus comportamientos.

De hecho, los usos apropiados dependen críticamente del factor moral. Conocidos son los casos en que una persuasión religiosa o ideológica impide a sus adeptos aceptar ciertas intervenciones terapéuticas (Testigos de Jehová con relación a transfusiones sanguíneas), realizar ciertas actividades en determinados días (judíos y adventistas), aceptar determinados alimentos o emplear técnicas que limitan la natalidad. La confesionalidad puede derivar hacia el fundamentalismo y éste hacia el fanatismo cuando los seguidores de un credo intentan imponer sus dictámenes a quienes no lo comparten. Los creyentes, cuando son mayoría, suelen ignorar a las minorías. Cuando son minoría, resistir e inmolarse o luchar y sobrevivir.

En realidad, lo que llamamos uso apropiado no se determina solamente por el mérito instrumental, que es su propiedad (o "corrección") técnica. Sin duda, hay que agregar la propiedad o corrección social, que es el mérito moral. La misma acción puede ser apropiada en lo técnico e injusta en lo social. Lo inverso, aunque ocurre, no debiera ser considerado moralmente aceptable. Nada hay que justifique una intervención técnicamente inadecuada, ni siquiera el argumento de que así se la hace más accesible. Dar, por ejemplo, un medicamento de baja calidad a la población simplemente porque su precio es bajo, viola el viejo principio hipocrático de que para ser un médico bueno bay que ser antes un buen médico. En la raíz misma de toda ética (como uso social razonable y apropiado) se encuentra el imperativo técnico. El "hacer bien" debe anteceder a todo intento de "hacer el bien" y nada releva al profesional de cuidar que su arte sea el más escrupuloso y el mejor para las circunstancias concretas.

Obsérvese como la intención beneficente de difundir algunas técnicas y tecnologías puede ser inmoral. Ocurre cuando ellas tienen dudoso fundamento o son manifiestamente inútiles e inadecuadas. Mas también debe tenerse presente que para establecer si algunas tecnologías son útiles o inútiles, ellas deben ser examinadas científicamente. 
La investigación empírica en salud enfrenta en alguna de sus etapas la necesidad de ensayos en individuos humanos o animales.

Ello plantea la necesidad de examinar el mérito cientifico de toda intervención, especialmente en las etapas previas a su aplicación, en las fases de desarrollo y prueba. A menudo ocurre que una idea apropiada no se convierte en un buen proyecto de investigación científica porque faltan eslabones argumentales o de información. Sin embargo, la misma intención benefactora que preside la investigación en medicina debe obligar a los responsables de evaluar proyectos a considerar, junto al mérito instrumental y al mérito moral, el científico, esto es, la fertilidad potencial de un proyecto para incrementar el conocimiento. A veces, un proyecto orientado en una dirección arroja informaciones que son relevantes para otra. El azar, cuando es metódico y está correctamente usado y valorado, es valioso en las ciencias y puede producir conocimientos inesperados. Como sólo se hacen visibles al ojo y la mente bien preparados, es imperativo moral de los científicos hacer bien lo suyo: inventar útiles realidades, estar vital e integralmente involucrados con su tarea, conjurar lo invisible. Sólo de esa manera el conocimiento aún no disponible pasará a estarlo y se hará útil.

El examen de toda propuesta tecnológica en salud comprende por lo tanto al menos tres aspectos: el instrumental, el socialy el científico. Sólo de la prudencia de los profesionales depende el justo balance entre ellos. Una perfecta tecnología, que cumple a cabalidad el propósito para el cual fue creada, si beneficia sólo a algunos, puede no ser una buena opción para una comunidad pobre. Una mediocre tecnología, aunque llegue a todo el mundo, nunca debe ser la respuesta a una demanda social. Una conciencia vigilante sobre usos alternativos o complementarios de las tecnologías disponibles debiera ser un imperativo moral para los expertos.

La unilateral preponderancia de cualquiera de estos aspectos constituye causa de efectos dañinos de las tecnologías. No todo lo que se puede hacer debe hacerse. Lo factible no se constituye de inmediato en lo obligado y, menos aún, en lo legítimo. La paradoja inherente al saber-hacer profesional es justificarse socialmente por la prudencia (phronesis), que también puede aconsejar abstenerse de hacer algo o hacerlo de modo distinto a como prescriben los tratados de otras latitudes. Lo que es usual en Manhattan puede no serlo en Chillán. El modo como se emplean las jeringas desechables puede no ser igual en todo lugar. La infalibilidad del conocimiento universal y necesario de las "leyes naturales", en el campo de la práctica, debe modularse por la prudencia.

El mérito técnico o instrumental se refiere a obtener resultados deseados en una forma correcta. El mérito científico alude a la potencial expansión del conocimiento que una técnica o tecnología permite. El mérito social permite apreciar la justicia y la equidad de las intervenciones. Estas tres dimensiones deben ser evaluadas en el contexto de las relaciones sociales en y por las cuales existen las tecnologías. Tales relaciones se modifican a tenor de los contextos en que ocurren. Así, determinadas instituciones imponen usos, modelan y modulan intervenciones, prohiben y prescriben. No es igual el significado y el uso del instrumental en un hospital sofisticadamente equipado que en un consultorio rural. La profunda desazón que experimentan algunos profesionales se debe a veces a que, si bien fueron preparados en una atmósfera de aplicaciones tecnológicas, la realidad que enfrentan en su práctica profesional es distinta y las demandas que reciben no se adaptan a las ofertas que proveen. La acrítica imposición de modelos cosmopolitas y supuestamente universales a la profesión médica produce frustración y desesperanza entre aquellos profesionales que no ven cabalmente realizadas sus posibilidades en la práctica. Pensar en grande, actuar en pequeño. Saber global, aplicación local. E1 verdadero arte de la investigación científica (observando las prácticas exitosas) parece consistir en convertir grandes ideas en pequeñas acciones. El ejercicio prudente de cualquier profesión implica lo mismo: adoptar y adaptar, modificar, traducir, cambiar.

\section{LOS RIESGOS DE LAS TECNOLOGÍAS}

Incompleta quedaría toda presentación de la racionalidad tecnológica en salud si no abordara, así sea brevemente, el problema de los riesgos. 
Los riesgos son problemas o peligros en potencia, esencialmente anticipables y prevenibles. Fue de estilo en una cierta época del siglo XX, y sigue siéndolo hoy para algunos grupos, abominar la tecnología, execrar su uso y demandar un retorno a lo "natural". Probablemente, los abusos han sido causantes de esta postura que pide limitar los usos. Es posible que en ello intervengan la confusa percepción de que las tecnologías contemporáneas han pasado de ser medios a convertirse en fines, alentadas por la racionalidad pecuniaria y la óptica del mercado que las obliga a crecientes perfecciones en sus propios términos y las excluye de considerar las primitivas motivaciones para su desarrollo y empleo. Esto es evidente no solamente en las tecnologías relacionadas con la salud y la vida sino en prácticamente todos los campos, al punto que puede afirmarse que la autonomía del sistema tecnocientífico no es excepción sino regla.

Uno de los riesgos más conspicuos es el uso imprudente. Puede derivar de no considerar suficientemente la circunstancia de aplicación. Así, una pesquisa masiva en una población, con cualquier método diagnóstico, esconde siempre la posibilidad de casos "falsamente positivos" y "falsamente negativos". En ellos la condición subyacente no es adecuadamente reflejada por el método.

Evidentemente, especificidad y sensibilidad de los procedimientos son asuntos técnicos que a los especialistas compete prever y resolver. Sin embargo, existe una responsabilidad inherente a difundir las informaciones y sobre todo en lo relativo al significado que se les atribuya. Los practicantes de oficios sanitarios, médicos, enfermeras, matronas y otros profesionales, suelen confiar en los líderes de opinión para la apreciación de las tecnologías nuevas o escasamente aplicadas. Un uso masivo e imprudente de una prueba diagnóstica de resultados imprecisos podría generar informaciones irrelevantes u obligar a intervenciones curativas o preventivas costosas o inútiles. Al bajar el "umbral de detección" de condiciones mórbidas gracias a la tecnología, los especialistas deben saber que ello implica una responsabilidad adicional, cual es la de atribuir correctos significados a los datos que generan. Tal es en efecto un riesgo del uso diagnóstico de las tecnologías: la mala interpretación de los resultados.
También puede ser imprudente el uso de tecnologías terapéuticas. El furor therapenticus, emplear masivamente todos los recursos disponibles aunque se manifiesten ineficaces, puede constituir un verdadero peligro, sobre todo porque puede no estar racionalmente fundamentado sino obedecer al anhelo de calmar la propia angustia del terapeuta o prevenir posibles acciones legales en su contra.

En muchos casos, la disponibilidad de un recurso tecnológico impulsa a usarlo. Debe recordarse que disponibilidad no es legitimidad de su empleo y que solamente la prudencia profesional puede equilibrar el uso. Es verdad que todo practicante concienzudo desea trabajar según el "estado del arte" y, de hecho, no respetarlo puede ser causa de acusación de mala práctica. Sin embargo, el practicante prudente puede decidir si la demanda se ajusta a lo disponible. El meollo del argumento es que no siempre la existencia de una técnica o una tecnología obliga a su uso.

Es un riesgo también la veneración irrestricta por la racionalidad tecnocrática, que debe contrastarse siempre con el horizonte de libertad que toda ética - religiosa o secular - inspira y proclama. La tecnificación de las relaciones humanas, la reducción de los procesos sociales a técnicas, el imperio de la necesidad mecánica, pueden conducir a esa curiosa "discrasia valórica" que muchos perciben en la contemporaneidad. Esa "mala mezcla" de libertades extremas con sujeciones brutales - las paradojas de la vida en ciudades atiborradas de incitación pero peligrosas en lo cotidiano- debe su origen, en alguna medida, a reemplazar la espontaneidad de la vida con la rigidez de lo mecánico. Al convertirse el mecanismo en la metáfora fundante de los usos sociales suele perderse la capacidad de disentir, la posibilidad de cambiar y la creativa presencia de la transgresión. Se pierde además la intimidad de lo privado, reducto último de la individualidad y la dignidad.

En el propio sistema tecnocientífico, tal como se ha desarrollado en tanto conjunto de relaciones sociales, existen riesgos y peligros. Ya hemos mencionado uno: la tendencia a la autonomía. Al segregarse de las motivaciones de la sociedad mayor, el sistema tecnocientífico deja de responder a las 
demandas que inicialmente lo generaron. Se replica a sí mismo, responde a sus propias necesidades, busca su propia perfección.

Otro riesgo es que la consecución del ideario tecnocrático entraña la producción infinita de bienes, los que por la dinámica de su producción exhiben dos caracteres: por una parte, son inaccesibles para algunas personas y por otra, llevan en sí el germen de su propia obsolescencia. El sistema técnico como productor de bienes y servicios alentado por el mercado crea productos a los que es necesario hacer deseables y necesarios y por ende reservados a algunos individuos. Su supervivencia depende de que ellos sean perecibles y entren en obsolescencia para que la necesidad se renueve constantemente. Estos dos atributos, unidos a la autonomía de facto del sistema, generan complejos de problemas cuando se intenta vincular la tecnología, la salud y la moral.

\section{CONSIDERACIONES FINALES}

Esta presentación ha contenido una definición de tecnología adecuada al cuidado de la salud y la vida, una descripción de posibles taxonomías y una discusión de las más pertinentes para el análisis del campo sanitario, un examen de los méritos de las tecnologías y una reflexión sobre la prudencia profesional en su aplicación.

Aunque quedan sin desarrollar líneas importantes de pensamiento, el centro de esta presentación está dado por la noción de "saberhacer" como núcleo de las tecnologías relacionadas con la salud y como expresión concreta de ellas, concebidas como técnicas más contextos de significado e interpretación.

Para una apropiada valoración y empleo de las tecnologías en salud se hace preciso advertir la "brecha epistémica" que existe entre distintos grupos sociales y la necesidad de una "ilustración tecnológica" de toda la sociedad, enseñando las dimensiones sociales y por ende morales incorporadas a todo uso apropiado de las tecnologías.

Los riesgos de las tecnologías derivan de la "autonomización" del sistema social que las sustenta (sistema tecnocientífico), de la veneración irrestricta y del uso imprudente. La técnica, con un mandato social emancipador, puede convertirse en sujeción si no es correctamente administrada mediante la ética, que como uso social, costumbre o carácter, la hace humana y servicial. 
VII

NUEVOS Y ANTIGUOS RIESGOS 


\section{ESTRATEGIAS DE INVESTIGACIÓN RELACIONADAS CON LA VIOLENCIA Y LA PRECARIZACIÓN DEL TRABAJO}

Carlos Minayo-Gómezy Sonia Maria da Fonseca Thedim-Costa*

El nuevo paradigma de producción industrial trae en su savia profundas transformaciones en todos los sectores de la economía. Entre sus secuelas, emergen, más allá de las evidentes, como el aumento del desempleo y el acelerado crecimiento del sector informal, también las que se traducen en la intensificación de patrones ilegítimos de tercerización y subcontratación.

El debilitamiento y la ruptura de los vínculos laborales han llevado a amplios sectores de la población hacia un trayecto de inseguridad, donde la convivencia con lo provisional pierde su carácter circunstancial. Se forma, incluso en un contexto adverso, un proceso de desestructuración/ reestructuración de identidades históricamente generadas en torno al trabajo. A este marco de degradación de las condiciones de trabajo y de vida, se le agrega la ausencia del Estado en la formulación y ejecución de políticas y estrategias de protección social.

Con el fin de descubrir las distintas implicaciones que tienen sobre los individuos y grupos arbitrariamente subyugados por ese nuevo problema social, desarrollamos una línea de investigación de corte cuantitativo y cualitativo, en el ámbito específico de Río de Janeiro, enfocada a caracterizar e interpretar el impacto de algunas de las caras de la precarización en la salud.

Se parte de la constatación de que la informalidad, la precarización del trabajo y el desempleo en masa y de larga duración, estarían inscritos en las profundas transformaciones del modelo económico proveniente de la reestructuración productiva, de la integración mundial de los mercados financieros, de la internacionalización de las economías, de la pérdida de regulación y la apertura de los mercados con la ruptura de las barreras proteccionistas. Sus consecuencias sociales vienen afectando, de forma acelerada y diferenciada, sobre todo en la última década, a amplios sectores de la población trabajadora. Estos cambios, diferentes en grado y extensión entre países y dentro de los mismos, generan permanentes incertidumbres, nuevas tensiones y profundización de las desigualdades sociales y de la exclusión social.

Esa degradación de las condiciones materiales de vida, de las formas de reproducción, aliada a la ausencia de mecanismos de protección social y a la desestructuración/reconstrucción de identidades generadas en torno al trabajo, configuran, en su complejidad, la nueva cuestión social.

La violencia en las grandes metrópolis, expresada en formas y espacios distintos, viene a agravar el conjunto de contradicciones de la vida contemporánea, constituyéndose otro de los efectos nefastos de esas transformaciones. Las repercusiones para la salud, de distinta naturaleza, se sitúan en el cierne de esta problemática que afecta a los trabajadores todavía insertos en el mercado formal, sobre todo los tercerizados, pero se refleja particularmente en el gran contingente de excluidos y en los segmentos más vulnerables del mercado informal, en continua expansión. Entre éstos, los que ejercen actividades de gran impacto en las tasas de morbimortalidad, no contempladas en los estudios sobre trabajo informal, por razones que van desde la falta de reconocimiento social hasta su carácter de ocupación al margen de la legalidad.

Frente a la dificultad de captar y estimar las dimensiones de esas implicaciones con el instrumental habitualmente utilizado, se invirtió en la construcción y operacionalización de estrategias metodológicas

Cesteh/Fiocruz. 
capaces de posibilitar la obtención de un cuadro más aproximado de los agravios a la salud, concebidos en su amplitud, pero en particular relacionados con el trabajo y con el no-trabajo.

Para ello, se recurrió a fuentes de información que, pese a sus limitaciones, permiten sobrepasar las estadísticas de la seguridad social, reconocidamente incompletas y restrictivas. De forma paralela, fueron desarrollados, en grupos determinados, estudios empíricos, de carácter cualitativo, que además de ampliar la base de información, revelan un conjunto de significados atribuidos por los sujetos a la relación entre la especificidad de su trabajo y los daños sufridos.

\section{PreCARIZACIÓN DEL TRABAJO}

El movimiento de globalización económica se caracteriza por la gran movilidad de masas de capitales, por el crecimiento de corporaciones transnacionales y por el predominio de las inversiones en el ámbito financiero, donde se da la mayor valorización del capital, incluso por corporaciones industriales o de servicios.

Los flujos financieros mundiales son de tal orden que corresponden en la actualidad a aproximadamente 78 veces más de los recursos aplicados productivamente (Pochmann, 1999). En consecuencia, se acelera la internacionalización de las grandes decisiones — de las cuales el trabajador en tanto actor social, ha sido sistemáticamente separado- con la concomitante reducción del papel de los Estados nacionales en la obtención de los recursos tributarios y en la formulación efectiva de políticas.

Por otra parte, los imperativos del crecimiento económico y de la competitividad del mercado rigen la alteración radical del paradigma productivo. Una lógica de flexibilización de las estructuras productivas y de las formas de organización y división social del trabajo intra e interempresarial intensifica el fenómeno visible de la fragmentación y de la dispersión de los procesos productivos por varias naciones, a través de filiales, empresas proveedoras, subcontratadas. Más allá de contemplar el aprovechamiento más eficiente de las tecnologías y materias primas existentes para un mercado consumidor global, se implanta también un proceso de flexibilización de la fuerza de trabajo.

De acuerdo con las conveniencias y coyunturas locales, se establecen varias formas de contratación: desde vínculos estables dentro de los cánones convencionales o con diversos niveles de precarización, que conforman los denominados empleos atípicos (Caire, 1997) -tercerizados, temporales, de tiempo parcial, por tareas-, hasta la utilización de la mano de obra familiar, lo que conduce a una alternación entre empleo y no-empleo.

Las críticas a la rigidez del modo de producción fordista, considerada factor limitativo de crecimiento, justifican la tendencia de exacerbar una flexibilización, fundamentada en dos premisas concomitantes e interligadas. Por una parte, se fomentan variables de productividad, buscando la calidad total de los procesos y productos. Asimismo, se incrementan las innovaciones tecnológicas como elementos clave para enfrentar la competencia mundial o se realizan reformas organizacionales sin inversión sustancial en nuevas tecnologías, con la idea de obtener los mismos resultados a costos más reducidos. Teniendo como foco las demandas del cliente y las fluctuaciones del mercado, se adopta la estrategia de obtener productos de calidad, en un corto plazo de tiempo, aunada a políticas de entrenamiento, de capacitación profesional y de protección social, que redunden en el perfeccionamiento de la organización del trabajo, con profesionales de elevado nivel de formación y remuneración. Por otro lado, se establecen contratos precarios de trabajo y subcontrataciones en cascada, caracterizados por una externalización de riesgos y responsabilidades, con reducción de salarios y de empleos.

La circulación mundial de capitales productivos se basa fundamentalmente en el potencial del mercado, de los recursos naturales, de la capacitación estratégica y de la búsqueda de eficiencia a través de inversiones en investigación y desarrollo en los países avanzados. Los capitales productivos se dirigen, entonces, hacia zonas con altas condiciones de comercialización e infraestructura de comunicaciones, así como de mantenimiento de equipos sofisticados y, además, donde la fuerza de trabajo, pese a ser cara, está altamente calificada, es 
polivalente y poseedora de una gran cantidad de habilidades para adaptarse a las fluctuaciones de la demanda. En contraposición, desarrollan también grandes inversiones en regiones donde el trabajo es barato, con menor contenido tecnológico, pero con una utilización intensiva de materia prima y mano de obra.

Ese cuadro de reestructuración de las empresas y de los sistemas productivos, incuestionable desde una óptica puramente económica, acarrea un pesado gasto, expresado, en última instancia, en la precarización y en la exclusión social, fuentes de alimento de la violencia actual. Una precarización que afecta no sólo a las poblaciones consideradas como vulnerables, sino a la sociedad en su conjunto, aunque de manera diferenciada, muchas veces bajo el eufemismo de nuevas formas de trabajo. Esta figura semántica - que revela aparentemente un avance en los parámetros tradicionales de ejercicio profesionalesconde, no obstante, la reducción de los puestos de trabajo y la fragilidad de nuevos arreglos laborales, como la oferta de empleos a tiempo parcial o de duración eventual; las limitaciones en la absorción de fuerza de trabajo joven, incluso calificada; la inestabilidad e irregularidad ocupacionales; el subempleo y el desempleo recurrente, duradero y sin perspectivas de inclusión en el mercado formal; las dificultades de inserción de mano de obra no calificada y los rendimientos decrecientes para una buena parte de las poblaciones ya empobrecidas.

La precarización económica y la regresión social convergen con la omisión del estado en funciones fundamentales en el ámbito del trabajo y de la protección social. En este contexto, se cuestiona la legitimidad de un Estado que, pautado por la racionalidad del orden económico dominante, se ausenta de la redefinición de las reglamentaciones contractuales y salariales anteriores y ni siquiera consigue desempeñar su papel en la compensación de las desigualdades y fragilidades sociales, así como en la reparación de las injusticias. Un Estado que, frente al enorme contingente del moderno "ejercito industrial de reserva" generado por el desempleo en masa, ofrece, cuando mucho, alternativas de reinserción circunstanciales negociadas con las empresas, por medio de incentivos financieros y reducción o exención de encargos sociales.

\section{LA NUEVA CUESTIÓN SOCIAL}

Nos encontramos hoy delante de la nueva cuestión social, cuya amplitud y centralismo se asemeja a la suscitada por la precariedad de la primera mitad del siglo xIX, como bien ha señalado Castell, para quien:

...en el momento en que los atributos vinculados al trabajo para caracterizar el estatus que sitúa y clasifica un individuo en la sociedad parecían haberse impuesto de manera definitiva, en detrimento de otros soportes de la identidad, como la pertenencia familiar o la inscripción en una comunidad determinada, que ese centralismo del trabajo está brutalmente colocado en cuestión en tanto sentido de la experiencia humana, incluso como factor asociado en el crecimiento ¿Habremos llegado a una cuarta etapa de una historia antropológica de la condición del asalariado, etapa en que una odisea se transforma en drama? (Castell, 1998:495-496).

La precarización, el no-trabajo, es más que desempleo. Como avala el propio autor, evocando a Hannah Arendt, incluso sin desconocer el frágil equilibrio de las décadas precedentes, se trata de la reaparición de un perfil de "trabajadores sin trabajo", los cuales ocupan en la sociedad, literalmente, un lugar de supranumerarios, de "inútiles para el mundo", que viene a engrosar el contingente poblacional, a veces "funcional", de las "masas desarraigadas" de los grupos "considerados superfluos" (Arendt, 1990), sin espacio en la vida económica, en la producción de bienes y servicios, y con reducidos derechos sociales y humanos. Una fuerza de trabajo atomizada, desprotegida socialmente, de cuyo infortunio nadie parece ser responsable, restándole apenas soluciones individuales. Esa fragilización o ruptura de vínculos comporta privación económica y se revierte en un profundo aislamiento.

El sentido de solidaridad que caracterizaba a los movimientos de trabajadores organizados está en declive. Las negociaciones colectivas se vuelcan prioritariamente a los trabajadores del cuadro funcional de las empresas, y las reivindicaciones tienen como foco central el mantenimiento del empleo y el posicionamiento frente a las propuestas de reducción de la jornada de trabajo, con la consecuente disminución del salario como alternativa de 
incorporación, bajo contratos precarios, de mano de obra desempleada.

Actualmente cuestionar la explotación económica que sufre el trabajador-mercancía por los modelos tayloristas y fordistas de producción, se ha vuelto anacrónico frente a la necesidad de mantener el empleo y de la urgencia de formular estrategias que propicien la inserción, sin mayores indagaciones, de segmentos de la población desempleada o con situación laboral precaria.

La vulnerabilidad inherente a las diversas caras de la precarización tiene como resultado final el desempleo recurrente y la exclusión social. Una exclusión caracterizada por "...trayectorias de debilidad de los vínculos sociales hasta una ruptura completa, atravesando 'terrenos' de disociación o desvinculación. Entre el inicio de la trayectoria y la ruptura total, existen situaciones (o zonas) intermedias de rupturas parciales de los vínculos, eventualmente reconstituidas a partir de la creación de nuevos vínculos más o menos infames” (Escorel, 1998:67).

En los países centrales, los mecanismos públicos de bienestar, así como las redes de protección social, suavizan estas situaciones e impiden, en cierta medida, que la exclusión social se realice en todo su potencial disgregador. En los países periféricos, como por ejemplo Brasil, su principal dimensión es la continua y creciente aproximación del empobrecimiento.

La exclusión social, en su configuración multifacética, se manifiesta en la sustracción de derechos humanos fundamentales, como el trabajo regular, dignamente remunerado, y la educación formal progresiva de niños y adolescentes obligados a ingresar de manera precoz y precaria al trabajo. Implica la negación de la equidad, de la justicia y de la ciudadanía, dando origen a un amplio abanico de categorías de exclusión.

Una vez instalados, la gravedad de la precarización y del desempleo radica en la tendencia a que se perpetúen, dada la ausencia de alternativas previsibles. Pasan a formar parte de la dinámica de erosión de una modernidad que apunta hacia la disgregación de la sociedad, del trabajo y del modelo del Estado de bienestar social (welfare State), cuyas bases de sustentación presuponían el pleno empleo, la estabilidad y la seguridad social. No se puede esperar que la lógica del libre juego de las reglas del mercado posibilite reabsorber esa población dislocada, al margen de cualquier sistema de seguridad social.

La competitividad y la rentabilidad no combinan con la solidaridad y la cohesión social. Enfrentar el acelerado crecimiento de contingentes ocupacionales económicamente innecesarios y superfluos que amplían las dimensiones del desempleo estructural, sin la menor oportunidad de acceso o reingreso a los puestos de trabajo, sin espacios en la vida económica, es el más grande desafío impuesto por el fenómeno de la exclusión. Esos cambios ponen en cuestión las bases futuras de los sistemas democráticos. Se trata de una crisis de mutación civilizatoria que elimina las perspectivas de inserción por la vía del trabajo (Forrester, 1997). La autora condena la hipocresía de políticos y gobernantes al prometer reiteradamente la superación de la crisis y la ampliación del mercado de trabajo. Considera falaz querer imponer la inserción social a través del vínculo con el mundo del trabajo cuando, en la práctica, ella está negada porque ese vínculo ha dejado de existir.

Algunos datos sirven como ilustración de una ruptura definitiva del antiguo paradigma del mercado de trabajo (Dupas, 1999) y de la ciudadanía regulada por la inclusión en el trabajo formal (Santos, 1979). Según la Organización Internacional del Trabajo (OIT), en América Latina el sector informal se sitúa entre $40 \%$ y $70 \%$ del mercado de trabajo, con una tasa decrecimiento anual superior a 4\%. En Brasil, en tan sólo una década, la ocupación predominante cambió de formal a informal, llegando al final de 1998 a la alarmante proporción de 55\% de la fuerza de trabajo metropolitana (Pochmann, 1999). El número de empleos generados con constancia firmada pasó de un crecimiento de 23\% (1986-1990) a una caída de 28\% (1991-1997).

En la actualidad, se estima que de cada diez nuevos empleos creados, sólo dos son asalariados del mercado formal, mientras hasta la década de los ochenta la proporción era de diez a ocho. La pérdida de un puesto de trabajo en el sector formal determinó una caída en el rendimiento medio del trabajador 
entre 30\% y 40\%. A partir de los años ochenta, el desempleo se duplicó: de 9\% a 18\%. Entre 1989 y 1996 creció relativamente, sobre todo en las personas con más de 11 años de escolaridad, en hombres con edades superiores a los 40 años y en la población negra. Se hizo menos grave para aquellos con menor grado de escolaridad, para las mujeres y para los que buscan otro empleo. Es una consecuencia, en cierta medida contradictoria, de un cambio en la calidad de los puestos de trabajos generados.

Otro hecho importante a destacar fue el declive de la participación relacionada con los trabajadores más jóvenes, en el grupo etario de hasta 29 años del total de la población empleada. Entre los años 1980 y 1995, cayó de $53,1 \%$ a $37,9 \%$ (Pochmann, 1999).

El aumento del desempleo y de las ocupaciones precarias en la última década cuestionan seriamente las políticas de generación de empleos y de renta. La estructuración del mercado de trabajo durante el ciclo de industrialización nacional se caracterizó por una gran expansión de trabajo asalariado con registro, desempleo reducido, gran heterogeneidad de los puestos de trabajo con diferencias salariales y predominio de bajos salarios, junto con informalidad de mano de obra y subempleo. En los años noventa se entra en una fase de bajas inversiones productivas y crecimiento de la población, sin una política favorecedora de ocupación, sin un proyecto consistente de reforma agraria capaz de crear empleos en el sector primario y de agroindustria y sin políticas adecuadas de bienestar social.

A pesar de disponer de un parque industrial complcjo y diversificado de los más avanzados de la periferia del capitalismo, en la actual coyuntura, Brasil carece de una política de generación de empleos que, por una parte, incorpore la mano de obra excedente y de baja escolaridad en la construcción de infraestructura material —vivienda, saneamiento básico, transporte, puertos-y por otra, la mano de obra más calificada en el ámbito de los servicios públicos —salud, educación, turismo y recreación, asistencia social. De esa manera, se lograrían algunos de los soportes requeridos para desarrollar las potencialidades del mercado interno y mejorar la distribución de la renta.

\section{El NUEVo PAPEL DEL ESTADO}

Según Dupas, "...los problemas centrales que envuelvan el futuro de las relaciones entre la sociedad y los Estados nacionales estarán relacionadas con la capacidad de estos Estados para asumir eficientemente un nuevo papel inductor-normativoregulador, al mismo tiempo que esas sociedades logren encontrar alternativas de cómo lidiar con las tendencias de creciente exclusión social provocadas por el actual modelo económico global" (Dupas, 1998, 87).

El welfare State, fundado sobre la expectativa de que el Estado podría armonizar la propiedad privada de los medios de producción con la gestión democrática de la economía, entró en crisis. Deslastrándose de la tarea de regulador del mercado, dejó de proveer las bases para un compromiso de clase, sustentado en el pleno empleo y en la redistribución de la renta, librándose además de su papel de proveedor de servicios sociales y mediador de conflictos. El dilema actual consiste en cómo garantizar cierta protección social a las crecientes poblaciones marginalizadas, cuando los recursos presupuestarios destinados a ese fin se vuelven escasos, en virtud de las restricciones señaladas anteriormente y particularmente de la absoluta primacía atribuida al mercado.

El cuestionamiento a la visión keynesiana ha venido simplificando las soluciones en dos vertientes. Una, que apunta a la creación de un Estado mínimo, sin interferencia en las reglas del libre mercado, apoyada en su ineficiencia y en la reducción del presupuesto público. A los gobiernos tocaría únicamente el monopolio de la defensa y de las armas, la garantía de mantenimiento de las leyes, del orden, de la justicia y de la seguridad, así como el establecimiento de reglas básicas que permitan movilidad a los agentes económicos. En oposición, se presiona por un Estado fuerte, dispuesto a lidiar con los conflictos propios de la globalización, entre los cuales se encuentran aquellos generados por la exclusión social.

El propio Banco Mundial cambió recientemente su concepción liberal de la función del Estado, afirmando la inviabilidad del desarrollo social y económico sustentable sin un Estado actuante - $-\mathrm{y}$ 
no un Estado mínimo- en cuanto socio y facilitador (World Bank, 1997). En esa misma dirección, la Organización Internacional del Trabajo insiste en la importancia del papel del Estado, contradiciendo la posición de los economistas que han llegado a insinuar la sustitución del gobierno por el mercado. El Banco Mundial opina que las intervenciones del gobierno no pueden ser vistas como contrarias a la operación de los mercados, ni la expansión de los mercados puede ser percibida como perjudicial a la efectividad de las acciones gubernamentales. La reducción de las dimensiones del Estado puede amenazar el mantenimiento del comercio a escala global. Lo que en realidad se necesita es de grandes gobiernos (ILO, 1997:98).

Ese nuevo Estado inductor-normativoregulador actuante tendría como misión intransferible viabilizar servicios públicos esenciales — salud, educación, vivienda y amparo contra la exclusión social- para la población económica y socialmente más vulnerable. Un Estado capaz de establecer políticas compensatorias para frenar el aumento del desempleo; de promover la reducción de las desigualdades y la mejor redistribución de oportunidades; el desarrollo de protecciones sociales y estrategias específicas para las poblaciones que sufren de un déficit de integración y probablemente sean imposibles de integrar.

Como consecuencia de esos cambios, el sistema de seguridad social necesitaría ser reestructurado. La asistencia pública está en descenso, fue proyectada para realidades muy diferentes de las actuales. El desequilibrio financiero ocasionado por el aumento de la expectativa de vida, aliado a la caída de las contribuciones asistenciales en función de las pérdidas salariales, al crecimiento del desempleo y del mercado informal, explican, en parte, la actual crisis. La solución introducida en algunos países latinoamericanos, de delegar a administradoras privadas la gerencia de los fondos de pensión a través de sistemas de capitalización individual, ha venido siendo fuertemente cuestionada.

Además de someter la pensión de los asegurados a la dependencia de la cantidad de recaudaciones y a las fluctuaciones del mercado financiero, esa alternativa se contrapone a los principios solidarios que fundamentan la seguridad social. Es imperativo establecer un nuevo contrato social, negociado de forma amplia con todos los segmentos de la sociedad civil y que, desde el punto de vista de la seguridad social, abarque todos los que pueden trabajar y garantice el indispensable auxilio a aquellos que no pueden o están exceptuados de tal exigencia por razones legítimas.

\section{LA VIOLENCIA: UNA RESULTANTE}

El aumento de las desigualdades sociales adquiere significaciones propias, con algunas semejanzas con relación a los comienzos de la revolución industrial, cuando la naciente clase obrera constituía una amenaza a la estabilidad social. En la actualidad, las relaciones industriales de producción no ocupan un lugar central de conflicto estructural inherente al antagonismo capital-trabajo. El foco de las situaciones de dominación y de las manifestaciones de resistencia del movimiento obrero frente a un adversario común se ha dislocado.

En el presente, el embate se deriva de las diversas formas de exclusión social y conduce a una violencia difusa, forjada en el cruce de lo social, de lo político y de lo cultural, que se asocia a un estado de disgregación, de descomposición social, de individualismo creciente. Usando la expresión de Wieviorka (1997), representa más una violencia infrapolitica, atribuible al debilitamiento de un Estado frecuentemente corrupto, ineficaz y deslegitimado, en virtud de sus propias carencias y de las prácticas inherentes al crimen organizado. Incluso la criminalidad más banal, aunque creciente, no emerge de conflictos sociales y políticos abiertos.

La anomia suscita violencia sin proyecto, devastadora y autodestructiva, difícil de controlar en la medida en que no hay un terreno de negociación, con el riesgo de explosiones en las zonas de fragilidad urbana. La violencia refleja:

...la imposibilidad que tiene el actor de estructurar su práctica en una relación de intercambio más o menos conflictiva. Ella expresa el desfase o el abismo entre las demandas subjetivas de personas o grupos y la oferta política, económica, institucional o simbólica; posee la marca de una subjetividad negada, 
arrebatada, herida, infeliz, frustrada, lo que se expresa por el actor que no puede existir en cuanto tal. Ella es la voz del sujeto no reconocido, rechazado y prisionero de la masa desdeñada por la exclusión social y por la discriminación racial (Wievorka, 1997:37).

En ciudades como Río de Janeiro, las desigualdades sociales están demarcadas por fronteras cada vez menos inmateriales. Surge un apartheid urbanosocial con configuraciones geográficas diferentes. Muros y cercas señalan, además de la defensa, la separación. Contradictoriamente, la rígida división del espacio urbano privado con la intención de evitar la violencia, acaba por estimularla, haciendo los espacios públicos, donde esa división es imposible, cada día más peligrosos. Por otra parte, la veloz expansión, en las grandes metrópolis, de actividades al margen de la legalidad ha venido extrapolando los límites convencionales de la economía informal y favoreciendo, directa o indirectamente, la escalada de la violencia. Y una vez más, la mayoría de las víctimas se encuentran entre los excluidos.

\section{VIOLENCIA Y SALUD PÚBLICA}

La problemática de la violencia social, bajo el ángulo de la salud pública, ha venido adquiriendo un lugar destacado en las agendas de las organizaciones internacionales del área y haciéndose objeto de estudios particulares y regionales en Brasil. Minayo (1994) hizo una síntesis del estado del arte, apuntando hacia la necesidad de ampliar el campo de investigación e implementar propuestas de acción e intervención en los servicios de salud. Desde esa perspectiva, intentamos contribuir a una descripción más amplia de los agravios incluidos en el gran grupo de Causas Externas (E800-E999) de la Clasificación Internacional de Enfermedades (CID), partiendo del presupuesto de que los referentes al trabajo, además de insuficientemente registrados, no se encuentran contemplados en toda su amplitud.

Una de las principales barreras para reducir lo que se conoce como subnotificación, es la visión predominante sobre lo relativo a la seguridad, que pauta el registro de datos sobre enfermedades y accidentes de trabajo, incluso en las informaciones obligatorias recogidas en los servicios de salud. Bajo esa lógica de concesión de beneficios relativos al seguro de accidentes de trabajo, el universo está compuesto apenas por trabajadores con vínculos formales, excluyendo entre ellos a los servidores públicos de las tres esferas de gobierno (sujetos a regímenes propios de asistencia), los trabajadores domésticos y los autónomos. A lo que cabe agregar, entre otras razones, la concepción, todavía dominante, de enfermedad o accidente restringida a los daños físicos; la falta de compromiso de las empresas, particularmente con los trabajadores tercerizados, al omitir accidentes que no se traducen en beneficios asistenciales y las estrategias de la propia seguridad social de eliminar el carácter de enfermedad a las relacionadas con el trabajo o del trabajo, en el ya reducido cuadro de clasificación. El caso de las Lesiones por Esfuerzos Repetitivos (LER) es, en la actualidad, el más sintomático de esa política de evitar costos.

Se trata, concomitantemente, de verificar la procedencia de las interpretaciones existentes sobre la reducción del número de accidentes, que, además de atribuirla a la "subnotificación", incluyen como otro tipo de determinantes la introducción de cambios tecnológicos, las inversiones en medidas de seguridad, así como la tercerización y la informalización —incluso en el mercado formal — de las actividades de riesgo.

El estudio tiene como premisa básica la necesidad de sobrepasar la noción de accidente en general, toda vez que corresponde a la agregación de diferentes fenómenos asociados a la interrelación entre el trabajador, su trabajo y alguna forma de agravio a la salud. Esa denominación amplia es funcional sólo en el ámbito de los derechos individuales del accidentado. Las enfermedades agudas, las crónicas y los traumas generados por el trayecto o por situaciones de riesgo presentes en el ambiente de trabajo se confunden en una casuística que involucra una variedad de eventos genéricamente calificados como "accidentes de trabajo".

Se señala una distinción inicial entre los accidentes típicos y los relacionados con la violencia. En los primeros, los más estudiados, principalmente en el sector secundario de la economía, se interpretan las condiciones generadoras de eventos susceptibles de provocar accidentes, a partir de los componentes 
técnicos y organizacionales del proceso de trabajo. En el segundo tipo, el procedimiento analítico está mediado por las especificidades del espacio público urbano.

\section{ESTRATEGIAS DE LA INVESTIGACIÓN}

Adoptamos algunas formas de aproximación, reveladoras de las manifestaciones actuales del panorama anteriormente presentado, que se encuentran en diferentes estadios de desarrollo. La lógica construida tuvo como premisa trasponer las limitaciones ya referidas de los sistemas de registro y emprender investigaciones junto a sectores más expuestos a situaciones de riesgo. Para la identificación de eventos que pueden ocasionar accidentes en el sector informal, distinguimos, a través de variables construidas, las ocurrencias por causas externas capaces de configurarse como consecuencia del trabajo. En el análisis, la calle —en tanto locus de sobrevivencia y de exposición a la violencia en sus diversas caras - se constituye en referente prioritario.

Presentamos a continuación un esbozo de tres de las estrategias utilizadas y en curso: en servicios públicos de salud, junto a adolescentes en situaciones extremas de riesgo y un análisis de situaciones en delegaciones policiales.

\section{A) Búsqueda ACTIVA EN SERVICIOS Públicos DE} SALUD

Consideramos que los servicios públicos de salud representan una primera fuente potencial de informaciones, por ser, en principio, accesibles al conjunto de los trabajadores, y tal vez los únicos para aquellos con vínculos precarios. Se destacan con este propósito en particular los hospitales de mayor complejidad, dotados de servicio de emergencia, sectores de hospitalización y ambulatorios especializados. La recolección de datos en los Boletines de Emergencia (BE) en dos de estos hospitales, complementada por entrevistas con pacientes internados en enfermerías, permitió evaluar su potencialidad.

Realizamos un trabajo de campo preliminar para observar la atención a pacientes que recurrieron a los sectores de emergencia. Tal actividad reveló los caminos por donde se pierde el registro de los Accidentes de Trabajo (AT). Los casos son identificados por el funcionario de la recepción que llena el encabezado del BE. Si el paciente refiere que el evento se relaciona con el trabajo y tiene carnet de trabajo, se le coloca el sello "AT", lo que a priori ya excluye a los trabajadores del sector informal.

Quienes pertenecen al sector formal están orientados a anotar el número del BE y a buscar posteriormente el sector de registro de datos. Ocurre con frecuencia que muchos pacientes, incluso del sector formal, no identifican como AT los accidentes de camino al trabajo. Observamos, incluso, que tratándose de accidentes de menor gravedad, cuando son atendidos y liberados por académicos, la ausencia de firma de un médico en el BE elimina el valor legal de un documento. En ninguna sala de atención es rutinaria la identificación del AT. Así, si ésta no es hecha en la recepción y el paciente no anota el número del BE, práctica generalizada, el rescate del evento para posteriores reivindicaciones de derechos laborales exige un largo recorrido. En síntesis, es la lógica asistencial exclusivamente, cuando es respetada, la que orienta los registros.

En las dos unidades - Hospital Municipal Miguel Couto (HMMC) y el Hospital Municipal Souza Aguiar (HMSA) - seleccionamos para el análisis los casos de pacientes con edades superiores a los 5 años y víctimas de causas externas en el período de una semana. Del total de las causas externas registradas en ese período, 1155 en el HMMC y 1250 en el HMSA, el número de accidentes de trabajo identificados fue de $63(5,5 \%)$ en el primero y 67 $(5,4 \%)$ en el segundo.

Las lagunas y deficiencias en el llenado de los campos del BE capaces de señalar eventos relacionados con el trabajo, incluso no registrados, tales como profesión de la víctima, causa de la lesión y lugar del accidente — sólo llenos respectivamente en $0,7 \%, 33 \%$ y $1,4 \%$ de los casos- limitó las expectativas que se tenían acerca del éxito de esa estrategia. Sin embargo, algunas constataciones pudieron ser hechas. En los dos hospitales, en el horario de 8:00 am a 6:00 pm, se constata un aumento significativo en los agravios por causas externas y es 
en ese horario que ocurre el mayor registro de AT: $77,8 \%$ en el HMMC y $64,2 \%$ en el HMSA del total de accidentes identificados como tal. Los boletines del HMMC revelan la concesión de 98 dispensas a personas que supuestamente tenían vínculos de trabajo, pero en apenas $18,4 \%$ de los casos se asociaban a la identificación de AT.

En el intento de superar las deficiencias señaladas, procedimos, en el período de un mes, a un levantamiento de todos los pacientes internados en las enfermerías de cuatro servicios del HMSA, considerados los más indicados para la finalidad de la investigación: cirugía general, cirugía pediátrica, neurocirugía y ortopedia.

A través del análisis de los datos contenidos en las historias de esos pacientes, complementados con las informaciones existentes en el servicio social, fueron seleccionados, para una posterior entrevista, las víctimas de causas externas.

De los pacientes internos (384) en el período de la investigación, 108 casos correspondían a causas externas. Debido a rechazos u obstáculos de otra naturaleza, fueron entrevistados 98 de esos pacientes. Cuando se presentaban dificultades o imposibilidad de comunicación, se recurrió a la ayuda de sus acompañantes.

Al comparar los datos cuantitativos obtenidos en las entrevistas con los registrados en las historias, se evidencian las elevadas proporciones de subnotificación. Fueron caracterizados 31 AT, mientras el hospital identificó sólo 5 , incluso como consecuencia de la iniciativa de los propios trabajadores en informar el AT en la atención inicial, del uso del uniforme de la empresa y de la interferencia de un participante de este estudio que alertó para el registro de la sala de emergencia. En ninguna historia constaba ni siquiera la profesión del paciente y su permanencia en la enfermería no contribuyó a nuevos registros, aunque diversos casos fueron del conocimiento del equipo médico. Tales omisiones reflejan la falta de orientación en cuanto a la importancia del registro de accidentes originados en actividades laborales y, por razones de distinta naturaleza, la propia cultura de los servicios.
La precariedad de los vínculos se presenta de manera diferente. En los accidentados internados en las respectivas enfermerías, 15 tenían carnet de trabajo; 4 realizaban, con vínculos informales, actividades propias del mercado formal -incluso con una antigüedad de hasta 7 años-; 12 eran trabajadores autónomos y 5 realizaban trabajos eventuales.

De los 26 AT no registrados, 11 se relacionaban con trabajadores con carnet $y$, en algunos casos, la propia empresa ya había reconocido el accidente. En ese hecho se combinan la lógica omisa del registro hospitalario y la propia comprensión de los trabajadores. Muchos de ellos con carnet de trabajo, hasta con 20 años de servicio, no identifican el accidente que ocurre fuera del lugar de trabajo, y los que tienen vínculos informales no demuestran interés en la identificación, por no redundar en beneficios asistenciales. Se restringen tan sólo a señalar la tragedia que el episodio representa para la manutención de la familia. En determinadas situaciones, la mayor preocupación reside en el resarcimiento de los daños personales y materiales sufridos, entre los cuales expresan, incluso, manifestaciones de venganza. $\mathrm{La}$ inmensa mayoría de los eventos relacionados con la violencia urbana encontrados en las enfermerías ocurrieron con trabajadores que ejercían actividades informales, los más expuestos y desprotegidos socialmente.

La introyección de la culpa personal permea las interpretaciones de los accidentes típicos, sea en el sector formal o informal, incluso relativizada algunas veces por la referencia a circunstancias de diversas órdenes, como no perjudicar la producción o garantizar el empleo. Aunque aparezca como razón del accidente la falta de entrenamiento y de políticas y prácticas de seguridad - como el uso de equipos deteriorados-, el fatalismo implícito en los testimonios insinúa la aceptación de los riesgos como inherentes al trabajo. Contrariamente, en los eventos derivados de la violencia se culpa al agresor directo o, de modo más amplio, a la ausencia de seguridad pública, con la consecuente y flagrante decepción de no saber a qué instancias recurrir.

La perspectiva para quienes tienen derechos garantizados es el retorno al trabajo, aunque algunos demuestren incertidumbre en cuanto a su continuidad, 
teman quedar incapacitados o hagan explícita su intención de cambiar de trabajo. Para los informales, se instaura la preocupación con la sobrevivencia del núcleo familiar y el constreñimiento frente a la dependencia económica de parientes. En ciertos casos, la inexistencia de expectativas es tan fuerte que sólo piensan en su situación actual, enfatizando la suerte de no haber muerto. En otros, después de la confrontación con la adversidad, se percibe hasta un optimismo frente a la vida, la esperanza de encontrar salidas y el vehemente descarte de otro accidente.

El Sistema de Informaciones de Mortalidad (SIM) del Ministerio de la Salud, construido por la compilación de actas de defunción, teóricamente, constituiría el mayor banco de datos para identificar y especificar los accidentes fatales. No obstante, presenta una serie de lagunas, que necesitan de determinados filtros para ser salvadas: edad, ocupación, calificación, entre otros. Las inversiones que venimos realizando para continuar el estudio anterior de Machado (1991) todavía no se concretiza en resultados significativos. De cualquier forma, para inferir conclusiones más expresivas a partir de las actas de defunción, será necesario realizar investigaciones cualitativas. Como demostró Mendes (1991), en un estudio de esa naturaleza efectuado en Porto Alegre en un período de tres meses, en 99 casos de muerte por causas externas fueron encontrados $18 \mathrm{AT}$, cuando en las actas constaban sólo tres. En su inmensa mayoría, las víctimas ejercían un trabajo precario y los accidentes ocurrieron en la vía pública. Las familias entrevistadas agregaron al sufrimiento proveniente de la pérdida de una vida por la violencia, la negación del amparo social que redujera, al menos, los efectos de la pérdida de un aporte financiero fundamental para su sobrevivencia.

\section{B) Adolescentes en situaciones eXtremas de RIESGO}

En la actualidad, cuando se mide el impacto de la violencia en trabajadores del mercado informal, se evidencia la vulnerabilidad de la población adolescente, sobre todo en los últimos diez años. Según datos del Ministerio de la Salud, en la década de los noventa, se constató un aumento significativo de las muertes de adolescentes, en el grupo etario de 15 a 19 años, ocasionadas por homicidios. En 1995, la mortalidad por causas externas en esa población alcanzó 78,32\% del total de las muertes, siendo $33,19 \%$ correspondientes a homicidios.

Los estudios realizados por el Centro Latinoamericano de Estudios sobre Violencia y Salud (Claves), de la Fundación Fiocruz, en el Municipio de Río de Janeiro, confirman ese expresivo crecimiento. Desde 1980 hasta 1994, la mortalidad por causas externas en este grupo aumentó de 169,5 por 100 mil habitantes en 1980 , a 177.5 en 1994 , mayoritariamente en el sexo masculino, quedando la tasa de homicidios en 62,2\%. Ya en 1995 las tasas de mortalidad por causas externas y por homicidios alcanzaron, respectivamente, 183,3 y 108,7. Como agravante se encuentra el hecho de que $47,1 \%$ de las muertes por causas externas, en el grupo entre $10 \mathrm{y}$ 19 años, se incluye en el grupo de lesiones ignoradas (Souza y Minayo, 1995).

No resulta descabellado suponer que, entre tales causas de configuración nebulosa, se sitúan las relacionadas con circunstancias que dificultan o impiden el esclarecimiento de las causas de decesos y agravios. Desde las que envuelven las consecuencias de actividades al margen de la legalidad a las que provienen del ejercicio de ocupaciones no reconocidas socialmente, aunque compongan, en el anonimato de sus actores, el escenario cotidiano de las grandes ciudades.

Algunos indicios de las causas provenientes de la red de violencia inherente al narcotráfico fueron obtenidos a través de estudios de caso, de corte cualitativo, sobre la mortalidad de adolescentes insertos en ese mercado, en una favela de Río de Janeiro con 15 mil habitantes (Meirelles, 1998). Los resultados son, por sí mismos, alarmantes. Solamente en el año 1997, ocurrieron 57 homicidios que alcanzaron aproximadamente el $27 \%$ de los adolescentes directamente envueltos en el narcotráfico. Tales datos, obviamente no figuran en las estadísticas sobre accidentes de trabajo y, por motivos distintos, es bastante probable que permanezcan ocultos o no relacionados con su verdadero origen. Los propios medios de prensa que cubren homicidios de esta naturaleza suministraron, para todo el estado, cifras 
que apenas se aproximan al doble de lo constatado en la favela estudiada. Asumimos como tarea lograr, al menos, estimados de esa casuística, en el ámbito de Río de Janeiro y de otros de gran significación, capaces de dar una mayor visibilidad a esas muertes anónimas.

Ese escenario refleja las consecuencias de captura de adolescentes por una alternativa de trabajo ausente del amplio abanico de actividades incluidas en la literatura sobre el mercado informal. No obstante, el proceso y la organización de ese trabajo ilegal le confiere características similares a las actuales actividades laborales. Las diversas funciones ejercidas, incluso bajo extremo autoritarismo, generan de manera diferenciada, situaciones de riesgo inminente de vida.

Pensar en estrategias preventivas impone descubrir los diversos ángulos de esa problemática - vinculada, aunque no restringida, a la situación de pobreza de carácter general- que, sin ignorar su complejidad, ciertamente guarda relación con las oportunidades de inclusión social sistemáticamente negadas a ese segmento de la población. Ello remite, incluso, al análisis de propuestas/programas de organizaciones gubernamentales y no gubernamentales tendientes a inhibir la atracción por cse mercado que no se reduzcan a la práctica represiva oficial.

\section{C) ANÁLiSiS DE LOS REGISTROS DE SUCESOS POLICIALES}

Los registros de sucesos de la policía civil representan también un acervo valioso que evidencia gran parte de la violencia social de que son víctimas los trabajadores en su recorrido por la ciudad e incluso en el propio lugar de trabajo. La investigación en curso en las delegaciones presenta limitaciones debido al descrédito de la población en recurrir a esa instancia.

Se estima que apenas el $20 \%$ de las personas víctimas de delitos reportan el suceso, dado que uno de los principales motivos para recurrir a la policía es presentar pruebas para tramitar procesos judiciales o relacionados con seguros. Este trabajo ha demostrado que los registros policiales confirman también la exclusividad de una visión de la seguridad social, incluso más restringida, al reconocer solamente los accidentes típicos, ocurridos en los propios lugares de trabajo. No obstante, permite hacer visible las diversas expresiones de violencia urbana que afectan a la población trabajadora y sobrepasan la concepción de legislación asistencialista, que considera accidente de trabajo el ocurrido durante el ejercicio de la actividad laboral (accidente típico) o en los desplazamientos hacia la residencia o hacia el comedor o lugar de comida (accidente de trayecto), provocando lesión corporal o perturbación funcional que lleve a la muerte, pérdida o reducción permanente o temporal de la capacidad de trabajo.

Constatamos agresiones, asaltos, robos, colisiones, en distintas dimensiones, que causan trastornos, no necesariamente de orden físico, pero no por eso menos graves que los de esa naturaleza, y la usurpación de instrumentos o medios de trabajo, con la consecuente interrupción de ingresos, generando situaciones de amenaza, con probables implicaciones psíquicas. En términos cuantitativos, algunos datos interpretados hasta el momento muestran el predominio absoluto de los efectos de la violencia en el sector servicios (84\% de los sucesos) y el reducido número de accidentes de trabajo registrados (1,3\% del conjunto de eventos). En virtud de las razones alegadas anteriormente para que la población recurra a esa institución, no fue posible detectar, de modo más preciso, la influencia de las formas de precarización del trabajo en el conjunto de eventos analizados.

\section{CONSIDERACIONES FINALES}

Este texto procuró sistematizar de manera sucinta lo que hoy se entiende por precarización del trabajo y señalar su relación con los procesos de exclusión y violencia social. En un segundo momento, buscó ilustrar, con relatos de investigación, las lagunas, la precariedad de los sistemas de información, particularmente en los servicios públicos de salud, para el reconocimiento de la morbilidad y mortalidad por accidentes de trabajo, en su magnitud y especificidad, destacando especialmente los relacionados con la violencia urbana.

En última instancia, esa reflexión señala la necesidad impostergable de descubrir ese universo problemático de la precarización y del no-trabajo. 
Nos encontramos frente a un babitus de ser en el mundo distinto, de una mutación en la sociedad salarial históricamente construida, donde el trabajo representa el principal fundamento de la ciudadanía y uno de los pocos vínculos de reconocimiento que la población trabajadora alcanzó en el país. La nueva cuestión social se une a antiguos dilemas, aunque no superados, y emerge, por afectar las condiciones generales de existencia, como desafío para quienes investigan y actúan en el ámbito de la salud colectiva.

\section{REFERENCIAS BIBLIOGRÁFICAS}

Arendt, H., 1990. Origens do totalitarismo. Sao Paulo: Companhia das Letras.

Caire, G., 1997. Normalisation des emplois atypiques. En: Précarisation sociale, travail et santé (Iresco / Institut de Recherche sur les Societés Contemproraines), pp. 239-252. París: Iresco.

Castell, R., 1998. As metamorfoses da questão social: uma crónica do salário. Petrópolis: Vozes.

Dupas, G., 1999. Economia global e exclusão social:pobreza, emprego, Estado e o futuro do capitalismo. Sao Paulo: Paz e Terra.

Escorel, S., 1999. Vidas ao léu: uma etnografia da exclusão social. Río de Janeiro: Fiocruz.

Forrester, V., 1997. O borror econômico. Sao Paulo: UNESP.

ILO (International Labor Organization), 1997-98. Industrial relations, democracy and social stability. Ginebra: World Labor Report.

Machado, J.M.H., 1991. Violencia no trabalho e na cidade: epidemiologia da mortalidade por acidentes de trabalho registrados no municipio do Rio de Janeiro em 1987 e 1998. Tesis de maestría, Río de Janeiro: Escola Nacional de Saúde Pública, Fundação Oswaldo Cruz.

Meireles, Z.V., 1998. Vida e trabalho de adolescentes no narcotráfico numa favela do Rio de Janeiro. Tesis de maestría, Río de Janeiro: Escola Nacional de Saúde Pública, Fundação Oswaldo Cruz.
Mendes, J.M.R., 1991. O verso e o anverso de uma bistória: $o$ acidente e a morte no trabalho. Tesis de doctorado, Sao Paulo: Pontifícia Universidade Católica.

Minayo, M.C.S., 1994. A violência social sob a perspectiva da saúde pública. Cadernos de Saúde Pública, 10 (suplemento): 07-18.

Pochmann, M., 1999. O trabalho sob jogo cruzado. Sao Paulo: Contexto.

Santos, W.G., 1979. Cidadania e justiça. Río de Janeiro: Campus.

Souza, E.R. \& Minayo, M.C.S., 1995. O impacto da violência sobre a saúde. En: Os muitos brasis: saúde e população na década de 80 (M.C.S. Minayo, org.), pp. 87-116. Sao Paulo: Hucitec.

Wieviorka, M., 1997. O novo paradigma da violência. Tempo Social, 9 (1):5-41.

World Bank, 1997. The State in a changing world. World development report. Washington DC: World Bank.

Traducción a español: antropólogo Júlio de Freitas Taylor. 


\title{
CONSECUENCIAS ECONÓMICAS DE LA LEISHMANIASIS CUTÁNEA EN PACIENTES TRATADOS EN TRUJILLO, ÁREA ANDINA DE VENEZUELA*
}

\author{
Benito Díaz, , Axel Kroeger ${ }^{* * *}$ y María Luisa Várquez.***
}

\section{INTRODUCCIÓN}

La leishmaniasis cutánea (LC) incluye un grupo de enfermedades del hombre y los animales, con variadas formas clínicas, causadas por parásitos protozoarios del género leishmania ${ }^{1}$. Parece existir acuerdo en que esta enfermedad era originalmente una zoonosis que se ha desarrollado a través de las eras geológica y biológica, convirtiéndose luego en una antropozoonosis (Houin \& Khouri, 1989). La enfermedad es transmitida por la picada de un insecto infectado previamente al alimentarse de un reservorio vertèbrado a su vez infectado. En Latinoamérica todos sus vectores pertenecen al género Lutromyia.

La leishmaniasis es una de las seis enfermedades blanco del programa especial de investigación de enfermedades tropicales de la Organización Mundial de la Salud y el Banco Mundial (WHO/World Bank/ TDR). Es endémica en 82 países, 70 de los cuales son subdesarrollados, donde existen cerca de 350 millones de personas en riesgo de contraer la enfermedad (WHO, 1990). A escala mundial se estima que, por ejemplo, sólo en 1992 hubo 1,5 millones de nuevos casos de leishmaniasis cutánea (Remme et al., 1993).
En Latinoamérica la LC es endémica en 20 países, pero existe subregistro de la enfermedad (Desjeux, 1991; Grimaldi et al., 1989), lo cual influye en la apreciación de la importancia de la LC como problema de salud pública. A pesar de su amplia distribución geográfica, no hay acuerdo sobre si la LC es una enfermedad autóctona o importada con la colonización Europea desde hace cinco siglos (Momen \& Grimaldi, 1989). No obstante, se ha discutido sobre las consecuencias políticas y económicas de la leishmaniasis hasta el punto de considerarse que esta enfermedad pudo haber afectado la expansión del imperio Inca y que sus patrones epidemiológicos actuales habrían cambiado desde la conquista y colonización europea (Le Moine \& Scott Raymond, 1987).

La respuesta social de las personas y comunidades afectadas ante la $\mathrm{LC}$ varía desde asumir la enfermedad y buscar opciones de cura en los sistemas de medicina (tradicional o científica) existentes, hasta luchar y exigir más atención a la LC por los gobiernos. Por ejemplo, en Perú, ante la falta de adecuada respuesta oficial, se han organizado asociaciones de pacientes de leishmaniasis para autoayuda y desde 1975 se le declaró una enfermedad ocupacional, Perú con derecho a conseguir

\footnotetext{
* La investigación fue financiada por el CDCHT-ULA, proyecto NURR-H-8694. Para cualquier comentario comunicarse a la dirección electrónica: beno17@,cantv.net.

** Sociólogo con maestría en Planificación y Financiamiento en Salud (Londres) y doctorado en la Escuela de Medicina Tropical de Liverpool, Inglaterra. Actualmente es coordinador del Taller de Práctica Investigativa de la Universidad de Los Andes en Trujillo, Venezuela.

*** Médico. Director del Centro Latinoamericano para Estudios de la Salud de la Universidad de Liverpool, profesor de Salud Internacional de la Escuela de Medicina Tropical de Liverpool, Inglaterra. Actualmente dirige proyectos de investigación en diez países de Latinoamérica sobre diferentes temas de salud.

**** Médico. Realizó una Maestría en Planificación y Financiamiento en Salud (Londres). Actualmente trabaja para una ONG especializada en planificación de sistemas de salud.

1 Nombrada así por Ross (1903) en honor a Sir William Leishman (1865-1926), quien describió el parásito.
} 
tratamiento gratuito y compensación laboral (Guthmann et al., 1998).

En general, aunque el conocimiento de aspectos biomédicos y epidemiológicos de LC se ha incrementado recientemente, poco se sabe sobre factores culturales y socioeconómicos relacionados con su transmisión, así como las consecuencias socioeconómicas que genera (Díaz, 1992). Las relaciones socioculturales y económicas de la LC han sido poco documentadas y por ello no son percibidas ni es apreciada su importancia (Wijeyaratne, 1988).

Podríamos resumir afirmando que los aspectos sociales de la leishmaniasis que han comenzado a ser indagados en América Latina se refieren principalmente a los conocimientos populares sobre la enfermedad y sus tratamientos tradicionales (Camino \& Anderson, 1992; Costa et al., 1987; Dobles-Ulloa \& Perriard, 1994; Arana, 1992; Magalhaes et al., 1990; Netto et al., 1985; Ruths, 1991; Vázquez et al., 1991; Kroeger et al., 1991; Isaza et al., 1999). Similarmente, también se ha iniciado la búsqueda de información sobre la utilización de los servicios de salud pública y estimaciones de costos o implicaciones económicas de los programas de control de la leishmaniasis (Castés et al., 1992; Dedet et al., 1995; Dedet et al., 1991; Llanos-Cuentas et al., 1992; Teodoro et al., 1991).

Sin embargo, a pesar de su importancia, hasta el presente no se han reportado estudios de los costos directos e indirectos de la leishmaniasis para los pacientes, los cuales podrían estar influyendo en la utilización de los servicios de salud por la población afectada, en el cumplimiento de los tratamientos conforme a los protocolos y en la eficacia de los programas de control de la leishmaniasis. Es hacia el abordaje de esta problemática que el presente estudio se propuso contribuir.

\section{CONTEXTO HISTÓRICO DE LA LEISHMANIASIS CUTÁNEA}

\section{en VeneZuela}

En Venezuela, el primer caso de LC fue reportado a principios de 1917 por Iturbe y González (Pifano, 1960). En ese mismo año, varios casos de
LC fueron descritos en la zona petrolera del estado Zulia (Tejera, 1917). En los comienzos de la industria petrolera en tierras vírgenes en el estado Zulia, a finales de la década de 1920 e inicios de 1930, la LC se convirtió en un problema de salud pública; incluso, la Academia Nacional de Medicina llegó a discutir un reporte sobre esta enfermedad en 1918 (Tejera, 1919). Las empresas petroleras extranjeras recién llegadas tenían problemas económicos como consecuencia de la LC, la malaria y otras patologías exóticas (De Bellard, 1923).

Se inició entonces una campaña para erradicar la malaria de las áreas de actividad petrolera, que posteriormente se extendió por el resto del país. Una vez controlada la malaria, el número de casos de LC declinó bruscamente, tal como ha sido observado en otros países con campañas antimalaria exitosas (WHO, 1990). Nuevos brotes epidémicos de LC ocurrieron en la década de 1960, al comenzar proyectos de colonización dentro de los programas de la Ley de Reforma Agraria (Ponds, 1968).

En 1955 se estableció un programa de registro de casos de LC en el Servicio Nacional de Dermatología del Ministerio de Sanidad. La data recogida desde ese momento señala que la LC está distribuida en 21 de los 23 estados del país, aunque se considera que las cifras oficiales contienen una subestimación de la prevalencia real de la enfermedad (Instituto de Biomedicina, 1986). Según Convit y Pinardi (1984), en Venezuela hay más de 4000 casos de LC por año. La mayoría de esos casos se registran en el área andina, la cual comprende los estados Trujillo, Mérida y Táchira. Estos tres estados producen más del 56\% de los casos de LC a nivel nacional, pero representan sólo el 3,3\% de la superficie del país (Scorza et al., 1985; Maingon et al., 1994).

Entre los estados del área andina, Trujillo tiene la peor situación socioeconómica (Vivas, 1992). El ingreso promedio de la población de este estado está por debajo del promedio de la población del resto del país, y $21,3 \%$ de los hogares trujillanos se encuentran en extrema pobreza (OCEI, 1993). Asimismo, el índice de desarrollo humano es uno de los más bajos del país, y muy inferior al promedio nacional (OCEI/PNUd, 1998). 


\section{OBJETIVOS Y METODOLOGÍA}

Los objetivos específicos de la investigación fueron examinar las consecuencias socioeconómicas de la LC en los enfermos y sus hogares, y estimar los costos directos e indirectos de la enfermedad para los pacientes. La recolección de información incluyó una encuesta de hogares (estudio transversal) y un seguimiento a pacientes (estudio longitudinal).

\section{LA ENCUESTA DE HOGARES}

La encuesta de hogares se condujo para explorar las consecuencias económicas de la LC, determinar prevalencias autorreportadas e identificar conocimientos y conductas curativas ante la enfermedad que pudieran influir en sus consecuencias económicas.

Se realizó un muestreo aleatorio estratificado (área urbana y área rural) en áreas de transmisión de LC. Las comunidades muestreadas se seleccionaron luego de revisar la procedencia de los casos en la lista de pacientes tratados en los últimos 10 años por el Servicio de Dermatología Sanitaria del Ministerio de Sanidad y por la Universidad de los Andes en el estado Trujillo.

La necesidad de evaluar conocimientos y prácticas populares antes que las tasas de prevalencia de LC, fue el principal criterio para determinar el tamaño muestral. El hogar fue la unidad de muestreo, aunque la unidad de análisis fueron ambos, hogar e individuo. Se estimó que un tamaño muestral de 1200 hogares en área urbana y 250 en área rural sería adecuado para el estudio. Para este fin dos marcos muestrales fueron usados: uno para área urbana y otro para área rural. Se encuestaron 1376 hogares, de los cuales 1135 se ubicaron en área urbana y 241 en área rural. El número previsto de hogares no pudo ser completado por limitaciones logísticas y por un pequeño número de no respondentes.

El área urbana estuvo compuesta por la ciudad de Trujillo y las siguientes poblaciones: San Lázaro, Santiago, Monte Carmelo, Escuque y Mendoza. El área rural comprendió asentamientos rurales y caseríos dispersos alrededor de San Lázaro, Santiago, Monte Carmelo y Escuque.
Los encuestadores en área urbana fueron estudiantes universitarios y en área rural, maestros de escuela, la mayoría de sexo femenino. Dos tercios de los supervisores fueron mujeres, casi todos profesionales universitarios. Todos fueron entrenados y seleccionados según su rendimiento.

El cuestionario se elaboró a partir de una historia clínica de pacientes y de entrevistas a casos de LC y a informantes clave. Luego se organizaron grupos de discusión focalizada. Esta versión inicial del instrumento se probó con pacientes que estaban recibiendo tratamiento antileishmaniasis. Luego de las correcciones, se editó una nueva versión que se utilizó en una prueba piloto en localidades diferentes a aquellas donde se aplicaría la versión definitiva del instrumento. La encuesta de hogares se aplicó entre junio y julio de 1994. La información fue procesada usando el programa Epi-Info.

\section{EL SEGUIMIENTO A PACIENTES}

El estudio longitudinal se condujo para determinar las consecuencias económicas de LC en pacientes que recibían tratamiento gratuito en establecimientos de salud pública. Se tomaron tres establecimientos en los cuales se ofrecía tratamiento gratuito: la Universidad de Los Andes y el Servicio de Dermatología Sanitaria en la ciudad de Trujillo, y la medicatura del Ministerio de Sanidad en la localidad de San Lázaro, cabecera de la parroquia Andrés Linares. La unidad de análisis fue el paciente de LC.

Se tomaron los primeros 112 pacientes nuevos que llegaron en busca de tratamiento entre septiembre y octubre de 1994. El seguimiento consistió en entrevistarlos desde la primera vez hasta que eran dados de alta o se perdían por abandono. Las entrevistas tenían lugar una vez por semana, al venir los pacientes a tratamiento. El número de entrevistas de cada paciente varió entre 2 y 21 veces, de acuerdo a la cantidad de veces que vino a consulta. En la medida que se iban dando de alta, los pacientes se iban desincorporando del estudio de seguimiento, concluyendo éste en mayo de 1995. Las entrevistas fueron realizadas por el investigador y tres asistentes que habían sido supervisores de la encuesta de hogares, quienes para este estudio recibieron mayor entrenamiento. 


\section{ANÁLISIS DE COSTOS DE LA LC}

Las consecuencias económicas de la LC investigadas fueron los costos directos e indirectos para los pacientes.

Costos directos: son el gasto de dinero efectuado para curarse de la enfermedad, incluyendo medicinas, exámenes, pago de consulta, transporte y otros gastos directamente relacionados. Se cuentan aquí los gastos en que el paciente haya incurrido para buscar ayuda y curarse, aunque éste no haya sido prescrito por el médico. Por ejemplo, aquéllos causados por la compra de tratamientos populares automedicados y complementarios al tratamiento médico, entre los que pueden señalarse el pago de misas, promesas, estampitas de José Gregorio Hernández o el Niño Jesús, compra de drogas automedicadas o gallinas negras. En resumen, los costos directos corresponden al pago en dinero (cash) o en especie que se hacen con el fin de curarse, independientemente de la eficacia del producto o servicio comprado para curar las lesiones.

Costos indirectos: comprenden las pérdidas económicas causadas por la enfermedad, en cuanto a tiempo de trabajo perdido y output afectado (disminución del rendimiento del trabajo, o actividades ocupacionales que dejan de realizarse debido a la enfermedad o al tratamiento). Por ejemplo, si el paciente es conductor de microbús y vive de prestar su servicio y cobrar pasajes, cuando gasta una mañana en tratamiento estará perdiendo medio día de ingreso. $\mathrm{O}$ si el paciente es caficultor y su tratamiento ocurre en la temporada de cosecha, estará perdiendo un día de trabajo en la temporada de mayor remuneración para él.

En el estudio transversal, a las personas que declaraban tener en el presente o haber tenido en el pasado LC, sólo se les indagaba si habían tenido costos directos o indirectos para curarse de la LC. Nunca se preguntaba por cantidades de dinero, puesto que su recuerdo en el tiempo podía ser muy impreciso o sesgado y el valor relativo de esas magnitudes debía haber cambiado mucho. Entonces, en la encuesta de hogares sólo se registraba la presencia o la ausencia de costos directos e indirectos, si había tenido o no la consecuencia económica.
En cambio, en el estudio longitudinal, además de identificar la presencia o ausencia de los costos directos e indirectos, se registró la cuantía del costo cada vez que el paciente venía a consulta. Aquí el lapso de tiempo de recuerdo era de una semana en promedio, pudiéndose lograr una estimación más fidedigna de la magnitud de los costos directos e indirectos debido a la LC. Se registraba si tenía o no costos el paciente. Como resultado se identificó presencia o ausencia de costos a lo largo del tratamiento. Aparte se estimó la cuantía del costo en dinero.

\section{RESULTADOS}

\section{Principales Resultados del estudio}

TRANSVERSAL

\section{A) Prevalencia de LC}

En el estudio transversal se encuestaron 1376 hogares con 6801 personas. Se les preguntó si habían adquirido LC en algún momento en su vida. En caso de respuesta afirmativa se les preguntaba por cicatrices de sus lesiones. La prevalencia reportada por este estudio es de casos declarados por las mismas personas, sin demostración parasitológica en el instante e independientemente del momento de ocurrencia (prevalencia acumulada).

La prevalencia acumulada fue de 6,8\% (465/ 6801). Los 465 casos de LC pertenecían a 285 hogares. En 20,7\% (285/1376) de los hogares al menos uno de sus miembros dijo haber sufrido de LC, variando el número de casos entre 1 y 11 personas por hogar positivo. 7,8\% (108/1376) de los jefes de hogar reportaron haber tenido LC. Las tasas de prevalencia acumulada fueron mayores en área rural que en área urbana y en casos femeninos que en masculinos (ambas diferencias estadísticamente significativas; rural vs. urbano $\mathrm{p}<=0.001$; femenino vs. masculino $\mathrm{p}<=0.05$ ).

\section{B) SISTEMA DE SALUD USADO PARA CURARSE LA LC}

La mayoría $(59,5 \%)$ de los 465 casos de LC en la muestra dijeron haber usado sólo los servicios 
de salud pública gratuita para curarse sus lesiones. Los casos que dijeron haber usado una mezcla de servicios público y tradicional, o público y privado, o privado y tradicional, fueron $19,4 \%$. Pocos dijeron haber usado sólo los servicios de la medicina privada $(8,8 \%)$. Mientras que un 12,3\% declaró haberse curado sólo en su casa con remedios caseros. Es decir, este $12,3 \%$ de casos de LC, no tuvieron acceso a los servicios de cuidado de la salud de los sistemas modernos de medicina (ni en el sector público ni en el privado lucrativo). Esta distribución fue similar en los enfermos de LC, independientemente de su sexo y tipo de área de residencia. Un resumen se presenta en la siguiente tabla. solos en su casa dijeron menos frecuentemente haber tenido costos directos.

En general, de los 465 casos el 46,7\% declaró haber tenido costos directos para curar sus lesiones de LC, aunque éstos fueron más frecuentes entre los residentes de área rural que en los de área urbana, siendo esta diferencia estadísticamente significativa $(\mathrm{p}=<0.001)$. Pero en cuanto a los costos indirectos, en promedio la mitad de los casos dijeron haberlos tenido, independientemente del tipo de servicios curativos que utilizaron y de su tipo de lugar de residencia.

Tabla 1. Sistema de salud usado para curarse la LC

N= 465 casos de LC, Encuesta de Hogares, estado Trujllo, Venezuela 1994

\begin{tabular}{lll|}
\hline & n & $\%-1-$ \\
Moderna medicina pública & 277 & 59,5 \\
Sistemas médicos mixtos & 90 & 19,4 \\
Medicina tradicional casera & 57 & 12,3 \\
Moderna medicina privada & 41 & 8,8 \\
\hline & & 100, \\
\hline
\end{tabular}

\section{c) COSTOS SEGÚN EL TIPO DE SISTEMA DE SALUD UTILIZADO}

En el estudio transversal se trató de determinar si el paciente había tenido costos directos e indirectos. Esta información se cruzó con el tipo de sistema de cuidado de la salud que había utilizado la persona para curarse sus lesiones de LC. Se encontró que los usuarios de servicios de salud del sector privado lucrativo, declararon tener costos directos muy pocas veces, por tener cobertura de seguros de medicina privada (en este grupo estuvieron trabajadores petroleros). Los usuarios de servicios del sector público tuvieron costos principalmente de transporte, y los que usaron tratamientos tradicionales o se curaton

\section{Principales Resultados Del estudio}

\section{LONGITUDINAL}

En los tres establecimientos de salud pública donde se realizó el estudio, se ejecutaban programas de tratamiento gratuito de pacientes. Es decir, no se les cobraba ni pedía colaboración o contribución para cubrir costos de funcionamiento de esos programas. Estos establecimientos eran instituciones gubernamentales con políticas de subsidio a los pacientes. No se evaluaron los costos de los programas institucionales, sino las consecuencias económicas que tenían los pacientes por curarse sus lesiones de LC. 
Se quiso tener más de 100 pacientes, por cuanto ese número permitiría hacer tablas adecuadas y era suficiente para observar diferencias. La muestra estuvo constituida por los primeros 112 pacientes que llegaron en seis semanas. De los cuales 71 eran del área urbana y 41 del área rural, 54 masculinos y 58 femeninos.

La estructura etárea de la muestra de los 112 pacientes fue exactamente igual a la de los 6801 personas integrantes de la muestra de la encuesta de hogares. $\mathrm{Al}$ ser divididos en tres grupos etáreos, los 112 pacientes se dividían así: $28,6 \%$ niños ( $0-14$ años); $66,1 \%$ en edad productiva (15-64 años) y 5,3\% ancianos ( $=>65$ años).

En cuanto al sector de ocupación en la muestra, la mayoría de los pacientes $(30,4 \%)$ trabajaba en el sector informal, seguido por estudiantes (20,5\%), agricultura (17\%), sector público $(11,6 \%)$, sector privado $(9,8 \%)$, y el resto eran infantes preescolares $(10,7 \%)$. Los niños no tenían consecuencias económicas directas pero sus padres sí, cuando los traían a consulta.

La estructura de las ocupaciones mostró mayor diferencia entre pacientes masculinos y femeninos que entre los del área urbana y el área rural. Las mujeres estaban ocupadas principalmente en el sector informal y oficios del hogar o eran estudiantes, mientras que la ocupación más frecuente entre los hombres era la agricultura. El estatus socioeconómico del paciente afectó el tipo de consecuencias de las lesiones para sus labores habituales. Un ejemplo se presenta en la caja $\mathrm{N}^{0} 1$.

\section{LOS COSTOS DE LA LC EN EL ESTUDIO LONGITUDINAL}

Los costos directos considerados fueron:

a) Gastos de transporte, los cuales incluyeron:

- Pago de pasajes desde su hogar a la consulta y retorno;

- Gastos en comidas y refrigerios desde que sale de su hogar para la consulta, mientras espera turno y retorno;

- Si vino acompañado a la consulta o vino solo. b) Gastos de tratamiento, los cuales incluyeron:

- Compra de medicamentos, independientemente de que fueran prescritos por el médico o automedicados;

- Pago de consulta;

- Pago de exámenes de laboratorio;

- Pago por cualquier otro bien relacionado con la cura, fuera o no prescrito por el médico (materiales de limpieza, otras drogas, pago de promesas religiosas).

Aunque el tratamiento era gratuito, algunos pacientes que tenían otros problemas de salud, o embarazos, o reacción al medicamento, tenían que comprar otras drogas. No se incluyeron los «regalos» o «donaciones» en especie que los pacientes daban al personal de la consulta por la atención de sus lesiones (entre ellos, pan, café, huevos, dulces, hortalizas, frutas, de elaboración o cultivo de los pacientes).

En cuanto a los costos directos, la mitad de la muestra tuvo costos de tratamiento y casi todos los pacientes $(95,5 \%)$ tuvieron costos de transporte, sin diferencias notables de frecuencia de la ocurrencia del costo entre los de área urbana y los de área rural. Las pacientes femeninas en general y las de área rural en particular tuvieron más costos de transporte, por viajar acompañadas más frecuentemente.

El promedio del costo directo en dinero para el tratamiento de cada uno de los pacientes fue de US\$20,1. El registro de gastos por paciente tiene una enorme variación, que va desde cero hasta US\$ 173,8. Discriminando, se observa que:

- Los pacientes que culminaron su tratamiento y fueron dados de alta gastaron tres veces más que aquellos que abandonaron (una mediana de US\$ 12,9 versus US $\$ 4,1$ )

- Los pacientes que tuvieron costos de tratamiento pagaron 7,7 veces más que aquellos que no (una media de US\$20,9 versus US\$2,7).

- Los casos de área urbana gastaron más que los de área rural. Los pacientes urbanos gastaron un promedio de US $\$ 21,3$ (5,3 salarios diarios), mientras que en los rurales el gasto fue de US\$ 16,9 (5,8 salarios diarios). 
- Mientras más tiempo el paciente permanece en tratamiento, más dinero gasta. Aquellos que estuvieron en tratamiento por encima de la media de tiempo de la muestra, gastaron 2,6 veces más (US\$17,3 versus US\$ 6,6).

\begin{abstract}
Características Socioeconómicas de los PACIENTES DE LC Y CONSECUENCIAS DE SUS LESIONES. Seguimiento a pacientes 1994 - 1995, Trujillo, Venezuela / Caja $\mathbf{N}^{\circ} 1$

Carolina, femenina, edad madura, grupo socioeconómico alto:

Lesión: Una, pequeña, parte superior de una pierna. Consecuencia: Pena y ansiedad, porque no podía usar traje de baño en la piscina de su casa en reuniones con invitados. Sus negocios continuaban su ritmo normal, y ninguna de sus actividades hogareñas dejaron de hacerse, porque ella tenía tres empleadas del servicio doméstico trabajando a tiempo completo dentro de su casa.
\end{abstract}

\section{NANCY, FEMENINA, EDAD MADURA, COCINERA EN} RESTAURANTE:

Lesión: Una, en borde de labios vaginales, otra en antebrazo.

Consecuencia: Intenso estrés, relaciones interpersonales afectadas. Cesó actividad sexual. Trabajaba en un restaurante y escondía su antebrazo. Comenzó tratamiento secretamente y apoyada por sus compañeros de labor, pero al enterarse el gerente la obligaron a tomarse vacaciones con la advertencia de que si no regresaba curada sería despedida.

\section{Goyo, MASCulino, EDAD MAdURA, DUEÑo DE PANADERÍA:}

Lesión: Una, pequeñita, en dedo de la mano; otra en espalda.
Consecuencia: Como dueño de panadería se preocupó por sus clientes y buscó ayuda pronto, al inicio de con la lesión. Dijo nunca haber tenido costos indirectos por sus lesiones.

\section{ARTURO, MASCULINO, EDAD MADURA, TERRATENIENTE:}

Lesión: Una, en un brazo.

Consecuencia: Él era dueño de tierras, con varios campesinos trabajando bajo diferentes esquemas de medianería. Siempre declaró en las entrevistas que no perdía tiempo de trabajo ni se había afectado el output de su ocupación debido a las lesiones.

\section{CAMILO, MASCULINO, JOVEN, SOLDADO:}

Lesión: Una, profunda, en la cintura.

Consecuencia: El era soldado y no podía usar el uniforme adecuadamente debido a la lesión. Tenía un reposo médico renovable, dependiendo de opinión médica.

\section{CARMEN, FEMENINA, ADULTO JOVEN, TRABAJADORA} TEXTIL:

Lesión: Una, profunda, en un glúteo.

Consecuencia: Ella era costurera trabajando en una máquina de coser en condiciones de empresa «maquiladora». No tenía cobertura de seguridad social; y era pagada por tarea cumplida y piezas elaboradas. Ella necesitaba sentarse para trabajar, pero esa postura le molestaba la lesión. En consecuencia, suspendía su trabajo al sentir dolor y pasaba días sin trabajar hasta que su necesidad económica la obligaba a regresar a trabajar.
La magnitud del costo directo para el paciente se mantuvo baja debido a la política de subsidios del Ministerio de Sanidad y la Universidad de Los Andes. Por ejemplo, el precio de mercado local de los exámenes de laboratorio practicados a cada paciente, en promedio fue de US\$21,4. El precio de la droga de elección en el mercado local para dos series de inyecciones por paciente era de US\$50,0. El precio de la consulta médica por paciente por todo el tratamiento fue de US\$36,1 en el mercado local. El 
costo de la droga, de los exámenes y de la consulta fue subsidiado para los pacientes, quienes los recibieron gratis sin tener que pagar por ellos. En promedio el subsidio por paciente fue de US $\$ 107,5$ (igual a 374\% del salario semanal del paciente).

Los costos indirectos considerados fueron:

a) Tiempo perdido: Si el paciente había perdido tiempo de sus ocupaciones debido las lesiones o al tratamiento.

b) Actividad perdida: Si la actividad ocupacional había sido interrumpida, o el resultado (output) afectado debido a las lesiones o el tratamiento. El outputde los pacientes se afectó de modo distinto, según las características del oficio desempeñado. Un ejemplo con trabajadores urbanos se presenta en la caja $\mathrm{N}^{\circ} 2$.

En la muestra, la pérdida de tiempo de trabajo (89,3\% de los casos) fue más frecuentemente reportada que la pérdida de actividad ocupacional (81,3\% de los casos), siendo ligeramente mas frecuentemente afectados los pacientes rurales que los urbanos. El precio de mercado del tiempo de trabajo perdido debido a la LC por pacientes ocupados en actividades pagadas fue en promedio US\$ 30,2 (igual a $104,2 \%$ de su salario semanal).

En resumen, sumando los costos directos e indirectos, los costos totales que tuvo el promedio de pacientes adultos en la muestra tratados en establecimientos de salud pública y con políticas de subsidios fue de US $\$ 50,3$ (igual a 174,2\% de su salario semanal). En promedio, los pacientes estuvieron en tratamiento durante 11,2 semanas, durante las cuales fueron a consulta 8,8 veces

\section{DiSCUSIÓN Y CONCLUSIONES}

\section{Costos directos E INDIRECTOS DEBIDO A LA LC}

En el estudio de seguimiento se evidenció que pacientes de $\mathrm{LC}$ recibiendo tratamiento gratuito en establecimientos de salud pública tenían costos directos e indirectos. Sus costos de transporte fueron mayores que sus costos de tratamiento.

En promedio y en términos monetarios, por todo el período de tratamiento:
- Los costos indirectos se estimaron equivalentes a $104,2 \%$ del salario básico semanal de un trabajador urbano.

- Los costos directos fueron equivalentes a 70\% del salario básico semanal de un trabajador urbano.

El total de costos directos e indirectos del paciente fue equivalente a $174 \%$ del salario básico semanal de un trabajador urbano, lo cual se estima es costoso comparado con lo que los pacientes de LC pueden pagar de su bolsillo. Esta carga económica pareció en esta investigación haber afectado el cumplimiento y permanencia de los pacientes con su tratamiento. Una situación similar fue observada en Tailandia, donde los tratamientos para la malaria eran gratuitos pero los costos directos e indirectos para los pacientes eran tan altos que los abandonaban (UndP/World Bank/WHO-TDR, 1991). También en Nepal se observó que una gran cantidad de pacientes usaban fuentes de tratamiento privadas, a pesar de ofrecerse tratamiento que era gratuito pero tenía costos para los pacientes (Mills, 1993).

Los costos de los pacientes en trabajos sobre control de leishmaniasis no son usualmente considerados. En los pocos casos que han sido reportados los costos de los pacientes, parecen muy altos con relación a sus ingresos. Por ejemplo, en Ecuador, los costos indirectos para el paciente fueron estimados equivalentes a 20 días de trabajo (Fundaciones Brethren y Unida, 1987). En Mérida, Venezuela, los costos indirectos de los pacientes de LC fueron estimados equivalentes a 78 días de trabajo (Scorza \& Rojas, 1990).

En general, ha sido señalado que los costos indirectos pueden exceder ampliamente los costos directos para los pacientes y convertirse en una barrera para la utilización de los servicios de la medicina moderna (Kroeger, 1983). Es por ello importante su estimación lo mas fielmente posible y buscar alternativas para aliviar sus consecuencias negativas.

Aun siendo gratuito en establecimientos de salud pública, los costos del tratamiento para el paciente pueden ser tan altos que pueden llegar a ser impagables para aquellos que no pueden estar ausentes de su trabajo por períodos de tiempo tan prolongados (Wijeyaratne et al., 1994). Por ejemplo, 
Costos IndiRECTOS DEBIDO A LA LC y ALGUNOS tipos de trabajadores urbanos. Seguimiento a pacientes 1994 - 1995, Trujillo, Venezuela / CAJA $\mathbf{N}^{\circ} 2$

\section{TobÍAs, CONDUCTOR DE MINIBÚs EN RUTA DE TRANSPORTE URBANO:}

Era miembro de una asociación de transportistas de pasajeros. Los conductores tenían que llegar tan temprano como fuera posible al comenzar cada día de trabajo y por ese orden de llegada recibían cada uno un número fijo que era su orden de «turno» para recoger pasajeros ese día. Cada conductor hacía su turno y tenía que esperar que todos los demás hicieran sus respectivos turnos para poder salir a buscar pasajeros en su turno de nuevo. Por eso, el tiempo de trabajo real que Tobías perdía cada vez que venía a curarse en la consulta era más que el tiempo de espera para ser atendido, porque estaba perdiendo su turno.

\section{BARTOLO, LICENCIADO EN CONTADURÍA, PROFESOR, CONSULTOR:}

Tenía registrado los gastos monetarios del tratamiento, incluso por cambios de dieta como consecuencia de los medicamentos que tomaba. Describió otros aspectos de sus costos directos, tales como la depreciación y el desgaste de partes consumibles de su vehículo, el estrés y los riesgos de accidente de carretera cuando buscaba cura todos los días (tuvo cambios de tratamientos debido a reacciones a las drogas usadas, fue hipersensible y su cura fue prolongada). Con respecto a sus costos indirectos él los colocaba en una perspectiva más amplia, por sus ocupaciones. Recuperar horas de clase perdidas, le restaba tiempo para su ejercicio privado y afectaba el tiempo de sus estudiantes también, pues era tutor de tesis universitarias y las había retrasado.

\section{MARIO, VENDEDOR AMBULANTE DE CAFÉ MANEJANDO UNA MOTO:}

Se desplazaba por diferentes sitios de la ciudad ofreciendo café caliente, el cual guardaba en termos en la parrilla de su moto. Cuando estaba esperando en la consulta para ser atendido perdía tiempo de trabajo aún más valioso para su oficio, por cuanto la hora de mayor actividad y rentabilidad correspondía al tiempo de la consulta; en otro horario le rendía diferente.

\section{Carola, cajera en un banco cerca de la CONSULTA:}

Ella llegaba temprano a la consulta para ser atendida a las 8:00 y luego se iba al banco a trabajar normalmente. Ella dijo que así llegaba 15 minutos tarde al trabajo pero que ella trabajaba 15 minutos extras cada vez para compensar.

\section{Alejo, lavador de CARRos EN LA CALle:}

Lavaba carros en un parque público y en las calles. Si no trabajaba no recibía ingreso. Cuando venía a tratamiento perdía ingreso pero él decía que lo recuperaba trabajando extra los domingos. en Brasil, 49,3\% de pacientes de LC atendidos en establecimientos de salud pública abandonaron sus tratamientos (Teodoro et al., 1991). En nuestro estudio, 36,6\% de pacientes de área rural y $28,2 \%$ de área urbana abandonaron sus tratamientos. Sin embargo, las relaciones entre costos y cumplimiento con el tratamiento requieren mayor investigación.

En el estudio longitudinal se observó que los pacientes acostumbraban llevar productos cosechados o elaborados por ellos mismos, como regalos al personal de salud. Esos regalos no fueron considerados, pero pudieron haber incrementado el costo real considerablemente.

Aunque los pacientes del medio rural perdieron más tiempo de trabajo que los del medio urbano, el valor monetario de sus pérdidas fueron aparentemente menores debido a que tenían salarios básicos más bajos. 


\section{Costos ECONÓMICOS Y CONTROL DE LA}

\section{LEISHMANIASIS}

De acuerdo con nuestra revisión de literatura, hasta el presente no han sido publicados trabajos en inglés o en español sobre los costos directos para el paciente debido a la LC. Sólo estimaciones de costos para las instituciones de salud han sido reportados en publicaciones sobre epidemiología y control de la leishmaniasis.

Algunos programas de intervención basados en la estrategia de atención primaria de salud para el control de leishmaniasis cutánea y mucocutánea, dicen haber alcanzado una reducción para los pacientes de los costos del tratamiento e incrementado el cumplimiento del paciente con el tratamiento de la medicina moderna en Perú (Llanos-Cuentas et al., 1992), en Costa Rica (Zeledón, 1992), en Colombia (Rojas, 1992) y en Bolivia (Dedet et al., 1995). Todas esas fucron estrategias de intervención sostenidas por apoyo financiero externo, basadas en educación del público y mejor acceso geográfico al tratamiento en áreas endémicas. Sin embargo, ninguna de ellas estimó los costos directos para el paciente debido a LC y su tratamiento.

En las circunstancias actuales de contracción financiera, de reducción de subsidios y restricción en el gasto público, los costos de la enfermedad y del tratamiento (para los pacientes y para las instituciones de salud) se convierten en un punto clave en la evaluación de alternativas para el control de la leishmaniasis (Díaz, 1996). Los resultados señalan que para una nueva droga o tratamiento ser exitosos debe considerarse tanto la eficacia contra el parásito como la accesibilidad y la posibilidad de pagar sus costos el paciente y el establecimiento de servicios de salud. Los hallazgos de nuestro estudio refuerzan la necesidad de considerar la importancia de los subsidios directos y la seguridad social efectiva para los pacientes si se aspira mejorar la eficacia de los programas de control de la leishmaniasis en el contexto de los debates sobre la reforma de los sistemas de salud.

\section{REFERENCIAS BIBLIOGRÁFICAS}

Arana B., 1992. Leishmaniasis en Guatemala: epidemiología, terapéutica y aspectos sociales. En: Enfermedades parasitarias de mayor prevalencia $y$ transmitidas por vectores en Centroamérica (H. Consensa \& A. Kroeger, edits.), pp. 199-206. Tegucigalpa: Editorial Universidad Nacional Autónoma de Honduras.

Camino, L. \& Anderson, A., 1992. Lenguaje, conocimiento y mito: análisis del saber empírico sobre la leishmaniasis en minorías étnicas y grupos mestizos. Revista Peruana de Epidemiología, 5 (1):32-35.

Castés, M.; Jiménez, M.; Castañeda, N.; Roda, A. \& Martín, I., 1992. Estudio de los aspectos epidemiológicos y socioeconómicos en mujeres con leishmaniasis. Fermentum, 2 (4):85-98.

Convit, J. \& Pinardi, M., 1984. Cutaneous leishmaniasis, the clinical and immunopatological spectrum in South America. En: Trypanosomiasis and leishmaniasis with special reference to Chagas disease. Amsterdam: CIBA Foundation Symposium 20.

Costa, J.; Vale, K.; Cecilio, I.; Osaki, N.; Netto, E.; Tada, M.; Franca, F.; Barreto, M. \& Marsden, P., 1987. Aspectos psicossociais e estigmatizantes da leishmaniose cutaneomucosa. Revista da Sociedade Brasileira de Medicina Tropical, 20 (2):77-82.

De Bellard, E.P., 1923. Venezuelan Sun Limited, Medical Department, first annual report 1922. Caracas: Tipografía Americana.

Dedet, J.P.; Pillot, B. \& Gentilini, M., 1991. Evaluation du cout socio-economique de la leishmaniose cutanée en Guyane Française. Revue de Epidémiologie et Santé Publique, 39:129-133.

Dedet, J.P.; Melogno, R.; Cárdenas, F.; Valda, L.; David, C.; Fernández, V.; Torrez, M.; Dimier-David, L.; Lyevre, P. \& Villarreal, M., 1995. Rural campaign to diagnose and treat mucocutaneous leishmaniasis in Bolivia. Bulletin of the World Health Organisation, 73 (3):339-345. 
Desjeux, P., 1991. Information on the epidemiology and control of the leishmaniasis by country or territory. WHO/LEISH/91.30. Ginebra: WHO.

Díaz, B., 1992. Social factors of the leishmaniasis with particular reference to Latin America. MSc Report, Londres: University of London.

Díaz, B., 1996. The socioeconomic consequences of cutaneous and visceral leishmaniasis in Trujillo, Andean Area of Venezuela. PhD thesis, Liverpool: University of Liverpool.

Dobles-Ulloa, A. \& Perriard, C., 1994. Representaciones, actitudes y prácticas respecto a la leishmaniasis cutánea en la población del Cantón de Acosta, Provincia de San José, Costa Rica. Estudio antropológico exploratorio. Cadernos de Saúde Pública, 10 (2):181-189.

Fundaciones Brethren y Unida, 1987. Leishmaniasis. Manual para tratamiento de leishmaniasis. Quito: Fundaciones Brethren y Unida.

Grimaldi, G.; Tesh, R. \& McMahon-Pratt, D. (1989). A review of the geographic distribution and epidemiology of leishmaniasis in the New World. American Journal of Tropical Medicine and Hygiene, 41 (6):687-725.

Guthmann, J.; Calmet, J.; Rosales, E.; Cruz, M.; Chang, J. \& Dedet, J., 1998. Las asociaciones de pacientes y el control de la leishmaniasis en el Perú. Revista Panamericana de Salud Pública, 3 (6):400-404.

Houin, R. \& Khouri, P., 1989. Leishmaniasis visceral \& cutaneous. Beirut: AJM, Fondation RhonePoulenc Sante.

Instituto de Biomedicina del Ministerio de Sanidad y Asistencia Social de Venezuela, 1986. Programa de dermatología sanitaria. En: VII Congreso Venezolano de Salud Publica, Memoria, tomo II, pp. 792-810. Caracas: MSAS.

Isaza, D.; Restrepo, B.; Arboleda, M.; Casas, E.; Hinestroza, H. \& Yurgaqui, T., 1999. La leishmaniasis: conocimientos y prácticas en poblaciones de la costa del Pacífico en Colombia. Revista Panamericana de Salud Pública, 6 (3):177-183.
Kroeger, A., 1983. Anthropological and socio-medical health care research in developing countries. Social Science and Medicine, 17 (3):147-161.

Kroeger, A.; Mancheno, M.; Ruiz, W. \& Estrella, E., 1991. Malaria y leishmaniasis cutánea en Ecuador. Un estudio interdisciplinario. Quito: Abya-Yala.

Le Moine, G. \& Scott Raymond, J., 1987. Leishmaniasis and Inca settlement in the Peruvian Jungle. Journal of Historical Geography, 13 (2):113-129.

Lima, A.P.; Junqueira, G.M.; Misuta, N.M.; Nerilo Sobrinho, A. \& de Lima E.M., 1991. Necessity to adopt and disseminate therapeutic schemes for the treatment of American tegumentary leishmaniasis in Parana. Revista do Instituto de Medicina Tropical de Sao Paulo, 33 (3):199-204.

Llanos-Cuentas, A.; Chang, O. \& Echevarria, J., 1992. Adapting anti-leishmanial therapy to peripheral health services and community health workers. En: Leishmaniasis control strategies: a critical evaluation of IDRC-supported research, IDRC Manuscript Report 322e.

Magalhaes, H.; Costa, J.; Costa, R.; Franca, F.; Vale, K.; Marsden, P. \& Magalhaes, A., 1990. Mudança do componente cognitivo da atitude de uma populaçao de regiao endemica do sul da Bahia diante da leishmaniose tegumentar. Revista da Sociedade Brasileira de Medicina Tropical, 23 (1):49-52.

Maingon, R.; Feliciangeli, D.; Guzman, B.; Rodriguez, N.; Convit, J.; Adamson, R.; Chance, M.; Petralanda, I.; Dougherty, M. \& Ward, R., 1994. Cutaneous leishmaniasis in Tachira State, Venezuela. Annals of Tropical Medicine and Parasitology, 88 (1):29-36.

Mills, A., 1993. The households costs of malaria in Nepal. Annals of Tropical Medicine and Parasitology, 44:9-13.

Momem, H. \& Grimaldi, J., 1989. Enzyme electrophoretic evidence for the importation of $\mathrm{L}$. infantum into the $\mathrm{New}$ World. En: Leishmaniasis. The current status and new strategies for control (D. Hart, ed.), pp 911-916. Nueva York: Plenun Press. 
Netto, E.; Tada, M.; Golightly, L.; Kalter, D.; Lago, E.; Barreto, A. \& Marsden, P., 1985. Conceitos de uma populaçao local a respeito da leishmaniose mucocutanea em uma área endemica. Revista da Sociedade Brasileira de Medicina Tropical, 18 (1):33-37.

OCEI (Oficina Central de Estadística e Informática), 1993. Mapa de la pobreza. Caracas: OcEI.

OCEI/PNud, 1998. Indice y entorno del desarrollo bumano en Venequela. Caracas: OcEI.

Pifano, F., 1960. Aspectos epidemiológicos de la leishmaniasis tegumentaria en la región neotrópica, con especial referencia a Venezuela. Archivos Venezolanos de Medicina Tropical y Parasitología Médica, III (2):31-61.

Ponds, A., 1968. Leishmaniasis tegumentaria americana en el asentamiento campesino Zipayare. Aspectos epidemiológicos, clínicos e inmunológicos. Su importancia en la Reforma Agraria. Kasmera, 3 (5):5-59.

Remme, J.; De Raadt, P. \& Godal, T., 1993. The burden of tropical diseases. The Medical Journal of Australia, 158 (7):465-469.

Rojas, C., 1992. Adapting leishmaniasis treatment to peripheral health centers and communities. En: Leishmaniasis control strategies: a critical evaluation of IDRC-supported research. IDRC Manuscript report 322e. Ottawa: IDRC.

Ruths, F., 1991. Conceptos y actitudes de la población frente a la leishmaniasis cutánea. En: Malaria y leishmaniasis cutanea en Ecuador. Un estudio interdisciplinario (A. Kroeger, M. Mancheno, W. Ruiz \& E. Estrella, edits.), pp. 325-336. Quito: Abya-Yala.

Scorza, J.V. \& Rojas, E., 1990. La leishmaniasis tegumentaria venezolana: problemática contemporánea en el estado Trujillo, soluciones. Boletín de la Dirección de Malariología y Saneamiento Ambiental, 30 (3-4):1-6.

Scorza, J.V.; Macias, P. \& Rojas, J., 1985. Encuesta epidemiológica sobre leishmaniasis cutánea urbana en la ciudad de Trujillo, Venezuela. Boletín de la Dirección de Malariología y Saneamiento Ambiental, 25 (34):73-81.
Tejera, E. 1919. La leishmaniasis americana en Venezuela. Memoria presentada a la Academia Nacional de Medicina (1918). Caracas: Imprenta Nacional.

Tejera, E., 1917. Varios casos de leishmaniasis americana en el estado Zulia. Nota preliminar. Gaceta Médica de Caracas, 24:145-146.

Teodoro, U.; Spinoza, R.P.; La Salvia Filho, V.; Guilherme, A.L.; Lima, A.P.; Junqueira, G.M.; Misuta, N.M.; Nerilo Sobrinho, A. \& de Lima, E.M., 1991. Necessity to adopt and disseminate therapeutic schemes for the treatment of American tegumentary leishmaniasis in Parana. Revista do Instituto de Medicina Tropical de Sao Paulo, 33 (3):199-204.

UnDP/World Bank/WHO-TDR, 1991. Social and economic research and leishmaniasis. Tenth Programme Report, 1989-1990. NY: UNDP/ World Bank/ WHO-TDR.

Vázquez, M.L.; Kroeger, A.; Lipowsky, R. \& Alzate, A., 1991. Conceptos populares sobre la leishmaniasis cutánea en Colombia y su aplicabilidad en programas de control. Boletin de la Oficina Sanitaria Panamericana, 110 (5):402-415.

Vivas, L., 1992. Los Andes venezolanos. Caracas: Academia Nacional de La Historia.

WHO, 1990. Control of the leishmaniases. WHO Technical Report Series 793. Ginebra: WHO.

Wijeyaratne, P., 1988. The leishmaniases and development: research issues. Research on control strategies for the leishmaniases. IDRC Manuscript report 184e. Ottawa: IDRC.

Wijeyaratne, P.; Jones, L.; Murphy, C., 1994. Endemic disease and development: the leishmaniases. Acta Tropica, 56:349-364.

Zeledon, R., 1992. Leishmaniasis as a public health problem with emphasis on Latin America. Leishmaniasis control strategies: a critical evaluation of IDRC-supported research. IDRCManuscript report 322e. Ottawa: IDRC.

Los autores testimonian su agradecimiento a los doctores José Vicente Scorza y Rosaura Hernández, directores de los programas institucionales donde se realizó el estudio de seguimiento a pacientes de leishmaniasis. 


\section{SituACIÓN MUNDIAL DE LA EPIDEMIA DEL SIDA}

Angela Torres*

\section{INTRODUCCIÓN}

El presente trabajo tiene la intención de dar a conocer una vasta panorámica sobre la situación mundial de la epidemia del VIH/SIDA, con énfasis en Latinoamérica. Hablamos de una epidemia que ha socavado los esfuerzos de los gobiernos nacionales, de las organizaciones no gubernamentales y de sus asociados en materia de salud, disminuyendo la esperanza de vida, aumentando la morbimortalidad y abarrotando los servicios de salud, afectando así el bienestar económico de los países — por los años de vida perdidos y las inversiones perdidas en la formación de recursos humanos que han muerto a causa del virus - e incluso la estabilidad política, especialmente en el mundo en desarrollo.

El análisis de los datos de vigilancia arrojan cifras cada vez más alarmantes. De acuerdo al Programa Conjunto de las Naciones Unidas sobre el Sida (Onusida) y la Organización Mundial de la Salud (OMS), copatrocinadora de ONUSIDA, a comienzos de 1998 había más de 33,4 millones de personas infectadas por el VIH y 11,7 millones de personas habían fallecido por esa enfermedad; se producen 16 mil nuevas infecciones diarias y solamente en 1997 se produjeron 5,8 millones de nuevas infecciones. América Latina está seriamente afectada por la epidemia, aunque en muchos de los países la vigilancia presenta serias deficiencias por falta de notificación, no se lleva registro de infectados, etc., lo que hace que el subregistro sea muy elevado. Los datos aportados son estimaciones, en muchos de ellos por la falta de información veraz (ONUSIDA, 1996-1997; Onusida/OMS, 1997; Bernard, 1998a).
En primer lugar trataremos de la casuística de personas afectadas por la epidemia; en segundo lugar el SIDA y las enfermedades infecciosas; en tercer lugar la situación de África; en cuarto lugar el SIDA en Asia; en quinto lugar la presencia del viH/SIDA en Norteamérica y Europa Occidental; en sexto lugar América Latina y el Caribe, con énfasis en América Latina, y finalmente concluimos con unas acciones que se están realizando y unas recomendaciones que a nuestro parecer ayudarían a disminuir notablemente esta problemática.

\section{ESTIMACIONES DE MORBIMORTALIDAD}

Según las estimaciones más recientes de Onusida (1998), a finales de ese año el número de personas que viven con el VIH (virus de inmunodeficiencia humana, el virus que causa el SIDA) aumentó hasta 33,4 millones, un 10\% más que el año anterior. La epidemia no ha sido controlada en ningún lugar. En prácticamente todos los países del mundo se produjeron nuevas infecciones en 1998 y son muchos los lugares en los que la epidemia está creciendo incontroladamente. Las nuevas infecciones alcanzaron a 5,8 millones y las defunciones a 2,5 millones, con un acumulado de 13,9 millones para el mismo año.

Médico cirujano. Postgrado en psiquiatría y en administración sanitaria. Asesora nacional del Programa de Sida para Venezuela, 1996-2000. Consultora de Sida para Venezuela y Antillas Holandesas (OPS/OMS), 1991-1996. 
ESTIMACIONES MUNDIALES A FINES DE 1998

Adultos Y niÑos / CuAdro 1

- Personas que viven con el vIH/SIDA

- Nuevas infecciones por el viH en 1998

- Defunciones por causa del VIH/SIDA en 1998

- Número acumulativo de defunciones por causa del VIH/SIDA
3,4 millones

5,8 millones

2,5 millones

13,9 millones

\section{ONUSIDA}

Programa Conjunto de las Naciones Unidas sobre el VIH/SIDA
Organización Mundial de la Salud
En la actualidad, más del 95\% de las personas infectadas por el VIH viven en el mundo en desarrollo, y es en estos países en los que se ha producido el $95 \%$ de todas las defunciones causadas por el SIDA hasta la fecha, sobre todo en adultos jóvenes que, en condiciones normales, se encontrarían en los años de máxima actividad productiva y reproductiva. Las múltiples repercusiones de estos fallecimientos están alcanzando proporciones de crisis en algunas partes del mundo. Sea cual sea el patrón de medida utilizado (deterioro de la supervivencia infantil, descenso de la esperanza de vida, sobrecarga de los sistemas de asistencia sanitaria, aumento de la orfandad o reducción de los beneficios empresariales), el SIDA plantea una gran amenaza para el desarrollo (Bernard et al., 1998).

De acuerdo a las últimas estimaciones de ONUSIDA/OMS, durante 1998 se produjeron, en todo el mundo, 11 infecciones de hombres, mujeres y niños por minuto, con un total cercano a 6 millones de personas. Una décima parte de las personas recién infectadas tenían menos de 15 años de edad, lo cual hace que el número de niños vivos con el VIH alcance ahora los 1,2 millones (Bernard, 1998b). Se cree que la mayor parte de ellos han contraído la infección a través de sus madres, antes del nacimiento, durante el parto, o bien a través de la lactancia materna. La transmisión de la madre al niño puede reducirse con la administración de fármacos antirretrovirales a las mujeres embarazadas VIH-positivas y sustitutos de la leche materna, aunque el objetivo final debe ser una prevención eficaz en las mujeres jóvenes, para evitar contraer la infección inicial. Por desgracia, en lo que respecta a la infección por el VIH, las mujeres parecen estar alcanzando una equiparación con los hombres. Mientras que en 1997 constituían un 41\% de los adultos infectados en todo el mundo, en la actualidad las mujeres representan un $43 \%$ de todas las personas de más de 15 años de edad que viven con el VIH y el SIDA. No hay indicio alguno de que esta tendencia a la igualdad en la relación hombre/ mujer vaya a invertirse.

En total, desde el inicio de la epidemia hace unas dos décadas, el VIH ha infectado a más de 47 millones de personas. Aunque se trata de un virus de acción lenta que puede tardar una década o más en causar una enfermedad grave y la muerte, el VIH ha costado ya la vida a casi 14 millones de adultos y niños.

\section{EL SIDA Y LAS ENFERMEDADES INFECCIOSAS}

Según las estimaciones recientes de la OMS, el paludismo causa más de un millón de muertes al año. 
En 1998, los fallecimientos debidos al SIDA ascendieron, como ya señalamos, a unos 2,5 millones. Ambas enfermedades se encuentran entre las cinco principales causas de defunciones en todo el mundo. Sin embargo, es importante que no pase desapercibida la dinámica de esta situación. Ya en el año 1954 fallecían millones de personas cada año a causa del paludismo. El SIDA es una epidemia que se encuentra todavía en fase emergente y el número de muertes que causa aumenta año tras año, al ticmpo que el número de personas que contraen la infección diariamente se incrementa en unas 16 mil.

La tuberculosis, la segunda causa de muerte infecciosa más importante, está aumentando también como consecuencia en gran parte de la epidemia del VIH. Las personas cuyas defensas inmunitarias se ven debilitadas por la infección por el VIH pasan a ser presa fácil para otros gérmenes, como el bacilo causante de la tuberculosis. Las infecciones a que ello da lugar (junto con algunos cánceres) son las causantes de las enfermedades recurrentes que, en sus fases avanzadas, se denominan "SIDA", y que conducen finalmente a la muerte. Alrededor del 30\% de todos los fallecimientos por SIDA son consecuencia directa de la tuberculosis.

Los individuos con una infección doble por VIH/ TB se enfrentan a un riesgo muy superior al de los portadores de TB que son VIH-negativos. En todo el mundo hay millones de personas que están infectadas por el VIH y a la vez por el bacilo de la tuberculosis, y el potencial de aumento de la coinfección en los países en desarrollo es amplio, teniendo en cuenta la abrumadora prevalencia de portadores de TB en la población general (aproximadamente $30 \%$ ) y cerca de 6 millones de nuevas infecciones por el VIH anuales. Para hacer frente a la doble epidemia serán necesarias medidas más firmes para la detección y tratamiento de los casos de TB (la tuberculosis puede curarse con antibióticos, con independencia de que la persona afectada esté o no infectada por el VIH), paralelamente con programas de prevención del SIDA más eficaces destinados a evitar nuevas infecciones por el VIH.

\section{ÁFrICA}

En el África subsahariana vive el 70\% de las personas que contrajeron la infección por el VIH durante 1999. También es la región en la que se produjeron las cuatro quintas partes del total de defunciones por SIDA en 1998. Desde el inicio de la epidemia, un $83 \%$ de las muertes debidas al SIDA se han producido hasta ahora en esta región. En cuanto a los niños menores de 15 años de edad, la cuota de África en las infecciones contraídas en 1998 fue de 9 de cada 10. El 95\% de todos los huérfanos causados por el sIDA son africanos. Sin embargo, tan sólo una décima parte de la población mundial vive en África subsahariana. La cifra absoluta de africanos afectados por la epidemia es abrumadora. Desde que se inició la propagación del VIH, se estima que 34 millones de personas de África subsahariana han contraído la infección por el virus. Unos 11,5 millones de ellas han fallecido ya, y una cuarta parte de esos casos eran niños. Se estima que durante 1998 el SIDA fue la causa de 2 millones de muertes en África (5.500 funerales al día). A pesar de la magnitud de la mortalidad, actualmente hay más africanos que antes viviendo con el VIH: 21,5 millones de adultos y un millón de niños (ONusida, 1998).

Aunque no hay ningún país de África que haya escapado al virus, algunos se han visto afectados de manera mucho más grave que otros. El mayor número de infecciones recientes continúa concentrándose en la parte oriental y especialmente en la meridional, donde se encuentran la mayoría de los países más gravemente afectados del mundo. En Botswana, Namibia, Swazilandia y Zimbabwe, las estimaciones actuales indican que entre el 20\% y el $26 \%$ de las personas de 15 a 49 años de edad viven con el VIH o el SIDA. Lamentablemente, se cree que en 1999 una de cada siete nuevas infecciones ocurridas en el continente corresponde a Sudáfrica, que se había mantenido por detrás de algunos de los países vecinos en cuanto a las cifras de infección por el VIH. Simbabwe es un país que se ha visto especialmente afectado; existen allí 25 centros de vigilancia en los que se extraen muestras de sangre a mujeres embarazadas para realizar análisis de manera anónima, como forma de seguir la evolución de la infección por el VIH. Los datos más recientes, correspondientes a 1997, indican que tan sólo en dos de esos centros se observó que la prevalencia del VIH se mantenía por debajo del 10\%. En los 23 centros restantes se observó que un $20-50 \%$ de las mujeres embarazadas estaban infectadas. Como mínimo una tercera parte 
de esas mujeres es probable que transmitan la infección a sus hijos recién nacidos.

Otras zonas del continente no son en modo alguno inmunes a esta epidemia. En la República Centroafricana y Kenya, uno o más de cada diez adultos está infectado por el VIH. Sin embargo, en general África oriental está menos afectada por el VIH que la parte del sur o la parte oriental del continente y algunos países del centro se han mantenido también relativamente estables en cuanto al VIH. Estas tasas más bajas pueden atribuirse en algunos casos a las medidas de prevención tempranas y sostenidas que se han aplicado; Senegal es un buen ejemplo de ello. Sin embargo, en otros lugares, en los que se ha hecho mucho menos por fomentar unas relaciones sexuales seguras, las causas de la relativa estabilidad no están claras. Se están realizando investigaciones para explicar las diferencias existentes entre las epidemias de diversos países. En esos estudios se examinan factores que pueden desempeñar algún papel, como los modelos de establecimiento de contactos sexuales, el grado de uso de preservativos con diferentes compañeros y el tratamiento o no de otras Infecciones de Transmisión Sexual (ITS), que facilitarían la transmisión del VIH a través de las relaciones sexuales.

\section{ASIA}

Cada vez se centra más la atención en la propagación del VIH a través del continente asiático, y en especial de Asia meridional y sudoriental. Aunque las tasas continúan siendo bajas en comparación con las de algunas otras regiones, hay más de 7 millones de habitantes de Asia infectados y el VIH está empezando a propagarse claramente de manera importante en las poblaciones de India y China.

La India nos ofrece un ejemplo interesante del cambio que se produce en los patrones de propagación del VIH:

Hasta hace poco se pensaba que la infección por el VIH en la segunda nación más poblada del mundo se concentraba en los consumidores de drogas intravenosas y en los profesionales del sexo y sus clientes urbanos de algunos estados. Los resultados de la última ronda de vigilancia centinela en dispensarios prenatales ponen de manifiesto que, por lo menos en cinco estados, más del 1\% de las mujeres embarazadas en las zonas urbanas están infectadas.

Se creía que las zonas rurales - en las que vive el 73\% de los 930 millones de habitantes del paísestaban relativamente poco afectadas por la epidemia. Los estudios recientes indican de nuevo que, al menos en algunas áreas, el VIH ha pasado a tener una frecuencia preocupante tanto en los pueblos como en las ciudades. En una encuesta reciente de familias elegidas aleatoriamente en Tamil Nadu se encontró que el 2,1\% de la población adulta en las zonas rurales tenía el virus, en comparación con el $0,7 \%$ de la población urbana. En el caso de este estado pequeño, con una población de 25 millones de habitantes, los resultados del estudio parecen indicar que hay cerca de medio millón de personas actualmente infectadas por el VIH en Tamil Nadu. Teniendo en cuenta que aproximadamente el $10 \%$ de las personas encuestadas tenían blenorragia, sífilis u otras ITS, el VIH dispone de un terreno fértil para su propagación.

El VIH está firmemente arraigado en la población general, y afecta a las mujeres cuyo único comportamiento de riesgo es tener relaciones sexuales sin protección con sus maridos. En un estudio de casi 400 mujeres que no eran profesionales del sexo y que acudieron a centros de tratamiento de ITS de Pune, el 93\% estaban casadas y el 91\% no habían tenido nunca relaciones sexuales con otras personas que no fueran sus maridos. Todas esas mujeres tenían una ITS y es de destacar que un 13,6\% de ellas dieron resultados positivos en las pruebas de detección del VIH (Bernard, 1998c).

\section{NorTEAMÉRICA y EUROPA OCCIDENTAL}

En América del Norte y Europa occidental, las nuevas combinaciones de medicamentos contra el VIH continúan reduciendo de manera significativa las defunciones por SIDA. Por ejemplo, las cifras publicadas recientemente indican que en 1997 la tasa de mortalidad por SIDA en Estados Unidos de América fue la más baja de la última década, casi dos tercios por debajo de las tasas registradas tan sólo dos años antes, cuando no se había iniciado el uso generalizado del tratamiento combinado. Sin embargo, como continúan produciéndose nuevas 
infecciones al tiempo que las combinaciones de medicamentos antirretrovirales mantienen con vida a las personas infectadas, la proporción de la población que vive con el VIH ha aumentado. Ello hace aumentar, obviamente, las demandas de asistencia e incrementa los obstáculos para la prevención a los que han de hacer frente los países.

El VIH continúa su escalada en los grupos de consumidores de drogas intravenosas de Europa oriental. Por el momento, Ucrania continúa siendo el país más afectado, aunque la Federación Rusa, Belarús y Moldova han registrado aumentos muy notables en los últimos años. El VIH está penetrando a través de los nuevos grupos de población consumidora de drogas, con lo que la posibilidad de una mayor propagación a través de las drogas y del sexo resulta innegable, teniendo en cuenta el vínculo existente entre las poblaciones de consumidores de drogas intravenosas y las de profesionales del sexo con los notables aumentos que se están produciendo en otras ETS. Así, por ejemplo, en la Federación Rusa las tasas de sífilis han pasado de los aproximadamente 10 casos por 100 mil habitantes que había a finales de los años ochenta a más de 260 casos por 100 mil habitantes un decenio después.

Durante 1998, América del Norte y Europa occidental no han registrado progreso alguno en cuanto a la reducción del número de nuevas infecciones. Los impresionantes aumentos iniciales del VIH se revirtieron con éxito hacia mediados y finales de los años ochenta gracias a las campañas de prevención, que contribuyeron a aumentar el uso del preservativo entre los hombres homosexuales de prácticamente el $0 \%$ a bastante por encima del 50\%. Pero durante el último decenio, la tasa de nuevas infecciones se ha mantenido estable en lugar de seguir bajando. Tan sólo durante 1998, contrajeron la infección por el VIH casi 75 mil personas, con lo que el total de personas que viven con el VIH en esas dos regiones pasó a ser de casi 1,4 millones.

Ciertamente, la epidemia ya no está fuera de control en los países de esas regiones. Pero también es cierto que no se ha detenido. Y en esa fase, los obstáculos para la prevención son mayores que nunca. Una razón de ello es que los esfuerzos de prevención ya han llegado a los grupos de fácil alcance, como las comunidades blancas gay con un elevado nivel de educación y organización. Otro motivo es que las infecciones por el VIH se están concentrando de forma creciente en los sectores más pobres de la población. En Estados Unidos, el VIH ha pasado a ser una amenaza desproporcionada para los ciudadanos estadounidenses de origen africano. Aunque los afroamericanos solamente representan el $13 \%$ de la población total de ese país, soportan una parte desproporcionada de la pobreza, el subempleo y el acceso insuficiente a la asistencia sanitaria. Hoy, los afroamericanos tienen una probabilidad de tener el VIH ocho veces superior a la de los individuos de raza blanca. Según los Centros para la Prevención y Control de Enfermedades (CDC), se calcula que la prevalencia nacional del VTH en los hombres de raza negra ha alcanzado un $2 \%$ y que el SIDA ha pasado a ser la primera causa de defunción en el grupo de edad de 25-44 años. En las mujeres negras del mismo grupo de edad, el siDA ocupa el segundo lugar como causa de defunción (Bernard, 1998d).

\section{AmÉrica Latina y el CARibe}

Se observó la presencia del virus de inmunodeficiencia humana a bajos niveles en toda la región desde principios del decenio de 1980 , posteriormente las tasas empezaron a aumentar, principalmente en Brasil, en algunos países de Centroamérica y, en especial, en Haití, donde la transmisión heterosexual predominó desde el comienzo. A fines de 1997, ya la mayoría de los países de la región tenían la epidemia claramente declarada, y las tasas más altas correspondían al Caribe. Hoy se estima que en América Latina y el Caribe hay aproximadamente 1,3 millones de personas que viven con el VIH. La prevalencia del VIH se calcula en casi todos los 44 países y territorios de la región. En el Caribe la vía sexual es la más frecuente; el grupo más afectado es el heterosexual, seguido por la transmisión vertical; la edad más frecuente está entre los 20 y los 39 años de edad y la población más afectada es la urbana.

En América Latina la tendencia de la propagación del VIH prácticamente la misma que en todos los países industrializados, de modo que en muchos de nuestros países los puntos focales de la infección por el VIH son los hombres que tienen 
relaciones sexuales no protegidas con otros hombres y los consumidores de drogas intravenosas que comparten agujas. En México algunos estudios indican que hasta un 30\% de los hombres que tienen sexo con hombres están infectados por el VIH y entre el 3\% y el 11\% de los usuarios de drogas intravenosas son seropositivos, mientras que en Argentina y Brasil esa proporción puede acercarse a la mitad de todos los que se infectan con drogas. Sin embargo la transmisión heterosexual está aumentando considerablemente, lo que se evidencia a través del número de mujeres infectadas. En Brasil, en 19861 de cada 17 casos era una mujer, hoy es 1 de cada 4 casos y una cuarta parte de 550 mil adultos de ese país que viven con el virus son mujeres.

En la mayoría de los países de la región, los seropositivos y los casos SIDA se producen en las grandes ciudades, en la población urbana; sin embargo, en algunos lugares se está produciendo un claro aumento entre los grupos más pobres y menos instruidos. Por ejemplo, en Brasil la mayoría de los primeros casos se produjeron en personas con estudios secundarios y/o universitarios, mientras que hoy el $60 \%$ de los afectados que viven con SIDA no han pasado de los estudios de primaria.

La vigilancia sistemática es escasa. El elevado uso de anticonceptivos en la región hace que una proporción menor de mujeres sexualmente activas queden embarazadas, por ello la prevalencia del VIH entre las mujeres embarazadas será probablemente menos representativa que las tasas que en otras partes del mundo en desarrollo, como África y Asia. No obstante, ello constituye uno de los mejores indicadores del VIH en la población general:

El VIH ha alcanzado niveles del 1\% entre las mujeres embarazadas en Honduras y de más del 3\% en Porto Alegre (Brasil). Esas tasas son notablemente más elevadas en el Caribe. En 1993 el 8\% de las mujeres embarazadas en Haití estaban infectadas por el VIH y la misma prevalencia se registró en un centro de vigilancia de República Dominicana en 1996.

En el siguiente cuadro podemos apreciar algunas características de cada uno de los países de Latinoamérica, comparando vías de transmisión, edad de mayor frecuencia de la infección y área de mayor incidencia. Así vemos que en todos los países la vía sexual es la más frecuente, la mayor incidencia está en los homo y bisexuales, exceptuando Guyana y Uruguay (heterosexuales). Los países con mayor problema de drogas y SIDA son Argentina, Brasil, Uruguay, Paraguay y Chile. Las personas que habitan en las zonas urbanas son las más afectadas y las edades oscilan entre los 20 y los 39 años de edad para toda la región.

En el siguiente cuadro se destaca la prevalencia por países, donde Guyana está en primer lugar, seguida de Belice, Honduras y Suriname.

En América Latina, Brasil ocupa el primer lugar de acuerdo al número de afectados, Argentina el segundo lugar, Venezuela el tercer lugar, seguida de Colombia en cuarto lugar y Perú en el quinto lugar.

En América Latina la población está muy expuesta al riesgo por varios factores, entre ellos podemos destacar lo cultural, lo social, lo económico y lo religioso.

Existen grupos vulnerables, como las mujeres, que no tienen poder de decisión a la hora de tener una relación sexual: la subordinación a la que está sometida la expone a contraer la infección en su propio hogar; igualmente las trabajadoras sexuales, las escolares que no reciben una educación sexual adecuada y todos los que están fuera del sistema escolar. Dentro de los grupos vulnerables están los hombres que tienen sexo con hombres. También los presos y los militares están expuestos al riesgo por la reclusión a que están sometidos.

El factor económico juega asimismo un rol muy importante, especialmente en esta época de crisis que está afectando a la región latinoamericana, lo que conlleva una pérdida de poder adquisitivo, con el consecuente aumento del comercio sexual para ambos sexos. Por otra parte, la desnutrición acarrea una disminución de las defensas del organismo contra el virus, disminuyendo el período de latencia de la enfermedad, con un aumento de la mortalidad.

La discriminación de que son objeto los afectados por el VIH/SIDA y sus familiares, que les obliga a aislarse y esconder su condición, les impide en consecuencia solicitar la prestación del servicio necesario, incluyendo la capacitación para evitar su reinfección y la infección a otros. Otro grupo 


\section{Cuadro 2}

\begin{tabular}{|c|c|c|c|c|c|c|}
\hline PAIS & \multicolumn{4}{|c|}{ VIA TRANSMISIÓN } & EDAD DE MAYOR & MAYOR \\
\hline Argentina & $\begin{array}{l}\text { Sexual: } \\
\text { UDI: } \\
\text { Sangre: } \\
\text { Perinatal: } \\
\text { Desc.: }\end{array}$ & $\begin{array}{r}36 \% \\
3 \% \\
4 \% \\
3 \%\end{array}$ & $\begin{array}{l}\text { Hetero: } \\
\text { Homo-bi: }\end{array}$ & $\begin{array}{l}18 \% \\
36 \%\end{array}$ & $20-39$ & Urbana \\
\hline Bolivia & N.E. & & & & $25-39$ & Urbana \\
\hline Brasil & $\begin{array}{l}\text { Sexual: } \\
\text { UDI: } \\
\text { Sangre: } \\
\text { Perinatal: } \\
\text { Desc.: }\end{array}$ & $\begin{array}{r}21 \% \\
4 \% \\
3 \% \\
20 \% \\
\end{array}$ & $\begin{array}{l}\text { Hetero: } \\
\text { Homo-bi: }\end{array}$ & $\begin{array}{l}20 \% \\
33 \%\end{array}$ & $25-39$ & $\begin{array}{c}\text { Urbana y } \\
\text { extendiéndose a la } \\
\text { rural }\end{array}$ \\
\hline Chile & $\begin{array}{l}\text { Sexual: } \\
\text { UDI: } \\
\text { Sangre: } \\
\text { Perinatal: } \\
\text { Desc.: }\end{array}$ & $\begin{array}{l}5 \% \\
2 \% \\
2 \% \\
9 \% \\
\end{array}$ & $\begin{array}{l}\text { Hetero: } \\
\text { Homo-bi: }\end{array}$ & $\begin{array}{l}20 \% \\
63 \%\end{array}$ & $20-39$ & Urbana \\
\hline Colombia & $\begin{array}{l}\text { Sexual: } \\
\text { UDI: } \\
\text { Sangre: } \\
\text { Perinatal: } \\
\text { Desc.: }\end{array}$ & $\begin{array}{r}0 \% \\
1 \% \\
1 \% \\
22 \% \\
\end{array}$ & $\begin{array}{l}\text { Hetero: } \\
\text { Homo-bi: }\end{array}$ & $\begin{array}{l}15 \% \\
60 \%\end{array}$ & $25-39$ & Urbana \\
\hline Ecuador & $\begin{array}{l}\text { Sexual: } \\
\text { UDI: } \\
\text { Sangre: } \\
\text { Perinatal: } \\
\text { Desc.: }\end{array}$ & $\begin{array}{l}1 \% \\
2 \% \\
1 \% \\
4 \% \\
\end{array}$ & $\begin{array}{l}\text { Hetero: } \\
\text { Homo-bi: }\end{array}$ & $\begin{array}{l}34 \% \\
57 \%\end{array}$ & $20-39$ & Urbana \\
\hline Guyana & $\begin{array}{l}\text { Sexual: } \\
\text { UDI: } \\
\text { Sangre: } \\
\text { Perinatal: } \\
\text { Desc.: }\end{array}$ & $\begin{array}{l}1 \% \\
2 \% \\
3 \% \\
7 \% \\
\end{array}$ & $\begin{array}{l}\text { Hetero: } \\
\text { Homo-bi: }\end{array}$ & $\begin{array}{l}69 \% \\
16 \%\end{array}$ & $20-39$ & Urbana \\
\hline Paraguay & $\begin{array}{l}\text { Sexual: } \\
\text { UDI: } \\
\text { Sangre: } \\
\text { Perinatal: } \\
\text { Desc.: }\end{array}$ & $\begin{array}{l}1 \% \\
2 \% \\
1 \% \\
4 \% \\
\end{array}$ & $\begin{array}{l}\text { Hetero: } \\
\text { Homo-bi: }\end{array}$ & $\begin{array}{l}69 \% \\
16 \%\end{array}$ & $20-39$ & Urbana \\
\hline $\begin{array}{l}\text { Paraguay } \\
\text { Perú }\end{array}$ & $\begin{array}{l}\text { N.E: } \\
\text { Sexual: } \\
\text { UDI: } \\
\text { Sangre: } \\
\text { Perinatal: } \\
\text { Desc.: }\end{array}$ & $\begin{array}{r}0 \% \\
2 \% \\
2 \% \\
19 \%\end{array}$ & $\begin{array}{l}\text { Hetero: } \\
\text { Homo-bi: }\end{array}$ & $\begin{array}{l}32 \% \\
44 \%\end{array}$ & $\begin{array}{l}20-39 \\
20-39\end{array}$ & $\begin{array}{l}\text { Urbana } \\
\text { Urbana }\end{array}$ \\
\hline Uruguay & $\begin{array}{l}\text { Sexual: } \\
\text { UDI: } \\
\text { Sangre: } \\
\text { Perinatal: } \\
\text { Desc.: }\end{array}$ & $\begin{array}{r}26 \% \\
1 \% \\
5 \% \\
19 \% \\
\end{array}$ & $\begin{array}{l}\text { Hetero: } \\
\text { Homo-bi: }\end{array}$ & $\begin{array}{r}22 \% \\
4 \%\end{array}$ & $25-39$ & Urbana \\
\hline Venezuela & $\begin{array}{l}\text { Sexual: } \\
\text { UDI: } \\
\text { Sangre: } \\
\text { Perinatal: } \\
\text { Desc.: }\end{array}$ & $\begin{array}{r}2 \% \\
4,4 \% \\
3,1 \% \\
36,6 \%\end{array}$ & $\begin{array}{l}\text { Hetero: } \\
\text { Homo-bi: }\end{array}$ & $\begin{array}{l}30,67 \% \\
59,36 \%\end{array}$ & $20-39$ & Urbana \\
\hline
\end{tabular}


ESTIMACIONES DE LA INFECCIÓN POR EL VIH EN LOS ADULTOS, FINALES DE 1997 / CUADRo 3

\begin{tabular}{|lcc|}
\hline América Latina & $\begin{array}{c}\text { Adultos }(15-49 \text { años }) \\
\text { que vivían con el viH/sidA }\end{array}$ & $\begin{array}{c}\text { Prevalencia en los } \\
\text { adultos }(\%)\end{array}$ \\
\hline Argentina & 120.000 & 0,69 \\
Belice & 2.100 & 1,89 \\
Bolivia & 2.600 & 0,07 \\
Brasil & 570.000 & 0,63 \\
Chile & 15.000 & 0,20 \\
Colombia & 72.000 & 0,36 \\
Costa Rica & 10.000 & 0,55 \\
Ecuador & 18.000 & 0,28 \\
El Salvador & 18.000 & 0,58 \\
Guatemala & 27.000 & 0,52 \\
Guyana & 10.000 & 2,13 \\
Honduras & 41.000 & 1,46 \\
México & 180.000 & 0.35 \\
Nicaragua & 4.100 & 0,19 \\
Panamá & 8.800 & 0,61 \\
Paraguay & 3.100 & 0,13 \\
Perú & 71.000 & 0,56 \\
Suriname & 2.700 & 0,69 \\
Uruguay & 5.200 & 0,17 \\
Venezuela & 81.000 & 0.69 \\
\hline
\end{tabular}

Las estimaciones arriba mencionadas incluyen a todos los adultos de 15 a 49 años de edad con la infección por el VIH (indistintamente de si han desarrollado o no síntomas del SIDA) que estaban con vida a finales de 1997. Para calcular las estimaciones de los países se aplicó la tasa de prevalencia de 1994, publicada por el Programa Mundial sobre el SIDA, de la OMS, a la población adulta (15-49 años) de cada país en 1997. 
vulnerable son los niños de la calle, quienes no tienen acceso a los servicios de salud ni a las medidas de protección para evitar infectarse.

Toda esta panorámica nos revela la situación de impotencia en la que estamos inmersos cuando los gobiernos no se sensibilizan ante la epidemia, ignorando que el VIH/SIDA es un problema de Estado.

Deteniéndonos un poco más en Venezuela, tenemos que la transmisión sexual ocupa el 90,03\% de los casos, de los cuales los hombres que tienen sexo con hombres son el $42 \%$, los bisexuales el 17,36\% y los heterosexuales el 30,67\%. Es notable el incremento en los heterosexuales, lo que ha llevado a aumentar la infección en la mujer — c la que el $80,55 \%$ es por la vía sexual—, la mayoría de ellas amas de casa, con pareja única, trayendo como consecuencia un importante aumento en la transmisión vertical (de madre a hijo), que se sitúa en un 3,2\%. Otro dato importante es que la mujer está siendo afectada a una edad más temprana que el hombre.

En la vía sanguínea se totaliza un 4,5\%, discriminados en transfusiones $1,03 \%$, hemofilicos $1,4 \%$ y drogas intravenosas $2,06 \%$. Si bien es cierto que los porcentajes en transfundidos y hemofilicos se han mantenido bajos, no ha sido así en los usuarios de drogas intravenosas, que han venido aumentando lentamente. También hay que destacar que en el país existe un alto porcentaje de casos desconocidos $(36,62 \%)$ y un marcado subregistro, que dificulta considerablemente conocer cuál es la verdadera situación de la epidemia, dónde atacar, cómo incidir, etc. (CIES, 1998, 1999; MSDS, 1999).

\section{CONCLUSIONES}

El vIH/SIDA está en todos los países del mundo, en mayor o menor medida. Los hombres son los más afectados por la epidemia, excepto en algunos países, como Haití. Las mujeres empiezan a sufrir los embates de la enfermedad y sus hijos también, y el número de huérfanos es preocupante.

Las pérdidas socioeconómicas y en salud que está produciendo el VIH/SIDA constituyen una carga insoportable para todos los gobiernos. En algunos países faltan programas intersectoriales y eficaces que permitan hacer un frente común a la epidemia.
Como respuesta a esta situación, el Programa Conjunto de las Naciones Unidas sobre el SIDA está trabajando como promotor principal de una acción mundial contra el VIH/SIDA, dirigiendo, fortaleciendo y apoyando una respuesta ampliada destinada a prevenir la transmisión del VIH, a proporcionar asistencia y apoyo, a reducir la vulnerabilidad de las personas y las comunidades al VIH/SIDA y a atenuar el impacto de la epidemia. En este sentido, ha logrado comprometer a algunos gobiernos en esta lucha, especialmente en países africanos; conjuntamente con la Organización Mundial de la Salud desarrolla un programa de vacunas que están siendo probadas en Brasil, Tailandia y Uganda; estableció un compromiso con algunos laboratorios para bajar los costos de algunos de los medicamentos para el SIDA; promociona los derechos humanos de los afectados; creó la Red de Vigilancia Epidemiológica para los países del área andina y apoya a todos los países con recursos humanos, asesoría técnica y financiera.

Es fundamental hacer prevención, dar una educación sexual adecuada a los educandos intra y extramuro, disminuir la vulnerabilidad de la mujer, reducir las desigualdades entre los hombres y las mujeres basadas en el género, capacitar a los grupos vulnerables - con énfasis en el hombre que tiene sexo con hombre-, reforzar los programas de intercambio de inyectadoras y enfatizar en el respeto a los derechos humanos y el tener acceso a los servicios de salud.

Sólo uniendo los esfuerzos de todos los sectores gubernamentales, no gubernamentales, sociedad civil, sector privado, instituciones científicas e Iglesia, podrá ser superada la epidemia del VIH/sIDA.

\section{REFERENCIAS BIBLIOGRÁFICAS}

Bernard, R. P.; Zellweger, U.; Wang, J.; Somaini, B., 1998. World status \& prospects. Ginebra: AIDS Feedback, Serie Geográfica de Análisis sobre HIV-SIDA.

Bernard, R.P., 1998a. Recency in regional HIV spread progression: 1997 - Incidence over 1997 . prevalence. Ginebra: Ains Feedback, Serie Geográfica de Análisis sobre HIV-SIDA. 
Bernard, R.P., 1998b. End-1997 Adult (15-49) HIV prevalence, \%. UNAIDS-WHO estimates in AFDisplay. Ginebra: Aids Feedback, Serie Geográfica de Análisis sobre HIV-sIDA.

Bernard, R.P., 1998c. Hemisphere-East End-1997 Adult (1549) HIV prevalence, Percent Adult. UNAIDsWHO estimates in AF-Display. Ginebra: AIDs Feedback, Serie Geográfica de Análisis sobre HIV-SIDA

Bernard, R.P., 1998d. Hemisphere-West end-1997 adult (15-49) HIV prevalence, percent adult. UNAIDS$W_{H O}$ estimates in AF-display. Ginebra: AIDs Fcedback, Serie Geográfica de Análisis sobre HIV-SIDA.

Bernard, R.P., 1999. Late 1990s - adult (15+) HIVincidence, BBy world region: baseline for millennialturn Trend assessment. Ginebra: AIDs Feedback, Serie Geográfica de Análisis sobre HIV-SIDA.

Cies (Centro de Investigaciones Económicas y Sociales), 1998. El VIH-SIDA en Veneruela. Análisis de situación y recomendaciones. Caracas: CIES.

CiEs, 1999. La amenaza del VIH-SIDA en Venezuela. Necesidad de una respuesta pública e inmediata. Caracas: Cies.

Msps (Ministerio de Sanidad y Desarrollo Social), 1999. Vigilancia epidemiológica. Estadísticas a agosto. Caracas: MSDS.

ONUSIDA, 1996-1997. Informe del ONUSIDA sobre los progresos realizados. Ginebra: ONUSIDA.

ONUSIDA, 1998. Informe sobre la epidemia mundial de VIHSIDA. Ginebra: ONUSIDA.

ONusida/OMS, 1997. Situación mundial de la infección por el VIH-SIDA. Ginebra: ONUSIDA/OMS. 


\section{PSiCOSOCIOLOGÍA DE LAS INFECCIONES DE TRANSMISIÓN SEXUAL Y EL SIDA}

Leoncio Barrios*

Las enfermedades de transmisión sexual (ETS), o infecciones de transmisión sexual - las ITS, como ahora se les llama-, son tan antiguas como la humanidad misma. No en vano, desde los romanos, tan dados a las fiestas de Baco, se habla de las enfermedades venéreas para referirse a aquellas transmitidas entre quienes disfrutaban de los montes de Venus, Diosa del amor. Pero estas enfermedades, por siempre objeto de vergüenza debido a su forma de transmisión, adquirieron relevancia pública a finales del siglo IXX; por un lado, como problema de salud, dado el alto número de personas afectadas, y por el otro, cuando la sífilis o la gonorrea afectaron a figuras públicas del mundo artístico, como Toulouse-Lautrec, Nietzche o Haydn, algunos de los poquísimos a los que la historia reconoce como víctimas de tan vergonzosos males. Junto a ellos, quién sabe a cuántos más hombres y mujeres de relevancia social, y precisamente por tal relevancia, se ha obligado al silencio de la discreción. Nobleza obliga, dicen. Así, históricamente se ha creído que esas infecciones sólo atacan a hombres — aunque inteligentes, de vida licenciosa - o a mujeres de "mala vida", mientras otros millares de seres anónimos, por su pobreza, podían quedar así, olvidados.

Afortunadamente, el descubrimiento de algunos medicamentos efectivos, como la penicilina, por un lado, más el desarrollo de ciertos métodos profilácticos y algunos cambios sociales, por el otro, contribuyeron a controlar el peligro de las ITS en el transcurso del siglo XX, con lo cual se aminoró el problema clínico y de alguna forma el social, en cuanto a sus consecuencias, mas no el de la estigmatización que producen estos males, lo cual es el tema central de este trabajo.
Pero resulta que también al final del siglo XX, otra epidemia con un gran peso sexual, la del viH/ SIDA, ha vuelto a poner a las ITS en la agenda de la salud pública mundial. A consecuencia del SIDA, en los últimos años han muerto figuras públicas, como el galán por excelencia del Hollywood de los cincuenta, Rock Hudson; estrellas del rock, como Freddy Mercury; así como el mejor balletista del siglo, Nureyev, por nombrar algunos notables entre los miles de artistas y gente del espectáculo de América y Europa que con su notable muerte le han dado relevancia al problema del SIDA y de nuevo a las ITS, como algunas otras figuras públicas lo hicieron hace un siglo.

Pero, obviamente, el VIH/SIDA no es un problema sólo de ricos y famosos. Ellos son unos pocos entre los millones de hombres, mujeres y niños que en su anonimato han producido, en veinte años de epidemia, la terrorífica cifra mundial de casi 15 millones de muertos desde el comienzo de la epidemia a principios de la década de los ochenta, de los cuales 2,5 murieron sólo en 1998: un promedio de 7 mil muertes diarias por esta causa (ONUSIDA, 1999). En 20 años de epidemia, el SIDA ha causado más muertos que las dos guerras mundiales de la primera mitad del siglo.

Así, el viH/sidA, debido a su gran impacto social, ha colocado a las ITS como punto relevante de la agenda social y acerca de esta epidemia se ha creado un discurso público sobre la base de la solidaridad que ha tenido una cierta resonancia social, aunque también hay que decir que persiste la discriminación y vejación para quienes sufren el VIH y otras ITS más despreciadas.

Psicólogo social, profesor-investigador de la Universidad Central de Venezuela, director del Programa Nacional de siDA e ITS, Ministerio de la Salud, Venezuela. E-mail: leobar@cantv.net. 
Esta situación probablemente se debe a lo que constituye el planteamiento central de este trabajo: las ITS no son infecciones o enfermedades como cualquier otras; ellas son aún más malignas porque están estigmatizadas, tanto social como clínicamente. Estigma que se ha creado bajo la creencia de que éstas son infecciones o enfermedades características de poblaciones con conductas socialmente sancionables. Es tan simple como el adjetivo que identifica a estas dolencias: "sexuales", y en nuestras culturas católicas todo lo perteneciente a ese ámbito sigue siendo, sin duda que en menor grado que en el pasado, pecaminoso, culposo, vergonzoso, y por tanto, oprobioso y condenable. Por ello, toda persona afectada por una ITS es, al menos, sospechosa de conducta "impropia", mientras no demuestre lo contrario...

Esta situación, si ya era cierta históricamente, se agudizó con la aparición del SIDA y sus primeras víctimas masivas: hombres homosexuales $\mathrm{O}$ drogadictos, dos poderosos motivos de estigma y sanción social.

Por ello, quienes trabajamos con este tipo de problemas tenemos, al menos, tres retos que asumir: evitar que haya nuevas infecciones, el logro de tratamientos y servicios más efectivos y vencer el prejuicio y la intolerancia producto del estigma, aun en nosotros mismos, hacia quienes sufren infecciones de este tipo.

El trabajo de prevención, sin que expresemos aquí indicadores precisos, ha avanzado. Hoy, sin duda, la gente, así en general, dispone de mucha más información sobre la sexualidad, el sexo y cómo mantenerse sana en este aspecto. A lo mejor esa información sigue siendo insuficiente, no sistemática, posiblemente no toda de calidad y no llega a todos por igual, pero es indiscutible que al final del siglo $\mathrm{XX}$, en todo el mundo, la gente tiene más información sobre lo sexual que nunca antes en la historia.

Igualmente ocurre con el acceso a recursos de prevención, y ello lo ilustramos con uno de los profilácticos más efectivos para reducir los riesgos de infecciones sexuales: el condón. Este es uno de los productos más populares de los últimos tiempos y uno de los mercados más prósperos y hacia el cual apuntan muchos inversores debido al aumento sostenido de la demanda.
Además, otros avances farmacéuticos como hace casi un siglo con otras ITS - parecen indicar que también la infección de VIH, bajo un tratamiento riguroso y costoso en esfuerzos y dinero, puede dejar de ser mortal, para convertirse en crónica. Esa es la tendencia en los países con un sistema de salud efectivo que garantice acceso a servicios de control clínico y a medicamentos antiretrovirales, lo cual no es, precisamente, el caso de la mayoría de los países que nos ocupan: los de América Latina.

Por el contrario, mientras no aparezca una vacuna contra el VIH o un tratamiento curativo para el SIDA accesibles a las mayorías, las prospectivas nos dicen que las condiciones económicas de América Latina, como del resto de los países pobres de Asia y África, condenan a muerte por SIDA a centenares de miles, sino a millones, de seres durante los próximos años. La frase de un corresponsal de la revista Newsweek sintetiza lo patético de esta situación: "Si la recomendación médica para vencer el VIH/SIDA fuese tomar agua potable, mucha gente de África no podría sobrevivir..." (Newssweek, 1996). Lamentablemente, la situación no es distinta para las mayorías de América Latina, quizás no por agua, sino por la calidad de la alimentación, la dificultad de acceso a servicios de salud y, por supuesto, a tratamientos tan altamente costosos como el de los antiretrovirales, cerca de mil dólares mensuales por persona, de por vida.

\section{LO QUE NOS DICEN LAS CIFRAS}

El informe de Onusida para finales del siglo XX — al cual hemos hecho referencia — señala que, en todo el mundo, cerca de 33 millones de personas viven afectadas por el VIH, cifra que tiene un crecimiento geométrico diario, con 16 mil nuevos casos, uno cada ocho segundos. Si estas cifras, y lo que ellas significan, ya son alarmantes, lo es más para quienes vivimos en regiones como América Latina. Ese mismo informe indica que el $95 \%$ de estos casos están concentrados en los países pobres como los nuestros, y que en Latinoamérica 1 millón y medio de personas están infectadas con el VIH, siendo las mujeres y los menores de 25 años los más afectados. Se estima que durante 1999, en nuestra región, cerca de 100 mil jóvenes se infectaron con el virus y muy 
probablemente la mayoría de ellos y ellas, debido a condiciones socioeconómicas, desarrollarán el SIDA.

Estas cifras son indicadores suficientes para decirnos de lo devastador de esta epidemia desarrollada, paradójicamente, en el siglo de mayor progreso de la ciencia y la tecnología. Esto ha obligado a la búsqueda de una respuesta global, como la que se intenta dar a través del ONUSIDA, programa conjunto de las Naciones Unidas para responder a esta problemática, o el Grupo de Cooperación Técnica Regional en VIH/SIDA que funciona entre los programas nacionales creados en América Latina para atender esta problemática.

Sin embargo, las otras infecciones por vía sexual, y algunas de las enfermedades que ellas generan, como la sífilis, la gonorrea, el herpes genital, el candiloma, siguen subestimadas, inclusive ignoradas; al punto de constituir una gran cifra negra que impide saber en qué dimensiones están afectando a la población. Precisamente, para la elaboración de este trabajo se trató de localizar datos regionales ante organismos autorizados y lo único accesible fueron cifras tan poco precisas como “...en Latinoamérica existen entre 40 o 50 millones de personas con alguna enfermedad de transmisión sexual" (cursivas nuestras).

Determinar cuáles infecciones, en qué grupos, ha sido difícil. Esto, a pesar de que por comentarios médicos, sociales y muy probablemente en cifras locales se pueda determinar un repunte en la región de la sífilis incluyendo la sífilis congénita-, de gonorrea y otra fuerte epidemia: la de VPH, el virus del papiloma humano, asociado con un noventa por ciento del cáncer de cuello uterino, una de las primeras causas de muerte en la mujeres latinoamericanas.

A pesar de la escasez de cifras que planteamos, el cuadro siguiente nos permitirá ver un mapa epidemiológico de las ITS, así en grueso, en la región, donde lo que destaca, por supuesto, es la situación del VIH/SIDA.

DATOS EPIDEMIOLÓGICOS DEL VIH/SIDA Y OTRAS ITS EN CINCO PAÍSES LATINOAMERICANOS

\begin{tabular}{|c|c|c|c|c|c|}
\hline & Brazil & Cuba & México & Venezuela & Haití \\
\hline Población total & 163.132 .000 & 11.068 .000 & 94.281 .000 & 22.777 .000 & 7.395 .000 \\
\hline Personas con VIH & 580.000 & 1.400 & 180.000 & 82.000 & 190.000 \\
\hline Seroprevalencia & 0,36 & 0,01 & 0,19 & 0,36 & 2,6 \\
\hline Casos de SIDA (estimado) & 310.000 & 690 & 98.000 & 7.900 & 91.000 \\
\hline Muertes por SIDA (acum.) & 290.000 & 640 & 91.000 & 6.600 & 85.000 \\
\hline Muertes diarias & 121 & 0,27 & 38 & 7 & 36 \\
\hline Huérfanos (acumulado) & 51.000 & 160 & 16.000 & 1.200 & 40.000 \\
\hline Casos oficiales reportados & 155.590 & 689 & 35.119 & 7.449 & 4.967 \\
\hline Vía sexual & $53 \%$ & $89 \%$ & $60 \%$ & $66 \%$ & $1 \%$ \\
\hline Vía sanguíneo & $25 \%$ & $2 \%$ & $9 \%$ & $4 \%$ & \\
\hline Vía perinatal & $3 \%$ & $3 \%$ & $1 \%$ & $1 \%$ & \\
\hline Desconocido & $19 \%$ & $6 \%$ & $30 \%$ & $26 \%$ & $99 \%$ \\
\hline Masculino & $78 \%$ & $70 \%$ & $85 \%$ & $90 \%$ & $54 \%$ \\
\hline Femenino & $22 \%$ & $24 \%$ & $15 \%$ & $10 \%$ & $46 \%$ \\
\hline $\begin{array}{l}\text { Casos de otras ITS } \\
\text { (en toda la región andina) }\end{array}$ & 12.523 .000 & 79.805 & 6.907 .000 & 7.511 .000 & 2.252 .000 \\
\hline
\end{tabular}

Fuente: UnAIDs (1998) (datos hasta 1997). 
Esta relativa ignorancia de las "otras ITS" distintas al VIH/SIDA demuestra el poco estudio y atención que se les presta a este tipo de infecciones, lo cual confirma nuestro planteamiento de que el estigma y subestimación es no sólo social sino profesional. Precisamente, la aparición del SIDA ha servido para ponerlas de nuevo en la agenda pública, pero al mismo tiempo, el problema del SIDA es de tal magnitud que opaca cualquier otra ITS, con el riesgo de que estas infecciones y enfermedades sigan subestimadas en cuanto al interés público, e inclusive de los gobiernos, a pesar de las consecuencias para quienes las sufren y el peligro para la población en general.

$\mathrm{Y}$ es que parte del impacto social que el viH/ SIDA ha causado tiene que ver con la época de su aparición: la de la globalización, que junto a facilitar el traslado del virus de una región a otra, lo ha masificado y glorificado mediáticamente con la difusión de información. Por un lado, por la forma enigmática, veloz y mortal que fue su ataque inicial y, por el otro, por haber afectado a sectores de poder: habitantes de Estados Unidos, de clase media y hombres, aunque homosexuales. ${ }^{1}$ Asimismo, el que haya causado un impacto similar en las regiones más ricas y poderosas de Europa, convirtió a la epidemia en objeto de preocupación y atención mundial.

Este hecho coyuntural produjo una geopolítica y una significación del problema absolutamente distinta a la que se hubiera planteado si el virus se queda circunscrito a África, o afectara sólo a mujeres y pobres de cualquier parte del mundo, como lo ampliaremos en lo que hemos llamado la psicosociología de estos problemas de salud.

\section{LA PSICOSOCIOLOGÍA DEL VIH/SIDA Y OTRAS ITS}

Como ya decíamos, las ITS han tenido una connotación asociada a un juicio moral, por ser producto de las relaciones sexuales, del contacto con la carne, o del pecado, si se le quiere dar otra lectura.
Por eso, sectores tan poderosos como la Iglesia siempre han condenado a quienes sufrieran enfermedades de este tipo, precisamente por pecadores y pecadoras. A esto se suma la reacción de los sectores puritanos de cualquier sociedad, por lo general también de poder, quienes siempre han visto con "malos ojos" y desprecio a quienes sufran este tipo de enfermedades porque hacen público su delito: haber sentido el placer de la carne, pecaminoso y vulgar.

Así, históricamente, las infecciones sexuales han estado asociadas a lo que les corresponde, a conductas sexuales, que - fuera del contexto científico- "no deben ser objeto del discurso público" (comillas nuestras). Y es que ellas son producto, claro está, de lo que la gente hace sexualmente $y$, como todos sabemos, el sexo y lo sexual, por los siglos de los siglos, ha sido (re)presentado como impúdico, vergonzoso, pecaminoso, censurable, feo y sucio, hasta llegar a ser indeseable, indebido, incomunicable, impensable, es decir, un tema tabú.

Por tanto, las consecuencias de esa conducta, como las ITS, arrastran conceptualmente todos los adjetivos que mencionamos en el párrafo anterior. Pero, además, estas infecciones se asocian a promiscuidad -entiéndase este término como conductas sexualmente indiscriminadas, con múltiples parejas y de diferente manera-, al incumplimiento del sagrado deber del celibato o al haber violado los votos de fidelidad conyugal, a la asistencia a burdeles, al uso de sexo comercial, ilegal; es decir, a lo indebido. Asimismo, las ITS también se han asociado a un problema de higiene: se supone que se infectan sexualmente quienes carecen de adecuados hábitos higiénicos: los sucios y sucias. Entonces este tipo de infecciones quedan asociadas a aquellos y aquellas que practican una doble suciedad: física y moral.

Por ello, sufrir una ITS implica, en el imaginario colectivo ( $y$ en muchos particulares también), ser una persona promiscua, pecaminosa, indecente y desaseada. Es ser violador o violadora de las

1 Permítaseme una aclaratoria a la frase "hombres, aunque homosexuales". Entre las características de la epidemia del siDA como construcción social está el que, prácticamente, hasta la década de los noventa en las estadísticas epidemiológicas de todo el mundo han sido los hombres el grupo social que ha aportado más casos. Esto quiere decir que es una epidemia que ha afectado al sector de más poder en cualquier país. Asimismo, el que haya afectado a la comunidad homosexual de Estados Unidos le dio fortaleza social al impacto porque este grupo, aunque minoría cuantitativa, ocupa importantes espacios políticos, económicos y culturales del país más poderoso del mundo. 
convenciones sociales, y por tanto, merecedor y merecedora de sanción social. Esto, a pesar de que entre las víctimas de estas infecciones estuvieran algunas mujeres, las parejas de los hombres "promiscuos", quienes, por no hacer pública su situación, se ocultaban, o se ocultan, a costa de su condición de salud o la comunican sufriendo la vergüenza de la humillación. Así, a los adjetivos negativos de la construcción social de las ITS que ya hemos señalado, se agrega el que las personas infectadas sexualmente se ven obligadas a hacer pública —al menos dentro del contexto médicolo más íntimo de su vida, lo sexual, con lo cual pasan a ser impúdicas.

Y es que, socioculturalmente, las ITS han sido construidas como un problema que debe quedar en el ámbito de lo privado, ocultado hasta donde más se pueda. No en vano en los centros públicos de atención a la salud los llamados servicios de venereología o de ETS suelen ser las salas de la vergüenza, las más retiradas y en lo posible ocultas. Es allí donde tratan a las personas "pervertidas", por decir, "putas, trasvestis, maricos y hombres promiscuos", como lo describiera un miembro de un equipo de salud que se ocupa de estos problemas. A esto hay que agregar: víctimas de la pobreza, otro elemento de vergüenza, porque si tuvieran recursos económicos acudirían a servicios privados, más discretos. Es decir, los servicios clínicos de ETS parafraseando a Frank Fanon- son para los condenados y condenadas de la tierra, para "execrables" sociales; son, por lo tanto, espacios donde las vejaciones son posibles y para algunos hasta justificables.

Todo esto ha llevado a que surja el estigma de las ITS, de quienes la sufren, de los servicios que se le prestan e, inclusive, del personal que trabaja con este tipo de problema porque todo lo que se asocie con sexo es sospechoso de "algo malo".

De este estigma, por supuesto, no se libran quienes sufren el VIH/SIDA, a pesar de la ola de solidaridad generada y de servicios de calidad que en algunas partes del mundo se les presta.

A lo anterior hay que agregar el hecho de que las conductas que arrojaron más infecciones de VIH durante los primeros años de la epidemia, y por lo tanto las que se asociaron al aprendizaje inicial sobre el SIDA, tienen que ver con la homosexualidad masculina, la prosmicuidad y/o el uso de drogas inyectadas. Todas ellas consideradas conductas "impropias", "indecentes" y "antisociales" por la mayoría moral. Así, el estigma histórico de las ITS resultó potenciado por la forma en que apareció el SIDA. Y aun cuando el perfil epidemiológico de las personas infectadas ha cambiado significativamente durante la última década, en gran parte de la población persiste la idea errada de que el SIDA es un problema de hombres homosexuales, de personas promiscuas $o$ adictas a drogas intravenosas.

Como si fuera poca la carga de connotación negativa que tiene el concepto del SIDA, éste se asocia con otros conceptos como "enfermedad", "contagio" y "muerte", los cuales tienen connotaciones que van desde lo indeseable, lo temible, pasando por lo vergonzante, hasta lo tabú o incomunicable.

Y es que las ITS, como lo dijera Fishbein (1989) al referirse al SIDA, son enfermedades conductuales, y por tanto socioculturales, por las consecuencias que tienen en ese ámbito, pero además — permítaseme usar esta expresión en un contexto científico- son enfermedades del alma, por las consecuencias emocionales que tienen. Las ITS movilizan muchos sentimientos que pudieran sentirse ante cualquier otra enfermedad, como el miedo, la rabia o la lástima, pero a ello se agrega el dolor que causa el rechazo y la discriminación. Y aunque eso no sea lo que sientan todas las personas con VIH o SIDA (gracias a la ola de solidaridad de la que ya hablamos), sí lo ha sido, y lo es, de millones que sufren otras ITS e inclusive el $\mathrm{VIH} /$ SIDA. Y esto ha llevado a las personas seropositivas en todo el mundo a organizar un movimiento por la defensa de sus derechos humanos, con una capacidad de movilización y organización social como posiblemente nunca antes en la historia lo haya producido un problema de salud.

Así, en todo el mundo, y Latinoamérica no es excepción en este caso, se ha creado una verdadera red de organizaciones no gubernamentales para prestar servicios en torno al SIDA y este hecho, de por sí valioso, también es inédito, por la diversidad social que se ha congregado para enfrentar esta epidemia. 
En un análisis sobre este hecho se dice:

...en esas redes convergen grupos disímiles y en apariencia irreconciliables, como pudieran ser los representantes de la pastoral familiar, las trabajadoras sexuales, las asociaciones femeninas o feministas, de hombres heterosexuales, las de homosexuales, sectores filantrópicos y académicos. Allí se discute, discrepa, se acuerda y se colabora mutuamente. Todos en función de una meta común: el contribuir a la lucha contra el VIH/SIDA. Una forma de organización social y una expresión de tolerancia, que tiene que ser considerado como un valioso logro. Uno de esos regalos paradojales que la epidemia del viH-SIDA le ha dado a nuestra sociedad (Barrios, 1998).

Y es que, precisamente, los derechos humanos es un punto fundamental en este tema de la estigmatización de las ITS y de quienes las sufren.

\section{LOS DERECHOS HUMANOS (EN ESTE CASO}

\section{SOLAMENTE DE LOS QUE VIVEN CON VIH/}

\section{SIDA)}

El tema de los derechos humanos y el VIH/ SIDA ha sido uno de los bastiones de lucha del activismo político de organizaciones no gubernamentales que trabajan en este ámbito. Estas organizaciones han considerado particularmente tres derechos fundamentales, sobre los cuales han volcado el interés de su defensa: el derecho a la nodiscriminación, el derecho a la salud y el derecho a la información.

Como parte de la respuesta de la sociedad civil se ha creado, a nivel regional, el Consejo Latinoamericano y del Caribe de ONG's con Servicio en VIH/Sida (LACCASO), con la finalidad, común a todos los países de la región, de fortalecer la capacidad institucional de los puntos focales nacionales; mejorar las habilidades de las ONG's para realizar acciones y dar respuestas efectivas particularmente en los campos de prevención del VIH-; la defensa, gestión y negociación con representantes gubernamentales y desarrollar estrategias, establecer vínculos de colaboración con iniciativas y redes regionales de ONG's de derechos humanos (ACCSI, 1999).
Pero esto no sólo ha sido una respuesta de la sociedad civil, ya que los gobiernos de la región, al asumir al vIH/sIDA como problema de salud pública, también han respondido con diferentes tonos y ritmos.

En Brasil, por ejemplo, debido a la fuerte incidencia de la epidemia (recordemos que es el país latinoamericano con más casos de VIH/SIDA), se ha atacado la problemática desde todos los ángulos posibles. En el área de prevención se han llevado a cabo proyectos conjuntos con ONG's, abarcando comunidades populares, el ejército, las prisiones, la población indígena. Se ha puesto en marcha una línea telefónica de información y se han creado centros de consejería. En el área asistencial existe una distribución nacional de medicamentos, e inclusive se han creado laboratorios farmacéuticos con capacidad para la elaboración de algunos fármacos antiretrovirales.

En México, donde también se ha dado una respuesta orgánica al problema, el ConAsida ha desarrollado campañas preventivas por etapas y en 1997-98 se cumplió la tercera, dirigida a los jóvenes. Asimismo, ha creado un fondo mutual que le permite suministrar los medicamentos antiretrovirales a los menores de 18 años infectados y a embarazadas, mientras otro grueso de la población infectada los recibe a través del sistema de seguridad social. Una efectiva descentralización del sistema de salud facilita la atención de la epidemia con sus particularidades. Otra fortaleza de este programa es el trabajar en colaboración con más de un centenar de ONG's en todo el país.

El modelo cubano, por la misma estructura política y económica del Estado, tiene particularidades con respecto a otros de la región. El programa de control y prevención del viH/sida de ese país ha enfocado sus esfuerzos a la transmisión sexual como medio único de infección. Para ello ha creado un amplio programa de educación para la salud dirigido a la población general y a los grupos específicos con conductas de alto riesgo, promovido una amplia participación intersectorial y multidisciplinaria en las acciones de prevención y control, realizado estudios conductuales en grupos de población con conducta de riesgo y epidemiológicos del $100 \%$ de los casos detectados, además de suministrar tratamiento 
ambulatorio o sanatorial a todos los casos diagnosticados.

Venezuela, por su parte, durante la primera década de la epidemia generó un programa con componentes de vigilancia epidemiológica, prevención, atención médica, capacitación del personal de salud y derechos humanos. Entre los logros de este programa destacan valiosas experiencias en torno a la educación de pares, como en el caso de las trabajadoras sexuales, y resoluciones ministeriales para tratar de evitar la discriminación con quienes sufren de la epidemia. A partir de 1999, este país ha puesto en marcha uno de los más ambiciosos programas públicos de distribución de medicamentos antiretrovirales en la región.

A pesar de que hemos referido la experiencia en sólo cuatro países de la región, los cuales pueden decirnos de una respuesta efectiva por parte de los gobiernos nacionales ante la epidemia del SIDA, como es de imaginar, la situación no es similar en toda la región. Pero aun así, en aquellos países en donde hay deficiencias la tendencia parece ser a superarlas.

\section{LAS PROSPECTIVAS}

Si bien las características de la epidemia en los primeros años de su aparición contribuyeron a creer en la existencia de grupos de riesgo - lo cual es responsable, en gran parte, de la estigmatización a la que nos hemos referido-, hoy existe un consenso en la comunidad científica acerca de que debe hablarse de conductas de riesgo.

$\mathrm{Y}$ es que, como ya decíamos apoyándonos en Fishbein, toda ITS es producto de una conducta. Nos infectamos sexualmente por lo que hacemos, el cómo lo hacemos y con quién. Esto lleva a que las estrategias de prevención de estas infecciones sean dirigidas a la difusión de las conductas de riesgo y el cómo evitarlas. Es decir, estrategias concebidas para el cambio de conductas. Y si bien el término grupos de riesgo ha sido sustituido, precisamente para reducir la confusión o estigmatización, el nuevo resulta casi un eufemismo: grupos vulnerables, para referirse a aquellos que por sus prácticas tienen más probabilidades de infectarse.

Así, el reporte de Onusida que hemos usado como referencia considera que los y las jóvenes menores de 25 años, junto a las mujeres sexualmente activas, constituyen los grupos más vulnerables a las ITS. Los y las jóvenes por ser, en las estadísticas, el grupo etario donde más se producen infecciones sexuales, pero, en esencia, debido a la cantidad de riesgos que corre, como pudieran ser la frecuencia de actividad sexual, la posibilidad de cambio de pareja sexual, el paradójico sentimiento de invulnerabilidad que lo caracteriza, el disfrute que muchos sienten con las situaciones de riesgo, junto a la carencia de información de algunos y algunas o la descalificación que hacen de ella, al pensar, por ejemplo, que "eso no es conmigo" o "eso no me pasará".

En cuanto a las mujeres, la fisionomía del aparato sexual y la falta de fuerza social que en muchas culturas y países aún este sector tiene para defender sus derechos humanos ( $\mathrm{y}$ los sexuales incluidos entre ellos, por supuesto), las hace vulnerables a infecciones completamente evitables.

Otro gran grupo vulnerable, aunque extrañamente casi nunca mencionado en los análisis de vulnerabilidad ante las ITS, es el de los hombres. Esta poca relevancia que se le ha dado es paradójica, cuando, de hecho, son los hombres que tienen sexo con hombres quienes siguen liderizando las estadísticas del viH/SIDA y otras ITS en todos los países del mundo. Pero igualmente están en riesgo los hombres que tienen sexo con mujeres, ya que ellos también se infectan. De hecho, son los hombres los que han servido de puente epidémico entre grupos de diferentes sexos y, a pesar de sus fortalezas socioculturales generalizadas, son vulnerables porque esas mismas fortalezas se convierten, irónicamente, en su debilidad ante las ITS (Barrios, 1997).

Pero asimismo habría que decir que los niños y niñas por nacer, con riesgo de infectarse sin haber ejecutado ninguna conducta, son entre todos los grupos los más vulnerables porque no tienen opción de protegerse. Por ello, la reducción de la transmisión vertical debe ser una prioridad en todos los países de la región. Esa es una meta completamente posible de lograr si se cumplen ciertas condiciones, como es el necesario control prenatal y la disposición de dinero para suministrarle medicamentos preventivos y servicios de calidad a las embarazadas seropositivas. 
Si bien los grupos mencionados pudieran ser los más vulnerables a las ITS por sus conductas, habría que agregarle una condición que puede ser común a la inmensa mayoría: la pobreza. Y es que el acceso a la información, a la educación, a condones, a higiene, a nutrición adecuada, a exámenes, a servicios médicos de calidad y a medicamentos, depende de las condiciones económicas de los países y de las personas. Todos los análisis prospectivos indican que hoy, más que nunca, y en un futuro también, las infecciones sexuales y el sIDA serán enfermedades, no exclusivas, pero sí marcadamente, de los sectores pobres.

Este mapa de la vulnerabilidad nos dice claramente que sólo están exceptos de riesgo de infecciones por vía sexual quienes se eximan de relaciones sexuales, quienes las mantengan exclusivamente con otra persona no infectada o usen condón en forma sistemática. E igualmente que, en caso de infección, la cura o tratamiento particularmente en el VIH/SIDA— es posible si las condiciones económicas lo permiten.

Todo pareciera factible de lograr, pero hay que reconocer que es difícil, si no imposible, el hacerlo para ciertas personas o sectores, por la fuerza de factores culturales. Si no se dan ninguna de las condiciones de excepción de riesgo que hemos mencionado, vale decir que toda la población sexualmente activa que no se proteja es susceptible de infectarse por esa vía, con todas las implicaciones físicas y sociales que ello tiene.

Por tanto, una meta del trabajo conjunto de las ciencias sociales y de los equipos de trabajo en salud es contribuir a deslastrar las infecciones de transmisión sexual de las fuertes connotaciones negativas que hemos comentado en este trabajo, y con ello, disminuir los vejámenes a los que son sometidos y sometidas quienes las sufren. A esto puede ayudar un abordaje integral de salud, en forma tal que el estigma se disipe en la atención a la persona como totalidad.

\section{REFERENCLAS BIBLIOGRÁFICAS}

ACCSI, 1999. Informe anual sobre derechos humanos y SIDA en Venezuela para 1998. Caracas: Accsi.

Barrios, L., 1997. Costos y beneficios de la masculinidad. AvEPSO (revista de la Asociación Venezolana de Psicología Social), XX (1):26-35.

Barrios, L., 1998. Impacto psico-socio-cultural de la epidemia del VIH-SIDA en Venezuela. Extramuros, 8:121-128.

Fishbein, M., 1989. Aids and behavior change. Ponencia presentada ante el XXII Congreso Interamericano de Psicología. Buenos Aires.

Nemsweek, 1996. The end of AIDS? 9 de diciembre:51-64.

ONUSIDA, 1999. La epidemia del SIDA: situación para 1999. Ginebra: ONUSIDA.

UnAIDs, 1998. Epidemiological fact sheet. Ginebra: ONU. 


\section{EPIDEMIOLOGÍA DE LA SALUD MENTAL}

Carlos L.M. Cornaglia*

\section{INTRODUCCIÓN}

Los estudios epidemiológicos de la salud mental poseen en América Latina una prolongada tradición. El objetivo de este trabajo es describir y analizar algunas líneas de investigación en epidemiología de la salud mental en América Latina, con relación al desarrollo de las ciencias sociales en el siglo XX. Antes que mostrar algunos resultados recientes, de nuestras investigaciones o de otros autores, hemos preferido pasar revista a un conjunto de producciones. Exposición en detalle sobre historia, métodos y resultados pueden encontrarse en las obras de N. de Almeida-Filho y G. Canino.

Basándonos en el material seleccionado y siguiendo un método comparativo, analítico, crítico (que incluye consideraciones lexicográficas, semánticas y conceptuales), intentamos captar las líneas centrales, seguidas por los diferentes investigadores, en referencia al concepto de salud mental/enfermedad mental, a los métodos, a las técnicas utilizadas y a las relaciones con las ciencias sociales.

El desarrollo de las ciencias humanas y sociales en el siglo XX muestra una diversidad notable en categorías, teorías, métodos y técnicas. Ya en el estudio lexicográfico y semántico aparecen un conjunto de imprecisiones y de utilización de vocablos en los más diversos sentidos y conceptos. Sigue a este estudio lexicográfico-semántico un estudio de las categorías y de las relaciones entre ellas. Aquí intentamos captar las invariantes categoriales, de método y técnica, que se limitan, centralmente, a un objeto que podríamos caracterizar como un individuo al que hay que investigar según conceptos nosográfico-nosológicos, basándonos en técnicas pertinentes.

Con estos resultados pasamos revista a algunos conceptos de las ciencias humanas y sociales desarrollados en el siglo $\mathrm{XX}$, que muestran un repertorio notable de posibilidades heurísticas no consideradas en la mayor parte del material objeto de nuestra indagación.

Uno de los ejes centrales de este desarrollo de las ciencias sociales y humanas podría ser la configuración de un método estructural-genético, que ha sido, al menos en el material investigado, casi totalmente ignorado.

Finalmente nos preguntamos, no sólo acerca de las posibles relaciones que podrían establecerse entre ese método, las categorías teóricas que le corresponden y los estudios epidemiológicos, sino también acerca de la posibilidad de una epidemiología de la salud mental, y no únicamente de la enfermedad mental, basada en un modelo "antroposemiótico".

\section{Material: algunos estudios ePIDEMIOLÓGICOS en AmÉrica LATINA}

Nuestro material surge a partir de 37 volúmenes de la revista Acta Psiquiátrica y Psicológica de América Latina publicados entre los años 1970 y 1992, disponibles, sin selección previa, en nuestra biblioteca. En estos volúmenes elegimos 25 trabajos, según los siguientes criterios: 1. Que el título explícitamente nombrara las palabras "epidemiología" y "mental"; o bien, 2. Que en sus resúmenes incluyeran material relacionado con el objeto de nuestra investigación; o bien, 3. Que por sus títulos, resúmenes y/o contenidos se relacionaran más directamente con nuestro tema. Los trabajos representan el período que va de 1970 a 1992. Incluimos, además, dos trabajos no publicados en la revista mencionada, pero que se encuentran en directa relación con dos de las publicaciones elegidas.

Licenciado en psicología. Médico cirujano. Doctor en Medicina. Profesor titular de la Universidad Nacional de Córdoba, Argentina. Director del Instituto Internacional de Postgrado en Psicoterapia, Psiquiatría y Salud Mental, Argentina. 
INVESTIGACIONES EPIDEMIOLÓGICAS RELATIVAS A LA SALUD MENTAL/ENFERMEDAD MENTAL Y CONTENIDOS CONEXOS AÑO 1970 A 1992 / TABLA 1

\begin{tabular}{|c|c|c|c|}
\hline año public. & título & autores & país \\
\hline 1970 & $\begin{array}{l}\text { Prevalencia de enfermedades mentales } \\
\text { en el partido de Lanús. Informe preliminar }\end{array}$ & Tarnopolsky, A. et al & Argentina \\
\hline 1970 & $\begin{array}{l}\text { Evaluación de instrumentos para el estudio } \\
\text { de la prevalencia de trastornos mentales }\end{array}$ & León, C.A. et al. & Colombia \\
\hline 1970 & $\begin{array}{l}\text { Prevalencia de problemas de salud mental } \\
\text { en Costa Rica }\end{array}$ & Adis Castro, G. et al. & Costa Rica \\
\hline 1970 & $\begin{array}{l}\text { Visión general de la investigación } \\
\text { epidemiológica en salud mental en Chile }\end{array}$ & Muñoz, L. \& Marconi, J. & Chile \\
\hline 1970 & $\begin{array}{l}\text { Estado actual de la investigación epidemiológica } \\
\text { en América Latina }\end{array}$ & Cabildo Arellano, $\mathrm{H}$. & México \\
\hline 1970 & Estudios de epidemiología psiquiátrica en el Perú & Mariátegui, J. & Perú \\
\hline 1970 & $\begin{array}{l}\text { Esbozo de modelos de valor epidemiológico } \\
\text { para la investigación y la acción en América Latina }\end{array}$ & Marconi, J. & Chile \\
\hline 1971 & $\begin{array}{l}\text { Opiniones comunitarias sobre la enfermedad } \\
\text { mental y su tratamiento en Cali, Colombia }\end{array}$ & León, A. \& Micklin, M. & Colombia \\
\hline 1973 & Enfermedad mental e incapacitación social & Tarnopolsky, A. et al. & Argentina \\
\hline 1976 & $\begin{array}{l}\text { Análisis de la situación de la salud mental } \\
\text { en la ciudad de Córdoba }\end{array}$ & Marconi, J. & Argentina \\
\hline 1976 & Tendencias de la salud mental en América Latina & González, R. & EEUU \\
\hline 1981 & $\begin{array}{l}\text { Prevalencia institucional de la patología } \\
\text { mental en la República Argentina }\end{array}$ & Puentes, M. et al. & Argentina \\
\hline 1982 & $\begin{array}{l}\text { Epidemiología descriptiva de los desórdenes } \\
\text { psiquiátricos en la ciudad de Trelew }\end{array}$ & $\begin{array}{l}\text { Ortiz, O.; Casullo, M.M. } \\
\text { \& Grillo, O. }\end{array}$ & Argentina \\
\hline 1982 & $\begin{array}{l}\text { Prevalencia de desórdenes mentales en el } \\
\text { área metropolitana de la República Argentina }\end{array}$ & DiMarco, G. & Argentina \\
\hline 1983 & $\begin{array}{l}\text { Patrones de bebida en el mejicano. } \\
\text { Resultados de una investigación de la OMS }\end{array}$ & Calderón Narvarz, G. & México \\
\hline 1985 & $\begin{array}{l}\text { Prevalencia de trastornos mentales y factores de } \\
\text { riesgo en una población de práctica médica general }\end{array}$ & Medina Mora, M. et al. & México \\
\hline 1985 & $\begin{array}{l}\text { Consideraciones generales sobre los estudios } \\
\text { epidemiológicos en psiquiatría }\end{array}$ & Casullo, M.M. & Argentina \\
\hline 1986 & $\begin{array}{l}\text { Estructuras culturales que determinan sufrimiento } \\
\text { en las poblaciones }\end{array}$ & Pagés Larraya, F. & Argentina \\
\hline 1986 & $\begin{array}{l}\text { Tasas ajustadas de prevalencia de trastornos mentales } \\
\text { en dos poblaciones en práctica médica general }\end{array}$ & Mas Condes, C. et al. & México \\
\hline 1987 & Los aspectos epidemiológicos de la deficiencia mental & Assumpçao, F. \& Sprovieri, M. & Brasil \\
\hline 1988 & Conocimiento y uso de drogas entre alumnos de Brasilia & Bucher, R. et al. & Brasil \\
\hline 1988 & Redes sociales y enfermedad mental & DiMarco, G. & Argentina \\
\hline 1988 & $\begin{array}{l}\text { La clasificación diagnóstica psiquiátrica } \\
\text { en estudios epidemiológicos transculturales }\end{array}$ & Canino, G. et al. & Puerto Rico \\
\hline 1989 & $\begin{array}{l}\text { El cuestionario de síntomas para la detección } \\
\text { de problemas en adultos }\end{array}$ & Climent, C. et al. & Colombia \\
\hline 1990 & $\begin{array}{l}\text { Variables económico-sociales, ambiente familiar } \\
\text { y salud mental infantil en un área urbana de } \\
\text { Salvador (Bahía), Brasil }\end{array}$ & $\begin{array}{l}\text { De Sousa Bastos, A. \& De } \\
\text { Almeida-Filho, N. }\end{array}$ & Brasil \\
\hline 1992 & Tabaquismo y Tercer Mundo & Lolas Stepke, F. & Chile \\
\hline 1992 & Trastornos mentales en Nicaragua: perspectiva familiar & Penayo, U. et al. & Nicaragua \\
\hline
\end{tabular}




\section{EXAMINANDO LA NOMENCLATURA}

Una primera aproximación a nuestro material indaga el léxico, los vocablos utilizados por los autores para dar título a sus investigaciones. Aunque esta aproximación nominativa pareciera registrar meras notas externas del material, representa una orientación rápida.

Nos centramos, en primer lugar, en la palabra 'mental' / 'mentales' y el vocablo de inmediata contigüidad gramatical.

En el material de referencia el vocablo 'mental' aparece vinculado a las siguientes palabras:

\begin{tabular}{|c|}
\hline ENFERMEDADES MENTALES \\
TRASTORNOS MENTALES \\
PROBLEMAS DE SALUD MENTAL \\
SALUD MENTAL \\
EPIDEMIOLOGÍA PSIQUIÁTRICA \\
LA ENFERMEDAD MENTAL \\
ENFERMEDAD MENTAL \\
PATOLOGÍA MENTAL \\
DESÓRDENES PSIQUIÁTRICOS \\
DESÓRDENES MENTALES \\
TRASTORNOS MENTALES \\
DEFICIENCIA MENTAL \\
ENFERMEDAD MENTAL \\
SALUD MENTAL INFANTIL \\
TRASTORNOS MENTALES
\end{tabular}

Sólo en 19 investigaciones aparece la denominación "mental" en su título. De estos 19 trabajos, únicamente en cuatro el vocablo "mental" califica al vocablo "salud". En 11 títulos aparece el "vocablo" mental calificando los "vocablos": "trastornos", "enfermedad", "patología", "desorden" y "deficiencia". También indirectamente aparece vinculado este vocablo a las palabras "problemas de salud". Además, derivados de la palabra "psique", aceptada a veces como sinónimo de "mente", aparecen en la palabra "psiquiátrico/a". Estos vocablos aparecen calificando las palabras "epidemiología" y "desórdenes".

De este breve inventario lexicográfico podemos derivar las siguientes conclusiones:

1. En el material seleccionado se ha tendido a titular estos estudios utilizando el vocablo 'mental' o sinónimos para calificar la palabra enfermedad y/o vocablos relacionados, como los ya mencionados.

2. De la muestra elegida, pocos trabajos parecen utilizar los vocablos "salud mental" para especificar el objeto del estudio epidemiológico.

3. De esta apreciación lexicográfica podríamos derivar la siguiente hipótesis heurística: es muy probable que los estudios epidemiológicos en América Latina vinculados con la salud/ enfermedad mental se hayan dedicado más al estudio de la enfermedad mental que a la salud mental.

4. El léxico utilizado para nominar los fenómenos estudiados es muy diverso. En efecto, o es necesario pensar que los vocablos "desorden", "trastorno", "patología", "enfermedad", "deficiencia", "problemas de salud mental" son sinónimos, o bien que cada uno de ellos se refiere a un objeto de investigación diferente.

\section{Cuestiones SEMÁNTICAS Y CONCEPTUALES}

Si bien, generalmente, suponemos que las palabras, los nombres, en nuestro caso los títulos de trabajos científicos, expresan ciertas significaciones y/ o conceptos más unívocamente que en el léxico y semántica popular, ello no parece ser así en el material objeto de estudio.

Si avanzamos en nuestra investigación y pasamos del título del trabajo a los resúmenes y luego a los contenidos específicos, nos encontraremos con diversos hechos. El primer trabajo que contiene los vocablos "salud mental", relacionado con el vocablo "problemas" de la salud mental, contiene en su resumen lo siguiente: "Se trata tanto de la sintomatología y signología psiquiátrica como de casos clínicos definidos" (Adis Castro et al., 1970).

Muñoz y Marconi (1970) comienzan su resumen así: "Los estudios descriptivos realizados hasta ahora en Chile se refieren a la prevalencia de los trastornos mentales, principalmente alcoholismo. En el nivel explicativo se están estudiando los factores determinantes del retardo intelectual y de la forma clínica de las psicosis, y, con la ayuda de las ciencias 
sociales, esos mismos factores respecto de la ingestión excesiva de alcohol".

Comparando estos dos títulos, publicados en el mismo volumen, de la misma revista, con relación a los respectivos resúmenes, encontramos que: el primero de los casos incluye la palabra "problemas de la salud mental" para hacer referencia a "sintomatología" y "signología" "psiquiátrica", así como "casos clínicos definidos"; en el segundo trabajo la extensión de los vocablos "salud mental" parece definirse en términos precisos como "trastornos mentales", principalmente "alcoholismo", pero también "retardo intelectual" y la "forma clínica de las psicosis".

De lo dicho podemos inferir que los términos "problemas de la salud mental" podrían aparecer como sinónimos de "salud mental".

Si observamos el resumen de la investigación de Marconi (1976), "Análisis de la situación de la salud mental en la ciudad de Córdoba", que también contiene los vocablos "salud mental", constatamos que: tras mencionar los caracteres básicos de los tres modelos de programa de salud mental, su autor expresa que "Se estima la prevalencia de desórdenes mentales en la ciudad y la demanda de consulta externa...". La "situación de la salud mental", en extensión, significa aquí: 1. "Modelos básicos de programas de salud mental" y 2. "prevalencia de desórdenes mentales". Este último aspecto coincide con el trabajo anterior de Muñoz y Marconi, en donde "salud mental" se refiere a "trastornos mentales" o a "desórdenes mentales".

Considerando ahora el resumen del trabajo "Tendencias de la salud mental en América Latina" (González, 1976), refiere el autor: “Estudios epidemiológicos revelan que las tasas de muerte por causa violenta (suicidios, homicidios y accidentes) son extremadamente altas en América Latina. Por otra parte, la prevalencia de los trastornos mentales es de un 5\% para el alcoholismo (población adulta), entre 1,5 y $5 \%$ para las psicosis, $1 \%$ para la epilepsia y el retardo mental, respectivamente, y del 5 al 20\% para las neurosis...". Aquí la significación y la extensión de los vocablos "salud mental" se amplía, con relación a los trabajos anteriores, e incluye "las tasas de muerte por causa violenta (suicidios, homicidios, accidente) además del "alcoholismo", "psicosis", "epilepsia", "retardo mental" y "neurosis".

Si continuamos ahora con la investigación "Salud mental infantil en Salvador (Bahía)" (De Sousa Bastos \& De Almeida-Filho, 1990), encontramos que en el resumen aparecen siempre los vocablos "salud mental", por lo cual (y a diferencia de los trabajos anteriores), al menos en el léxico, los autores mantienen una uniformidad nominativa.

Tras esta incursión en los resúmenes de trabajos donde aparecen los vocablos "salud mental", podemos concluir que: 1. Los vocablos "salud mental" contenidos en los títulos de los trabajos investigados hacen referencia, cuando investigamos los resúmenes, a "sintomatología, signología psiquiátrica" o "casos clínicos" o bien a "trastornos mentales" o "desórdenes mentales"; sólo en un trabajo aparecen nuevamente, en el resumen, los vocablos "salud mental", y 2. En la mayor parte de los estudios objeto de nuestras observaciones no encontramos, en los resúmenes, los vocablos "salud mental".

Ahora podríamos formularnos la siguiente pregunta con relación a otros estudios epidemiológicos de la salud mental en América Latina: ¿será probable que gran parte de los estudios epidemiológicos de salud mental en América Latina conceptualicen y signifiquen el vocablo salud mental en términos de enfermedades y/o desórdenes y/o trastornos y/o síntomatología y/o signología psiquiátrica, entre otros?

El acercamiento lexicográfico y semántico nos permite adentrarnos en un análisis más detallado de los conceptos, las categorías, instrumentos, métodos y técnicas contenidos en nuestro material.

\section{Conceptos, CATEgorías,}

\section{INSTRUMENTOS, MÉTODOS Y TÉCNICAS DE LOS ESTUDIOS EPIDEMIOLÓGICOS}

Hemos decidido comenzar el estudio de las investigaciones seleccionadas desde una aproximación lexicográfica y semántica elemental, porque ella podría mostrar, al menos presuntivamente, algo de 10 ocurrido en las investigaciones epidemiológicas de la salud mental en América Latina. 
Dada la extensión de nuestra labor, sólo consideraremos aquí algunos trabajos que, por sus características, pueden orientar sobre el conjunto del material (queda al lector la laboriosa tarea del pormenorizado estudio cualitativo). Por ello las apreciaciones que siguen deberían ser entendidas como conjeturas heurísticas para la totalidad del material, y no susceptibles de ser generalizados a todas las investigaciones realizadas sobre el tema en América Latina.

\section{ESTUDIOS DE PREVALENCIA INSTITUCIONAL Y POBLACIONAL EN ARGENTINA (1979-}

\section{3)}

Como contenido de referencia, consideraremos las investigaciones contenidas en el programa de epidemiología más extenso e intenso que se desarrolló en Argentina con relación al objeto de nuestro estudio: el Programa de Investigaciones sobre Epidemiología Psiquiátrica.

Nuestro material incluye una de estas investigaciones: "Epidemiología descriptiva de los desórdenes psiquiátricos en la ciudad de Trelew" (Ortiz, Casullo \& Grillo, 1982). Su objetivo explícito es el estudio de la prevalencia de patologías mentales. Para dar contenido a la categoría de "case finding" fue utilizado el PSE (Present State Examination). El PSE recaba información sobre la presencia de 140 síntomas. El estudio brinda datos sobre el origen y configuración de la actual ciudad de Trelew. También es especificado el "entrenamiento de los encuestadores". Otra dimensión considerada es la "elección de la muestra". Para la "presentación de los datos obtenidos" son incluidas las siguientes categorías: síndromes, categorías descriptivas, índices de definición y categorías diagnósticas. Los síndromes incluyen 38 categorías, derivados en forma no excluyente de los 140 síntomas. Los síndromes más frecuentes en la muestra son: preocupaciones, tensión, irritabilidad, otros síntomas de depresión y neurosis obsesiva. Los autores estudian las correlaciones con las variables sexo, edad, nivel económico-social, tenencia o no de hijos y estado civil. Entre las categorías descriptivas son incluidas: síndromes neuróticos específicos, síndromes neuróticos no específicos, síndromes delirantes y alucinatorios, síndromes de comportamiento y lenguaje. Las diversas combinaciones de síndromes son elaboradas en un programa de computación (CATEGO) y clasificadas según los criterios de la CIE.9-OMS. De ello surgen las siguientes cifras: $\sin$ datos 1,86 de mujeres. En mujeres, al código CIE.9-295 corresponden 11,18\%; al 296: 16,15\%; al 297: 0,62\%; al 300: 11,18\%. En los varones las cifras son: $295: 11,4 \% ; 296: 10,23 \% ; 297$ : $2,28 \%$ y $300: 3,41 \%$.

Otra categoría de investigación contenida en este trabajo es la medicación consumida por el entrevistado y miembros de la familia a la que pertenece, al momento de la entrevista (es la única publicación con una referencia de este tipo).

Es importante resaltar que el PSE y el programa CATEgo no detectan los casos que corresponden a los diagnósticos OMS "dependencia de alcohol" o "retraso mental", entre otros.

Comparando este trabajo con otros del mismo grupo de investigadores y del mismo proyecto de investigación, llaman nuestra atención algunos de los siguientes aspectos:

1. Lejos de mantenerse un léxico idéntico para nominar el objeto de estudio, encontramos en cuatro trabajos diversas nominaciones: "patología mental" (Puentes et al., 1981), "desórdenes psiquiátricos" (Ortiz, Casullo \& Grillo, 1982), "desórdenes mentales" (Di Marco, 1981) y la denominación de conjunto "epidemiología psiquiátrica" (Casullo, 1985).

2. Mientras que en los estudios de prevalencia institucional realizados como parte del mismo proyecto se consideran 29 códigos diagnósticos de la CIE.9, incluso "síndrome de dependencia al alcohol", "dependencia de las drogas", "abuso de drogas, sin dependencia" y "retraso mental", estas categorías no están incluidas en los estudios poblacionales como el de Trelew. Mencionemos que el Programa de Epidemiología Psiquiátrica (PEPSI) se desarrolló entre 1979 y 1983 tanto en hospitales psiquiátricos y generales estatales, como en 28 localidades de todo el territorio argentino. En otro trabajo (Cornaglia, 1996) hemos analizado detalladamente algunas de las 
incongruencias conceptuales y metódicas de estos estudios epidemiológicos en lo referido a los problemas vinculados al consumo de bebidas alcohólicas y otras drogas legales. Aquí nos interesa remarcar la no correspondencia entre el estudio poblacional y el institucional, que se hace evidente al comparar las categorías diagnósticas consideradas en uno y en otro. Esta incongruencia parece esbozarse también al considerar la nominación del objeto de estudio.

\section{VISIÓN GENERAL DE LA INVESTIGACIÓN}

\section{EPIDEMIOLÓGICA EN SALUD MENTAL EN}

\section{CHILE}

A los efectos comparativos nos interesa analizar ahora estudios que, conceptualmente, podrían ubicarse como polo contrapuesto al anterior, al menos en algunos aspectos. Si hay una referencia muy clara que diferencia al estudio epidemiológico de mayor volumen poblacional realizado en Argentina (recién referido), de los estudios chilenos, ella puede encontrarse en las categorías relacionadas con el consumo de bebidas alcohólicas. En efecto, mientras que los estudios del Pepsi (Argentina 1979-1983) excluyen explícitamente a nivel poblacional la posibilidad diagnóstica de "dependencia del alcohol" y el "retraso mental", en los estudios chilenos de referencia se incluyen "principalmente el alcoholismo" y además los factores determinantes del "retardo intelectual" y de la "forma clínica de las psicosis" y "con la ayuda de las ciencias sociales, esos mismos factores respecto de la ingestión excesiva de alcohol" (Muñoz \& Marconi, 1970). Según estos autores, hasta 1970 los estudios chilenos eran: estudios epidemiológicos acerca de alcohol y alcoholismo en Chile, que pueden agruparse en tres rubros: prevalencia de diversos tipos de bebedores (bebedores normales y anormales), consecuencias de la ingestión anormal de alcohol y estudio de los patrones socioculturales de ingestión de alcohol. Además, refieren los autores en la investigación ahora analizada: 1. Programa de control y prevención del alcoholismo; 2. Programa tradicional; 3. Programa comunitario. Respecto a los estudios epidemiológicos acerca de otros desórdenes mentales en Chile se enumeran: 1. El "estudio del Gran Santiago 1958", donde se analizaron la prevalencia de neurosis, epilepsia y psicosis y cifras estimativas para las tasas de oligofrenia y demencia; 2. La relación entre la prevalencia de desórdenes mentales y estrato socioeconómico, 1965-1966; 3. Estudio del Gran Santiago 1967-1968. En los tres estudios se incluyen las categorías: "oligofrenia, epilepsia, neurosis, psicosis, cuadro orgánico difuso, alcoholismo". Finalmente los autores incluyen como otro aspecto de su trabajo un "esbozo del programa nacional de salud mental en Chile". Los autores elaboraron "un modelo de cuestionario precodificado en el cual se pesquisaba existencia de los seis modelos psicopatológicos básicos (ya mencionados) y el grado de invalidez por ellos causados".

\section{Comparando modelos epidemiológicos}

\section{CHILENOS Y ARGENTINOS}

La polaridad comparable de estos dos modelos de investigación puede resumirse así: 1 . Uno incluye justamente las categorías que el otro excluye (sin que conozcamos con claridad las decisiones previas que se toman para ello y qué referencias teóricas, metódicas y lógicas las sostienen); 2. Uno utiliza un instrumento de pesquisa de elaboración propia, el otro utiliza un instrumento elaborado en país europeo; 3 . Uno vincula el trabajo epidemiológico con los programas de control y prevención del alcoholismo y con el programa nacional de salud mental de Chile, el otro no plantea relación directa entre sus estudios y los programas de salud o de salud mental.

Por otra parte, y como denominador común a estos dos modelos polares, encontramos la preocupación por estudiar categorías de "desórdenes mentales" y/o "patología mental" y/o "desórdenes psiquiátricos" y/o de "trastornos mentales" y/o "trastornos psiquiátricos" y definit formas específicas de cada uno de ellos. Pareciera que en este punto la polaridad dejara amplio espacio a una homogeneidad categorial general: es decir, categorías nosográficas. 


\section{Comparando modelos EPIDEMIOLÓgicos}

\section{ARGENTINOS Y CHILENOS CON OTROS}

\section{ESTUdios EPIDEMIOLÓGICOS EN AMÉRICA}

\section{LATINA}

No pretendemos alcanzar aquí un estudio de la totalidad de los trabajos epidemiológicos latinoamericanos de la salud mental/enfermedad mental, sino solamente esbozar algunos tipos básicos a partir del material seleccionado.

Si avanzamos en nuestro estudio comparativo y observamos trabajos epidemiológicos próximos en el tiempo, e incluso publicados en el mismo volumen de la revista $A$ cta, tendremos oportunidad de ampliar nuestras observaciones.

Las siete primeras investigaciones de nuestro material corresponden a un volumen de Acta que, históricamente, representa un hito en la investigación de epidemiología psiquiátrica en América Latina. A pesar de los esfuerzos de los autores, especialmente los argentinos y chilenos, en tener en cuenta mutuamente los trabajos de investigación de uno y otro país e incluso de utilizar instrumentos de investigación idénticos, ya aparecen en este volumen algunas de las líneas invariantes que podemos observar comparando todo el material.

La investigación realizada en Colombia por León et al. (1970), comparada con el trabajo chileno ya mencionado, muestra que:

a) Los objetivos y la metodología no poseen, prácticamente, punto alguno de contacto.

b) Los instrumentos utilizados para el estudio son totalmente diferentes. En el estudio de Colombia fueron utilizadas algunas de las preguntas de Health Opinion Survey y el "método de administración de una lista de síntomas" o "premisas" a un "informante idóneo" y el examen clínico psiquiátrico.

c) Los autores colombianos pretenden investigar "psicosis", "epilepsia" y "deficiencia mental".

d) Fueron estudiados sujetos entre 20 y 49 años.

e) Por medio de la entrevista psiquiátrica y tomando como referencia el "Manual diagnóstico y estadístico de la Asociación Psiquiátrica Americana" (1952), en una submuestra aleatoria fueron indagadas las siguientes categorías: "esquizofrenia, psiconeurosis, reacciones psicofisiológicas, desórdenes de la personalidad, otros".

f) También se investigó la correlación de los trastornos mentales con diversas variables socioeconómicas, como: ingreso mensual per cápita; promedio de residencia en la población de los diversos grupos; comparación de los promedios del número de miembros por familia, del número de hijos de cada persona, del número de hijos que habría deseado tener o que desearía tener y de la tasa de hacinamiento.

Sin entrar en más consideraciones de detalle, es evidente que las diferencias entre los estudios argentinos y chilenos con el estudio colombiano aparecen en cada aspecto de la investigación. Pero al mismo tiempo se sostienen algunas categorías invariantes: 1 . El estudio colombiano recurre, como en los anteriores, a categorías nosográficas; 2 . Se trata de establecer correlaciones entre estas categorías y otras de índole socioeconómico.

Hasta aquí resultaría casi imposible intentar establecer alguna comparación acerca de las prevalencias obtenidas en los diferentes estudios, a pesar de utilizar todos ellos categorías nosográficas, pues: 1. La nomenclatura de las categorías nosográficas estudiadas es siempre diferente; 2. En cada investigación son estudiadas categorías siempre diversas; 3. Los diagnósticos nosográficos son realizados por instrumentos totalmente distintos; 4 . El objeto diagnosticado nunca es el mismo, pudiéndose tratar de síntomas, síndromes y enfermedades (o trastornos o desórdenes); 5. Categorías nosográficas centrales para un estudio no figuran en otro (por ejemplo alcoholismo).

Llegados a este punto podríamos pensar que estas constataciones son exclusivas del tipo de comparación que hemos realizado y del número de trabajos investigados. Por lo tanto deberíamos continuar con nuestra labor comparativa.

Si nos mantenemos, aún, en el conjunto de trabajos del volumen de epidemiología de 1970 e 
incluimos el trabajo "Prevalencia de problemas de salud mental en Costa Rica" (Adis Castro et al., 1970), observamos que: 1) El objeto es establecer índices de prevalencia tanto de sintomatología y signología psiquiátrica como de casos clínicos definidos; 2) Los estudios realizados en ámbitos rurales y metropolitanos incluyen seres humanos de ambos sexos con una edad mínima de 18 años; 3) La investigación incluye la definición operacional de las variables, tales como criterio para delimitar qué es una zona urbana o una rural. Se consideran dos tipos de prevalencia momentánea, a saber: prevalencia de síntomas y signos y prevalencia de casos clínicos per se (o como entidades nosológicas definidas); 4) La evaluación psiquiátrica fue realizada según las "normas" del Diagnostic and Statistical Manual, Mental Disorders de la American Psychiatric Association (1952); 5) "La evaluación del estado de salud mental y de la presencia de psicopatología" incluyó las categorías "ausente, moderado, severa"; 6) Como instrumentos de medición se utilizaron cuestionario y una tarjeta psiquiátrica. Los cuestionarios utilizados incluyeron varias escalas relacionadas con diferentes tipos de sintomatología: alcoholismo, nivel de ansiedad, trastornos de conducta, síntomas psiquiátricos, ajuste social-sexual, nivel de energía; 7) La prevalencia de alcoholismo se estimó con una escala de la Universidad de Johns Hopkins y para la sintomatología psiquiátrica se utilizaron preguntas de The California Medical Survey; 8) Se indican datos también acerca del "personal" que realizó la investigación.

Todo esto confirma nuestro punto de vista respecto a las dificultades para comparar resultados.

\section{EPIDEMiología y CATEGorías}

\section{NOSOGRÁFICAS, NOSOLÓGICAS}

De lo dicho hasta aquí, y más allá de las diversidades en nomenclatura y conceptos (objetivos, instrumentos de indagación, características y volúmenes demográficos, variables sociales y culturales consideradas, tipos de "síntomas", "síndromes" "patologías", "desórdenes", "trastornos" mentales estudiados y resultados obtenidos), podemos constatar que la mayoría de los trabajos mantiene invariantes algunas de las siguientes notas:

1. Todos parecen considerar que al realizar estudios epidemiológicos de la salud/enfermedad mental resulta ineludible estudiar individuos.

2. Se considera imprescindible aplicar a los casos identificados las categorías de síntomas, signos, síndromes y/o enfermedad mental, es decir, conceptos nosológicos.

3. Cuando son utilizadas estas categorías nosográficas/nosológicas no se las vincula con otras categorías nosográficas propias de la patología somática, ni tampoco a categorías de salud mental, aun en los trabajos que incluyen en sus títulos estos vocablos.

4. La inclusión de algunas categorías nosográficas es simultánea con la exclusión de la gran mayoría de las categorías del mismo tipo.

5. Las referencias a las ciencias sociales alcanzan solamente a algunas, como: la demografía, la sociología, la antropología y la psicología social, pero en sus aspectos más simples y elementales.

6. El modelo dominante de estudio epidemiológico de la salud mental (enfermedad mental) parece basarse, en bloque, en el modelo de la epidemiología de las llamadas "enfermedades somáticas".

7. Parece no incluirse otros conceptos y categorías de la psicología/psicopatología y/o de las ciencias sociales desarrollados en el siglo XX, tales como los conceptos: de la teoría de la comunicación humana y de la semiótica, los conceptos sistémicos y estructurales (psicoanalíticos, psicológico individuales, de la psicología analítica, de la psicología social operativa, de la psicología del campo, de la psicología de la familia, de la psicología institucional y de las comunidades, entre otras), de la psicología genético-estructural, de la psicología de la conducta, de la psicología cognitiva, del enfoque multimodal, entre otras. Menos aún parece considerarse la posibilidad de incluir conceptos, métodos y técnicas de la antropología estructural, de la lingüística y de la fonología. 
8. Parece tomarse sólo en consideración, tal vez sin plena conciencia de ello, los resultados de los métodos analíticos descriptivos y sintéticos nosógraficos-nosológicos que caracterizaron las formas más elementales de la psiquiatría/ psicopatología de fines del siglo IXX y comienzos del XX.

9. A esta tendencia nosográfica parece sumársele ineludiblemente consideraciones de índole estadística, como si este método técnico constituyera de manera exclusiva una nota intrínseca de cualquier estudio epidemiológico.

10. En la mayoría de los trabajos no se especifican los criterios por los cuales se consideran solamente determinadas categorías nosográficas y no otras.

11. Tampoco se expresa por qué no se incluyen en los trabajos epidemiológicos a niños, adolescentes de todas las edades y ancianos.

12. No se consideran categorías de la biología, especialmente de los estudios psicosociobiológicos genéticos (estudios de niños adoptados, estudios de gemelos homocigotas/ dicigotas) y psicosociales de la familia, que abundan en la bibliografía de la segunda mitad del siglo XX.

\section{EPidemiología de LA SALUd/}

\section{ENFERMEDAD MENTAL Y LAS ENSEÑANZAS DE}

\section{LAS CIENCIAS SOCIALES EN EL SIGLO XX}

La denominación epidemiología y los conceptos que pueden corresponderle no prejuzgan en restringir su alcance a las notas reconocidas en los estudios investigados. O nos ubicamos en el punto de vista según el cual la epidemiología de la salud/ enfermedad mental debe restringirse a las referencias científicas encontradas repetidamente, o bien pensamos la epidemiología de la salud/enfermedad mental como una forma flexible dispuesta a llenarse de los variados contenidos científicos que caracterizan el desarrollo de las ciencias en el siglo XX y en particular de las ciencias psicosociales (incluidas las relaciones de éstas con la biología).
Es sabido que en la ciencia los resultados obtenidos en un campo pueden llegar a enriquecer los desarrollos en otros, más aún cuando las relaciones de implicancia entre las diferentes formas de conocimientos (en especial entre las ciencias sociales y humanas) contiene, a veces, disponibilidades conceptuales, metódicas y técnicas que han producido resultados pragmáticos $\mathrm{y} / \mathrm{o}$ de conocimiento.

Existe, hoy, un notable desarrollo de epistemología comparada (entre todas las formas de ciencia, como entre las ciencias sociales) que permitiría, al menos, estimular otros desarrollos en nuestro campo de investigación. Un ejemplo fructífero de esta comparación epistemológica la podemos encontrar en los estudios de la escuela ginebrina de epistemología genética (Piaget, 1972), y en América Latina, en los aportes de Fernando Lolas, referidos a una teoría de la medicina (1992); los de Mario Bunge, vinculados a los sistemas sociales (1995), y, especialmente por su íntima relación con nuestro campo de estudio, en la denominada "epistemología convergente" desarrollada por E. Pichon-Rivière (1984), y en sus referencias antropológico-filósoficas en Jorge Saurí.

En lo que sigue indicamos algunas referencias conceptuales (en un inventario que de ninguna manera queda agotado por los contenidos referidos) de diversos desarrollos científicos en las ciencias sociales del siglo XX.

\section{LOS APORTES DEL PSICOANÁLISIS, DE DIFERENTES}

\section{PSICOLOGÍAS Y DE LA PSICOLOGÍA SOCIAL}

\section{LOS APORTES DEL PSICOANÁLISIS}

Freud había planteado que la relación entre el psicoanálisis y la psiquiatría es equivalente a la relación entre la anatomía y la histología (Freud, 1916). Se refería Freud a la psiquiatría de su época, al mismo modelo al que se vincula buena parte de la epidemiología de la salud/enfermedad mental. Pero ya Freud captaba claramente que el desarrollo del psicoanálisis requería su inclusión en el conjunto de las ciencias humanas, incluida la biología, y dentro de las primeras, la historia de la civilización, la filología, 
la literatura, el estudio de los proverbios y cantos de los pueblos, el folklore, la historia de las religiones y de la mitología. Todo esto en una época en la cual muchas de las ciencias humanas y sociales, hoy constituidas, se hallaban aún in status nascendi. Lacan (1971) amplió este listado incluyendo la interrelación con la lingüística, la fonología, la estocástica o teoría de los juegos, la retórica, la teoría estructural, la matemática y la topología, entre otras.

Este desarrollo de apertura e interrelación científica daría lugar en Freud a trabajos que señalan claramente una comprensión de lo que ocurre en el "pueblo" ("demo"): La moral sexual cultural y la nerviosidad moderna (1908) y "El malestar en la cultura", así como en la vida cotidiana (Psicopatología de la vida cotidiana, 1901). Estas consideraciones psicoanalíticas muestran categorías y métodos muy diferentes de los incluidos en la epidemiología corriente. Freud no necesita de la acumulación ad infinitum de casos sino que, siguiendo un método que más adelante llegaría a denominarse "estructural", puede captar estructuras fundamentales del bienestar y malestar humanos.

\section{LOS APORTES DE LA PSICOLOGÍA ANALÍTICA (C.G. JUNG)}

Siguiendo estas líneas investigativas del psicoanálisis, C.G. Jung realiza, por así decirlo, una "epidemiología de las manifestaciones de los arquetipos". Aunque diferente, en el contenido, a lo planteado en Freud, ciertos principios de método se mantienen invariantes. Un breve ejemplo de esta propuesta es ilustrado por la investigación de Jung sobre "Wotan" (1936): "Por eso se puede hablar de un arquetipo Wotan que como factor autónomo del alma produce efectos colectivos y bosqueja así un cuadro de su propia natura". Otro ejemplo en el mismo Jung puede encontrarse en la "tipología epidemiológica" de lo dionisíaco y lo apolíneo originada en Nietzche (El origen de la tragedia).

\section{APORTES DEL ANÁLISIS DEL CARÁCTER}

En W. Reich encontramos un desarrollo que excede conceptualmente los aportes anteriores, pero que mantiene una línea de investigación basada en datos cualitativos obtenidos a partir de aplicación de métodos analíticos (en este caso del carácter) a seres humanos individuales, en el curso de labores terapéuticas, que implican cuantitativamente gran cantidad de horas de observación, que a su vez se vinculan con datos obtenidos a partir de la observación directa en la vida cotidiana de cualquier ser humano (cf. Freud, 1901).

El concepto de "plaga emocional" representa en la obra de Reich (1965) "una biopatía crónica del organismo". Apareció, según Reich, "con la primera supresión en masa de la vida amorosa genital; se convirtió en una epidemia y ha atormentado a los pueblos de la tierra durante millares de años". Periódicamente, “como cualquiera otra plaga, la peste bubónica o el cólera, por ejemplo, la plaga emocional asume las dimensiones de una pandemia, en forma de una gigantesca irrupción de sadismo y criminalidad, tal como la Inquisición católica de la Edad Media o del fascismo internacional de nuestros días".

Aparece en Reich explícitamente las palabras epidemia y pandemia, que no eran incluidas en las obras de Jung y Freud, así como la denominación plaga y su equiparación con otras plagas con relación a las cuales surgieron los primeros conceptos epidemiológicos.

\section{EL MIEDO A LA LIBERTAD. SER Y TENER}

Otros ejemplos del mismo tipo lógico general, pero de otro nivel interpretativo, podemos encontrarlos en los conceptos de Erich Fromm vinculados al "miedo a la libertad" (1974) y al "Ser y el Tener" (1993). Se trata nuevamente de dos modalidades de organización de la vida psíquica de los sujetos de un mismo pueblo o de varios pueblos, sostenidos por un determinado tipo de configuración cultural propio de una época.

\section{LAS METAPATOLOGÍAS}

Como hemos observado en diferentes estudios epidemiológicos de la salud/enfermedad mental incluidos en nuestro material, las categorías nosográficas-nosológicas propias de la psicopatología de fin del siglo IXX y comienzos del XX, constituyen las referencias obligadas y aparentemente únicas. Abraham Maslow (1991) ha creado categorías que 
trascienden estas referencias tan repetidas y acuñó la denominación de "metapatologías" ("disminuciones de lo humano"). Existe cierta coincidencia, según Maslow, entre ellas y los "trastornos sociológicos y políticos, 'patologías sociales' ". Maslow desarrolló el concepto de metapatologias generales y especificas.

\section{TEORÍA DE LA ENFERMEDAD ÚNICA Y GRUPOS OPERATIVOS}

En Argentina se desarrolló desde 1938 una teoría de la "enfermedad única" (Pichon-Rivière, 1984) vinculada a la teoría de los "grupos operativos". Los dos conceptos surgen, a su vez, de una epistemología convergente como paso metódico ulterior de una epistemología divergente. Todo ello basado en cuatro principios centrales: 1) Principio de la policausalidad; 2) Principio de pluralidad fenoménica; 3) Principio de continuidad genética y funcional; 4) Principio de movilidad de las estructuras.

Según Pichon-Rivière (1983), “podríamos hablar de una enfermedad única con un núcleo patogenético depresivo y una instrumentación que tiene como mecanismo central la escisión o splitting del yo, del objeto y de los vínculos del yo con los objetos". La alternancia "e intrincación de la posición depresiva y esquizoparanoide configuran una continuidad subyacente a los distintos aspectos fenoménicos característicos de los diversos cuadros clínicos".

Esta teoría de la enfermedad única es vinculada por Pichon-Rivière con una teoría de los "grupos operativos" que permite comprender y explicar la enfermedad/salud humana, y no sólo la enfermedad/salud mental, desde el concepto de grupo humano, sea éste un grupo primario, como la familia, o cualquier otro grupo secundario. La articulación entre el grupo y el individuo es elaborada en esta teoría desde los conceptos de horizontalidad (grupo) y verticalidad (el individuo y su historia propia), como también por medio de conceptos provenientes de la sociología, la teoría del campo y el psicodrama, como la idea de rol, de portavoz y chivo emisario.

Desde una concepción como la aquí mencionada podrían investigarse epidemiológicamente las dimensiones verticales (individuo) y horizontales de la salud/enfermedad humana (grupo) simultáneamente. Además ello presupondría un pormenorizado estudio de las formas depresivas del desarrollo humano y su expresión en diferentes áreas (mente, cuerpo, mundo externo), con el concepto de una continuidad genética y movilidad de las estructuras que daría lugar a estudiar tanto fenómenos mentales, como corporales y sociales en la unidad grupalindividual y/o individual-grupal. Todo ello permitiría, a su vez, incluir un estudio simultáneo tanto de las formas de salud/enfermedad mental, como de las formas de salud/enfermedad somática y de expresión social. Teniendo en cuenta, además, que para Pichon-Rivière todas ellas son formas de adaptación activo/pasivas, o de aprendizaje activo/ perturbado o formas realizadas/perturbadas de comunicación. A nivel grupal son investigados vectores tales como: afiliación, pertenencia, pertinencia, comunicación, cooperación, telé, actitud ante el cambio.

Nos hemos extendido con mayor detalle en algunos de los conceptos de esta teoría por ser menos conocida que las anteriores y porque su difusión, como suele ocurrir con muchos brillantes aportes de investigadores de los países de América Latina, ha sido muy escasa.

\section{RESUMIENDO}

Con lo dicho en este apartado hemos intentado mostrar un conjunto de categorías, nociones y nominaciones de conceptos y métodos de la psicología del siglo XX que lamentablemente no parecen haber sido acogidos como referencias en los estudios epidemiológicos. Pareciera que la epidemiología no pudiera integrar dentro de sí los desarrollos de todo un siglo y que debiera limitarse a una esquemática y elemental relación entre algunas categorías nosográficas-nosológicas y estadísticas. Nada parece haber aprendido la epidemiología de la salud/enfermedad mental de estos aportes.

Un estudio pormenorizado de estas referencias en relación con los objetivos epidemiológicos nos permitirían reelaborar estos últimos y a su vez enriquecer los primeros. 


\section{LOS APORTES DE LA SEMIOLOGÍA Y DE LA SEMIÓTICA}

La definición de semiología creada por De Saussure (1972) como "...ciencia que estudie la vida de los signos en el seno de la vida social", ciencia que “....sería parte de la psicología social, y por consiguiente de la psicología general" parece no haber sido registrada en la psicología y menos aún en la epidemiología de la salud/enfermedad mental. ¿Acaso el epidemiólogo no investiga signos (de salud/ enfermedad mental) en el seno de la vida social? Pero no sólo esta definición de semiología ha sido dejada totalmente al margen en las investigaciones epidemiológicas de la salud/enfermedad mental, sino que también los actuales conceptos de semiótica parecen ser totalmente ignorados. $¿ E s$ que nociones tan fructíferas como las de "código" (cf. Lolas, 1992, biogramática y psicogramática), las de s-códigos y las de comunicación (Eco, 1984) no resultarían de interés para el epidemiólogo, interesado en investigar las correlaciones y las relaciones existentes entre fenómenos individuales y colectivos o poblacionales? Al menos ciertas regiones de la epidemiología, como las dedicadas al estudio de los fenómenos de consumo de sustancias, a los procesos de adaptación de diverso tipo, podrían beneficiarse por estos aportes. Estos conceptos semióticos, como mínimo, podrían simplificar de manera increíble buena parte de la investigación epidemiológica. Captado cierto código, podrían luego derivarse ciertos contenidos y formas de comunicación de salud/enfermedad mental, en tanto que la comunicación depende siempre de un código.

No podemos extendernos aquí en los aportes de la semiología y la semiótica pero podríamos pensar en posibilidades de desarrollo del conocimiento epidemiológico, basándose en sus aportes.

\section{LOS APORTES DE LA ANTROPOLOGÍA ESTRUCTURAL, LA}

\section{LINGUÚSTICA Y LA FONOLOGÍA}

Lévi-Strauss, entre los antropólogos, registró y desarrolló in extenso las posibilidades que la semiología, la lingüística y la fonología abrieron en las ciencias sociales: "...la antropología ocupa, de buena fe, ese campo de la semiología que la lingüística no ha reivindicado todavía para sí, a la espera de que, al menos para ciertos sectores de dicho dominio, se constituyan ciencias especiales dentro de la antropología" (Levi-Strauss, 1969).

El lingüista (según Levi-Strauss, 1969) "verá que a menudo, investigadores de disciplinas vecinas pero diferentes se inspiran en su ejemplo e intentan seguir su camino. Nobleza obliga: una revista de lingüística como Word no puede limitarse a ilustrar tesis y puntos de vista estrictamente lingüisticos; se obliga también a psicólogos, sociólogos y etnógrafos ansiosos de aprender de la lingüística moderna la ruta que conduce al conocimiento positivo de los hechos sociales".

Respecto a esas relaciones entre la "cosa colectiva" y los individuos que intenta estudiar el epidemiólogo, Levi-Strauss (1969) piensa que “...cabría la posibilidad de superar un día la antinomia entre la cultura, que es cosa colectiva, y los individuos que la encarnan, puesto que en esta nueva perspectiva la pretendida 'conciencia colectiva' se reducirá a una expresión, en el plano del pensamiento y las conductas individuales, de cierta modalidad temporales de las leyes universales en que consiste la actividad inconsciente del espíritu".

De las colaboraciones entre los antropólogos y los lingüistas y de los descubrimientos que de ello surjan no se verá beneficiada, según Levi-Strauss (1969), ninguna de ellas como hoy las conocemos, sino “...una 'antropología' entendida en el sentido más amplio del término, es decir, un conocimiento del hombre que asocie diferentes métodos y disciplinas, y que nos revelará un día los resortes secretos que mueven a este huésped, presente en nuestros debates sin haber sido invitado: el espíritu humano".

No podemos seguir imaginando una epidemiología para los próximos decenios aislada del conjunto de las ciencias sociales y estereotipada en sus relaciones con esquemas estadísticos-nosográficos elementales. Un tal cuadro de la epidemiología seguiría llevando en su intimidad “...un espíritu humano dividido en compartimentos hasta tal punto estancos que nada puede pasar a través" (Levi-Strauss, 1969).

Finalmente, y siguiendo los caminos señalados por Levi-Strauss, resulta de interés 
considerar el método de la fonología esbozado por Trubetzkov (1952) con sus cuatro pasos fundamentales: “...en primer lugar, la fonología pasa del estudio de los fenómenos lingüísticos 'conscientes' al de su estructura 'inconsciente'; rehusa tratar los términos como entidades independientes, y toma como base de su análisis, por el contrario, las relaciones entre los términos; introduce la noción de 'sistema': la fonología actual no se limita a declarar que los fonemas son siempre miembros de un sistema; ella 'muestra' sistemas fonológicos concretos y pone en evidencia su estructura; en fin, busca descubrir 'leyes generales' ya sea que las encuentre por inducción o bien 'deduciéndolas lógicamente' ".

Según Levi-Strauss (1969), la “...fonología no puede dejar de cumplir, respecto de las ciencias sociales, el mismo papel que la física nuclear, por ejemplo, ha desempeñado para el conjunto de las ciencias exactas".

Lo mínimo que la epidemiología podría aprender de la fonología es su investigación de las relaciones entre los términos investigados, rehusando tratarlos como entidades independientes. Sea que estas entidades independientes estén representadas por individuos, o por entidades nosográficas psicopatológicas, o por la enfermedad mental desvinculada de la salud mental.

En otros términos, una epidemiología que continuara, en el campo que le corresponde, estas enseñanzas podría estudiar individuos, pero siempre incluidos en las relaciones familiares y grupales; a la familia a su vez en sus relaciones institucionales, comunitarias y sociales. Por otra parte, a una tal epidemiología no le sería posible estudiar ni la enfermedad mental desvinculada de la salud mental, ni a ambas desvinculadas de la salud/enfermedad somática, ni a ninguna de estas relaciones desvinculadas de las formas de relaciones sociales.

Estas relaciones pueden concebirse sólo en un concepto circular de las ciencias que al mismo tiempo diferencie sus respectivos niveles de integración.

\section{LOS APORTES DE LA PSICOLOGÍA Y DE LA}

\section{EPISTEMOLOGÍA GENÉTICO-ESTRUICTURALES}

Las relaciones dentro de las ciencias sociales, y de éstas con las ciencias biológicas, en sus líneas más generales y elementales, han ganado en claridad en el siglo XX, por los aportes de las investigaciones de J. Piaget y su grupo. En los trabajos que hemos estudiado no parece registrarse impronta alguna de este extenso desarrollo de la psicología genético-estructural y de la epistemología genética de ella surgida.

Piaget (1971) considera con Lévi-Strauss que "la etnología es ante todo una psicología", y según su propia opinión, "la psicología es ante todo una biología". Las ciencias, para Piaget (1971), "forman un círculo y no una serie lineal, descender de la biología a la física es remontarse luego de éstas a las matemáticas y finalmente regresar... digamos, al hombre, para no decidir entre su organismo y su espíritu".

Una conclusión de esta envergadura parece ser sólo posible en un investigador que, comenzando sus indagaciones en la biología, fue capaz de extenderlas, durante años, a la psicología, entrando, para desarrollar una epistemología genética, en contacto con todas las ciencias sociales, humanas, con las matemáticas, la lógica y la física.

Por otro lado, teóricamente, esta labor fue posible para Piaget por haber seguido un método que podría considerarse uno de los ejes de todas las ciencias sociales (aunque no exclusivamente de ellas) en el siglo XX: el método estructural. La ausencia casi total en la epidemiología de todos los aportes del método estructural puede encontrarse tal vez en las mismas dificultades que tuvo este método para ser organizado en el interior de las ciencias, es decir, "...la tendencia natural del espíritu (...) en proceder de lo simple a lo complejo, y en ignorar, por consiguiente, las interdependencias y los sistemas de conjunto, antes que las dificultades del análisis impongan su reconocimiento. Luego se debió a que las estructuras no son observables como tales, y se sitúan en planos en los cuales es necesario abstraer las formas o los sistemas a la enésima potencia, lo cual exige un esfuerzo particular de abstracción reflexiva" (Piaget, 1971). 
Es así como el estudio de las estructuras, según Piaget (1970), "no puede ser exclusivo y no suprime, en especial en las ciencias del hombre y de la vida en general, ninguna de las otras dimensiones de la investigación. Muy por el contrario, este estudio tiende a integrarlas, y de la manera en que se hacen las integraciones en el pensamiento científico: según el modo de la reciprocidad y de las interacciones".

Pero no sólo estos aportes de Piaget han sido totalmente ignorados, sino también los métodos específicos de sus investigaciones psicológicas y los resultados a que arribó.

Piaget (1973) desarrolló, en sus investigaciones psicológicas, un "método clínico" que permite "rebasar el método de la observación pura y, sin caer en los inconvenientes del test, alcanzar las principales ventajas de la experimentación". Piaget opta así por el "método clínico cualitativo antes que por los cuadros numéricos y las pruebas estandardizadas" (Vinh-Bang, 1970) y sus resultados, notables, han enriquecido toda la psicología de este siglo.

Los epidemiólogos de la "salud mental", aun quienes han estudiado esporádicamente a los niños (como si éstos fueran tan pocos con relación a la población total en América Latina), han ignorado totalmente que la salud mental, a partir de los estudios de Piaget, incluye nociones tan imprescindibles como las de "operación", de "acomodación y asimilación", las diversas formas del desarrollo de la lógica y la inteligencia o la función semiótica, entre otras. Tampoco ha sido registrado que todas estas nociones sólo pueden comprenderse, según Piaget, si se recurre simultáneamente al proceso de maduración biológica, al desarrollo propio de las estructuras del sujeto epistémico y a las condiciones sociales en que se sitúan.

\section{RESUMiendo: el método estruCtURAL, UN EJE DE}

\section{LAS CIENCIAS SOCLALES}

Tanto en lo referido a las psicologías mencionadas, como a los aportes de otras ciencias sociales, tales como la semiología/semiótica, la fonología, la lingüística, la antropología estructural, la epistemología genética, encontramos expresiones diversas de un mismo método de investigación, concientizado en el siglo XX: el método estructural.
Los principios básicos de este método han sido expresados con precisión y simpleza por Lévi-Strauss (1969): economía de explicación, unidad de solución, posibilidad de reconstruir el conjunto a partir de un fragmento, y de prever los desarrollos ulteriores a partir de datos actuales. Nosotros hemos construido modalidades cualitativo-cuantitativas de investigación y acción, en el marco de la atención de seres humanos afectados por el consumo de bebidas alcohólicas (Cornaglia, 1996) y por el consumo de benzodiazepinas (Cornaglia, 1997), basados en estos principios.

Estos modelos epidemiológicos estructurales permiten, en la acción sanitaria, una economía de acción, una unidad de solución y las posibilidades de actuar en un conjunto actuando en un fragmento, como también de actuar en desarrollos ulteriores al mismo tiempo que se actúan en situaciones actuales. La relación entre estructura y génesis permite la organización de la investigación y de la acción tanto en un sentido sincrónico como diacrónico (cf. PichonRivière, principio de continuidad genética y movilidad de las estructuras).

Luego de esta revisión conceptual retornemos a nuestro material para observar los restantes trabajos.

\section{Aportes ePIDEMIOLÓGicos EN LAS \\ DÉCADAS DE LOS OCHENTA Y NOVENTA EN}

\section{AmÉRICA LATINA}

Si ahora observamos los trabajos citados de la década de los ochenta, podemos constatar que tanto en sus títulos como en los resúmenes y en el desarrollo de los mismos, las líneas centrales de método tienden a permanecer invariantes, pero en 1988 vemos surgir un trabajo que incluye por primera vez, al menos en el nivel de los títulos, el vocablo "redes sociales". En efecto, Di Marco (1988) plantea una relación entre la "enfermedad mental" y las "redes sociales" como objeto de su investigación. En Córdoba esta línea de investigación basada en las redes y en las "familias llaves" (Bertucelli et al., 1995) comenzó a desarrollarse en la acción y heurísticamente desde mediados de la década de los setenta. Resulta de interés señalar que en la matemática aparecen los vocablos y los conceptos de "grupo matemático" y 
de "red" como parte del desarrollo en esta ciencia (Piaget, 1971). Además el concepto de "grupo matemático" es una de las referencias, como la de tipos lógicos, centrales en el pensamiento sistémico desarrollado por Watzlawick et al. (1980).

En la investigación de De Sousa Bastos y De Almeida-Filho (1990) resulta de sumo interés encontrar (en el título) presentes, simultáneamente, tres conceptos que no habían aparecido en nuestro inventario: "variables económicosociales", "ambiente familiar" y "salud mental infantil". A pesar de la repetida utilización de los vocablos "salud mental" en el resumen, el contenido del trabajo nos muestra nuevamente que "Para evaluar los niveles de salud mental de los niños y de los padres, fueron utilizados dos instrumentos de screening: el Cuestionario de Morbilidad Psiquiátrica Infantil (QMPT), desarrollado por Almeida-Filho y el Cuestionario de Morbilidad Psiquiátrica de Adultos (QMPA) (...). Para estudiar la calidad de estimulación disponible en el ambiente doméstico, se empleó el inventario home (...) con dos formas: una para niños entre 0 y 3 años (HOME A) y otra para niños de 3 a 6 años (HOME B)". Nuevamente la salud mental es evaluada en términos de "morbilidad psiquiátrica". Se avanza en el estudio en varios sentidos: 1 . Se intenta plantear nominativamente con más énfasis un estudio de salud mental; 2. Los niños son incluidos desde 0 años; 3 . Se intenta indagar la asociación entre condición económicosocial, salud mental de los padres y ambiente familiar precoz y salud mental infantil.

En 1992 Penayo et al. publican la investigación "Trastornos mentales en Nicaragua: perspectiva familiar", cuyo objetivo es "...examinar la estructura de familias con individuos aquejados de trastornos mentales, en León, Nicaragua", en comparación con familias sanas de la misma muestra. Presentan el "genograma en un estudio epidemiológico" estudiando hasta miembros de la cuarta generación. Si bien en otros estudios mencionados fueron incluidas variables referidas a la familia, recién en éste aparece el concepto de "mapa de familia" o "genograma". A pesar de que Pichon-Rivière había comenzado en las décadas de los treinta y los cuarenta a conceptualizar la salud y la enfermedad mental como un fenómeno no solamente individual sino también familiar, los estudios epidemiológicos de la salud-enfermedad mental parecen no haber podido acoger más tempranamente estas posibilidades conceptuales.

Recordemos también que ya en 1939 Luxemburger realizaba extensas investigaciones de la herencia de perturbaciones psíquicas abarcando varias generaciones. Los estudios de mellizos, de niños dados a instituciones-hogares (Heimkinderstudien), de adopción y de riesgo en esquizofrenia (High-riskStudien) (Scharfetter, 1990) son un excelente ejemplo de la articulación, no sólo de la biología y la psicología, sino también de las dimensiones individuales y familiares, sea en el nivel de integración bioquímico, biológico, como en el nivel psicológico y psicosocial.

Si bien los estudios de Penayo y de Di Marco comienzan a vincular posibilidades muy fructíferas para la epidemiología de la salud/enfermedad mental, en la bibliografía que venimos analizando no aparecen estudios que efectivamente consideren la salud mental como objeto empírico y formal de sus investigaciones.

También en 1992 registramos un breve aporte de Lolas (1992) acerca del tabaquismo (Tabaquismo y Tercer mundo: un problema de salud mental), que a nuestro juicio merece atención pues: 1. Lolas incluye un "problema de salud mental" no habitualmente incluido en los estudios epidemiológicos de la salud/ enfermedad mental; 2. Lo hace de una manera simple, breve y clara, sin necesidad de malabarismos estadísticos (el método: observación directa y análisis crítico); 3. Muestra un problema de salud mental vinculado con toda la salud humana, en íntima relación con estructuras económico-político-sociales; 4. Espera que: el público en general identifique a los profesionales de la salud mental entre los que deben ser consultados, no sólo para "soluciones" sino, ante todo, para "formulaciones" del problema.

Otra línea de interés para futuras realizaciones epidemiológicas de la salud/enfermedad mental, desde la perspectiva del sufrimiento humano, la encontramos en la investigación de Pagés Larraya (1986). Ideas como: las del "loco y su discurso como espejo y enigma de su comunidad cultural”, enigma que pasa por "...el sufrimiento, la violencia y el ardid propio de las creaciones culturales"; la inclusión de 
lo "trágico y lo siniestro"; la original concepción de un "eranismo trágico", y desde él, el inicio de un diálogo con las hermenéuticas de Nietzsche, Freud y Heidegger, muestran indicaciones metódicas que tal vez rendirán sus resultados en décadas venideras.

\section{Pasos HaCia UnA EPIDEMIOLOGÍA DE LA}

\section{SALUD MENTAL}

Después de este recorrido por innumerables estudios epidemiológicos realizados en América Latina $\mathrm{y}$ de indicar algunos aportes de las ciencias humanas y sociales durante el siglo XX, ¿cómo nos podríamos imaginar futuros desarrollos epidemiológicos de la salud mental?

Futuros estudios epidemiológicos podrían precisar la utilización de los vocablos "salud mental" / "enfermedad mental", intentando no confundir uno con otro. Esto implicaría, además, un concepto más claro de uno y otro término. Uno de los trabajos incluidos en nuestro material expresa: "Pues si entendemos salud mental en el sentido estricto de la expresión, esto es, en su concepto positivo de bienestar y buen funcionamiento, no mucho podría hablarse aparte de decir que no es muy alto y que en varios sitios tiende a deteriorarse, sin tener realmente indicadores más o menos precisos que nos den una idea de magnitud. Desgraciadamente todavía no tenemos parámetros para medir el grado de felicidad y bienestar de los pueblos y sólo disponemos de la medidas negativas, aquellas que nos dicen de la magnitud del daño, ya sea en forma de vidas perdidas o de enfermedad o invalidez" (González Uzcátegui, 1976).

González Uzcátegui nos muestra la existencia de un concepto positivo de salud mental, pero considera sus indicadores como más o menos precisos. Afirmar que "no tenemos parámetros para medir el grado de felicidad y bienestar..." implica, por lo menos, que el autor piensa solamente en "medir". Ya cuando eran escritas estas palabras existían disponibilidades metódicas suficientes para intentar una captación epidemiológica de la salud mental en sentido positivo. Más aún, existían conceptos muy elaborados y trabajados, tanto en los desarrollos chilenos de Marconi y sus colaboradores, como en los trabajos que ya hemos citado de Pichon-Rivière. Los conceptos de afiliación, pertinencia, pertenencia, comunicación, cooperación, etc., ya estaban precisamente organizados. Además, Pichon-Rivière (1984:155) había conceptualizado la salud mental de manera muy breve y precisa como "adaptación activa a la realidad" y había planteado diversos aportes de método, apoyándose, entre otros, en K. Lewin, “cuyo método es doblemente experimental: a) es un esfucrzo por hacer práctica la experimentación sociológica, y b) tiende a una forma nueva de experimentación: la investigación activa" (PichonRivière, 1984). Con anterioridad a estas referencias, ya en 1950 Bermann (1966) proponía la idea de salud mental en sentido positivo.

Si en años pasados la investigación de la salud mental puede haber resultado difícil, hoy existen múltiples puntos de apoyo para una investigación de ese tipo. En efecto, los conceptos de "protección social", "optimismo" y "la capacidad de actuar sobre sí-mismo", "hardiness" y el "sentido de coherencia" en la vida, con sus respectivos aspectos, constituyen dimensiones investigadas e investigables, no sólo de la salud mental, sino también de la salud en general (Kaluza, 1996).

Pero la salud mental no puede ser investigada cometiendo el mismo tipo de error acontecido al estudiar la enfermedad mental, es decir, investigar uno de los miembros de lo que constituye una relación. La mayor parte de la bibliografía del siglo $\mathrm{XX}$ ha demostrado más que claramente que salud mental/enfermedad mental son grados de un continuum en el interior de la salud/enfermedad humana. Ahora bien, si como decía Piaget, la psicología es ante todo biología, ningún estudio de la salud mental/enfermedad mental podrá eludir el estudio simultáneo de la correlación y relación de la salud somática/enfermedad somática. Recordemos, en este orden de cosas, que Levi-Strauss entendía que la etnología es psicología. Por lo tanto, ningún estudio de la salud mental/enfermedad mental/salud somática/enfermedad somática estará en condiciones de negar la necesidad de estudios antropológicos de estas relaciones.

Pero luego de las enseñanzas de la semiología y de la semiótica en los sentidos de Saussure y Eco, 
nos conducirán necesariamente a estudiar estas relaciones en términos de signos en el seno de la vida social, y de comunicación/información determinados por códigos, sean éstos semióticos o genéticos.

Ello a su vez implica el estudio, en otro nivel, en dos direcciones: a) de los signos de salud mental/ enfermedad mental (salud somática-enfermedad somática) en el seno de la vida social que requicre conocer la "vida social", patrimonio, al menos desde ciertos puntos de vista, de la sociología; y b) el estudio de la genética.

Estos dos puntos de vista requieren, a su vez, de dos planos de estudios centrados en el mismo objeto empírico: la familia y las redes sociales. Cualquier indagación de la salud mental/enfermedad mental (salud somática/corporal) requiere de datos epidemiológicos precisos de las diversas formas, estructuras y funciones de la familia (para lo cual contamos con un notable inventario de aportes: Cf. Bateson et al., 1974; Hildenbrand, 1991) y de las redes sociales.

Ahora bien, la organización conceptual de empresas epistémicas y pragmáticas, del tipo aquí propuesto, requiere de un soporte y estructura guía que podemos encontrar en conceptos como los de la dialógica (Hcrzka, 1996), en la idea de methodologische besinnung — sentido metodológico- Jaspers, 1973), o en la idea de la antroposemiótica (Cornaglia, 1992, 1999) y la epistemología convergente (Pichon-Rivière, 1984).

Todas estas perspectivas muestran de manera precisa —aunque desde diversos puntos de vista - la necesidad de trabajar simultáneamente con diferentes teorías, métodos y técnicas, en diferentes niveles.

Las posibilidades abiertas por los desarrollos de las ciencias sociales en el siglo XX nos ofrecen la oportunidad de ampliar considerablemente la investigación epidemiológica. Para ello no es necesario que ésta abandone lo que ha realizado hasta aquí. Sí resulta, de alguna manera, urgente que la epidemiología de la salud mental intente enriquecerse de todas las producciones cientificas de las ciencias sociales.

El esquema que sigue brinda una visión sintética de gran parte de lo que hemos desarrollado hasta aquí. No es posible desarrollar cada uno de los contenidos que integran nuestro cuadro, pero cada investigador puede ir situando en él los aportes de tantas ciencias particulares como hipotéticamente pueda imaginar. A veces aparece en la ciencia el extraño fenómeno de la "xenofobia". Así como a nadie de le ocurriría plantear hoy la existencia universal y exclusiva de una lengua, excluyendo a otras, tampoco podemos en la ciencia excluir, sin más recurso que la negación o la renegación, los aportes de tantas disciplinas.

Tal vez nos podemos imaginar un esfuerzo científico que intente construir puentes entre las ciencias sociales, y entre éstas y las otras ciencias. La epidemiología de la salud mental es un campo propicio para ello. El desarrollo de la antropología (en su más amplio sentido) y de la semiótica —en el siglo XX - nos permite plantear como hipótesis heurística epistemológica un modelo "antroposemiótico".

Tanto la antropología como la semiótica se han esforzado en mantenerse abiertas a los desarrollos de todas las ciencias sociales, e incluso de otras disciplinas.

La semiótica ocupa, al menos hipotéticamente, y ocupará, un lugar privilegiado en las ciencias sociales, en tanto ella se proclama como la ciencia general del estudio de los signos en el seno de la vida social.

Por ello, pensamos que un desarrollo que vincule la antropología (en todas sus manifestaciones: biología, psicología, sociología, ecología, fonología, etc.) con la semiótica abrirá a ambas un porvenir más fructífero.

La antroposemiótica intenta hacerse eco de este desarrollo, facilitando la comunicación interepistémica, por eso ella es, ante todo, una estructura abierta que promueve vinculaciones pero no las agota.

Por lo tanto, el esquema que sigue muestra, en los contenidos, sólo algunas posibilidades; pero en su forma indica un movimiento vinculante que puede orientar las investigaciones epidemiológicas de la salud mental /enfermedad mental. 
ANTROPOSEMIÓTICA

\section{Lógica}

Epistemología estructural-genética

Epistemologías: epistemología convergente

Dialógica

Metodología: sentido metodológico

Teotía (Pertinentes a los diversos niveles de integración) (organización bipolar de los conceptos) Praxis

$\begin{array}{llllll}\text { Código Estructura Sincronía } & \begin{array}{l}\text { Repetición } \\ \text { Estereotipia }\end{array} & \begin{array}{l}\text { Adaptación pasiva } \\ \text { Acomodación }\end{array} & \text { Cambio } & \text { de Tipo } 1 & \text { Dialógica }\end{array}$

Métodos Lógicos Abstractos

Métodos Lógicos Concretos

Métodos Técnicos

Logística

Comunicación Génesis Diacronía Elaboración Adaptación activa Cambio Dialéctica de Tipo 2

Ámbitos: individual, grupal, institucional, comunitario (relación de inclusión de cada uno en el siguiente) (Teorías pertinentes a cada uno de los ámbitos) 
El futuro nos mostrará, o una epidemiología estereotipada, confusa en sus referencias más elementales, o una epidemiología en permanente desarrollo y apertura. Esta apertura significará, probablemente, no sólo una posibilidad para una epidemiología de la salud mental, sino también una posibilidad de salud mental para la epidemiología y para quienes intentamos darles formas y contenidos humanos.

\section{REFERENCIAS BIBLIOGRÁFICAS}

Adis Castro, G. et al., 1970. Prevalencia de problemas de salud mental en Costa Rica. Acta Psiquiátrica y Psicológica de América Latina, s/d.

Assumpçao, F. \& Sprovieri, M., 1987. Los aspectos epidemiológicos de la deficiencia mental. Acta Psiquiátrica y Psicológica de América Latina, 33:296-304.

Bateson, G. et al., 1974. Interacción familiar. Buenos Aires: Tiempo Contemporáneo.

Bermann, G., 1966. Problemas psiquiátricos. Buenos Aires: Paidós.

Bertucelli, S. et al., 1995. Centros de Acción Comunitaria. Una nueva y antigua estrategia institucional para generar políticas sociales. En: Redes. El lenguaje de los vínculos. Hacia la reconstrucción y el fortalecimiento de la sociedad civil. Buenos Aires: Paidós.

Bucher, R. et al., 1988. Conocimiento y uso de drogas entre alumnos de Brasilia. Acta Psiquiátrica y Psicológica de América Latina, 34:113-126.

Bunge, M., 1995. Sistemas socialesy filosofía. Buenos Aires: Sudamericana.

Cabildo Arellano, H., 1970. Estado actual de la investigación epidemiológica en América Latina. Acta Psiquiátrica y Psicológica de América Latina, s/d.

Calderón Narvarz, G., 1983. Patrones de bebida en el mejicano. Resultados de una investigación de la OMS. Acta Psiquiátrica y Psicológica de América Latina, 29:193-206.

Canino, G. et al., 1988. La clasificación diagnóstica psiquiátrica en estudios epidemiológicos transculturales. Acta Psiquiátrica y Psicológica de América Latina, 34 (3):251-259.
Casullo, M.M., 1985. Consideraciones generales sobre los estudios epidemiólogicos en Psiquiatría. Córdoba, Argentina: Escuela de Salud Pública, Universidad Nacional de Córdoba.

Climent, C. et al., 1989. El cuestionario de síntomas para la detección de problemas en adultos. Acta Psiquiátrica y Psicológica de América Latina, 35 (3-4):124-131.

Cornaglia, C., 1992. Antroposemiótica de la institución psiquiátrica argentina. En: Ciencias sociales y medicina (F. Lolas Stepke et al.). Santiago de Chile: Editorial Universitaria.

Cornaglia, C., 1996. A-dicción en epidemiologia: consumo de drogas legales. Caracas: Fundación José Felix Ribas.

Cornaglia, C., 1999. Antroposemiótica: una propuesta acerca de las relaciones entre ciencias sociales y salud. En: Ciencias sociales y salud en América Latina: un balance (R. Briceño-León, comp.). Caracas: Fundación Polar / Lacso.

De Saussure, F., 1972. Curso de lingüistica general. Buenos Aires: Losada.

De Sousa Bastos, A. \& De Almeida-Filho, N., 1990. Variables económicosociales, ambiente familiar y salud mental infantil en un área urbana de Salvador (Bahía). Acta Psiquiátrica y Psicológica de América Latina, 36 (3-4):147-154.

Di Marco, G., 1982. Prevalencia de desórdenes mentales en el área metropolitana de la República Argentina. Acta Psiquiátrica y Psicológica de América Latina, 28:93.

Di Marco, G., 1988. Redes sociales y enfermedad mental. Acta Psiquiátrica y Psicológica de América Latina, 34:157-168.

Eco, U., 1985. Tratado de semiótica general. Barcelona, España: Lumen.

Freud, S., 1901. Psicopatología de la vida cotidiana. Obras Completas, I. Madrid: Biblioteca Nueva, 1968

Freud, S., 1908. La moral sexual cultural y la nerviosidad moderna. Obras Completas, I. Madrid: Biblioteca Nueva, 1968.

Freud, S., 1916. Introducción al psicoanálisis. Obras Completas, I. Madrid: Biblioteca Nueva, 1968. 
Freud, S., 1931. El malestar en la cultura. Obras Completas, I. Madrid: Biblioteca Nueva, 1968.

Fromm, E., 1974. El miedo a la libertad. Buenos Aires: Paidós.

Fromm, E., 1993. Ser y tener. Buenos Aires: Fondo de Cultura Económica.

González Uzcátegui, R., 1976. Tendencias de la salud mental en América Latina. Acta Psiquiátrica y Psicológica de América Latina, 22:232.

Herzka, H., 1996. La nueva infancia. San Luis: s/e.

Hildebrand, B., 1991. Alltag als therapie. Berna: Huber.

Jaspers, K., 1973. Allgemeine psychopathologie. Berlín: Springer.

Jung, C.G., 1936. Tipos psicológicos. Buenos Aires: Sudamericana, 1960.

Jung, C.G., 1968. Consideraciones sobre la historia actual. Madrid: Guadarrama.

Kaluza, G., 1996. Gelassen und sicher im stress. Berlín: Springer.

Lacan, J., 1971. Lectura estructuralista de Freud. México DF: Siglo XXI.

León, C.A. \& Micklin, M., 1971. Opiniones comunitarias sobre la enfermedad mental y su tratamiento en Cali, Colombia. Acta Psiquiátrica y Psicológica de América Latina, 17:385.

León, C.A. et al., 1970. Evaluación de instrumentos para el estudio de la prevalencia de trastornos mentales. Acta Psiquiátrica y Psicológica de América Latina, s/d.

Lévi-Strauss, Cl., 1969. Antropología estructural. Buenos Aires: Eudeba, 1984.

Lolas Stepke, F., 1992. Tabaquismo y tercer mundo: un problema de salud mental. Acta Psiquiátrica y Psicológica de América Latina, 38 (3):187-188.

Luxemburger, H., 1939. Die vererbung der psychischen störungen. Berlín: Bumkes Handbuch.

Marconi, J., 1970. Esbozo de modelos de valor epidemiológico para la investigación y la acción en América Latina. Acta Psiquiátrica y Psicológica de América Latina, s/d.
Marconi, J., 1976. Análisis de la situación de la salud mental en la ciudad de Córdoba. Acta Psiquiátrica y Psicológica de América Latina, 22:167.

Mariátegui, J., 1970. Estudios de epidemiología psiquiátrica en el Perú. Acta Psiquiátrica y Psicológica de América Latina, s/d.

Mas Condes, C. et al., 1986. Tasas ajustadas de prevalencia de trastornos mentales en dos poblaciones en práctica médica general. Acta Psiquiátricay Psicológica de América Latina, 32:307-312.

Maslow, A., 1991. La personalidad creadora. Buenos Aires: Troquel.

Medina Mora, M. et al., 1985. Prevalencia de trastornos mentales y factores de riesgo en una población de práctica médica general. Acta Psiquiátricay Psicológica de América Latina, 31:53-61.

Muñoz, L. \& Marconi, J., 1970. Visión General de la investigación epidemiológica en salud mental en Chile. Acta Psiquiátricay Psicológica de América Latina, s/d.

Ortiz, O.; Casullo, M.M. \& Grillo, O., 1982. Epidemiología descriptiva de los desórdenes psiquiátricos en la ciudad de Trelew. Acta Psiquiátrica y Psicológica de América Latina, s/d.

Pagés Larraya, F., 1986. Estructuras culturales que determinan sufrimiento en las poblaciones. Acta Psiquiátrica y Psicológica de América Latina, 32:169-182.

Penayo, U. et al., 1992. Trastornos mentales en Nicaragua: perspectiva familiar. Acta Psiquiátrica y Psicológica de América Latina, 38 (3):213-222.

Piaget, J., 1971. El estructuralismo. Buenos Aires: Proteo.

Piaget, J., 1972. Epistemología de las ciencias humanas. Buenos Aires: Proteo.

Piaget, J., 1973. La representación del mundo en el niño. Madrid: Morata.

Pichon-Rivière, E., 1983. La psiquiatría, una nueva problemática. Buenos Aires: Nueva Visión. 
Pichon-Rivière, E., 1984. El proceso grupal. Buenos Aires: Nueva Visión.

Puentes, M. et al., 1981. Prevalencia institucional de la patología mental en la República Argentina. Acta Psiquiátrica y Psicológica de América Latina, s/d.

Reich, W., 1965. Análisis del carácter. Buenos Aires: Paidós.

Scharfetter, Ch., 1990. Schizophrene Menschen. München: Verlags Union.

Tarnopolsky, A. et al., 1970. Prevalencia de enfermedades mentales en el partido de Lanús. Informe Preliminar. Acta Psiquiátrica y Psicológica de América Latina, s/d.

Tarnopolsky, A. et al., 1973. Enfermedad mental e incapacitación social. Acta Psiquiátrica y Psicológica de América Latina, 19:316.

Vinh-Bang, 1970. El método clínico y la investigación en psicología del niño. En: Psicología y epistemología genéticas. Buenos Aires: Proteo.

Watzlawick, P. et al., 1980. Cambio. Barcelona, España: Herder. 


\title{
LA SALUD Y EL BIENESTAR DE LOS ADULTOS MAYORES
}

\author{
Aquiles R. Salas J. *, Julieta González. de Gago ${ }^{* *}$ y Walter Mosca***
}

\section{INTRODUCCIÓN}

El envejecimiento de la población se ha asociado con las naciones industrializadas de Europa y América del Norte, donde encontramos numerosos países con un quinto o más del total de la población mayor de 60 años.

A medida que los países en desarrollo han estado luchando contra las causas más comunes de morbilidad y mortalidad, han logrado mejorar sus condiciones de vida. En el siglo XX, la principal causa de muerte en casi todos los países ha cambiado de diarrea e infecciones bacterianas agudas o virales en la infancia, a enfermedades del corazón mucho más tarde en la vida. Esta desviación, asociada con avances tecnológicos en educación y salud, incrementó la expectativa de vida en una o dos generaciones por 20 o 30 años. Aunque existen problemas económicos y de salud, la población está viviendo mayor tiempo. La expectativa de vida al nacer en estos países se ha incrementado y seguirá mejorando en los próximos 20 años (Kinsella, 1994).

Los adultos mayores son un grupo especial por varias razones: patologías múltiples, mayor riesgo de enfermedades crónicas discapacitantes, problemas yatrogénicos, práctica de intervenciones prematuras que a menudo ocasionan dependencia, y el hecho de ser víctimas de la actitud negativa de los profesionales, la sociedad y ellos mismos, al atribuir a la vejez problemas que se pueden solucionar o mejorar.
El aumento del número de ciudadanos mayores ha provocado intensos debates públicos sobre temas tales como costos de seguro social, atención de la salud, inversión educativa, que están directamente relacionados con los cambios en la estructura de edad de la población. Hoy en día muchos países en desarrollo - especialmente América Latina, el Caribe y Asia- están experimentando cambios similares en la estructura por edad de la población y se registran también debates sobre inversión económica y la capacidad de los gobiernos para mejorar el bienestar financiero de sus ciudadanos de mayor edad (Frenk, Bobadilla y Lozano, 1991).

\section{Situación demográfica de AmÉrICA LATINA Y EL CARIBE}

El envejecimiento de la población se refiere simplemente a la proporción de incremento de personas mayores dentro de la estructura de edad de la población general. Este proceso es primariamente determinado por tasas de fertilidad (nacimientos) y por tasas de mortalidad (defunciones); así, las poblaciones con alta fertilidad tienden a tener baja proporción de personas ancianas y viceversa. Los demógrafos usan el término "transición demográfica" para referirse a un proceso gradual en el cual una sociedad pasa de una situación de alta fertilidad/alta natalidad a una de baja fertilidad/baja mortalidad (Frenk, Bobadilla y Lozano, 1991). Esta transición se

Médico egresado de la Universidad Central de Venezuela (UCV). Postgrado en Medicina Interna y Magister en Medicina Interna UCV. Research Fellow in Geriatric Medicine, Harvard University. Master in Public Health, Harvard University. Profesor de la Escuela de Medicina Luis Razetti, Departamento de Medicina Interna, Hospital Universitario de Caracas, UCV, desde 1981.

** Socióloga, mención política, egresada de la Escuela de Sociología y Antropología de la UCV. Magister en Ciencias Administrativas, mención Informática y magister en Práctica Social y de Salud. Actualmente ejerce la jefatura de la Cátedra de Salud Pública, Departamento de Medicina Preventiva y Social de la Escuela de Medicina Luis Razetti, UCV.

*** Médico egresado de la UCV. Entrenamiento en investigación clínica en cardiología, Laboratorio de Investigaciones Cardiovasculares de la Facultad de Medicina de la Universidad de Ohio, EEUU. Profesor titular de la Facultad de Medicina de la UCV. Coordinador del laboratorio de Fisiopatología del Instituto de Biomedicina de la Facultad de Medicina de esta universidad. 
caracteriza primero por disminuciones en la mortalidad infantil y de la niñez a medida que se erradican las principales enfermedades infecciosas y parasitarias. La mejor resultante en la esperanza de vida al nacer ocurre mientras la fecundidad tiende a seguir siempre alta, produciendo de ese modo grandes cohortes de nacimiento y una proporción en aumento de niños con relación a adultos.

Cuando desciende la fecundidad y las tasas de mortalidad continúan mejorando, la población comienza a envejecer. La migración internacional por lo general no desempeña una función clave en el proceso de envejecimiento de la población, pero puede ser importante en las poblaciones más pequeñas.

De acuerdo con las proyecciones, la población mundial se incrementará de 4.800 millones en 1985 a 6.176 millones en el año 2000 y hasta 8.188 millones en el año 2025. Casi el 75\% de esta población vivirá en África, Asia o América (excluyendo Estados Unidos y Canadá), países que compartirán las siguientes condiciones: elevada tasa de crecimiento, alta tasa de nacimiento y tasa de mortalidad con tendencia a disminuir (Kinsella, 1994).

Para el año 2000 se calcula que dos de cada tres de los 600 millones de adultos mayores estará viviendo en países en desarrollo. El incremento de la población será particularmente marcado en Asia, primariamente como resultado del rápido crecimiento de los envejecidos en China y la India.

En 1980, la población de 60 años o más en Latinoamérica y el Caribe se estimó en 23,5 millones y las proyecciones fueron 42,1 millones para el año 2000 y de 96,6 millones para el 2025. Esto representa el $6,5 \%, 7,8 \%$ y $12,7 \%$ de la población total respectivamente (Anzola-Pérez, 1985).

En el cuadro 1 se puede apreciar el porcentaje de la población en los grupos de edad mayor y la edad media de la población, por regiones y países seleccionados para 1991.

El Caribe es hoy la región en desarrollo "más vieja" del mundo, pues más de $9 \%$ de su población total es mayor de 60 años. América Central y América del Sur tienen una estructura de edad más joven, en la que $6,9 \%$ de la población total es de 60 y más años. Este porcentaje es inferior a la cifra correspondiente a Asia en su totalidad (cuadro 1), pero mucho mayor que para África y el Oriente Medio. Las tasas correspondientes a Europa y a América del Norte son 16,8 y 19,1\% respectivamente, $y$ va en aumento

En América Latina y el Caribe más de 32 millones de personas tienen en la actualidad por lo menos 60 años de edad; $55 \%$ son mujeres. La población de 60 años y más está aumentando a una tasa anual del $3 \%$, comparado con el 1,9\% de la tasa de crecimiento de la población total. Además, la expectativa de vida al nacer se incrementará de 51,2 años en el período 1950-1955 a 72,8 años en el período 2020-2025, lo que significa un incremento de 21,6 años.

La figura 1 ilustra la transición histórica reciente y proyectada de la estructura por edad de la población de América Latina y el Caribe. En 1950 la situación general se caracterizaba por un descenso de la mortalidad a las edades más jóvenes mientras que la fecundidad era todavía alta (en promedio, las mujeres tenían unos seis hijos), dando lugar a grandes aumentos en la base de la pirámide de población. En 1985 todavía estaban aumentando las cohortes de nacimiento, pero se había reducido la diferencia relativa entre el tamaño de los grupos de edad más jóvenes. La pirámide había perdido su forma estrictamente triangular y la porción de ancianas de la población total había aumentado ligeramente. Para 2020, la base de la pirámide será rectangular y habrá tantas personas de más de 30 años como las hay de menos de 30. Se proyecta que en 2020 la población anciana constituirá el 12\% del total, en comparación con $5 \%$ en 1950.

Dentro de las cifras globales para América Latina y el Caribe, hay una amplia diversidad nacional que refleja las diferencias históricas demográficas y socioeconómicas de diversos países. Algunas naciones - por ejemplo, Cuba, Argentina y Uruguay- están bastante avanzadas en el proceso de envejecimiento, mientras que otras - como Haití, Bolivia y Guatemala- continúan teniendo niveles comparablemente altos de fecundidad, lo que excluirá el envejecimiento significativo de poblaciones en un futuro previsible. 
PoRCENTAJE de LA POBLACIÓN EN LOS GRUPOS DE EDAD MÁS ANCIANOS Y EDAD MEDIANA DE LA POBLACIÓN, POR REGIONES/PAíseS SELECCIONADOS: 1991 / CUADRO 1

\begin{tabular}{|c|c|c|c|c|c|}
\hline \multirow[b]{2}{*}{ Región/país } & \multicolumn{2}{|c|}{$\begin{array}{l}\text { Porcentaje de } 60 \text { años } \\
\qquad \text { y más }\end{array}$} & \multicolumn{2}{|c|}{$\begin{array}{l}\text { Porcentaje de } 75 \text { años } \\
\text { y más }\end{array}$} & \multirow[t]{2}{*}{ Edad mediana } \\
\hline & Hombres & Mujeres & Hombres & Mujeres & \\
\hline África al sur del Sahara & 4,3 & 4,6 & 0,7 & 0,7 & 17 \\
\hline \multicolumn{6}{|l|}{ Cercano oriente/ } \\
\hline norte de África & 5,6 & 6,3 & 1,1 & 1,3 & 20 \\
\hline Asia & 7,1 & 8,1 & 1,3 & 1,8 & 24 \\
\hline América del Norte & 14,6 & 19,0 & 3,9 & 6,6 & 33 \\
\hline Europa & 16,0 & 21,9 & 4,2 & 7,6 & 35 \\
\hline Caribe & 8,6 & 9,6 & 2,4 & 3,0 & 24 \\
\hline Barbados & 11,2 & 15,6 & 3,7 & 5,8 & 28 \\
\hline Cuba & 11,8 & 12,6 & 3,6 & 4,0 & 28 \\
\hline Haití & 6,3 & 6,1 & 1,5 & 1,8 & 18 \\
\hline Jamaica & 8,3 & 9,8 & 2,3 & 3,1 & 22 \\
\hline República Dominicana & 5,5 & 6,7 & 1,0 & 4,0 & 28 \\
\hline Trinidad y Tobago & 7,2 & 8,1 & 1,6 & 2,3 & 24 \\
\hline América Latina & 6,2 & 7,5 & 1,3 & 1,8 & 22 \\
\hline Argentina & 11,4 & 14,6 & 2,5 & 4,0 & 28 \\
\hline Belice & 4,8 & 5,4 & 1,0 & 1,3 & 18 \\
\hline Bolivia & 5,7 & 6,5 & 0,9 & 1,2 & 20 \\
\hline Brasil & 5,8 & 7,4 & 1,1 & 1,7 & 22 \\
\hline Colombia & 5,7 & 6,6 & 1,0 & 1,4 & 23 \\
\hline Costa Rica & 6,4 & 7,1 & 1,6 & 1,9 & 22 \\
\hline Chile & 8,0 & 10,3 & 1,6 & 2,7 & 26 \\
\hline Ecuador & 5,5 & 6,2 & 1,2 & 1,6 & 20 \\
\hline El Salvador & 5,4 & 6,2 & 0,9 & 1,3 & 18 \\
\hline Guayana Francesa & 6,4 & 7,2 & 1,2 & 1,9 & 24 \\
\hline Guatemala & 5,2 & 5,2 & 1,0 & 1,1 & 18 \\
\hline Guyana & 5,8 & 6,6 & 1,2 & 1,7 & 21 \\
\hline Honduras & 4,9 & 5,2 & 1,2 & 1,3 & 17 \\
\hline México & 5,4 & 6,0 & 1,3 & 1,6 & 20 \\
\hline Nicaragua & 3,6 & 4,4 & 0,5 & 0,8 & 17 \\
\hline Panamá & 7,3 & 7,5 & 1,7 & 1,9 & 22 \\
\hline Paraguay & 5,6 & 6,5 & 1,2 & 1,6 & 19 \\
\hline Perú & 5,5 & 6,4 & 1,0 & 1,3 & 21 \\
\hline Suriname & 6,5 & 7,3 & 1,2 & 1,5 & 22 \\
\hline Uruguay & 14,8 & 18,4 & 3,6 & 5,8 & 31 \\
\hline Venezuela & 5,6 & 6,5 & 1,1 & 1,6 & 21 \\
\hline
\end{tabular}

Fuente: Oficina del Censo de los Estados Unidos de América, Centro para la Investigación Internacional, Base de Datos Internacionales sobre el Envejecimiento 
Figura 1 - Estructura DE EDAD DE LA PROBLACIÓN DE América Latina y el Caribe. 1950-2020

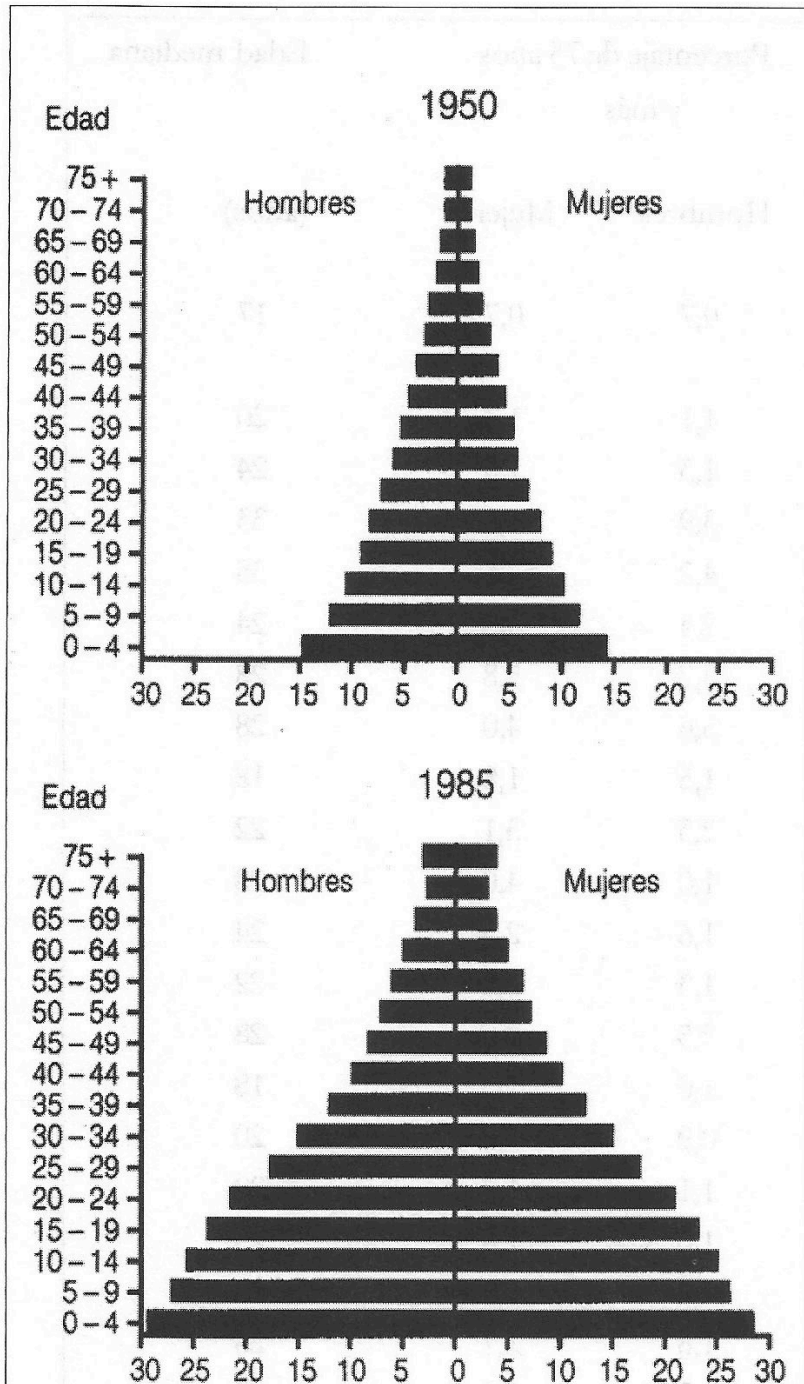

Edad 2020

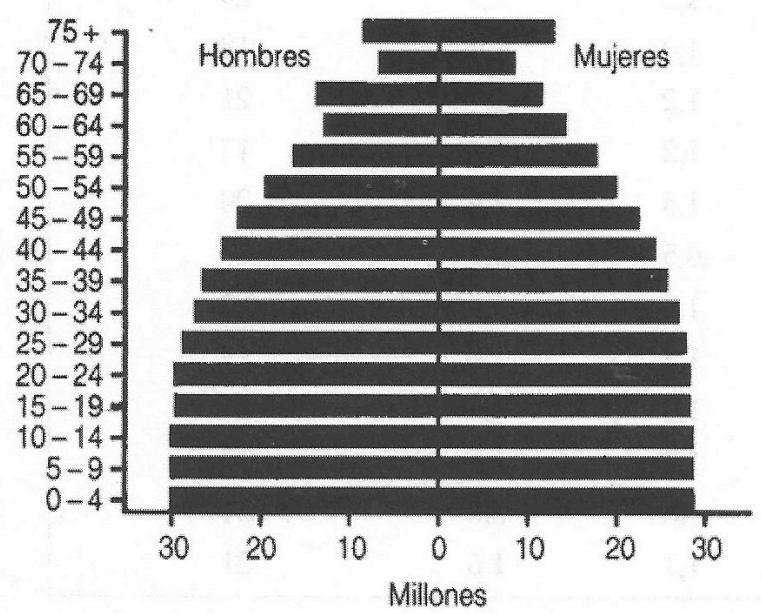

Se proyecta que entre 1991 y 2020 la población de mayor edad aumentará más rapidamente que la población total en todos los países de América Latina.

En general, los países que ahora tienen proporciones relativamente altas de población mayor experimentarán un crecimiento más pequeño de porcentaje, mientras que los menos mayores de la región tenderán a tener aumentos superiores de porcentaje (cuadro 2).

Se proyecta que la población envejecida se duplicará durante este período, especialmente en Venezuela, Colombia, Ecuador y varios países centroamericanos.

En Venezuela, han ocurrido cambios en su estructura de población y vemos como ha variado la representación gráfica desde una forma triangular de base muy ancha (censo de 1950) a una distribución de la población de forma romboidal (censo de 1980), con un incremento en los grupos de edad de $60 \mathrm{y}$ más años. Ha ocurrido igualmente un incremento en la expectativa de vida al nacer, ubicándose en el período 1990-1995 en 70,33 años para la población total, siendo para la mujer 73,5 años y para el hombre 67,31 años. En el período 1995-2000, se estimó en 70,96 años para la población total, 67,91 años para los hombres y 74,17 años para la mujer. La expectativa de vida al nacer se ha estimado para el período 20202025 en 73,67 años para la población total, 70,50 años para los hombres y 77,00 años para la mujer (OCEI, 1990).

Las estimaciones de población de 60 y más años en Venezuela se expresan en la siguiente tabla:

\begin{tabular}{|ccc|}
\hline Año & Población total & Porcentaje \\
\hline 1980 & 15.023 .880 & $4,98 \%$ \\
1990 & 19.734 .968 & $5,70 \%$ \\
2000 & 24.715 .097 & $6,50 \%$ \\
2010 & 30.005 .657 & $8,00 \%$ \\
2020 & 35.393 .992 & $10,25 \%$ \\
\hline
\end{tabular}

Fuente: Censo 1990, OCEI 
CAmbio proyectado de porcentaje en la población total y de ancianos (DE 60 años y más) en 25 Países Seleccionados, 1991-2020 / CuAdro 2

\begin{tabular}{|c|c|c|c|}
\hline \multirow[b]{2}{*}{ País } & \multicolumn{2}{|c|}{ Porcentaje de cambio en: } & \multirow{2}{*}{$\begin{array}{l}\text { Tamaño proyectado } \\
\text { de la población } \\
\text { anciana en } 2020\end{array}$} \\
\hline & Población total & Población anciana & \\
\hline Argentina & 32,8 & 66,2 & 7053900 \\
\hline Barbados & 11,4 & 67,1 & 57200 \\
\hline Bolivia & 73,9 & 164,4 & 1149000 \\
\hline Brasil & 49,1 & 174,8 & 28121700 \\
\hline Colombia & 52,3 & 228,2 & 6850700 \\
\hline Costa Rica & 69,1 & 225,1 & 682300 \\
\hline Cuba & 18,8 & 99,1 & 2603700 \\
\hline Chile & 44,3 & 165,6 & 3245800 \\
\hline Ecuador & 61,8 & 205,7 & 1191200 \\
\hline El Salvador & 65,6 & 123,0 & 703400 \\
\hline Guatemala & 68,7 & 166,7 & 1291400 \\
\hline Guyana & 12,0 & 110,1 & 96900 \\
\hline Haití & 80,9 & 87,6 & 735500 \\
\hline Honduras & 83,1 & 184,9 & 718000 \\
\hline Jamaica & 41,9 & 94,6 & 439400 \\
\hline México & 66,6 & 200,1 & 15574700 \\
\hline Nicaragua & 84,2 & 222,1 & 151600 \\
\hline Panamá & 57,4 & 177,4 & 506200 \\
\hline Paraguay & 83,6 & 184,2 & 828600 \\
\hline Perú & 53,8 & 187,7 & 3827200 \\
\hline República Dominicana & 51,3 & 195,5 & 1327500 \\
\hline Suriname & 50,8 & 129,1 & 63600 \\
\hline Trinidad y Tobago & 34,0 & 146,4 & 241900 \\
\hline Uruguay & 16,0 & 22,3 & 635700 \\
\hline Venezuela & 68,6 & 241,2 & 4169600 \\
\hline
\end{tabular}

Fuente: Oficina del Censo de los Estados Unidos de América, Centro para la Investigación Internacional, Base de Datos Internacionales sobre el Envejecimiento 
Otro aspecto importante que se debe considerar es la situación de transición demográfica que está ocurriendo en Venezuela, similar a lo que ha ocurrido en la mayoría de los países alrededor del mundo. Así, vemos que para el quinquenio 1985-1990 la tasa de natalidad se ubicó en 30,72 por mil; para el quinquenio $1995-2000$ se estimó en 26,03 por mil; igualmente se aprecia que las tasas brutas de mortalidad se han mantenido en cifras de 5,43 por mil para el período 1985-1990; en 5,25 por mil en el período 19901995 y se estimó una tasa de 5,34 por mil para el período 1995-2000. Estas cifras nos permiten concluir que la población venezolana está envejeciendo y nos corresponde afrontar el reto de ofrecerle a este grupo de la población las oportunidades dentro de la sociedad para garantizar su bienestar.

\section{POLÍTICA DE SERVICIOS Y ATENCIÓN PARA}

\section{ADULTOS MAYORES}

Aunque la velocidad a la cual la población está envejeciendo generalmente se reconoce y es motivo de preocupación, muy poca planificación activa se ha hecho. Muchos países creen que la familia extendida y sus valores tradicionales y el respeto por los adultos mayores los preservará, pero la experiencia nos está enseñando rápidamente que esto puede no ser cierto. Hay la tendencia en la población a concentrarse en áreas urbanas, ocasionando de esta manera una situación donde o bien el adulto mayor migra con sus hijos a las ciudades, donde ellos son improductivos, están solos y aislados, o bien permanecen en áreas rurales, donde la sobrevivencia depende del soporte de los hijos a distancia.

Por todo lo anterior, es obvio que en los próximos años los adultos mayores serán un problema creciente, para el cual debemos desarrollar alternativas, antes que alcance proporciones que no permitan su solución (Robert \& Binstock, 1982). Es esencial definir una política articulada en la realidad, basándonos en nuestros valores y no en principios, muy bonitos en el papel, pero que no se corresponden con nuestra realidad social y cultural. Este es un problema central a nuestra organización social, que afectará fundamentalmente los valores que tenemos como sociedad.
En la mayoría de las sociedades, antes de la época industrial los adultos mayores recibían un gran respeto y eran considerados un factor fundamental en la sociedad. A medida que el proceso industrial se universaliza, se afecta significativamente la organización tradicional de los grupos sociales. El adulto mayor pasa de ser, por su experiencia y conocimiento, un componente importante y fundamental del grupo social, a ser considerado en cierta manera una carga. Este proceso social tiene una contrapartida en el ámbito personal, ya que en muchas ocasiones la política de jubilación obligatoria origina una pérdida de estima en el jubilado. En una sociedad centrada en valores mercantiles, donde se es productor y luego consumidor, el jubilado siente que pierde su rol. La ausencia de alternativas que le permitan un nuevo rol social condiciona la aparición de conflictos personales y con su entorno social.

Con el fin de propiciar que los adultos mayores puedan buscar soluciones a sus problemas y aceptar las pérdidas inevitables, de modo de sentirse satisfecho con la vida y no temer a la muerte, debe implementarse una política de Estado cuyo objetivo sea lograr que el envejecimiento se convierta en un proceso individual de adaptación a condiciones cambiantes, provenientes del propio organismo y/o del medio social. Esta política debe lograr que el adulto mayor tenga un buen nivel de bienestar, capacitándolo para enfrentar esos cambios y adaptarse a ellos adecuadamente sin perder su participación en el quehacer cotidiano de su grupo social (Kinsella, 1989; Tapia-Videla, 1994).

Para poder desarrollar estas políticas es básico tener una comprensión adecuada de las variables de la problemática que estamos analizando. Una fundamental es la fisiología del envejecimiento y sus implicaciones.

Tradicionalmente se ha conceptualizado la vejez como déficit e involución. No obstante, aun cuando el organismo humano experimenta un desgaste acorde con la finitud de los seres vivos, esto no se tiene que expresarse como un déficit limitante. El organismo funciona con niveles de reserva importantes, $y$ los avances del conocimiento permiten intervenir para atenuar y contrarrestar los efectos que tales detrimentos tendrían sobre la capacidad de los 
individuos para así permitirles continuar desempeñando sus actividades.

Para poder comprender mejor ese proceso y poder intervenir en él con más efectividad, se ha dividido el proceso de envejecimiento en dos categorías:

1. Envejecimiento satisfactorio: se refiere a los sujetos en los que se observa sólo el decremento funcional atribuible al proceso de envejecimiento, y donde ni la enfermedad ni los factores ambientales o de estilo de vida complican o acrecientan el deterioro.

2. Envejecimiento usual: se observan cambios determinados por el efecto combinado de la enfermedad y el estilo de vida sobre el proceso de envejecimiento intrínseco. A los efectos fisiológicos del envejecimiento se asocian, y lo complican, condiciones extrínsecas a él (Rowe \& Kahn, 1987).

Es importante entender que esta simple clasificación, como todo fenómeno biológico, tiene un espectro, en el cual cada individuo se ubica en función de sus características personales y de los efectos de su entorno (Rowe \& Wang, 1989).

Por todo lo anterior, un elemento fundamental de la política a ser definida e implementada es lograr que la mayoría de los adultos mayores tengan un envejecimiento satisfactorio. Para lograrlo es primordial abordar el problema desde tres aspectos diferentes:

- Salud pública: centrada en la educación del adulto mayor para que sea el promotor de su salud y en una adecuada atención medica.

- Educativo: se debe preparar y adaptar al adulto mayor de nuestra sociedad para que la realidad social cambiante que estamos experimentando no lo atropelle y limite su participación y socialización.

- Social: hay que desarrollar alternativas de organización social y comunitaria que, contrariamente a la situación actual, le permitan al adulto mayor continuar siendo parte de la estructura social y participar activamente en ella.

Estos aspectos deberían formar parte de lo que podríamos llamar una "Política de Servicios y Atención para Adultos Mayores".
Es fundamental que esta política asegure que los adultos mayores puedan vivir sus últimos años con dignidad y comodidad y a un costo que la sociedad pueda afrontar. Otro aspecto de importancia es el relacionado con la salud de este grupo social, el cual, por sus características, tiende a enfermarse más. Por lo tanto, otro aspecto central de la política a ser implementada debe ser aumentar los recursos humanos y económicos asignados para esto, ya que el número de adultos mayores está aumentando en todas nuestras sociedades.

La Política de Servicios y Atención para Adultos Mayores debe incluir cinco sistemas:

- Seguridad social en su sentido genérico.

- Salud.

- Educación.

- Adiestramiento para el empleo.

- Servicios sociales personales.

Dentro de la inevitable complejidad de esta política es importante resaltar ciertos principios rectores necesarios para su éxito:

- Debe hacerse operacional basándose en nuestros valores, y no aplicando paradigmas de servicio a la población de edad avanzada utilizados en el mundo desarrollado.

- Debe optimizar la utilización de los recursos disponibles y no duplicar actividades.

- Debe evitarse que los servicios a los adultos mayores sean aislados, sino que conformen un sistema que pueda atender en forma aceptable las necesidades de este grupo social.

- Es fundamental que este sistema sca flexible, evaluado constantemente y ajustado según la evaluación, para poder adaptarse rápidamente a los cambios que se generan en nuestro mundo cada día más globalizado.

- Debe coordinar los servicios y entes que atienden al adulto mayor, con el fin de optimizar el uso de los recursos disponibles.

- Debe entenderse a los adultos mayores como un grupo social. La ejecución de esta política debe ser suficientemente flexible para tomar en cuenta 
a los individuos, pero la orientación general debe ser hacia ellos como un grupo social.

Desde el punto de vista de salud esta política debe incluir los siguientes servicios específicos:

- Servicios para los adultos mayores relativamente sanos e independientes.

- Servicios para aquellos individuos con limitaciones que requieren apoyo para evitar una institucionalización prematura e innecesaria.

- Servicios para atender aquellos adultos mayores que requieren cuidado institucionalizado o su equivalente a largo plazo o permanente.

Como es evidente, este esquema implica una atención progresiva y creciente del adulto mayor a medida que es requerida. Sin embargo, la institucionalización de éste debe ser pospuesta mientras sea posible, fomentándose el uso de la familia y la comunidad como la alternativa más humanitaria y flexible.

En la problemática del adulto mayor hay un contexto socioeconómico que no puede perderse de vista. En términos generales, en nuestras sociedades este grupo social tiene una posición difícil económicamente y en cuanto a peso político. Deben dárseles las herramientas para poder mejorar su situación económica (readaptación para el trabajo) y enseñársele a utilizar la presión política para propiciar los objetivos de su grupo social.

Por otra parte se debe lograr que la sociedad tome conciencia de esta problemática, ya que generalmente la actitud de nuestras sociedades pareciera ser de negación de un problema que ya es real y origina tensiones sociales en nuestras ciudades. Consecuentemente, esta política debe incluir un componente comunicacional para hacer consciente el problema y promover una actitud positiva de los otros grupos sociales (Tapia-Videla, 1994; Kalache, 1994).

Un aspecto importante es el revertir la tendencia que existe a asumir soluciones como la de otros países, donde se han convertido en un grupo separado del resto de la sociedad. Una de nuestras características más positivas es la de que no hemos separado la familia en grupos sino que la entendemos como un todo. Esto debe potenciarse y el núcleo familiar debe ser parte fundamental en la implementación de estas políticas.

Hay que abrir espacios para la socialización del adulto mayor, teniendo siempre presente que con ella debe lograrse su integración y no su separación.

Debe revertirse la tendencia que presenta la vejez como una carga social. Si tenemos sentido común y creatividad podemos insertarlos, en diferentes roles, en la sociedad; logrando que sean un factor de cambios positivos, especialmente en problemas que requieren de comprensión, afecto y respeto, características que usualmente tienden a profundizarse con la edad. Hay ejemplos positivos de esto, como el programa de abuelos voluntarios en Estados Unidos para ayudar menores con problemas. La participación de adultos mayores en el programa de control de SIDA en Argentina. En Venezuela, como parte de la crisis económica que está atravesando nuestro país, las condiciones de vida de los adultos mayores se han deteriorado acentuadamente en pocos años. Lo anterior, aunado a la crisis del sector salud, determinó que surgieran organizaciones no gubernamentales tratando de generar soluciones a estos problemas. A ellas se unen los comités de salud y en conjunto generan acciones para disminuir la situación de exclusión y de impotencia de los adultos mayores de zonas marginales de la ciudad (González, 1997). Así nace un movimiento de comités de salud de pensionados y jubilados que comienzan a ejercer presión política y han abierto la posibilidad de que los adultos mayores puedan crear su propia identidad participando en actividades recreacionales, de promoción de la salud, rescate de la historia del vecindario, talleres de manualidades, propiciando centro sociales donde pueden reunirse e interactuar con el resto de la comunidad, minimizando la necesidad de ser institucionalizados.

La experiencias reportadas demuestran que es posible cambiar el rol de nosotros y de los adultos mayores en nuestras sociedades. 


\section{REFERENCIAS BIBLIOGRÁFICAS}

Anzola-Pérez, E., 1985. El envejecimiento en América Latina y el Caribe. En: La atención de los ancianos: un desafío para los años noventa (E. Anzola, D. Galinsky, F. Morales, A. Salas \& M. Sánchez, eds.), pp. 9-24. Washington DC: OPS, Publicación Científica 546.

Frenk, J.; Bobadilla, J.L. \& Lozano, R., 1991. The epidemiologic transition in developing countries: the Latin American experience. Trabajo presentado en el Seminar on Causes and Prevention of Adult Mortality in Developing Countries. Santiago de Chile: International Union for the Scientific Study of Population.

González de G., Julieta, 1997. Aproximación sociopolítica de la vejez en Venezuela. Trabajo presentado en las Jornadas Nacionales de Psicología. Coro, Venezuela.

Kahn, A.J. \& Kamerman, S.B., 1980. Social services in international perspectives: the emergence of the sixth system. New Brunswick, NJ: Transaction Book.

Kalache, A., 1994. ¿Qué repercusiones tiene el envejecimiento de la población en el futuro previsible? En: La atención de los ancianos: un desafío para los años noventa (E. Anzola, D. Galinsky, F. Morales, A. Salas \& M. Sánchez, eds.), pp. 453-456. Washington DC: OPS, Publicación Científica 546.

Kinsella, K., 1979. Aging in the third world. Washington DC: US Bureau of the Census, International Populations Report Series.

Kinsella, K., 1994. Dimensiones demográficas y de salud en América Latina y el Caribe. En: La atención de los ancianos: un desafío para los años noventa (E. Anzola, D. Galinsky, F. Morales, A. Salas \& M. Sánchez, eds.), pp. 3-18. Washington DC: OPS, Publicación Científica 546.

OCEI (Oficina Central de Estadística e Informática), 1990. Estimaciones y proyecciones de población: 1950-2025. Caracas: OCEI.

Robert, H.; Binstock, W.S. \& Schulz, J.H. (eds.), 1982. International perspective of agiend:population and policy challenges. Nueva York: United Population Fund.

Rowe, J.W. \& Kahn, R.L., 1987. Human aging: usual versus successful. Science, 237:143.

Rowe, J.W. \& Wang, S., 1989. The biology and physiology of aging. En: Geriatric medicine (J.W. Rowe \& R. Besdine, eds.), pp. 1-11. NY: Litle, Brown and Company.

Tapia Videla, J., 1994. Los ancianos y las políticas de servicios en América Latina y El Caribe. En: La atención de los ancianos: un desafio para los años noventa (E. Anzola, D. Galinsky, F. Morales, A. Salas \& M. Sánchez, eds.), pp. 19-33. Washington DC: OPS, Publicación Científica 546. 
VIII

SALUD Y GÉNERO 


\section{MASCULINIDAD Y GÉNERO}

Ellen Hardy ${ }^{*}$ y Ana Luisa Jiménez **

\section{INTRODUCCIÓN}

La palabra masculinidad sugiere la idea de hombre, y el título de este trabajo podría sugerir que vamos a referimos solamente a los hombres, haciendo una apología de ellos o al contrario, que el objetivo es desprestigiarlos. Sin embargo, el título no excluye la feminidad, inseparable y complementaria de la masculinidad. Ni todos los hombres tienen las mismas actitudes y comportamientos definidos como masculinos, ni todas las mujeres carecen de este tipo de rasgos. Como veremos más adelante, la masculinidad parece tener una serie de ventajas, por las cuales los hombres aceptarian de buen grado cumplir los roles masculinos y las mujeres desearían adoptar por lo menos algunas de las características atribuidas a ellos.

Sin embargo, como la masculinidad, de la misma forma que la feminidad, son construcciones sociales, la adhesión de hombres y mujeres a una o a la otra dependerá de la educación que reciban en la infancia y de las influencias a que sean sometidos a lo largo de su vida. Pero nada impide que los hombres adopten algunas conductas consideradas femeninas y las mujeres conductas masculinas. Cuando esto ocurra tendrán que enfrentar conflictos de distinta gravedad, en la medida en que la sociedad en que viven acepte o rechace estos desafíos a la norma.

La aceptación o rechazo de la masculinidad, como norma que prevalece en una sociedad, tiene un impacto importante en la calidad de vida de los hombres y de las mujeres. Esto explica la necesidad de analizar cómo se construye ésta y qué importancia tiene para la vida en sociedad, por ejemplo. Desde esta perspectiva, comenzamos abordando la construcción de la masculinidad, las relaciones de género y el precio de la masculinidad. Estos aspectos fueron enfocados desde una perspectiva holística, que incluyó presentar al varón como una construcción genérica, inserto en una sociedad y en constante interrelación con otras personas.

El último tema presentado es llamado "Camino hacia la democracia de las relaciones de género". Consideramos que este es el punto crucial del trabajo, porque no sólo lleva implícito propuestas de cambio que nos conduzcan a un relacionamiento menos desigual y con más equidad de oportunidades y de responsabilidades, sino que también implica una redefinición de los roles que el hombre y la mujer han desempeñado durante demasiado tiempo.

Finalmente, se hace necesario recordar lo que dice Mansfield (1998): que la cualidad llamada "masculinidad" puede ser elevada a la posición de virtud, en la medida que la hombría se humanice y permita en ella la participación de las mujeres. Actualmente, los varones enfrentan el dilema de cómo ser "hombres" y al mismo tiempo ser justos con las mujeres. El dilema de las mujeres es cómo hacer las cosas que los varones hacen y reafirmarse como mujeres.

\section{SEXo, GÉNERO Y MASCULINIDAD}

Se hace necesario definir sexo y género porque frecuentemente estos conceptos son considerados sinónimos. Sin embargo, se trata de categorías diferentes porque las características anatómicas determinan el sexo al cual pertenece el individuo mientras que género es una construcción social que define lo que significa ser de un sexo o del otro en la sociedad (Careaga, 1996).

\footnotetext{
Socióloga, egresada de la Universidad Católica de Chile, con doctorado en Salud Pública Por la Universidad de Sao Paulo. Profesorainvestigadora del Departamento de Obstetricia e Ginecologia, Faculdade de Ciências Médicas, Universidade Estadual de Campinas (UNICAMP), Sao Paulo.

** Investigadora del Centro de Pesquisa das Doenças Materno-Infantis de Campinas (CemrCamp), Campinas, Sao Paulo.
} 
El diccionario define "sexo" como la conformación particular que distingue el macho de la hembra, en los animales y en los vegetales, atribuyéndoles un papel determinado en la procreación y otorgándoles ciertas características distintivas. El sexo es definido por las características biológicas de hombres y mujeres, tanto aquellas específicas de la anatomía y funcionamiento del aparato reproductivo femenino y masculino, como los caracteres sexuales secundarios determinados por la acción hormonal específica de cada sexo. Las personas nacen con un sexo biológico y éste acaba determinando la forma como serán tratadas socialmente por los padres, la familia y por la comunidad a la que pertenecen, para llegar a ser hombres y mujeres con atributos aceptados socialmente. Este proceso varía de una sociedad a otra y también de acuerdo al tiempo histórico en que estas personas están insertas.

Si por un lado, la biología determina las características funcionales de la reproducción de un macho y de una hembra, por otro, el ambiente y el contexto social determinan las expresiones de los comportamientos asociados a lo que se acostumbra llamar de masculinidad y de feminidad (Careaga, 1996).

Género puede ser definido como una categoría dinámica, construida socialmente, que tiene como base las diferencias sexuales biológicas. A partir de estas diferencias se determinan los papeles sociales de hombres y mujeres. El género es construido en un cuerpo que tiene un sexo definido y al que se le atribuyen características psicológicas, sociales y económicas, lo que resulta en acciones y comportamientos específicos, que casi siempre se traducen en relaciones de poder unilaterales: dominación masculina vs. sumisión femenina (Figueroa \& Liendro, 1995; Scott, 1996; Szasz, 1999).

Si reconocemos que las características de género de hombres y mujeres son una construcción social y no diferencias "naturales" legitimizadas por la biología, podemos entender que género es una categoría dinámica que puede ser modificada. Esta noción de género permite colocar en jaque el discurso que afirma que las mujeres nacen con cualidades "femeninas" que determinan que tengan que desempeñar tareas domésticas y cuidar de los hijos, y que los hombres nacen con cualidades "masculinas" que presuponen habilidades para ejercer el poder en el ámbito público y doméstico.

Masculinidad, según el diccionario, es la cualidad de masculino, que incluye la virilidad y el ser varonil, enérgico, fuerte y macho. Se observa que la masculinidad se basa en valores físicos que posteriormente se transforman en valores morales. Además, la masculinidad se ha sexualizado y es tratada como sinónimo de virilidad (Barbosa, 1998). La sexualización de la palabra masculinidad y sus representaciones simbólicas están asociadas al falo y a los comportamientos resultantes del hecho de poseerlo y de dar pruebas de su funcionamiento (Parker, 1991). Para muchos hombres, la masculinidad está relacionada con la geometría del órgano sexual masculino. Este se usa como instrumento para medir la virilidad y representa la masculinidad (Barbosa, 1998).

\section{CONSTRUCCIÓN DE LA MASCULINIDAD}

La construcción de la masculinidad de un nuevo ser puede comenzar cuando la pareja planifica un embarazo o cuando la mujer descubre que está embarazada. Los futuros padres empiezan a imaginarse las características que tendrá el hijo, incluyendo su sexo. Según se imaginen un niño o una niña los padres tendrán un comportamiento diferente que comenzaría antes del parto, incluyendo la preparación del ajuar. Después del nacimiento, el tratamiento diferencial continúa, con la participación de todas las personas que se relacionan con el niño(a).

A partir del nacimiento, el bebé de sexo masculino ya comienza a darse cuenta de lo que se espera de él por tener las características de sus órganos genitales. Sin embargo, no basta nacer con un pene para transformarse en hombre, hay un camino por recorrer hasta llegar a serlo. Los primeros años de vida son fundamentales y responsables por las características del hombre que va a surgir (Vieira, 1986).

La familia, la escuela, los medios de comunicación y la sociedad en general le enseñan explícita e implícitamente la forma en que debe pensar, sentir y actuar como "hombre". Por ejemplo, no puede llorar, debe ser fuerte, no debe mostrar 
sus sentimientos, no puede tener miedo, y debe ser viril. Estas enseñanzas comienzan a afectar la forma como el niño se relaciona consigo mismo y con los demás.

Al nacer, el hijo es absolutamente dependiente de su madre, figura que ocupa el lugar preponderante de su vida, especialmente porque satisface sus necesidades físicas, ejerciendo funciones que permiten su supervivencia. Durante el primer año de vida existe un alejamiento entre el niño y la figura masculina, lo que puede afectar la personalidad de ese individuo (Kaufman, 1994; Vieira, 1996). Esta es una primera manifestación de la influencia de los papeles de género que atribuyen a la madre el cuidado del hijo y al padre el proveer económicamente a la familia, sin tener responsabilidades domésticas.

El fin de la relación de dependencia con la madre es un proceso que para la mayoría se da al final del periodo infantil. Junto con ocurrir esta ruptura, el niño va asumiendo actitudes que corresponden al rol masculino. La figura paterna tendrá una función libertadora, rompiendo el vínculo cerrado entre madre e hijo. En ausencia del padre otro hombre tomará su lugar (abuelo, tío, hermano mayor), y en algunos casos la propia madre pasa a desempeñar funciones y a adoptar actitudes que culturalmente se interpretan como masculinas. La figura paterna se presenta como un conductor que enseña orden, disciplina y responsabilidad (Vieira, 1986). En ese ambiente de patriarcado es que el niño crece y se desarrolla.

Además de la familia, la escuela (desde la sala cuna hasta la universidad) refuerza los papeles de género. No sólo los textos escolares reproducen la sociedad patriarcal, los profesores de ambos sexos aceptan y hasta exigen conductas diferentes de los niños y de las niñas, reforzando las relaciones de poder favorables a los varones.

La mayor parte de las religiones también contribuye a reforzar el poder masculino, ya que la jerarquía de todas ellas está absolutamente dominada por hombres y las mujeres ocupan un lugar de total subordinación. A pesar de que ha habido algunos progresos en contadas religiones, otras resisten obstinadamente cualquier aproximación a la igualdad de géneros.
La masculinidad posee un elemento clave, que es el poder; ser hombre significa tener y ejercer poder. El poder asociado a la masculinidad exige poseer algunas características, tales como ganar, ordenar, lograr objetivos y ser duro. Por otra parte, las características genéricas atribuidas al hombre, tales como objetividad y racionalidad, le otorgan un dominio sobre la mujer. Aplicado en un sentido amplio, poder también significa controlar sentimientos, emociones y necesidades afectivas, para evitar la pérdida de dominio y el control sobre los otros, y también por el temor de que le atribuyan características femeninas, que son absolutamente rechazadas (Kaufman, 1994).

De esta forma, la masculinidad se ha transformado en alienación, ya que implica suprimir emociones, sentimientos y negar necesidades. El varón llega a temer que si experimenta y demuestra sentimientos de ternura y afecto puede transformarse nuevamente en un niño dependiente. Se siente obligado a creer que la mujer le pertenece y que las relaciones con ella deben ser más de poder que afectivas (Vieira, 1986). Así, el varón se aísla no sólo de la mujer, sino de otros hombres, por lo que raras veces desarrolla una verdadera intimidad con personas de su mismo sexo (Kaufman, 1994).

En la medida en que la sociedad caracteriza al varón como una persona dura, que rechaza los afectos, principalmente con personas de su mismo sexo, es fácil entender que el adolescente que tiene y a quien le gustaría expresar sentimientos de ternura comience a tener dudas sobre su masculinidad. Se entiende que cuanto más exigentes son los atributos del macho en una sociedad, más difícil será identificarse como tal. La respuesta puede ser tanto una ruptura e identificación homosexual como una conducta exageradamente machista para ocultar y disimular las dudas sobre su propia masculinidad. Casi siempre habrá conflictos y tensiones frente a la bisexualidad, a la cual se renuncia inconscientemente optando por la heterosexualidad, sobre la cual se construye la masculinidad (Figueroa, 1998).

Superadas esas crisis de identidad, la cultura en que los hombres están inmersos les enseñó que la norma supone la imposibilidad de dominar sus impulsos sexuales, sintiéndose, por lo tanto, obligados 
a no perder oportunidades y creer que siempre, o casi siempre, deben ser satisfechos sexualmente (Morris, 1999; Gogna, 1998; Villela, 1997). Las conquistas amorosas, la erección del pene, la penetración y las proezas sexuales son símbolos de autoafirmación de la virilidad. De esta forma, la afirmación de su identidad masculina exige del varón comportamientos sexuales que se basan en correr riesgos y en una falta de cuidados de ellos mismos y de sus parejas. Esta total indiferencia con relación a actitudes preventivas, así como las relaciones sexuales irresponsables, son conductas que favorecen las enfermedades de transmisión sexual (ETS) y el embarazo no deseado (Bronfman \& Minello, 1995; Paiva, 1996; Barbosa \& Uziel, 1996).

En esta cultura patriarcal, la sexualidad erótica que está centrada en su propio placer es una expresión más del poder del varón, en el cual la mujer es el objeto del deseo sexual y la proveedora de ese placer. La masculinidad, dentro de esa construcción, se mide de acuerdo a la exclusividad y multiplicidad de sus parejas heterosexuales. La satisfacción está centrada en los genitales y en la penetración. Se caracteriza también por la homofobia y el rechazo a cualquier feminización de sus conductas (Figueroa, 1998; Kaufman, 1994; Parker, 1991).

Otra función atribuida socialmente al hombre es el trabajo remunerado, lo que constituye el centro de su respetabilidad en la sociedad. El trabajo le permite obtener reconocimiento social y le otorga seguridad y autonomía (Valdés \& Olavarría, 1998). Por eso mismo, la pérdida del empleo genera tensiones no solamente económicas, sino también afectivas y de identidad. El trabajo remunerado ha pasado a ser un papel tan arraigado en el varón que la pérdida del empleo se traduce en una disminución de su masculinidad, tanto desde la percepción del propio varón como de su mujer y de sus hijos (LewStarowicz \& Wieczorek, 1999). Se ha descrito que hombres que quedan sin trabajo serían más violentos con las esposas e hijos, deprimidos y hasta más adictos al alcohol (Katzman, 1991).

Por otro lado, el hombre sin trabajo también tendría dificultad para asumir las tareas domésticas, pues encuentra que éstas son propias de la mujer y por lo tanto despreciables. Esto se explica por el hecho de que no recibió una educación en que esas tareas fueran parte de sus actividades (Careaga, 1996; Figueroa \& Liendro, 1995).

La masculinidad construida a lo largo de la vida (poder y control sobre los demás, superioridad, sexo erótico inagotable, por ejemplo) varía de acuerdo a las características sociales, económicas y demográficas del varón, y del ambiente en que crece y vive. Por otra parte, la masculinidad es considerada una cualidad que así como se obtiene se puede perder, de acuerdo a las circunstancias y a la historia de cada individuo (Figueroa \& Liendro, 1995).

\section{RELACIONES DE GÉNERO}

De la misma forma como se construye la masculinidad, la feminidad también inicia su construcción desde antes del nacimiento y continúa a lo largo de la vida. Los niños son estimulados a jugar en espacios abiertos, en la calle, a la pelota, con autos y a la guerra. Las niñas juegan con muñecas, imitan las tareas domésticas ejercidas por su madre y raras veces les es permitido jugar fuera de su casa. Desde pequeños los varones comienzan a percibir su fuerza y las niñas su dependencia. Se le enseña a cada uno de ellos el lugar social que ocupan, en que el varón siempre tiene poder y ventajas. Es común que a las niñas se les mande a lavar los platos o a arreglar la cama (de ella y de su hermano) mientras que al niño no se le atribuyen tareas domésticas.

Culturalmente son definidos algunos patrones de comportamiento en donde el poder y la desigualdad son elementos que favorecen al hombre y donde la mujer debe postergarse a un segundo plano. La moral se mide con diferente vara si se es hombre o mujer: el hecho de tener deslices fuera del matrimonio en el hombre es permitido y considerado natural mientras que a la mujer se le exige castidad, fidelidad y guardar silencio frente a la infidelidad masculina (Paiva, 1996; Gogna, 1998; Villela, 1997; Barbosa \& Uziel, 1996). En familias de bajo nivel económico la mujer tiene menos independencia y menor importancia social. Esta desigualdad crea mayor obligación de someterse, por tener menos opciones de vida. 
En el ámbito público, una de las principales quejas de las mujeres con relación a la masculinidad, es que las excluye. Se trata de hacerlas creer que es mejor ser frágil, sumisa y poco inteligente, cuando en realidad los hombres piensan que es mejor ser fuerte, agresivo e inteligente. Otra queja es que se apropian de las cosas buenas de la vida... (Friedan, 1963). Por lo tanto, sería mejor ser hombre. En el ámbito doméstico el poder no se ejercita solamente a través de la violencia, también puede ejercerse considerando la mujer y los hijos como una categoría de empleados, dependientes y sumisos, lo que resulta en una falta de autonomía y de autocuidado de éstos (Szasz, 1999).

La desigualdad de poder entre géneros trae también graves consecuencias para la salud de la mujer y, en menor grado, también para la del hombre. La manifestación más clara de la influencia de las diferencias de poder entre géneros sobre la salud de la mujer es el trauma que resulta de la violencia doméstica. Esta violencia, física, psicológica y sexual, es otra manifestación del poder de los hombres sobre mujeres y niños, tanto dentro como fuera del ambiente familiar (Szasz, 1999). Diversos estudios realizados en países desarrollados y subdesarrollados y en poblaciones de diferente nivel socioeconómico, muestran una alarmante prevalencia de violencia contra la mujer. Albuquerque et al. (1998) estudiaron las causas muertes de mujeres entre 10 y 49 años de edad. Encontró que las muertes por violencia fueron la primera causa entre las mujeres de hasta 29 años. Según el Movimiento Nacional de Derechos Humanos (MNDH, Brasil), compañeros o ex compañeros fueron responsables por $72,3 \%$ de los asesinatos de mujeres en Brasil, en 1996 (CFemea, 1999).

Además del trauma físico, que es la consecuencia más común, la violencia doméstica provoca una serie de otras consecuencias para la salud de la mujer, que van desde una mayor frecuencia de uso de cigarrillos y alcohol, alteraciones psicológicas como depresión, hasta manifestaciones somáticas gastrointestinales y ginecológicas (Dickinson et al., 1998).

Una forma de violencia con consecuencias particularmente graves es la violencia sexual, también de alta prevalencia y frecuentemente causada por personas próximas y conocidas de la víctima. De acuerdo con el Programa Nacional por Amostra de Domicilios (PNAD, Brasil) de 1988, las mujeres constituían el 63\% de las víctimas de agresiones físicas cometidas por parientes en el espacio doméstico. Otros autores (Dearwater et al., 1998; Dickinson et al., 1998) observaron que la violencia física y/o sexual perpetrada por el compañero o ex compañero sexual varió entre menos de 5\% y más de $40 \%$ de las mujeres estudiadas. Los principales riesgos de la violencia sexual son las ETS, incluyendo el SIDA y el embarazo no deseado. Las primeras pueden llevar a secuelas como dolor pélvico crónico, embarazo ectópico y esterilidad; el sIDA mata, y el embarazo no deseado frecuentemente termina en aborto provocado.

Referente a este último, a pesar de que en la mayoría de los países latinoamericanos la ley no penaliza la interrupción de un embarazo que es resultado de una violación, con raras excepciones los hospitales ofrecen estos servicios y las mujeres se ven obligadas a recurrir a abortos clandestinos, con grave riesgo de complicación y de muerte. Basta recordar que alrededor de $15 \%$ de todas las muertes maternas en América Latina son el resultado de este tipo de aborto (WHO, 1993).

Aun en casos en que no hay una violencia manifiesta, otra forma de dominación masculina es que al hombre le corresponden las decisiones acerca de la relación sexual (Szasz, 1999; Villela, 1997; Goldstein, 1996). En este caso, el poder masculino se manifiesta por la falta de control de la mujer sobre cuándo, con quién y en qué condiciones tiene relaciones sexuales, lo que se ilustra claramente en la dificultad o imposibilidad de negociar el uso de condom (Villela, 1997).

Otra forma en que el poder masculino influye en la salud de la mujer es a través de las relaciones intrafamiliares, porque muchas veces se da prioridad a la salud del hombre, sea esposo, abuelo o hijo varón, sobre la salud de las mujeres de la misma familia, independientemente de la real necesidad de cuidado (Szasz, 1999; Careaga, 1996). La diferencia de género se manifiesta con relación a la distribución de alimentos y de cuidados en el ámbito doméstico, que favorecen al hombre (Zolla \& Carrillo, 1998; Careaga, 1996). El poder masculino también puede afectar la 
salud de la mujer a través de la falta de libertad para salir de su casa, aun para buscar cuidados médicos, ya sea para consulta o para tratamiento. Esa falta de libertad puede deberse al exceso de trabajo doméstico que la mujer debe asumir sola, a celos o a simple coerción (Szasz, 1999).

En los servicios de salud también es posible observar el poder ejercido por los hombres, porque en muchas ocasiones el proveedor decide lo que es más apropiado para la mujer, sobre todo si ella es de bajo estatus sociocconómico. Le indica el método anticonceptivo que debe usar sin darle la oportunidad de elegir de forma libre e informada, lo que debería ser la norma. Este tipo de imposición es aún más grave en el caso de métodos irreversibles, como la esterilización femenina (Hardy et al., 1996). Todo esto es resultado de la falta de autonomía de la mujer para decidir y de su desvalorización social en los servicios de salud (Diniz \& d'Oliveira, 1998; Faúndes, 1996). Sin embargo, la relación de poder entre el proveedor de servicios y la cliente es menos jerárquico cuando el proveedor es mujer y el usuario hombre (Castro \& Bronfman, 1998).

Otra manifestación de desigualdad en las relaciones de género se observa en el mercado de trabajo. Lo habitual es que se dé preferencia al hombre tanto en lo que se refiere al acceso a cargos como al nivel de responsabilidad y a los salarios que se le atribuyen. Diversos estudios muestran que los salarios pagados a mujeres son inferiores a los recibidos por hombres que ejercen las mismas funciones (García, 1998; Lara, 1998; Ravelo, 1995; Stemberg \& Wall, 1995). Otra diferencia importante es que mientras la mujer que trabaja fuera de la casa continúa ejerciendo por lo menos algunas de las tareas domésticas, lo que constituye la llamada doble jornada de trabajo, el hombre que trabaja considera que esto lo libera de cualquier obligación doméstica (Bronfman \& Gómez, 1998, García, 1998; Langer \& Lozano, 1998).

\section{EL PRECIO DE LA MASCULINIDAD}

La identidad genérica masculina influye en la salud del individuo. De acuerdo a la cultura en que él está inserto, la masculinidad se asocia con correr riesgo, con someterse a situaciones peligrosas y violentas. La salud masculina es construida de acuerdo al contexto social y a lo que significa en ella ser hombre. La morbimortalidad en el hombre es mayor que en la mujer, debido principalmente al efecto de la violencia física y psicológica. Considerando que la masculinidad es aprendida en la niñez y está centrada en el modelo del héroe, es el padre o la figura paterna el que refuerza esa imagen de hombre, el que le dice que "debe ser y debe comportarse como un hombre". Por otro lado, el cuerpo masculino aparece como aquel que busca o se expone a riesgos y por ende desarrolla la violencia y el enfrentamiento como una forma de obtener respeto de la mujer y de otros hombres. El varón necesita que su vida sea ilustrada por hechos heroicos y al mismo tiempo tener historias para contar (Fagundes, 1995; Gastaldo, 1995).

Se observa que en esta sociedad los hombres mueren primero que las mujeres y que habitualmente las causas de muerte reflejan una exposición deliberada de enfrentar riesgos y peligros. Las diferencias se observan en el mayor número de muertes entre los hombres causadas por violencia y accidentes, y también en la mayor morbimortalidad por alcoholismo o sus consecuencias (Langer \& Lozano, 1998; Bronfman \& Gómez, 1998). En el campo laboral, existe una división social del trabajo entre el hombre y la mujer en que generalmente el varón asume las actividades más peligrosas, violentas y que requieren de mayor capacidad física (Langer \& Lozano, 1998).

El hecho de correr riesgo, que se considera parte de la naturaleza masculina, se manifiesta inclusive en la salud reproductiva, porque habitualmente los varones no se protegen, ni tampoco protegen a sus parejas del riesgo de transmisión de enfermedades (Guimarães, 1996; Villela, 1997; Gogna, 1998). Una manifestación de esta conducta masculina es la sobremortalidad en hombres por HIV/SIDA en todo el mundo, con la excepción de África al Sur del Sahara (ONUSIDA/OMS, 1999).

La necesidad de responder a una norma de masculinidad también afecta la solicitud de la atención en los servicios de salud. Para el hombre es muy difícil ocupar el papel de paciente y con frecuencia niega la posibilidad de estar enfermo y acude a un médico en último momento, ya que lo contrario sería asumir 
un papel pasivo, dependiente y de fragilidad (Careaga, 1996). El modelo aceptado de masculinidad hace también muy difícil que el varón acepte estar enfermo dentro de su familia y de su grupo social.

Figueroa (1998) refiere que en asuntos relacionados a la salud reproductiva, la discusión de la masculinidad se ha centrado en torno a la participación masculina en la anticoncepción, o en asumir el cuidado de los hijos. Pero no se ha discutido que existe en la sexualidad del varón un componente de autodestrucción, producto de las relaciones de poder que ellos mantienen. El análisis de género en salud reproductiva se ha limitado a resaltar la desigualdad y la discriminación que sufre la mujer por el hombre, así como la exclusión del varón de diferentes responsabilidades. Se ha olvidado discutir acerca del sentimiento de aislamiento sufrido por el varón, por tener que estar constantemente demostrando y ejerciendo un papel que históricamente ha creado su identidad (Figueroa \& Liendro, 1995).

De la misma manera, la necesidad de ser y parecer fuerte, viril, se transforma en un obstáculo para que los hombres acepten la posibilidad de tener problemas de infertilidad, y difícilmente comparten con la mujer el proceso diagnóstico en las parejas que no consiguen tener hijos. Esta actitud afecta ciertamente a la mujer, que se somete a exámenes que no serían necesarios si desde el inicio un simple espermiograma hubiera diagnosticado un factor masculino de esterilidad. Sin embargo, también afecta al hombre, porque retarda su diagnóstico y tratamiento, que se hace más difícil si la enfermedad es evolutiva. Asimismo, el concepto de que la fertilidad es un componente importante de la virilidad hace que el hombre estéril se sienta disminuido en su masculinidad, le cueste aceptar la situación, culpe a su mujer y tenga dificultades en encarar el problema, tanto frente a los servicios de salud como frente a la sociedad.

\section{El CAMINo haCia LA DEMOCRACIA DE LAS RELACIONES DE GÉNERO}

En este momento se está hablando de una crisis de la masculinidad debido a los cambios ocurridos en el campo cultural, económico y social; parte de estos cambios lo constituye la liberación y mayor integración de la mujer en el espacio público (Figueroa \& Liendro, 1995). La lucha de las mujeres para hacer desaparecer el patriarcado ha conseguido disminuir la influencia de éste en algunas estructuras políticas, sociales y económicas.

Actualmente existe un gran número de hombres que aceptan y apoyan los movimientos feministas. Muchos, estando a favor o en contra, ya han percibido que el mundo está cambiando. Algunos de ellos continúan defendiendo el patriarcado, otros llenos de dudas y temores acompañan el cambio sin decidir qué actitud tomar y por último, existen aquellos que entienden que los estereotipos actuales deben desaparecer y defienden la igualdad de poder entre géneros (Kaufman, 1994).

La aparición del feminismo ha afectado el desequilibrio de poder que existía entre ambos géneros, con una tendencia a mayor equidad entre hombres y mujeres. Algunos hombres han comenzado a expresar socialmente el problema que significa la mantención de la opresión femenina. Esta tenue transformación muestra que el género es dinámico y requiere de reformulaciones y cambios periódicos dentro de las relaciones entre hombres y mujeres (Kaufman, 1994).

En los últimos años la mujer ha conseguido conquistar un mayor espacio social, incursionando en algunos ambientes que eran de exclusividad masculina. De esta forma, el espacio público está paulatinamente integrando a la mujer y pasando a ser responsabilidad de individuos de ambos sexos. Sin embargo, el espacio doméstico continúa siendo de responsabilidad femenina y el hombre es solamente un cooperador cuando quiere y puede (Careaga, 1996).

Algunas disciplinas, como la demografía y la medicina, que tradicionalmente no le habían dado la debida importancia a los hombres en el proceso reproductivo, comenzaron a cambiar esta actitud. Las Encuestas sobre Demografía y Salud, antiguamente llamadas Encuestas de Fertilidad, comenzaron a incluir una muestra de hombres en los últimos años, después de décadas en que sólo las mujeres eran entrevistadas. De la misma forma, no se involucraba al hombre en 
la atención al embarazo y al parto, considerándolo responsable solamente de provocar la gestación (Figueroa, 1998). Actualmente, se observa una tendencia cada vez mayor a estimular la participación del hombre en la atención prenatal, en la preparación para el parto y en su presencia durante el nacimiento. Asimismo, los investigadores de nuevos métodos anticonceptivos están mostrando una mayor preocupación por el desarrollo de métodos masculinos.

Según Figueroa (1998), la perspectiva de género permite repensar lo que verdaderamente significa ser mujer y ser hombre, como una posibilidad para resignificarnos como individuos. El análisis de género permite también redefinir las diferencias entre hombres y mujeres desde el punto de vista de las normas morales, y reconstruirlas con esta nueva perspectiva. Ese proceso no debe quedar en el discurso, sino traducirse en cambios conductuales en la vida social y familiar. En salud reproductiva, llevar a cabo este proceso es doloroso, porque significa para el hombre replantearse la propia identidad para poder asumir responsabilidades que no había aprendido a reconocer como propias. Se hace necesario favorecer la participación del hombre en forma efectiva, a través de estrategias que lo ayuden a reconocer sus necesidades, a hablar de sí mismo, a analizar las transgresiones de normas y formas de vida, así como a propiciar el autocuidado de su cuerpo, olvidando estereotipos que lo someten a riesgos innecesarios.

Según Figueroa \& Liendro (1995), algunos cambios que se han producido en la masculinidad, más que resultados de transformaciones en las creencias y valores de los varones, se deberían principalmente a presiones socioeconómicas que los obligan a aceptar el trabajo de la mujer, escapando de la norma. Esto resultaría en una cierta crisis vivida por los hombres al verse impedidos de ejercer ampliamente su dominio, como en el antiguo referencial de masculinidad.

Horowitz \& Kaufman (1989) hablan de la teoría de la liberación masculina, que trata de escaparse de los comportamientos típicos de la masculinidad, tales como la opresión, agresión y dominación de la mujer. Esta liberación se daría a través de la discusión e identificación de algunas áreas conflictivas relacionadas con el sexo, como bisexualidad, actividad y pasividad (Figueroa, 1998).

En el ámbito doméstico, las funciones que eran supremacía del varón (autoridad, proveedor y protector) se han desvalorizado, porque la mujer ha ido caminando progresivamente hacia la liberación y la igualdad. Estos cambios provocan conflictos emocionales en los varones, al sentir que su papel está siendo cuestionado. Se vive una crisis de la masculinidad en el ámbito público por el surgimiento de la competencia femenina y en lo privado, porque paulatinamente se vislumbra la democratización de ese espacio (Careaga, 1996).

\section{Comentarios}

En el camino hacia la igualdad, es fundamental terminar con la separación de los dos espacios en masculinos y femeninos, y con los desequilibrios entre los géneros en la vida diaria. Se debe aprender a vivir sobre una base de igualdad, y ese aprendizaje debe comenzar a partir del nacimicnto. Se hace necesario un cuestionamiento profundo que lleve a una transformación del espacio social, al mismo tiempo que se discutan las condiciones que favorecerían una inserción más igualitaria del hombre en el espacio privado. Para que estos cambios ocurran, los hombres tienen que llegar a entender que las normas actuales que aparentemente les dan las ventajas del poder, al mismo tiempo los hacen prisioneros de estereotipos que los atan y ahogan en una camisa de fuerza artificialmente construida por la cultura patriarcal.

Lo que hemos discutido hasta aquí, no ha tenido la pretensión de decir la última palabra sino de contribuir constructivamente en los esfuerzos para alcanzar una sociedad en que el sexo biológico de la mitad de los seres humanos no sea más un motivo de discriminación.

\section{REFERENCIAS BIBLIOGRÁfICAS}

Albuquerque, R.M.; Cecatti, J.G.; Hardy, E. \& Faúndes, A., 1998. Causas e fatores associados à mortalidade de mulheres em idade reprodutiva em Recife, Brasil. Cadernos de Saúde Pública, 14 (1):41-48. 
Barbosa, M.J., 1998. Chorar, verbo intransitivo. Cadernos PAGU, 11:321-343.

Barbosa, R. \& Uziel, W., 1996. Gender and power: sexual negotiation in time of AIDS. Trabajo presentado en: International Conference on Reconceiving Sexuality: International Perspectives on Gender, Sexuality and Sexual Health. Río de Janeiro, 14-17 de abril.

Bronfman, M. \& Gómez, D., 1998. La condición de la mujer y la salud infantil. En: La condición de la mujer en el espacio de la salud (J.G. Figueroa, coord.). México DF: El Colegio de México.

Bronfman, M. \& Minello, N., 1995. Hábitos sexuales de los migrantes temporales mexicanos a los Estados Unidos. Prácticas de riesgo para la infección por VIH. En: SIDA en México. Migración, adolescencia y género (M. Bronfman, ed.). México DF: Información Profesional Especializada.

Careaga, G.P., 1996. Las relaciones entre los géneros en la salud reproductiva. México DF: Comité Promotor por una Maternidad sin Riesgos en México.

Castro, R. \& Bronfman, M., 1998. Teoría feminista y sociología médica: bases para una discusión. En: La condición de la mujer en el espacio de la salud (J.G. Figueroa, coord.). México DF: El Colegio de México.

CFemea (Centro Feminista de Estudos e Assessoria), 1999. Os direitos das mulheres e o legislativo no Brasil. Brasilia DF: CFEMEA.

Costa, R., 1998. De clonagens e de paternidades: as encruzilhadas do gênero. Cadernos PAGU, 11:157-199.

De Oliveira, F. \& Díaz, M., 1998. Relações de gênero. En: Afetividade e sexualidade na educaşão: um novo olhar (E. Santa Rosa, G. Seara \& L. Nemer, coords.). Belo Horizonte: Gráfica e Editora Rona Ltda.

Dearwater, S.R.; Coben, J.H.; Campbell, J.C. et al., 1998. Prevalence of intimate partner abuse in women treated at community Hospital Emergency Departments. JAMA, 280 (5):433-438.
Dickinson, L.M.; deGruy, F.V.; Dickinson, W.P. \& Candib, L.M., 1998. Health-related quality of life and symptom profiles of female survivors of sexual abuse. I Arch Family Medecine, 8 (1):35-43.

Diniz, S.G. \& d'Oliveira, A.F., 1998. Gender, violence and reproductive health. International Journal of Gynaecology and Obstet, 63 (1):33-42.

Fagundes, D., 1995. Performances, reproducción e producción dos corpos masculinos. En: Corpo y significado (O. Fachel, org.). Porto Alegre: Universidade Federal do Rio Grande do Sul.

Faúndes, A., 1996. Gênero, poder e direitos sexuais reproductivos. Femina, 24 (7):661-670.

Figueroa, J.G. \& Liendro, E.Z., 1995. La presencia del varón en la salud reproductiva. En: Ciências sociais e medicina. Atualidades e perspectivas latino-americanas (E. Hardy, M.J. Osis \& E.R. Crespo, eds.). Campinas: Centro de Pesquisas das Doenças MaternoInfantis de Campinas.

Figueroa, J.G., 1998. Algunos elementos para interpretar la presencia de los varones en los procesos de salud reproductiva. Cadernos de Sáude Pública, 14 (1):87-96.

Friedan, B., 1963. The femenine mystique. Nueva York: Dell Publishing.

García, B., 1998. Comentarios al trabajo: investigación sobre trabajo femenino y salud: avances y propuestas. En: La condición de la mujer en el espacio de la salud (J.G. Figueroa, coord.). México DF: El Colegio de México.

Gastaldo, E., 1995. A forja do homem de ferro: a corporalidad nos esportes de combate. En: Corpo y significado (O. Fachel, org.). Porto Alegre: Universidade Federal do Rio Grande do Sul.

Gogna, M., 1998. Factores psicosociales y culturales en la prevención y tratamiento de las enfermedades de transmisión sexual. Cadernos de Sáude Pública, 14 (1):81-85. 
Goldstein, D., 1996. O lugar da mulher no discurso sobre AIDS no Brasil. En: Quebrando o silêncio: mulheres e AIDS no Brasil (R. Parker $\&$ J. Galvão, orgs.). Río de Janeiro: RelumeDumará Editores.

Guimarães, K., 1996. Nas raízes do silêncio: a representação cultural da sexualidade feminina e a prevenção do HIV/AIDS. En: Quebrando o silêncio: mulheres e AIDS no Brasil (R. Parker \& J. Galvão, orgs.). Río de Janeiro: Relume-Dumará Editores.

Hardy, E; Bahamondes, L; Osis, M.J. et al., 1996. Risk factors for tubal sterilization regret, detectable before surgery. Contraception, 54: 159-162.

Horowitz, G. \& Kaufman, M., 1989. Sexualidad masculina: hacia una teoría de liberación. En: Hombres: placer, poder y cambio (M. Kaufman, ed.). República Dominicana: Centro de Investigación para la Acción Femenina.

Katzman, R., 1991. ¿Por qué los hombres son tan irresponsables? Ponencia presentada en el Taller Trabajo, Familia, Desarrollo y Dinámica de Población en América Latina y el Caribe. Santiago de Chile: CepalCelade.

Kaufman, M., 1994. Men, feminism and men's contradictory experiences of power. En: Theorizing masculinities ( $\mathrm{H}$. Broad \& $\mathrm{M}$. Kaufman, eds.). Thousand Oaks: Sage.

Langer, A. \& Lozano, R., 1998. Condición de la mujer y salud. En: La condición de la mujer en el espacio de la salud (J.G. Figueroa, coord.). México DF: El Colegio de México.

Lara, A., 1998. Investigación sobre trabajo femenino y salud: avances y propuestas. En: $L a$ condición de la mujer en el espacio de la salud (J.G. Figueroa, coord.). México DF: El Colegio de México.

Lew-Starowicz Z. \& Wieczorek, K., 1999. Changing roles in the families of unemployed men. Ponencia presentada en el $10^{\circ}$ Congreso Mundial de Reproducción Humana, Salvador de Bahía, mayo.
Mansfield, H., 1998. The partial eclipse of manliness. Reproductive Health Matters, 6 (12):116-121.

Morris, B., 1999. Addicted to sex. Fortune, 9:30-39.

ONUSIDA/OMS, 1999. La epidemia de SIDA: situación en diciembre de 1998. Boletín Onusidal $O M S$.

Paiva, V., 1996. The sexual subject: societal vulnerability, gender and empowerment. Ponencia presentada en: International Conference on Reconceiving Sexuality: International Perspectives on Gender, Sexuality and Sexual Health. Río de Janeiro, 14-17 de abril.

Parker, R., 1991. Corpos, prazeres e paixões: a cultura sexual no Brasil contemporâneo. Sao Paulo: Editora Best Seller.

Ravelo, P., 1995. Género y salud femenina: una revisión de las investigaciones en México. En: Las mujeres y la salud (S. González, comp.). México DF: El Colegio de México.

Scott, J., 1996. El género: una categoría útil para el análisis histórico. En: Elgénero: la construcción cultural de la diferencia sexual (M. Lamas, comp.). México DF: Universidad Autónoma de México/Porrúa.

Stemberg, B. \& Wall, S., 1995. Why do women report "sick building symptoms" more often than men? Social Sciences and Medicine, 41 (4):491502.

Szasz, I., 1999. Género y salud. Propuestas para el análisis de una relación compleja. En: Salud, cambio socialy politica. Perspectivas desde América Latina (M. Bronfman \& R. Castro, coords.). México DF: Edamex.

Valdés, T. \& Olavarría, J., 1998. Ser hombre en Santiago de Chile: a pesar de todo, un mismo modelo. En: Masculinidades y equidad de género en América Latina (T. Valdés, \& J. Olavarría, eds.). Santiago de Chile: FLACSO.

Vieira, I.M., 1986. Identidade do homem na sociedade patriarcal. En: Macho, masculino, bomem: a sexualidade, o machismo e a crise de identidade do homem brasileiro (M. Costa, org.). Porto Alegre: Editora LPM. 
Villela, W., 1997. Práticas de saúde, gênero e prevenção de HIV/AIDS. In: II Seminário Saúde Reprodutiva em Tempos de AIDS (J. Galvão, R. Barbosa \& R. Parker, coords.). Río de Janeiro: ABIA.

WHO, 1993. Abortion: a tabulation of available data on the fequency and mortality of unsafe abortion. Ginebra: WHO, Division of Family Health.

Zolla, C. \& Carrillo, A.M., 1998. Mujeres, saberes médicos e institucionalización. En: La condición de la mujer en el espacio de la salud (J.G. Figueroa, coord.). México DF: El Colegio de México.

Agradecimientos: a nuestros colegas y amigos Anibal Faúndes, Maria Yolanda Makuch y Francisco De Oliveira por el apoyo en la revisión bibliográfica y por sus comentarios. 


\title{
ELEMENTOS PARA LA CONSTRUCCIÓN DE LA MASCULINIDAD: SEXUALIDAD, PATERNIDAD, COMPORTAMIENTO Y SALUD REPRODUCTIVA
}

\author{
Morelba Jiménez García
}

\section{PRESENTACIÓN}

El presente trabajo tiene como objetivo identificar algunos elementos del comportamiento reproductivo masculino que contribuyen a la construcción de la identidad masculina y que nos permiten explicar la relación de complementariedad que existe entre los géneros en el proceso de la reproducción humana.

El estudio de la masculinidad surge como necesidad de producir elementos teóricos que nos permitan conocer e interpretar la complementariedad de los géneros, tarea impostergable para quienes consideramos que el género es la vía hacia la construcción de una cultura igualitaria.

Metodológicamente, este ensayo parte de la revisión de algunos planteamientos hechos por investigadoras e investigadores de América Latina, quienes vienen perfilando una teoría de la masculinidad del hombre en la región. ${ }^{1}$ Luego de esa muy sucinta revisión, comparamos los criterios allí señalados con una experiencia de investigación que iniciamos en el año 1997 sobre el comportamiento reproductivo de los hombres de una comunidad de pescadores ubicada en el oriente venezolano, Río Caribe, estado Sucre, con el objetivo de compartir ideas sobre posibles constantes que pudieran encontrarse en el comportamiento de los varones latinoamericanos.

En este trabajo la categoría de género es utilizada como el instrumento fundamental para el análisis del comportamiento reproductivo masculino, entendida ésta como construcción social y cultural que tiene como base las diferencias sexuales y que traduce estas diferencias en desigualdad social (Lamas, 1986; Scott, 1990).

Como construcción social, el género explica lo masculino y lo femenino como procesos que se definen por actuaciones específicas resultado de acciones social, cultural, económica e históricamente determinadas, y que son susceptibles de transformación. Lo masculino (poder y dominación) y lo femenino (subordinación y discriminación) sitúan la sexualidad y la procreación como componentes definitorios de la construcción de las relaciones de género.

Las relaciones de género han estado mediadas por la dualidad poder-dominación/ subordinacióndiscriminación, privilegiando para los valores los procesos de producción y dejando a las mujeres la reproducción.

En la explicación sobre la reproducción humana el centro de reflexión ha sido tradicionalmente la mujer y sobre ella recae toda la responsabilidad de la práctica del comportamiento reproductivo. Poco se ha producido sobre el papel de los varones en el proceso de procreación (Lemer, 1998). Diversos son los argumentos que tienden a explicar esta desviación; no es este el lugar para tal tarea, lo que queremos resaltar aquí es la necesidad de producir conocimiento que exprese las relaciones de complementariedad, que muestren las dos dimensiones del proceso de la reproducción humana.

Socióloga e investigadora de la Escuela de Sociología, Universidad Central de Venezuela, y asesora del Grupo Temático de Géneto de Naciones Unidas en Venezuela.

1 Aunque no desconocemos la producción bibliográfica de importantes investigadores, como Michael Kimmel y M. Kaufman (1989), nos referimos fundamentalmente a la bibliografía latinoamericana, que apenas comienza a producirse. 
El orden sociocultural ha entrado en crisis. Lo público y lo privado se trastocan, así como el papel del proveedor se resiente, resquebranjándose también el poder del patriarcado. A este nuevo orden cultural vienen aproximándose nuevas prácticas sociales a las cuales hay que darles respuestas desde una perspectiva de género que brinde garantías a la reconstrucción de una sociedad donde no persistan las desigualdades.

Las mujeres hemos realizado, en búsqueda de mejores y mayores oportunidades para el logro del empoderamiento (empowerment), importantes modificaciones en el orden social que han producido transformaciones en la vida de los hombres.

Hablar de masculinidad desde las mujeres es, probablemente para algunos, una impertinencia o, mejor, una no-pertenencia; pero por el contrario, es un ejercicio teórico necesario para quienes hemos tomado conciencia de que los cambios en las relaciones entre los géneros son y serán a la larga beneficiosos para el conjunto de la humanidad.

\section{Ser hombre. El mismo modelo en tReS PAÍSES}

La más reciente investigación realizada en Chile por Teresa Valdés y Jorge Olavarría, "Construcción social de la masculinidad en Chile, crisis del modelo tradicional" (1998), basada en entrevistas a profundidad con hombres en tres diferentes etapas de sus vidas y de dos sectores sociales (medio alto y bajo), todos con hijos y con parejas, caracteriza la masculinidad desde dos variables muy concretas: la biológico-genital y la cultural.

...ser hombre es tener pene y bien puesto está. No me sobra ni me falta... Ser hombre es trabajar porque eso me da independencia y puedo alimentar a mi familia... Ser hombre en la sociedad en donde viven es incorporar pautas de comportamiento, vivencias y mandatos sociales... es ser activo, afrontar las situaciones fuertes, no tener miedo, no expresar emociones ni llorar. El hombre es de la calle, los hombres son conquistadores les gustan las mujeres, son fuertes, tienen cargas y responsabilidades (Valdés y Olavarría, 1998).
En el campo de la sexualidad, los hombres asocian su identidad sexual y se "bautizan" como tales sólo cuando ejercen las relaciones sexuales. $\mathrm{La}$ genitalidad, o mejor dicho la expresión biológica de ella, es lo que los define como hombres en forma inmediata; tienen pene, con ello nacieron y eso los identifica.

El trabajo es la otra variable fundamental que define lo masculino: “...el trabajo hace al hombre y el hombre es del trabajo" (Valdés y Olavarría, 1998:27). Éste le da al hombre poder, seguridad, prestigio y autoridad. Es una actividad de la calle, el trabajo justifica su función de proveedor. Sexo y trabajo caracterizan la identidad del hombre chileno.

Las conclusiones señalan que ser hombre en Santiago de Chile responde a un modelo hegemónico, independientemente de su condición social, y que estas estructuras se vivencian con mayor frustración por parte de los jóvenes de los sectores populares.

Según la antropóloga Norma Fuller — quien en su estudio "La construcción social de la identidad de género entre varones del Perú" (1998) entrevistó 120 hombres jóvenes y adultos en tres ciudades: Lima, Cuzco e Iquitos-, las poblaciones estudiadas comparten una definición general sobre lo "masculino", que contempla tres variables: la natural, lo doméstico y lo exterior (público/calle).

La natural se refiere al aspecto físico, a los órganos sexuales y a la fuerza física. Lo doméstico está referido al orden de la socialización; esta tarea está a cargo de la escuela y la familia. Y lo exterior es lo público: la calle se asocia a la virilidad y es la dimensión desordenada y no domesticada del mundo; en la calle se aprende lo que es ser hombre...

...ser macho significa romper con alguna de las reglas de los mundos domésticos y público (Fuller, 1998).

También para los varones peruanos el trabajo significa el elemento central de la masculinidad. Ingresar al mundo laboral es alcanzar la condición de adulto que permite establecer una familia, y ello constituye la principal fuente de reconocimiento social.

Desde este punto de vista doméstico, las mujeres se definen en cierto tipo de contrato; ellas 
hacen las labores domésticas y ellos son los que ejercen el control de la sexualidad. Este tipo de relación complementaria hace posible el proyecto familiar.

La paternidad consagra la hombría. Ser padre y jefe de familia es ser el eje y protagonista de un nuevo núcleo social; el vínculo padre-hijo, donde está la verdadera dimensión de la hombría, debe trascender a través del reconocimiento público.

La identidad de género se construye dentro de la multiplicidad de diferencias de edad, clase y etnicidad, etc. De este modo la experiencia de género de un varón no se determina únicamente por el sexo sino por el lugar que ocupa dentro de las categorías raciales, de clase, étnicas de regiones (Fuller, 1998:57).

Al igual que en Chile, los rasgos más específicos que definen la masculinidad son el trabajo, los hijos y los caracteres sociales (los roles) y genitales (sexo): ser fuerte, tener pene y ejercerlo.

En Venezuela, dos investigaciones nos servirán para hablar de los antecedentes sobre estudios de masculinidad.

El trabajo de Jeanette Abouhamad titulado "Los Hombres de Venezuela, sus necesidades y aspiraciones" (1978), pese a no ser un estudio sobre la masculinidad, constituye un valioso aporte en este tema, ya que desde el punto de vista sociológico nos permite reunir algunos rasgos que sirven a la identificación de la masculinidad en nuestro entorno sociocultural.

Los estudios de Felipe Carrera Damas, El comportamiento sexual del venezolano (1974) y i Es Ud. un macho? (1980), se refieren a los comportamientos biológicos y socioculturales que caracterizan a la población masculina venezolana. Es importante aclarar que en los años que estas investigaciones fueron realizadas la discusión sobre género no estaba presente en el país, y sin embargo la encuesta de la investigación sobre machismo se realizó con la participación de hombres y mujeres. El trabajo de Carrera Damas cuyo interés fundamental fue el estudio del comportamiento sexual- consistió en una encuesta realizada a 3.636 hombres y mujeres ubicados en áreas urbanas.
Carrera plantea allí las características que definen "lo masculino" en el hombre venezolano. Las consideraciones obtenidas no se diferencian de lo señalado por las investigaciones en Chile ni en Perú: se es macho cuando se tiene una genética cromosómica XY (Badinter, 1993), lo cual define su sexo: pene y testículos en ejercicio. “...el hombre es rudo y mandón, debe ofrecer seguridad a la mujer, para el venezolano tener hijos es una función de su masculinidad ...como buen machista cree que la función de padrote es honrosa, es el blasón de su virilidad" (Carrera Damas, 1980:113).

A los rasgos genéticos hay que agregar los condicionantes socioculturales. Ser hombre es además tener fuerza física, mantener el hogar y ser nominado como jefe del mismo.

Ser hombre en Venezuela tiene algunos de los matices señalados por Norma Fuller (la etnicidad y la clase social) y también por Valdés y Olavaría (ser hombre es importante).

Ser hombre en Venezuela tiene su especificidad cultural ligada también al campo de los contenidos sociocconómicos y culturales.

\section{MASCULINIDAD Y SALUD REPRODUCTIVA EN VENEZUELA ${ }^{2}$}

La necesidad de producir conocimientos que identifiquen las prácticas de los hombres en el proceso reproductivo para elaborar estrategias de análisis más comprensivas sobre el fenómeno de reproducción humana fue el objetivo que inspiró la investigación realizada en una comunidad pesquera ubicada en la parte oriental del país.

Río Caribe, comunidad situada en el estado Sucre frente al mar Caribe, es considerada una de las entidades de mayor producción pesquera del estado. Caracterizada además por presentar una de las más altas tasas de fecundidad que se mantienen en el país: 6 hijos por mujer a lo largo de su vida.

La investigación, que titulamos Estudio sobre el comportamiento reproductivo de los hombres de Río Caribe

2 El concepto de salud reproductiva al que hacemos referencia en este trabajo fue desarrollado en la IV Conferencia de Población y Desarrollo de El Cairo (1994) como "la capacidad de disfrutar de una vida sexual satisfactoria y la libertad para decidir procrear o no". 
(Jiménez, Romero y González, 1996), buscaba conocer, entre otros factores, el papel que los hombres juegan en el proceso de la reproducción, el lugar que ellos ocupan al enfrentar las decisiones reproductivas y cómo estos espacios contribuyen a la construcción de su masculinidad.

Para ello se entrevistó un grupo conformado por 200 hombres en edades comprendidas entre los 15 y 60 años, habitantes de una comunidad rural, con altos índices de pobreza.

Utilizamos la encuesta como instrumento de recolección de información para obtener conocimientos sobre la sexualidad e identificar el comportamiento procreativo. Estamos conscientes de las limitaciones que instrumentos de esta naturaleza muestran para acercarse a una realidad tan sensible como es la sexualidad, pero ello nos permitió conocer las tendencias de comportamiento de este grupo de población frente al hecho de la paternidad, la sexualidad y la masculinidad.

La edad promedio de los entrevistados es de 35,7 años, siendo bien importante el grupo por debajo de los treinta años, que constituye el 44,6\%, la mayoría de ellos menores de veintiséis.

En su conjunto, un grupo alfabetizado que sabe leer y escribir (93,1\%); pero en su mayoría $(57,9 \%)$ con bajo nivel educativo. Además sólo una cuarta parte $(24,5 \%)$ se encuentra estudiando actualmente, lo que coincide con el grupo más joven.

En cuanto al ingreso, el promedio, según lo que declaran, es de 68.600 bolívares —un poco más de 4 salarios mínimos (el salario mínimo para el momento de la recolección era de 15.000 bolívares), el equivalente a $\$ 145,95$. La mayotía de ellos (62,7\%) reciben entre 30 mil y 70 mil bolívares (entre 2 y 4 y medio salarios mínimos, equivalentes a US\$ 63,82 y US\$148,93). Es importante señalar que para el primer semestre de 1996 el costo de la canasta básica era de 80.767 bolívares. El promedio nacional es de 90 mil bolívares y ellos están por debajo del promedio nacional.

Casi la mitad (46,1\%) mantiene un vínculo conyugal legalizado por vía del matrimonio civil. De significativa importancia es el grupo de los que declaró mantener una unión consensual (19,1\%). Los solteros constituyen casi la cuarta parte $(24,5 \%)$.
El grupo más numeroso (68\%) tiene menos de 5 hijos, estando el promedio alrededor de 3 . Eso podría estar asociado a la juventud de los entrevistados. No obstante, es significativo que el $32 \%$ de ellos tenga más de 5 hijos.

No olvidemos en este análisis que el comportamiento reproductivo es un proceso que muestra una tendencia. Si el promedio de hijos se encuentra en esta población ya en tres hijos, a lo largo del ciclo reproductivo (no definido en límite de edad en el caso de los hombres) potencialmente se podría establecer una posible duplicación al final de la vida.

Entre los casados o unidos (154 hombres), trece $(8,4 \%)$ mantienen actualmente relaciones conyugales con otras mujeres además de su esposa o concubina. Las razones que éstos aportan para justificar otra unión están vinculadas, en la mitad de los casos, a la insatisfacción en la primera.

De los que en el pasado mantuvieron y los que mantienen relaciones no permanentes con otras mujeres, 21 han tenido hijos con ellas. La mayoría $(57,1 \%)$ solamente un hijo/a.

Entre los que no están casados ni unidos, la mayoría $(75,5 \%)$ manifestó tener relaciones sexuales.

Para todos los hombres (casados, unidos, solteros), el inicio de la sexualidad se produjo antes de los veinte años de edad (97,9\%). Es interesante el hecho de que el 37,5\% las haya tenido antes de los quince.

El 72,3\% manifiesta no haberse cuidado en su primera relación.

En cuanto a la frecuencia de las relaciones sexuales (incluyendo a casados, unidos y solteros), lo más común es que las tengan varias veces por semana.

La información que manejan sobre la sexualidad fue aportada básicamente por amigos de la misma edad y los maestros.

El 98,5\% de los entrevistados conoce al menos un método anticonceptivo.

La casi totalidad (98,5\%) conoce el preservativo o condón, aunque apenas lo usa el $13,5 \%$. 
El coito interrumpido es conocido por el $62,3 \%$ y usado en la actualidad por el $12,5 \%$, aunque el $48,8 \%$ lo ha utilizado alguna vez.

El método del ritmo lo conoce el $44,1 \%$, y es aplicado actualmente por el 12,2\%.

El $47,5 \%$ conoce la vasectomía; sólo uno de 200 entrevistados $(1,03 \%)$ declaró que se había esterilizado recientemente.

El método de la ligadura es conocido por las tres cuartas partes $(75,5 \%)$. De los entrevistados, apenas el 16,8\% manifestó que su pareja actualmente está "ligada" y sólo uno de ellos expresó que su compañera se esterilizó en época anterior.

Las píldoras anticonceptivas son conocidas por la inmensa mayoría de los entrevistados $(91,7 \%)$, sin embargo, para el momento de la entrevista sólo eran usadas por el 15,5\% de las parejas.

El llamado "aparato" es conocido por la mayoría de los hombres entrevistados (61,3\%), de los cuales sólo el 4,8\% declaró que su pareja lo usaba al momento de la entrevista.

En definitiva, se tiene que el método más conocido es el de preservativo o condón. Hasta el presente el método que las parejas han utilizado más es el coito interrumpido, seguido del preservativo (41\%), y el menos que han usado es la vasectomía.

Los que no han usado ningún método dan como razones fundamentales la falta de información $(36,5 \%)$, los daños a la salud $(31,7 \%)$, porque no quieren evitar los hijos $(12,6 \%)$ y que es un asunto de mujeres $(9,5 \%)$.

La razón fundamental para dejar de usarlo, de acuerdo a lo que declaraban los hombres entrevistados, es que les estaba haciendo daño (44\%).

Una manifiesta disposición a la paternidad (99\% respondió al deseo de ser padre), “...Un hombre sin hijos es como un árbol sin frutos", sumado a la definición de la paternidad como "la responsabilidad de mantenerlos", configura el concepto de ser hombre en estos entrevistados. Ligado a una concepción de que la responsabilidad en la crianza de los hijos corresponde a las mujeres, también a ellas la obligación de la casa y el trabajo doméstico porque son ellas las que deben estar allí, ya que "los hombres son de la calle y las mujeres de la casa".

Los hallazgos más importantes de este estudio tienen que ver con los elementos que configuran la sexualidad de los hombres que entrevistamos. A la situación sobre qué es ser hombres para ellos, básicamente responden:

Ser hombre es tener hijos. Un hijo constituye la prueba de su virilidad, los testimonios indican: “...un hombre sin hijos es un elemento raro que no responde a la naturaleza para la cual fue diseñado". Frases muy agresivas y denigrantes definen a quienes no cumplen con esta función. Esto explica por qué a la edad de 37 años ya se tiene tres hijos, y en una importante parte en más de una pareja.

Las relaciones sexuales iniciadas a edades muy tempranas son la respuesta al deseo de demostrar la virilidad y la reproducción. Mientras más temprano tenga el hombre los hijos, más rápido demuestra su capacidad de procrear y su identidad sexual.

...no se es hombre hasta que no se tienen hijos ... un hombre sin hijos es como una gallina que pone huevos de tierra, no sirve para nada. Es el peor hombre del mundo... es un desgraciado es un castrado es un ser inferior, infeliz... ¡Coño un hombre sin hijos, mal! Todavía estuviera allí de vagabundo, la esperanza de uno es ser padre... (testimonio).

Quizás por ello los métodos de anticoncepción más comunes son el condón y el coitus interruptus, sobre los cuales tienen mayor dominio para decidir cuándo y con quién los utilizan.

...yo uso preservativos cuando me voy a acostar con una mujer de la calle, porque con mi pareja no lo necesito, no necesito cuidarme (testimonio).

En el caso de los entrevistados, la sexualidad se vive como la reproducción, la forma de perpetuarse. Es por ello que la anticoncepción es vista como una forma de castración:

...Los orientales no, el pescador no, nada de eso [de métodos anticonceptivos]. Ya después que uno está viejo se queda seco, pero si uno está joven, ¿va a estar usando esa broma? ...no, no puede ser... (testimonio). 


\section{Ser hombre es hacer "cosas de hombres".} La cultura del machismo lleva a las madres a darle una educación a los hijos varones que les reafirme su masculinidad o machismo. Los hombres no lavan ni planchan porque serían afeminados. Esas son cuestiones de las mujeres.

...mamá nunca nos enseñó a nosotros los varones a hacer nada de eso, lavar, planchar. Yo recuerdo que un día me puse a lavar un pantalón y cuando me agaché para echarle el detergente ACE, mamá agarró un palo y me lo pegó por la espalda para que yo dejara eso, porque eso no es cosa de hombres (testimonio).

Estas tendencias asoman elementos de la construcción social de la masculinidad. La norma que parece prevalecer en nuestra cultura.

Lo masculino se define desde la sexualidad con los mismos conceptos que los descritos por los hombres de Lima y de Santiago de Chile; por la genitalidad y la reproducción. También la oposición a determinadas pautas sociales asignadas a la mujeres y prohibidas a los hombres, como son la tareas domésticas, complementan la definición de masculinidad.

Las respuestas de los entrevistados nos sugieren que ser hombre es seguir un modelo que la sociedad ha caracterizado e impuesto; es ser fuerte, no participar de lo doméstico, iniciarse temprano en la sexualidad y tener trabajo para poder asumir la responsabilidad de mantener la familia.

La mayor parte de los hombres de la comunidad de Río Caribe, principalmente los pescadores, se inician en la actividad pesquera desde los 7 años, primero acompañando a sus padres en la faena para luego dejar la escuela y dedicarse de lleno a la actividad productiva y tener una familia.

La pesca es una actividad fundamentalmente masculina, a las mujeres no se les permite pescar. Pueden estar asociadas a trabajos complementarios de la pesca, como remendar las redes y limpiar y vender el pescado, pero esos no son considerados elementos productivos (Jiménez, 1992).

Esta ubicación en la esfera de lo productivo para los hombres y para las mujeres lo doméstico y lo reproductivo - la casa, el cuidado de los hijos y los ancianos-, consolida los mismos modelos que han descrito otros investigadores del tema en América Latina. Tales comportamientos son trasmitidos desde el momento mismo que se conoce el sexo, aún en el vientre materno, por la madre y el padre, y se consolidan con la escuela y la familia así como el entorno cultural.

\section{AL FINAL}

La masculinidad, en las sociedades latinoamericanas, privilegia una estructura de relación entre tres variables: la sexualidad, la reproducción y el poder, que admite variaciones de clase y particularidades históricas y étnicas.

Ser hombre pareciera responder al mismo modelo en Santiago, en Iquitos, en Río Caribe. Los hombres de estos países de la región definen su masculinidad respondiendo a un guión basado en las variables de trabajo y sexo-genitalidad, reproducción, perpetuación y "paternidad". Aceptando las variaciones propias de la cultura, las generaciones y las clases sociales.

La sociedad patriarcal ha orientado las explicaciones sobre las relaciones entre hombres y mujeres hacia dualidades antagónicas: poder/ discriminación, activo/pasivo, fuerte/débil, que sólo han contribuido a una situación de incomunicación.

Para entender las masculinidad es necesario verla desde la perspectiva de relaciones de género, desde lo que las mujeres sienten como masculino y los hombres como femenino.

La investigación que realizamos entre los hombres de Río Caribe nos permitió determinar que la construcción de la masculinidad responde a una estructura que la cultura tradicional ha mantenido como definitorio: lo sexual como lo varonil. Tener relaciones sexuales y procrear es un mandato; un mandato que se expresa a través del ejercicio de los roles: los hombres no lavan, discursos: quien no tiene hijos es una gallina, y control comunitario: un hombre sin hijos es un árbol sin frutos, ello por encima de sus deseos y su placer (Lerner, 1998).

Las hipótesis sobre la masculinidad deberán ser construidas desde la explicación de un enfoque 
de género. Como categoría relacional, ésta considera variables como los condiciones socioculturales, económicas, sexuales y también las experiencias individuales y subjetivas de los dos géneros. Ésta nos permitirá establecer relaciones que ninguna otra opción teórica visibiliza.

Es necesario profundizar en los aspectos de la identidad masculina, su sexualidad y su salud reproductiva, desde una relación masculinidad/ feminidad, donde lograremos desde una posición adecuada resolver los dilemas que nos plantea la reproducción humana.

\section{REFERENCIAS BIBLIOGRÁFICAS}

Abouhamad, J., 1978. Los hombres de Venezuela, sus necesidades y aspiraciones. Caracas: Ediciones de la Universidad Central de Venezuela.

Badinter, E., 1993. XY, la identidad masculina. Bogotá: Norma.

Carrera Damas, F., 1980. ¿Es Ud. un macho? El machismo en Veneruela. Caracas: Seleven.

Colina, A. \& Izaguirre, J., 1996. Los derechos sexuales y reproductivos en la comunidad de Rio Caribe. Tesis de Grado, Caracas: Escuela de Sociología, Universidad Central de Venezuela.

Fuller, N., 1998. La construcción social de la identidad de género entre varones del Perú. En: Masculinidades y equidad de género en América Latina (T. Valdés \& J. Olavarría, eds.). Santiago de Chile: FLACSO.

Jiménez M., 1992. Esos que no son trabajos. Familia y mujer en la comunidad pesquera de El Morro de Puerto Santo. Caracas (mimeo).

Jiménez, M; Romero, A. y González, D., 1996. Estudio sobre el comportamiento reproductivo de los hombres de Río Caribe. Caracas: FNUAP/UCV (mimeo).

Kaufman, M., 1989. Hombres: placer, poder y cambio. Santo Domingo, República Dominicana: Centro de Investigación para la Acción Femenina.

Lamas, M., 1986. La antropología feminista y la categoría de género. Nueva Antropología, VIII (30):146-187.
Lerner, S., 1998. Participación del varón en el proceso reproductivo: recuento de perspectivas analíticas y hallazgos de investigación. En: Varones, sexualidad y reproduccion: diversas perspectivas teórico- metodológicas y ballazgos de investigación (S. Lerner, ed.), pp 137-162. México DF: El Colegio de México, Centro de Estudios Demográficos y de Desarrollo Urbano.

Scott, J., 1996. El género: una categoría útil para el análisis histórico. En: El género: la construcción cultural de la diferencia sexual (M. Lamas, comp.), pp. 265-302. México DF: Universidad Nacional Autónoma de México, Programa Universitario de Estudios de Género.

Valdés, T. y Olavarría, J., 1998. Ser hombre en Santiago; a pesar de todo un mismo modelo. En: Masculinidades y equidad de género en América Latina (T. Valdés \& J. Olavarría, eds.). Santiago de Chile: FLACso. 


\section{IX \\ LAS PUBLICACIONES EN CIENCIAS \\ SOCIALES Y SALUD Y LA COMUNIDAD CIENTIIFICA}




\section{DESAFÍOS DEL TRABAJO EDITORIAL CIENTÍFICO EN CIENCIAS SOCIALES Y SALUD COLECTIVA EN AMÉRICA LATINA}

Carlos E. A. Coimbra Jr. *

La vitalidad de la ciencia de un país o región determinada puede ser evaluada, entre otras maneras, a través del análisis de su producción editorial científica, incluso por las publicaciones periódicas que produce y en las que sus investigadores publican. A lo largo de los últimos siglos, el medio impreso se ha consolidado como la vía más importante de documentación de la actividad científica. Las publicaciones periódicas se han constituido en elementos primordiales para la divulgación de los resultados de investigaciones, además de ser piezas fundamentales en la atribución de la autoría y prioridad sobre una idea determinada, tesis o descubrimiento. De igual modo, las publicaciones científicas cumplen un papel importante en tanto depositarias de la "memoria de la ciencia", sea ésta regional o universal.

La expansión de las revistas editadas con base en el principio de "revisión por pares" (peer review) se produjo de manera rápida en las principales academias europeas de ciencia en los siglos XVIII y XIX. Comparadas con los libros, la mayor agilidad de las revistas se hace innegable, lo que, en términos generales, les garantiza mayor eficiencia como vehículos de divulgación y difusión científica. ${ }^{1}$ En el siglo XX, la producción global de periódicos científicos experimentó una gran expansión, principalmente a partir de los años 50 . Si en la década de los sesenta se calculaban en 35 mil el número de títulos periódicos publicados en el mundo (Gottschalk y Desmond, 1963), hoy ese total supera los $150 \mathrm{mil}$, según la última edición del Ulrich's International Periodicals Directory (http://www.bowker.com). En lo que respecta a la posición de América Latina en el escenario global, es imposible afirmar con precisión el número de revistas publicadas en la región, toda vez que una parte significativa de éstas ni siquiera posee registro en el IssN (International Standard Serial Number). ${ }^{2}$

Además de la ausencia de los sistemas más difundidos de catalogación, otra característica de las publicaciones latinoamericanas es la extrema concentración en lo que se refiere a los centros y los países en las que son generadas. Unos pocos países responden por más de la mitad del total de publicaciones periódicas registradas en la región; Brasil se destaca como el país con el mayor número de registros en el IssN, con un total de 6.193 títulos, seguido por Argentina (4.457), México (3.179), Venezuela (1.529) y Chile (1.357) (Issn, 1999). Los demás países poseen, como máximo, algunas pocas centenas de títulos registrados (no siendo raros totales inferiores a 100). No obstante, debe tomarse en cuenta que estas cifran subestiman el número de

Escuela Nacional de Salud Pública, Fundación Oswaldo Cruz, Río de Janeiro.

1 En la actualidad, a pesar de la existencia de otros medios para la divulgación de la información científica, en general electrónicos (v.g. video, CD-rom y, más recientemente, internet), las revistas impresas continúan siendo el más importante para el área de la salud. Cabe señalar que algunas revistas tradicionales en el área de la biomedicina ya poseen sites en internet, a través de los cuales el interesado puede "accesar" listas de contenido, índices remisivos, resumes e incluso artículos enteros, así como informaciones complementarias a la versión impresa (entrevistas, figuras a colores, etc.).

2 El Issn es el sistema internacional más importante para la identificación de publicaciones periódicas, sean éstas revistas, prensa u otro tipo de publicaciones en serie. El sistema es ampliamente utilizado por editoras, bibliotecas y empresas especializadas en la reproducción y la distribución de publicaciones periódicas científicas. La red IssN es una organización no gubernamental, con sede en París y oficinas de representación en decenas de países. En lo referente a América de Sur, actualmente sólo Bolivia, Paraguay y Perú no son miembros de la red Issn (Cf. http://www.issn.org). En el resto de América Latina y el Caribe, solamente Costa Rica, Guadalupe, Martinica y México se encuentran integrados al sistema Issn. Actualmente la base IssN contiene informaciones acerca de más de 900 mil títulos periódicos, originarios de unos 180 países. 
revistas publicadas, toda vez que, como ha sido mencionado anteriormente, un gran número de éstas no son registradas en el IssN.

Con relación a la temática o áreas de especialización, cerca del $55 \%$ de los títulos publicados en América Latina están vinculados al área de la salud (principalmente medicina) y la biología, ocupando el segundo lugar las ciencias agroflorestales (17\%). Se debe señalar que solamente entre el 4 y $5 \%$ de las revistas biomédicas se ubican en el área de la salud colectiva/salud pública (Hilton, 1970). Esa tendencia hacia las ciencias médicas y biológicas se evidencia también bajo otros ángulos; por ejemplo, aproximadamente el $40 \%$ de las revistas latinoamericanas indexadas por el ISI (Institute for Scientific Information $)^{3}$ están clasificadas en el área biomédica (Krauskopf \& Vera, 1975). Los análisis bibliométricos realizados a partir de las bases bibliográficas de ese instituto también confirman esa tendencia. En la década de los 80 , entre el 60 y $70 \%$ del total de los artículos publicados por autores latinoamericanos en revistas indexadas por el ISI abordaban temas médicos o biológicos (Krauskopf et al., 1986); ese perfil no es reciente, haciéndose notar ya desde los años 50 y 60 (Cetto \& Alonso-Gamboa, 1998; Hilton, 1970; Unión Panamericana, 1962).

En vista de la enorme dificultad en obtener informaciones acerca de las publicaciones periódicas realizadas en América Latina (comúnmente es imposible saber si un determinado título continúa activo, pues no son raros los atrasos e irregularidades), no es una tarea fácil efectuar un análisis de la producción y de la trayectoria de las revistas científicas latinoamericanas. Debido a la irregularidad y a la mala distribución de gran parte de las publicaciones científicas editadas en la región, incluso los propios investigadores latinoamericanos tienen poca familiaridad con los títulos existentes.

El objetivo de este trabajo es entonces el contribuir a la profundización de la discusión acerca de los desafíos del trabajo editorial en América Latina, enfocando particularmente el área de la salud colectiva/ciencias sociales. El enfoque predominante se centra en los dilemas y desafíos que enfrentamos en la búsqueda de hacer que la literatura científica generada en América Latina, región tildada siempre como periférica desde el punto de vista científico y económico, sea mejor conocida y difundida no sólo internamente sino también a escala global.

\section{LOS DESAFÍOS DEL TRABAJO EDITORIAL CIENTífICO en AMÉRICA LATINA}

\section{LA DIFÍCIL SOBREVIVENCIA}

En uno de los primeros levantamientos extensos sobre información en ciencia efectuados en América Latina, Hilton (1970) llegó a la conclusión de que existe una gran dificultad, por más simple que parezca ser, para elaborar una lista de las revistas existentes en la región. Ese diagnóstico, tan poco favorable, efectuado hace más de 20 años, lamentablemente sigue siendo válido hasta el presente.

Aparentemente, con relativa facilidad universidades, institutos de investigación, asociaciones científicas y órganos gubernamentales lanzan revistas que, con frecuencia, sobreviven sólo durante la gestión de su "director-fundador". La falta de estudios previos (incluso de mercado) y de objetivos claros que justifiquen la aparición de un nuevo título, junto a la inexperiencia editorial, apoyo técnico inadecuado y financiamiento irregular, han contribuido al fracaso de centenas de títulos lanzados en América Latina a lo largo del siglo XX.

Según el historiador Thomas Glick, el desarrollo de la ciencia en América Latina como actividad institucionalizada, raramente se ha dado de forma lineal; por el contrario, según este autor: “. . .ha estado llena de falsos comienzos, con períodos de

3 El Institute for Scientific Information, mejor conocido como ISI, es una empresa privada norteameticana, con sede en Filadelfia, especializada en información científica. Sus bases bibliográficas incluyen alrededor de 8.400 revistas a partir de las cuales se generan innumerables subproductos. Entre los más conocidos se destacan las series del Current Contents (life, sciences, social and behavioral sciences, etc.) y diversos índices de citas bibliográficas. Recientemente, la empresa lanzó el proyecto Web of Science, a través del cual se puede tener acceso de forma integrada y simultánea al Science Citation Index Expanded (que incluye 5.600 revistas a partir de 1973), al Social science Citation Index (incluye 1.700 revistas a partir de 1973) y al Arts \& Humanities Citation Index (incluye 1.140 revistas a partir de 1975) (http://www.isinet.com/ products/citation/wos/html). 
consolidación seguidos por períodos de fragmentación... en general por razones políticas" (Glick, 1994:463). ${ }^{4}$ De cierta manera, se puede afirmar que la inestabilidad político-administrativa y económica que ha marcado la trayectoria de las instituciones latinoamericanas de investigación y enseñanza se refleja también en las revistas científicas editadas en la región. Lamentablemente, la baja "esperanza de vida al nacer" y la irregularidad (tanto en lo que se refiere a la periodicidad como a la calidad del contenido) han sido una constante de la producción editorial científica en América Latina.

El caso brasileño es ilustrativo. Siendo el país responsable de la publicación del mayor número de revistas en la región, es también (lo cual no nos sorprende) uno de los que tiene el mayor número de títulos extintos. Revistas muy conocidas en el área de la biomedicina, muchas de las cuales poseían más de 30 volúmenes impresos (lo que significa un récord para la región), y en cuyas páginas importantes personajes de la academia brasileña publicaron sus trabajos, rompieron de manera repentina su continuidad a mediados del siglo XX.

De los casi 750 títulos publicados sobre biología y medicina en Brasil entre 1960 y 1970, sólo el 18\% continuaba existiendo a principios de los años ochenta (Valerio, 1994). Guardando las debidas proporciones, ese panorama general se aplica a la trayectoria de las publicaciones científicas en América Latina como un todo, razón por la cual no es motivo de sorpresa el hecho de que apenas una ínfima fracción de las muchas decenas de publicaciones periódicas de corte científico que se iniciaron en la región en el siglo XIX sobrevive hasta el presente. ${ }^{5}$

A lo largo de la segunda mitad del siglo XX, y en especial a partir de los años setenta y ochenta, la comunidad científica internacional presenció importantes cambios en la "esencia" de la publicación científica. Si en el pasado parecía suficiente publicar en las revistas o boletines de las instituciones de los propios investigadores, producidas no pocas veces de manera aficionada o artesanal, una nueva generación pasó a enfrentar la actividad de publicar de forma distinta; ya no bastaba con publicar, sino que había que asegurar que el trabajo alcanzara la "comunidad internacional". En muchas áreas, como por ejemplo en las ciencias biomédicas, ello significaba enviar los artículos a publicaciones periódicas que gozaran de reputación en el medio profesional (asegurado en gran parte por la existencia de un consejo editorial externo a los miembros de la institución), con circulación internacional y con indexación en las base bibliográficas consideradas más importantes, tales como MEDLINE, ISI, Biosis, etc.

Pocas revistas editadas en América Latina estaban preparadas para atender ese nuevo perfil de demanda. Aquellas publicadas bajo los auspicios de órganos gubernamentales (generalmente mal impresas, atrasadas y de circulación restringida) parecen haber tenido más dificultades en acompañar los cambios que se produjeron en el trabajo editorial científico en ese período. Por ejemplo, al final de los años setenta e inicios de los ochenta todas las revistas vinculadas al Ministerio de Salud de Brasil dejaron de circular, a pesar de que muchas de ellas venían publicándose desde hacía más de veinte años. Fue ese el caso de la Revista Brasileira de Leprologia (posteriormente renombrada con el título de Revista Brasileira de Dermatologia Sanitária), la Revista Brasileira de Tuberculose (posteriormente llamada Revista Brasileira de Pneumonologia Sanitária), la Revista Brasileira de Malariologia e Doenças Tropicais, los Arquivos Brasileiros de Nutrição y la Revista da Fundação SESP. ${ }^{6}$

En lo que se refiere a las revistas editadas por asociaciones científicas, universidades e institutos de investigación, las dificultades de financiamiento

4 "...it has been replete with false starts, with periods of consolidation followed by periods of fragmentation... often for political reasons" (en inglés en el original portugués, N.T.).

5 Entre los pocos títulos latinoamericanos centenarios que continúan siendo publicados (aunque en algunos casos de forma irregular) se pueden citar el Boletim do Museu Paraense Emilio Goeldi (Belem de Pará, Brasil), el Boletín de la Sociedad Mexicana de Geografía y Estadística (México) y la Revista Médica de Chile (Santiago).

6 En los años ochenta se llegó a lanzar por parte del Ministerio de la Salud la revista Saúde no Brasil. Pese a su innovadora línea editorial, se vio repentinamente interrumpida después de la publicación de unos pocos fascículos. En la década de los noventa, el mismo Ministerio inició un nuevo proyecto de publicación periódica, el Informe Exidemiológico do SUS, de circulación irregular en la actualidad. 
continuo comprometieron, en gran parte, los esfuerzos de muchas de estas publicaciones en el sentido de la mejoría de la calidad de impresión, regularidad y distribución. Ejemplo de una revista exitosa que sobrevivió a ese período de transición, modernizándose y conquistando espacios importantes, lo constituye Memórias do Instituto Oswaldo Cruz, fundada en 1909 en Río de Janeiro (Briquet de Lemos, 1993). En la actualidad, ésta es la revista biomédica latinoamericana con uno de los más altos índices de citas (según los criterios del ISI), especialmente en el área de la medicina tropical.

En las secciones que siguen trataré de profundizar tres puntos relacionados con la política editorial y la producción de publicaciones periódicas de corte académico: el idioma de la publicación, los factores relacionados con la difusión y distribución y, para finalizar, la indexación. Lamentablemente, por falta de espacio, otros puntos de igual importancia, tales como la organización del trabajo editorial, la administración y el financiamiento de revistas, la estandarización y el control de calidad, entre otros, no serán abordados en detalle.

\section{¿ESPAÑOL, INGLÉS O PORTUGUÉS?}

El problema del idioma de la publicación es uno de los grandes desafíos a ser enfrentados por todos aquellos relacionados con la divulgación y difusión del conocimiento científico generado en América Latina. Específicamente, la principal discusión a este respecto se centra en la eventual adopción del inglés como principal idioma a ser utilizado por las revistas editadas en la región.

El caso europeo es paradigmático en lo referente a la expansión del inglés en la literatura científica, particularmente en lo que concierne a Alemania y los países escandinavos. Después de la Segunda Guerra Mundial, el inglés fue rápidamente adoptado con exclusividad por un gran número de revistas científicas europeas, principalmente en las áreas básicas (matemática, física y química) y biomédicas.
Esa estrategia buscaba atender, entre otras demandas, aquellas originarias de la propia comunidad de investigadores de los diversos países europeos. El interés se centraba en alcanzar una mayor cantidad de público, en especial el anglosajón; por consiguiente, se comenzó a darle preferencia a las revistas inglesas y norteamericanas. Por otro lado, también el problema financiero tenía un gran peso, pues los subsidios estatales para la publicación científica se habían hecho insuficientes para garantizar la continuidad de la mayoría de las revistas y, al mismo tiempo, era prácticamente imposible aumentar de forma significativa el número de suscriptores de las revistas publicadas en lenguas de relativa poca circulación, como el alemán, el sueco o el noruego.

Según Götze (1997), habría sido imposible, desde el punto de vista financiero, la sobrevivencia de las editoriales académicas alemanas si no hubiesen adoptado el inglés como lengua franca en las principales revistas y series de libros técnicos publicados en el país. ${ }^{7}$ Publicaciones tradicionales, como por ejemplo el Zeitschrift für Hygiene und Infektionskrankbeiten, fundado por el eminente bacteriólogo Robert Koch, pasó a llamarse en los años sesenta Journal of Hygiene and Infectious Diseases y a publicar exclusivamente en inglés.

En cuanto a las revistas escandinavas, más allá de la adopción del inglés, hubo una tendencia a la fusión de publicaciones periódicas que abordaban temáticas similares, editados en Suecia, Noruega y Dinamarca, en general con el título de European o Scandinavian Journal of... (occupational medicine, social medicine, etc.). En la mayoría de los casos, las respectivas lenguas nacionales fueron suprimidas, incluso en los resúmenes de los artículos.

En el contexto europeo, las revistas editadas en francés quizás sean las que por más tiempo resistieron la adopción del inglés. Ello ocurrió a pesar de los elevados costos financieros y editoriales que esa política produjo, la cual desembocó no sólo en serias dificultades para aumentar el número de suscriptores, sino también en la "pérdida" de artículos

7 Japón es otro ejemplo de adopción del inglés como "lengua científica" considerado exitoso. Después de la Segunda Guerra Mundial, las publicaciones técnicas que continuaron editándose en japonés fueron aquellas de carácter estrictamente regional y/o volcadas prioritariamente al público estudiantil. Las revistas científicas japonesas en inglés cubren en la actualidad todos los campos de la academia (particularmente las ciencias básicas, biomédicas y tecnológicas), haciéndose presentes en las principales bibliotecas del mundo y publicando artículos de autores norteamericanos y europeos cada vez con mayor frecuencia. 
de autores nacionales que dieron preferencia al idioma inglés, enviando sus trabajos a publicaciones en el exterior (Bernier \& Bonfils, 1976; Götze, 1997; Locquin, 1983).

Pese a la polémica, que persiste hasta la actualidad, involucrando desde científicos hasta ministros de Estado, ${ }^{8}$ un creciente número de revistas biomédicas francesas y canadienses están publicando más de la mitad de sus artículos en inglés (véase, por cjemplo, los Annales de l'Institute Pasteur, cuyos títulos periódicos Virology y Microbiology publican de manera casi exclusiva en inglés, Annales de Medicine Interne, Canadian Medical Association Journal).

Es importante destacar que, además del creciente interés por las publicaciones en inglés por parte de los propios investigadores-autores en áreas como medicina y biología, así como de presiones ejercidas por el mercado (representado por distribuidores internacionales y suscriptores de publicaciones periódicas en general), también los principales servicios de indexación de literatura científica han privilegiado las revistas publicadas en inglés. Es el caso de los varios productos del ISI, como el Current Contents o Science Citation Index y del mismo Index Medicus MedLine (Gil-Arnao et al., 1998; Haiqui et al., 1997; Pestaña, 1997).

$\mathrm{Al}$ menos en teoría, la adopción de una lengua "común" (en este caso, el inglés), a pesar de ser una lengua extranjera, ciertamente puede facilitar enormemente la comunicación internacional entre los investigadores de un determinado campo. Para algunos autores latinoamericanos, la publicación de trabajos científicos en inglés ha llegado a constituirse en un verdadero acto de "solidaridad" para con la comunidad científica internacional (Zapata \& Larrain, 1995); en América Latina, ese punto de vista parece tener más fuerza en las áreas médicas y biológicas.

En un esfuerzo por captar los mejores artículos de investigadores nacionales $\mathrm{y}$, también con miras a aumentar su "impacto" internacional, importantes revistas biomédicas de la región sufrieron profundas reformas en sus políticas editoriales, llegando incluso a cambiar de título (trasladándolo del español o del portugués al inglés) y, a lo largo de los últimos 15-20 años, adoptando en un número cada vez mayor el inglés como lengua oficial. Por ejemplo, la Revista Brasileira de Genética (Riberão Preto), Revista Brasileira de Pesquisas Médicas e Biológicas (Riberão Preto), Archivos de Biología y Medicina Experimental y Archivos de Investigación Médica (México) pasaron a llamarse, respectivamente: Brazilian Journal of Genetics, Brasilian Journal of Medical and Biological Research, Biological Research y Archives of Medical Research. En el caso de publicaciones con menos tiempo de circulación, algunas han sido lanzadas directamente en inglés, como por ejemplo las revistas brasileñas Virus Reviens \& Research (iniciada en 1998) y Brazilian Journal of Infectious Diseases (iniciada en 1997); de esta manera se hace evidente que, al menos en lo que se refiere a las revistas biomédicas latinoamericanas, la adopción del inglés parece ser, como en el caso europeo, un proceso indetenible. Visto en el contexto de las tendencias editoriales internacionales, parece ocurrir hasta un con un cierto "atraso" con relación a lo que se ha dado en otros países y regiones del mundo.

Pese al relativo aumento del español como lengua de comunicación global (principalmente en las áreas comercial y turística), según Gil-Arnao et al. (1998) no parece seguir tal tendencia su importancia como lengua científica. Recientemente, en un levantamiento efectuado por estos autores junto a las bases del Science Citation Index y Social Sciences Citation Index, apenas el 8\% de los 270.051 artículos de autoría de investigadores afiliados a instituciones iberoamericanas publicados entre 1981 y 1995 , fueron escritos en español.

Este panorama ha sido particularmente dominante en las ciencias biomédicas, cuyas revistas latinoamericanas, como ya hemos visto, tienden a adoptar el inglés. Se debe resaltar, sin embargo, que la situación en ciencias sociales es distinta, pues, en el mismo período, de un total de 15.629 artículos acreditados a autores iberoamericanos, Gil-Arnao y sus colaboradores constataron que cerca del $40 \%$ fueron publicados en español. A pesar de que se

8 Sobre la interminable polémica acerca del uso (o del abandono) del francés en la literatura biomédica, véase Bocardi (1989), Drapeau et al. (1981), Hauteville (1995) y Toubon (1994), entre otros. 
desconocen estudios sobre la presencia del portugués en la literatura científica contemporánea, su impacto debe ser, sin duda alguna, todavía menor que el del español. Esto se debe a que, aunado a la ya reducida comunidad científica de habla portuguesa, hay incluso en América Latina dificultad de difusión de los trabajos escritos en portugués, tanto de libros como de revistas.

Considerando la competencia que representan las publicaciones periódicas en lengua inglesa (generalmente más ágiles, más citadas y mejor impresas) y su creciente potencial de "atraer" trabajos de alta relevancia, firmados por autores afiliados a los principales centros de investigación latinoamericanos, ¿cómo encaminar la discusión acerca de qué lengua debe utilizarse en las revistas editadas en la región?

Específicamente, en lo referente a las revistas de salud colectiva/salud pública editadas en América Latina, no creo posible e, incluso, recomendable, que los pocos títulos existentes adopten el inglés con carácter exclusivo. Esa estrategia puede funcionar bien para las revistas de medicina y biología; sin embargo, en el campo de la salud colectiva/salud pública me parece más razonable (o realista) la adopción de una política editorial que contemple la posibilidad de la publicación de artículos en cualquiera de estas tres lenguas, español, inglés o portugués (obviamente, siempre garantizando un buen resumen en inglés). Siguiendo esa lógica, las publicaciones como Cadernos de Saúde Pública (Río de Janeiro), Revista Panamericana de Salud (Washington DC) y la Revista de Saúde Pública (Sao Paulo) publican artículos en esas tres lenguas, mientras que la revista Salud Pública de México (México) sólo publica en español o en inglés.

$\mathrm{Al}$ menos en el presente, las ventajas en tener el inglés como una alternativa (además del español y el portugués) residen no sólo en el hecho de facilitar la comprensión científica intrarregional, sino favorecer a aquellos que, más identificados con la comunidad científica global, deseen o necesiten expresarse en esa lengua. Considerando el objetivo y la heterogeneidad del campo de la salud colectiva en América Latina, en el cual hay grupos de investigadores con grados variados de relación con la comunidad científica mundial, es importante garantizar espacios diferenciados. También debe considerarse que las revistas latinoamericanas de salud colectiva cumplen un papel muy importante en la divulgación de trabajos provenientes de los servicios regionales de salud, en los que la opción del inglés puede darse muy raramente.

\section{DIFUSIÓN Y DISTRIBUICIÓN}

Un factor que dificulta enormemente la difusión y la distribución de las revistas latinoamericanas, incluso en la misma región, es la frecuente ausencia de éstas en las bases de información bibliográfica e indexación. Como ya hemos visto, una parte significativa de los títulos de las publicaciones periódicas de América Latina ni siquiera poseen registro del IssN. Asimismo, éstas tampoco constan en los catálogos de las principales distribuidoras internacionales de este tipo de publicaciones, como por ejemplo la Swets \& Zeitlinger o la EBSCO, ${ }^{9}$ a partir de las cuales un gran número de bibliotecas de investigación alrededor del mundo hacen sus compras anuales de revistas. Según un estudio de Cetto \& Alonso-Gamboa (1998), de un total de 15.049 títulos provenientes de alguna parte de América Latina registrados en el IssN, apenas un 35\% figuraba en el catálogo Ulrich's, otra importante fuente de información sobre revistas en general, ampliamente utilizada.

La ausencia crónica de informaciones hace difícil la adquisición de publicaciones periódicas por parte de las bibliotecas. Debo mencionar también que las legislaciones cambiarias, el poco uso de tarjetas de crédito y las dificultades para efectuar depósitos de cheques en monedas extranjeras (incluso en el caso del dólar norteamericano) dificultan de igual forma la

9 La Swets \& Zeitlinger es una de las empresas especializadas en la venta de suscripciones y distribución de revistas científicas más importantes en todo el mundo (http://www.swets.nl/index.html). Con sede en Holanda y escritorios de representación en dieciocho países (incluso en Brasil), la empresa es responsable por la distribución y la venta anual de suscripciones de publicaciones en serie a unas 30.000 instituciones en todo el mundo. Su catálogo contiene aproximadamente 130.000 títulos, pocos de los cuales son editados en América Latina. Sobre la EBSCO, pueden encontrarse informaciones en: http://www-au.ebsco.com. 
circulación de las publicaciones latinoamericanas. Por increíble que parezca, una de las barreras que se enfrenta en la distribución de revistas producidas en América Latina es la de conseguir venderlas en la región, a veces hasta en los propios países donde son publicadas.

Es bastante común que una parte, a veces sustancial, de los tirajes de las revistas científicas latinoamericanas sea distribuida gratuitamente. A mi manera de ver, tal estrategia sólo tiende a descalificar o disminuir el valor de la publicación; además, tampoco es garantía de que las bibliotecas, en particular las europeas y norteamericanas, vayan a incorporar en sus acervos tales materiales no solicitados. Por si fuera poco, la distribución gratuita compromete la sobrevivencia a medio y largo plazo de la publicación, salvo en las (raras) situaciones que haya un subsidio continuo por parte del gobierno o, en el caso de algunas revistas médicas, por el aporte derivado de la publicidad pagada, en general por la industria farmacéutica (aunque raramente sea ese el caso de las revistas sobre salud colectiva).

La inexistencia de un sistema de distribución de publicaciones periódicas y libros científicos constituye otro de los serios impedimentos en la difusión de la producción editorial latinoamericana. Las casas editoriales que tienen sede en México y en Argentina, por más que ejercen un reconocido dominio sobre el mercado editorial en América Latina, básicamente distribuyen publicaciones en español, en especial libros, siendo mínima la circulación de revistas científica (Altbach \& Rathgeber, 1980; Lewry, 1995). Por otro lado pese a la base industrial gráfica-editorial existente en Brasil, sumado al hecho de tratarse del país responsable de la publicación del mayor número de revistas en toda la región, la producción brasileña de libros y revistas permanece en gran parte al margen del mercado latinoamericano. Por más que algunos autores caractericen la academia latinoamericana como constituida por "hablantes"

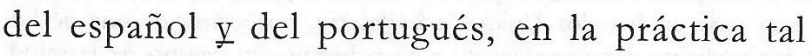
integración está lejos de ocurrir (cf. Altbach \& Rathberger, 1980: 63-64; Andrade, 1974; García, 1965; Kolb, 1976).

\section{INDEXACIÓN}

Dado que una cantidad significativa de las publicaciones periódicas en América Latina no posee registro de IsSN y no están listadas en los catálogos de referencia o comerciales más utilizados, no es de extrañar el hecho de estar también cubiertos marginalmente por los servicios internacionales de indexación bibliográfica. Según Cetto \& AllonsoGamboa (1998), sólo el 20\% de las revistas latinoamericanas que aparecieron en el catálogo Ulrich's entre 1996 y 1997 se encontraban indexadas en alguna base de información bibliográfica internacional.

Además de la relativa invisibilidad de las revistas latinoamericanas, resultado de la poca atención que se la ha dado a los aspectos formales involucrados en el registro internacional de una publicación periódica de corte científico, en palabras de Gil-Arnao y colaboradores: “....sustentar una revista en los índices bibliográficos más exigentes requiere controlar los parámetros de calidad, periodicidad, financiamiento y distribución eficiente de la publicación, condiciones difícilmente satisfechas por las revistas científicas latinoamericanas" (1998:33). Por consiguiente, el atraso, la irregularidad y la mala calidad editorial, entre otros factores, hacen un gran número de revistas científicas editadas en América Latina incompatibles con los criterios de inclusión adoptados por los indexadores internacionales.

Desde el punto de vista de los usuarios inmediatos de las revistas, es decir, autores y lectores, los sistemas de indexación son los medios más eficientes para la realización de levantamientos bibliográficos. Además del acceso al título y al resumen de un determinado artículo, en la mayoría de los casos el lector interesado también podrá obtener la dirección de los autores a partir de las bases de información, incluso sin acceso a la revista donde el trabajo fue publicado. Así, los investigadores que trabajan sobre un tema determinado en diferentes países del mundo, por más que no tengan contacto entre sí, tienen la oportunidad, entre otras cosas, de comunicarse, solicitar separatas, etc.

Es importante recordar que la indexación de la bibliografía científica no constituye una "invención" 
reciente de la era de la informática. Esta práctica comenzó a finales del siglo XIX e inicios del XX, fruto de la iniciativa de grupos de investigadores que, imposibilitados de dar seguimiento desde sus cubículos a la cada vez mayor cantidad de materiales que se publicaban en el mundo sobre un determinado tema, se vieron en la obligación de desarrollar sistemas que racionalizaran y facilitaran el acceso a las informaciones. Por ejemplo, en 1864 la Zoological Society of London y el British Museum of Natural History iniciaron la publicación de Zoological Records. Entre 1917 y 1918 surgió el Abstracts of Bacteriology y el Botanical Abstracts, compilados, respectivamente, por la Society of Americans bacteriologists y por un grupo de editores de revistas norteamericanas de botánica. El éxito de estos dos Abstracts fue tal, que pocos años después de sus lanzamientos se fundicron para constituir el Biological Abstracts. ${ }^{10}$

En el área de las ciencias de la salud en general, el Index Medicus, compilado por la National Library of Medicine (Washington DC) desde 1879, es la base bibliográfica más utilizada en todo el mundo. A partir de mediados de los años sesenta, las referencias pasaron a estar informatizadas, formando así el sistema MedLars (Medical Literature Retrieval System), que actualmente integra alrededor de 40 bases de datos, entre las cuales está el MeDLine, la más conocida y utilizada, y que desde 1997 tiene acceso on-line gratuito. El sistema MEDLINE incluye, en su totalidad, unos 9 millones de referencias bibliográficas (de las cuales el 80\% está en idioma inglés), a partir de 1966, extraídas de 3.900 revistas originarias de más de 70 países (http:// www.ncbi.nlm.nih.gov).

Este trabajo no busca presentar en detalle cada una de las bases internacionales de información bibliográfica potencialmente útiles al área de las ciencias de la salud. Entre otras bases relevantes, especialmente en lo referente a salud pública/salud colectiva, se destacan, en orden alfabético, $C A B$ Abstracts, EMBASE/
Excerpeta Medica, LiLACS y Sociological Abstracts. A mi juicio, es importante destacar el hecho de que, en su conjunto, estas bases se han convertido en instrumentos esenciales en la difusión de la información científica. Bajo la perspectiva de los autores, publicar en revistas indexadas en las bases más ampliamente utilizadas por los investigadores aumenta enormemente las oportunidades de que sus trabajos vayan a ser leídos y posteriormente citados. Por su parte, para los editores de revistas científicas no tiene sentido ignorar o subestimar la relevancia de la indexación, tanto para la divulgación de la publicación como en lo referente a la captación de trabajos de los investigadores más reconocidos en una determinada área de conocimiento.

A lo largo del tiempo, en una escala global, la inclusión de un título por parte de los indexadores calificados como más "tradicionales" pasó a ser visto como una característica que confiere prestigio a la publicación. La evaluación de la "calidad" de una publicación determinada no fue en realidad el objetivo de quienes iniciaron estos sistemas de evaluación bibliográfica en la ciencia; sin embargo, en la actualidad esa asociación entre indexación y evaluación o calificación es cada vez más común. Hablando en términos históricos, existió entre las bases una tendencia a no ser selectivas, procurando incluir el mayor número posible de items sobre un tema determinado; con el paso del tiempo, se ha hecho cada vez más difícil asegurar una cobertura universal.

Recordemos que hasta hace muy poco tiempo las etapas que componían el proceso de indexación se realizaban de forma manual, e incluían, entre otras tareas, la transcripción a máquina (o más modernamente, en computadora) de títulos, autores, direcciones y resúmenes publicados en una determinada revista; es decir, una tarea extremadamente ardua en términos de costos y de tiempo. El aumento exponencial del número de artículos producidos anualmente y el continuo

10 El Biological Abstracts y el Zoological Records componen actualmente la base bibliográfica Brosis (http://www.biosis.org). Se trata de una base producida por una organización del mismo nombre, sin fines de lucro, con sede en Estados Unidos e Inglaterra, poseedora de una de las bases de información bibliográfica más extensas en ciencias biológicas y biomedicina. En lo referente a su cobertura en campo de la salud pública, incluye publicaciones periódicas sobre entomología médica, parasitología, ecología y control de vectores, microbiología aplicada y toxicología, entre otros temas. Biosis contempla varias revistas publicadas en América Latina. Actualmente, el sistema informacional Biosis contiene cerca de 13 millones de referencias bibliográficas que pueden ser accesadas de diferentes maneras, incluso on-line (Freedman, 1995) 
surgimiento de revistas hicieron imposible la compilación de indices que englobaran la totalidad de la bibliografía mundial sobre un tema particular, como ya lo vaticinaban los pioneros de la indexación en el siglo XIX. En consecuencia, dependiendo de los objetivos específicos de cada sistema de información bibliográfica (lo cual incluye su especialidad, su temática, el público a la que va dirigida, etc.) fueron desarrollados e implementados criterios de selección para determinar cuáles publicaciones periódicas podían incluirse y cuáles no.

La polémica en torno a los criterios de inclusión de publicaciones periódicas en las principales bases de indexación es enorme. La concepción y la implementación de esos criterios ha generado verdaderas batallas entre editores, investigadoresautores, técnicos de órganos de fomento, bibliotecarios y, en fin, entre todos aquellos agentes involucrados en las diversas instancias del proceso de producción y divulgación del conocimiento científico.

Algunas bases tienen entre sus políticas la de anunciar públicamente esos criterios; por ejemplo, en el caso del MedLine, una de las bases que divulga sus criterios, se reúne periódicamente un Comité Técnico coordinado por la propia directora de la National Library of Medicine, a fin de considerar nuevas propuestas de inclusión de revistas o el eventual retiro de títulos incluidos en la base. Entre los varios puntos considerados en la evaluación de los títulos a ser incluidos o eliminados del MEDLINE, se destacan los méritos científicos, la regularidad, la calidad editorial, la disponibilidad de buenos resúmenes en inglés así como los aspectos técnicos generales de la publicación (tipo de papel utilizado, calidad de impresión, arte final, etc.), entre otros. ${ }^{11}$

Por más que se autodefina como una base de información bibliográfica internacional (y su cobertura sea, ciertamente, amplia en comparación con otras bases), en la práctica el MeDLine confiere una atención especial a las revistas médicas norteamericanas. Después de todo, el trabajo de archivar, indexar y divulgar la literatura médica norteamericana son atribuciones institucionales de la National Library of Medicine, que guarda estrecha relación con el National Institute of Health. Por ello, puede causarnos asombro el hecho de que en el MedLine estén indexadas revistas norteamericanas de circulación internacional muy restringida, editadas por asociaciones médicas de poca expresión fuera de los ámbitos estatales o regionales norteamericanos.

Hablando en términos realistas, no hay por qué esperar que el MEDLINE o cualquier otra base de información bibliográfica extranjera tenga que incluir necesariamente la totalidad de las revistas publicadas en el mundo. Países como Inglaterra y Francia, por ejemplo, han desarrollado sus propias bases, los sistemas CAB y PASCAL, respectivamente, los cuales se han convertido, al igual que el MEDLINE, en canales muy importantes para la difusión de la producción científica de esos países. Merece especial atención el caso del PASCAL, pues, definiéndose incluso como una base con cobertura internacional (incluye, por ejemplo 22 título publicados en América Latina), tiene especial énfasis en las publicaciones francesas, incluyendo tesis y monografías. Esta base no sólo permite la realización de levantamientos bibliográficos sino también la realización de estudios bibliométricos (Patou, 1996/1997). ${ }^{12}$

Diversos países europeos y asiáticos han creado sus propios sistemas de indexación y de alerta bibliográfica que, sin pretensión de poseer cobertura internacional, constituyen importantes instrumentos que atienden las necesidades nacionales en lo que respecta a la difusión de información y evaluación de la producción científica (véanse, por ejemplo, Abstracts of Bulgarian Scientific Medical Literature, Index Medicus Yugoslavicus, China Medical Abstracts).

11 Los criterios y procedimientos de evaluación de publicaciones periódicas indexadas por el MedLiNe se encuentran disponibles en la página electrónica de la National Library of Medicine (http://www.index.nlm.nih.gov/pubs/factsheets/jsel.html).

12 Recientemente, el proyecto SciELO, desarrollándose en Brasil a través de un consorcio que involucra la FApESP (Fundação de Amparo e Pesquisa do Estado de São Paulo), la BIREME (Biblioteca Regional de Medicina/OPS) y el ISI, busca agrupar para su consulta textos completos de una selección de revistas científicas brasileñas en diferentes áreas del conocimiento para maximizar su visibilidad. El proyecto también contempla la construcción de una base bibliográfica nacional que permita, a mediano y largo plazo, la realización de investigaciones bibliométricas y de "impacto" de citas, tal como el tipo de estudios que se realizan a partir de los indicadores bibliométricos provistos por el ISI (http://www.scielo.br). 
Es posible que ningún otro producto generado por los sistemas de información suscite tanta polémica como aquellos derivados de las bases bibliográficas del Institute for Scientific Information (ISI) (véase nota al pie $\mathrm{N}^{\circ}$ 3). De esta manera, es importante realizar algunos comentarios respecto al uso $\mathrm{y}$, frecuentemente, mal uso de ciertos índices bibliométricos que tienen su origen en esas bases. En América Latina, la polémica surge y cobra fuerza a partir del momento en que las instituciones de investigación y de fomento, por no disponer de bases de información internacionales adecuadas, adoptan los índices de citas e impacto generados por el ISI, a través de sus Science Citation Index y Social Sciences Citation Index. El Journal Citation Reports, otro producto del ISI, también ha sido utilizado por algunos como el gold standard para la evaluación de las revistas editadas en la región.

Los criterios de inclusión adoptados por el ISI no tienen como premisa el alcanzar una cobertura representativa de la ciencia producida en los diversos países y regiones del mundo. ${ }^{13}$ Por ejemplo, las revistas publicadas fuera del eje anglosajón, especialmente las editadas en lenguas como el español y el portugués, están muy poco representadas en las bases bibliográficas del ISI (Gil-Arnao et al., 1998; MaciasChapula, 1994; Spinak, 1995). El propio Eugene Garfield, director emérito del ISI, afirma que la constitución de esas bases no está orientada por un principio de "representatividad" geográfica. Las revistas cubiertas por el ISI constituyen lo que Garficld denomina "la parte del león" (the lion's share) de la literatura científica mundial; es decir, aquellas revistas más leídas, citadas y, por consiguiente, de mayor "impacto" (Garfield, 1995:88). ${ }^{14}$

Este principio de "la parte del león" tiene repercusiones profundas en lo que respecta a la indexación de la bibliografia producida en América Latina. La representación latinoamericana en el ISI se hace apenas con una docena de publicaciones periódicas, editados en Argentina, Brasil, Chile y
México (Garfield, 1995). En lo que se refiere a la presencia de autores de la región, sólo el 1,5\% del total de artículos indexados anualmente por el ISI son de investigadores latinoamericanos (Garfield, 1995); por ello, es cuestionable la adopción de los parámetros del ISI para la evaluación de la producción científica (medida a través del número de papers publicados en revistas indexadas por el ISI) y de la calidad de las revistas editadas en la región. Según Spinak (1995:354), la utilización acrítica de esos indicadores revela poca claridad o, incluso, falta de entendimiento acerca de la lógica que estructura la constitución de esas bases.

La utilización de los "factores de impacto" generados por el ISI para evaluar la calidad de la producción científica en América Latina produce un panorama completamente distorsionado e incompleto, además de estar cargado de importantes implicaciones políticas. Resulta fundamental dejar muy en claro que la utilización de tales "factores de impacto" no posee el mismo potencial para las diversas áreas de conocimiento. El impacto no está asociado solamente a la calidad intrínseca del conocimiento científico generado, sino también a una compleja configuración política y sociológica relacionada con las posibilidades de incorporación de conocimientos producidos en contextos regionales-locales en las bases internacionales de indexación, cuyos criterios poseen sus propias contingencias.

En la óptica bajo la que se enfoca una base como el ISI, el área de la salud colectiva/salud pública, tanto en América Latina como en otras partes del mundo, ocupa y siempre ocupará una posición periférica con relación a las áreas calificadas como básicas (es decir, biología, química, medicina experimental, etc.).

Con relación a la salud colectiva/salud pública existe una enorme variabilidad interna con respecto a sus disciplinas constitutivas, lo que se asocia con prácticas de publicaciones y de construcción de citas

13 Véase "The ISI Database: The Journal Selection Process" (http://www.isinet.com/hot/essays/199701.html).

14 La idea de "impacto", la cual es aplicable al trabajo de investigadores, instituciones y revistas, tiene su origen en los primeros estudios realizados a partir de las bases bibliográficas ofrecidas por el ISI, originando posteriormente la idea de literatura de corriente principal o mainsteam, es decir, aquella que responde por el mayor número de citas (Price, 1963). Obviamente, la cantidad de citas está relacionada, entre otros factores, a la lengua en la cual se publica, procedencia del investigador y tamaño de la comunidad de investigadores en un
determinado campo científico. 
particulares. Para el editor de una revista de salud pública, confrontar un panorama tan heterogéneo representa un gran desafío. No es de extrañar que en un mismo fascículo se publiquen artículos de ciencias sociales, epidemiología, evaluación nutricional, microbiología de alimentos, toxicología, políticas de medicamentos y control de insectos, para mencionar solamente una fracción de los temas eventualmente cubiertos.

Por ejemplo, si tomamos en cuenta los Cadernos de Saúde Pública, revista en cuya edición participo desde hace ocho años, se observa que son muy claras las variaciones en las formas de hacer las citas de la literatura cientifica entre las diferentes disciplinas representadas en la revista. Los artículos sobre epidemiología (principalmente los que tratan sobre enfermedades calificadas como "tropicales"), ecología, control de vectores y evaluación, así como en epidemiología nutricional, entre otras áreas, no sólo parecen hacer más uso de la literatura latinoamericana (es decir, citándola con más frecuencia), sino también son citados por otros autores en, relativamente, poco tiempo después de su publicación.

Por otro lado, en el área de las ciencias sociales se producen, de alguna manera, menos artículos y se tiende a citar una mayor cantidad de libros, capítulos, tesis, relatorías u otros tipos de documentos de más difícil acceso. Esta característica de las ciencias sociales con relación al uso de la bibliografía y prácticas de citar ha sido observada también por otros autores. En este sentido, Hicks (1999), por ejemplo, recomienda cautela en la utilización de los índices de citas del ISI para la realización de estudios bibliométricos en ciencias sociales, pues alrededor del $40 \%$ o más de las citas en esa área se refieren a libros o capítulos de libro (materiales que no son indexados por el ISI).

Una parte importante de la producción académica latinoamericana en el área de la salud colectiva/salud pública está constituida por trabajos de orientación sociopolítica o socioantropológica, áreas éstas que presentan normas de realización de las citas particulares. Por ello, no se puede dejar de tomar en consideración las interrelaciones entre esas peculiaridades y los resultados obtenidos a partir del cálculo de índices de impacto generados a través de las bases del ISI, cuya lógica, como hemos visto, se estructura sobre otros presupuestos. Así, al contrario de lo que nos puede sugerir un "índice de impacto" de valor numérico $x$ o $y$ atribuido a un autor o revista en particular, no se está necesariamente cerca de una caracterización "imparcial" u "objetiva" del mérito de un trabajo o publicación.

Es importante hacer notar que estas reflexiones no se limitan a las revistas latinoamericanas sobre salud colectiva/salud pública. Por ejemplo, ninguna revista extranjera en el área, tales como el American Journal of Public Health o el International Journal of Epidemiology, figuran en la lista de las "50 más citadas", periódicamente divulgadas por el ISI (por cierto, tampoco constan entre las "100 más citadas"). Una visita a la página que mantiene el ISI en internet revela que las revistas sobre salud colectiva/salud pública tampoco aparecen en la tan "alabada" sección "What's Hot in Research" (http://www.isinet.com/ hot/research/19990419/a.html). A título de curiosidad, el "Hot Paper in Medicine" del primer bimestre de 1999 señala un trial sobre terapéutica contra el HIV publicado en 1997 en el New England of Medicine (el mismo recibió 35 citas en un período de 2 meses). En el área de las "ciencias de la vida", los artículos que más comúnmente figuran en este tipo de listas y secciones proviene de revistas como Cell Biology, Biochemistry, Genomics o Genetics.

El "impacto" de las revistas sobre salud colectiva/salud pública, especialmente en lo que concierne a América Latina, debe ser medido o evaluado por otros medios, sin limitarse a la ortodoxia de los indicadores ISI. La evaluación del "impacto" está revestida de mucho más complejidad de la que generalmente se le atribuye. Como advierte Velho (1986), en el estudio de la sociología de las citas bibliográficas no se puede dejar de considerar, además de los factores obvios como la lengua y la accesibilidad de la publicación, el poco crédito que los investigadores vinculados a los centros de excelencia del primer mundo le otorgan a las publicaciones provenientes de países científicamente periféricos.

Según un estudio bibliométrico realizado por Cruz (1995), que incluyó una muestra de 45 revistas biomédicas latinoamericanas en el período 
comprendido entre 1985 y 1992 , se publicaron 8.644 artículos, que a su vez generaron 82.143 citas. El Boletín de la Oficina Sanitaria Panamericana (actualmente Revista Panamericana de la Salud) fue la publicación más citada (38\% del total de las citas). Es de hacer notar que, pese a su comprobada importancia para la investigación en salud pública en la región, el mencionado boletín no está indexado por el ISI (Cruz, 1995; Spinak, 1995). Incluso, según Cruz (1995), lo que podríamos considerar el "hot paper" en salud pública en el período fue un estudio sobre la enfermedad del mal de Chagas transfusional, publicado en 1972, que fue citado 18 veces durante los ocho años que comprendió la investigación.

Dos puntos sumamente importantes derivan de la observación realizada en el párrafo anterior, la primera de ellas es que se puede concluir que incluso los llamados "hot papers" en salud pública presentan una tasa de citas infinitamente menor que sus equivalentes en medicina experimental y biología (en esas áreas no es raro que los artículos sean citados decenas de veces en pocos meses). Obviamente, el tamaño de las comunidades científicas y la velocidad de producción de la investigación están íntimamente asociados al número de veces que un artículo sea citado. En segundo lugar, un estudio sobre la enfermedad del mal de Chagas transfusional jamás podría convertirse en un "hot paper in medicine" del ISI, pues sencillamente se trata de una endemia que, en esencia, se relaciona solamente con América Latina y cuyo estudio no se encuentra dentro de la pauta de prioridades de investigación de los centros europeos y norteamericanos. ${ }^{15}$

En resumen, algunos de los puntos que considero particularmente importantes en la integración salud colectiva/salud pública en América Latina de cara a la indexación en bases bibliográficas internacionales que abordé en esta sección, son los siguientes: (a) los editores de publicaciones periódicas sobre salud colectiva y áreas afines deben realizar seguimientos cuidadosos de las publicaciones bajo su responsabilidad con miras a ampliar su presencia en los sistemas de información bibliográfica internacionales; (b) debido a la propia naturaleza de la investigación en salud colectiva/salud pública, que no pocas veces cubre temáticas locales-regionales y que presenta patrones particulares en las citas que de éstos se hagan, no tiene sentido lanzarnos en una carrera desenfrenada que busque aumentar los índices de "impacto" que respondan a los patrones del ISI; (c) se deben desarrollar criterios alternativos a los índices de "impacto" que contemplen un mejor conocimiento y un más amplio entendimiento del proceso de producción científica en América Latina. Como es de todos conocido, la investigación en salud pública puede tener "impactos" en las políticas, la planificación de estrategias de intervención y programas de salud, así como sobre la organización de servicios, que, con mucho, sobrepasan la mera cuantificación de referencias y citas bibliográficas.

\section{Consideraciones FINALES}

A lo largo de este artículo he intentado demostrar que existen enormes desafíos que deben ser superados para que la producción científica en salud colectiva/salud pública en América Latina ocupe un mayor espacio y visibilidad en el escenario internacional. En mi opinión, pese a los obstáculos estructurales y coyunturales, no es imposible promover cambios significativos a mediano y a largo plazo. Particularmente, creo que uno de los primeros pasos que deben darse es el de crear una mayor concientización y capacitación de la comunidad de investigadores latinoamericanos con relación al escenario socioeconómico y político en el cual se inserta el trabajo editorial científico en el mundo contemporáneo.

\section{REFERENCIAS BIBLIOGRÁFICAS}
Altbach, P.G. \& Rathgeber, E.M., 1980. Publishing in the Third World: trend report and bibliography. Nueva York: Praeger.

Andrade, O.S., 1974. O livro brasileiro. Río de Janeiro: Editora Paralelo.

Bernier, J.J. \& Bonfils, S., 1976. Use of French as the language of scientific publication. Warning

15 Véase Porta (1996), Spinak (1995) y Sancho (1992) para análisis críticos de las limitaciones e implicaciones de los índices ISI en la evaluación de la producción científica en salud pública, particularmente en lo que se refiere a América Latina. 
concerning the "paper-drain". Archives Francaises de Pediatrie, 33:1004-1006.

Boccardi, V., 1989. French language journals. L ancet, 2:508.

Briquet de Lemos, A.A., 1993. Análise crítica de uma revista institucional: as Memórias do Instituto Oswaldo Cruz. Cadernos de Saúde Pública, 9:161-169.

Cetto, A.M. \& Alonso-Gamboa, O., 1998. Scientific periodicals in Latin America and the Caribbean: a global perspective. Interciencia, 23:84-93.

Cruz, A., 1995. Influencia de las publicaciones de la OPS en la producción científica en salud en América Latina y el Caribe. Boletin de la Oficina Sanitaria Panamericana, 119:515-528.

Drapeau, A.J.; Demers, P. \& Pechere, J.C., 1981. Scientific French in free-fall. Union Medicale du Canada, 110:927-931.

Garcia, E.A., 1965. Desarrollo de la Industria Editorial Argentina. Buenos Aires: Fundación Interamericana de Bibliotecología Franklin.

Garfield, E., 1995. Quantitative analysis of the scientific literature and its implications for science policymaking in Latin America and the Caribbean. Bulletin of the Pan American Organization, 29:87-95.

Gil-Arnao, F., Rodulfodegil, E.; Rivera, V. \& Molina, J., 1998. El español en los índices SCI y SSCI. Lapso 1981-1995. Interciencia, 23:33-40.

Glick, T.F., 1994. Science and society in twentiethcentury Latin America. In: The Cambridge History of Latin America (L. Bethel, ed.), pp. 463-535. Cambridge: Cambridge University Press.

Gottschalk, C.M. \& Desmond, W.F., 1963. Worldwide census of scientific and technical serials. American Documentation, July, 188-192.

Götz, H., 1997. The English language in scientific publishing. Publishing Research Quarterly, 13:52-72.

Haiqi, Z.; Yamazaki, S. \& Urate, K., 1997. The tendency toward English-language papers in MEdLine. Bulletin of the Medical Library Association, 85:432-434.
Hauteville, D., 1995. On the use of English in French scientific publications. Annales de Medecine Interne (Paris), 146:29-32.

Hicks, D., 1999. The difficulty of achieving full coverage of international social science literature and the bibliometric consequences. Scientometrics, 44:193-215.

Hilton, R., 1970. The Scientific Institutions of Latin America (with special reference to their organization and information facilities). Stanford: California Institute of International Studies.

IssN (International Standard Serial Number), 1999. Map of the ISSN network. Accesado el 16 de abril de 1999 [http://www.issn.org].

Kolb, R., 1976. Mexico. En: The Book Trade of the World (S. Taubert, ed.), vol. 2, pp. 220-233. Nueva York: Bowker.

Krauskopf, M.; Pessot, R. \& Vicuña, R., 1986. Science in Latin America. How much and along what lines? Scientometrics, 10:199-206.

Krauskopf, M. \& Vera, M.I., 1995. Las revistas latinoamericanas de corriente principal: indicadores y estrategias para su consolidación. Interciencia, 20:144-148.

Lewry, P., 1995. Latin America: En: International book publishing: an encyclopedia (P.G. Altbach \& E.S. Hoshino, eds.), pp. 575-585. Nueva York/ Londres: Garland Publishing, Inc.

Locquin, M.V., 1983. The French language in the biological and medical sciences. Bulletin de l'Academie Nationale de Medecine, 167:41-48.

Macias-Chapula, C.A., 1994. Non-SCI subject visibility of the Latin American scientific production in the health field. Scientometrics, 30:97-104.

Patou, C., 1996/1997. The PASCAL and Francis data bases of the Institut d'Information Scientifique et Technique (France): presentation and statistics. Publishing Research Quarterly, 12:24-35.

Pestaña, A., 1997. El MedLine como fuente de información bibliométrica de la producción española en biomedicina y ciencias médicas. Comparación com el Science Citation Index. Medicina Clínica (Barcelona, España), 109:506-511. 
Porta, M., 1996. The bibliographic "impact factor" of the Institute for Scientific Information: how relevant is it really for public health journals? Journal of Epidemiology and Community Health, 50:606-610.

Price, D.S., 1963. Little science, big science. Nueva York: Columbia University Press.

Sancho, R., 1992. Misjudgments and shortcomings in the measurement of scientific activities in less developed countries. Scientometrics, 23:221-233.

Spinak, E., 1995. Quantitative analyses of scientific literature and their validity for judging Latin American Production. Bulletin of the Pan American Organization, 29:352-359.

Toubon, J., 1994. Interview with Jacques Toubon, the Minister of Affaires Culturelles et de la Francophonie. What is the future of the
French language in the medical and scientific community? Annales de Medecine Interne (París), 145:388-390.

Unión Panamericana, 1962. Guía de Publicaciones Periódicas Científicas y Técnicas de América Latina. México, DF: Unión Panamericana/ Centro de Documentación Científica y Técnica.

Valério, P.M., 1994. Espelho da Ciência. Río da Janeiro: Finep/IBICT.

Velho, L., 1986. The "meaning" of citation in the context of a scientifically peripheral country. Scientometrics, 9:71-89.

Zapata, P. \& Larrain, C., 1995. Desarrollo de una revista biológica latinoamericana. En: Publicaciones cientificas en América Latina (A.M. Cetto \& K.I. Hillerud, eds.), pp. 89-101. México, DF: Fondo de Cultura Económica.

\section{Salud y Equidad: una mirada desde las}

ciencias sociales quedó totalmente

impreso y encuadernado el agosto de 2000.

La labor se realizó en los talleres del Editora

Fiocruz, Rua Leopoldo Bulhões, 1480, térreo, Manguinhos, Rio de Janeiro, RJ, Brasil. CEP 21041-210.

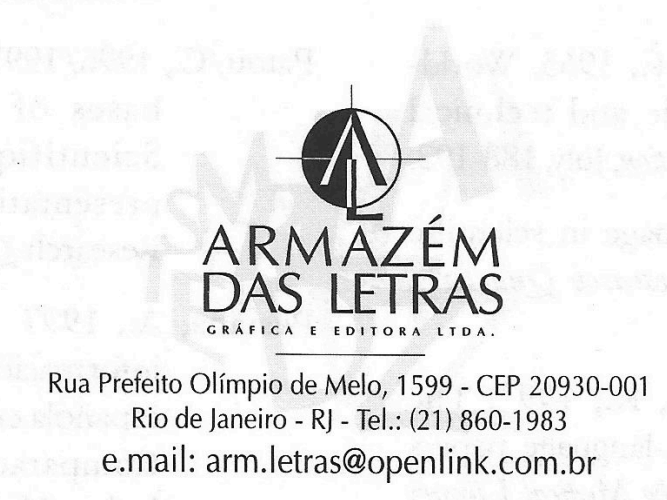

